\title{
DISCLAIMER
}

This report was prepared as an account of work sponsored by an agency of the United States Government. Neither the United States Government nor any agency thereof, nor any of their employees, makes any warranty, express or implied, or assumes any legal liability or responsibility for the accuracy, completeness, or usefulness of any information, apparatus, product, or process disclosed, or represents that its use would not infringe privately owned rights. Reference herein to any specific commercial product, process, or service by trade name, trademark, manufacturer, or otherwise does not necessarily constitute or imply its endorsement, recommendation, or favoring by the United States Government or any agency thereof. The views and opinions of authors expressed herein do not necessarily state or reflect those of the United States Government or any agency thereof.

\section{International Energy Outlook} 1998

\section{April 1998 \\ DISTRIBUTION OF THIS DOCLIEENT IS UNLMUTED MASTER \\ Energy Information Administration \\ Office of Integrated Analysis and Forecasting \\ U.S. Department of Energy \\ Washington, DC 20585}

This report was prepared by the Energy Information Administration, the independent statistical and analytical agency within the Department of Energy. The information contained herein should be attributed to the Energy Information Administration and should not be construed as advocating or reflecting any policy position of the Department of Energy or of any other organization. 


\title{
Contacts
}

The International Energy Outlook is prepared by the Energy Information Administration (EIA). General questions concerning the contents of the report should be referred to Mary J. Hutzler (202/586-2222), Director, Office of Integrated Analysis and Forecasting, or
Arthur T. Andersen (202/586-1441), Director, International, Economic, and Greenhouse Gases Division. Specific questions about the report should be referred to Linda E. Doman (202/586-1041) or the following analysts:

(art.andersen@eia.doe.gov, 202/586-1441)

(linda.doman@eia.doe.gov, (george.butler@eia.doe.gov, 202/586-1041) Linda E. Doman World Oil Markets . . . . . . . . G. Daniel Butler Perry Lindstrom

Reformulated Gasoline . . . . . Stacy MacIntyre Natural Gas . . . . . . . . . . Linda E. Doman Phyllis Martin

Coal . . . . . . . . . . . . . Michael Mellish (perry.lindstrom@eia.doe.gov, 202/586-9503) (stacy.macintyre@eia.doe.gov, 202/586-0934) 202/586-9795) (linda.doman@eia.doe.gov, (phyllis.martin@eia.doe.gov, 202/586-1041) 202/586-9592) (michael.mellish@eia.doe.gov, 202/586-2136)

U.S. Minemouth Coal Prices . . . Richard Newcombe Nuclear. . . . . . . . . . . Laura Church Renewable Energy . . . . . . Linda E. Doman Electricity. . . . . . . . . . . Kevin Lillis Economic Growth . . . . . . . Kay A. Smith (richard.newcombe@eia.doe.gov, 202/586-2415)

(laura.church@eia.doe.gov, 202/586-1494)

(linda.doman@eia.doe.gov, 202/586-1041)

(kevin.lillis@eia.doe.gov, 202/586-1395)

(kay.smith@eia.doe.gov,

\section{Electronic Access and Related Reports}

The IEO98 will be available on CD-ROM and the EIA Home Page (http://wwweia.doe.gov/oiaf/ieo98/home.html) by May 1998, including text, forecast tables, and graphics. To download the entire publication in Portable Document Format (PDF), go to ftp://ftp.eia.doe.gov/pub/pdf/international/048498.pdf.

For ordering information and questions on other energy statistics available from ELA, please contact EIA's National Energy Information Center. Addresses, telephone numbers, and hours are as follows:

\author{
National Energy Information Center, EI-231 \\ Energy Information Administration \\ Forrestal Building, Room 1F-048 \\ Washington, DC 20585
}

Telephone: 202/586-8800

TTY: For people who are deaf or hard of hearing: 202/586-1181

9 a.m. to 4 p.m., eastern time, M-F
E-mail: infoctr@eia.doe.gov World Wide Web Site: http://www.eia.doe.gov Gopher Site: gopher://gopher.eia.doe.gov FTP Site: ftp://ftp.eia.doe.gov 


\section{DISCLAIMER}

Portions of this document may be illegible electronic image products. Images are produced from the best available original document. 
Preface $\ldots \ldots \ldots \ldots \ldots \ldots \ldots \ldots \ldots \ldots \ldots \ldots \ldots \ldots \ldots \ldots \ldots \ldots \ldots \ldots \ldots$

Highlights $\ldots \ldots \ldots \ldots \ldots \ldots \ldots \ldots \ldots \ldots \ldots \ldots \ldots \ldots \ldots \ldots \ldots \ldots \ldots \ldots$

World Energy Consumption $\ldots \ldots \ldots \ldots \ldots \ldots \ldots \ldots \ldots \ldots \ldots \ldots \ldots$

Alternative Growth Cases . . . . . . . . . . . . . . . . . . . . . 9

Trends in Energy Intensity . . . . . . . . . . . . . . . . . . . . . . . . . 13

Emissions of Greenhouse Gases and the Kyoto Protocol . . . . . . . . . . . . . . . . . . 15

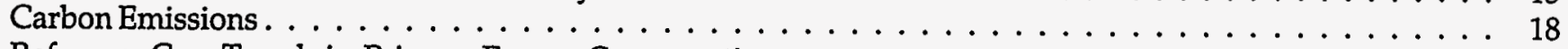

Reference Case Trends in Primary Energy Consumption. . . . . . . . . . . . . . . . . . . 20

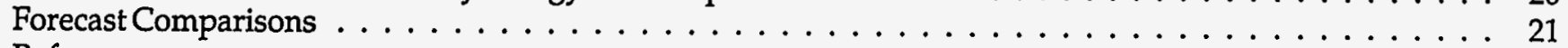

References . . . . . . . . . . . . . . . . . . . . . . . . . 24

The World Oil Market . . . . . . . . . . . . . . . . . . . . . . . . . 25

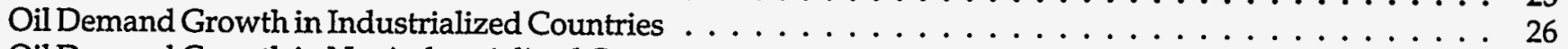

Oil Demand Growth in Nonindustrialized Countries . . . . . . . . . . . . . . . . . . . . . . . 27

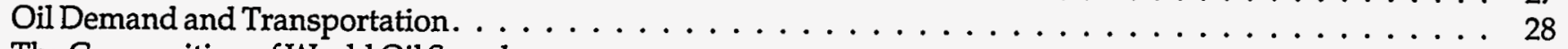

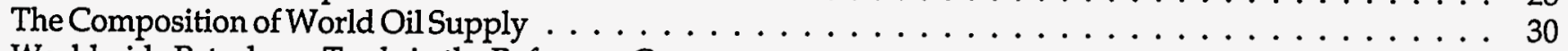

Worldwide Petroleum Trade in the Reference Case . . . . . . . . . . . . . . . . . . . . 35

World Oil Price Projections. . . . . . . . . . . . . . . . . . . . . . . . . . 37

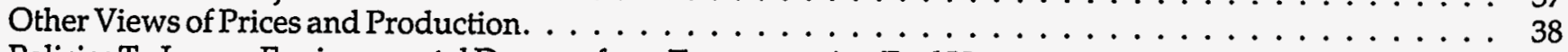

Policies To Lessen Environmental Damage from Transportation Fuel Use . . . . . . . . . . . . . . 40

References . . . . . . . . . . . . . . . . . . . . . . . . 47

Natural Gas . . . . . . . . . . . . . . . . . . . . . . . . . . . 49

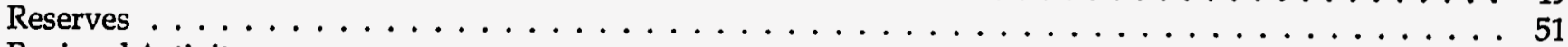

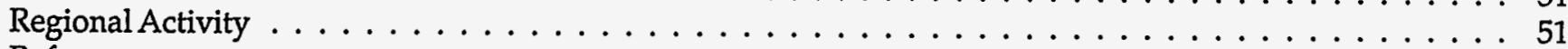

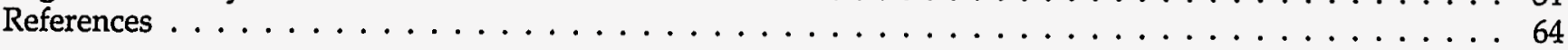

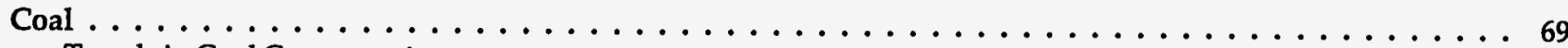

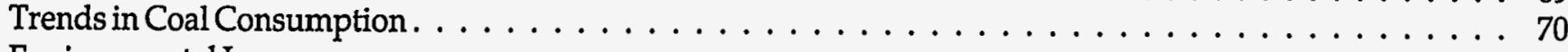

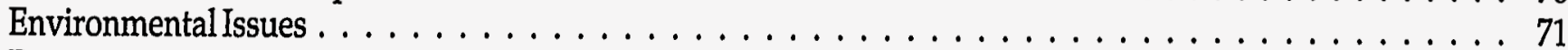

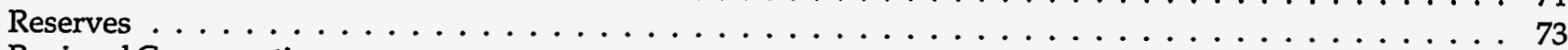

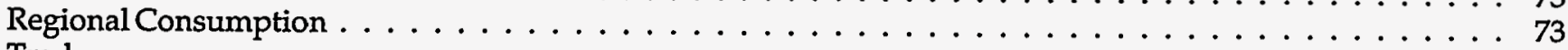

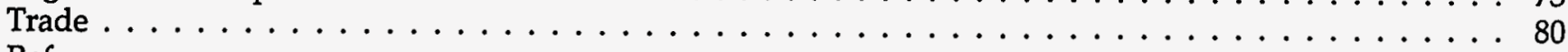

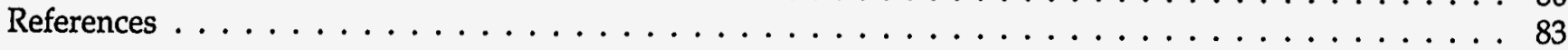

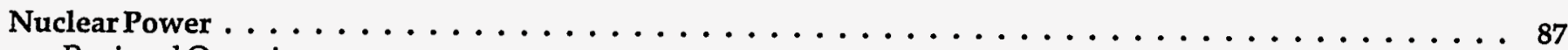

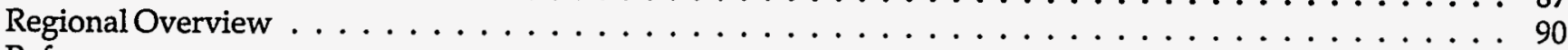

References $\ldots \ldots \ldots \ldots \ldots \ldots \ldots \ldots \ldots \ldots \ldots \ldots \ldots \ldots \ldots$

Hydroelectricity and Other Renewable Resources. . . . . . . . . . . . . . . . . . 97

Regional Activity. . . . . . . . . . . . . . . . . . . . . . . . . . . . . . . . . . . . . . . . . . . . . . .

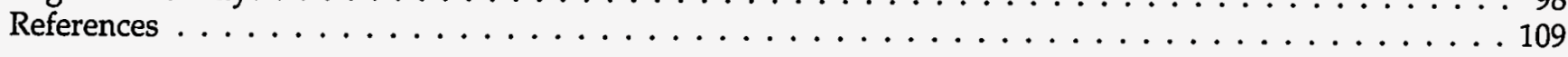

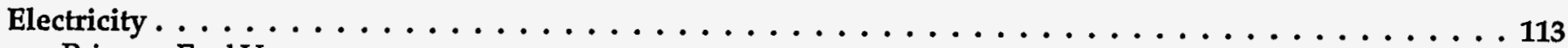

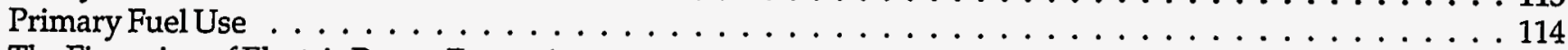

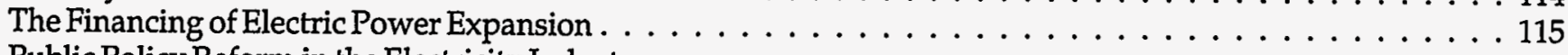

Public Policy Reform in the Electricity Industry . . . . . . . . . . . . . . . . . . . . . 115

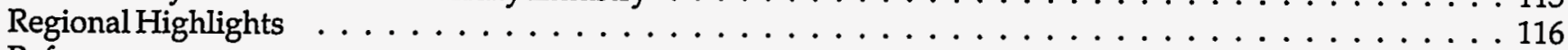

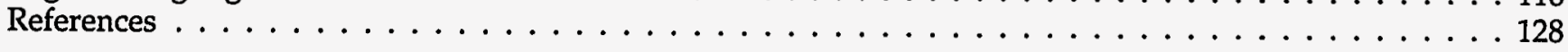




\section{Appendixes}

A. World Energy Consumption, Carbon Emissions, Oil Production, and Nuclear Power Capacity Tables . . . . 131

B. World Energy Projection System . . . . . . . . . . . . . . . . . . . . . . . . . . . . . . 189

C. A Status Report on Developing Transportation for Caspian Basin Oil and Gas Production . . . . . . . . . . . 191

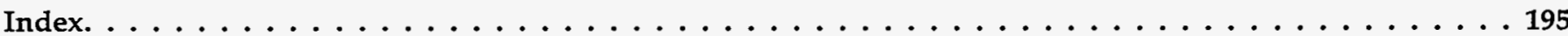

\section{Tables}

1. Energy Consumption and Carbon Emissions by Region, 1990-2020 . . . . . . . . . . . . . . . 3

2. World Energy Consumption by Energy Source, $1970-2020 \ldots \ldots \ldots \ldots \ldots$. . . . . . . . . 8

3. World Energy Consumption by Region, $1970-2020 \ldots \ldots \ldots \ldots \ldots \ldots \ldots$. . . . . . . . . . . 9

4. Energy Use and Economic Growth for Selected Developing Asian Countries, 1985-1995 _ . . . . . . . . . 9

5. Annual Growth Rates in Gross Domestic Product by Region ánd for Selected Countries, 1970-2020 . . . . . 10

6. Annual World Energy Consumption by Region in Three Economic Growth Cases, 1970-2020 . . . . . . . 13

7. Average Energy Elasticity by Region, $1970-2020 \ldots \ldots \ldots \ldots \ldots$. . . . . . . . . . . . 14

8. Carbon Emissions in the Annex ICountries, 1990 and 2010, and the Effects of Kyoto Protocol in 2010 . . . . 16

9. Comparison of Energy Consumption Growth Rates, 1993-2010, by Region . . . . . . . . . . . . . . . 21

10. Comparison of Economic Growth Rates, 1993-2010, by Region . . . . . . . . . . . . . . . . . . 22

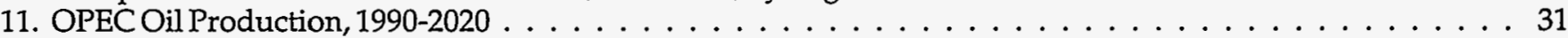

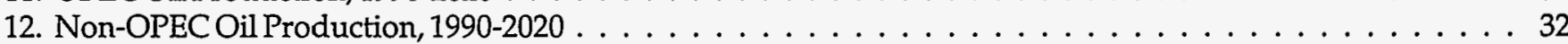

13. Worldwide Petroleum Trade in the Reference Case, 1995 and $2020 \ldots \ldots$. . . . . . . . . . . . 36

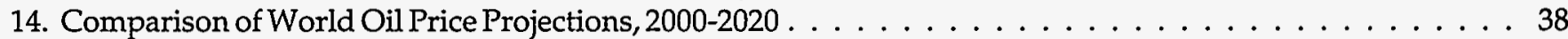

15. Comparison of World Oil Production Forecasts. . . . . . . . . . . . . . . . . . . . . . . . . . 39

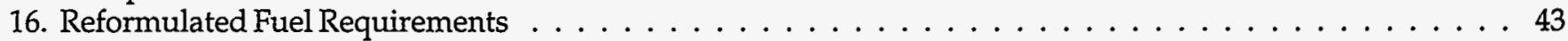

17. Selected Reformulated Gasoline Requirements by Country . . . . . . . . . . . . . . . . . . . . . 45

18. Selected Reformulated Diesel Fuel Requirements by Country . . . . . . . . . . . . . . . . . . . 46

19. World Natural Gas Reserves by Country as of January 1,1998 . . . . . . . . . . . . . . . . . . . . . 51

20. Contracts in Place for Natural Gas Sales from the United Kingdom's Interconnector to Mainland Europe . . . 55

21. World Coal Flows by Importing and Exporting Regions, Reference Case, 1996, 2010, and 2020 . . . . . . . 81

22. Historical and Projected Operable Nuclear Capacities by Region, 1995-2020 . . . . . . . . . . . . . . . . 89

23. Postponed Indonesian Geothermal Power Projects, 1997 . . . . . . . . . . . . . . . . . . . . . . . . 104

24. Brazilian Hydroelectric Tenders . . . . . . . . . . . . . . . . . . . . . . . . 108

25. World Net Electricity Consumption by Region, $1990-2020$. . . . . . . . . . . . . . . . . . . . 113

26. World Energy Consumption for Electricity Generation by Region and Fuel, 1995-2020 . . . . . . . . . . 115

27. Cumulative Projected Worldwide Electric Power Investments by Region, 1995-2010 . . . . . . . . . . . 116

A1. World Total Energy Consumption by Region, Reference Case, 1990-2020 . . . . . . . . . . . . . . . . . 133

A2. World Total Energy Consumption by Region and Fuel, Reference Case, 1990-2020 . . . . . . . . . . . . . 134

A3. World Total Oil Consumption by Region, Reference Case, $1990-2020$. . . . . . . . . . . . . . . . 136

A4. World Total Natural Gas Consumption by Region, Reference Case, 1990-2020 . . . . . . . . . . . . . . 137

A5. World Total Coal Consumption by Region, Reference Case, 1990-2020 . . . . . . . . . . . . . . . . 138

A6. World Net Nuclear Energy Consumption by Region, Reference Case, 1990-2020 . . . . . . . . . . . . . 139

A7. World Consumption of Hydroelectricity and Other Renewable Energy by Region, Reference Case,

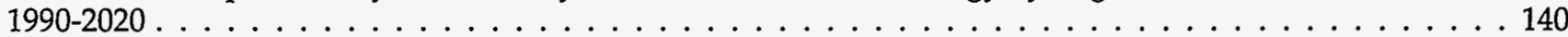

A8. World Total Net Electricity Consumption by Region, Reference Case, 1990-2020 . . . . . . . . . . . . . . 141

A9. World Total Carbon Emissions by Region, Reference Case, 1990-2020 . . . . . . . . . . . . . . . . . . 142

A10. World Carbon Emissions from Oil Use by Region, Reference Case, 1990-2020 . . . . . . . . . . . . . . . . 143

A11. World Carbon Emissions from Natural Gas Use by Region, Reference Case, 1990-2020 . . . . . . . . . . . . 144

A12. World Carbon Emissions from Coal Use by Region, Reference Case, 1990-2020 . . . . . . . . . . . . . . 145

A13. World Total Energy Consumption in Oil-Equivalent Units by Region, Reference Case, 1990-2020 . . . . . . 146

A14. World Total Energy Consumption by Region, High Economic Growth Case, 1990-2020 . . . . . . . . . . 147

A15. World Total Energy Consumption by Region and Fuel, High Economic Growth Case, 1990-2020 . . . . . . 148

A16. World Total Oil Consumption by Region, High Economic Growth Case, 1990-2020 . . . . . . . . . . . . 150

A17. World Total Natural Gas Consumption by Region, High Economic Growth Case, 1990-2020 . . . . . . . . 151

A18. World Total Coal Consumption by Region, High Economic Growth Case, 1990-2020 . . . . . . . . . 152

A19. World Net Nuclear Energy Consumption by Region, High Economic Growth Case, 1990-2020 . . . . . . . 153

A20. World Consumption of Hydroelectricity and Other Renewable Energy by Region, 


\section{Tables (Continued)}

A21. World Total Net Electricity Consumption by Region, High Economic Growth Case, 1990-2020 . . . . . . . 155

A22. World Total Carbon Emissions by Region, High Economic Growth Case, 1990-2020 . . . . . . . . . . . . 156

A23. World Carbon Emissions from Oil Use by Region, High Economic Growth Case, 1990-2020 . . . . . . . . 157

A24. World Carbon Emissions from Natural Gas Use by Region, High Economic Growth Case,

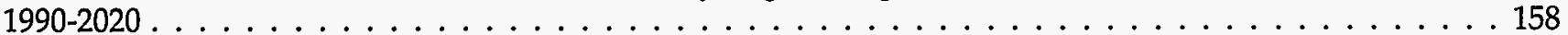

A25. World Carbon Emissions from Coal Use by Region, High Economic Growth Case, 1990-2020. . . . . . . . 159

A26. World Total Energy Consumption in Oil-Equivalent Units by Region,

High Economic Growth Case, $1990-2020$. . . . . . . . . . . . . . . . . . . . . . . . . . . 160

A27. World Total Energy Consumption by Region, Low Economic Growth Case, 1990-2020 . . . . . . . . . . . 161

A28. World Total Energy Consumption by Region and Fuel, Low Economic Growth Case, 1990-2020 . . . . . . 162

A29. World Total Oil Consumption by Region, Low Economic Growth Case, 1990-2020 . . . . . . . . . . . . . 164

A30. World Total Natural Gas Consumption by Region, Low Economic Growth Case, 1990-2020 . . . . . . . . 165

A31. World Total Coal Consumption by Region, Low Economic Growth Case, 1990-2020 . . . . . . . . . . 166

A32. World Net Nuclear Energy Consumption by Region, Low Economic Growth Case, 1990-2020 . . . . . . . 167

A33. World Consumption of Hydroelectricity and Other Renewable Energy by Region,

Low Economic Growth Case, $1990-2020$. . . . . . . . . . . . . . . . . . . . . . . . . . . 168

A34. World Total Net Electricity Consumption by Region, Low Economic Growth Case, 1990-2020 . . . . . . . 169

A35. World Total Carbon Emissions by Region, Low Economic Growth Case, 1990-2020 . . . . . . . . . . . . 170

A36. World Carbon Emissions from Oil Use by Region, Low Economic Growth Case, 1990-2020 . . . . . . . . . 171

A37. World Carbon Emissions from Natural Gas Use by Region, Low Economic Growth Case,

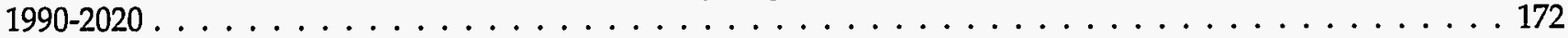

A38. World Carbon Emissions from Coal Use by Region, Low Economic Growth Case, 1990-2020 . . . . . . . . 173

A39. World Total Energy Consumption in Oil-Equivalent Units by Region,

Low Economic Growth Case, 1990-2020 . . . . . . . . . . . . . . . . . . . . . . . . . . . 174

A40. World Oil Production Capacity by Region and Country, Reference Case, 1990-2020 . . . . . . . . . . . 175

A41. World Oil Production Capacity by Region and Country, High Oil Price Case, 1990-2020 . . . . . . . . . . 176

A42. World Oil Production Capacity by Region and Country, Low Oil Price Case, 1990-2020 . . . . . . . . . . 177

A43. World Oil Production Capacity by Region and Country, High Non-OPEC Supply Case, 1990-2020 . . . . . 178

A44. World Oil Production by Region and Country, Reference Case, $1990-2020$. . . . . . . . . . . . . . . . . 179

A45. World Oil Production by Region and Country, High Oil Price Case, 1990-2020 . . . . . . . . . . . . . . . 180

A46. World Oil Production by Region and Country, Low Oil Price Case, 1990-2020 . . . . . . . . . . . . . 181

A47. World Oil Production by Region and Country, High Non-OPEC Supply Case, 1990-2020 . . . . . . . . . 182

A48. World Nuclear Generating Capacity by Region and Country, Reference Case, 1995-2020 . . . . . . . . . 183

A49. World Nuclear Generating Capacity by Region and Country, Low Nuclear Case, 1995-2020 . . . . . . . . 185

A50. World Nuclear Generating Capacity by Region and Country, High Nuclear Case, 1995-2020 . . . . . . . . 187

\section{Figures}

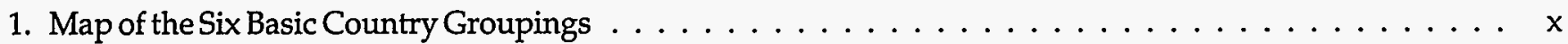

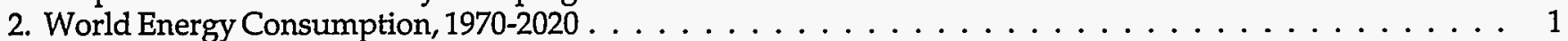

3. World Energy Consumption by Region, $1995-2020 \ldots \ldots \ldots \ldots \ldots \ldots \ldots \ldots \ldots$. . . . . . . . . . 1

4. Energy Consumption in Industrialized and Developing Regions, $1970-2020 \ldots \ldots \ldots \ldots$

5. World Energy Consumption Shares by Region, 1995-2020 . . . . . . . . . . . . . . . . . 2

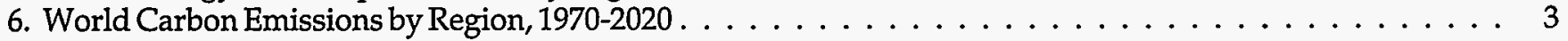

7. Comparison of 1997 and 1998 World Oil Price Projections . . . . . . . . . . . . . . . . . . . 3

8. World Energy Consumption Shares by Energy Source, $1995-2020 \ldots \ldots \ldots \ldots$. . . . . . . . . . . . . . 4

9. World Energy Consumption by Energy Source, $1970-2020 \ldots \ldots \ldots \ldots$. . . . . . . . . . . . 4

10. Net Electricity Consumption per Capita by Region, $1995-2020 \ldots \ldots \ldots \ldots \ldots \ldots$

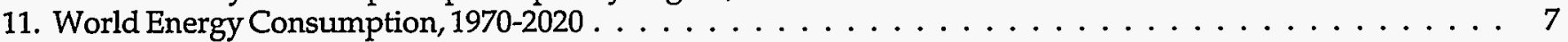

12. World Energy Consumption by Fuel Type, $1970-2020 \ldots \ldots \ldots \ldots$. . . . . . . . . . . . . . 7

13. Nonindustrialized Energy Consumption by Region, $1970-2020 \ldots \ldots \ldots \ldots$. . . . . . . . . . . . 8

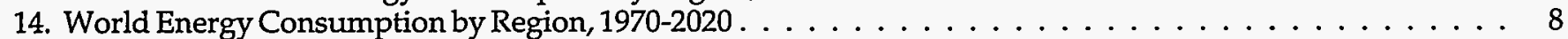

15. World Energy Consumption by Economic Growth Case, $1970-2020 \ldots \ldots \ldots \ldots \ldots$. . . . . . . 12

16. Energy, GDP, and Population Trends in Industrialized Countries, 1995-2020 . . . . . . . . . . . . 13

17. Energy, GDP, and Population Trends in Developing Countries, 1995-2020 . . . . . . . . . . . . . 14

18. World Energy Consumption per Capita by Region, $1970-2020 \ldots \ldots \ldots \ldots \ldots \ldots$

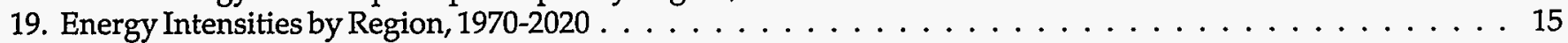




\section{Figures (Continued)}

20. World Carbon Emissions by Fuel Type, $1970-2020 \ldots \ldots \ldots \ldots \ldots \ldots \ldots \ldots$. . . . . . . . . 18

21. World Carbon Emissions by Region and Fuel Type, 1990, 2010, and $2020 \ldots \ldots$. . . . . . . . . . 18

22. World Carbon Emissions by Region, $1970-2020 \ldots \ldots \ldots \ldots \ldots \ldots$. . . . . . . . . . . . . . 19

23. Carbon Emissions per Capita by Region, 1990, 2010, and 2020 . . . . . . . . . . . . . . . . . 19

24. Carbon Emissions per Capita for Selected Regions and Countries, 1990-2020 . . . . . . . . . . . . . . 19

25. Comparison of IEO Forecasts with 1990 Energy Consumption in Market Economies . . . . . . . . . . . . 23

26. Comparison of IEO Forecasts with 1995 Energy Consumption in Market Economies . . . . . . . . . . . 23

27. Comparison of IEO Forecasts with 1995 World Energy Consumption. . . . . . . . . . . . . . . . . . . . 24

28. World Oil Prices in Three Cases, 1970-2020 . . . . . . . . . . . . . . . . . . . . . . . . . . . . 25

29. Oil Demand in Industrialized Countries, 1970, 1995, and 2020 . . . . . . . . . . . . . . . . . . 27

30. Nonindustrialized Oil Demand by Region, 1970, 1995, and 2020 . . . . . . . . . . . . . . . . . 27

31. Oil Demand for Transportation in Developing Asia, 1995-2020 . . . . . . . . . . . . . . . . . . 29

32. Vehicle Stocks in Selected Developing Asian Countries, 1975-1995 . . . . . . . . . . . . . . . . . . . . 29

33. U.S. and Total World Vehicle Fleets, $1970-1995 \ldots \ldots \ldots$. . . . . . . . . . . . . . . . . . . . . . . . 29

34. Vehicle Ownership in Selected Industrialized Countries, 1995 . . . . . . . . . . . . . . . . . . . . 30

35. Vehicle Ownership in Nonindustrialized Regions, $1995 \ldots \ldots \ldots \ldots \ldots \ldots \ldots \ldots$

36. World Oil Production in the Reference Case by Region, 1970-2020 . . . . . . . . . . . . . . . . . . . . 31

37. OPEC Oil Production in Three Oil Price Cases, 1970-2020 . . . . . . . . . . . . . . . . . . . . . . 31

38. OPEC and Non-OPEC Oil Production in Two Cases, 1990-2020 . . . . . . . . . . . . . . . . . . . . 35

39. Non-OPEC Oil Production by Region in Two Cases, $2020 \ldots \ldots \ldots \ldots$. . . . . . . . . . . . . 35

40. Imports of Persian Gulf Oil by Importing Region, 1995 and 2020 . . . . . . . . . . . . . . . . . . . . 35

41. Crude Oil Reserves in Three Undiscovered Oil Cases, 1995-2020 . . . . . . . . . . . . . . . . . . 37

42. Current Market Shares of Unleaded Gasoline by Country . . . . . . . . . . . . . . . . . . . . . . . . . 42

43. World Natural Gas Consumption in Three Cases, 1970-2020 . . . . . . . . . . . . . . . . . . . . . 49

44. Natural Gas Use for Electricity Generation and for All Other Uses, 1995-2020 . . . . . . . . . . . . . . . . 49

45. World Natural Gas Consumption by Region, 1970-2020 . . . . . . . . . . . . . . . . . . . . 50

46. World Natural Gas Reserves by Region, 1975-1998 . . . . . . . . . . . . . . . . . . . . . . . . . . 51

47. World Natural Gas Reserves by Region as of January 1,1998 . . . . . . . . . . . . . . . . . . . . . 51

48. Natural Gas Consumption in North America by Country, 1970-2020 . . . . . . . . . . . . . . . . . . 52

49. Natural Gas Consumption in Western Europe, $1970-2020 \ldots \ldots \ldots \ldots$. . . . . . . . . . . . . 53

50. Current Status of Western European Natural Gas Pipelines, 1997 . . . . . . . . . . . . . . . . . 55

51. Natural Gas Consumption in the EE/FSU Region, $1970-2020 \ldots \ldots \ldots \ldots$. . . . . . . . . . . . . 58

52. Natural Gas Consumption in Brazil and Other Central and South America, 1970-2020 . . . . . . . . . . . . 59

53. Natural Gas Consumption in the Middle East and Africa, 1970-2020 . . . . . . . . . . . . . . . 60

54. Natural Gas Consumption in Asia by Region, 1970-2020 . . . . . . . . . . . . . . . . . . . . 62

55. Coal Share of World Energy Consumption by Sector, 1995 and $2020 \ldots \ldots$. . . . . . . . . . . . 69

56. Coal Share of Regional Energy Consumption, $1970-2020 \ldots \ldots \ldots \ldots$. . . . . . . . . . . . 70

57. World Coal Consumption in Three Cases, $1970-2020 \ldots \ldots \ldots \ldots$. . . . . . . . . . . . . . 71

58. Projected Cumulative Growth in World Carbon Emissions by Region, 1990-2010 . . . . . . . . . . . . . 72

59. Coal Share of Total Carbon Emissions by Region, 1995 and $2010 \ldots \ldots \ldots \ldots \ldots \ldots$

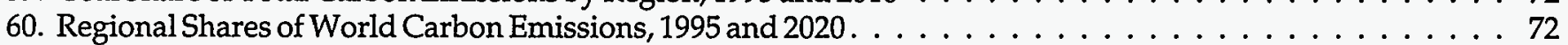

61. World Recoverable Coal Reserves . . . . . . . . . . . . . . . . . . . . . . . . . . 73

62. World Coal Consumption by Region, 1980,1995 , and $2020 \ldots \ldots \ldots \ldots$. . . . . . . . . . . . . 74

63. Production and Imports of Hard Coal by Region, 1985, 1990, and 1996 . . . . . . . . . . . . . . . . . . 80

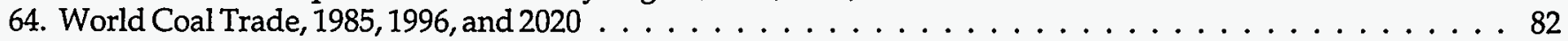

65. Nuclear Shares of National Electricity Generation, $1996 \ldots \ldots \ldots$. . . . . . . . . . . . . . . . . 87

66. World Nuclear Capacity by Region, $1970-2020 \ldots \ldots$. . . . . . . . . . . . . . . . . . . . . . 87

67. World Nuclear Capacity in Three Cases, 1970-2020 . . . . . . . . . . . . . . . . . . . . . . 88

68. World Nuclear and Total Electricity Consumption, 1995-2020 . . . . . . . . . . . . . . . . . . 88

69. World Consumption of Hydroelectricity and Other Renewable Energy in Three Cases, 1970-2020 . . . . . 97

70. Renewable Energy Share of World Energy Consumption, 1970-2020 . . . . . . . . . . . . . . . . . . . 97

71. Renewable Energy Consumption by Region, 1970,1995 , and $2020 \ldots \ldots \ldots$. . . . . . . . . . . 98

72. Renewable Energy Consumption in North America, 1975-2020 . . . . . . . . . . . . . . . . 98

73. Grid-Connected Wind Power Plants in the United States as of December 31, 1996. . . . . . . . . . . . . . . . 99

74. Renewable Energy Consumption in Western Europe, 1980-2020 . . . . . . . . . . . . . . . . . . . . . 100

75. Renewable Energy Consumption in Asia, 1970-2020 . . . . . . . . . . . . . . . . . . . 102 


\section{Figures (Continued)}

76. Energy Consumption for Electricity Generation in China, 1995 and 2020 . . . . . . . . . . . . . 117

77. Energy Consumption for Electricity Generation in India, 1995 and $2020 \ldots \ldots \ldots$

78. Energy Consumption for Electricity Generation in Central and South America, 1995 and 2020 . . . . . . . 121

79. Energy Consumption for Electricity Generation in the United States, 1995 and 2020 . . . . . . . . . . . 122

80. Energy Consumption for Electricity Generation in Mexico, 1995 and 2020 . . . . . . . . . . . . . . . 122

81. Energy Consumption for Electricity Generation in Western Europe, 1995 and 2020 . . . . . . . . . . . 124

82. U.S. Direct Investment in Overseas Utilities, 1988-1996 . . . . . . . . . . . . . . . . . . . . . . . . . . 125

83. Energy Consumption for Electricity Generation in Japan, 1995 and 2020 . . . . . . . . . . . . . . . . 125

84. Energy Consumption for Electricity Generation in Australasia, 1995 and 2020 . . . . . . . . . . . 125

85. Energy Consumption for Electricity Generation in Eastern Europe, 1995 and 2020 . . . . . . . . . . . . . 127

86. Energy Consumption for Electricity Generation in the Middle East, 1995 and 2020 . . . . . . . . . . . 127

87. Energy Consumption for Electricity Generation in Africa, 1995 and 2020 . . . . . . . . . . . . . . . 128

C1. Caspian Sea Region Oil Production and Export Potential, 1990-2020 . . . . . . . . . . . . . . . . . . . 192 


\section{Preface}

\section{The Energy Information Administration's outlook for world energy trends is presented in this report. Model projections now extending to the year 2020 are reported, and regional trends are discussed.}

The International Energy Outlook 1998 (IEO98) presents an assessment by the Energy Information Administration (EIA) of the outlook for international energy markets through 2020. The report is an extension of the EIA's Annual Energy Outlook 1998 (AEO98), which was prepared using the National Energy Modeling System (NEMS). U.S. projections appearing in IEO98 are consistent with those published in AEO98. IEO98 is provided as a statistical service to energy managers and analysts, both in government and in the private sector. The projections are used by international agencies, Federal and State governments, trade associations, and other planners and decisionmakers. They are published pursuant to the Department of Energy Organization Act of 1977 (Public Law 95-91), Section 205(c). The IEO98 projections are based on U.S. and foreign government policies in effect on October 1, 1997.

Projections in IEO98 are displayed according to six basic country groupings (Figure 1). The industrialized region includes projections for four individual countries-the United States, Canada, Mexico, and Japan-along with the subgroups Western Europe and Australasia (defined as Australia, New Zealand, and the U.S. Territories). The developing countries are represented by four separate regional subgroups: developing Asia, Africa, Middle East, and Central and South America. China and India are represented in developing Asia. New to this year's report, country-level projections are provided for Brazil-which is represented in Central and South America. Eastern Europe and the former Soviet Union (EE/FSU) are considered as a separate country grouping.

The report begins with a review of world trends in energy demand. The historical time frame starts with data from 1970 and extends to 1996, providing readers with a 26-year historical view of energy demand. For the first time, IEO98 projections are extended to 2020, so that the forecasts cover a 24-year period.

High economic growth and low economic growth cases, based on different rates of growth in regional gross domestic product (GDP), are used to depict a set of alternative growth paths for the energy forecast. The projections and the uncertainty associated with making international energy projections in general are discussed in the first chapter of the report. The status of environmental issues, including global carbon emissions, is reviewed. Comparisons of the IEO98 projections with other available international energy forecasts are also included in the first chapter, along with a review of the performance of EIA's international energy projections from previous editions of the IEO.

The next part of the report is organized by energy source. Regional consumption projections for oil, natural gas, coal, nuclear power, and renewable energy (hydroelectricity, geothermal, wind, solar, and other renewables) are presented in five fuel chapters, with a review of the current status of each fuel on a worldwide basis. This IEO98 includes expanded coverage of the transportation sector. A discussion of energy use in the transportation sector-where EIA expects robust growth over the next 25 years-has been added to the chapter on world oil markets. The last chapter of the report contains a discussion of energy use for electricity production.

Summary tables of the IEO98 projections for world energy consumption, carbon emissions, oil production, and nuclear power generating capacity are provided in Appendix A. The reference case projections for total foreign energy consumption and for natural gas, coal, and renewable energy were prepared using EIA's World Energy Projection System (WEPS) model, as were projections of carbon emissions, net electricity consumption, and energy use for electricity generation. Reference case projections of foreign oil production and consumption were prepared using the International Energy Module of the National Energy Modeling System (NEMS). The NEMS Coal Export Submodule (CES) was used to derive flows in international coal trade. Nuclear consumption projections were derived from the International Nuclear Model, PC Version (PCINM). Alternatively, nuclear capacity projections were developed by two methods: the nuclear reference case and low growth case projections were based on analysts' knowledge of the nuclear programs in different countries; the high growth case was generated by the World Integrated Nuclear Evaluation System (WINES), a demand-driven model. 
Figure 1. Map of the Six Basic Country Groupings

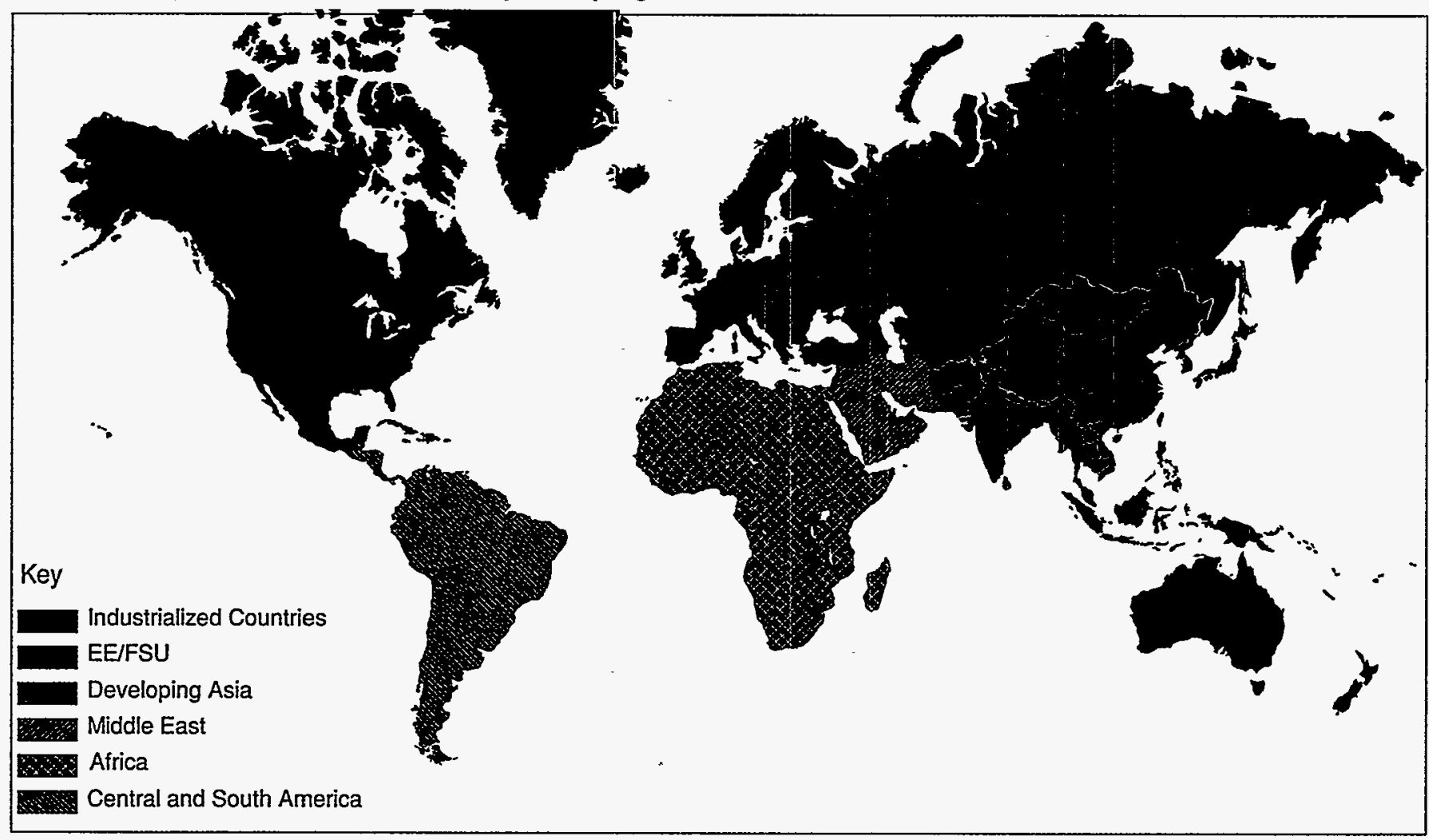

Source: Energy Information Administration, Office of Integrated Analysis and Forecasting.

The six basic country groupings used in this report (Figure 1) are defined as follows:

- Industrialized Countries (the industrialized countries contain 18 percent of the 1997 world population): Australia, Austria, Belgium, Canada, Denmark, Finland, France, Germany, Greece, Iceland, Ireland, Italy, Japan, Luxembourg, Mexico, the Netherlands, New Zealand, Norway, Portugal, Spain, Sweden, Switzerland, Turkey, the United Kingdom, and the United States. The industrialized countries actually represent all the countries that are members of the Organization for Economic Cooperation and Development (OECD), with the exceptions of the most recent additions-the Czech Republic, Hungary, Poland, and South Korea.

- Eastern Europe and the former Soviet Union (EE/FSU) (7 percent of the 1997 world population):

- Eastern Europe: Albania, Bosnia and Herzegovina, Bulgaria, Croatia, Czech Republic, Hungary, Macedonia, Poland, Romania, Serbia and Montenegro, Slovakia, and Slovenia.

- Former Soviet Union (FSU): The Baltic States of Estonia, Latvia, and Lithuania, as well as Armenia, Azerbaijan, Belarus, Georgia, Kazakhstan,
Kyrgyzstan, Moldova, Russia, Tajikistan, Turkmenistan, Ukraine, and Uzbekistan.

- Developing Asia (54 percent of the 1997 world population): Afghanistan, Bangladesh, Bhutan, Brunei, Cambodia (Kampuchea), China, Fiji, French Polynesia, Hong Kong, India, Indonesia, Kiribatia, Laos, Malaysia, Macau, Maldives, Mongolia, Myanmar (Burma), Nauru, Nepal, New Caledonia, Niue, North Korea, Pakistan, Papua New Guinea, Philippines, Samoa, Singapore, Solomon Islands, South Korea, Sri Lanka, Taiwan, Thailand, Tonga, Vanuatu, and Vietnam.

- Middle East (2 percent of the 1997 world population): Bahrain, Cyprus, Iran, Iraq, Israel, Jordan, Kuwait, Lebanon, Oman, Qatar, Saudi Arabia, Syria, the United Arab Emirates, and Yemen.

- Africa (12 percent of the 1997 world population): Algeria, Angola, Benin, Botswana, Burkina Faso, Burundi, Cameroon, Cape Verde, Central African Republic, Chad, Comoros, Congo (Brazzaville), Congo (Kinshasa), Djibouti, Egypt, Equatorial Guinea, Eritrea, Ethiopia, Gabon, Gambia, Ghana, Guinea, Guinea-Bissau, Ivory Coast, Kenya, Lesotho, Liberia, Libya, Madagascar, Malawi, Mali, Mauritania, Mauritius, Morocco, Mozambique, Namibia, Niger, Nigeria, Reunion, 
Rwanda, Sao Tome and Principe, Senegal, Seychelles, Sierra Leone, Somalia, South Africa, St. Helena, Sudan, Swaziland, Tanzania, Togo, Tunisia, Uganda, Western Sahara, Zambia, and Zimbabwe.

- Central and South America (6 percent of the 1997 world population): Antarctica, Antigua and Barbuda, Argentina, Aruba, Bahama Islands, Barbados, Belize, Bolivia, Brazil, British Virgin Islands, Cayman Islands, Chile, Colombia, Costa Rica, Cuba, Dominica, Dominican Republic, Ecuador, El Salvador, Falkland Islands, French Guiana, Grenada, Guadeloupe, Guatemala, Guyana, Haiti, Honduras, Jamaica, Martinique, Montserrat, Netherlands Antilles, Nicaragua, Panama Republic, Paraguay, Peru, St. Kitts-Nevis, St. Lucia, St. Vincent/Grenadines, Suriname, Trinidad and Tobago, Uruguay, and Venezuela.

In addition, the following commonly used country groupings are referenced in this report:

- G-7 Countries: United States, Japan, Canada, United Kingdom, France, Germany, and Italy.

- Organization of Petroleum Exporting Countries (OPEC): Algeria, Gabon, Indonesia, Iran, Iraq, Kuwait, Libya, Nigeria, Qatar, Saudi Arabia, the United Arab Emirates, and Venezuela.
- Pacific Rim Developing Countries: Hong Kong, Indonesia, Malaysia, Philippines, Singapore, South Korea, Taiwan, and Thailand.

- Persian Gulf: Bahrain, Iran, Iraq, Kuwait, Qatar, Saudi Arabia, and the United Arab Emirates.

- Organization for Economic Cooperation and Development (OECD): Australia, Austria, Belgium, Canada, Czech Republic, Denmark, Finland, France, Germany, Greece, Hungary, Iceland, Ireland, Italy, Japan, Luxembourg, Mexico, the Netherlands, New Zealand, Norway, Poland, Portugal, South Korea, Spain, Sweden, Switzerland, Turkey, the United Kingdom, and the United States.

- Annex I Countries (countries participating in the Kyoto Protocol on Greenhouse Gas Emissions): Australia, Austria, Belarus, Belgium, Bulgaria, Canada, Croatia, Czech Republic, Denmark, European Economic Commission, Estonia, Finland, France, Germany, Greece, Hungary, Iceland, Ireland, Italy, Japan, Latvia, Lithuania, Luxembourg, the Netherlands, New Zealand, Norway, Poland, Portugal, Romania, Russia, Slovakia, Slovenia, Spain, Sweden, Switzerland, Turkey, ${ }^{1}$ the Ukraine, the United Kingdom, and the United States.

The projections in IEO98 are not statements of what will happen, but what might happen given the specific assumptions and methodologies used. These projections provide an objective, policy-neutral reference case that can be used to analyze international energy markets. As a policy-neutral data and analysis organization, EIA does not propose, advocate, or speculate on future legislative and regulatory changes. The projections are based on current U.S. and foreign government policies. Assuming current policies, even knowing that changes will occur, will naturally result in projections that differ from the final data.

Models are abstractions of energy production and consumption activities, regulatory activities, and producer and consumer behavior. The forecasts are highly dependent on the data, analytical methodologies, model structures, and specific assumptions used in their development. Trends depicted in the analysis are indicative of tendencies in the real world rather than representations of specific real-world outcomes. Even where trends are stable and well understood, the projections are subject to uncertainty. Many events that shape energy markets are random and cannot be anticipated, and assumptions concerning future technology characteristics, demographics, and resource availability cannot be known with any degree of certainty.

${ }^{1}$ Although Turkey is an Annex I country, it did not commit to a quantified reduction in greenhouse gas emissions under the Kyoto Protocol 


\section{Highlights}

\section{Growth in energy use is projected worldwide through 2020. The demand for electricity in homes, business, and industry is growing in all regions, as is the demand for petroleum-powered personal transportation.}

The International Energy Outlook 1998 (IEO98) reference case forecast indicates that by 2020 , the world will consume three times the energy it consumed 28 years ago in 1970 (Figure 2). Much of the projected growth in energy consumption is attributed to expectations of rapid increases in energy use in the developing world-especially in Asia. Although the economic downturn in Asia that began in mid-1997 and continues into 1998 has lowered expectations for near-term growth in the region, the forecast still suggests that almost half the world's projected increase in energy consumption will be in developing Asia (Figure 3). Strong long-term economic growth in the Asia Pacific is expected to result in improved standards of living which, in turn, will mean increased use of energy for a variety of residential and commercial purposes and for personal transportation. By 2020, the projected energy consumption in developing Asia (including China and India, but excluding Japan, Australia, and New Zealand) surpasses that of all North America by more than 50 quadrillion Btu (36 percent).

Total world energy consumption in the IEO98 reference case is projected to reach 639 quadrillion Btu in 2020, an

Figure 2. World Energy Consumption, 1970-2020

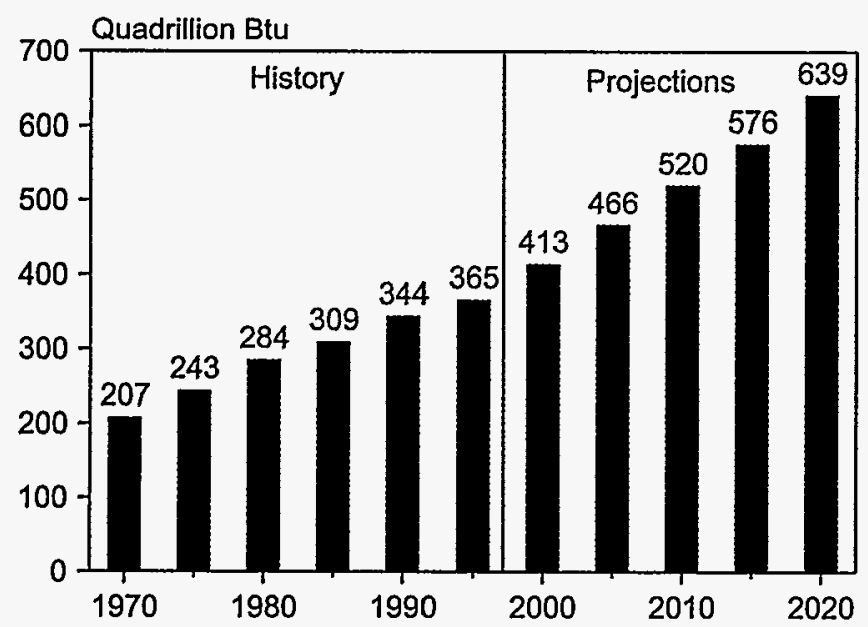

Sources: History: Energy Information Administration (EIA), Office of Energy Markets and End Use, International Statistics Database and International Energy Annual 1996, DOE/EIA0219(96) (Washington, DC, February 1998). Projections: EIA, World Energy Projection System (1998). increase of almost 274 quadrillion Btu ( 75 percent) over 1995 levels (Figure 2). The developing world will account for 174 quadrillion Btu (64 percent) of the world's increment in energy use. In 1995, energy consumption in the industrialized countries exceeded that in the developing countries by 86 quadrillion Btu (76 percent), but by 2020 the developing countries surpass the industrialized countries by 16 quadrillion Btu ( 6 percent) (Figure 4). Developing Asia accounted for only 20 percent of the world's energy use in 1995, but its share grows to over 30 percent by 2020 in the IEO98 reference case (Figure 5), with an increment of 128 quadrillion Btu (178 percent) projected for the countries of that region over the forecast.

Two developments in 1997 may substantially impact future energy demand levels: the deep economic recession in Southeast Asia and the potential consequences of the Kyoto Climate Change Protocol. The Asian economic downturn has resulted in some short-term reductions in expectations for the energy use there. No adjustments were made to the projections to account for the effects of the Kyoto Protocol, however, because the IEO98 forecast is based on current laws and regulations.

Figure 3. World Energy Consumption by Region, 1995-2020

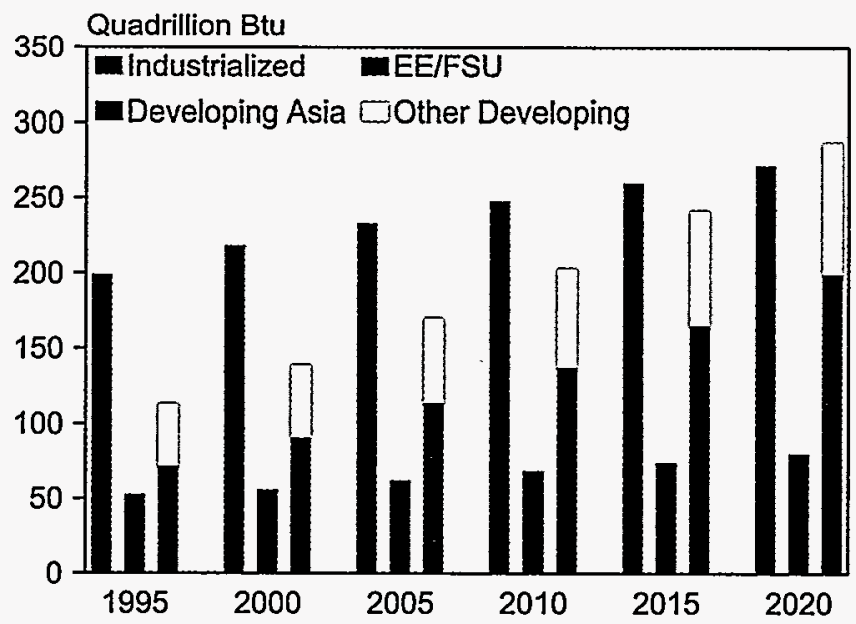

Sources: 1995: Energy Information Administration (EIA), Office of Energy Markets and End Use, International Energy Annual 1996, DOE/EIA-0219(96) (Washington, DC, February 1998). Projections: EIA, World Energy Projection System (1998). 
Figure 4. Energy Consumption in Industrialized and Developing Regions, 1970-2020

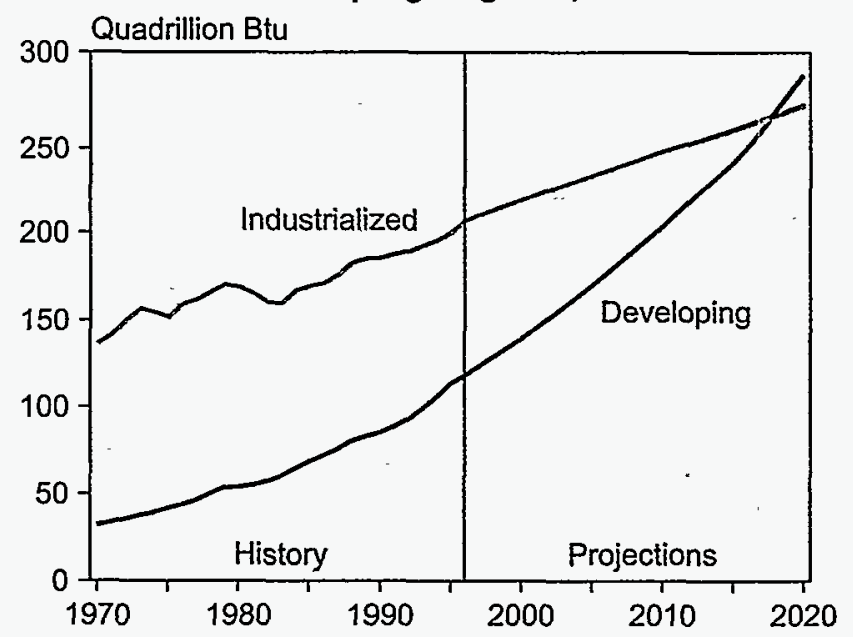

Sources: History: Energy Information Administration (EIA), Office of Energy Markets and End Use, International Statistics Database and International Energy Annual 1996, DOE/EIA0219(96) (Washington, DC, February 1998). Projections: EIA, World Energy Projection System (1998).

None of the participating counties had ratified the treaty at the time this report was prepared for publication.

The Kyoto Protocol could profoundly affect energy growth in the industrialized countries. For the emissions targets specified by the Protocol to be achieved by industrialized countries solely through reduction of fossil fuel use, projected energy demand in 2020 would have to be scaled back by 40 to 60 quadrillion Btu-equivalent to between 20 and 30 million barrels of oil per day. The expectation is that, with fuel-switching opportunities, emissions trading, and other offsets allowed under the Protocol, such as reforestation, a more modest reduction in fossil fuel use will be needed.

The economic crisis in Southeast Asia may put some of the projected increase in energy use for developing Asia at risk. The countries most harmed by Asia's currency and debt crisis include South Korea, Indonesia, Thailand, and Malaysia, which currently account for just under 20 percent of the energy use in developing Asia. The recession has already caused delays of many energy projects in those countries, and a quick economic recovery will be needed to support their completion.

If world energy consumption reaches the levels projected in the IEO98 reference case, annual carbon emissions will increase by 4.6 billion metric tons between 1995 and 2020 (Table 1). According to this projection, world carbon emissions would exceed 1990 levels by 81 percent at the end of the forecast period. By 2010, emissions in the developing world are projected to be nearly equal to those of the industrialized nations (Figure 6). Between 1990 and 2010, 78 percent of the world's increment in carbon emissions is attributed to the developing
Figure 5. World Energy Consumption Shares by Region, 1995-2020

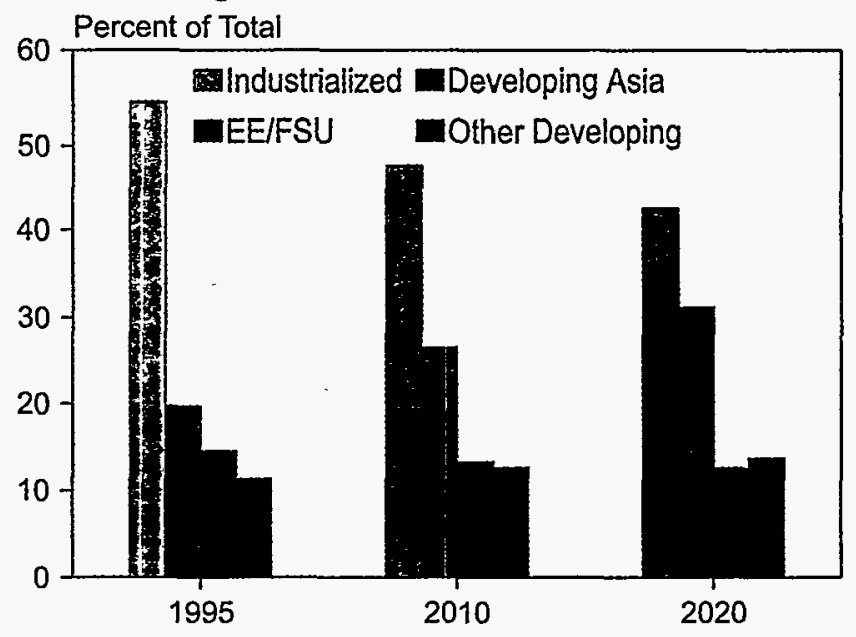

Sources: 1995: Energy Information Administration (EIA), Office of Energy Markets and End Use, International Energy Annual 1996, DOE/EIA-0219(96) (Washington, DC, February 1998). Projections: EIA, World Energy Projection System (1998).

countries. If the Annex I countries that are parties to theKyoto Protocol were able to achieve the proposed target reductions, the forecast for their emissions would be altered; but emissions levels worldwide would continue to increase. Should the Annex I countries meet their targets exactly, their projected level of emissions could be reduced by as much as 700 million metric tons. Many issues remain to be resolved, however, with regard to credits for controlling greenhouse gases other than carbon dioxide, sequestering carbon through forestry and other activities, and trading emissions rights with countries whose emissions are below the caps set by the Kyoto agreement and related protocols.

The long-term projections for world oil prices in the IEO98 reference case remain virtually unchanged from those in last year's report (Figure 7). The long-term trend in this year's forecast shows oil prices rising slowly in real terms, reaching about $\$ 22.00$ (constant 1996 U.S. dollars) per barrel in 2020 from the current price of $\$ 17.00$. The year-end 1996 price was $\$ 24.00$ a barrel. General perceptions are that near-term price risks are more heavily weighted on the downside, rather than the upside; many analysts have lowered their near-term projections by $\$ 1.00$ or more per barrel over at least the next year, a sharp reversal of the views held in early 1997. In the next year or so, prices are expected to recover from present levels as the demand for oil begins to grow more rapidly, especially in developing regions.

Over the longer term, oil prices are expected to remain relatively low throughout the projection period. The recent expansion of non-OPEC oil production is expected to continue in the short term, given that technological 
Table 1. Energy Consumption and Carbon Emissions by Region, 1990-2020

\begin{tabular}{|c|c|c|c|c|c|c|c|c|}
\hline \multirow[b]{2}{*}{ Region } & \multicolumn{4}{|c|}{ Energy Consumption (Quadrillion Btu) } & \multicolumn{4}{|c|}{ Carbon Emissions (Million Metric Tons) } \\
\hline & 1990 & 1995 & 2010 & 2020 & 1990 & 1995 & 2010 & 2020 \\
\hline \multicolumn{9}{|l|}{ Annex I Countries } \\
\hline Industrialized $^{\mathrm{a}} \ldots$ & 179.8 & 193.7 & 238.7 & 260.5 & 2,807 & 2,851 & 3,535 & 3,907 \\
\hline $\mathrm{EE} / \mathrm{FSU} \mathrm{b}^{\mathrm{b}} \ldots$ & 73.6 & 53.2 & 69.0 & 80.4 & 1,290 & 866 & 1,072 & 1,223 \\
\hline Total . . & 253.4 & 246.8 & 307.6 & 340.9 & 4,097 & 3,717 & 4,607 & 5,130 \\
\hline \multicolumn{9}{|l|}{ Non-Annex I Countries } \\
\hline Asia . . . . . . . . & 51.4 & 71.8 & 137.4 & 199.4 & 1,065 & 1,427 & 2,603 & 3,835 \\
\hline Other. . . . . . . & 39.0 & 46.9 & 74.7 & 99.1 & 624 & 692 & 1,120 & 1,482 \\
\hline Total $\ldots \ldots \ldots$ & 90.4 & 118.7 & 212.0 & 298.5 & 1,689 & 2,121 & 3,723 & 5,317 \\
\hline Total World. & 343.8 & 365.6 & 519.6 & 639.4 & 5,786 & 5,841 & 8,330 & 10,447 \\
\hline
\end{tabular}

${ }^{a}$ Excludes Mexico. Mexico is included in Non-Annex I Other.

${ }^{b}$ IEO98 does not project separately for countries in the EE/FSU. However, emissions from Annex I countries in the EE/FSU region currently account for 87 percent of total regional emissions. Hence, this number is slightly overstated.

Sources: History: Energy Information Administration (EIA), International Energy Annual 1996, DOE/EIA-0219(96) (Washington, DC, February 1998). Projections: EIA, World Energy Projection System (1998).

Figure 6. World Carbon Emissions by Region, 1970-2020

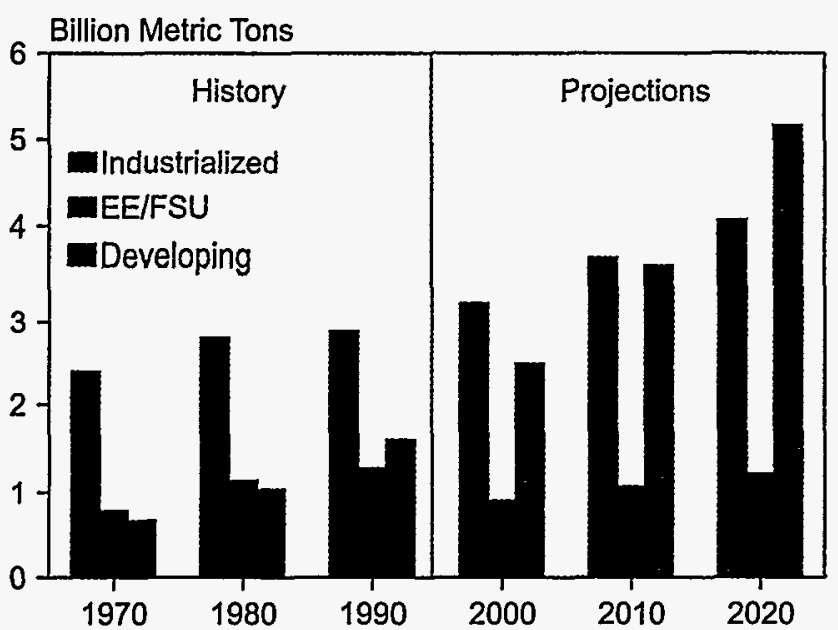

Sources: History: Energy Information Administration (EIA), Office of Energy Markets and End Use, International Statistics Database and International Energy Annual 1996, DOE/EIA0219(96) (Washington, DC, February 1998). Projections: EIA, World Energy Projection System (1998).

improvements have expanded non-OPEC production possibilities. Nevertheless, OPEC producers are projected to gain share in the world oil production market, providing about 52 percent of the world's oil supply in 2020, compared with 39 percent in 1996.

There is now agreement among many analysts that resources are not a key constraint in satisfying substantial increases in oil demand through 2020. Rather more important to the development of oil markets are political, economic, and environmental circumstances. Uncertainties with regard to the final settlement of sanctions in
Figure 7. Comparison of 1997 and 1998 World Oil Price Projections

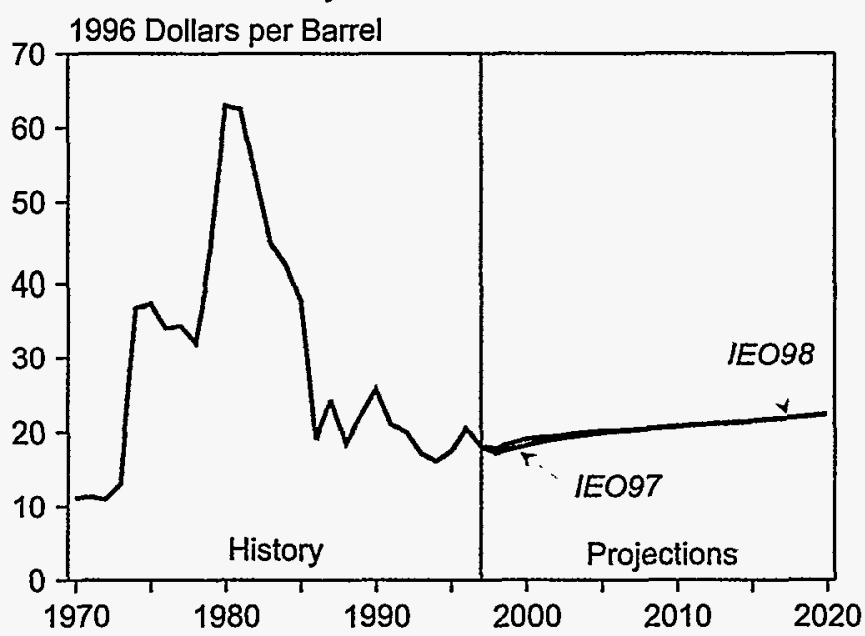

Sources: History: Energy Information Administration (EIA), Office of Energy Markets and End Use, International Statistics Database and International Energy Annual 1996, DOE/EIA0219(96) (Washington, DC, February 1998). Projections: EIA, World Energy Projection System (1998).

Iraq and the development of suitable transportation infrastructure for the marketing of oil from the Caspian region are two obvious examples; the future behavior of OPEC is another. OPEC recently increased its output quota by 10 percent, from 25 million barrels per day to 27.5 million barrels per day. While some argue that the adjustment-led by Saudi Arabia-signals a determination by the Saudis to improve their share of the world oil production market, others suggest that it merely reflects an effort by OPEC to develop a path for future production levels that will accommodate the continued expansion of world oil markets. 
Two current developments are likely to contribute to a situation of excess supply in world oil markets in the short term. On the demand side, the onset of the Asian recession portends a slowing of oil demand growth in a region that currently accounts for one-fourth of the world's oil consumption. On the supply side, the Iraqi crisis-if settled peacefully-could lead to an acceleration of oil exports even as oil prices decline. That is, since allowable Iraqi exports are defined in dollars, as the oil price declines, more oil supplies can enter the market. Increases in the dollar allowance for export earnings also raise the prospect of oversupply.

Large increases in oil consumption are expected in the IEO98 reference case. Between 1995 and 2020, oil demand grows at an average rate of 2 percent annually, resulting in an increment of more than 45 million barrels per day. Even given this growth in demand, oil's share of total energy use declines over the projection period, falling from 39 percent in 1995 to 37 percent in 2020, as natural gas becomes an increasingly powerful competitor to oil in all end uses except transportation (Figure 8). In the industrialized countries, oil use grows by 1.1 percent per year-mainly in the transportation sector, where it has limited competition. Oil use in the developing countries is projected to grow by 3.5 percent annually, increasing in all end-use sectors. Higher standards of living are expected to encourage increased demand for personal transportation and larger and better equipped homes in the world's developing countries, many of which do not have natural gas distribution infrastructures that would allow competition with oil.

\section{Figure 8. World Energy Consumption Shares by Energy Source, 1995-2020}

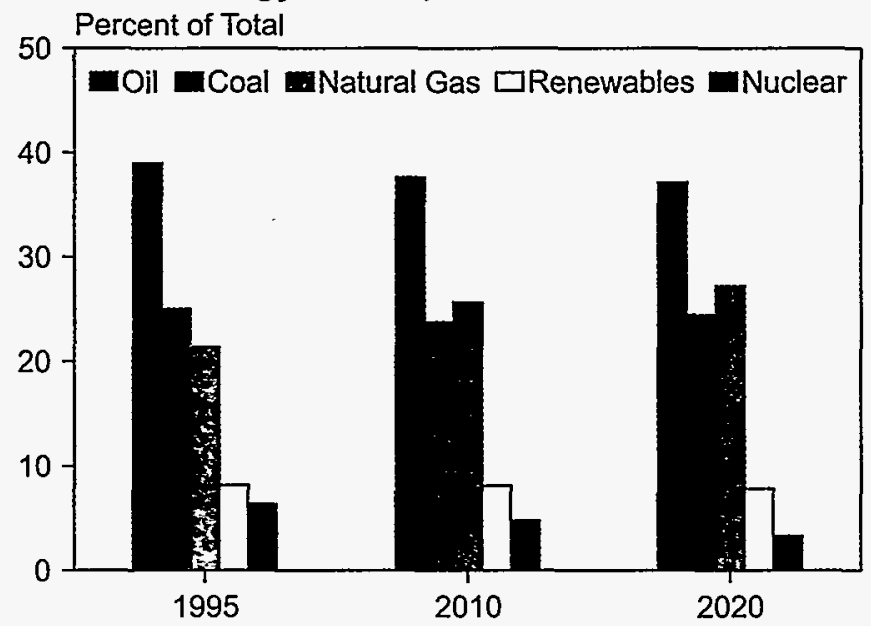

Sources: 1995: Energy Information Administration (EIA), Office of Energy Markets and End Use, International Energy Annual 1996, DOE/EIA-0219(96) (Washington, DC, February 1998). Projections: EIA, World Energy Projection System (1998).
Natural gas demand more than doubles over the projection period, reaching 172 trillion cubic feet in 2020. Worldwide, gas use grows faster than any other primary energy source, 3.2 percent per year compared to about 2 percent for oil and coal. On a Btu basis, worldwide gas consumption surpasses coal consumption by 2005 in the reference case. By 2020, natural gas demand is 11 percent higher than coal demand (Figure 9). Much of the increment in gas usage will fuel electricity generation, particularly in the industrialized countries, where natural gas can replace the other, relatively more carbon-intense fossil fuels.

Gas demand is expected to grow most quickly in the world's developing countries. In developing Asia, natural gas consumption grows by 7 percent annually even given the region's recent economic turmoil. Central and South America also are expected to experience fastpaced growth in gas demand, by 7 percent annually between 1995 and 2020. In Brazil alone, gas use increases by 14 percent per year in the reference case. There is robust activity in the region to develop the infrastructure needed to deliver natural gas to industrial consumers and electric power generators. Construction on several major pipelines began in 1997, including work on the $\$ 2$ billion Bolivia-Brazil pipeline.

Coal's role in energy use worldwide has shifted substantially over the decades, from a fuel used extensively in all sectors of the economy to one that is now used primarily for electricity generation and in a few key industrial sectors, such as steel, cement, and chemicals.

Figure 9. World Energy Consumption by Energy Source, 1970-2020

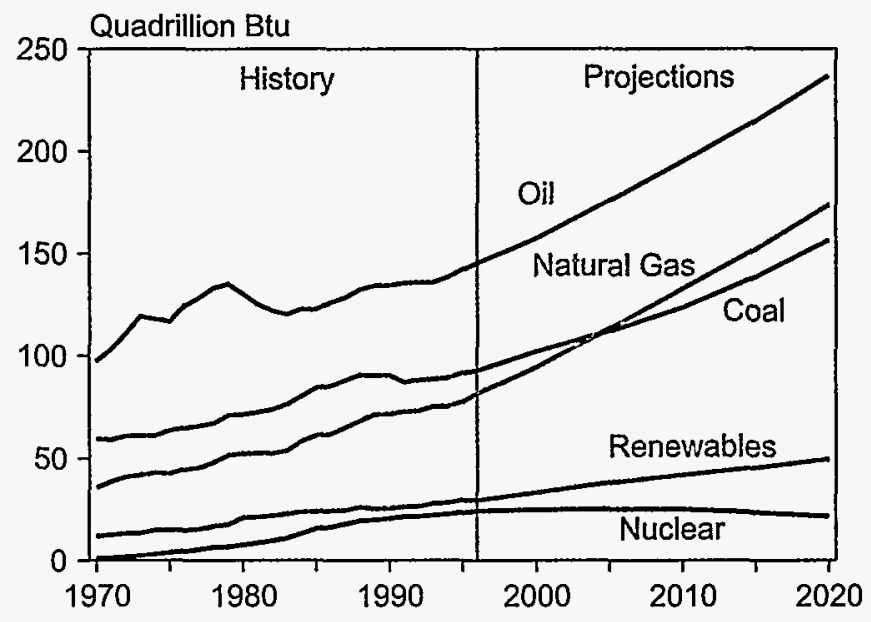

Sources: History: Energy Information Administration (EIA), Office of Energy Markets and End Use, International Statistics Database and International Energy Annual 1996, DOE/ElA0219(96) (Washington, DC, February 1998). Projections: EIA, World Energy Projection System (1998). 
Coal consumption is expected to increase by about 3.5 billion short tons over the next 25 years (an increase of about 69 percent).

The coal share of total energy consumption decreases only slightly, from 25 percent in 1995 to 24 percent in 2020, mostly because of large increases projected in developing Asia. Coal use is expected to decline in Eastern Europe and the former Soviet Union (EE/FSU) and grow slowly in the industrialized world. The relatively stable outlook portrayed for coal in the IEO98 forecast could change substantially as a result of the reductions in carbon emissions targeted in the Kyoto Protocol. If the proposed reductions occur, the coal industry could face a rapidly declining market for its product in the years ahead.

Worldwide nuclear capacity is projected to increase from 351 gigawatts in 1995 to 356 gigawatts in 2005, before declining to 304 gigawatts in 2020. Aggressive plans to expand nuclear capacity, mainly in the Far East, drive the near-term increase; but retirements of existing units-particularly in the United States, where replacement by new nuclear units is not expected-outweigh the expected development in Asia.

Nuclear power provided 17 percent of total electricity generation in 1996. In nine countries it provided more than 40 percent of electricity generation. Nevertheless, market competition from natural gas, public concern about the safety of nuclear reactor operations, and problems associated with the disposal of nuclear waste are constraining the expansion of nuclear power programs in many nations. The widespread trend toward privatization and deregulation of the electric utility sector has also undermined the viability of the nuclear option, because of the high costs associated with building and operating nuclear power plants. It is possible, however, that ratification of the Kyoto Protocol could change the outlook for nuclear power. Industrialized countries could conceivably extend the lives of their nuclear plants in efforts to constrain greenhouse gas emissions.

Low fossil fuel prices are expected to continue to hamper the development of renewable energy sources. Again, however, the impact of the Kyoto Protocol on renewables initiatives is not yet known, and many of the industrialized Annex I countries may turn to renewables to help meet their carbon emissions reduction targets. Although the IEO98 projections do not address the potential of hydroelectricity and other renewable energy sources under the terms of the Protocol, consumption of renewables in the reference case is projected to grow by 67 percent, to about 50 quadrillion Btu in 2020. While renewable energy sources are not expected to gain market share, they are projected to retain an 8-percent share of world energy use in 2020. Large-scale hydroelectric projects in developing Asia, such as China's 18.2gigawatt Three Gorges Dam project scheduled for completion in 2009, support expectations that the use of renewables for electricity generation will more than double in that region over the next 25 years.

Net electricity consumption exceeds 23 trillion kilowatthours in the IEO98 reference case in 2020, a 97-percent increase from the 1995 level of 12 trillion kilowatthours. Growth in electricity demand in developing countries is projected to more than triple between 1995 and 2020, and even though growth is expected to be slower in the industrialized countries, per capita consumption is expected to rise as new uses for electricity proliferate among residential, commercial, and industrial consumers (Figure 10). Per capita electricity consumption in the industrialized countries grows from 7.2 thousand kilowatthours per person in 1995 to 10.3 thousand kilowatthours per person in 2020, a 42-percent increase. The greatest gains are expected in developing Asia and in Central and South America, where rising standards of living are leading to greater electrification and intensive use of modern appliances, space heating, air conditioning, and lighting.

\section{Figure 10. Net Electricity Consumption per Capita by Region, 1995-2020}

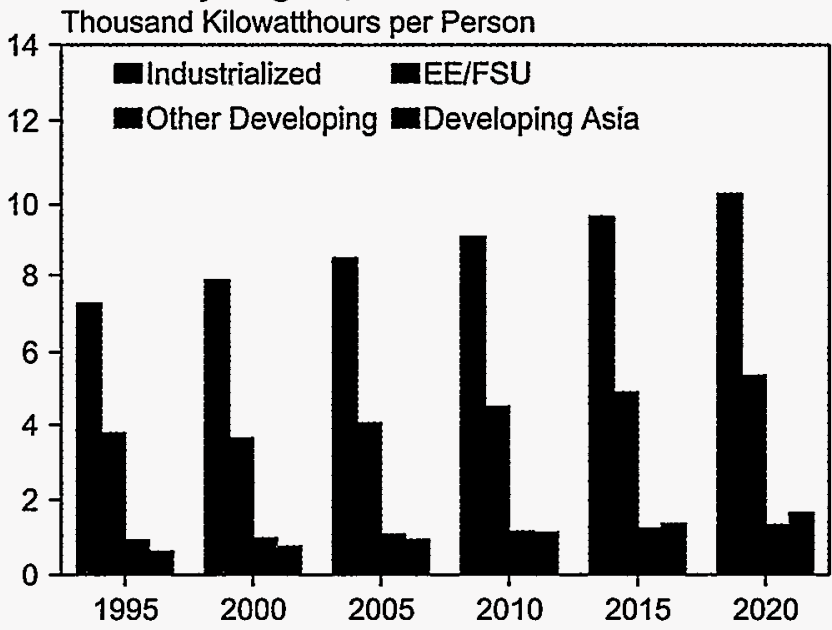

Sources: 1995: Energy Information Administration (EIA), Office of Energy Markets and End Use, International Energy Annual 1996, DOE/EIA-0219(96) (Washington, DC, February 1998). Projections: EIA, World Energy Projection System (1998). 


\title{
World Energy Consumption
}

\author{
IEO98 projects that total annual world energy consumption could be 75 percent higher \\ in 2020 than it was in 1995. Demand for all sources of energy except \\ nuclear power is expected to grow over the projection period.
}

By 2020 the world is projected to consume three times the amount of energy it used 25 years ago (Figure 11). Despite the recent economic crisis in Southeast Asia, which may reduce expected growth of energy consumption in the short term, EIA believes that almost half of the world's projected energy increment will occur in developing Asia. Indeed, the IEO98 reference case projections for Asia adopt the widely held expectation that the recession in that part of the world will not be protracted, and that by 2000 there will be a return to the strong economic growth-and, as a result, strong growth in energy demand-that was expected before the crisis emerged. By 2010, energy use in developing Asia (including China and India, but excluding Japan, Australia, and New Zealand) is projected to surpass consumption in all of North America; and by 2020 it is expected to exceed North American consumption by more than 50 quadrillion British thermal units (Btu) (36 percent).

Figure 11. World Energy Consumption, 1970-2020

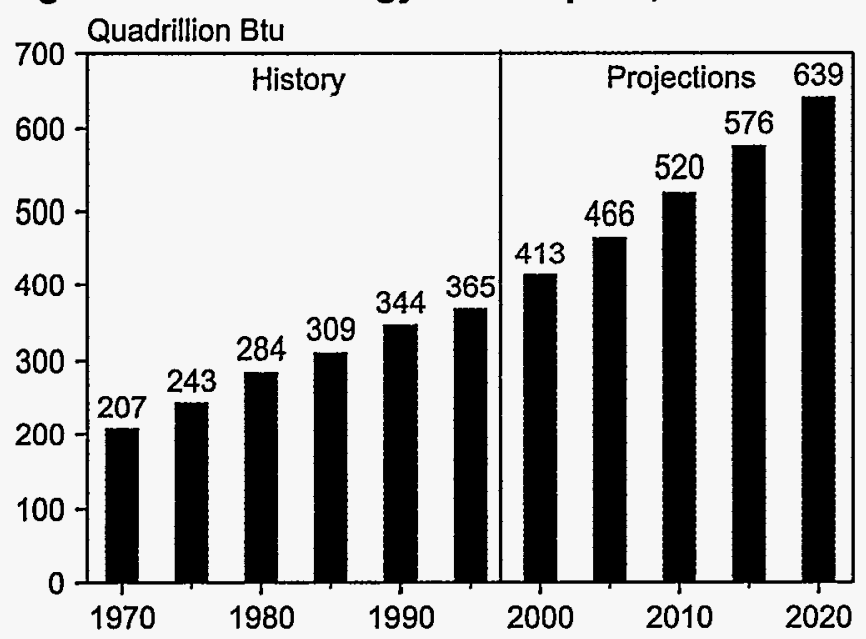

Sources: History: Energy Information Administration (EIA), Office of Energy Markets and End Use, International Statistics Database and International Energy Annual 1996, DOE/EIA0219(96) (Washington, DC, February 1998). Projections: EIA, World Energy Projection System (1998).

IEO98 projects that total world energy consumption will reach 639 quadrillion Btu, growing by 2.3 percent annually between 1995 and 2020, as much as it had in the previous 25-year period (Table 2). All sources of energy except nuclear are expected to grow over the projection period (Figure 12). Renewables are not expected to grow as quickly in the forecast period as they have in the past 25 years. By 2020, the total increment in world energy consumption from its 1995 level is projected to be about 274 quadrillion Btu, representing a 75-percent increase in total energy consumption from 1995 to 2020.

Figure 12. World Energy Consumption by Fuel Type, 1970-2020

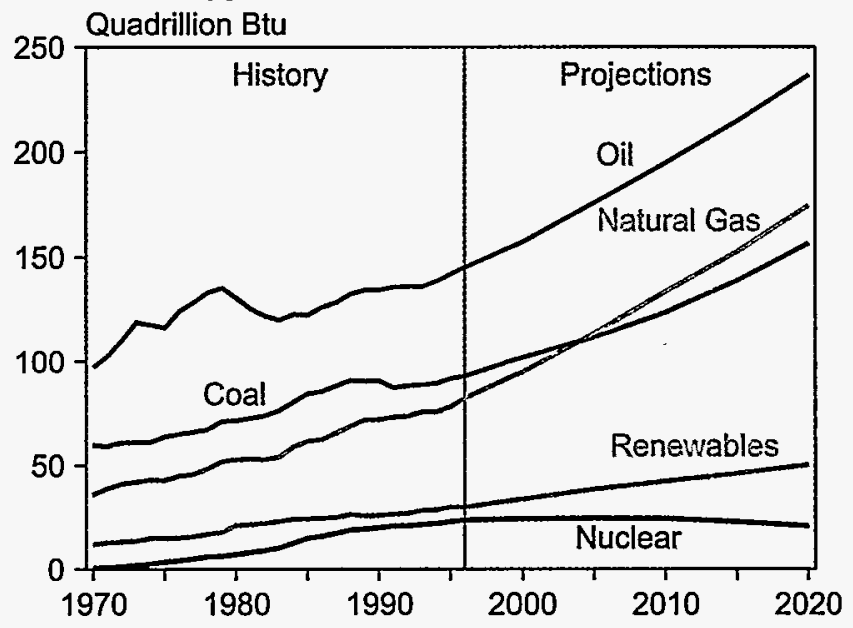

Sources: History: Energy Information Administration (EIA), Office of Energy Markets and End Use, International Statistics Database and International Energy Annual 1996, DOE/EIA0219(96) (Washington, DC, February 1998). Projections: EIA, World Energy Projection System (1998).

Much of the growth in energy consumption occurs outside the industrialized world, which today consumes about 86 quadrillion Btu more than the developing countries (Figure 13 and Table 3). In fact, by 2005, nonindustrialized countries are projected to consume as much energy as the industrialized countries. And by the end of the forecast, energy consumption in the developing countries (developing Asia, Africa, the Middle East, and Central and South America) exceeds that of the industrialized world by 16 quadrillion Btu (Figure 14). Such large increases will have an enormous impact on the energy markets of the future. The projections assume substantial levels of new investment in all phases of energy production and distribution. To achieve such investment in many areas of the world, government policies must continue to evolve, favoring private incentives for saving, trade, and development.

Two events in 1997 have rendered the assessment of energy supply and demand scenarios even more hazardous than usual. Under any conditions, substantial uncertainty attends the development of any long-term 
Table 2. World Energy Consumption by Energy Source, 1970-2020

(Quadrillion Btu)

\begin{tabular}{|c|c|c|c|c|c|c|}
\hline \multirow[b]{2}{*}{ Energy Source } & \multirow[b]{2}{*}{1970} & \multirow[b]{2}{*}{1995} & \multirow[b]{2}{*}{2010} & \multirow[b]{2}{*}{2020} & \multicolumn{2}{|c|}{ Annual Percent Change } \\
\hline & & & & & 1970-1995 & $1995-2020$ \\
\hline$\ldots \ldots \ldots$ & 97.8 & 142.5 & 195.5 & 237.3 & 1.5 & 2.1 \\
\hline Natural Gas . . & 36.1 & 78.1 & 133.3 & 174.2 & 3.1 & 3.3 \\
\hline Coal. . . . . & 59.7 & 91.6 & 123.6 & 156.4 & 1.7 & 2.2 \\
\hline Nuclear & 0.9 & 23.3 & 24.9 & 21.3 & 13.9 & -0.4 \\
\hline Renewables. . & 12.2 & 30.1 & 42.4 & 50.2 & 3.7 & 2.1 \\
\hline$\ldots \ldots \ldots$ & 206.7 & 365.6 & 519.6 & 639.4 & 2.3 & 2.3 \\
\hline
\end{tabular}

Sources: History: Energy Information Administration (EIA), Office of Energy Markets and End Use, International Statistics Database and International Energy Annual 1996, DOE/EIA-0219(96) (Washington, DC, February 1998). Projections: EIA, World Energy Projection System (1998).

scenario for world energy supply and demand. Assumptions must be made about the rate and regional composition of worldwide economic growth, and many characteristics of the relationship between economic growth and energy use patterns must be specified, as must feasible paths of energy supply development. Added to such normal sources of uncertainty are the new issues that arose in 1997. First, the potential consequences of the Kyoto Climate Change Protocol for energy and economic growth are substantial. Second, the extent of economic disruption that could flow from economic recessions currently underway in the Asia Pacific region is not known.

The Kyoto Protocol could forestall much energy demand growth in the industrialized world. Most business-as-usual projections currently available would have industrialized countries accounting for about onethird of world growth in energy demand between now and 2010. Were emissions targets identified in the

Figure 13. Nonindustrialized Energy Consumption by Region, 1970-2020

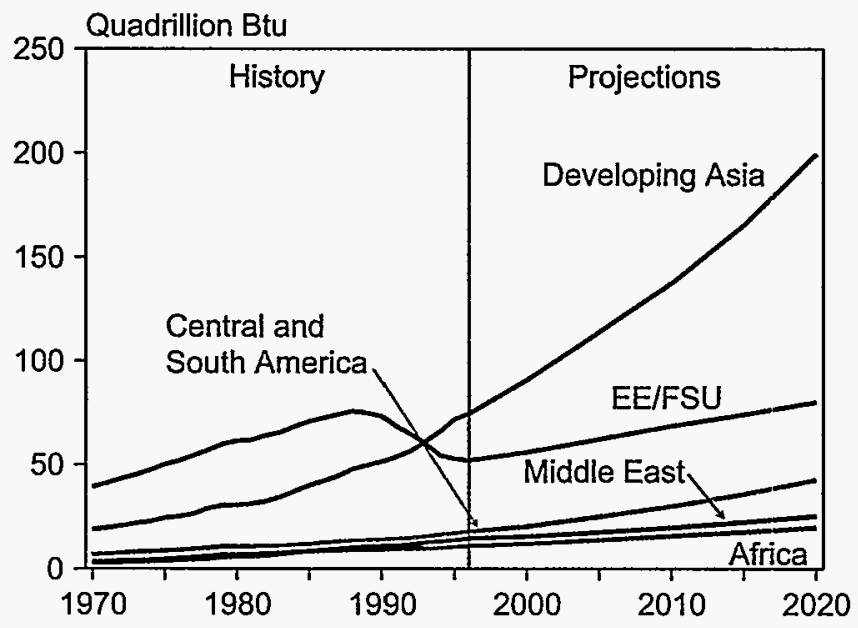

Sources: History: Energy Information Administration (EIA), Office of Energy Markets and End Use, International Statistics Database and International Energy Annual 1996, DOE/EIA0219(96) (Washington, DC, February 1998). Projections: EIA, World Energy Projection System (1998).
Protocol to be achieved by reducing fossil energy usage, energy consumption overall could be reduced by between 40 and 60 quadrillion Btu-equivalent to between 20 and 30 million barrels per day of oil demand. On the other hand, potential fuel switching opportunities could soften the effects of the agreement.

Even though the 1995 energy demand in developing Asia was only 36 percent of the total energy demand in industrialized countries, the rate of expected growth is such that more incremental demand-an increase of more than 65 quadrillion Btu by 2010-is expected in this region than from all industrialized countries combined. Thus, in the context of the projections prepared in 1997, the Asian economic crisis and the Kyoto Protocol put at risk about 100 quadrillion Btu or two-thirds of potential growth in energy demand through 2010.

The current projections of near-term energy demand presented in this IEO have been adjusted downward

\section{Figure 14. World Energy Consumption by Region, 1970-2020}

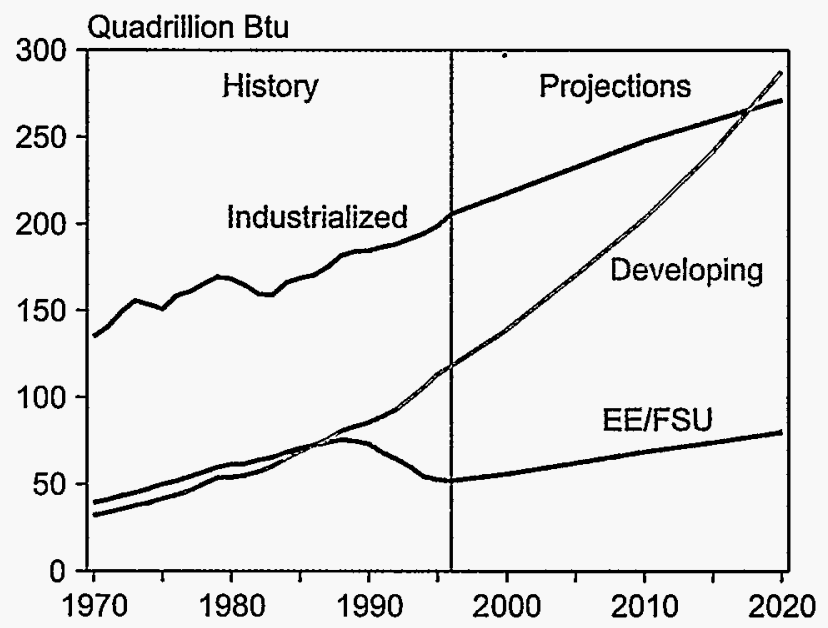

Sources: History: Energy Information Administration (EIA), Office of Energy Markets and End Use, International Statistics Database and International Energy Annual 1996, DOE/EIA0219(96) (Washington, DC, February 1998). Projections: EIA, World Energy Projection System (1998). 
Table 3. World Energy Consumption by Region, 1970-2020

(Quadrillion Btu)

\begin{tabular}{|c|c|c|c|c|c|c|}
\hline \multirow[b]{2}{*}{ Region } & \multirow[b]{2}{*}{1970} & \multirow[b]{2}{*}{1995} & \multirow[b]{2}{*}{2010} & \multirow[b]{2}{*}{2020} & \multicolumn{2}{|c|}{ Annual Percent Change } \\
\hline & & & & & $1970-1995$ & $1995-2020$ \\
\hline Industrialized . . . . & 135.1 & 199.1 & 247.5 & 271.5 & 1.6 & 1.2 \\
\hline United States. & 67.6 & 90.4 & 112.2 & 118.6 & 1.2 & 1.1 \\
\hline Developing & 32.0 & 113.3 & 203.0 & 287.5 & 5.2 & 3.8 \\
\hline Developing Asia & 18.9 & 71.8 & 137.4 & 199.4 & 5.5 & 4.2 \\
\hline EE/FSU . . . . & 39.7 & 53.2 & 69.0 & 80.4 & 1.2 & 1.7 \\
\hline Total World. & 206.7 & 365.4 & 519.5 & 639.4 & 2.3 & 2.3 \\
\hline
\end{tabular}

Sources: History: Energy Information Administration (EIA), Office of Energy Markets and End Use, International Statistics Database and International Energy Annual 1996, DOE/EIA-0219(96) (Washington, DC, February 1998). Projections: EIA, World Energy Projection System (1998).

only modestly relative to last year's edition. No adjustments are made to try to account for the potential impacts of the Kyoto Protocol (see discussion on page 15), because the IEO98 projections consider only current laws and regulations as of October 1, 1997. As of March 1998 , the Kyoto agreement has not yet been ratified by the conference participants. Those adjustments which have been made reflect an effort to account for current economic troubles in Asia. The reference case projection for Asia reflects adoption of the most broadly held expectation - that economic recession in the region will be sharp but not protracted. Thus, it is expected that, by 2000 , economic expansion in Asia will resume at rates above the average for the world economy as a whole.

To date, the countries most harmed by currency and debt crises include South Korea, Thailand, Malaysia, and Indonesia. Although these countries accounted for less than 15 percent of energy consumption for all of Asia in 1995 (Table 4), increases in their consumption account for 25 percent of the change in energy demand for the entire region since 1985. In each of the four countries, energy demand has grown more rapidly than gross domestic product (GDP) over the past decade. Thus, quick economic recovery in the region is important if a wide range of energy development projects currently underway or planned are to be profitable. The effects of the recession are already evident from the variety of actions that have been initiated to stretch out or postpone projects to expand liquefied natural gas (LNG) trade, electric power generation, and oil refining.

The IEO98 assumes that world economic growth will average about 3.1 percent annually between 1995 and 2020 . Over the past quarter century, world GDP grew by about \$12 trillion (1990 U.S. dollars). Over the next 25 years, GDP is expected to increase by more than twice that amount, reaching $\$ 53$ trillion by 2020 . The bulk of the growth occurs in the developing countries, which average 5.2 percent annual growth-compared with 2.3 percent annual growth in the industrialized countries and 3.7 percent in the recovering economies of Eastern Europe and the former Soviet Union (EE/FSU) (Table 5).

\section{Alternative Growth Cases}

Current discussions underscore the uncertainties inherent in economic growth projections, both near- and longterm. Discussion surrounding the Asian financial crisis reveals two predominant perspectives (as of winter 1998). One perspective, adopted for the IEO98 reference case, likens current developments to those experienced in Mexico beginning in 1990-severe currency devaluation, debt repayment difficulties, shortage of investible funds, and crisis in confidence. The Mexican economic crisis led to rescue efforts by international agencies and internal policy adjustments that promoted reform and recovery and relatively quick movement toward

Table 4. Energy Use and Economic Growth for Selected Developing Asian Countries, 1985-1995

\begin{tabular}{|c|c|c|c|c|}
\hline \multirow[b]{2}{*}{ Country } & \multicolumn{2}{|c|}{1995 Energy Consumption } & \multicolumn{2}{|c|}{ Average Annual Growth, 1985-1995 } \\
\hline & Quadrillion Btu & $\begin{array}{l}\text { Percent of } \\
\text { Total Asia }\end{array}$ & $\begin{array}{c}\text { Energy Use } \\
\text { (Percent per Year) }\end{array}$ & $\begin{array}{c}\text { Gross Domestic Product } \\
\text { (Percent per Year) }\end{array}$ \\
\hline Indonesia . . . . & 3.3 & 3.4 & 7.2 & 6.7 \\
\hline Malaysia . . . . . . . . & 1.5 & 1.5 & 7.8 & 7.7 \\
\hline South Korea . . . & 6.5 & 6.6 & 11.2 & 8.9 \\
\hline Thailand . . . . . . . . & 2.2 & 2.2 & 12.2 & 9.4 \\
\hline$\ldots \ldots \ldots$ & 13.5 & 13.7 & 9.8 & 8.3 \\
\hline
\end{tabular}

Sources: Energy Information Administration, International Energy Annual 1996, DOE/EIA-0219(96) (Washington, DC, February 1998); and WEFA Energy, World Economic Outlook: 20-Year Extension (Eddystone, PA, April 1997). 
Table 5. Annual Growth Rates in Gross Domestic Product by Region and for Selected Countries, 1970-2020 (Average Annual Percent Growth)

\begin{tabular}{|c|c|c|c|c|c|c|}
\hline \multirow[b]{2}{*}{ Region/Country } & \multicolumn{2}{|c|}{ History } & \multicolumn{4}{|c|}{ Projected } \\
\hline & $1970-1980$ & $1980-1990$ & $1990-2000$ & $2000-2010$ & $2010-2020$ & $1995-2020$ \\
\hline Industrialized $\ldots \ldots \ldots$ & 3.1 & 2.9 & 2.0 & 2.4 & 2.2 & 2.3 \\
\hline North America. . . . . . . . . & 2.8 & 2.8 & 2.1 & 2.3 & 1.9 & 2.1 \\
\hline Western Europe. . . . . . . . . & 2.9 & 2.4 & 2.1 & 2.5 & 2.4 & 2.4 \\
\hline Pacific. . . . . . . . . & 4.5 & 3.9 & 1.7 & 2.5 & 2.5 & 2.3 \\
\hline Nonindustrialized . . . . . . . & 4.3 & 2.6 & 2.2 & 5.2 & 5.1 & 4.9 \\
\hline EE/FSU $\ldots \ldots \ldots \ldots$ & 2.6 & 1.9 & -3.8 & 4.8 & 3.6 & 3.7 \\
\hline Former Soviet Union. . . . . . & 2.6 & 2.0 & -4.4 & 4.8 & 3.4 & 3.6 \\
\hline Eastern Europe . . . . . . . & 2.9 & 0.8 & 1.6 & 4.6 & 4.4 & 4.4 \\
\hline Developing. . . . & 5.6 & 3.1 & 4.8 & 5.3 & 5.4 & 5.2 \\
\hline Developing Asia . . . . . . & 5.8 & 7.3 & 6.8 & 6.3 & 6.4 & 6.2 \\
\hline China . . . . . . . . & 5.3 & 9.3 & 10.0 & 7.8 & 8.0 & 7.9 \\
\hline Other $\ldots \ldots \ldots \ldots$ & 5.9 & 6.7 & 5.5 & 5.4 & 5.2 & 5.2 \\
\hline Middle East $\ldots \ldots \ldots$ & 5.7 & 0.2 & 3.0 & 3.7 & 4.1 & 3.8 \\
\hline Africa. . . . . & 3.6 & 2.1 & 2.6 & 4.1 & 4.2 & 4.1 \\
\hline Central and South America . . & 6.3 & 0.9 & 3.5 & 4.5 & 4.2 & 4.3 \\
\hline Total World . . . . . . . . & 3.4 & 2.8 & 2.1 & 3.2 & 3.2 & 3.1 \\
\hline
\end{tabular}

Note: India is including in developing other Asia.

Sources: Derived from WEFA Energy, World Economic Outlook: 20-Year Extension (Eddystone, PA, April 1997). U.S. data from Energy Information Administration (EIA), Annual Energy Outlook 1998, DOE/EIA-0383(98) (Washington, DC, December 1997); and EIA, World Energy Projection System (1998).

renewed economic expansion. Those holding similar expectations for Asia point to the wide array of actions underway or promised which are expected to have beneficial effects on confidence in international capital markets and the functioning of indigenous economies.

A more pessimistic perspective likens current and prospective Asian developments to the Latin American debt crisis of the 1980s, after which long-term regional growth nearly ceased for a decade. This view emphasizes the difficulty of affecting economic reforms already promised within such countries as Indonesia, Thailand, and South Korea. The view also reflects an expectation that the adverse economic effects evident in a few countries will spread to others, including most notably China and Japan, both of which are sensitive to the increased competition in export markets that could follow the devaluation of many Southeast Asian currencies.

Experience demonstrates that growth prospects can change markedly and for extended periods of time, involving major sections of the world economy. A major case in point is the collapse of the former Soviet Union in the 1990s, in stark contrast to the remarkable growth record of developing Asia.

IEO98 includes a high economic growth case and a low economic growth case in addition to the reference case. The reference case forecast was formulated by establishing a set of regional assumptions about economic growth paths and energy elasticity (the relationship between changes in energy consumption and changes in GDP). The two alternative growth cases, based on alternative ideas about the possible paths of economic growth, were formulated to provide users with a way to quantify the range of uncertainty associated with the reference case.

For the high and low economic growth cases, different assumptions were made about the range of possible economic growth rates for developing and industrialized nations, reflecting the greater uncertainty inherent in attempts to forecast economic growth in developing economies. The same pattern of change in energy intensity relative to change in GDP (discussed below) was assumed for the high and low growth cases as for the reference case. For industrialized countries, increments of +1.0 and -1.0 percentage points, respectively, were added to the reference case growth rates to generate the high and low growth cases. For nonindustrialized countries and/or regions, apart from China and EE/FSU, increments of +1.5 and -1.5 percentage points were used to generate the high and low growth cases.

China and the EE/FSU countries are special cases with regard to prospects for future economic growth. China has experienced quite high economic growth in the past few years, and the EE/FSU region has suffered a severe economic downturn. In both regions there is opportunity for a substantial change in growth: China has the 


\section{Uncertainties in Economic Growth}

The economic crisis in East Asia began in the summer of 1997 and continued to deepen into the winter of 1998. In most of the countries of the region, local currencies have fallen drastically relative to the U.S. dollar. The Malaysian ringitt lost 47 percent of its value compared to the dollar between January 2, 1997, and January 9, 1998; the Thai baht 41 percent; the Korean won 53 percent; and the Indonesian rupiah 77 percent (see table below). As of January 1998, the International Monetary Fund (IMF) had arranged more than $\$ 100$ billion in funding for South Korea, Indonesia, and Thailand-loans that will require them to cut energy subsidies and to deregulate and privatize their energy industries [1]. Indonesia has agreed to phase out subsidies on fuel and electricity as part of its IMF loan package. Thailand's government has put oil and gas privatization on a "fast track."

These recent economic events have highlighted the uncertainties attached to any economic growth forecasts-both short-term and long-run. Most of the major uncertainties regarding economic growth have centered in the developing world, since their economies need to devote much of their economic resources to improving infrastructure (education, transportation, and communication as well as energy resources) and tend to rely on international capital flows to finance much of their investment. But international capital flows, especially portfolio investment, are volatile and may have substantial impacts on short-term growth. Whether long-run growth is also affected depends on the reasons for the financial instability, the underlying economic characteristics of the country (such as the skill of the labor force), the domestic savings rate, the prospects for traded goods in global competition, and the infrastructure that supports the economy.

The long-run potential for economic growth depends on the economy's capacity to expand aggregate supply, or potential output. Potential GDP is that level of output that could be produced if all resources were fully employed. The growth in aggregate supply depends upon the increase in the labor force, the growth of capital stock, and productivity improvements. Labor force growth depends upon population and demographic growth and labor force participation rates. Also critical to long-run expansion of aggregate supply are capital stock accumulation and productivity growth, as well as fiscal and monetary policies.

The analysis of the short-run behavior of the economy focuses on the business cycle and emphasizes factors that determine how close or how far actual output varies from potential. On an international scale, international capital flows can typically be explained by short-run phenomena; however, if fiscal or monetary policies imposed in response to short-run capital market fluctuations lead to increased rigidity in the markets, then the growth of output can be hindered.

Starting in late spring 1997, currency markets in Southeast Asia became extremely volatile, with Thailand, Malaysia, and Indonesia experiencing sharp depreciations first, followed shortly by the Philippines and South Korea. Since the beginning of 1997, the dollar has risen by 61 percent against the Thai baht, nearly 43 percent against the Malaysian ringitt, and more than 45 percent against the South Korean won. These economies share many characteristics: relatively rapid growth over the past 3 to 6 years; high domestic savings rates; export-led instead of domestic demand growth to sustain economic expansion; high current account deficits; high foreign capital inflows; and relatively lax financial regulations.

In Thailand, Indonesia, and South Korea, the IMF has agreed to supply increased capital in exchange for agreement to a set of fiscal and monetary policies designed to reduce volatility in financial markets. The policies are aimed at decreasing government expenditures, removing some government controls over the financial sector, allowing insolvent financial institutions and businesses to fail, and allowing more foreign ownership to encourage foreign direct investment. The short-run impacts of such policies are likely to be higher inflation, lower imports, and reductions in sectors of the economy that are sensitive to interest rates (such as construction and investment). One result is projected lower growth rates for the next several years.

Whether these sharp currency devaluations will lead to lower growth rates over the next 25 years depends in large part on the type of policies enacted in response to short-run phenomena. If the financial reforms enacted make financial transactions more transparent, then market conditions will judge the efficacy of new investments. Making investment decisions more marketdriven will lead to potentially higher long-run potential growth, especially given the relatively high education levels and savings rates of the labor force in Southeast Asia.

The economic growth rates used in the IEO98 forecast represent long-term trend forecasts, which abstract the impacts of exogenous shocks or business cycles. Economic output is assumed to converge toward its potential maximum, with all resources fully utilized. 


\section{Uncertainties in Economic Growth (Continued)}

Asian Currencies Relative to the U.S. Dollar, January 2, 1997, to January 9, 1998 (Currency per U.S. Dollar)

\begin{tabular}{|c|c|c|c|c|c|c|c|}
\hline \multirow[b]{2}{*}{ Country } & \multicolumn{6}{|c|}{ Date } & \multirow{2}{*}{$\begin{array}{c}\text { Depreciation, } \\
\text { 1997-1998 } \\
\text { (Percent) } \\
\end{array}$} \\
\hline & 1/2/97 & 11/17/97 & $12 / 1 / 97$ & $12 / 11 / 97$ & $1 / 2 / 98$ & $1 / 9 / 98$ & \\
\hline India (rupee). . . . & 35.84 & 36.68 & 38.50 & 39.00 & 39.21 & 39.64 & -9.5 \\
\hline Pakistan (rupee) . . . . . & 40.07 & 44.00 & 45.40 & 44.00 & 44.00 & 44.00 & -8.9 \\
\hline Bangladesh (taka). . . . & 42.45 & 45.00 & 45.30 & 45.45 & 45.45 & 45.45 & -6.6 \\
\hline Malaysia (ringitt). & 2.48 & 3.29 & 3.50 & 3.66 & 3.89 & 4.68 & -47.0 \\
\hline Thailand (baht) . & 25.68 & 38.70 & 39.85 & 42.35 & 48.15 & 53.47 & -40.9 \\
\hline Indonesia (rupiah) . . . . & $2,372.5$ & $3,445.0$ & $3,645.0$ & $4,405.0$ & $5,495.0$ & $10,100.0$ & -76.5 \\
\hline Philippines (peso) . & 26.30 & 33.48 & 34.65 & 35.25 & 39.90 & 44.92 & -41.4 \\
\hline Singapore (dollar) . . . . & 1.40 & 1.57 & 1.59 & 1.61 & 1.68 & 1.78 & -21.3 \\
\hline Vietnam (dong) . . . . & $11,183.3$ & $12,202.5$ & $12,224.0$ & $12,291.5$ & $12,292.5$ & $12,292.0$ & -9.0 \\
\hline Hong Kong (dollar) & 7.73 & 7.73 & 7.73 & 7.74 & 7.74 & 7.74 & -0.1 \\
\hline China (yuan) . . . . . . & 8.29 & 8.28 & 8.28 & 8.28 & 8.28 & 8.27 & +0.2 \\
\hline Taiwan (dollar). . . . . . & 27.40 & 31.00 & 32.07 & 32.23 & 32.66 & 34.36 & -20.3 \\
\hline South Korea (won) & 848.1 & 988.7 & $1,119.5$ & $1,565.9$ & $1,695.1$ & $1,787.5$ & -52.6 \\
\hline Japan (yen) . . . & 117.10 & 125.88 & 126.95 & 129.02 & 130.01 & 132.63 & -11.7 \\
\hline Australia (dollar) . . . . . & 1.27 & 1.44 & 1.47 & 1.49 & 1.53 & 1.57 & -19.1 \\
\hline New Zealand (dollar) . . & 1.41 & 1.60 & 1.62 & 1.66 & 1.72 & 1.76 & -19.8 \\
\hline
\end{tabular}

potential for a larger decline in growth rate given its currently high rate, and there are prospects for a substantial increase in the rate of growth for EE/FSU nations should their current political and institutional problems be moderated sufficiently for the recovery of a considerable industrial base. Reflecting these uncertainties, -3 percentage points were added to China's growth rate for the low economic growth case and +1.5 for the high case; and +3.0 percentage points were added to the EE/FSU growth rate for the high economic growth case and -1.5 for the low case.

In the reference case, total world energy consumption is projected to reach 639 quadrillion Btu in 2020, with industrialized countries consuming 271 quadrillion Btu and the rest of the world 368 quadrillion Btu (Table 6 and Figure 15). Under the assumptions of the high economic growth case, total world energy consumption would be 781 quadrillion Btu in 2020, 142 quadrillion Btu higher than the reference case projection. In the low economic growth case, worldwide consumption would be 519 quadrillion Btu, 121 quadrillion Btu less than in the reference case. Thus there is a substantial range between low and high economic growth cases. The range between the cases for total world energy consumption-262 quadrillion Btu-is more than 40 percent of the total reference case consumption projected for 2020 .
Developing nations contribute 159 quadrillion Btu to this spread, reflecting the uncertainty associated with their economic prospects.

Figure 15. World Energy Consumption by Economic Growth Case, 1970-2020

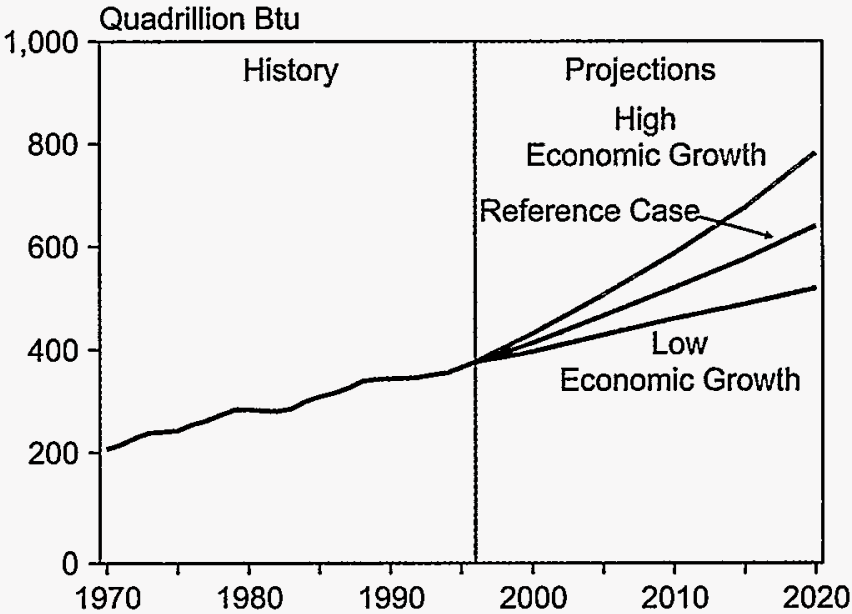

Sources: History: Energy Information Administration (EIA), Office of Energy Markets and End Use, International Statistics Database and International Energy Annual 1996, DOE/EIA0219(96) (Washington, DC, February 1998). Projections: EIA, World Energy Projection System (1998). 
Table 6. Annual World Energy Consumption by Region in Three Economic Growth Cases, 1970-2020 (Quadrillion Btu)

\begin{tabular}{c|r|r|r|r|r|r|r|r}
\hline & \multicolumn{2}{|c|}{ History } & \multicolumn{3}{c|}{2010} & \multicolumn{3}{c}{2020} \\
\cline { 2 - 9 } Region & \multicolumn{1}{|c|}{1970} & \multicolumn{1}{c|}{1995} & \multicolumn{1}{c|}{ Low } & Reference & \multicolumn{1}{c}{ High } & \multicolumn{1}{c}{ Low } & Reference & High \\
\hline Industrialized. . & 135.1 & 199.1 & 231.5 & 247.6 & 264.1 & 242.1 & 271.5 & 303.0 \\
EE/FSU . . . . . & 39.7 & 53.2 & 62.4 & 69.0 & 84.2 & 68.2 & 80.4 & 111.2 \\
Developing . . . & 32.0 & 113.3 & 166.1 & 203.0 & 237.2 & 208.4 & 287.5 & 366.9 \\
China. . . . . & 11.6 & 36.4 & 55.4 & 71.3 & 80.8 & 72.6 & 109.7 & 134.5 \\
Other Asia . . & 7.2 & 35.4 & 55.3 & 66.0 & 78.7 & 68.9 & 89.8 & 116.6 \\
Total World . . . & 206.7 & 365.6 & 460.0 & 519.6 & 585.5 & 518.8 & 639.4 & $\mathbf{7 8 1 . 1}$ \\
\hline
\end{tabular}

Sources: 1970: Energy Information Administration (EIA), Office of Energy Markets and End Use, International Statistics Database. 1995: EIA, International Energy Annual 1996, DOE/EIA-0219(96) (Washington, DC, February 1998). Projections: ElA, Annual Energy Outlook 1998, DOE/EIA-0383(98) (Washington, DC, December 1997), and World Energy Projection System (1998).

\section{Trends in Energy Intensity}

Still another dimension of uncertainty regarding longterm energy demand is the way in which energy demand evolves relative to GDP over time. Economic growth and energy demand are linked, but the strength of that link varies among regions and stages of economic development (Table 7). In industrialized countries, history shows the link to be relatively weak-that is, energy demand growth trails economic growth. For every percent increase in economic activity, energy demand increases only about half a percent. In developing countries, demand and economic growth have tended to be more closely linked, with energy demand growth tending to track the rate of economic expansion. Historic behavior in the FSU is more problematic. Until 1990, increases in economic activity were more than matched by increased energy consumption. From 1990 to 1995, however, economic problems in the EE/FSU distorted

Figure 16. Energy, GDP, and Population Trends in Industrialized Countries, 1995-2020

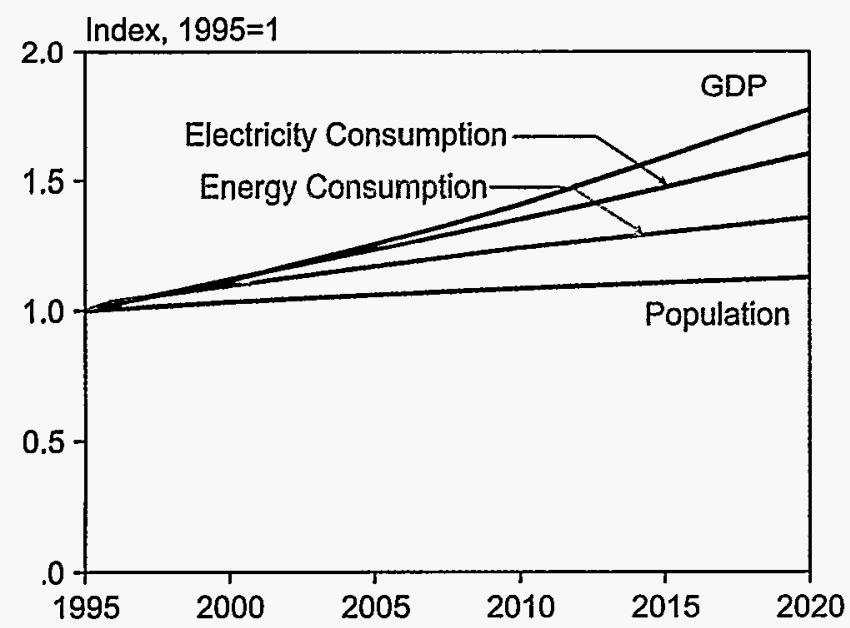

Sources: 1995: Energy Information Administration (EIA), Office of Energy Markets and End Use, International Energy Annual 1996, DOE/EIA-0219(96) (Washington, DC, February 1998). Projections: EIA, World Energy Projection System (1998). the region's energy intensities. GDP and energy consumption were both declining, but GDP fell more rapidly, causing a rise in energy intensity and a positive energy-to-GDP elasticity.

The stage of economic development and the standard of living of individuals in each region strongly condition the link between economic growth and energy demand. Advanced economies with high living standards tend to have relatively high energy use per capita, but they also tend to be economies where per capita energy use is relatively stable or changes very slowly. In this context, rising energy demand tends to track employment and population growth (Figure 16). In industrialized countries, use of modern appliances and personal transport equipment is widespread. As a result, increments to per- sonal income tend to result in spending on goods and services that are not energy intensive. To the extent that spending is directed at energy-using goods, it involves more often than not purchases of new equipment to replace old capital stock. The new stock is often more efficient than the equipment it is replacing, so that the relation between income and energy demand is weaker. In developing countries, standards of living, while rising, tend to be low relative to those in more advanced economies. As a result, many energy-using devices are being widely adopted for the first time, causing energy use to track more closely with rising income levels (Figure 17).

The growth in energy consumption in the developing countries also indicates improving lifestyles made possible by rising personal incomes. In the developing world, income per capita is expected to increase by almost 149 percent between 1995 and 2020, from $\$ 1,104$ to $\$ 2,744$ per person. While this increase is impressive, the developing world will still —on a per capita basis-consume less than one-fifth the energy of the industrialized world (Figure 18). Moreover, per capita energy use in the Middle East and Africa is not expected grow at all between 1995 and 2020, because a near doubling of their population levels over the 25 -year period offsets the growth in energy consumption. 
Table 7. Average Energy Elasticity by Region, $1970-2020$

(Change in Energy Consumption vs. Change in GDP)

\begin{tabular}{|c|c|c|c|c|c|c|c|c|c|c|}
\hline Region & $\begin{array}{l}1970- \\
1975 \\
\end{array}$ & $\begin{array}{l}1975- \\
1980 \\
\end{array}$ & $\begin{array}{l}1980- \\
1985 \\
\end{array}$ & $\begin{array}{l}1985- \\
1990 \\
\end{array}$ & $\begin{array}{l}1990- \\
1995 \\
\end{array}$ & $\begin{array}{l}1995- \\
2000 \\
\end{array}$ & $\begin{array}{r}2000- \\
2005 \\
\end{array}$ & $\begin{array}{l}2005- \\
2010 \\
\end{array}$ & $\begin{array}{l}2010- \\
2015 \\
\end{array}$ & $\begin{array}{l}2015 * \\
2020 \\
\end{array}$ \\
\hline Industrialized & 0.74 & 0.69 & 0.03 & 0.55 & 0.84 & 0.83 & 0.54 & 0.53 & 0.42 & 0.41 \\
\hline EE/FSU & 1.27 & 2.89 & 1.39 & 0.39 & 0.68 & 0.55 & 0.43 & 0.43 & 0.43 & 0.43 \\
\hline Developing & 0.98 & 0.94 & 1.77 & 1.33 & 1.17 & 0.89 & 0.79 & 0.68 & 0.66 & 0.65 \\
\hline Asia... . & 1.03 & 0.71 & 0.81 & 0.66 & 0.88 & 0.84 & 0.73 & 0.62 & 0.60 & 0.60 \\
\hline China & 0.88 & 0.63 & 0.48 & 0.51 & 0.51 & 0.60 & 0.59 & 0.56 & 0.55 & 0.55 \\
\hline $\begin{array}{l}\text { Developing Asia } \\
\text { Without China. }\end{array}$ & 1.21 & 0.95 & 1.05 & 0.84 & 1.22 & 1.03 & 0.83 & 0.63 & 0.60 & 0.60 \\
\hline Total Worid . . & 0.95 & 0.94 & 0.69 & 0.69 & 0.85 & 0.92 & 0.75 & 0.69 & 0.65 & 0.65 \\
\hline
\end{tabular}

Notes: EE/FSU = Eastern Europe/Former Soviet Union. The elasticities for each 5-year period were calculated by dividing the percentage change in energy consumption by the percentage change in gross domestic product (GDP).

Sources: History: Derived using GDP data from WEFA Energy, World Economic Outlook: 20-Year Extension (Eddystone, PA, April 1997), and energy consumption data from Energy Information Administration (EIA), Office of Energy Markets and End Use, International Energy Statistics Database (1970-1979) and International Energy Annual 1996, DOE/ElA-0219(96) (Washington, DC, February 1998) (1980-1995). Projections: EIA, World Energy Projection System (1998).

Rising levels of personal income mean that more areas of the world are-for the first time - gaining access to electricity. Access to electricity means an expansion in the amount and variety of home appliances that can be used. Simultaneously, the demand for personal automobiles also becomes an important part of consumer demand in the industrializing areas-which, of course, results in higher consumption of petroleum products for transportation. In many Asian countries, such as South Korea, Thailand, India, and China, growth rates for automobile ownership have exceeded 10 percent in recent years. The potential market in the countries of this region is enormous. By one estimate, there are only about 6.6 motor vehicles per thousand persons in China,

Figure 17. Energy, GDP, and Population Trends in Developing Countries, 1995-2020

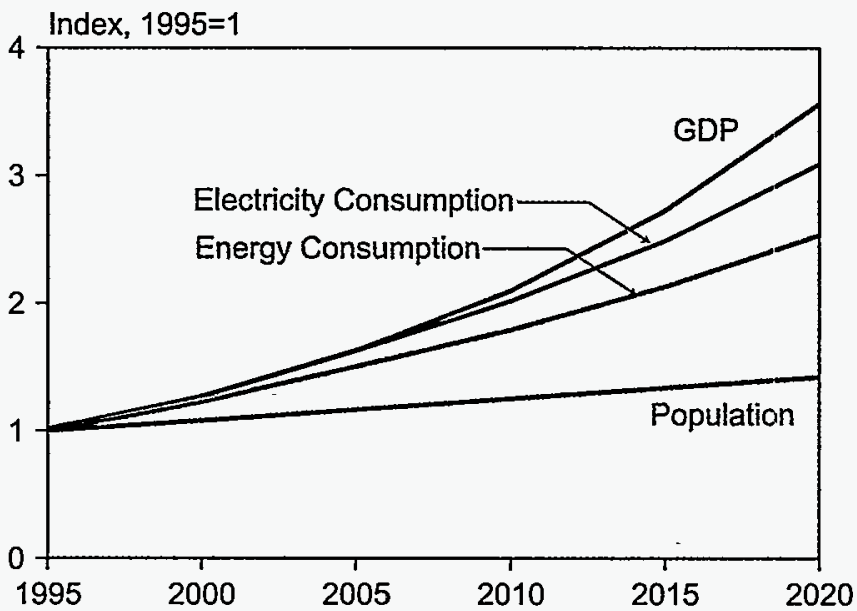

Sources: 1995: Energy Information Administration (EIA), Office of Energy Markets and End Use, International Energy Annual 1996, DOE/EIA-0219(96) (Washington, DC, February 1998). Projections: ElA, World Energy Projection System (1998). as compared with 720 in the United States, 520 in Japan, and 130 in South Korea [2].

The composition of industrial activity also affects the relationship between economic activity and energy consumption. For example, steel and cement production are important for China as it undertakes to build modern infrastructure throughout the country. China is currently the world's largest producer of iron, steel, and cement which even with the most modern production technology are among the most energy-intensive industrial activities. The FSU was also a center of large-scale, energy-intensive industrial activity prior to the initiation of efforts at market reform. In both regions,

Figure 18. World Energy Consumption per Capita by Region, $1970-2020$

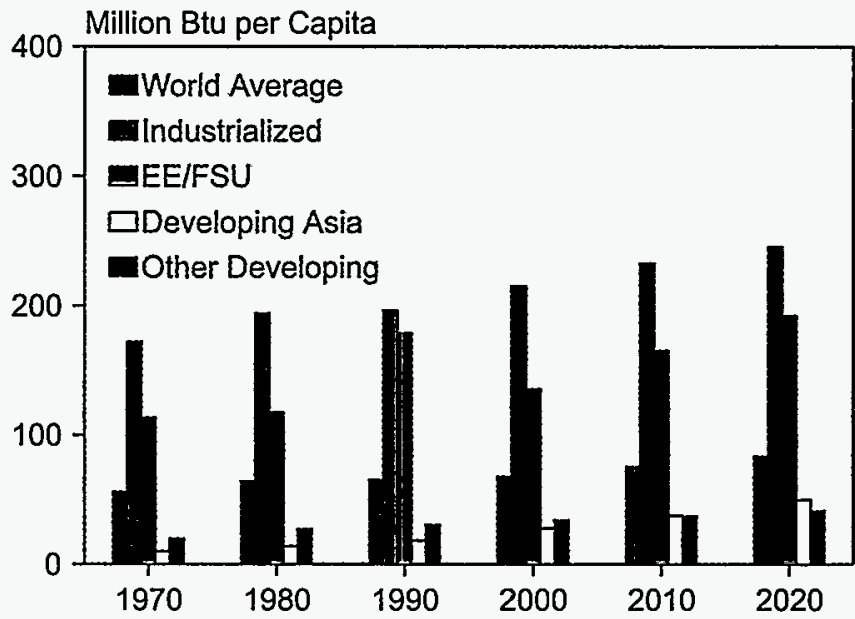

Sources: History: Energy Information Administration (EIA), Office of Energy Markets and End Use, International Statistics Database and International Energy Annual 1996, DOE/EIA0219(96) (Washington, DC, February 1998). Projections: EIA, World Energy Projection System (1998). 
relatively high energy use per dollar of output reflects heavy reliance on production from energy-intensive industries.

Given historic differences across regions, what can be expected in the future? The reference case projections assume declining ratios of energy use per dollar of GDP. Thus, energy demand growth is projected to trail economic growth. While world economic growth is projected to average 3.1 percent per year between 1995 and 2020, energy growth is projected at 2.3 percent per year. This assumes a nearly 25-percent reduction in energy intensity worldwide, with declines of one-third or more in the developing countries and in the EE/FSU.

The decline in energy-to-GDP elasticity for developing nations is projected to continue through 2020 , but at a slower rate than for the industrialized nations (Figure 19). The projected decline in energy intensity is based on the assumption that energy-efficient technologies used in the industrialized world will also be adopted in the developing world. The widespread use of efficient technology could come about through pressures for economic efficiency as developing and transitional economies become more market-driven and more integrated into the global economy. It is also possible, however, that the drive for modern living standards could lead to significant further increases in energy use per capita, pushing world energy requirements well beyond the reference case projections. In recent years, most projections for developing countries have indicated an expectation of declining energy intensities. For many countries, however, economic growth and energy growth have moved together, making it necessary to move back the expected dates for declines in energy

Figure 19. Energy Intensities by Region, 1970-2020

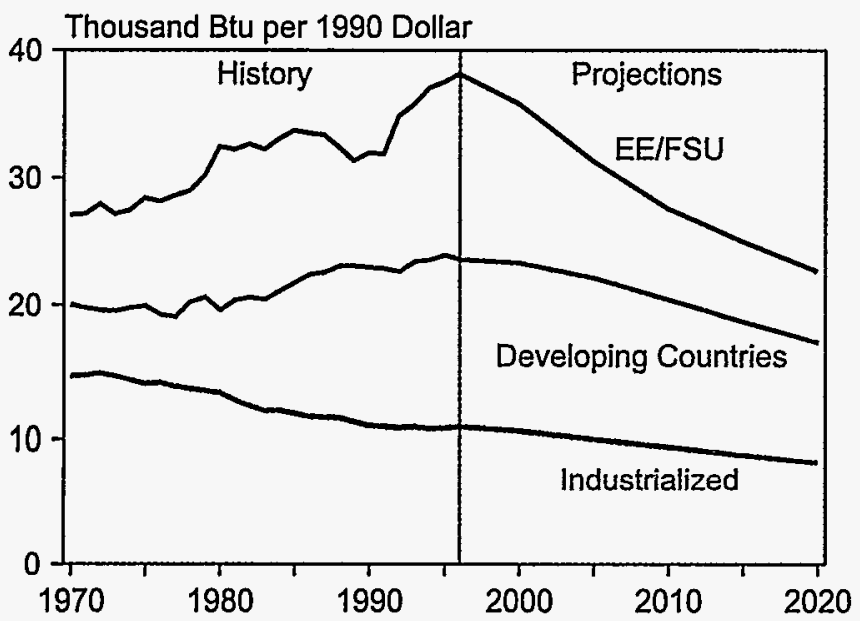

Sources: History: Energy Information Administration (EIA), Office of Energy Markets and End Use, International Statistics Database and International Energy Annual 1996, DOE/EIA0219(96) (Washington, DC, February 1998). Projections: EIA, World Energy Projection System (1998). growth relative to GDP growth, and causing upward revisions to expectations of world energy requirements.

On the other hand, recent commitments by industrialized countries to reduce greenhouse gas emissions below 1990 levels, to be achieved, would require substantial reductions in the ratio of energy growth to GDP growth. For the commitments to be achieved through reduced energy use alone, the projected rate of decline in energy intensity would have to nearly triple relative to current expectations.

\section{Emissions of Greenhouse Gases and the Kyoto Protocol}

In 1992, a Framework Convention on Climate Change was endorsed in Brazil, with a stated aim of stabilizing atmospheric concentrations of greenhouse gases. The initial agreement called for voluntary actions by Annex I countries (including all industrialized countries, except Mexico, and including Belarus, Bulgaria, Croatia, the Czech Republic, Estonia, Hungary, Latvia, Lithuania, Poland, Romania, Russia, Slovakia, Slovenia, and the Ukraine) that would stabilize greenhouse gas emissions at 1990 levels by 2000 .

By 1995 it was recognized that progress toward emissions stabilization among the Annex I countries was insufficient and that additional steps were needed to identify a path toward emissions stabilization for the industrialized countries. As a consequence, new negotiations were initiated under what came to be known as the "Berlin Mandate" to elaborate and agree upon targets and timetables for reducing greenhouse gas emissions after 2000.

On December 11, 1997, in Kyoto, Japan, the parties to the Framework Convention agreed to a new set of commitments for reducing greenhouse gas emissions. The agreement-the Kyoto Protocol-may signal a significant change in the level of effort among industrialized countries to reduce greenhouse gas emissions [3]. The pledge, if realized, will markedly reduce or change energy use among signatory participants. If the agreement proves to be meaningful, substantial shifts in the composition of energy supply away from high-carbon fuels, substantial reductions in energy use intensity, or some combination will have to be achieved in developed countries. Table 8 summarizes the extent of change projected to be required relative to current reference case projections for countries committing to fixed targets under the Protocol. It should be noted that the percent reduction in emissions that a country would have to make relative to the 1990 levels could change, based on sinks and offsets that must be evaluated for each country. Further, international carbon trading permits could lessen the cost of compliance or the severity of the reductions. 
Table 8. Carbon Emissions in the Annex I Countries, 1990 and 2010, and the Effects of Kyoto Protocol in 2010

\begin{tabular}{|c|c|c|c|c|c|c|}
\hline \multirow[b]{2}{*}{ Country } & \multicolumn{4}{|c|}{ Million Metric Tons Carbon } & \multicolumn{2}{|c|}{ Percent Change } \\
\hline & $\begin{array}{c}1990 \\
\text { Emissions }\end{array}$ & $\begin{array}{c}2010 \\
\text { Baseline } \\
\text { Projection }\end{array}$ & $\begin{array}{c}2010 \\
\text { Kyoto } \\
\text { Target } \\
\end{array}$ & $\begin{array}{c}\text { Reduction } \\
\text { from } 2010 \\
\text { Baseline } \\
\end{array}$ & From 1990 & $\begin{array}{c}\text { From } 2010 \\
\text { Baseline }\end{array}$ \\
\hline \multicolumn{7}{|l|}{ Annex I Industrialized Countries } \\
\hline United States . . . . . . . . . & 1,346 & 1,803 & 1,252 & 552 & -7 & -31 \\
\hline 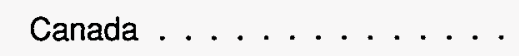 & 126 & 170 & 118 & 52 & -6 & -30 \\
\hline$\ldots \ldots \ldots \ldots$ & 274 & 342 & 258 & 85 & -6 & -25 \\
\hline Western Europe . . . . . . . . . & 971 & 1,101 & 893 & 208 & -8 & -19 \\
\hline Australasia. . . . . . . . . & 90 & 119 & 97 & 22 & 8 & -18 \\
\hline Total . . . . . . . . . . & 2,807 & 3,535 & 2,618 & 917 & -7 & -26 \\
\hline \multicolumn{7}{|l|}{ Annex I Transitional Economies ${ }^{a}$} \\
\hline Former Soviet Union . . . . . . . & 991 & 792 & 991 & -199 & 0 & 25 \\
\hline Eastern Europe . . . . . . . . . & 299 & 280 & 277 & 3 & -7 & -1 \\
\hline Total . . . . . . . . . & 1,290 & 1,072 & 1,268 & -196 & -2 & 18 \\
\hline Total Annex I Countries. . . . . . . & 4,097 & 4,607 & 3,886 & 721 & -5 & -16 \\
\hline
\end{tabular}

To achieve the targets proposed under the Kyoto Protocol, emissions in 2010 would have to be 26 percent lower than those currently projected for the industrialized Annex I countries in the IEO98 reference case (Table 8). In the United States and Canada alone, meeting the targets would require reductions of 31 and 30 percent, respectively, from 2010 projected emissions. In contrast, emissions in the EE/FSU are so much lower now than they were in 1990 that it is doubtful they could be restored to those levels by 2010. If energy consumption in the countries of the FSU grew as shown in the reference case forecast, carbon emissions would remain about 25 percent below levels allowed under the Kyoto Protocol, which requires no reductions to the 1990 emissions levels in the transitional economies of the FSU. ${ }^{2}$ Even in Eastern Europe-where countries are expected to hold emissions to 7 percent below their 1990 levels by 2010 - carbon emissions must be reduced by only 1 percent from the reference case projections.

There are many possible paths to the fulfillment of national commitments under the Protocol. In the energy arena, nonfossil energy may be substituted for fossil fuels. Alternately, high-carbon fuels-notably coalmay be replaced by low-carbon fuels-particularly natural gas. Further, improved end-use efficiency or reduced reliance on energy-intensive activities may serve to reduce the link between rising economic activity and increased energy consumption. Emissions can also be reduced through reductions in the demand for energy services, such as lowering thermostats, driving cars less, or switching to mass transit.

Actions not related to energy may also promote programs toward the goals set out by the Protocol. In addition to carbon dioxide, five categories of gases were identified as greenhouse gases to be controlled and for which control credits could be counted in moving toward Protocol targets (see box). The gases include methane $\left(\mathrm{CH}_{4}\right)$, nitrous oxide $\left(\mathrm{N}_{2} \mathrm{O}\right)$, hydrofluorocarbons (HFCs), perfluorocarbons (PFCs), and sulfur hexafluoride $\left(\mathrm{SF}_{6}\right)$. Reductions for carbon dioxide, methane, and nitrous oxide-gases which represent the bulk of all emissions-will be calculated from a 1990 baseline. Reductions of other gases will be credited in comparison with a 1995 baseline. In addition, actions which enhance carbon storage or sequestration in forests may also provide credit toward targeted commitments. Lastly, carbon permits may be earned through international agreements to moderate the degree of reduction needed to be judged in compliance with national commitments. The implementation of the latter path to compliance is subject to further negotiation and specification over the next year.

Since fossil fuel use is the major source of anthropogenic greenhouse gas emissions (for example, 84 percent of U.S. greenhouse gas emissions consist of carbon produced by energy-related activities [4, p. ix]), it is difficult to contemplate achievements of commitments without

2 Note that not all the countries of the former Soviet Union agreed to the Kyoto Protocol. Russia, the Ukraine, and the three Baltic Republics (Estonia, Latvia, and Lithuania) acceded to the Protocol. Armenia, Azerbaijan, Belarus, Georgia, Kazakhstan, Kyrgyzstan, Moldova, Tajikistan, Turkmenistan, and Uzbekistan did not. 


\section{Greenhouse Gases Targeted Under the Kyoto Protocol}

A number of greenhouse gases have been targeted for reduction under the Kyoto Protocol. Provided below is a description of each of the targeted greenhouse gases and, whenever possible, an estimate of world emissions of each gas [4, pp. 3-5]. Carbon dioxide is the most abundant greenhouse gas. Others, while volumetrically less significant, can have disproportionate effects in trapping heat in the Earth's atmosphere.

Carbon Dioxide. Carbon is a common element on the planet, and immense quantities can be found in the atmosphere, in soils, in carbonate rocks, and dissolved in ocean water. Records from Antarctic ice cores indicate that the carbon cycle* has been in a state of imbalance for the past 200 years, with carbon dioxide emissions into the atmosphere exceeding absorption. As a result, atmospheric carbon dioxide concentrations have been rising steadily.

The most important natural sources of carbon dioxide are releases from the oceans ( 90 billion metric tons per year), aerobic decay of vegetation ( 30 billion metric tons per year), and plant and animal respiration (30 billion metric tons per year) [5]. Known anthropogenic sources account for 7 billion metric tons of carbon per year. The principal anthropogenic source is the combustion of fossil fuels, which accounts for about 75 percent of total anthropogenic emissions of carbon worldwide.

Methane. Methane $\left(\mathrm{CH}_{4}\right)$ is also a common compound. Methane is released primarily by anaerobic decay of vegetation, by the digestive tracts of termites in the tropics, and by several other lesser sources. The main anthropogenic sources are leaks from the production of fossil fuels, human-promoted anaerobic decay in landfills, and the digestive tracts of domestic animals. Known and unknown sources of methane are estimated to total about 600 million metric tons annually; known sinks (i.e., absorption by natural processes) total about 560 million metric tons. The annual increase in methane concentration in the atmosphere accounts for the difference of 35 to 40 million metric tons.

Nitrous Oxide. The sources and absorption of nitrous oxide $\left(\mathrm{N}_{2} \mathrm{O}\right)$ are much more speculative than those for other greenhouse gases. The major sources are thought to be bacterial breakdown of nitrogen compounds in soils, particularly forest soils, and fluxes from ocean upwellings. The primary human-made sources are enhancement of natural processes through application of nitrogen fertilizers, combustion of fuels, and certain industrial processes. The most important sink is thought to be decomposition in the stratosphere. Worldwide estimated known sources of nitrous oxide total 13 to 20 million metric tons annually, and known sinks total 10 to 17 million metric tons.

Hydrofluorocarbons. Hydrofluorocarbons (HFCs) are engineered chemicals that do not exist in nature. They were rare prior to 1990 but since then have come into widespread use as refrigerants and blowing agents, replacing chlorofluorocarbons, which are being phased out under the terms of the 1987 Montreal Protocol. The most commonly used HFC, HFC-134a, is now the standard refrigerant used in automobile air conditioners and home refrigerators in the United States.

Perfluorocarbons. Perfluorocarbons (PFCs) are chemicals composed of one or two carbon atoms and four to six fluorine atoms, containing no chlorine. They are emitted as a byproduct of aluminum smelting and are also used in semiconductor manufacturing.

Sulfur Hexafluoride. Sulfur hexafluoride $\left(\mathrm{SF}_{6}\right)$ is an engineered chemical, produced in very small quantities, which has direct radiative forcing effects. It is a colorless gas, soluble in alcohol and ether and slightly soluble in water. $\mathrm{SF}_{6}$ is used as a dielectric in electronics and is also a fugitive emission from magnesium smelting. Worldwide emissions in 1995 were about 5,700 metric tons.

*The "carbon cycle" is the process by which carbon dioxide $\left(\mathrm{CO}_{2}\right)$ is extracted from the air by plants and decomposed into carbon and oxygen, with the carbon being incorporated into plant biomass and the oxygen released into the atmosphere. Plant biomass, in turn, ultimately decays (oxidizes), releasing carbon dioxide back into the atmosphere, or storing organic carbon in soil or rock. There are vast exchanges of carbon dioxide between the ocean and the atmosphere, with the ocean absorbing carbon from the atmosphere and plant life in the ocean absorbing carbon from water, dying, and spreading organic carbon on the sea bottom, where it is eventually incorporated into carbonate rocks. 
marked changes in energy supply and usage. As noted earlier, if the industrialized Annex I countries were to meet emissions targets specified by the Kyoto Protocol solely by reducing the consumption of fossil fuels, the reference case forecast could face decreases in energy use in the range of 40 to 60 quadrillion Btu by 2010 . However, because fuel switching and emissions trading will also be used to reduce a country's emissions, the potential fossil fuel consumption reductions noted above are probably overstated.

\section{Carbon Emissions}

Because of the recency of the Kyoto Protocol agreement and the many possible paths to compliance, no explicit adjustment has been made to the IEO98 forecasts, which were based on current laws and regulations in effect on October 1, 1997. The countries that agreed to the reductions in the Protocol had not yet ratified or even signed the treaty at the time this report was prepared for publication.

If energy consumption grows to levels projected in the reference case, annual carbon emissions will reach 8.3 billion metric tons by 2010 and 10.4 billion metric tons by 2020 (Figure 20). The resulting emissions would exceed 1990 levels by 44 percent in 2010 and by 81 percent in 2020. Emissions are projected to grow by 2.5 billion metric tons between 1990 and 2010 and another 2.1 billion metric tons by the end of the projection period. Coal contributes 1.7 billion metric tons to the overall increase between 1990 and 2020, oil 1.5 billion metric tons, and natural gas 1.4 billion metric tons.

Figure 20. World Carbon Emissions by Fuel Type, 1970-2020

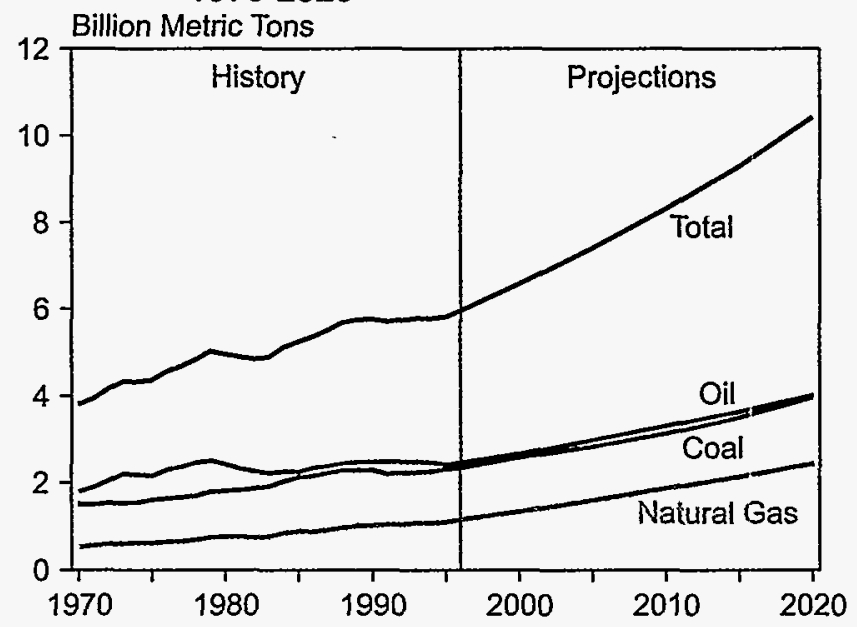

Sources: History: Energy Information Administration (EIA), Office of Energy Markets and End Use, International Statistics Database and International Energy Annual 1996, DOE/EIA0219(96) (Washington, DC, February 1998). Projections: EIA, World Energy Projection System (1998).
Emissions in the industrialized world increase by 1.2 billion metric tons between 1990 and 2020, reaching 4.1 billion metric tons at the end of the forecast period (Figure 21). About half of the increase in emissions is attributed to additional use of natural gas. Carbon emissions from natural gas use are almost equivalent to those from coal by the end of the projection period, reflecting the strong growth in natural gas consumption relative to coal. In 1990, carbon emissions from natural gas use were only about half of those from coal use. Oil remains the dominant source of carbon emissions in the industrialized world, where petroleum remains the main source of transportation fuel. Emissions from petroleum products, which accounted for 49 percent of total emissions in the industrialized countries in 1990, are projected to decline to 46 percent by 2020 as a result of increases in natural gas consumption over the forecast period.

\section{Figure 21. World Carbon Emissions by Region and} Fuel Type, 1990, 2010, and 2020

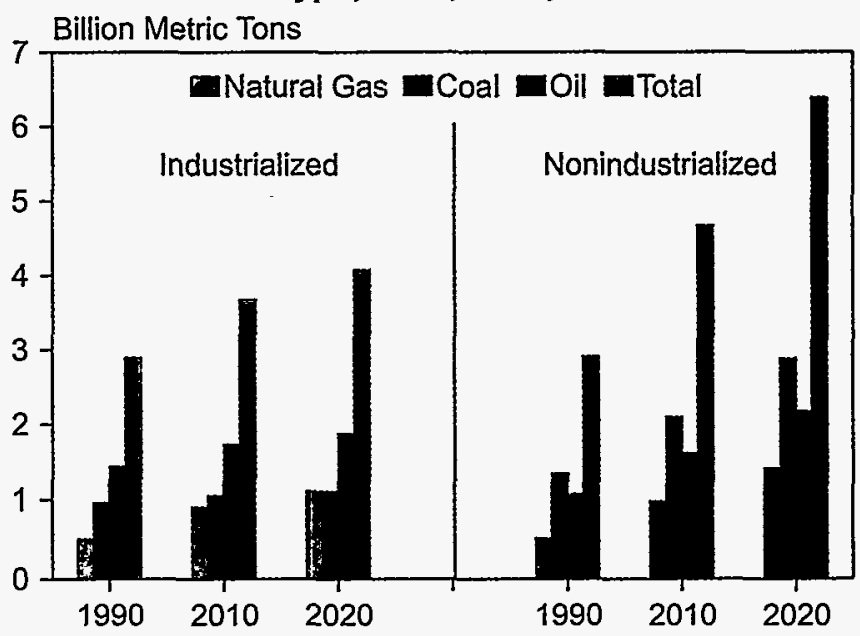

Sources: 1990: Energy Information Administration (EIA), Office of Energy Markets and End Use, International Energy Annual 1996, DOE/ElA-0219(96) (Washington, DC, February 1998). Projections: EIA, World Energy Projection System (1998).

By 2010, carbon emissions from the developing countries are expected nearly to equal those in the industrialized world (Figure 22). Developing countries will, by that time, consume about 40 percent more coal but only about two-thirds as much oil and natural gas as are consumed in the industrialized countries. But by 2020 , the developing countries are expected to consume 95 percent as much oil as the industrialized countries, 74 percent as much gas, and more than twice as much coal. Indeed, if energy consumption in the developing economies approaches the levels projected in the IEO98 reference case, they will emit 5.2 billion metric tons of carbon, an amount nearly equal to total world carbon emissions in 1990.

In the IEO98 reference case projections, developing Asia accounts for more than half the increment in world 
Figure 22. World Carbon Emissions by Region, 1970-2020

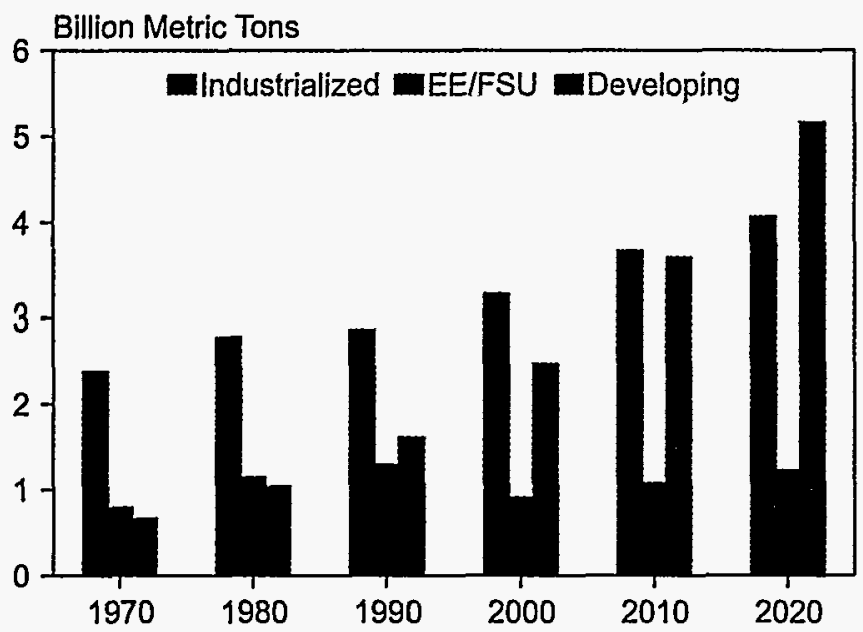

Sources: History: Energy Information Administration (EIA), Office of Energy Markets and End Use, International Statistics Database and International Energy Annual 1996, DOE/EIA0219(96) (Washington, DC, February 1998). Projections: EIA, World Energy Projection System (1998).

carbon emissions between 1990 and 2020 and threefourths of the increment for all the developing countries. The increase reflects the region's continuing heavy reliance on coal, the most carbon-intensive of the fossil fuels. Increased coal use accounts for 1.7 billion metric tons of developing Asia's 2.8 billion metric ton increment in carbon emissions. At the end of the forecast period, emissions in China alone surpass those of the United States.

Worldwide, carbon emissions per person grow from 1.1 metric tons in 1990 to 1.2 metric tons in 2010 and to 1.4 metric tons in 2020 (Figure 23). Per capita carbon emissions for the Annex I countries remain markedly higher than those for other countries throughout the forecast period, increasing from a 1990 level of 3.2 metric tons of carbon per person in 1990 to 3.7 metric tons per person in 2020. In comparison, the 1990 level for non-Annex I countries was 0.4 metric tons per person, and the projected 2020 level of 0.8 metric tons is one-fourth the 1990 level of per capita emissions for the Annex I countries. On the other hand, the increments for the Annex I and non-Annex I countries over the forecast period are actually equivalent. The non-Annex I countries accounted for 75 percent of the world's population in 1990; in 2020 they will account for almost 82 percent of the world's population; therefore, the effects of relatively small increases in per capita emissions for non-Annex I countries on overall emissions levels will be far greater than the effects of equivalent per capita increases for the Annex I countries.

Within the Annex I countries, the United States and Canada have the highest per capita emissions levels
Figure 23. Carbon Emissions per Capita by Region, 1990, 2010, and 2020

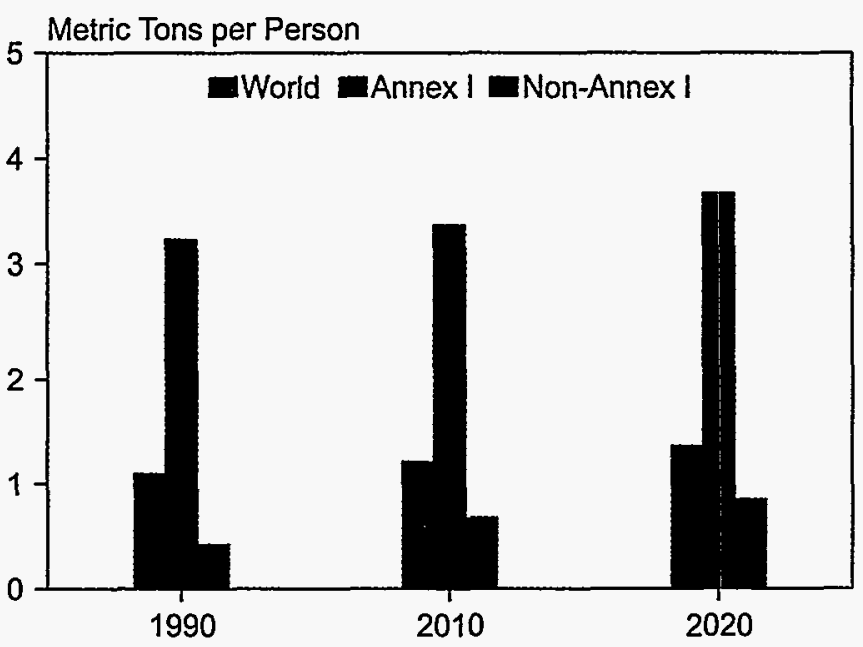

Sources: 1990: Energy Information Administration (EIA), Office of Energy Markets and End Use, International Energy Annual 1996, DOE/EIA-0219(96) (Washington, DC, February 1998). Projections: EIA, World Energy Projection System (1998).

throughout the forecast, reaching 6.0 and 5.6 metric tons per person in 2020, respectively (Figure 24). However, the growth rate of per capita emissions in both countries is projected to be fairly flat after 2000 . In contrast, outside the Annex I countries, per capita emissions are projected to increase more rapidly. In China, for instance, per capita carbon emissions in 2020 are projected to be more than triple their 1990 level, reflecting fast-paced industrialization based largely on fossil fuel consumption over the forecast period.

\section{Figure 24. Carbon Emissions per Capita for Selected Regions and Countries, 1990-2020}

Metric Tons per Person

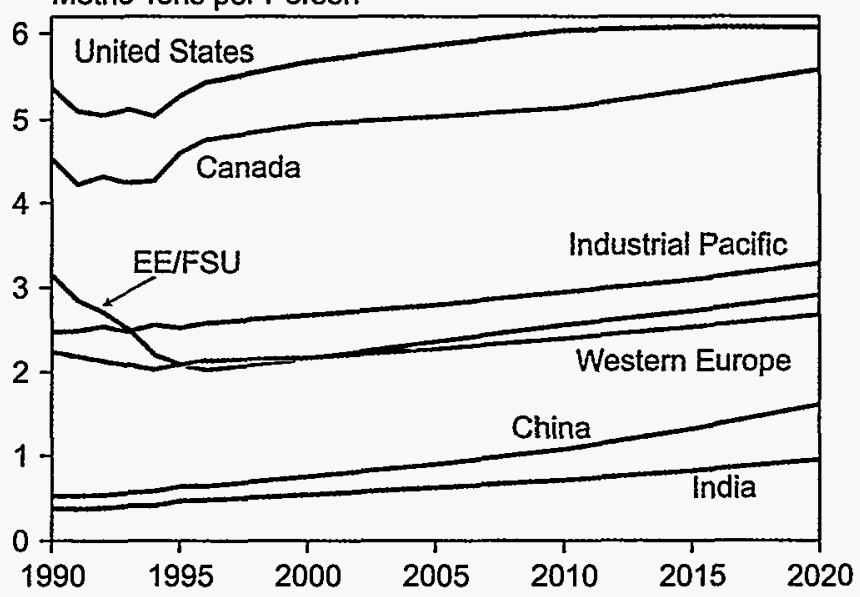

Sources: History: Energy Information Administration (EIA), Office of Energy Markets and End Use, International Energy Annual 1996, DOE/EIA-0219(96) (Washington, DC, February 1998). Projections: EIA, World Energy Projection System (1998). 


\section{Reference Case Trends in Primary Energy Consumption}

World energy consumption is projected to reach 639 quadrillion Btu by 2020 in the IEO98 reference case, representing a 75-percent increase in total energy use from 1995 to 2020. Much of the growth stems from increased fossil fuel use. Natural gas use is expected to have the fastest growth rate among primary energy sources, at 3.3 percent per year on a Btu basis, but use of all fossil fuels is projected to grow faster over the next 25 years than in the previous 25 years.

By 2020, oil consumption is expected to reach 116 million barrels per day, a 66-percent increase over the 1995 level. Oil has been the dominant energy source historically and is expected to remain so over the projection period. However, oil demand is expected to grow more slowly than total energy consumption in the forecast, as it has for the past 25 years. In the industrialized countries, oil use continues to grow in the transportation sector, where petroleum fuels have only limited competition from other energy sources. In the rest of the world, oil demand is expected to grow in all economic sectors.

The worldwide growth in oil demand is expected to result in some increase in oil prices over the projection period. Prices rise from $\$ 18$ per barrel (U.S. 1996 dollars) in 1995 to over $\$ 22$ per barrel in 2020 . In the low world oil price case included in the IEO98 forecast, oil prices reach about $\$ 14$ per barrel. In the high world oil price case, they reach $\$ 29$ per barrel.

The IEO98 expects that oil prices will generally stay low because non-OPEC nations will be able to continue to expand oil production in the short term. Improvements in technology associated with oil exploration, development, and production will allow the non-OPEC producers to achieve these expectations. The use of threedimensional seismic imaging, horizontal drilling, and subsea well completion technologies has helped to extend the productive life of mature oil fields and to reduce development and production costs at new fields. While the Middle East may possess the largest reserves that can be developed most economically, the reserves and production potential of other areas of the world have been substantially broadened.

Among all primary energy sources, natural gas is expected to grow most rapidly, by 3.3 percent annually over the next 25 years. Natural gas use surpasses coal by 2005 , and by 2020 it exceeds coal demand by almost 18 quadrillion Btu (gas demand is about 13 quadrillion Btu less than coal today). Natural gas resources are fairly widespread and burn more cleanly than other fossil fuels. Much of the future growth in gas demand will be for electricity generation. Combined-cycle gas-fired generators require shorter construction periods and are often more efficient than other fossil fuel generators or nuclear power plants. There is much activity designed to expand natural gas infrastructure worldwide. In February 1997, 11,000 miles of gas pipeline were under construction and expected to be completed by the end of the year, and over 34,000 miles of gas pipelines were planned for years beyond 1997 [6].

Worldwide coal consumption grows 1.7 times above the 1995 levels, reaching 8.6 billion short tons by 2020 . The strongest growth in coal use occurs in Asia in the IEO98 forecast. Indeed, nearly 90 percent of the increase in coal use is attributed to the countries of developing Asia. Moreover, 95 percent of the increase in developing Asia is attributed to only two countries, China and India, where coal continues to be the major primary fuel source. Outside of China, almost all of the increase in coal use will be for electricity generation.

Nuclear power consumption declines over the forecast horizon, and the source loses share of total energy consumption, falling from 6 percent in 1995 to 3 percent in 2020. At the end of the projection period, electricity generation from nuclear energy falls to only 2,021 billion kilowatthours, somewhat below the 2,203 billion kilowatthours consumed in 1995 . Use of this energy source is expected to peak in 2005 at 2,368 billion kilowatthours, after which the United States and other countries with mature nuclear programs are expected to phase out their nuclear generation and retire nuclear capacity without replacing it. A substantial reduction in nuclear capacity is also expected in the former Soviet Union after 2010. Nevertheless, some countries-particularly, Japan and some of the developing countries of Asia-have plans to increase their reliance on nuclear power for electricity generation.

Hydroelectricity and other renewable resources are expected to retain their 8-percent share of total energy consumption throughout the forecast period. Low fossil fuel prices make it difficult for renewables to compete for market share. In the reference case, renewables grow by 67 percent worldwide, with strongest growth projections in the developing world. There are some efforts in the industrialized countries to increase the penetration of renewable energy sources to help stem the growth of greenhouse gases. In particular, in November 1997, the European Union announced a package to stimulate the growth of renewables and plans to invest about $\$ 11$ billion (U.S.) in wind plants with a view to install 10 gigawatts of wind farms by 2010 [7]. 


\section{Forecast Comparisons}

\section{Comparisons with Other Forecasts}

An alternative way to illustrate the uncertainty in the IEO98 projections (in addition to the alternative economic growth cases presented above) is to compare them with other forecasts. Three organizations provide forecasts comparable to those in IEO98. The International Energy Agency provided two scenarios in its 1996 World Energy Outlook-the Capacity Constraints Case (IEA CC) and the Energy Savings Case (IEA ES). The IEA Outlook was last updated in April 1996 and, therefore, may be considered somewhat dated. ${ }^{3}$ Petroleum Economics, Ltd. (PEL) and Petroleum Industry Research Associates (PIRA) also publish energy forecasts for the world. Because the IEA in its Outlook provided the latest historical data only for 1993, and all the other forecasts but one (PEL) published 1993 estimates, comparisons among the forecasts are made for the period 1993-2010. The period 1995-2010 was used for PEL, which included historical data for 1995 in its energy consumption tables. One of the forecasts (PIRA) projects stronger worldwide energy demand growth than does IEO98 for 1993 to 2010. The other three (IEA CC, IEA ES, and PEL) project lower growth.
Generally the forecasts of total energy consumption fall within the span defined by the IEO98 low and high economic growth cases (Table 9). There are some exceptions, however. For instance, PEL is more pessimistic about recovery in the FSU economies than are the other forecasts, including IEO98. Energy use in the FSU is expected to fall by 0.4 percent annually between 1995 and 2010 in the PEL forecast (1993 unavailable). In comparison, even in the low economic growth case for IEO98, the projected decline in energy consumption in the FSU averages only 0.1 percent per year between 1993 and 2010.

There is wide variation in expected energy demand growth for the Middle East region. The IEO98 low economic growth case projects an increase of 1.8 percent per year between 1993 and 2010, and the high economic growth case 3.6 percent per year. However, growth projections in one of the forecasts (IEA CC) exceed the annual growth rates expected in the IEO98 high case. The IEO98 reference case forecast of 2.7 percent annual growth in energy demand for the Middle East actually represents an upward adjustment from the IEO97 forecast of 2.1 percent per year. Similarly, the IEO98 projections for Africa are higher than the IEO97

Table 9. Comparison of Energy Consumption Growth Rates, 1993-2010, by Region (Average Annual Percent Growth)

\begin{tabular}{|c|c|c|c|c|c|c|c|c|}
\hline \multirow[b]{2}{*}{ Region } & \multicolumn{3}{|c|}{ IEO98 } & \multirow[b]{2}{*}{ IEO97 } & \multirow[b]{2}{*}{ IEA CC } & \multirow[b]{2}{*}{ IEA ES } & \multirow[b]{2}{*}{$\mathrm{PEL}^{\mathrm{a}}$} & \multirow[b]{2}{*}{ PIRA } \\
\hline & $\begin{array}{l}\text { Low } \\
\text { Growth }\end{array}$ & Reference & $\begin{array}{c}\text { High } \\
\text { Growth }\end{array}$ & & & & & \\
\hline Industrialized Countries . . . . . & 1.1 & 1.5 & 1.9 & 1.5 & 1.4 & 0.8 & 1.1 & 1.4 \\
\hline North America . . . . . . . . & 1.3 & 1.6 & 1.9 & 1.5 & 1.3 & 0.8 & 1.2 & 1.3 \\
\hline Western Europe . . . . . . . & 0.9 & 1.3 & 1.8 & 1.3 & 1.1 & 0.5 & 0.9 & 1.5 \\
\hline Pacific $\ldots \ldots \ldots$ & 1.1 & 1.6 & 2.1 & 2.0 & 2.1 & 1.6 & 1.0 & 2.0 \\
\hline EE/FSU & 0.2 & 0.8 & 2.0 & 1.0 & 0.8 & 0.0 & 0.2 & 1.1 \\
\hline Former Soviet Union. . . . . . & -0.1 & 0.5 & 1.7 & 0.8 & 0.5 & -0.3 & -0.4 & - \\
\hline Eastern Europe $\ldots \ldots \ldots$ & 1.2 & 1.8 & 3.0 & 1.8 & 1.7 & 1.0 & 1.9 & - \\
\hline Developing Countries . . . . & 3.1 & 4.3 & 5.3 & 4.0 & 4.3 & 4.0 & 4.0 & 4.7 \\
\hline Asia $\ldots \ldots \ldots$ & 3.5 & 4.9 & 5.8 & 4.7 & 4.6 & 4.4 & 4.4 & 5.3 \\
\hline China & 3.4 & 5.0 & 5.7 & 4.7 & 4.2 & 4.1 & 3.8 & 5.2 \\
\hline Other Asia ${ }^{b}$. & 3.7 & 4.8 & 5.8 & 4.7 & 5.1 & 4.7 & 4.9 & 5.3 \\
\hline Middle East. . . . . . . . . & 1.8 & 2.7 & 3.6 & 2.1 & 4.2 & 3.4 & 3.2 & 3.4 \\
\hline Africa. . . . . . . . . & 1.9 & 2.8 & 3.7 & 2.3 & 4.0 & 3.5 & 2.9 & 3.2 \\
\hline Central and South America & 2.8 & 4.0 & 5.2 & 3.1 & 3.1 & 2.4 & 3.6 & 3.8 \\
\hline Total World . . . . . . . . & 1.6 & 2.3 & 3.1 & 2.2 & 2.2 & 1.8 & 2.0 & 2.6 \\
\hline
\end{tabular}

${ }^{2} \mathrm{PEL}$ growth rates are for the period 1995-2010.

bother Asia includes India.

Sources: IEO98: Energy Information Administration (EIA), World Energy Projection System (1998). IEO97: EIA, International Energy Outlook 1997, DOE/EIA-0484(97) (Washington, DC, April 1997), Table A1, p. 115. IEA CC: International Energy Agency, World Energy Outlook 1996 (Paris, France, 1996), Capacity Constraints Case, pp. 237-249. IEA ES: International Energy Agency, World Energy Outlook 1996 (Paris, France, 1996), Energy Savings Case, pp. 257-269. PEL: Petroleum Economics, Ltd., Oil and Energy Outlook to 2010 (London, United Kingdom, January 1998). PIRA: PIRA Energy Group, Retainer Client Seminar-Part One (New York, NY, October 1997), Tables II-1 and II-2.

\footnotetext{
3 The International Energy Agency plans to release an updated edition of the World Energy Outlook in 1998.
} 
projections. The improved economic growth expectations for these developing regions are attributed to improved expectations for market reform. The IEA CC energy growth forecast for Africa surpasses the IEO98 high economic growth case projections.

The projected economic growth rates for Central and South America are also higher in IEO98 than they were in IEO97. The countries of the region are recovering from the early 1990s currency crisis more rapidly than originally expected. The Asian economic recession could affect the growth of some Central and South American economies, but far more important is the continued progress toward economic deregulation and market integration that has bolstered opportunities for domestic and international investment. The IEO98 reference case projection for growth in Central and South America is the highest among the forecasts compared here.

Key to the differences among the forecasts are different expectations about future economic growth rates. Expectations for economic growth between 1993 and 2010 for the industrialized countries are substantially alike among most of the forecasters (Table 10). IEO98 expects GDP among the industrialized countries to grow by 2.3 percent annually, PEL projects annual growth of 2.1 percent, and PIRA 2.4 percent. The IEA projects a somewhat higher annual economic growth rate, 2.5 percent, but its forecasts were made in April
1996, before the recent economic downturns in Asia. In fact, a downward revision to the IEO98 economic growth rate for Japan-the largest economy in industrialized Asia-compared with IEO97 results in lower expectations for the developed economies as a whole.

Assumptions about GDP growth rates for the EE/FSU region over the 1993-2010 time period vary more widely, as might be expected in a region of substantial uncertainty. While IEO98 assumes annual GDP growth of 2.3 percent for the region, IEA projects a more optimistic 2.9 percent per year and PIRA an even more optimistic 3.4 percent per year. PEL remains somewhat pessimistic about the recovery of the economies in the region, projecting economic growth rates of 1.1 percent per year for the FSU and 2.1 percent per year for Eastern Europe.

All the forecasts agree that the highest economic growth will occur in the developing countries of the world over the two-decade period from 1993 to 2010, especially in the Asian countries. For China, the forecasts of annual economic growth range from 7.2 percent per year (PIRA) to 9.0 percent per year (PEL). In the other countries of developing Asia (including India), expectations for GDP growth range from 5.0 percent per year (PIRA) to 6.4 percent per year (PEL). As for other developing regions, IEO98 has higher growth rates than do the other forecasts for Central and South America. For Africa and the Middle East, the IEO98 GDP growth rate projections fall within the range defined by the other forecasts.

Table 10. Comparison of Economic Growth Rates, 1993-2010, by Region (Average Annual Percent Growth)

\begin{tabular}{|c|c|c|c|c|c|c|c|}
\hline \multirow[b]{2}{*}{ Region } & \multicolumn{3}{|c|}{ IEO98 } & \multirow[b]{2}{*}{ IEO97 } & \multirow[b]{2}{*}{ IEA } & \multirow[b]{2}{*}{ PEL } & \multirow[b]{2}{*}{ PIRA } \\
\hline & $\begin{array}{l}\text { Low } \\
\text { Growth }\end{array}$ & Reference & $\begin{array}{l}\text { High } \\
\text { Growth }\end{array}$ & & & & \\
\hline Industrialized Countries . . . . . & 1.4 & 2.3 & 3.2 & 2.6 & 2.5 & 2.1 & 2.4 \\
\hline North America . . . . . . . . & 1.4 & 2.3 & 3.2 & 2.6 & 2.6 & 2.2 & 2.5 \\
\hline Western Europe & 1.6 & 2.4 & 3.3 & 2.5 & 2.5 & 2.1 & 2.4 \\
\hline Pacific . . . . & 1.2 & 2.1 & 3.0 & 2.7 & 2.5 & 2.1 & 2.1 \\
\hline 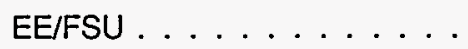 & 1.0 & 2.3 & 4.9 & 2.4 & 2.9 & - & 3.4 \\
\hline Former Soviet Union. . . . . . & 0.7 & 2.0 & 4.6 & 2.1 & 2.3 & 1.1 & - \\
\hline Eastern Europe . . . . . & 3.0 & 4.3 & 7.0 & 4.0 & 4.1 & 2.1 & - \\
\hline Developing Countries. & 3.6 & 5.1 & 6.5 & 4.8 & 5.4 & - & 5.6 \\
\hline Asia . . . . . . . . & 4.6 & 6.4 & 7.7 & 6.4 & 6.6 & - & 7.1 \\
\hline China $\ldots \ldots \ldots \ldots$ & 5.6 & 8.3 & 9.6 & 7.9 & 7.8 & 9.0 & 7.2 \\
\hline Other Asia ${ }^{a} \ldots \ldots \ldots$ & 4.1 & 5.4 & 6.7 & 5.6 & 6.0 & 6.4 & 5.0 \\
\hline Middle East . & 2.1 & 3.5 & 4.8 & 2.5 & 3.6 & 3.3 & 3.7 \\
\hline Africa $\ldots \ldots \ldots$ & 2.5 & 3.9 & 5.2 & 3.3 & 4.1 & 2.5 & 3.3 \\
\hline Central and South America . . & 3.0 & 4.4 & 5.7 & 3.6 & 3.7 & 3.0 & 3.8 \\
\hline Total World . . . . . . . . . . . & 1.9 & 2.9 & 4.1 & 3.0 & 3.2 & 2.8 & 4.0 \\
\hline
\end{tabular}

${ }^{\mathrm{a}}$ Other Asia includes India.

Sources: IEO98: Energy Information Administration (EIA), World Energy Projection System (1998). IEO97: EIA, International Energy Outlook 1997, DOE/EIA-0484(97) (Washington, DC, April 1997), Table A1, p. 115. IEA: International Energy Agency, World Energy Outlook 1996 (Paris, France, 1996), Capacity Constraints Case, pp. 237-249. PEL: Petroleum Economics, Ltd., Oil and Energy Outlook to 2010 (London, United Kingdom, January 1998). PIRA: PIRA Energy Group, Retainer Client Seminar-Part One (New York, NY, October 1997), Tables II-1 and II-2. 


\section{Performance of Past IEO Forecasts for 1990 and 1995}

In an attempt to measure how well the International Energy Outlook (IEO) projections have estimated future energy consumption trends over its 13-year history, we present a comparison of IEO forecasts produced for years 1990 and 1995. The forecasts can be compared with actual data published in EIA's International Energy Annual 1996 (IEA96). This comparison was undertaken as part of EIA's commitment to provide users of the IEO with a set of performance measures to assess the forecasts produced by this agency [8].

EIA has published the IEO since 1985. In IEO85, midterm projections were derived only for the world's market economies. That is, no projections were produced for the centrally planned economies (CPE) of the Soviet Union, Eastern Europe, Cambodia, China, Cuba, Laos, Mongolia, North Korea, and Vietnam. The IEO85 projections extended to 1995 and included forecasts of total energy consumption for 1990 and 1995 and primary consumption of oil, natural gas, coal, and "other fuels." IEO85 projections were also presented for several individual countries and subregions: the United States, Canada, Japan, the United Kingdom, France, West Germany, Italy, the Netherlands, other European countries in the Organization for Economic Cooperation and Development (OECD), other OECD (Australia, New Zealand, and the U.S. Territories), OPEC, and other developing countries. Beginning with IEO86, nuclear power projections were published separately from the "other fuel" category.

Figure 25. Comparison of IEO Forecasts with 1990 Energy Consumption in Market Economies

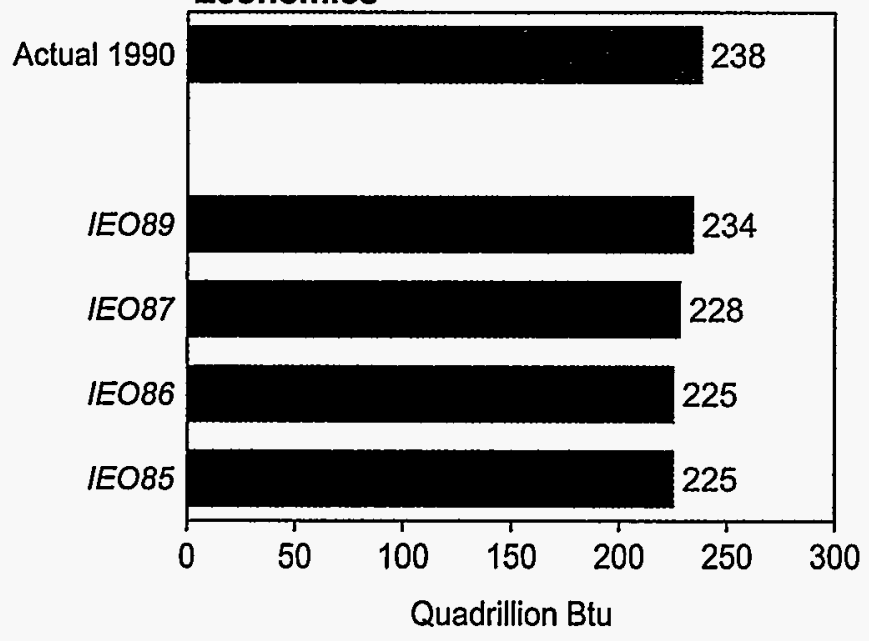

Sources: 1990: Energy Information Administration (EIA), Office of Energy Markets and End Use, International Energy Annual 1996, DOE/ElA-0219(96) (Washington, DC, February 1998). 1990 Projections: EIA, International Energy Outlook, DOE/EIA-0484 (Washington, DC, various years).
The regional aggregation has changed from report to report. In 1990, the report coverage was expanded to include projections for China, the former Soviet Union, and other CPE countries, making IEO90 the first edition to represent the entire world in the energy consumption forecast.

The data for total regional energy consumption in 1990 show that the IEO projections were-with few exceptions-lower than the actual data for the market economies. For the four editions of the IEO printed between 1985 and 1989 (no IEO was published in 1988) in which 1990 projections were presented, total projected energy consumption in the market economies ran between 2 and 5 percent lower than the actual consumption number published in the IEA96 (Figure 25).

In addition, market economy projections for 1995 in the 1985 through 1993 outlook reports (EIA did not release an international forecast for 1995 in either the 1994 or 1995 edition of the report) were consistently lower than the actual 1995 data (Figure 26). Most of the difference was for countries outside the OECD. Through the years, EIA's economic growth assumptions for OPEC and other market economy countries outside the OECD have been low. The 1993 forecast, which was, as might be expected, the closest to the actual 1995 number, still was more than 10 percent lower than the actual value.

In IEO90, energy consumption forecasts for the entire world were first released. Since then, the IEO forecasts of world energy consumption for 1995 have been

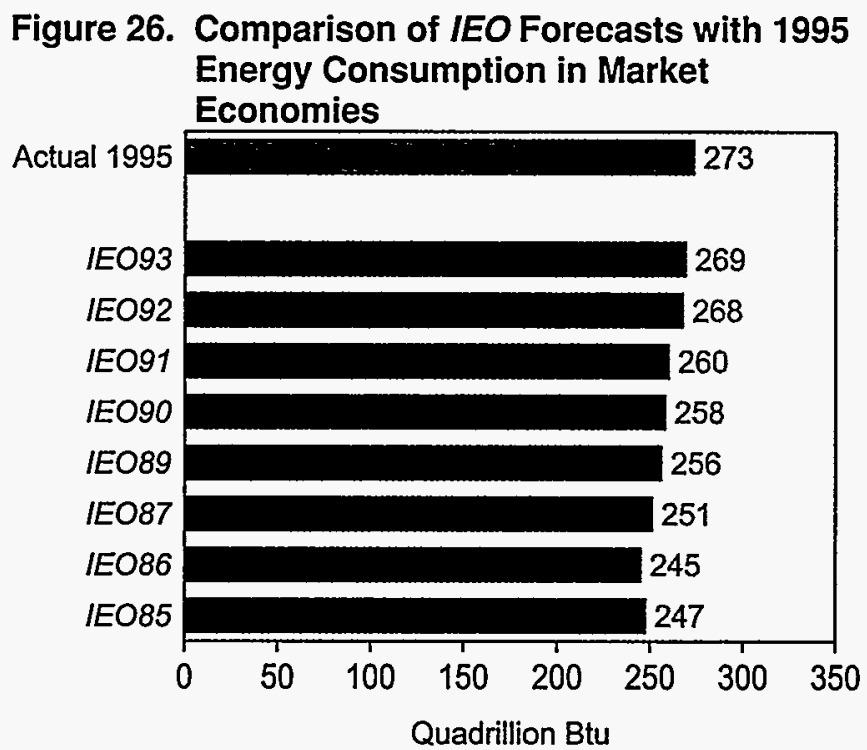

Sources: 1995: Energy Information Administration (EIA), Office of Energy Markets and End Use, International Energy Annual 1996, DOE/EIA-0219(96) (Washington, DC, February 1998). 1995 Projections: EIA, International Energy Outlook, DOE/EIA-0484 (Washington, DC, various years). 
Figure 27. Comparison of IEO Forecasts with 1995 World Energy Consumption

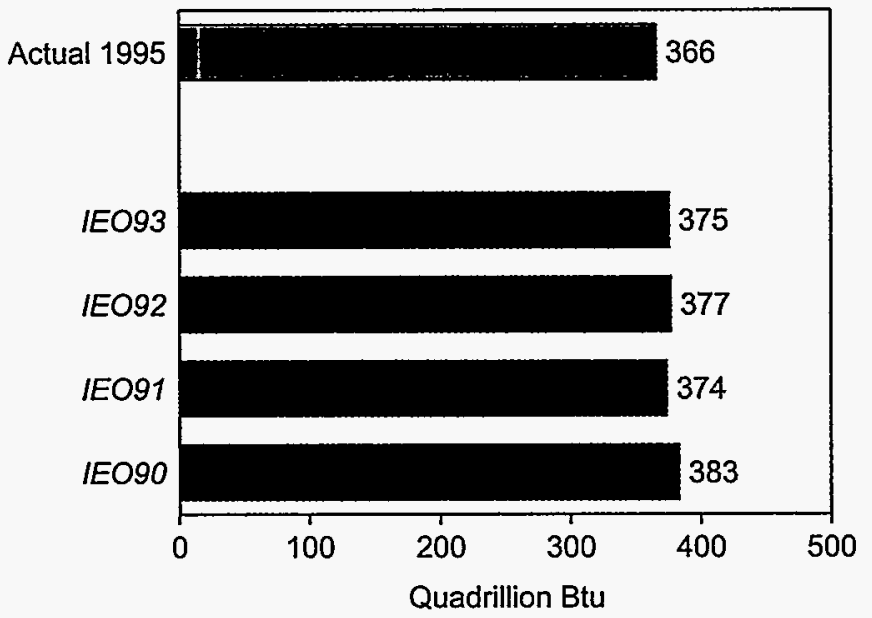

Sources: 1995: Energy Information Administration (EIA), Office of Energy Markets and End Use, International Energy Annual 1996, DOE/EIA-0219(96) (Washington, DC, February 1998). 1995 Projections: EIA, International Energy Outlook, DOE/EIA-0484 (Washington, DC, various years).

consistently higher than the amount actually consumed (Figure 27), primarily because of the unanticipated collapse of the Soviet Union economies. IEO90 projected that the FSU would consume 66 quadrillion Btu, whereas 40 quadrillion Btu of energy was actually consumed. The "other CPE" countries-driven mainly by consumption in the countries of Eastern Europe but also including Cambodia, Cuba, Laos, Mongolia, North Korea, and Vietnam-showed a similar pattern. The magnitude and duration of the economic declines in the FSU were not anticipated, and projections for the region ran about 30 percent higher than actual consumption.

As might be expected, the IEO projections for the use of specific fuels reflect the tendency of the total regional consumption projections to underestimate energy use in the market economies outside the OECD and overestimate energy use in the FSU and "other CPE." For instance, IEO85 underestimated 1995 oil use in the "other developing market economies" by more than 40 percent, and IEO90 overestimated 1995 oil use in the FSU by 84 percent.

It is interesting to consider the forecasts in the historical context that certainly influenced the analytical thinking of the day. For example, IEO85, published after the oil price shocks of the 1973-1974 Arab embargo and the 1979-1980 Iranian revolution but before the Chernobyl nuclear accident of 1986, projected that oil would lose share of total energy consumption in the market economies over the 1985-1995 decade, declining by as much as 5 percentage points as natural gas, coal, and "other fuels" all gained share. Nuclear was expected to be the fastest growing energy source, with a projected growth rate of nearly 4 percent per year.
In reality, the IEO85 forecast for nuclear energy turned out to be fairly accurate. Nuclear power consumption did increase more rapidly than any other energy source in the market economies, at a rate of nearly 5 percent per year between 1985 and 1995. On the other hand, oil use did not decline as projected but maintained a 45 -percent share of energy consumption. The natural gas share grew more slowly than projected, reaching 21 percent of energy consumption in the market economies by 1995, rather than the projected 22-percent share. The largest divergence between projected and actual trends was for coal, which in IEO85 was expected to see increasing use for electricity generation and industrial applications in Western Europe. Those expectations did not materialize. Coal's share of energy consumption in the market economies declined from 21 percent in 1985 to 18 percent in 1995, whereas IEO85 had projected an increase to a 22percent share in 1995.

\section{References}

1. Energy Information Administration, East Asia: The Energy Situation, web site www.eia.doe.gov/emeu/ cabs/ eastasia.html (February 9, 1998).

2. D. Howes, "GM Trails Honda in China Deal," The Detroit News (November 4, 1997).

3. The text of the Kyoto Protocol is available on the Internet through the official web site of the Climate Change Secretariat (www.unfccc.de/index.html).

4. Energy Information Administration, Emissions of Greenhouse Gases in the United States 1996, DOE/EIA0573(96) (Washington, DC, October 1997).

5. Intergovernmental Panel on Climate Change, Climate Change 1995: The Science of Climate Change (Cambridge, UK, Cambridge University Press, 1996), p. 77.

6. W.R. True, "World Pipeline Construction Looks To Remain Robust to Century's Turn," Oil and Gas Journal (February 10, 1997), pp. 36 and 37.

7. "European Union Maps Plans for Major Renewables Expansion," Wind Energy Weekly, Vol. 16, No. 776 (December 8, 1997), pp. 1-2.

8. For an analysis of EIA's record for world oil price forecasts, see S.H. Holte, "Annual Energy Outlook Forecast Evaluation," in Energy Information Administration, Issues in Midterm Analysis and Forecasting 1997, DOE/EIA-0607(97) (Washington, DC, July 1997), pp. 100-101. 


\section{The World Oil Market}

\section{Oil prices are expected to remain relatively low, and resources are not expected to constrain substantial increases in oil demand through 2020. Oil use continues to dominate transportation energy markets.}

In the early 1990s, oil demand was relatively flat: oil consumption worldwide was only 1 million barrels per day higher in 1993 than it was in 1989. Since 1993, however, the world's demand for oil has risen by almost 7 million barrels per day, to 73.7 million barrels per day in 1997 [1]. Nonetheless, oil prices moved down sharply during 1997, falling from the $\$ 23$ to $\$ 24$ range in January to a range of $\$ 18$ to $\$ 19$ per barrel in the fall. Many analysts have lowered their near-term price projections by $\$ 1.00$ or more per barrel over at least the next year. General perceptions are that near-term price risks are more heavily weighted on the down, rather than the up side. This is a sharp reversal of views generally held in early 1997.

Current price movements have not modified EIA's intermediate and long-term price expectations. Three longterm price paths are posited. The reference case price track for this outlook is essentially unchanged from last year's, except that the end year of the projection has been extended to 2020. In that context, the long-term trend in oil prices is assumed to rise slowly in real terms, reaching about $\$ 23.00$ a barrel in 2020 relative to current prices of $\$ 17.00$ and year-end 1996 prices of $\$ 24.00$ (Figure 28).

Figure 28. World Oil Prices in Three Cases, 1970-2020

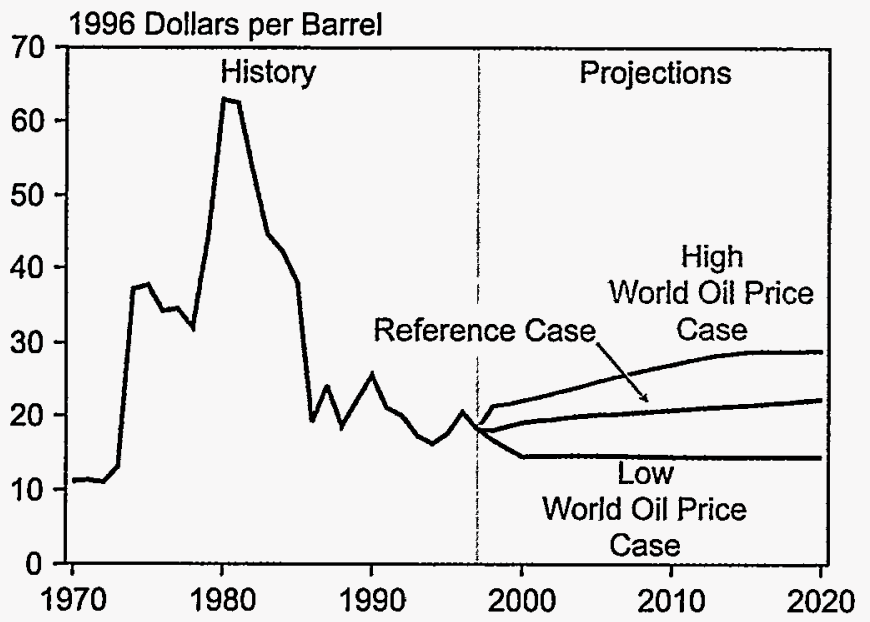

Sources: History: Energy Information Administration (EIA), Annual Energy Review 1996, DOE/EIA-0384(96) (Washington, DC, July 1997). Projections: EIA, Annual Energy Outlook 1998, DOE/EIA-0383(98) (Washington, DC, December 1997).
The reference case projections show large increases in both oil demand and supply. Between 1995 and 2020, oil demand is expected to grow at an average rate of 2 percent per year, resulting in an increase of more than 40 million barrels per day relative to 1997. In 2020, world oil consumption is projected to exceed 115 million barrels per day. A higher or lower oil price track is possible, but the expected range is limited. Over the past 25 years, oil prices have been highly volatile. In the future one can expect volatile behavior to recur principally because of unforeseen political and economic circumstances. It is well recognized that tensions in the Middle East, for example, could easily give rise to serious disruptions in normal oil production and trading patterns. On the other hand, significant excursions from the reference price trajectory are not likely to be long sustained. High real prices deter consumption and encourage the emergence of significant competition from marginal but large sources of oil and non-oil energy supplies. Persistently low prices have the opposite effects.

Limits to long-term oil price escalation include substitution of other fuels (such as natural gas) for oil, marginal sources of conventional oil that become reserves when prices rise, and nonconventional sources of oil that become reserves at still higher prices. Advances in exploration and production technologies bring down the price where these additional resources become part of the reserve base. There are also important limits to the potential range of oil price declines relative to reference case expectations. Lower prices deter investment in exploration and development, causing the expansion of oil supply capabilities to be diminished. At the same time, low prices encourage increased oil use, so that reserves are consumed without being replaced through exploration activity.

It should be noted that, regardless of the IEO98 price scenario, oil demand rises significantly over the projection period. In the high and low world oil price cases, the projected rise in oil consumption ranges from a low of 25 to as much as 60 million barrels per day. There is now widespread agreement that resources are not a key constraint in satisfying increases in world oil demand to 2020. Rather more important are the political, economic, and environmental circumstances conditioning supply and demand development. 
Although there is substantial optimism in long-run expectations for oil markets, current developments suggest potential challenges to demand-supply equilibrium. The onset of recession in Southeast Asia could slow oil demand growth in a region that has accounted for 40 percent of the growth in world oil demand since 1990. On the supply side, the crisis in Iraq, if settled peacefully, could lead to an acceleration of oil exports even as oil prices are in decline. The denomination of allowable Iraqi exports in dollar terms means that as oil prices decline, more physical supply must enter the market. The impact is compounded as the dollar quota is increased. The 1997 United Nations quota permitted exports in the range of 700,000 to 800,000 barrels per day. In February 1998, the quota was more than doubled (from $\$ 2$ billion to $\$ 5.2$ billion in sales for 6 months). At current prices, the implied permitted export volume would exceed current Iraqi supply capabilities, which are estimated at more than 2 million barrels per day [2].

Some analysts argue that still another factor weakening the near-term prospects for oil prices is the recent decision by the Organization of Petroleum Exporting Countries (OPEC) to raise output quotas by 10 percent, from 25 million barrels per day to 27.5 million barrels per day. Within OPEC the move to increase quotas was led by Saudi Arabia. It has been suggested that the initiative signals a determination by Saudi Arabia to improve its share of production in world oil markets. If this were pursued, near-term oil prices would fall. As of this writing, however, Saudi Arabia has not increased production beyond the levels it reached before the quota adjustment. A more benign interpretation of the quota adjustment would be that it was needed to reflect the realities of current production patterns and to develop a framework for coping with future adjustments likely to be necessary as world oil markets continue to grow.

The latter view is one of the underpinnings for the reference case price projection presented in IEO98. Still another important assumption is that the financial downturn now being suffered in countries such as Thailand, Indonesia, Malaysia, and South Korea will not spread to China, India, and other parts of developing Asia. While the short term (1998 through 2000) may see lower GDP, it is expected that in the medium term the economies of these developing countries will recover, and that economic growth in Japan will be typical of the industrialized world.

Highlights of the IEO98 projections for the world oil market are as follows:

- While the economies of the developing Asian countries are currently experiencing a downturn, it is not expected to last long. The mid- to longterm trend appears to be continued economic growth with resultant increases in oil demand. Oil consumption in the developing countries of Asia is projected to grow by 3.8 percent per year, from 11.3 million barrels per day in 1995 to about 28.6 million barrels per day in 2020. The level of consumption projected for 2020 would exceed the projected level of consumption in the United States (24.4 million barrels per day in 2020).

- Enhanced subsea technologies continue to contribute to significant optimism about the longterm potential for offshore oil production. The focus on offshore activity by major oil companies has led to record levels of demand for equipment capable of operating in water depths up to 10,000 feet. Vast areas of offshore West Africa are now considered to be promising sites for future development.

- There is enormous potential for oil production from the Caspian Basin. There are estimated reserves of over 200 billion barrels in the Caspian Basin. Exports from the region, currently less than 1 million barrels per day, could exceed 6 million barrels per day by 2020 .

- OPEC has increased its output quota from 25 to 27.5 million barrels per day. The new quota more closely tracks production levels already achieved in 1997.

- OPEC members outside the Persian Gulf region are expected to improve their market share over the next decade. There is significant potential for offshore oil production in Nigeria, as well as aggressive plans to expand the oil production capacity of Venezuela. Substantial increases in oil output are also expected for Algeria and Indonesia over the next 10 years.

\section{Oil Demand Growth in Industrialized Countries}

Oil demand in the industrialized countries is projected to grow by 1.1 percent per year, from 42.4 million barrels per day in 1995 to 55.3 million barrels per day in 2020 (Figure 29). Although oil is still the most important energy source in the majority of industrialized countries, its share of total energy consumption is expected to drop by 2 percentage points (from 43 to 41 percent) over the 1995 to 2020 period. The decline reflects a continuation of trends in Europe, Japan, North America, and other countries, in which newer technologies use oil more efficiently and natural gas and other energy sources replace oil for many uses. The major portion of oil's growth within industrialized economies is in fuels used for transportation, where it has no substantial competition. 
Figure 29. Oil Demand in Industrialized Countries, 1970, 1995, and 2020

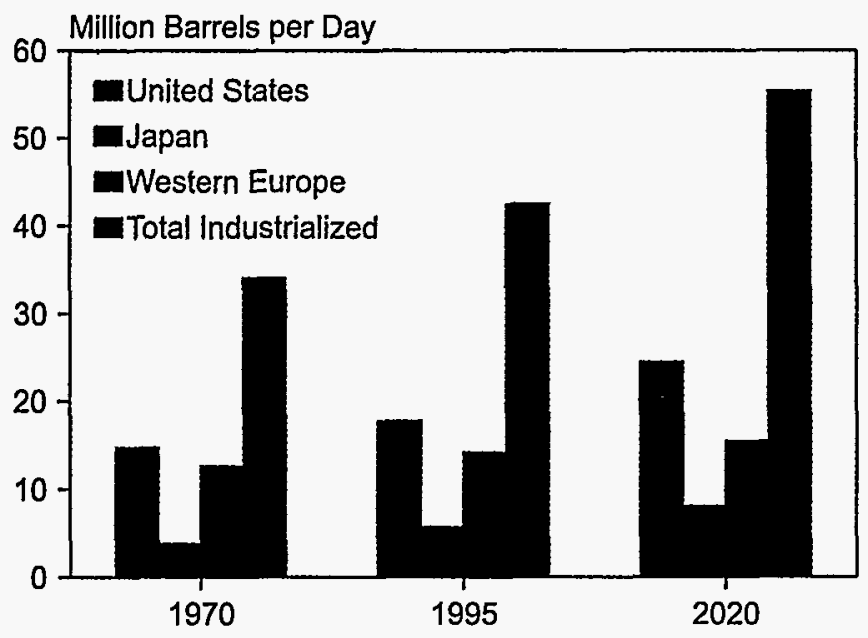

Sources: 1970 and 1995: Energy Information Administration (EIA), Office of Energy Markets and End Use, International Statistics Database and International Energy Annual 1996, DOE/EIA-0219(96) (Washington, DC, February 1998). 2020: EIA, World Energy Projection System (1998).

The industrialized countries in 1995 accounted for almost two-thirds of total world oil demand, whereas over the next two decades they are expected to account for only one-third of the increase in demand. The reference case projection anticipates about 55 million barrels per day of oil demand in 2020 for the industrialized countries, up by almost 13 million barrels per day from 1995. North America-the United States, Canada, and Mexico-is expected to account for 8.4 million barrels per day of incremental demand. The projected growth in U.S. oil demand is the slowest within North America (1.3 percent per year). U.S. consumption in 2020 is expected to be nearly 6.7 million barrels per day higher than 1995 levels. Mexico has the highest projected percentage increase in North America (2.3 percent per year), primarily because economic growth is expected to proceed at twice the rate of growth for the United States and Canada.

Oil demand in industrialized Asia is projected to rise from 7 million barrels per day in 1995 to 10 million in 2020. The reference case projection is more uncertain for Japan than for North America because of its close ties to countries currently experiencing currency and debt difficulties.

The slowest growth in oil use is projected for Western Europe, where overall oil demand is expected to rise by less than 2 million barrels per day from 1995 to 2020 . Oil use for power generation and home heating is declining and being replaced by natural gas throughout the region. Oil is also losing market share to natural gas and electricity in many industrial energy uses. In addition, energy-intensive industries are beginning to be replaced by service industries, which are more likely to use natural gas and electricity than oil.

A looming uncertainty not addressed in IEO98 relates to consequences that may flow from commitments under the Kyoto Protocol. In North America, half of all growth in carbon emissions in the IEO98 projections is associated with increased use of oil, especially in transportation. The Kyoto initiatives could prompt changes in the fuel use characteristics of motor vehicles, with the possibility that as much as 8 million barrels per day of oil demand growth could be curtailed.

It should be noted that the IEO98 projections for U.S. oil demand reflect an upward revision relative to those presented in IEO97. Key forces driving that revision were relatively low oil prices and rising personal income, which encourage consumers to travel more and to travel in larger and less fuel-efficient vehicles.

\section{Oil Demand Growth in Nonindustrialized Countries}

In developing countries, the increase in oil demand between 1995 and 2020 in the reference case is more than 29 million barrels per day. The major impetus to growth is expected from Asia. Oil consumption in the developing countries of Asia is projected to grow by 3.8 percent per year, from 11.3 million barrels per day in 1995 to about 28.6 million barrels per day in 2020 (Figure 30).

Figure 30. Nonindustrialized Oil Demand by Region, 1970, 1995, and 2020

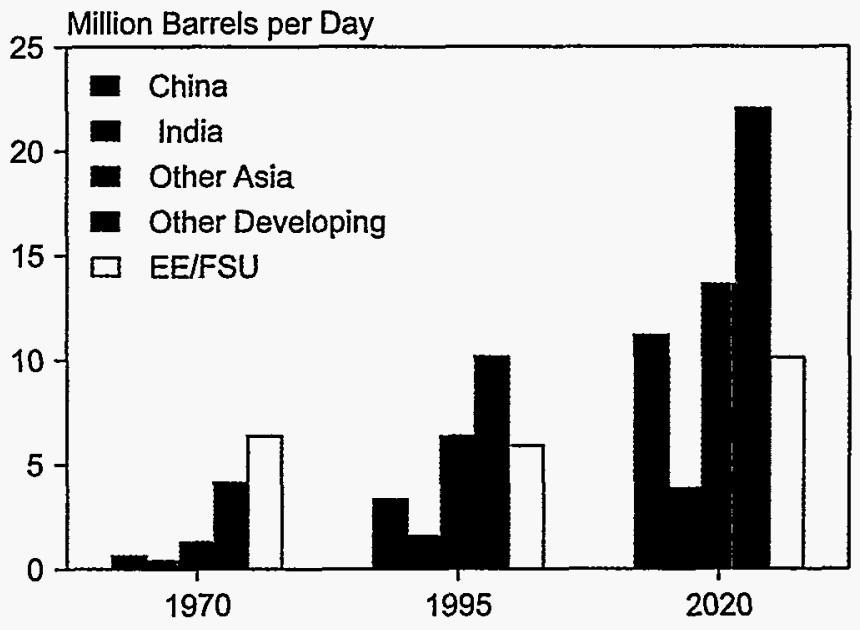

Sources: 1970 and 1995: Energy Information Administration (EIA), Office of Energy Markets and End Use, International Statistics Database and International Energy Annual 1996, DOE/EIA-0219(96) (Washington, DC, February 1998). 2020: ElA, World Energy Projection System (1998).

The developing economies of Asia will become a dominant force on the demand side of the world oil market over the projection period. The region's oil demand in 
the year 2000 is expected to average 13.3 million barrels per day-close to Western Europe's 14.3 million barrels per day-and its expected level of 28.6 million barrels per day in 2020 is greater than the projected consumption in the United States (24.4 million barrels per day). High rates of economic growth and rising standards of living drive these expectations.

In China, oil consumption is expected to grow at an average rate of 5.0 percent per year from 1995 to 2020, with oil consumption tripling (Figure 30). As compared with 19 percent in 1995, oil is expected to account for 21 percent of China's total energy consumption in 2020. The potential for oil demand growth in China is large, given its huge population, its potential for sustained long-term economic growth, and the characteristics of its transportation sector, as discussed below.

The transportation sector in China is underdeveloped relative to other economic sectors and has a substantial rail component. The rail system depends heavily on coal-fired engines but is switching to diesel or electric engines, which will lead to some increase in the demand for oil. More importantly, road transportation in China is limited, both for freight hauling and for personal travel, and is likely to develop rapidly in the future. The increase in demand for motor fuels will lead to an increase in the use of lighter petroleum products in China. The industrial sector will continue to be dominated by coal, but moderate growth in oil use is expected. Increases in oil use for heating and cooking are also expected in the residential and commercial sectors.

In India, where GDP growth is expected to be slower than China's, growth in oil demand is projected to average 3.6 percent per year between 1995 and 2020 (compared with 5.0 percent per year in China). India currently imports refined petroleum products, as well as crude oil to feed domestic refineries. Its import requirement for petroleum products is expected to grow until new refining capacity comes on stream, at which time the import emphasis will switch from products to crude oil.

If the future growth of oil demand in China and India were to match the historical rate for South Korea, the IEO98 projection could be low by several tens of millions of barrels per day. Although high growth rates in oil use are projected for China and India in the reference case, the rates are much lower than those seen in the recent past for the rapidly growing economies of Indonesia, Malaysia, South Korea, Taiwan, and Thailand. In South Korea, for example, oil consumption grew at an average rate of 13.5 percent per year from 1985 to 1995, and in 1995 the country's annual oil consumption was 16.5 barrels per capita [3]. In China and India, oil consumption currently is less than 1 barrel per capita annually, even though their usage levels have increased by 77 percent and 76 percent, respectively, since 1985. Oil demand is highly income-elastic, especially in countries like China and India, which have underdeveloped personal transportation systems but 38 percent of the world's population.

Substantial growth in oil demand is also anticipated outside Asia, in other developing regions. In Central and South America, oil consumption is expected to more than double between 1995 to 2020. Following the reforms in government policies led by developments in Argentina and Chile, substantial economic growth is projected-twice the rate for developed economies. Such growth (4.3 percent annually) can promote improvements in living standards and, in concert, strong increases in demand for energy and oil-using products. In this region, large increases in transportation fuel use can be expected, and demand for nontransportation uses will also grow. While the share of baseload electricity generation fueled by oil will decrease, oil consumption in the electricity sector is projected to increase in absolute terms, primarily in remote areas and for peak load generation. Large investments are being made in gas and electricity transmission in Central and South America, and a significant portion of incremental power generation is expected to rely on natural gas; however, diesel-fired combustion turbines will continue to be used to satisfy a significant portion of the region's demand for electric power.

The reference case projection for Eastern Europe and the former Soviet union (EE/FSU) depicts a near doubling of oil demand between 1995 and 2020, which would return consumption levels to those last seen in 1990, before economic depression befell the region. Signs of economic recovery are now clearly evident in Eastern Europe, with growth in GDP at 4 percent or more per year. For the FSU, 1997 appears to mark the beginning of economic turnaround, and average annual growth of about 3.5 percent is projected through 2020 . Still, oil demand projections for the EE/FSU region are highly uncertain. Obvious uncertainties relate to privatization and the institution of market-based economic reforms, which if successful would increase per capita incomes. As in Asia, there is a strong potential for oil demand beyond that currently projected, especially in relation to personal transportation, if reforms are successful.

\section{Oil Demand and Transportation}

In developed countries, the bulk of oil demand and the prospective growth in demand are associated with transportation. Oil price shocks in the 1970s drove efforts to substitute other fuels for oil, an objective largely achieved except in the provision of transportation services. With high vehicle ownership rates, per capita oil use for transportation tends to be high in the industrialized nations: about 15 barrels per person per 
year. Not much growth in total per capita oil use is expected, however, and thus oil demand in industrialized countries tends to increase mostly in proportion to population. 4

The greatest potential for growth in transportation energy demand is in the developing world. The largest increase is projected for China, where oil use for transportation rises from about 1 million barrels per day in 1995 to 3.5 in 2020, an increase of 250 percent (Figure 31). For India, the projected increase is 1.2 million barrels per day, or 165 percent; and for the rest of developing Asia combined, transportation oil use grows from about 2.7 million barrels per day to 6.6 million barrels per day, an increase of 3.9 million barrels or 144 percent. Because vehicle ownership rates can have a large impact on transportation energy demand, the following discussion focuses on the implications of rising vehicle ownership rates for oil demand, particularly in developing countries.

Figure 31. Oil Demand for Transportation in Developing Asia, 1995-2020

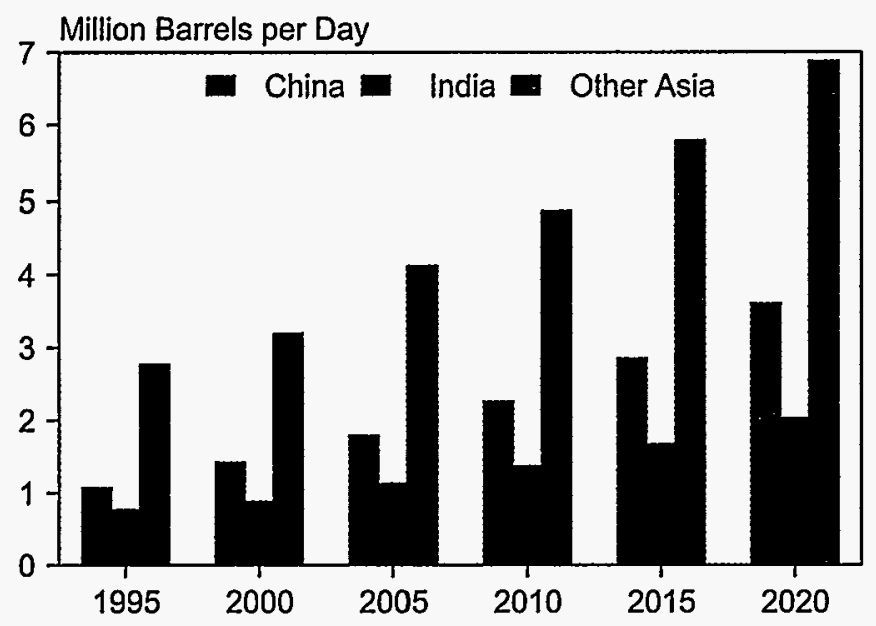

Sources: 1995: Derived from Energy Information Administration (EIA), Office of Energy Markets and End Use, International Energy Annual 1996, DOE/EIA-0219(96) (Washington, DC, February 1998). Projections: EIA, World Energy Projection System (1998).

Despite recent turmoil in the economies of developing Asia, the potential for long-term growth in transportation demand is the greatest in this region. Until late in 1997 these economies had been growing by more than 8 percent a year. Increasing business and industrial activity as well as increasing household incomes and growing urban populations have led to a rising demand for transportation. In 1995, transportation energy demand in developing Asia was 9.6 quadrillion Btu, accounting for 13.4 percent of total energy consumption. By 2020, transportation energy demand for the region is projected to surpass 26 quadrillion Btu, nearly half of which will be in China and India. The primary reason for the rapid growth is the increasing motorization of Asia (Figure 32) as a result of projected robust economic growth in the medium to long term.

\section{Figure 32. Vehicle Stocks in Selected Developing Asian Countries, 1975-1995}

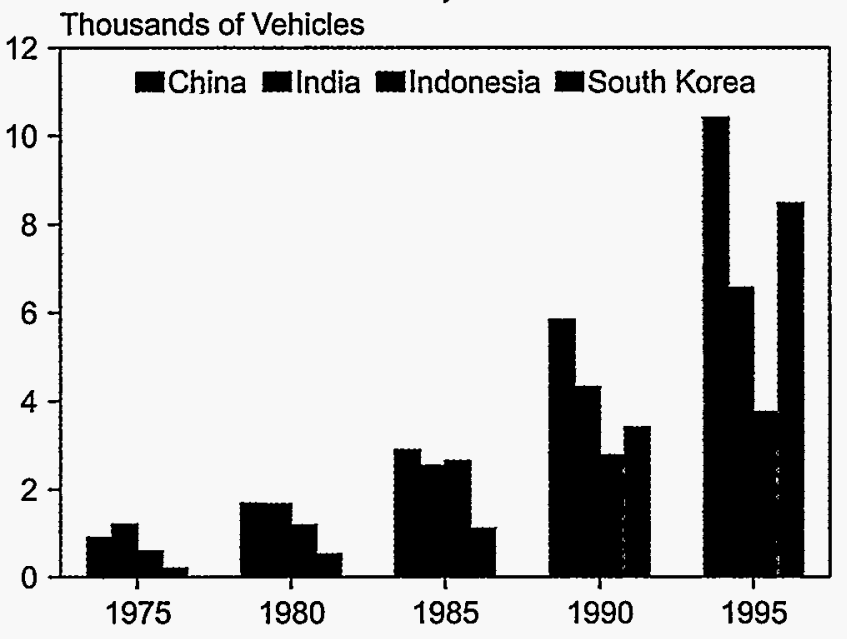

Source: American Automobile Manufacturers Association, World Motor Vehicle Data 1997 (Detroit, Ml, 1997).

Passenger car ownership rates differ among the countries of developing Asia. South Korea has a passenger car density of 132 cars per 1,000 inhabitants; both China and India have rates of approximately 3 to 4 cars per 1,000 inhabitants [4]. Between 1994 and 1995, new car registration grew by almost 40 percent in China, India, and Malaysia. By 2015, China is projected to have 51 million cars and India 16 million [5].

Rapid growth in vehicle ownership rates has been seen in many countries as income per capita has risen. When incomes rise above subsistence levels, demand for vehicle ownership tends to be highly income-elastic [5, pp. 12-13], as demonstrated by the legendary traffic jams of Bangkok, Manila, Mexico City, and elsewhere. From 1960 to 1973, the ratio of vehicles to population grew by 24 percent per year in Japan and by 19 and 14 percent, respectively, in Spain and Italy. In South Korea, the ratio increased by 16 percent per year between 1970 and 1991. If China sustains a growth rate in vehicle ownership of 10 percent per year for the next two decades, its vehicle population will approximate the U.S. vehicle population by 2015 . Even at that rate, however, China would have

${ }^{4}$ In the industrialized countries (especially the United States), several important trends have been influencing the personal car market and, consequently, energy consumption. More powerful engines and cars with increased safety and luxury features reduce average gas mileage and cause overall fuel consumption to rise. The trend has been somewhat offset by technological advances that have allowed increased horsepower while maintaining better gas mileage than would have been the case in the past. The switch to light-duty trucks and sport utility vehicles, which are less fuel efficient than ordinary passenger cars, has also hurt average gas mileage. Finally, people are quite simply driving their cars more. Years of stable and relatively low gasoline and diesel fuel prices, coupled with increasing incomes in industrialized countries, has meant more people driving more miles and therefore increased energy consumption. 
fewer vehicles per capita in 2015 than Japan and South Korea have already [5, p. 25]. In 1970, 44 percent of the world vehicle population was in the United States, but by 1995 the U.S. share had dropped to 31 percent, even though U.S. vehicle ownership had nearly doubled (Figure 33).

Figure 33. U.S. and Total World Vehicle Fleets, 1970-1995

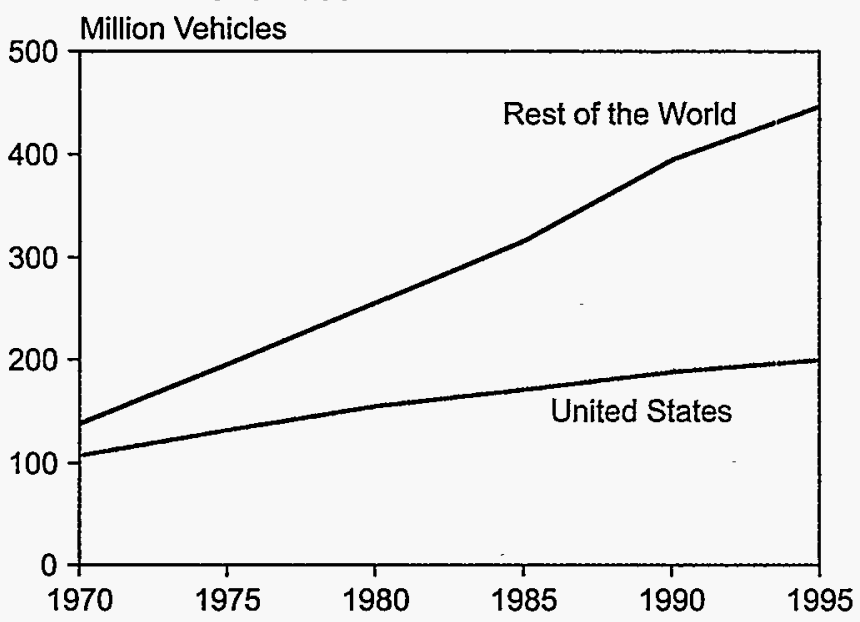

Source: American Automobile Manufacturers Association, World Motor Vehicle Data 1997 (Detroit, Ml, 1997).

Figure 34 shows vehicle ownership rates for selected industrialized countries. Figure 35 reports on regions of the developing world and Russia. Industrialization, with higher per capita incomes, appears to give rise to vehicle ownership rates which are orders of magnitude greater than now evident in emerging economies. Thus, sustained economic growth is likely to drive large increases in petroleum demand, given current fuel use technologies for motor vehicles.

Figure 34. Vehicle Ownership in Selected Industrialized Countries, 1995

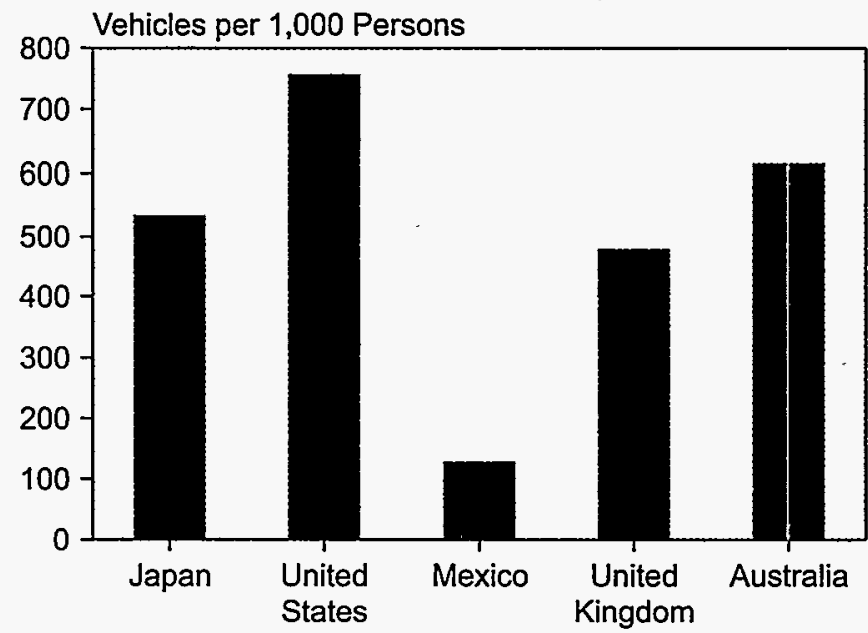

Source: American Automobile Manufacturers Association, World Motor Vehicle Data 1997 (Detroit, MI, 1997).

\section{The Composition of World Oil Supply}

The IEO98 reference case projects an increase in world oil supply of 40 million barrels per day over the next 25 years. Gains in production are expected for both OPEC and non-OPEC regions; however, only one-fourth of the production rise is expected to come from non-OPEC areas. Over the past two decades, the growth in nonOPEC oil supply has eroded OPEC's market share, and the long-term outlook for non-OPEC supply remains optimistic even in the face of lower world oil prices. New exploration and production technologies, aggressive cost-reduction programs by industry, and attractive fiscal terms to producers by governments all contribute to the outlook for continued growth in non-OPEC oil production.

On the other hand, the reference case projection anticipates that as much as three-fourths of the increase in demand over the next two decades will be met by increases in production by members of OPEC rather than by non-OPEC suppliers. OPEC production capacity in 2020 is projected to be more than 32 million barrels per day higher than it was in 1996 (Figure 36). Some analysts suggest that OPEC might prefer and pursue significant price escalation through conservative capacity expansion decisions rather than undertaking such an ambitious production expansion effort. The view presented in this outlook discounts such an expectation.

\section{Expansion of OPEC Production Capacity}

There is general agreement that OPEC members with large reserves and relatively low production capacity expansion costs can accommodate sizable increases in

Figure 35. Vehicle Ownership in Nonindustrialized Regions, 1995

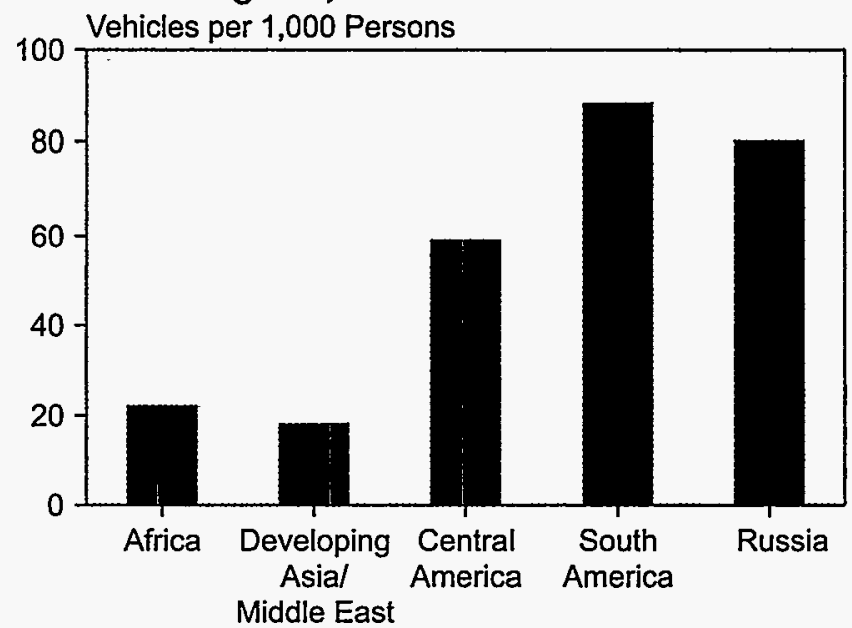

Source: American Automobile Manufacturers Association, World Motor Vehicle Data 1997 (Detroit, MI, 1997). 
petroleum demand. In the IEO98 reference case, the production call on OPEC producers grows at a robust annual rate of 3.1 percent (Table 11 and Figure 37). With the expected growth in demand, especially in the developing countries of the Pacific Rim, OPEC capacity utilization is expected to increase sharply after 2000, reaching 95 percent by 2010 and remaining there for the duration of the forecast period.

Given the requirements for OPEC production capacity expansion implied by the IEO98 estimates, much attention has been focused on the oil development, production, and operating costs of individual OPEC producers.

\section{Figure 36. World Oil Production in the Reference Case by Region, 1970-2020}

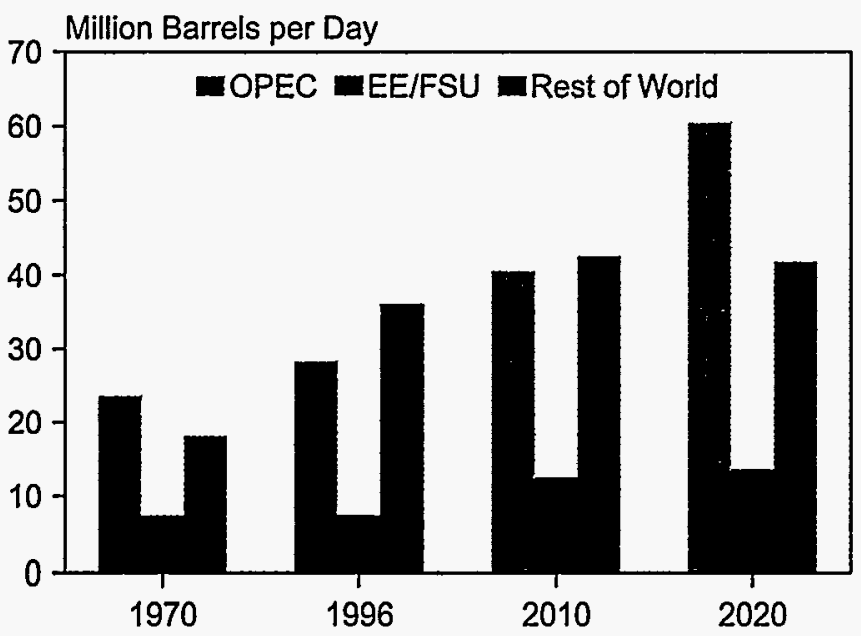

Sources: 1970-1979: Energy Information Administration (EIA), Office of Energy Markets and End Use, International Statistics Database. 1980-1996: EIA, International Energy Annual 1996, DOE/EIA-0219(96) (Washington, DC, February 1998). Projections: EIA, World Energy Projection System (1998).

Table 11. OPEC Oil Production, 1990-2020 (Million Barrels per Day)

\begin{tabular}{|c|c|c|c|}
\hline Year & $\begin{array}{c}\text { Reference } \\
\text { Case }\end{array}$ & $\begin{array}{c}\text { High } \\
\text { Oil Price }\end{array}$ & $\begin{array}{c}\text { Low } \\
\text { Oil Price }\end{array}$ \\
\hline \multicolumn{4}{|l|}{ History . } \\
\hline 1990 & 24.5 & - & - \\
\hline $1996 \ldots \ldots$ & 28.3 & - & - \\
\hline \multicolumn{4}{|l|}{ Projections. . } \\
\hline $2000 \ldots \ldots$ & 29.9 & 28.2 & 32.1 \\
\hline $2005 \ldots \ldots$ & 34.3 & 30.9 & 39.9 \\
\hline $2010 \ldots \ldots$ & 40.6 & 35.3 & 48.8 \\
\hline $2015 \ldots \ldots$ & 49.9 & 42.6 & 60.2 \\
\hline $2020 \ldots \ldots \ldots$ & 60.5 & 52.5 & 72.9 \\
\hline
\end{tabular}

Note: Includes the production of crude oil, natural gas plant liquids, refinery gain, and other liquid fuels.

Sources: History: Energy Information Administration (EIA), International Petroleum Statistics Report, DOE/EIA0520(97/12) (Washington, DC, December 1997), Table 1.4. Projections: EIA, World Energy Projection System (1998).
Figure 37. OPEC Oil Production in Three Oil Price Cases, 1970-2020

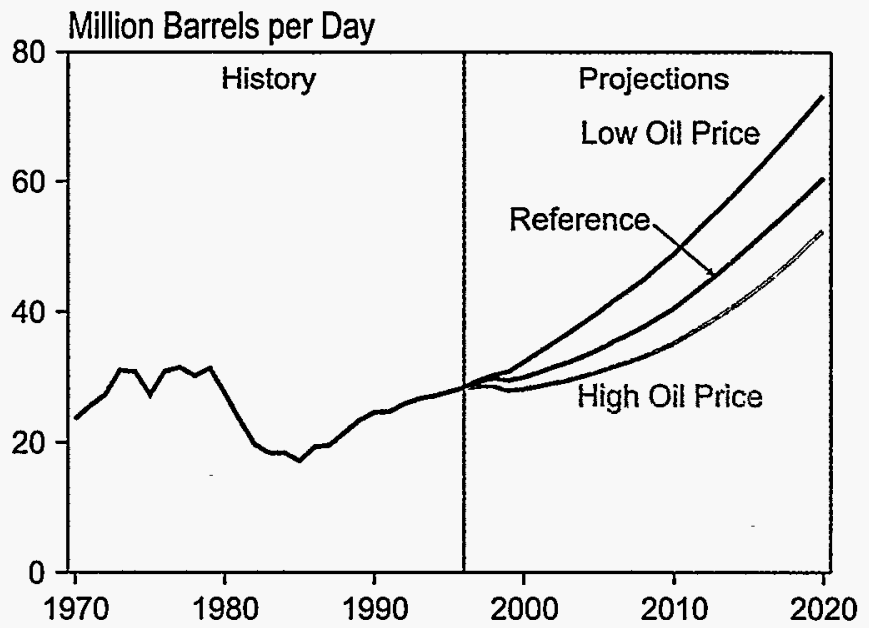

Sources: 1970-1979: Energy Information Administration (EIA), Office of Energy Markets and End Use, International Statistics Database. 1980-1996: EIA, International Energy Annual 1996, DOE/EIA-0219(96) (Washington, DC, February 1998). Projections: EIA, World Energy Projection System (1998).

With the reserve-to-production ratio of Persian Gulf producers exceeding 80 years, significant capacity expansion is obviously feasible.

The cost to produce a barrel of oil in Persian Gulf OPEC nations ranges between $\$ 0.99$ and $\$ 1.49$ per barrel, depending on field size. The capital investment required to increase production capacity by 1 barrel per day in Persian Gulf OPEC nations ranges between $\$ 2,525$ and $\$ 4,866$ [6], also depending on field size. Assuming the IEO98 low price case and mid-size fields only, total development and operating costs over the entire forecast period as a percentage of gross revenues range only between 15 and 20 percent. Thus, for the Persian Gulf producers, the total cost of capacity expansion is a relatively small percentage of projected gross revenue even in the low price case.

For OPEC producers outside the Persian Gulf, the cost to expand production capacity by 1 barrel per day is considerably greater, ranging from $\$ 7,610$ (Indonesia) to $\$ 10,240$ (Venezuela). Nevertheless, even this group of producers can expect margins in excess of 40 percent on investments to expand production capacity over the long term in the low price case [7]. Venezuela has the greatest potential for capacity expansion and has already announced plans to increase its production capacity to 4.5 million barrels per day by 2005 . Tables A40-A47 in Appendix A show the ranges of production potential for both OPEC and non-OPEC producers.

The reference case projection implies aggressive efforts by OPEC to apply or attract investment capital to implement a wide range of production capacity expansion projects. If those projects were not undertaken, world oil 
prices could escalate; however, the combination of potential profitability and the threat of competition from non-OPEC suppliers argues for the pursuit of an aggressive expansion strategy.

In IEO98, the projections for oil production from OPEC members outside the Persian Gulf have been bolstered somewhat over the IEO97 projections. Recent discoveries of significant Nigerian offshore production potential, as well as increased optimism with regard to Algerian, Indonesian, and Venezuelan output, have contributed to this reassessment. OPEC production outside the Persian Gulf is expected to increase by at least 1 million barrels per day early in the next century and continue for the duration of the forecast period. As a result, the world's projected dependence on Persian Gulf oil is 3 to 5 percent lower than was projected in IEO97.

\section{Non-OPEC Supply}

The growth in non-OPEC oil supplies has eroded OPEC's market share over the past two decades. During that period, non-OPEC oil supply has become increasingly diverse. North America dominated non-OPEC supply in the early 1970s, the North Sea and Mexico emerged as major producers in the 1980s, and much of the new production in the 1990s has come from developing countries. In the IEO98 reference case, non-OPEC supply from proven reserves is expected to increase steadily, from 43.5 million barrels per day in 1996 to 55.3 million in 2020 (Table 12).

Table 12. Non-OPEC Oil Production, 1990-2020 (Million Barrels per Day)

\begin{tabular}{|c|c|c|c|}
\hline Year & $\begin{array}{l}\text { Reference } \\
\text { Case }\end{array}$ & $\begin{array}{c}\text { High } \\
\text { Oil Price }\end{array}$ & $\begin{array}{c}\text { Low } \\
\text { Oil Price }\end{array}$ \\
\hline \multicolumn{4}{|l|}{ History } \\
\hline 1990. & 42.2 & - & - \\
\hline $1996 .$. & 43.5 & - & - \\
\hline \multicolumn{4}{|l|}{ Projections. } \\
\hline $2000 \ldots$ & 47.3 & 47.9 & 46.6 \\
\hline 2005. & 52.0 & 53.0 & 50.2 \\
\hline 2010 . & 55.0 & 56.7 & 52.6 \\
\hline 2015 & 55.2 & 57.6 & 52.5 \\
\hline 2020 . & 55.3 & 57.7 & 52.4 \\
\hline
\end{tabular}

Note: Includes the production of crude oil, natural gas plant liquids, refinery gain, and other liquid fuels.

Sources: History: Energy Information Administration (EIA), International Petroleum Statistics Report, DOE/EIA0520(97/12) (Washington, DC, December 1997), Table 1.4. Projections: ElA, World Energy Projection System (1998).

There are several important differences between the IEO98 production profiles and those published in IEO97:
- U.S. production does not decline as severely in the IEO98 projections, as a result of technological advances and increased offshore Texas Gulf production.

- North Sea production does not peak until after 2000 and is more than 1 million barrels per day higher in IEO98, as a result of enhanced subsea technology.

- Projected production from the former Soviet Union is some 2 million barrels per day higher in 2015 in IEO98, as a result of increased optimism about the oil resources of the Caspian Basin. Political uncertainty still remains a potential barrier to the development of the region's vast resources.

- The production outlook for the developing countries of Africa is more optimistic by at least 1 million barrels per day in IEO98, as a result of significant West African offshore finds.

In the IEO98 forecast, North Sea production reaches a peak in 2003, exceeding 7.6 million barrels per day. Production from Norway, Western Europe's largest producer, is expected to peak at about 3.8 million barrels per day in 2003 and then gradually decline to about 3.1 million barrels per day by the end of the forecast period with the maturing of some of its larger and older fields. The United Kingdom sector is expected to produce about 3.6 million barrels per day early in the next decade, followed by a decline to about 2.3 million barrels per day in 2020.

Two non-OPEC Persian Gulf producers are expected to increase output gradually into the beginning of the next decade. Enhanced recovery techniques are expected to increase current output in Oman by about 40,000 barrels per day, and only a modest decline in production is anticipated beyond 2005. Current oil production in Yemen could increase by almost 100,000 barrels per day early in the next century, and those levels could be maintained throughout the forecast period. Syria's production is expected to show a steady decline.

Oil producers in the Far East are beginning to reap the benefits of enhanced exploration and production technologies. India is expected to show a modest production increase into the next decade and exhibit very little decline in output thereafter. Deepwater fields offshore from the Philippines are expected to produce in excess of 200,000 barrels per day by the year 2000 . There has been much optimism about the long-term production potential for Vietnam, where output is projected to exceed 450,000 barrels per day by 2020 . Australian production is expected to peak at about 870,000 barrels per day in the 
early years of the next decade, but enhanced production technologies will temper the production declines somewhat after 2005. Malaysia's output will peak at about 810,000 barrels per day by the turn of the century and gradually decline to about 650,000 barrels per day by 2020 . Exploration and test-well activity have indicated some production potential for Bangladesh and Mongolia, but significant output is not expected until the turn of the century.

Central and South America's producers have significant potential for increasing output over the next decade. By the turn of the century, both Brazil and Colombia will have joined the relatively short list of worldwide producers whose output exceeds 1 million barrels per day. Colombia's output is projected to reach almost $1.3 \mathrm{mil}-$ lion barrels per day early in the next decade and to remain at that level through 2020. Brazil is viewed as having vast untapped production potential and, given a favorable climate for attracting foreign investment, could exceed 1.8 million barrels per day by 2020 . Argentina is expected to raise its production levels modestly out to the end of this decade, and former OPEC member Ecuador is expected to increase its production capacity to allow additional output of more than 100,000 barrels per day.

West African producers Angola, Congo Brazzaville, and Congo Kinshasa will reap the benefits of substantial offshore exploration activity and combine for an additional 700,000 barrels per day in output in the early part of the next decade. Production levels are expected to increase modestly for the remainder of the forecast period. North African producers Tunisia and Egypt produce from mainly mature fields, which are likely to be in gradual decline after 2000. Chad and the Sudan are expected to combine for 600,000 barrels per day of output by the turn of the century. Other African producers with output potential beyond 2000 include the Ivory Coast, Equatorial Guinea, Somalia, and South Africa.

For North America, the falling U.S. output is more than offset by production increases from Canada and Mexico. Canada's output is expected to increase by 200,000 barrels per day by the end of the decade, mainly from Newfoundland's Hibernia oil project, which could produce 140,000 barrels per day at its peak, some time near the turn of the century. Canada will add an additional 500,000 barrels per day in output from a combination of frontier area offshore projects and oil from tar sands. Offshore discoveries in the Gulf of Mexico, incremental Alaskan production from Cook Inlet, and technological advances in production methods will temper the decline in U.S. production. In Mexico, with the continuation of government energy policies that encourage the efficient development of its vast resource base, production volumes are expected to reach 4 million barrels per day by
2005 and hold at that level for the remainder of the forecast period.

Oil production in the former Soviet Union is expected to reach 9.5 million barrels per day by 2005 and to exceed 13.1 million barrels per day by 2020 . Thus, by the end of the forecast period, the FSU would be a net exporter of almost 5.7 million barrels per day. Much of the export potential for the FSU region is in the resource-rich Caspian Basin (see box). While China's output is expected to increase steadily, to more than 3.6 million barrels per day by 2015, it will find itself importing large volumes of petroleum to meet its burgeoning domestic demand.

The IEO98 estimates of non-OPEC oil production are based on such parameters as numbers of exploration wells, finding rates, reserve-to-production ratios, advances in both exploration and production technologies, and world oil prices. Non-OPEC production potential could be significantly greater if no constraints were placed on the exploration and development of undiscovered resources. For the IEO98 reference case, low oil price, and high oil price assessments, it was assumed that no more than 15 percent of the mean U.S. Geological Survey (USGS) estimate of undiscovered oil would be developed over the forecast period. Tables A40-A47 in Appendix A show the ranges of production potential for both OPEC and non-OPEC producers.

\section{High Non-OPEC Supply Case}

For non-OPEC production potential, the world oil price is the only variable across the low price, reference, and high price cases. As a result, the range of non-OPEC supply projections is modest, varying by only slightly more than 5.2 million barrels per day at the end of the forecast period. A fourth view of non-OPEC production-the high non-OPEC supply case-was therefore provided, assuming that some portion of the undiscovered oil (based on USGS estimates) in non-OPEC nations will be developed and produced before 2020 .

The high non-OPEC supply case was developed from the following assumptions:

- World oil prices are the same as in the reference case.

- U.S. production is the same as in the reference case.

- The estimates of undiscovered oil in the former Soviet Union, Latin America, and West Africa are higher than in the reference case, reflecting increased optimism about the production potential of offshore fields. 


\section{Caspian Basin Oil Production Potential}

The Caspian Basin is an area of vast resource potential. Only the United States and Saudi Arabia are thought to have more ultimately recoverable conventional oil resources, and only the United States, Russia, and Iran are thought to have more ultimately recoverable conventional natural gas resources. Three of the independent states of the former Soviet Union-Azerbaijan, Kazakhstan, and Turkmenistan-have the greatest oil production potential in the Caspian Sea region. Russia, Uzbekistan, and Iran have lesser potential.

Proven oil reserves are those quantities for which geological and engineering evidence indicates a reasonable certainty for recovery under current economic and technological conditions. The concept of potential oil resources is much more speculative, based on seismic and other tests as opposed to actual drilling. Caspian Basin oil resource estimates are shown in the following table.

\section{Oil Resources in the Caspian Sea Region (Billion Barrels)}

\begin{tabular}{c|ccc|c} 
Country & $\begin{array}{c}\text { Proven } \\
\text { Reserves }\end{array}$ & $\begin{array}{c}\text { Potential } \\
\text { Resources }\end{array}$ & $\begin{array}{c}\text { Total } \\
\text { Resources }\end{array}$ \\
\hline Azerbaijan. . . . & 12.5 & 32 & 45 \\
Iran . . . . . . & 0.1 & 15 & 15 \\
Kazakhstan . . . & 17.6 & 92 & 110 \\
Russia. . . . . . & 0.3 & 7 & 7 \\
Turkmenistan . . & 1.7 & 38 & 40 \\
Uzbekistan . . . & 0.3 & 2 & 2 \\
Total. . . . . & 32.5 & 186 & 218 \\
\hline
\end{tabular}

Source: "DESTINY" International Energy Forecast Software (Houston, TX: Petroconsultants, 1998).

The development of transportation infrastructures is key to enabling the Caspian region to join the ranks of major suppliers in world oil trade (see Appendix C). Azerbaijan, Kazakhstan, and Turkmenistan are surrounded by other countries and cannot get oil to market without crossing someone else's territory.
Currently, Caspian oil, in relatively small quantities, is able to flow through pipelines into Russia. By the end of this decade, several pipeline routes to the Black Sea are expected to become available. After the turn of the century, significantly larger volumes are expected to flow via pipeline through Turkey to the Mediterranean Sea and across Iran to the Persian Gulf. Even China has indicated interest in obtaining supplies by pipeline for its use [8].

Access to Caspian oil is a function of several difficult geopolitical issues, including ownership of the resources; financing the exploration, production, and distribution of the oil; and environmental concerns. The manner in which these issues are resolved, whether adversarial or cooperative, will determine how quickly oil from the Caspian Basin penetrates world markets. IEO98 takes an optimistic view of the potential for both production and exports of Caspian oil, as shown in the chart below.

\section{Caspian Sea Region Oil Production and Export Potential, 1990-2020}

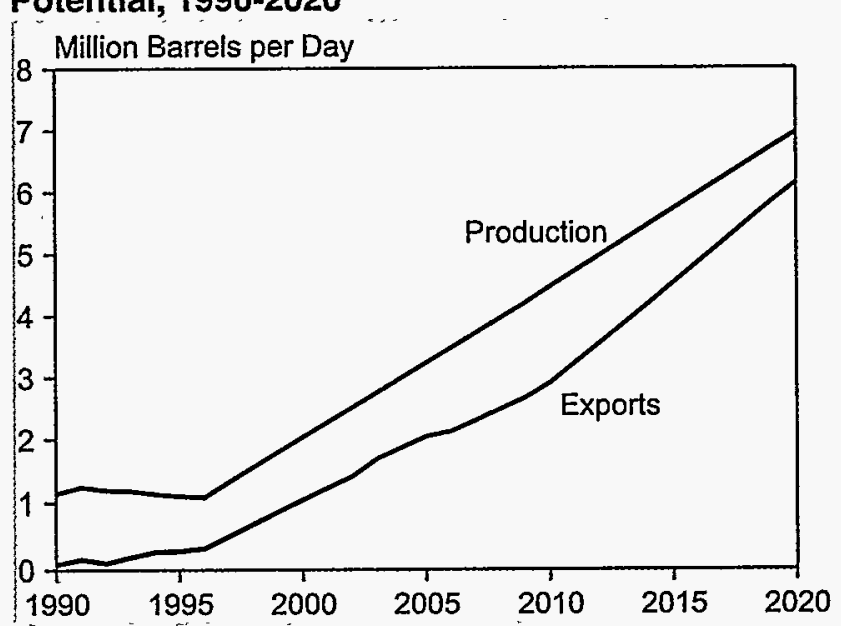

Source: "DESTINY" International Energy Forecast Software (Houston, TX: Petroconsultants, 1998).
- One-third of the world's undiscovered oil is considered economical to develop over the forecast period.

- Technology improvements over the forecast period are assumed to be transferrable worldwide.

- It is assumed that no institutional barriers will constrain production.

- A reserve-to-production ratio of 15 years (slightly less than the current non-OPEC ratio) is used as a lower bound for production estimates.
Figure 38 compares OPEC and non-OPEC production estimates in the reference and high non-OPEC supply cases. In the high case, the annual growth rate for nonOPEC production is projected to be 1.4 percent, compared with 1.0 percent in the reference case. Non-OPEC production reaches a peak of 60.5 million barrels per day in the high case in 2020, compared with 55.4 million barrels per day in the reference case. Figure 39 compares peak production levels for six non-OPEC regions in the reference and high non-OPEC supply cases.

In the reference case, OPEC production peaks at 60.5 million barrels per day, and the OPEC share of 
worldwide production does not begin to exceed that of non-OPEC suppliers until 2018. In the high non-OPEC supply case, OPEC production peaks at 55.3 million barrels per day and never assumes the majority market share over the forecast period.

Figure 38. OPEC and Non-OPEC Oil Production in Two Cases, 1990-2020

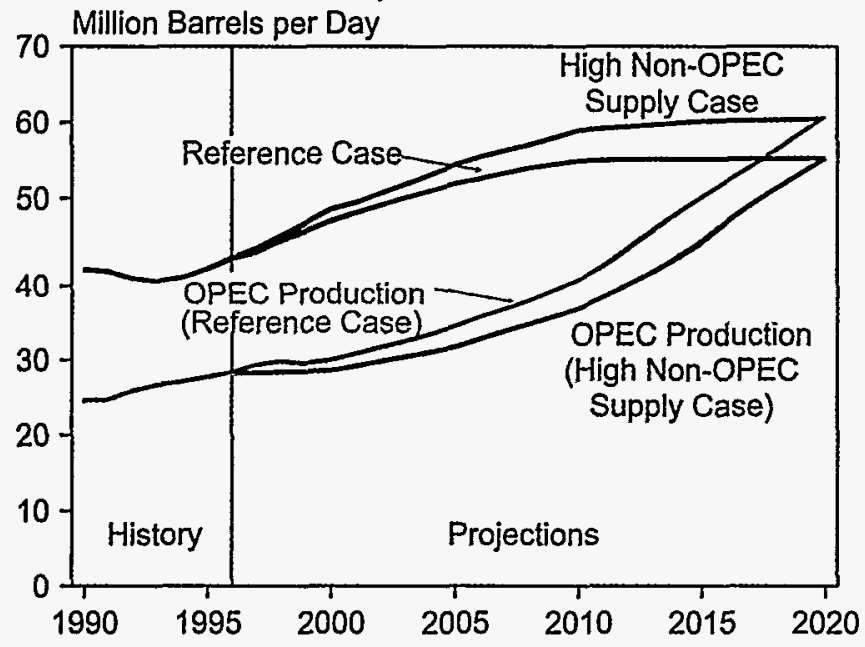

Sources: History: Energy Information Administration (EIA), International Energy Annual 1996, DOE/EIA-0219(96) (Washington, DC, February 1998). Projections: EIA, World Energy Projection System (1998).

Figure 39. Non-OPEC Oil Production by Region in Two Cases, 2020

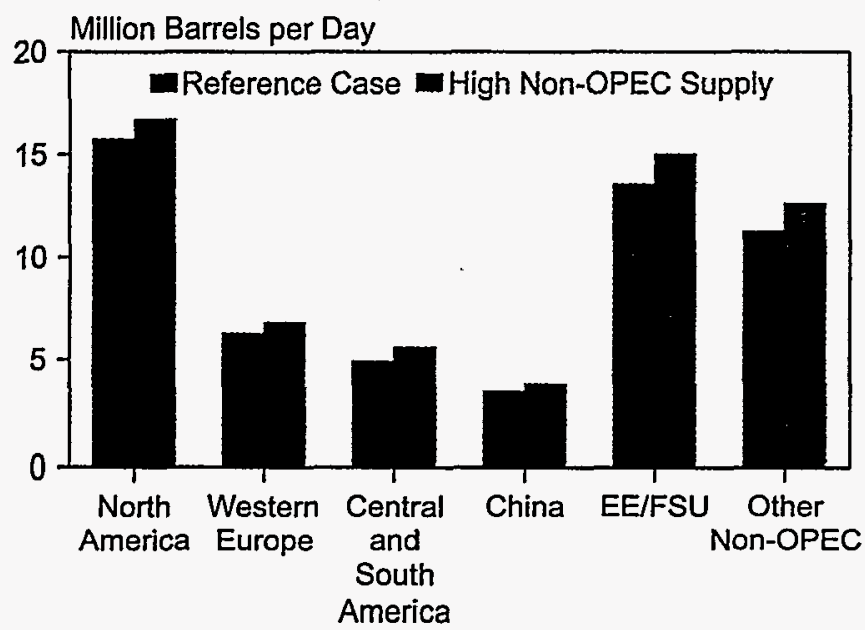

Source: Energy Information Administration, World Energy Projection System (1998).

\section{Worldwide Petroleum Trade in the Reference Case}

In 1995, industrialized countries imported 15.8 million barrels of oil per day from OPEC producers. Of that total, 9.4 million barrels per day came from the Persian Gulf region. Oil movements to industrialized countries represented more than two-thirds of the total petroleum exported by OPEC member nations and more than 60 percent of all Persian Gulf exports (Table 13). By the end of the forecast period, OPEC exports to industrialized countries are estimated to be more than 6 million barrels per day higher than their 1995 level, with almost threequarters of the projected increase coming from the Persian Gulf region.

Despite such a substantial increase, the projected share of total petroleum exports in 2020 that goes to the industrialized nations is lower than their 1995 share, at slightly over 50 percent. Their share of all Persian Gulf exports falls even more dramatically, to around 33 percent. This significant shift in the balance of OPEC export shares between the industrialized and nonindustrialized nations is a direct result of the robust economic growth anticipated for the developing nations of the world, especially those of Asia. OPEC petroleum exports to developing countries are expected to increase by more than 22 million barrels per day over the forecast period, with about two-thirds of the increase going to the developing countries of Asia. China, alone, will most likely import almost 7 million barrels per day from OPEC by the year 2020, virtually all of which is expected to come from Persian Gulf producers.

North America's petroleum imports from the Persian Gulf are expected to increase by more than 70 percent over the forecast period (Figure 40); however, almost three-fourths of total North American imports in 2020 will be from Atlantic Basin producers and refiners. Large increases in crude oil imports are anticipated from Latin American producers, including Venezuela, Brazil, Colombia, and Mexico. West African producers, including Nigeria and Angola, are also expected to increase their export volumes to North America. Caribbean Basin refiners are expected to account for most of the increase in North American imports of refined products.

Figure 40. Imports of Persian Gulf Oil by Importing Region, 1995 and 2020

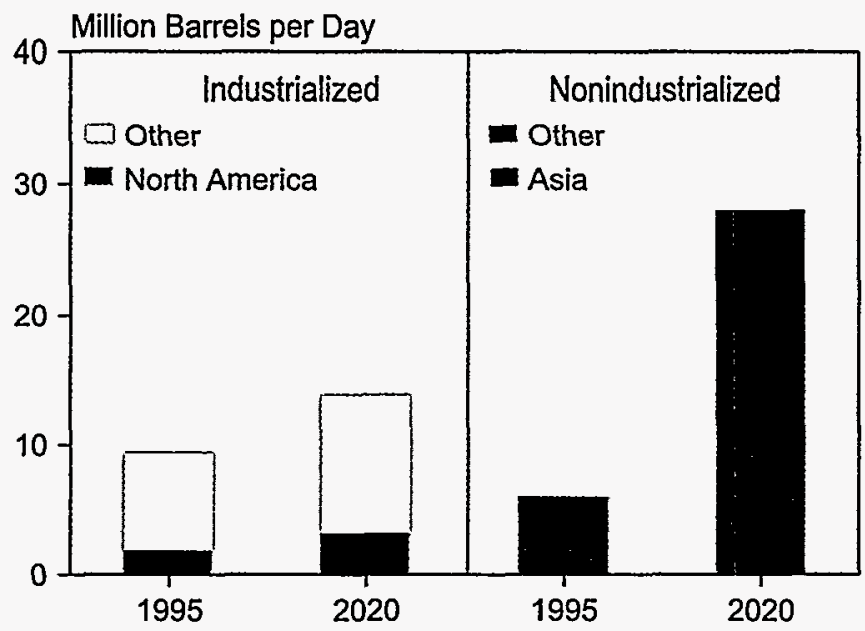

Sources: 1995: Energy Information Administration (EIA), Energy Markets and Contingency Information Division. 2020: EIA, Office of Integrated Analysis and Forecasting, WORLD Reference Model. 
Table 13. Worldwide Petroleum Trade in the Reference Case, 1995 and 2020 (Million Barrels per Day)

\begin{tabular}{|c|c|c|c|c|c|c|c|c|}
\hline \multirow[b]{3}{*}{ Exporting Region } & \multicolumn{8}{|c|}{ Importing Region } \\
\hline & \multicolumn{4}{|c|}{ Industrialized } & \multicolumn{4}{|c|}{ Nonindustrialized } \\
\hline & $\begin{array}{c}\text { North } \\
\text { America }\end{array}$ & $\begin{array}{l}\text { Western } \\
\text { Europe }\end{array}$ & Asia & Total & $\begin{array}{c}\text { Pacific } \\
\text { Rim }\end{array}$ & China & $\begin{array}{c}\text { Rest of } \\
\text { World }\end{array}$ & Total \\
\hline & \multicolumn{8}{|c|}{1995} \\
\hline \multicolumn{9}{|l|}{ OPEC } \\
\hline Persian Gulf & 1.8 & 3.4 & 4.2 & 9.4 & 4.1 & 0.4 & 1.5 & 6.0 \\
\hline North Africa $\ldots \ldots \ldots \ldots$ & 0.3 & 1.9 & 0.0 & 2.2 & 0.0 & 0.0 & 0.1 & 0.1 \\
\hline West Africa . . . . . . . . . . & 1.0 & 0.6 & 0.1 & 1.7 & 0.3 & 0.0 & 0.1 & 0.4 \\
\hline South America . . . . . . . . . & 1.6 & 0.3 & 0.0 & 1.9 & 0.1 & 0.0 & 0.6 & 0.7 \\
\hline Asia . . . . . . . . . & 0.1 & 0.0 & 0.5 & 0.6 & 0.1 & 0.0 & 0.0 & 0.1 \\
\hline Total OPEC . . . . . . . . . & 4.8 & 6.2 & 4.8 & 15.8 & 4.6 & 0.4 & 2.3 & 7.3 \\
\hline \multicolumn{9}{|l|}{ Non-OPEC } \\
\hline North Sea. . . . . . . . . . . . . & 0.7 & 3.4 & 0.1 & 4.2 & 0.0 & 0.0 & 0.4 & 0.4 \\
\hline Caribbean Basin . . . . . . . . & 2.8 & 0.3 & 0.1 & 3.2 & 0.1 & 0.0 & 0.9 & 1.0 \\
\hline Former Soviet Union . . . . . . . . & 0.0 & 1.6 & 0.0 & 1.6 & 0.3 & 0.0 & 0.7 & 1.0 \\
\hline Other Non-OPEC $\ldots \ldots \ldots \ldots$ & 0.6 & 0.2 & 1.1 & 1.9 & 0.1 & 0.2 & 0.4 & 0.7 \\
\hline Total Non-OPEC . . . . . . . . & 4.1 & 5.5 & 1.3 & 10.9 & 0.5 & 0.2 & 2.4 & 3.1 \\
\hline \multirow[t]{2}{*}{ World Total Petroleum Imports . . } & 8.9 & 11.7 & 6.1 & 26.7 & 5.1 & 0.6 & 4.7 & 10.4 \\
\hline & \multicolumn{8}{|c|}{2020} \\
\hline \multicolumn{9}{|l|}{ OPEC } \\
\hline Persian Gulf . . . . . . . . . . & 3.1 & 3.8 & 6.9 & 13.8 & 10.1 & 6.9 & 11.0 & 28.0 \\
\hline North Africa. . . . . . . . . . & 0.3 & 1.9 & 0.2 & 2.4 & 0.1 & 0.0 & 0.2 & 0.3 \\
\hline West Africa . . . . . . . . . . & 1.3 & 0.5 & 0.3 & 2.1 & 0.1 & 0.0 & 0.1 & 0.2 \\
\hline South America $\ldots \ldots \ldots$ & 2.9 & 0.4 & 0.1 & 3.4 & 0.1 & 0.0 & 0.8 & 0.9 \\
\hline Asia. . . . . . . . . . & 0.0 & 0.0 & 0.2 & 0.2 & 0.1 & 0.0 & 0.0 & 0.1 \\
\hline Total OPEC $\ldots \ldots \ldots \ldots$ & 7.6 & 6.6 & 7.7 & 21.9 & 10.5 & 6.9 & 12.1 & 29.5 \\
\hline \multicolumn{9}{|l|}{ Non-OPEC. } \\
\hline North Sea. . . . . . . . . . . . & 0.9 & 2.7 & 0.0 & 3.6 & 0.1 & 0.0 & 0.4 & 0.5 \\
\hline Caribbean Basin . . . . . . . . & 3.9 & 0.1 & 0.1 & 4.1 & 0.1 & 0.0 & 1.8 & 1.9 \\
\hline Former Soviet Union . . . . . . . . & 0.6 & 2.4 & 0.5 & 3.5 & 0.8 & 0.4 & 0.9 & 2.1 \\
\hline Other Non-OPEC $\ldots \ldots \ldots \ldots$ & 2.2 & 0.5 & 0.2 & 2.9 & 0.2 & 0.2 & 0.5 & 0.9 \\
\hline Total Non-OPEC $\ldots \ldots \ldots$ & 7.6 & 5.7 & 0.8 & 14.1 & 1.2 & 0.6 & 3.6 & 5.4 \\
\hline World Total Petroleum Imports . . & 15.2 & 12.3 & 8.5 & 36.0 & 11.7 & 7.5 & 15.7 & 34.9 \\
\hline
\end{tabular}

Notes: Totals may not equal sum of components due to independent rounding.

Sources: 1995: Energy Information Administration (EIA), Energy Markets and Contingency Information Division. 2020: EIA, Office of Integrated Analysis and Forecasting, WORLD Reference Model (1998).

As North Sea oil production declines moderately, Western Europe is expected to import increasing amounts from OPEC producers in the Persian Gulf, North Africa, and West Africa, as well as substantial quantities from the Caspian Basin. Industrialized Asian nations are expected to increase their already heavy dependency on Persian Gulf oil.

Worldwide crude oil distillation refining capacity was 76.1 million barrels per day at the beginning of 1997 . To meet the projected growth in international oil demand in the reference case, worldwide refining capacity will have to increase by more than 50 million barrels per day by 2020 . Substantial growth in distillation capacity is expected in the Middle East, Central and South America, and especially in the Asia Pacific region. Refiners in North America and Europe, while making only modest additions to their distillation capacity, will continue to improve product quality and enhance the usefulness of the heavier portion of the barrel through investment in 
downstream capacity. Likewise, future investments by developing countries must also include more advanced configurations in order to meet the anticipated increase in demand for lighter products.

\section{World Oil Price Projections}

The three world oil price paths for IEO98 (see Figure 28) are similar to the IEO97 forecasts out to the year 2015. The price projections continue to reflect a view that world oil production can rise dramatically without raising world oil prices substantially. Beyond 2015, a gradual rise in oil prices is expected in the reference case, from \$21.48 per barrel (in constant 1996 dollars) in 2015 to $\$ 22.32$ in 2020 . In nominal dollars, the reference case reaches $\$ 47$ per barrel in 2020 .

By 2020 , there is a spread of about $\$ 8$ per barrel between the reference case and the low price case and about $\$ 6$ per barrel between the reference case and the high price case. The IEO97 low and high price cases were symmetrical in their divergence from the reference case; however, the IEO98 high price case reflects the view that alternative or nonconventional energy supplies would become economically viable only if the world oil price reached about $\$ 28$ per barrel, and that oil prices are unlikely to exceed that level for any sustained period of time.

The IEO98 low and high price cases are derived by assuming alternative levels of OPEC oil production. The low price case is associated with vigorous growth in OPEC production capacity and assumes the availability of outside investment capital for such expansion. The high price case is associated with more modest growth in OPEC production capacity and assumes that production capacity expansion will be financed mainly by the oil revenues of the producing nations themselves.

In the past oil prices have been quite volatile, and volatile price behavior can be expected in the future, principally as the result of unforeseen political and economic circumstances. The IEO98 projections assume, however, that significant volatility is not likely to be long sustained. High real prices deter consumption and encourage the emergence of competition from alternative sources of oil and other energy supplies. Low prices have the opposite effect.

This outlook continues the optimism expressed in IEO97 with regard to long-term oil production possibilities. Technologies continue to evolve that significantly enhance both exploration and production capabilities. Subsea drilling technology has permitted economical access to resource-rich, deepwater areas that were heretofore considered too harsh or environmentally risky for development. Significant offshore additions to the resource base have been achieved in the United States, the North Sea, and deepwater areas off the coasts of Brazil and West Africa.

The stability of government institutions and the investment climate created by government energy policies cannot be overlooked as being of equal importance to the adequacy of the underlying resource base. Policies that encourage private investment for resource development continue to evolve in both OPEC and non-OPEC nations.

Despite the optimism regarding long-term oil supply potential, it is not uncommon to find "gloom-anddoom" scenarios in publications or on the internet predicting that the world will run out of oil within the next decade. A few simple calculations cast substantial doubt on such claims. At the beginning of 1997, there was slightly more than 1 trillion barrels of oil in proven reserves worldwide. "Proven" means that there is considerable geologic and engineering evidence that supports the ability to develop such resources under current economic and technological environments. Using the IEO98 reference case production projections and assuming that no additional oil is discovered worldwide over the forecast period, proven reserves could easily meet oil demand through 2020 (Figure 41, "No Reserves Added").

\section{Figure 41. Crude Oil Reserves in Three} Undiscovered Oil Cases, 1995-2020

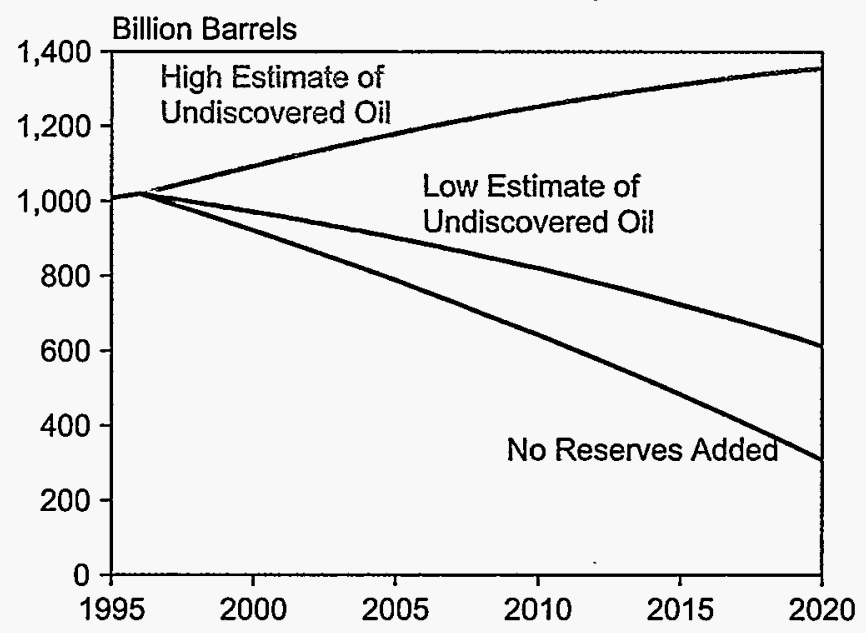

Sources: History: Energy Information Administration (EIA), Office of Energy Markets and End Use, International Energy Annual 1996, DOE/EIA-0219(96) (Washington, DC, February 1998). Projections: C. Masters, E. Attanasi, and D. Root (U.S. Geological Survey), "World Petroleum Assessment and Analysis," in Proceedings of the Fourteenth World Petroleum Congress (New York, NY: John Wiley and Sons, 1994), and EIA, World Energy Projection System (1998).

Moreover, it seems unduly pessimistic to suggest that no additional reserves will be added to the resource base over the forecast period. The USGS, in its assessment for the World Petroleum Congress, attempted to 
bracket an estimate of undiscovered oil resources. The USGS maintained that there is a 95-percent chance of finding an additional 292 billion barrels of oil worldwide but only a 5-percent chance of finding at least another trillion barrels [9]. Again, using the IEO98 reference case production projections and assuming the high and low USGS estimates of undiscovered oil, it is clear that the world is not imminently running out of oil (Figure 41). In addition, the USGS assessment was based only on current technology and economic environments. If technological advances are projected into the longer term, the probability of enlarging the ultimately recoverable oil resource base increases.

If the above argument is not sufficiently compelling, then an additional argument can be made with respect to nonconventional oil. The term "nonconventional oil" refers to a vast resource base (at least 5 trillion barrels by some estimates [10]) of oil that is suspended in some geological medium such as tar sands (as in Canada and Venezuela) or shale (as in the United States). Although the technology to segregate the efficiently oil is either not sufficiently developed or too expensive to be applied at present, the ability to extract oil from tar sands has improved over the past decade. Canada has dramatically lowered the operating costs for extraction and processing, to less than $\$ 15$ per barrel, but the initial capital investment required keeps tar sand production at today's modest levels [11]. If the world oil price were to rise to $\$ 25$ a barrel early in the next century, some forecasts suggest that significant volumes of nonconventional oil (as much as 15 million barrels per day) could become available by 2020. As technology brings the cost of producing a nonconventional barrel of oil closer to that of a conventional barrel, it becomes reasonable to view oil as a viable energy source well into the twentysecond century.

\section{Other Views of Prices and Production}

World oil price forecasts are prepared by many oil market analysts. Widely used forecasts generally present a conservative view of the prospects for significant oil price escalation over the next decade or so. Table 14 compares the IEO98 projections with similar forecasts from DRI/McGraw-Hill (DRI), the International Energy Agency (IEA), Petroleum Economics, Ltd. (PEL), Petroleum Industry Research Associates, Inc. (PIRA), the Gas Research Institute (GRI), Natural Resources Canada (NRCan), and NatWest Securities, Ltd. (NatWest).

Table 14. Comparison of World Oil Price Projections, 2000-2020 (1996 Dollars per Barrel)

\begin{tabular}{|c|c|c|c|c|c|}
\hline Forecast & 2000 & 2005 & 2010 & 2015 & 2020 \\
\hline \multicolumn{6}{|l|}{ IEO98 } \\
\hline Reference Case $\ldots \ldots \ldots$ & 19.11 & 20.20 & 20.81 & 21.48 & 22.32 \\
\hline High Price Case . . . . . . . . & 21.86 & 24.51 & 26.97 & 28.59 & 28.71 \\
\hline Low Price Case. . . . . . . . . . & 14.47 & 14.59 & 14.44 & 14.42 & 14.43 \\
\hline DRl. . . . . . . . . . . . & 17.29 & 19.27 & 21.07 & 23.43 & 26.16 \\
\hline \multicolumn{6}{|l|}{ IEA. ............ } \\
\hline Capacity Constraints (CC) Case . . & 18.18 & 26.73 & 26.73 & NA & NA \\
\hline Energy Savings (ES) Case. . . . . & 18.18 & 18.18 & 18.18 & NA & NA \\
\hline PEL $\ldots \ldots \ldots \ldots \ldots \ldots$ & 15.31 & 13.97 & 13.14 & 12.71 & NA \\
\hline PIRA ............. & 19.52 & 18.54 & 19.13 & NA & NA \\
\hline WEFA. & 18.35 & 19.05 & 19.77 & 20.53 & 21.31 \\
\hline$\ldots \ldots \ldots$ & 17.05 & 17.06 & 17.05 & 17.06 & NA \\
\hline$\ldots \ldots \ldots$ & 20.38 & 20.38 & 20.38 & 20.38 & 20.38 \\
\hline$\cdots \cdots \cdots$ & 19.00 & 19.00 & 19.00 & 19.00 & NA \\
\hline
\end{tabular}

Notes: IEO98 projections are for average landed imports to the United States. DRI, GRI, and WEFA projections are for composite refiner acquisition prices. PEL projections are for Brent crude oil. PIRA and NRCan projections are for West Texas Intermediate crude oil at Cushing.

Sources: IEO98: Energy Information Administration, Annual Energy Outlook 1998, DOE/EIA-0383(98) (Washington, DC, December 1997). DRI: DRI/McGraw-Hill, World Energy Service: U.S. Outlook, Spring 1997 (Lexington, MA, April 1997), p. 22. IEA: International Energy Agency, World Energy Outlook 1996 (Paris, France, 1996), pp. 231-232. PEL: Petroleum Economics, Ltd., Long Term Oil and Energy Outlook to 2015 (London, United Kingdom, February 1998) (preliminary numbers). PIRA: PIRA Energy Group, Retainer Client Seminar-Part One (New York, NY, October 1997), Table II-3. WEFA: WEFA Group, U.S. Long-Term Economic Outlook, Spring/Summer 1997, p. 3.9. GRI: Gas Research Institute, 1998 Data Book of the GRI Baseline Projections of U.S. Energy Supply and Demand to 2015 (Washington, DC, August 1997), p. SUM-21. NRCan: Natural Resources Canada, Canada's Energy Outlook, 1996-2020, Annex C2 (Ottawa, Ontario, Canada, April 1997). NatWest: NatWest Securities, Ltd., Oil Perspectives (London, United Kingdom, September 1997). 
Among the forecasts, the IEO98 price expectations tend to be higher than most of the comparable forecasts. However, this comparative set represents a very broad range of prices: the 2005 price estimates range from $\$ 13.97$ per barrel in constant 1996 dollars (PEL) to $\$ 26.73$ (IEA CC), with IEO98 at $\$ 20.19$ in the reference case. For 2010 , the range is $\$ 13.14$ (PEL) to $\$ 26.73$ (IEA CC), with
IEO98 at $\$ 20.81$. For 2015 , the range is $\$ 12.71$ (PEL) to $\$ 23.43$ (DRI), with IEO98 at $\$ 21.48$. PEL price projections, in fact, remain the lowest of the set through 2015 , the last year of the PEL forecast. By 2020, the range narrows (only four of the forecasts extend to 2020). Prices in 2020 range from $\$ 20.38$ (NRCan) to $\$ 26.16$ (DRI), with the IEO98 price at \$22.32. The IEA CC and

Table 15. Comparison of World Oil Production Forecasts (Percent of World Total)

\begin{tabular}{|c|c|c|c|}
\hline Forecast & OPEC & EE/FSUa & Rest of World \\
\hline \multicolumn{4}{|l|}{ History } \\
\hline $1996 \ldots \ldots \ldots \ldots \ldots \ldots$ & 39 & 10 & 51 \\
\hline \multicolumn{4}{|l|}{ Projections } \\
\hline \multicolumn{4}{|l|}{2000} \\
\hline IEO98 $\ldots \ldots \ldots \ldots \ldots \ldots$ & 39 & 10 & 51 \\
\hline DRI . . . . . . . . . . . & 43 & 9 & 48 \\
\hline IEA Capacity Constraints Case . . . . & 42 & 11 & 48 \\
\hline IEA Energy Savings Case . . . . . . . . & 40 & 11 & 49 \\
\hline PEL $\ldots \ldots \ldots \ldots \ldots \ldots$ & 41 & 10 & 49 \\
\hline PIRA . . . . . . . . . & 36 & 10 & 55 \\
\hline NatWest . . . . . . . . . . & 41 & 10 & 48 \\
\hline \multicolumn{4}{|l|}{2005} \\
\hline$\ldots \ldots \ldots \ldots$ & 40 & 11 & 49 \\
\hline DRI. . . . . . . . . . . . & 44 & 10 & 45 \\
\hline PEL $\ldots \ldots \ldots \ldots \ldots$ & 42 & 11 & 48 \\
\hline PIRA $\ldots \ldots \ldots \ldots$ & 36 & 11 & 53 \\
\hline NatWest . . . . . . . . . & 44 & 11 & 45 \\
\hline \multicolumn{4}{|l|}{2010} \\
\hline IEO98 $\ldots \ldots \ldots \ldots \ldots \ldots$ & 42 & 13 & 44 \\
\hline 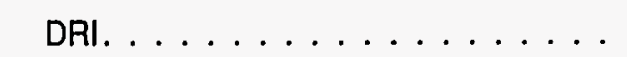 & 46 & 10 & 44 \\
\hline IEA Capacity Constraints Case . . . . . & 51 & 11 & 38 \\
\hline IEA Energy Savings Case . . . . . . . . & 54 & 11 & 35 \\
\hline PEL $\ldots \ldots \ldots \ldots \ldots \ldots$ & 45 & 12 & 43 \\
\hline PIRA $\ldots \ldots \ldots \ldots$ & 38 & 12 & 50 \\
\hline NatWest . . . . . . . . . . & 46 & 11 & 43 \\
\hline \multicolumn{4}{|l|}{2015} \\
\hline IEO98 $\ldots \ldots \ldots \ldots$ & 47 & 12 & 40 \\
\hline DRI. . . . . . . . . . . & 46 & 10 & 43 \\
\hline PEL $\ldots \ldots \ldots \ldots \ldots$ & 50 & 12 & 38 \\
\hline NatWest $\ldots \ldots \ldots \ldots \ldots$ & 48 & 12 & 41 \\
\hline \multicolumn{4}{|l|}{2020} \\
\hline IEO98 $\ldots \ldots \ldots \ldots \ldots$ & 52 & 12 & 36 \\
\hline 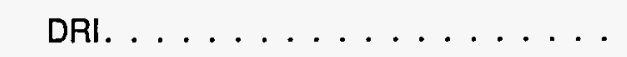 & 48 & 11 & 41 \\
\hline 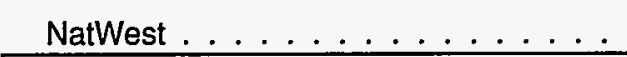 & 49 & 12 & 39 \\
\hline
\end{tabular}

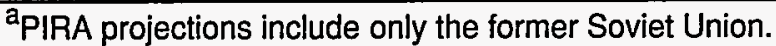
Note: Percentages may not add to 100 due to independent rounding.

Sources: IEO98: Energy Information Administration, World Energy Projection System (1998) and "DESTINY" International Energy Forecast Software (Dallas, TX: Petroconsultants, 1998). DRI: DRI/McGraw-Hill, World Energy Service: World Outlook 1997 (Lexington, MA, February 1997). IEA: International Energy Agency, World Energy Outlook 1996 (Paris, France, 1996), p. 31. PEL: Petroleum Economics, Ltd., Long Term Oil and Energy Outlook to 2015 (London, United Kingdom, February 1998) (preliminary numbers). PIRA: PIRA Energy Group, Retainer Client Seminar-Part One (New York, NY, October 1997). NatWest: NatWest Securities, Ltd., fax from Adam Sieminski (November 21, 1997). 
IEA ES forecasts were formulated in April 1996 and, as a result, can be considered somewhat dated in relation to the more recent price forecasts from IEO98, PIRA, PEL, and NatWest.

The price forecasts are strongly influenced by different views about the anticipated composition of world oil production. Two factors are especially influential: (1) the extent to which OPEC production will be expanded, and (2) the timing of a recovery in EE/FSU production. All the forecasts agree that EE/FSU oil production will recover slowly. None expects the EE/FSU share of world production to increase above 11 percent until 2010, and none expects the share to exceed 13 percent (Table 15). IEO98 is the most optimistic about EE/FSU recovery, projecting a 13-percent share of world oil production for the EE/FSU region in 2010, which falls to 12 percent in 2015 and remains there for the rest of the forecast period. DRI is most pessimistic about the EE/FSU recovery, projecting a 10-percent production share that increases only to 11 percent in 2020.

Expectations for the split between OPEC producers and the rest of the world (excluding the EE/FSU) vary more widely. The IEO98 reference case has the highest estimate for the OPEC share, growing from 39 percent in 2000 to 42 percent in 2010 and then to 52 percent in 2020. The lowest estimate is in the PIRA forecast, which shows the OPEC share of production reaching 36 percent in 2000 and rising to 38 percent in 2010.

For the rest of the world (outside of OPEC and excluding the EE/FSU), PIRA presents the most optimistic forecast of oil production. In the PIRA forecast, the non-OPEC share of the world's oil production falls from 55 percent in 2000 to 50 percent in 2010. In contrast, IEO98 shows a sharper decline in the non-OPEC share, which falls from 51 percent in 2000 to 44 percent in 2010. DRI, PEL, and NatWest all project non-OPEC production shares greater than or equal to 43 percent through 2010; however, the PEL non-OPEC share falls to 38 percent and the NatWest non-OPEC share falls to 41 percent in 2015. DRI is the most optimistic about the ability of non-OPEC producers to maintain strong production levels beyond 2010, projecting a 43-percent share of world production for the non-OPEC nations in 2015. IEO98 projects a nonOPEC share of 40 percent in 2015, but by 2020 the nonOPEC share is only 36 percent in the IEO98 projection, compared with 39 percent in the NatWest forecast and 41 percent in the DRI forecast.

\section{Policies To Lessen Environmental Damage from Transportation Fuel Use}

The increasing importance of the transportation sector in the demand for oil products and the rising demand for oil in developing countries will be key factors in the future course of world oil use. The relationship between economic expansion and vehicle use in the developing nations will in large part determine the rate of growth in world oil demand over the next 20 to 25 years. It will also be pivotal in shaping future environmental challenges.

Increased combustion of oil as a transportation fuel will result in higher levels of carbon dioxide emissions. Thus far no developing country has committed to stabilizing carbon dioxide emissions, but many are seriously concerned about the prospects of worsening air pollution. In addition to carbon dioxide, oil consumption emits a number of pollutants that have more localized consequences, such as lead exposure, ground-level ozone formation, and carbon monoxide and particulate matter pollution.

The use of leaded gasoline in automobiles is a major source of human exposure to lead, typically accounting for more than 90 percent of all lead emissions in urban areas [12]. In addition to airborne lead, which is inhaled, lead also accumulates in soil, drinking water, and the food chain [13]. In a 1996 study, the World Bank referred to lead as "one of the most serious environmental health hazards affecting growing urban populations," citing estimates that in developing countries, all urban children under the age of 2 and 80 percent of those between 3 and 5 years old have lead poisoning. Many industrialized countries either have already removed lead additives from gasoline or are in the process of phasing them out; however, technological and economic circumstances in other countries have slowed the shift to unleaded gasoline. For example, half the gasoline sold in Russia is unleaded, but Russia remains the world's largest consumer of leaded gasoline, with little prospect of phasing it out. In countries that continue to rely on leaded gasoline, more gasoline consumption will create more lead contamination.

Both gasoline and diesel fuel emit volatile organic compounds (VOCs) and nitrogen oxides $\left(\mathrm{NO}_{\mathrm{x}}\right)$, which contribute to ground-level ozone, otherwise known as "smog." Although ozone is thought of as an urban problem, recent studies in the United States have shown that it is actually a regional problem [14], because the pollution can travel for hundreds of miles. For instance, emissions in a city may cause ozone problems for rural areas lying downwind. 
Oil consumption also produces emissions of carbon monoxide, benzene, and particulate matter, which contribute to local pollution. The severity of pollution in a given area depends not only on the type and quantity of fuel consumption but also on technological and climate factors. Thus far, policies to reduce such emissions from mobile sources have focused on either cleaning up vehicles or cleaning up fuels. Efforts to improve automobile technology focus on engine performance and exhaust systems. On the other hand, the fuels themselves can be made cleaner by improving their combustion characteristics and by removing elements such as lead and sulfur, which reduce the effectiveness of automobile exhaust cleaning systems.

Air pollution is a concern in almost every country of the world. Because emissions from transportation fuels are linked to many types of pollution, regulating the properties of gasoline and diesel fuel has emerged as a mechanism for fighting pollution. Motor fuels regulations have been used to achieve two distinct goals: the phaseout of lead from gasoline and the adoption of cleaner burning "reformulated" gasoline and diesel fuel.

Lead-based additives were widely used in gasoline between the 1930s and 1970s to enhance engine performance. In the 1970s, however, automobile engines with catalytic converter technology were developed as a means of reducing automobile emissions. The newer engines required unleaded gasoline, because lead hampers the emissions reducing ability of the catalytic converter. At the same time, it was becoming evident that lead pollution is a threat to public health. In the 1970s and 1980s, many industrialized countries moved to phase out leaded gasoline [15], and in recent years similar initiatives have been undertaken in other countries.

Over the past 10 years, motor fuels regulations in some countries have gone beyond simply banning lead in gasoline to putting restrictions on a number of the properties, or fuel qualities, of gasoline and diesel fuel, which have been "reformulated" to reduce tailpipe emissions of carbon monoxide, VOCs, $\mathrm{NO}_{\mathrm{x}}$, and air toxics. Fuel quality standards can be tailored to reduce one or a combination of emissions, depending on local pollution problems, and "reformulated" gasoline or diesel in one area may not be the same as "reformulated" gasoline or diesel in another area. Because a nation's restrictions on gasoline or diesel characteristics will affect the supply of acceptable imports for those products, many countries are working together to develop regional fuel standards. The tightening of fuel quality standards has developed into a clear but uneven international trend. While some countries are focusing solely on phasing out lead, and others are phasing out lead and reformulating fuels at the same time.

\section{Unleaded Gasoline}

Although leaded gasoline has been entirely phased out in 20 countries around the world, gasoline with a high lead content is still the norm in many parts of Africa, the Middle East, Asia, Latin America, and Eastern Europe (Figure 42). Auto emissions are the primary source of lead pollution, and the problem is expected to worsen as driving populations grow. The World Bank has completed a number of studies on the use of leaded gasoline and has worked with a number of developing nations to phase out lead. As a first step the World Bank encourages countries using gasoline with a high lead content to set a maximum limit of 0.15 grams per liter of gasoline.

\section{Industrialized Countries}

Many industrialized countries have made great progress toward phasing out lead. Austria, Canada, Denmark, Finland, Japan, Sweden, and the United States already have complete bans on leaded gasoline, and unleaded gasoline holds a market share of at least 70 percent in Belgium, Germany, Iceland, Luxembourg, the Netherlands, Norway, and Switzerland. The European Union (EU) has set the maximum lead content for leaded gasoline at 0.15 grams per liter and plans to phase lead out entirely by 2000 . A 5-year delay will be allowed for EU member nations that are heavily reliant on older automobiles without catalytic converters [16, p. 3].

\section{Eastern Europe/Former Soviet Union}

In 1995, Slovakia completed a 3-year phaseout of leaded gasoline with the assistance of the World Bank. Croatia also has made progress toward lead removal, reducing leaded gasoline to a 10-percent market share. The Czech Republic, Hungary, Poland, and the Baltic States are politically motivated to match EU lead restrictions as a prerequisite to joining the EU. In the other EE/FSU countries, however, economic and structural problems overshadow the need to phase out leaded gasoline [17].

\section{Central and South America}

Gasoline in Antigua, Argentina, Bermuda, Bolivia, Brazil, Colombia, Costa Rica, El Salvador, Guatemala, Honduras, and Nicaragua is already lead-free (Figure 42). Four other countries-Barbados, Belize, Ecuador, and Mexico-plan to complete lead phaseouts by 2000 , which will give unleaded gasoline an 83-percent market share in the region. Other countries have set phaseout goals for years beyond 2000, including Jamaica and St. Lucia (2001), Panama (2002), Trinidad and Tobago (2005), Venezuela (2007), and Peru (2009) [18, pp. 24-25].

\section{Developing Asia}

After updating refineries to produce unleaded gasoline, Thailand banned leaded gasoline in 1995. China will require unleaded gasoline in eight major cities 


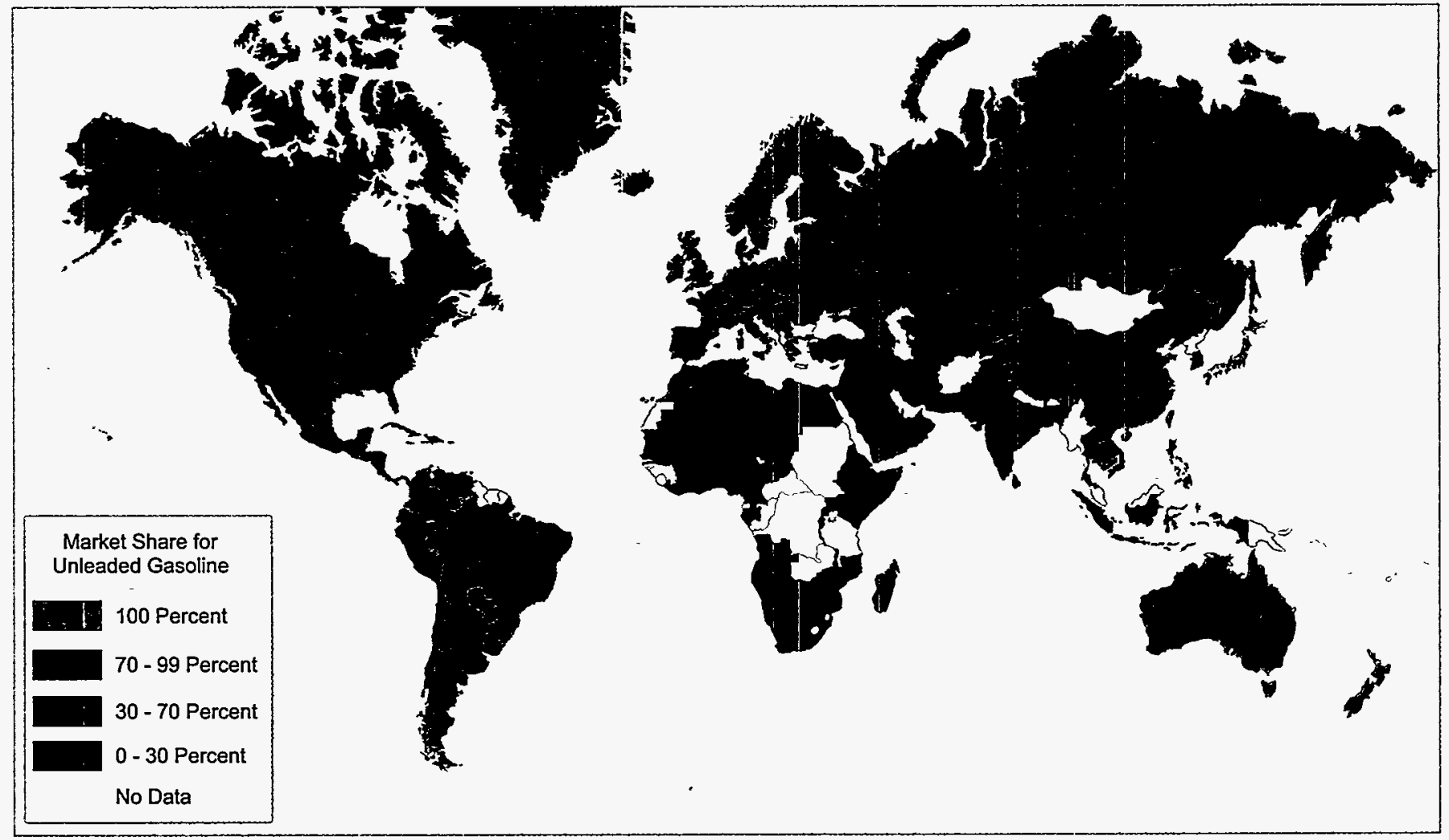

Source: World Bank, Phasing Out Lead from Gasoline: World-Wide Experience and Policy Implications (Washington, DC, August 1996). World Bank, Annex A: Worldwide Use of Lead in Gasoline, provided by Magda Lovei (updated 1997). Information on Greenland is based on discussions with a representative of the Danish embassy.

beginning in 1998 and throughout the nation by 2000. Indonesia has also made plans to phase out lead by 1999. Although its national market share of unleaded gasoline is small, India does consume unleaded gasoline in its four largest cities.

\section{Barriers to Lead Removal}

One perceived hurdle to phasing out lead has been the notion that unleaded gasoline harms the valves in older vehicle engines. In the 1970s and 1980s, phasing out lead was tied to the turnover rates for vehicle fleets. During the late 1980s and early 1990s, however, studies in the United States and Europe indicated that only a small amount of lead is required for lubrication in older cars. As health concerns over leaded gasoline heightened, countries began phasing out lead despite the continued use of older cars in their vehicle fleets. In Austria, Sweden, Slovakia, and Thailand-all of which are leadfree- the needs of older cars have been met by blending lubricating additives into unleaded gasoline. Slovakia had totally removed lead from gasoline by 1994, despite the fact that 70 percent of its car fleet had older engines $[15$, p. ii $]$.

The other challenge in phasing out lead is replacing its octane content. Complex refineries have more refinery processes, providing them with greater flexibility to increase gasoline octane than can be achieved at less advanced refineries. In complex refineries, octane can be boosted by increasing the severity of catalytic reformers and increasing the use of etherification, alkylation, isomerization, and polymerization processes. For less sophisticated refineries, the options are limited to increasing the severity of the reformer and/or blending in octane enhancing additives such as alcohols and ethers.

In the United States in the 1980s, catalytic reforming was key to boosting octane, and the alkylation and isomerization processes played a lesser role [18, p. 10]. Much of the required octane was replaced by other hydrocarbon streams, such as butane and aromatics, each of which contributes to air quality problems in its own way. Butane raises the volatility of gasoline, increasing emissions of VOCs. Aromatics contribute to VOC, $\mathrm{NO}_{\mathrm{x}^{\prime}}$ and air toxics emissions. Concerns about these changes in the composition of gasoline formed the basis for additional gasoline regulations in the United States during the 1980s and 1990s. One aromatic compound, benzene, was identified as a carcinogen and has since been restricted in gasoline in the United States. Other countries are also likely to limit the benzene content of unleaded gasoline. 
Another method of boosting octane that was introduced in the 1980s was the addition of octane enhancers, such as ethanol and methyl tertiary butyl ether (MTBE). MTBE, because of its relatively low volatility, became increasingly important as an octane enhancer in the United States after the first summertime restrictions on gasoline volatility were enacted in 1989. MTBE is already widely used in Europe, because it provides an economical way to boost octane without the need for changes in refinery processes. As more countries phase out lead, demand for MTBE can be expected to rise, leading to an expansion of production capacity for MTBE at petrochemical plants and refineries. MTBE is produced from a combination of petroleum blendstocks and methanol, a derivative of natural gas. Increased blending with MTBE will also increase the market for methanol.

\section{Reformulated Fuels}

Fuel characteristics can be formulated to reduce particular types of emissions. In gasoline, for instance, Reid vapor pressure (Rvp) can be limited to reduce emissions of VOCs; oxygen can be added to reduce carbon monoxide emissions; sulfur can be limited to reduce emissions of $\mathrm{NO}_{x}$; and aromatics can be limited to reduce air toxics. In diesel fuel, emissions of particulate matter can be reduced by restricting sulfur content; and cetane, a measure of ignition quality, can be raised to reduce hydrocarbon emissions. Because of the number and combinations of fuel characteristics that can be formulated to reduce emissions, the development of reformulated fuels has taken different paths in different countries (Table 16).

Standards requiring a minimum oxygen content in gasoline have been widely debated because they necessitate blending with oxygenates such as MTBE and ethanol. The addition of oxygenates reduces carbon monoxide emissions from the gasoline. The choice of which oxygenate to use is based on relative cost as well as the comparative value of the blending characteristics. Beyond their use as oxygenates, ethanol and MTBE are also added to boost gasoline octane, which prevents engine knock. In the United States, economics have made

Table 16. Reformulated Fuel Requirements

\begin{tabular}{|c|c|c|}
\hline Year & Location & Reformulated Fuel Requirements \\
\hline 1988 & $\ldots \ldots$ & Low-sulfur diesel \\
\hline 1989 & United States . . . . . . . . . & Reid vapor pressure (Rvp) restrictions for summertime gasoline \\
\hline 1992 & $\begin{array}{l}\text { Denmark. . . . . . . . . . . . } \\
\text { United States . . . . . . . . . . . } \\
\text { United States . . . . . . . . . }\end{array}$ & $\begin{array}{l}\text { "Light diesel" } \\
\text { Oxygenated gasoline in some areas during wintertime } \\
\text { Phase II Rvp restrictions for summertime gasoline }\end{array}$ \\
\hline 1994 & 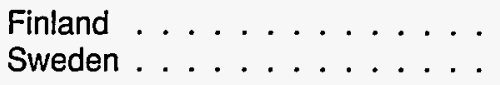 & $\begin{array}{l}\text { Reformulated gasoline } \\
\text { Reformulated gasoline }\end{array}$ \\
\hline 1995 & $\begin{array}{l}\text { Norway } \ldots \ldots \ldots \\
\text { United States } \ldots \ldots \ldots \ldots\end{array}$ & $\begin{array}{l}\text { "Light diesel" } \\
\text { Reformulated gasoline }\end{array}$ \\
\hline 1997 & Japan ............. & Low-sulfur diesel \\
\hline 1998 & South Korea . . . . . . . . & Low-sulfur diesel \\
\hline 2000 & 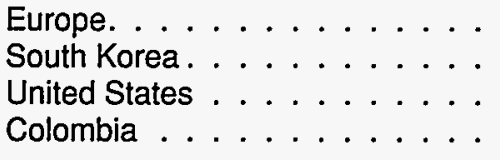 & $\begin{array}{l}\text { Reformulated gasoline and diesel } \\
\text { Reformulated diesel fuel proposed } \\
\text { Further restrictions on reformulated gasoline (Phase II) } \\
\text { Oxygenated gasoline required }\end{array}$ \\
\hline 2001 & Latin America/Caribbean . . . . . & Proposed standards for reformulated gasoline and diesel \\
\hline 2005 & 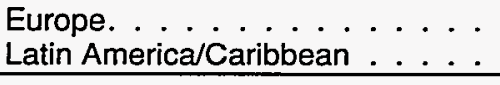 & $\begin{array}{l}\text { Further restrictions proposed for reformulated gasoline and diesel } \\
\text { Further restrictions proposed for reformulated gasoline and diesel }\end{array}$ \\
\hline
\end{tabular}

Sources: Mexico City and Mexico: G. Unzelman, "Pemex Leads Fuel Reformulation; Clean Air Follows," Hart's Fuel Technology Management (March 1997). United States: Title II, Clean Air Act Amendments of 1990. Denmark, Finland, Norway, Sweden, and South Korea: M. Joutsimo, "The Reformulated Fuels in Nordic Countries," presentation at the 1997 European Oil Refining Conference and Exhibition (Lisbon, Portugal, June 19, 1997). Japan: "How Evolving New Fuel Specs are Challenging Asia's Refiners," Oil and Gas Journal (July 7, 1997). Europe: Commission of the European Communities, Communication from the Commission to the European Parliament (Brussels, Belgium, October 16, 1997). State of California: Title 13, California Code of Regulations. Colombia: C. Keplinger, "Colombia Eyes Ethanol To Fill Oxygen Standard," Oxy-Fuel News (November 17, 1997). Latin America/Caribbean: The World Bank, telefax of proposed standards (December 10, 1997). 
MTBE the most widely used oxygenate. Questions about the possible environmental and health effects of MTBE have fueled some resistance to its use in pockets of the United States. In California, where MTBE has been found in some water supplies, State legislators have proposed banning its use.

Like the oxygen requirement, setting sulfur limits on gasoline and diesel fuel has also been controversial. Sulfur reduction results in a reduction in emissions of $\mathrm{NO}_{\mathrm{x}}$ and, to a lesser extent, air toxics and VOCs. While the benefits of reducing sulfur are widely recognized, much debate has centered around the degree of sulfur reduction. More stringent limits on sulfur are thought to require more costly refinery investments. Nevertheless, studies in support of the development of low-emissions vehicles in the United States and in Europe indicate that the next generation of engines may require fuels with a sulfur content of about one-tenth of current levels (around 40 parts per million).

\section{Reformulated Gasoline}

In general, regulations to reduce auto emissions by reformulating gasoline have been limited to industrialized countries. Reformulated gasoline initiatives began in the United States in 1989 with restrictions on the summertime Rvp of gasoline. The Clean Air Act Amendments of 1990 included a number of fuel-related requirements aimed at cleaning up emissions. In 1992, areas of the country with the worst carbon monoxide pollution were required to use gasoline with a higher oxygen content during the wintertime. In 1995, in areas with the worst ozone problems (and in areas with less severe problems that opted into the program), only reformulated gasoline could be sold.

Initially, reformulated gasoline was defined by a uniform set of standards promulgated by the U.S. Environmental Protection Agency. Beginning in 1998, it will be defined on the basis of performance results. The new definition, known as the "complex model," will require reformulated gasoline to meet specific emissions reductions for $\mathrm{NO}_{x}, \mathrm{VOCs}$, and air toxics from 1990 baseline levels. Other than stipulating an oxygen requirement of 2 percent by weight and a benzene limit of 1 percent by volume, the complex model does not specify how the gasoline should be formulated to achieve the emissions reductions.

In 2000, further emissions reductions will be required, and they are likely to lead to a significant reduction in sulfur content for reformulated gasoline. The State of California developed its own set of fuel restrictions in order to deal with its unique severe pollution problems. The fuel requirements for California's "cleaner burning gasoline" include limits on the contents of aromatics, olefins, and sulfur which are more stringent than the initial Federal reformulated gasoline requirements.
Federal requirements after 2000 are expected to be comparable with the California gasoline requirements.

Reformulated gasoline was also introduced in Finland and Sweden in 1994. Unlike reformulated gasoline consumption in the United States, which is mandated, reformulated fuel consumption in these countries is based on consumer preference and tax policy. At the pump, the additional processing cost for the reformulated fuel is offset by lower taxes than those on conventional gasoline. In Finland, the tax policy and a heightened environmental consciousness have resulted in a 95-percent market share for reformulated gasoline [19]. Finland and Sweden have their own unique sets of gasoline standards (Table 17).

By 2000 , the voluntary consumption of reformulated fuel in the Nordic countries will be replaced by a mandated requirement for reformulated gasoline throughout Europe. As of March 1998, both the European Parliament and the Council of Ministers had proposed unleaded gasoline standards for the year 2000. Negotiations to reconcile the two proposals may be ongoing through June 1998, when a final directive is expected. The appropriate sulfur limit was a major issue in developing the standards, with earlier proposals ranging from 100 to 200 parts per million (ppm), compared with the current European content of $500 \mathrm{ppm}$. Both the Parliament and Council proposals settled on a $150 \mathrm{ppm}$ standard. The Council proposal would allow member nations such as Greece and Portugal, which will require substantial refinery investments, to postpone the requirement until 2003 [16].

Although the two European proposals agree on the sulfur standard, the Parliament proposal has more stringent standards for aromatics and olefins and would allow a lower oxygen content than the Council proposal. Both the Parliament and the Council call for the sulfur standard to be tightened further by 2005 . The tighter sulfur limits will be based on ongoing research on new auto pollution abatement technologies. Recent research by the American Automobile Manufacturers Association and the Association of International Automobile Manufacturers indicates that "the benefits of low emission vehicle hardware (engines) diminish as fuel sulfur increases above $40 \mathrm{ppm}$ " [20].

Although the primary goal in Latin America is to phase out lead, a recently proposed unleaded gasoline standard for the Latin American/Caribbean region includes limits on both sulfur and benzene, as well as an oxygen requirement (Table 17). The proposed standard does not aim to reduce olefins or aromatics, because such standards would require more sophisticated refineries. Some Latin American countries already have standards that exceed elements of the proposed Latin American/ Caribbean standards. For instance, Colombia passed 
Table 17. Selected Reformulated Gasoline Requirements by Country

\begin{tabular}{|c|c|c|c|c|c|c|c|}
\hline \multirow[b]{2}{*}{ Qualities } & \multirow{2}{*}{$\begin{array}{l}\text { Finland: } \\
\text { Current }\end{array}$} & \multirow{2}{*}{$\begin{array}{c}\text { Sweden: } \\
\text { Fall } \\
1998\end{array}$} & \multirow{2}{*}{$\begin{array}{l}\text { State of } \\
\text { California: } \\
\text { Current }\end{array}$} & \multicolumn{2}{|c|}{ U.S. Phase I Complex Model } & \multirow{2}{*}{$\begin{array}{c}\text { Europe: } 2000, \\
\text { Range of } \\
\text { Proposals }\end{array}$} & \multirow{2}{*}{$\begin{array}{l}\text { Latin America/ } \\
\text { Caribbean: } \\
\text { Proposed }\end{array}$} \\
\hline & & & & Current & 2000 & & \\
\hline Aromatics $^{\mathrm{a}}$ & NA & NA & 25 & NA & $\mathrm{NA}$ & 35 or 42 & 45 \\
\hline Benzene $^{\mathrm{a}}$ & 1 & 2 & 1 & 1 & 1 & 1 & 2.5 \\
\hline Olefins $^{2}$ & NA & 15 & 6 & NA & NA & 14 or 18 & 25 \\
\hline Oxygen ${ }^{b}$ & 2.1 to 2.7 & 2.0 max. & $2.0 \mathrm{~min}$. & $2.0 \mathrm{~min}$. & $2.0 \mathrm{~min}$. & 2.3 or 2.7 & $2.7 \max$. \\
\hline Reid Vapor Pressure ${ }^{c}$ & NA & NA & & NA & NA & NA & $9-12.5$ \\
\hline Sulfur ${ }^{d}$ & 100 & 100 & 30 & NA & NA & 150 & $\begin{array}{c}1,000 \text { by } 2001 \\
400 \text { by } 2005\end{array}$ \\
\hline Nitrogen Oxides ${ }^{e}$ & NA & NA & NA & No increase & 5.5 & NA & NA \\
\hline Toxics $^{\theta}$ & $\mathrm{NA}$ & NA & NA & 15 & 20 & NA & NA \\
\hline $\begin{array}{l}\text { Volatile Organic } \\
\text { Compoundse }\end{array}$ & NA & NA & NA & $\begin{array}{l}\text { South } 35.1 \\
\text { North } 15.6\end{array}$ & $\begin{array}{l}\text { South } 27.5 \\
\text { North } 25.9\end{array}$ & NA & NA \\
\hline
\end{tabular}

${ }^{a}$ Maximum percentage content by volume.

Maximum percentage content by weight.

${ }^{\mathrm{C}}$ Pounds per square inch absolute (psia), $100^{\circ} \mathrm{F}$.

'Maximum parts per million (ppm) by weight.

${ }^{\Theta}$ Percent reduction from 1990 baseline gasoline.

NA $=$ not applicable.

Sources: Finland: "Reformulated Gasoline 95ER: Product Data Sheet," Neste. Sweden: "Environmental Class 1, Product Specifications," DuPont Conoco Nordic telefax (March 3, 1998). State of California: Title 13, California Code of Regulations. United States: U.S. Environmental Protection Agency, Federal Register, 40 CFR Part 80 (February 16, 1994). Europe: European Parliament proposal (February 18, 1998); and Commission of the European Communities, Communication from the Commission to the European Parliament (Brussels, Belgium, October 16, 1997). Latin America/Caribbean: The World Bank, telefax of proposed standards (December 10, 1997).

legislation in 1995 to require oxygenates in all gasoline by the year 2001. Colombia is considering ethanol produced from sugar cane to meet the new requirement [21].

\section{Reformulated Diesel}

Like reformulated gasoline, the use of reformulated diesel fuel is limited primarily to the industrialized countries. Thus far, the major focus of diesel regulations has been to reduce sulfur because of its contribution to particulate matter emissions. Specifications proposed for the future generally tend to reduce sulfur beyond existing limits and add a minimum cetane requirement or maximum aromatics content (Table 18).

Mexico initiated the first diesel fuel regulations in 1988 when it began to limit the sulfur content of diesel fuel used in Mexico City to 5,000 ppm. The requirement was extended nationwide in 1993 [22]. Since that time, lowsulfur diesel standards have been introduced in a number of other areas of the world. The severity of the sulfur limit has evolved to less than 10 percent of the Mexican limit in many countries.

In 1993, the United States enacted a nationwide lowsulfur diesel standard of $500 \mathrm{ppm}$ maximum for onhighway diesel and a cetane index of 40 . The State of California enacted more stringent diesel standards, including a limit on aromatics content of 10 percent by volume. Variations of reformulated diesel were introduced between 1991 and 1995 throughout the Nordic Countries (Finland, Sweden, Denmark, and Norway), where the limit on sulfur content ranges between 10 and $55 \mathrm{ppm}$ in addition to minimum cetane requirements.

In 1996, Europe adopted a "Eurodiesel" standard, which restricts sulfur to $500 \mathrm{ppm}$ and requires a minimum cetane level of 49. In 2000, the Council of Ministers proposes to reduce the sulfur content to $350 \mathrm{ppm}$ and raise the cetane number to 51. The European Parliament proposes a more severe sulfur reduction to $200 \mathrm{ppm}$ (Table 18). Diesel fuel standards will be tightened even further in 2005 to reflect ongoing research in fuel and vehicle technology.

Both Japan and South Korea are scheduled to enact new low-sulfur diesel standards of $500 \mathrm{ppm}$ maximum by weight during 1998. In addition, South Korea has proposed reformulated diesel specifications for 2000. Studies of new engines and fuels are ongoing in both Japan and South Korea. India, which has less sophisticated refineries than Japan and South Korea, has also been moving toward reduced sulfur diesel. In 1996 India reduced the maximum sulfur content from $10,000 \mathrm{ppm}$ to 5,000 ppm for diesel sold in four metropolitan cities. The sulfur limit for those cities will be reduced again in 1999 to 2,500 ppm. In June 1997 the government approved diesel desulfurization projects in nine of 
Table 18. Selected Reformulated Diesel Fuel Requirements by Country

\begin{tabular}{|c|c|c|c|c|c|c|c|c|c|}
\hline Qualities & $\begin{array}{l}\text { Europe: } \\
\text { Current }\end{array}$ & $\begin{array}{c}\text { Japan and } \\
\text { South } \\
\text { Korea: } \\
1998 \\
\end{array}$ & $\begin{array}{l}\text { Mexico: } \\
\text { Current }\end{array}$ & $\begin{array}{c}\text { State of } \\
\text { California: } \\
\text { Current } \\
\end{array}$ & $\begin{array}{l}\text { Sweden: } \\
\text { Current }\end{array}$ & $\begin{array}{l}\text { United } \\
\text { States: } \\
\text { Current }\end{array}$ & $\begin{array}{c}\text { Europe: } \\
2000, \\
\text { Range of } \\
\text { Proposals }\end{array}$ & $\begin{array}{l}\text { Latin America/ } \\
\text { Caribbean: } \\
\text { Proposed }\end{array}$ & $\begin{array}{c}\text { South } \\
\text { Korea: } \\
\text { Proposed } \\
2000\end{array}$ \\
\hline Sulfur $^{a}$ & 500 & 500 & 5,000 & 500 & 50 & 500 & $200-350$ & $\begin{array}{l}5,000 \text { by } 2001, \\
2,000 \text { by } 2005\end{array}$ & 300 \\
\hline $\begin{array}{l}\text { Cetane } \\
\text { Index }\end{array}$ & NA & NA & NA & NA & 50 & 40 & NA & NA & 50 \\
\hline $\begin{array}{l}\text { Cetane } \\
\text { Number }\end{array}$ & 49 & NA & NA & NA & NA & NA & 51 & $\begin{array}{l}45 \text { by } 2001, \\
47 \text { by } 2005\end{array}$ & NA \\
\hline Aromatics & NA & NA & NA & 10 & 5 & $\begin{array}{c}\text { NA } \\
\text { (35-40\% } \\
\text { cetane } \\
\text { equivalent) }\end{array}$ & NA & NA & 20 \\
\hline
\end{tabular}

Sources: Europe: European Parliament proposal (February 18, 1998); and Commission of the European Communities, Communication from the Commission to the European Parliament (Brussels, Belgium, October 16, 1997). Japan: "How Evolving New Fuel Specs are Challenging Asia's Refiners," Oil and Gas Journal (July 7, 1997). South Korea: M. Joutsimo, "The Reformulated Fuels in Nordic Countries," presentation at the 1997 European Oil Refining Conference and Exhibition (Lisbon, Portugal, June 19, 1997). Mexico: G. Unzelman, "Pemex Leads Fuel Reformulation; Clean Air Follows," Hart's Fuel Technology Management (March 1997). State of California: Title 13, California Code of Regulations. Sweden: "Diesel Class 1 Specification," Dupont Conoco Nordic (February 19, 1998). United States: U.S. Environmental Protection Agency, Federal Register, 40 CFR Part 80 (February 16, 1994). Latin America/Caribbean: The World Bank, telefax of proposed standards (December 10, 1997).

India's refineries, which should allow them to meet the 1999 requirements [23].

Proposed diesel fuel standards for Latin America and the Caribbean reflect less advanced refining technology and the quality of crude oil supplies in the region. While proposed standards aim to improve diesel fuel quality in the region, they are less stringent than the standards in Europe, the United States, and parts of Asia. The standards proposed for the year 2001 include a sulfur standard comparable to the existing Mexican standard of $5,000 \mathrm{ppm}$, to be reduced to $2,000 \mathrm{ppm}$ in 2005 . The standards also specify cetane numbers of 45 for 2001 and 47 for 2005.

\section{Implications of Reformulation Requirements}

Refiners have three basic ways of responding to gasoline and diesel fuel reformulation requirements: changing refinery inputs, increasing oxygenate blending, and investing in refinery processes. The first two options, may be used to avoid refinery investment if the fuel standards are not too severe.

In Europe, much of the debate about new product specifications has centered around sulfur requirements, because the severity of the sulfur reduction will affect the tradeoff between refinery investments and shifting to higher quality crude oils. The tightening of product specifications, especially on sulfur, seems to point to a growing demand for higher quality crude oils. The opposite occurred in the United States, however, where the quality of crude oil inputs actually declined after refinery investments were made in the early 1990s. Many refiners in the United States made refinery upgrades beyond those necessitated by tightened product standards [24]. Refinery investments added complexity to U.S. refineries, giving them the ability to produce cleaner fuels with crude oil inputs of lower quality. The same outcome may occur in other reformulated fuels markets as refineries are upgraded.

Reformulated fuel requirements may cause some refiners to consider switching to liquid feedstocks derived from natural gas. High-quality diesel fuel and gasoline can be produced from little-used gas-to-liquids (GTL) conversion processes, such as the Fischer-Tropsch process. Although GTL processes are not yet economically feasible, increased demand for cleaner products might make them commercially attractive. GTL processes would be most attractive in areas with inexpensive natural gas resources but no pipeline infrastructure.

Areas that require oxygen in their gasoline standards will see increased demand for oxygenates, especially MTBE. The need for oxygenates may be met by blending with ethanol or with MTBE produced at petrochemical plants, or by adding MTBE production capacity at refineries. MTBE production is likely to be limited to more complex refineries. 
New gasoline and diesel specifications will undoubtedly result in investments to upgrade refineries. Oxygen requirements for gasoline may lead some complex refineries to add processes that produce MTBE or other oxygenates. In addition, sulfur requirements may lead refiners to invest in processes that either desulfurize feedstocks before they are refined or desulfurize the refined products. The process of hydrotreating feedstocks to the fluid catalytic cracking unit results in the greatest sulfur reduction but also requires the greatest capital investment [25]. Some refineries that are now only marginally profitable may not be deemed worthy of the required investments and may be closed. In the United States, a number of smaller refineries were not upgraded to meet reformulated gasoline or diesel specifications but remained opened by providing solely conventional fuels to niche markets. Similar specialization may occur in new reformulated fuels markets.

International trade in petroleum will also be affected by the growing demand for reformulated fuels. Refiners in countries outside the reformulated fuels markets that wish to export to those markets will have to make the necessary refining and blending adjustments. Programs to upgrade refineries in Canada and Mexico are already underway [26].

\section{Summary}

The international trend toward regulation of fuel qualities has resulted in the displacement of dirtier fuels by cleaner burning gasoline and diesel fuel. In many countries, leaded gasoline has been replaced by unleaded gasoline or is in the process of being replaced. A growing number of countries have either introduced reformulated gasoline and diesel fuel or have plans to do so.

Goals to remove lead as a gasoline additive in China, Europe, and Latin America may require additional blending with oxygenates such as MTBE and ethanol. Demand for oxygenates may also rise where reformulated gasoline has a minimum oxygen content. Reformulated gasoline in the United States, Finland and Sweden already require the addition of oxygenates, and the proposed standards for the Latin America/Caribbean countries include an oxygen requirement.

Potential reductions in $\mathrm{NO}_{x^{\prime}}$ VOC, air toxic, and particulate matter emissions from lowering the sulfur content of gasoline and diesel have made sulfur reduction a major focus in the development of reformulated fuels, although sulfur limits vary. For example, proposed Latin American/Caribbean standards for diesel fuel require a maximum sulfur content of $5,000 \mathrm{ppm}$ in 2001, whereas Finland, Sweden, and the State of California already require diesel fuel containing less than $50 \mathrm{ppm}$. Sulfur reductions are proposed for gasoline and diesel fuel in Europe and the Latin America/Caribbean region.
In addition, tighter emissions requirements for gasoline in the year 2000 are expected to necessitate lower sulfur content in the United States. Stiffer limits on sulfur may cause some refineries to switch to crude oils that are relatively low in sulfur. Investment in refinery desulfurization processes will also play a major role in the production of reformulated fuels.

\section{References}

1. Energy Information Administration, Short-Term Energy Outlook, First Quarter 1998, DOE/EIA0202(98/1Q) (Washington, DC, January 1998), Table A3.

2. Y.M. Ibrahim, "Baghdad's Ability To Sell Oil Is Hurt by Poor Maintenance," New York Times, Vol. 147, No. 51,083 (March 1, 1998), p. 12.

3. Energy Information Administration, International Energy Annual.1996, DOE/EIA-0219(96) (Washington, DC, February 1998). 1985 data from historical data series available on line at web site www.eia.doe.gov.

4. American Automobile Manufacturers Association, World Motor Vehicle Data 1997 (Detroit, MI, 1997).

5. J. Darjay and D. Gately, Income's Effect on Car and Vehicle Ownership Worldwide: 1960-2015 (New York, NY, September 1997).

6. DRI/McGraw-Hill, Oil Market Outlook (Lexington, MA, July 1995), Table 1, p. 10.

7. Energy Information Administration, Oil Production Capacity Expansion Costs for the Persian Gulf, DOE/EIA-TR/0606 (Washington, DC, February 1996).

8. G. Kemp, Energy Super Bowl: Strategic Politics and the Persian Gulf and Caspian Basin (Washington, DC: Nixon Center for Peace and Freedom, 1997).

9. C. Masters, E. Attanasi, and D. Root (U.S. Geological Survey), "World Petroleum Assessment and Analysis," in Proceedings of the Fourteenth World Petroleum Congress (New York, NY: John Wiley and Sons, 1994).

10. Statoil Energy Studies Program, Oil Price Scenarios Towards 2020 (Oslo, Norway, June 1996).

11. National Oil Sands Task Force, Canada's Oil Sands Industry: Yesterday, Today, and Tomorrow (Alberta, Canada, Spring 1995).

12. M. Lovei, Phasing Out Lead from Gasoline: WorldWide Experience and Policy Implications, World Bank Technical Paper No. 397 (Washington, DC, January 1998), p. 2. 
13. "World Bank Recommends Global Phase-Out of Leaded Gasoline," World Bank News Release No. 96/68s (May 16, 1996).

14. Ozone Transport Assessment Group, Final Report: Volume 2, Summary and Integration Results (Washington, DC, May 1997).

15. World Bank, Phasing Out Lead from Gasoline: WorldWide Experience and Policy Implications, M. Lovei, ed. (Washington, DC, August 1996).

16. Commission of the European Communities, Communication from the Commission to the European Parliament (Brussels, Belgium, October 16, 1997).

17. World Bank, Phasing Out Lead from Gasoline in Central and Eastern Europe, M. Lovei, ed. (Washington, DC, June 1997), p. $x$; and telephone conversation with Magda Lovei, editor.

18. World Bank, Elimination of Lead in Gasoline in Latin America and the Caribbean, Report No. 194/97EN (Washington, DC, December 1996).

19. "Scandinavian Countries Lead the Way," Petroleum Economist (July 1997), pp. 13-14.
20. "New Automaker Study Shows Fuel Sulfur's Emissions Effect," 21st Century Fuels (December 1997).

21. C. Keplinger, "Colombia Eyes Ethanol To Fill Oxygen Standard," Oxy-Fuel News (November 17, 1997).

22. G. Unzelman, "Pemex Leads Fuel Reformulation; Clean Air Follows," Hart's Fuel Technology Management (March 1997).

23. M.J. Reidy, Economic Liberalization in the Petroleum, Petroleum Products and Motor Fuels Sectors of China and India (New York, NY, 1997), p. 32.

24. Energy Information Administration, Petroleum 1996: Issues and Trends, DOE/EIA-0615(96) (Washington, DC, September 1997).

25. L. Upson and M.W. Schnaith, "Low-Sulfur Specifications Cause Refiners To Look at Hydrotreating Options," Oil and Gas Journal (December 8, 1997).

26. J.E. Sinor Consultants Inc., The Clean Fuels and Electric Vehicles Report (June 1997), p. 157. 


\section{Natural Gas}

\section{By 2020, the world's annual consumption.of natural gas is projected to be more than double the 1995 level. Much of the growth is expected to fuel electricity generation worldwide.}

Natural gas is expected to be the fastest-growing primary energy source in the world over the next 25 years. In the IEO98 reference case, gas consumption grows by 3.3 percent annually through 2020 , as compared with 2.1-percent annual growth for oil and renewables and 2.2 percent for coal. By 2020, the world's consumption of natural gas is projected to equal 172 trillion cubic feet, more than double the 1995 level (Figure 43). Much of the growth is expected to fuel electricity generation worldwide (Figure 44), but resource availability, cost, and environmental considerations will also contribute to growing use of gas in industrial, residential, and commercial sector applications.

Figure 43. World Natural Gas Consumption in Three Cases, 1970-2020

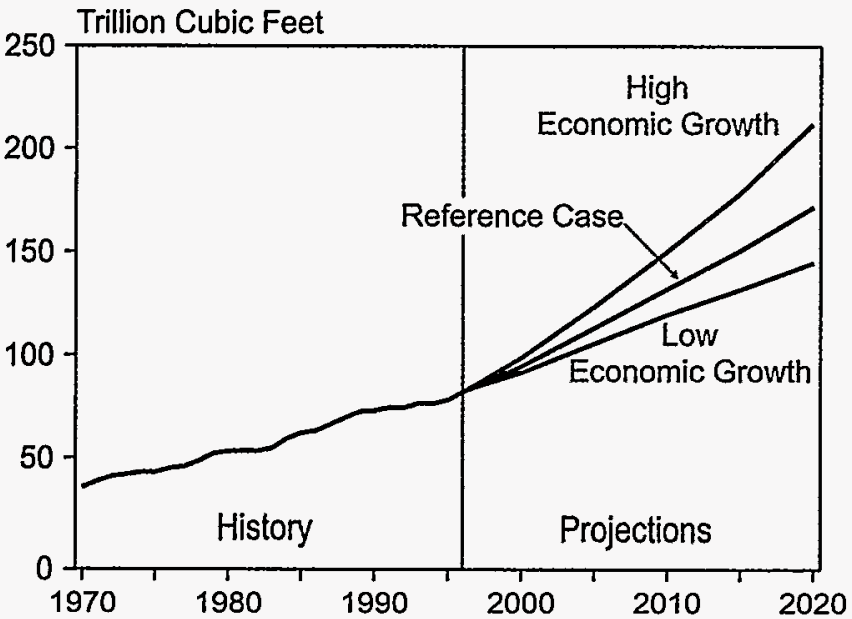

Sources: History: Energy Information Administration (EIA), Office of Energy Markets and End Use, International Statistics Database and International Energy Annual 1996, DOE/EIA0219(96) (Washington, DC, February 1998). Projections: EIA, World Energy Projection System (1998).

Worldwide there is a great deal of construction activity to develop gas distribution and transmission systems. According to the International Pipe Line and Offshore Contractors Association, 53,000 miles of new pipeline are expected to be installed between 1998 and 2000, including 34,000 miles of natural gas pipelines [1]. The survey included only firm projects that have secured financing and did not include projects in the former Soviet Union and China.

Gas demand will grow fastest in the developing countries of the world. IEO98 expects gas consumption in the
Figure 44. Natural Gas Use for Electricity Generation and for All Other Uses, 1995-2020

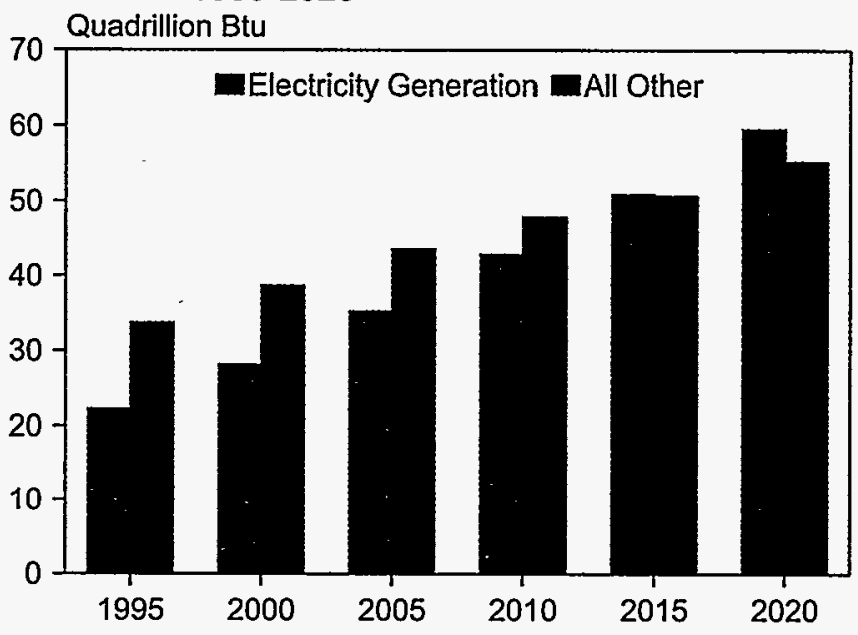

Sources: 1995: Energy Information Administration (EIA), Office of Energy Markets and End Use, International Energy Annual 1996, DOE/EIA-0219(96) (Washington, DC, February 1998). Projections: EIA, World Energy Projection System (1998).

developing countries to grow by about 5.6 percent annually over the next 25 years, compared with 2.5 percent per year in the industrialized countries and 2.4 percent in Eastern Europe and the former Soviet Union (EE/FSU) (Figure 45). Gas use in developing Asia grows by more than 7 percent annually over the forecast period, despite the recent economic downturn in the region. While some expensive gas projects in the developing nations of Asia may be postponed, many others are continuing as planned.

Robust activity is also continuing in Central and South America to develop the infrastructure needed to deliver natural gas to industrial consumers and electric power generators. In the region as a whole, natural gas consumption grows by 6.7 percent annually over the projection period. In Brazil, gas use is expected to increase by about 14 percent per year. The countries of Central and South America are moving to diversify fuel sources for power generation. Hydropower has dominated electricity generation in the region, but rapid demand growth and periodic water shortages have led to some power shortages. Natural gas is an attractive alternative to oiland coal-fired generation. Construction on several major pipelines and various power plants and industrial 
Figure 45. World Natural Gas Consumption by Region, 1970-2020

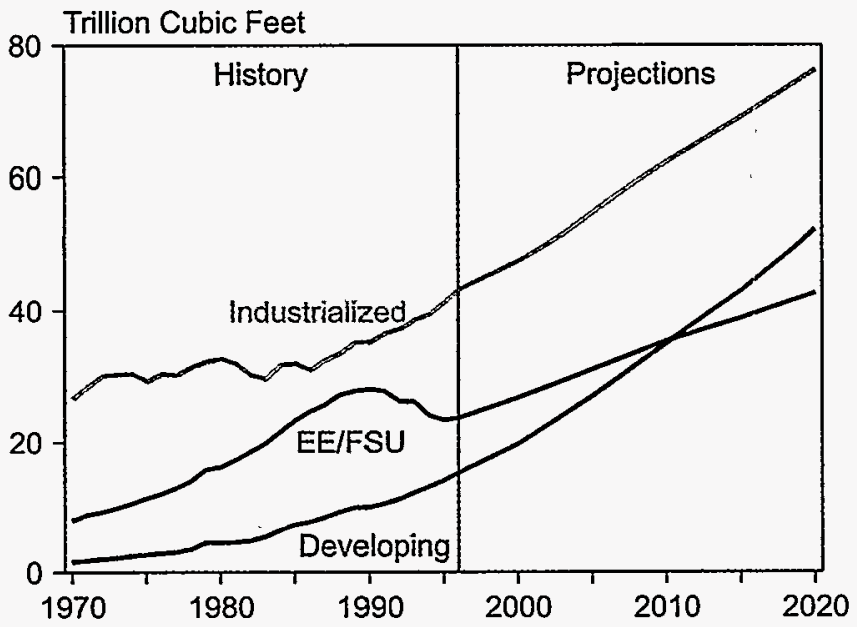

Sources: History: Energy Information Administration (EIA), Office of Energy Markets and End Use, International Statistics Database and International Energy Annual 1996, DOE/EIA0219(96) (Washington, DC, February 1998). Projections: EIA, World Energy Projection System (1998).

operations began in 1997, including work on the $\$ 2$ billion Bolivia-Brazil pipeline.

In 1997 Eastern European countries like the Czech Republic-currently heavily dependent on the FSU to meet their natural gas needs-began efforts to diversify their natural gas supplies. The Czech Republic signed a 20-year contract with Norway's Gas Negotiating Committee to purchase a peak level of 106 billion cubic feet of gas per year. Natural gas consumption in the EE/FSU is expected to grow by 2.4 percent annually between 1995 and 2020; but the region's strongest growth occurs in the countries of Eastern Europe, where economic recovery occurs more rapidly over the forecast than in the FSU. Annual gas consumption growth approaches 4.0 percent per year in Eastern Europe, compared with only 2.2 percent per year in the FSU.

In the industrialized world, gas demand grows by 85 percent over the forecast horizon, reaching 76 trillion cubic feet in 2020. Some of the most robust growth among the industrialized countries occurs in Western Europe, where gas demand is expected to increase by 3.8 percent annually over the 25 -year projection period. The European Union has agreed on a timetable for instituting the European Gas Directive, which will allow for the deregulation of West European gas markets. Privatization and restructuring of the electric utility sector beyond the requirements of the Gas Directive have already occurred in many European countries where there are plans to increase natural gas use for generating electricity. Moreover, in a number of Western European countries, plans for reducing greenhouse gases include the use of natural gas to replace more carbon-intensive coal- and oil-fired generating capacity.

Some key developments supporting the world's natural gas markets in 1997 include:

- Installation of NorFra, the world's longest subsea pipeline, was completed in August 1997. The pipeline extends more than 520 miles from Draupner, offshore Norway, to Dunkirk, France. Gas delivery to France is scheduled to begin in October 1998 [2].

- Vibrant growth in Central and South America was demonstrated by the completion of the GasAndes pipeline. This pipeline, completed in August 1997, provided the first natural gas supplies to Santiago, Chile. Beginning in October, 60 million cubic feet per day of natural gas was supplied from Mendoza, Argentina, for use by the Chilean gas distributor, Metrogas, through the pipeline. Progress was also made on other major pipeline projects, including the Bolivia-Brazil pipeline and the Atacama pipeline, in 1997.

- Development of Iran's South Par natural gas field moved closer to reality as Total, Gazprom, and Petrogas signed a $\$ 2$ billion contract to develop 2 billion cubic feet per day from the field. Despite the threat of penalty from enforcement of the 1996 U.S. Iran-Libya Sanctions Act, plans for the South Par project were finalized in 1997. Gas from the project will eventually be exported to Turkey, perhaps as early as 1999 . As a method to deter international terrorist activities in Libya and Iran, the Sanctions Act penalizes nonU.S. firms investing more than $\$ 40$ million (reduced to $\$ 20$ million in August 1997) in the energy industries of the two countries.

- Substantial planned increase in pipeline capacity between the United States and Canada is underway. U.S. imports of natural gas, primarily from Canada, are forecast in the Annual Energy Outlook 1998 (AEO98) to increase from 2.9 to 5.2 trillion cubic feet between 1995 and 2020, with more than half the increase occurring by 2000 . Most of the capacity expansion needed to support the increase between now and 2000 is either already under construction or in the planning stages. Although year-to-date 1997 figures reflect little increase, imports are expected to expand as planned capacity comes on line. 


\section{Reserves}

As of January 1, 1998, proven world natural gas reserves, ${ }^{5}$ as reported by Oil \& Gas Journal, were estimated at 5,086 trillion cubic feet, 141 trillion cubic feet higher than the estimate for 1997. All the increases in reserves are attributed to the developing countries, with virtually no changes in the industrialized regions or the $\mathrm{EE} / \mathrm{FSU}$. Small reserve declines in developing Asia were more than offset by increases in the Middle East (109 trillion cubic feet), Africa ( 20 trillion cubic feet), and Central and South America (14 trillion cubic feet).

About 73 percent of the world's natural gas reserves are located in the FSU and countries of the Middle East. Russia and Iran alone account for almost half of the world's gas reserves (Table 19). In the industrialized world, reserves have remained fairly stable over the past 20 years, although they have continued to decline since 1993 (Figure 46). Reserves in the EE/FSU and developing countries have, in contrast, more than doubled over the past two decades.

Figure 46. World Natural Gas Reserves by Region, 1975-1998

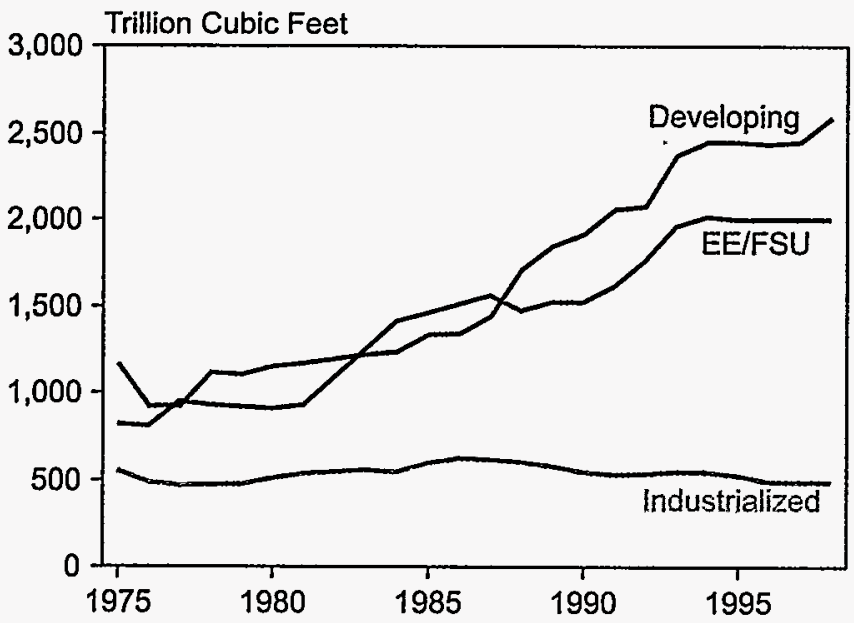

Sources: 1975-1997: "Worldwide Oil and Gas at a Glance," International Petroleum Encyclopedia (Tulsa, OK: PennWell Publishing, various issues). 1998: Oil \& Gas Journal, Vol. 95, No. 53 (December 31, 1997), pp. 38-39.

Worldwide, natural gas reserves are more widespread geographically than oil reserves. Outside the EE/FSU and the Middle East, reserves are fairly evenly spread, except in the Industrial Pacific region (Figure 47). Moreover, despite high rates of increase in gas consumption, especially in the past 10 years, most regional reserves-toproduction ratios have remained high. Central and South America has a reserves-to-production ratio of about 70.2 years, the FSU 81.1 years, and the Middle East and Africa both more than 100 years $[3$, p. 20].
Table 19. World Natural Gas Reserves by Country as of January 1, 1998

\begin{tabular}{|c|c|c|}
\hline Country & $\begin{array}{c}\text { Reserves } \\
\text { (Trillion } \\
\text { Cubic Feet) }\end{array}$ & $\begin{array}{l}\text { Percent of } \\
\text { World Total }\end{array}$ \\
\hline World . . . . . . . & 5,086 & 100.0 \\
\hline Top 20 Countries . . . . . & 4,549 & 89.4 \\
\hline Russian Federation. . . . . & 1,700 & 33.4 \\
\hline$\cdots \cdots \cdots$ & 810 & 15.9 \\
\hline 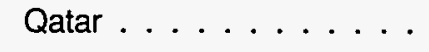 & 300 & 5.9 \\
\hline United Arab Emirates . . . . & 205 & 4.0 \\
\hline Saudi Arabia . . . . . . & 190 & 3.7 \\
\hline United States . . . . . . . . & 166 & 3.3 \\
\hline Venezuela ....... & 143 & 2.8 \\
\hline$\ldots \ldots \ldots$ & 131 & 2.6 \\
\hline $\operatorname{Iraq} \ldots \ldots \ldots$ & 110 & 2.2 \\
\hline Nigeria . . . . . . & 115 & 2.3 \\
\hline Turkmenistan . . . . . . . . & 101 & 2.0 \\
\hline Malaysia . . . . . . . & 80 & 1.6 \\
\hline Indonesia . . . . . . & 72 & 1.4 \\
\hline Uzbekistan . . . . . . & 66 & 1.3 \\
\hline Canada . . . . . . . & 65 & 1.3 \\
\hline Kazakhstan . . . . . . . & 65 & 1.3 \\
\hline Mexico . . . . . . . & 64 & 1.3 \\
\hline Netherlands. . . . . . . & 61 & 1.2 \\
\hline Kuwait. . . . . . . & 52 & 1.0 \\
\hline Norway . . . . . . . & 52 & 1.0 \\
\hline Rest of World . . . . . . & 538 & 10.6 \\
\hline
\end{tabular}

Source: "Worldwide Look at Reserves and Production," Oil \& Gas Journal, Vol. 95, No. 52 (December 29, 1997), pp. 38-39.

Figure 47. World Natural Gas Reserves by Region as of January 1, 1998

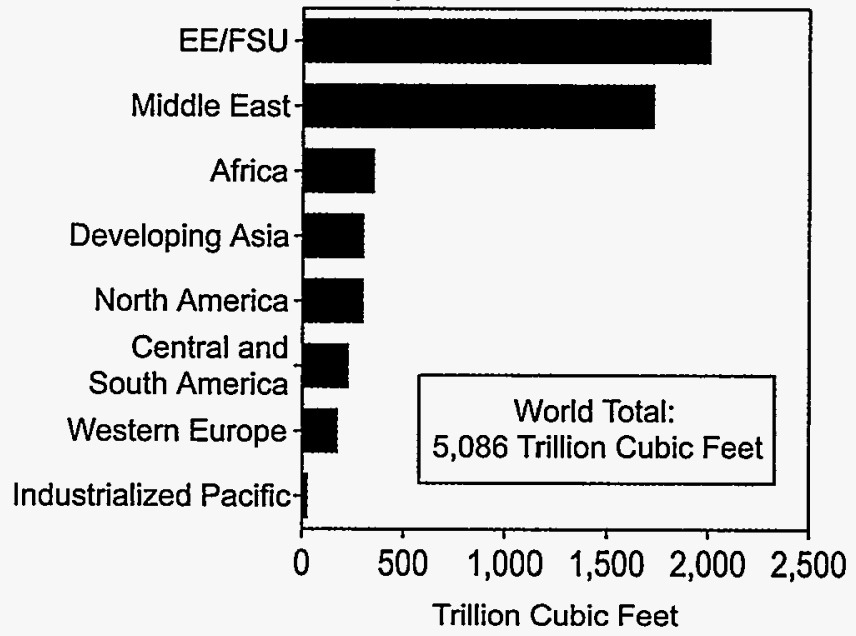

Source: Oil \& Gas Journal, Vol. 95, No. 53 (December 31, 1997), pp. 38-39.

5 Proven reserves are the estimated quantities that analyses of geological and engineering data demonstrate with reasonable certainty to be recoverable in future years from known reservoirs under existing economic and operating conditions. However, significant reserves in the probable category are included in "reserves" estimates for various countries, including those of the former Soviet Union. 


\section{Regional Activity}

\section{North America}

The IEO98 forecast shows a 55-percent increase in North American natural gas consumption, from 25.4 trillion cubic feet in 1995 to 39.4 trillion cubic feet in 2020. Consumption in the United States and Canada is projected to grow by 49 and 53 percent, respectively, and consumption in Mexico by 180 percent (Figure 48). Growth in natural gas consumption in other areas of the world is even faster than the growth in North American consumption (with the exception of Mexico), and North America's share of total world natural gas consumption declines from 32 percent in 1995 to 23 percent in 2020. North America's share of natural gas consumption in industrialized countries also falls, from 62 percent in 1995 to 52 percent in 2020.

Figure 48. Natural Gas Consumption in North America by Country, 1970-2020

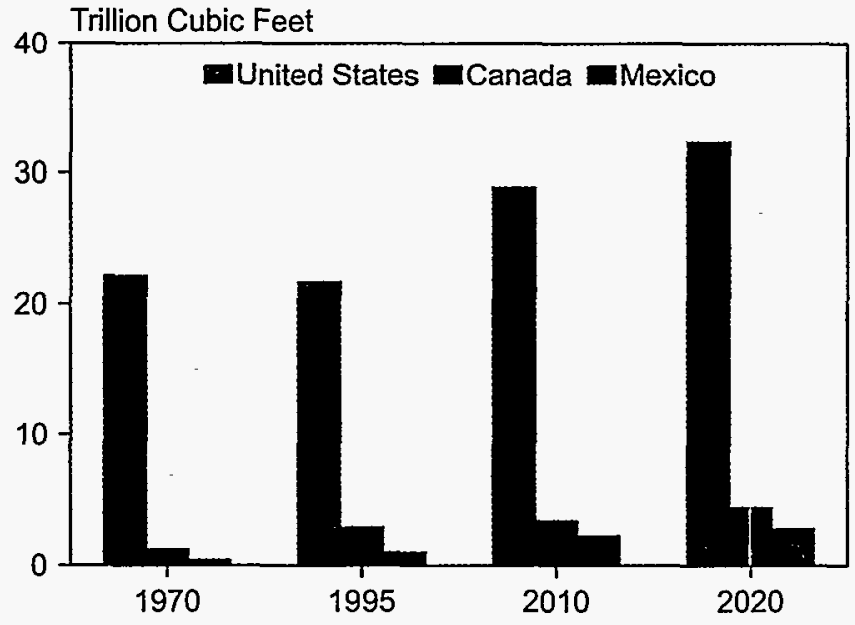

Sources: History: Energy Information Administration (EIA), Office of Energy Markets and End Use, International Statistics Database and International Energy Annual 1996, DOE/EIA0219(96) (Washington, DC, February 1998). Projections: EIA, World Energy Projection System (1998).

In all three North American countries electric utility sector restructuring is either underway or under consideration, and the primary driving force behind the projected increases in natural gas consumption is its use as a fuel for electricity generation. In EIA's Annual Energy Outlook 1998 (AEO98) reference case, natural gas consumption in the U.S. electricity generation sector almost triples between 1995 and 2020, from 3.4 trillion cubic feet a year in 1995 to 9.9 trillion cubic feet in 2020 . The increase stems from expectations of expanded utilization of existing gas-fired power plants, additions of new turbines and combined-cycle facilities, and the opening up of new opportunities for gas-fired generation as a result of restructuring in the electric utility industry. Although the greatest anticipated increase in U.S. natural gas consumption is in the electricity generation sector, increases are also projected for all the end-use sectors.
The Canadian Gas Association (CGA) expects strong growth in Canadian natural gas consumption for power generation, projecting that consumption in the power generation sector will more than double between 1997 and 2010, from about 158 billion cubic feet in 1997 to 321 billion cubic feet in 2010. The strongest growth is expected between now and 2001, as electricity sector restructuring takes hold. The CGA indicates that its forecast is heavily influenced by the restructuring of the electricity sector that is currently either underway or anticipated in many provinces. While growth in gas use in the residential and commercial sectors is expected to slow as a result of conservation and efficiency improvements, the CGA still anticipates modest growth for those sectors as well [4].

In Mexico, the Comision Federal de Electricidad (CFE), the state utility that currently serves 99 percent of the Mexican power market, has been exploring options for the restructuring of the electricity sector for about 2 years. Although no clear restructuring strategy has yet emerged, strong growth for natural gas consumption for power generation is anticipated. Natural gas demand for power generation has grown by more than 5 percent per year for several years, and the CFE hopes to install 13 gigawatts of predominantly gas-fired combined-cycle new capacity over the next 5 years (the CFE has indicated that it plans to have 47 gigawatts of installed capacity by 2006). In addition, conversions of 12 existing fuel-oil plants to natural gas are expected to increase gas demand at those units from 22 million cubic feet per day in 1996 to 872 million cubic feet per day in 1999. A major impetus for the conversions is environmental concerns. By 2006, overall CFE gas consumption is expected to quintuple from the current rate of 500 million cubic feet per day [5].

Infrastructure expansion is both underway and expected to continue throughout North America to meet increasing demand. More than 40 pipeline construction projects, including 10 new pipelines, were completed in the United States in 1997, adding more than 6.6 billion cubic feet per day of capacity [6]. The AEO98 projects continued expansion of interstate pipeline capacity between now and 2020, with the biggest increases along corridors that move Canadian and Gulf Coast supplies to markets in the eastern half of the United States. Increases in storage capacity are projected for most regions of the United States. A considerable increase in pipeline capacity both within Canada and between Canada and the United States is expected to provide access to western Canadian supplies and Sable Island supplies in the offshore Atlantic, significantly enhancing the possibilities for trade between the United States and Canada.

Trade between the United States and Mexico is also expected to grow, with U.S. exports to Mexico increasing 
to help meet Mexico's anticipated consumption growth. Two new natural gas export lines to Mexico, totaling 237 million cubic feet per day of new capacity, were placed in service in 1997. The completion of the lines increased U.S. export capability to Mexico by 27 percent [6]. A past hindrance to imports of U.S. gas supplies into Mexico has been a 6-percent tariff on U.S. gas imported into Mexico. On June 13, 1997, a petition signed by the Natural Gas Supply Association and four others was filed with the U.S. Trade Representative, seeking early elimination of the tariff [7]. The request is now being considered by trade officials of both countries. The tariff, paid by Mexican businesses and consumers, has kept U.S. supplies from competing with natural gas produced by Mexico's monopoly supplier, Petroleos Mexicano (PEMEX). Its elimination would foster competition between PEMEX and imported gas and lower the overall cost of gas in Mexico [8].

Privatization of Mexico's natural gas industry-begun in May of 1995 with the mandated liberalization of the transmission, distribution and storage of natural gascontinues. Eight distributorships have already been privatized (three have completed the process and five have been awarded permits), and four additional concessions are slated to be offered in the near future [9, p. 155]. PEMEX is currently preparing a tender to be issued in early 1998 for Mexico's first natural gas storage project, reportedly to be both built and operated by private companies [10].

Although the Mexican constitution prohibits foreign participation in oil and gas exploration, production and refining, there has been speculation that the government would try to allow foreign firms to produce gas in the northern Mexico's Burgos Basin by designing a contract that would be a service contract with performance incentives tied to output. PEMEX has called a tender for the development of Burgos Basin fields in order to increase domestic supplies in the area and head off competition from U.S. producers, which are gaining access to the region as a result of the opening of the natural gas pipeline sector to foreign investment [11].

\section{Western Europe}

Western Europe is expected to see some of the most rapid growth in natural gas consumption among the industrialized countries. In the IEO98 forecast, gas use in Western Europe rises from 13 trillion cubic feet in 1995 to more than 32 trillion cubic feet in 2020 (Figure 49). In large part, the growth can be attributed to the privatization that many European countries are currently undergoing in the energy sector, as well as government encouragement to develop the natural gas infrastructure as a way of reducing greenhouse gas emissions. In addition, the European Union (EU) is attempting to liberalize Europe's energy markets, and year-long negotiations resulted in an approved timetable for the EU's Gas
Directive, which allows for the deregulation of Western Europe's gas markets (see box on page 54).

\section{Figure 49. Natural Gas Consumption in Western Europe, 1970-2020}

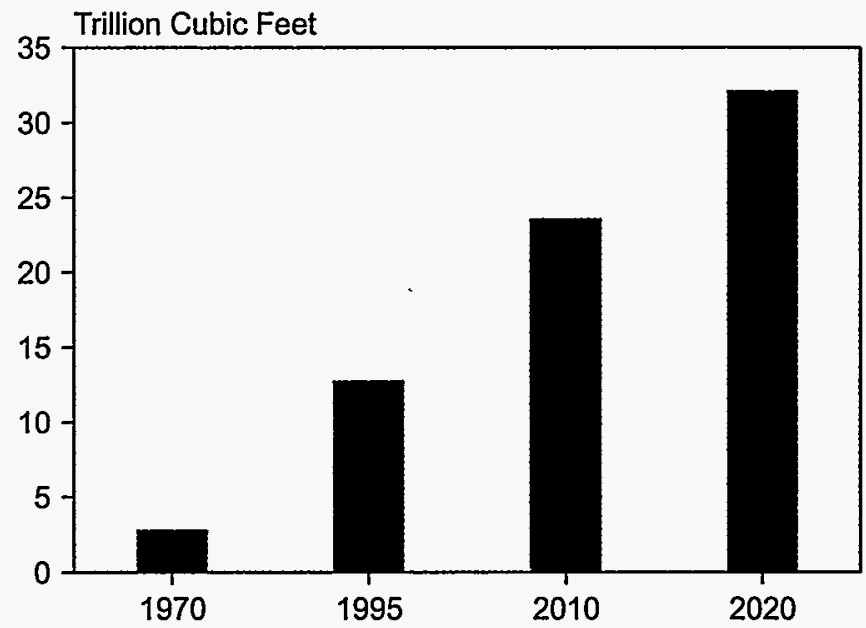

Sources: History: Energy Information Administration (EIA), Office of Energy Markets and End Use, International Statistics Database and International Energy Annual 1996, DOE/EIA0219(96) (Washington, DC, February 1998). Projections: EIA, World Energy Projection System (1998).

The United Kingdom started to liberalize its natural gas markets in 1986, and they should be fully open by the end of 1998. The market restructuring has resulted in substantial growth in gas-fired electric power generation in the country and plans for further expansion in the future. Since 1990, 11.4 gigawatts of combined-cycle gas-fired electricity generation capacity has been built in the United Kingdom. An additional 4.5 gigawatts of capacity is currently under construction, 7.5 gigawatts has been approved for construction, and an additional 7.9 gigawatts has been proposed, which may or may not receive approval [14, p. 263]. In 1996 alone, 2.3 gigawatts of new gas-fired electricity generating capacity was added.

The current status of Western European natural gas pipelines is shown in Figure 50. In October 1998, the Interconnector pipeline should be completed, linking Bacton, England, and Zeebrugge, Belgium. The pipeline will have an export capacity from Bacton to the continent of 706 billion cubic feet per year and an import capacity of 388 billion cubic feet per year. While it seems unlikely that the United Kingdom will be able to use the Interconnector to export substantial gas to the European continent until gas prices rise, several export contracts have been signed with the German utilities Wingas, Ruhrgas, and Thyssengas for a total of 1,589 billion cubic feet, and with Norsk Hydro for an additional 424 billion cubic feet. The contract periods range from 7 to 15 years, beginning at the end of 1998; thus, between 18 and 70 billion cubic feet per year will be delivered under each contract [15] (Table 20). These contracts will allow German utilities to diversify their gas supplies. 


\section{European Union Natural Gas Directive}

Since 1990, the European Union (formerly, the European Economic Community) has worked to develop an agreement to liberalize Western Europe's energy markets. In 1990, the EU adopted the Electricity Transit Directive, followed in 1991 by the Natural Gas Transit Directive and the Gas and Electricity Price Transparency Directive. These three directives defined the first part of a three-phase program to open European energy markets and establish an internal market for the "production, distribution, and transmission of energy in order to increase energy efficiency and transparency of cost."

The Electricity Directive and the Natural Gas Directive form the second phase of the plan. In 1996, the Electricity Directive was approved. It requires members to deregulate 23 percent of their electricity markets by 1999. A timetable establishing the EU's Natural Gas Directive and thereby deregulating European gas markets was approved on December 8, 1997. The objective of the Natural Gas Directive is to "establish common rules for access to the market and for the criteria and procedures to be used when licensing the transmission, storage, and distribution of natural gas" in the $\$ 100$ billion European gas market.

The natural gas markets will be opened in three phases over a 10-year period [12]. In each EU member state, 20 percent of the market is to be opened for the first 5 years, 28 percent for the next 5 years, and 33 percent after the end of the 10-year transition period.

The largest impediment to securing an agreement between the EU member states was to determine the minimum share of the gas markets that would have to be liberalized in the three phases of the plan. The EU ministers had been debating the minimum level for opening the gas markets for almost a year, since the time the Electricity Directive was approved. France and Belgium wished to limit the deregulation to a minimum of 15 percent of the gas markets, whereas the United Kingdom and Germany wished to have at least 28 percent of the gas markets opened in the first phase of the plan.

In France and Belgium, limiting deregulation is a way to protect Gaz de France and Distrigaz, which are both virtual monopoly companies in terms of natural gas imports and distribution for their respective countries [13, p. 22]. Alternatively, the United Kingdom government believes that competitive markets will allow consumers and producers to arrive at optimal gas prices, and that faster deregulation will speed the process. Germany felt that the 10-year phased liberalization of gas markets would be too slow, favoring more rapid deregulation to move the process along [13, p. 20].

Negotiations on other aspects of the Natural Gas Directive also continued throughout 1997. In October, EU energy ministers agreed on a review procedure for long-term gas deals, allowing regulators from member states to decide whether future take-or-pay contracts would be exempt from the directive's provisions, with a chain of rules that would allow the European Commission to challenge the position of the regulator. Challenges to the Commission's ultimate positions will be resolved only through the European Court of Justice.

Under the Natural Gas Directive, all power producers will have the right to choose suppliers. European Union members may, however, restrict supplier access to cogenerators that use less than the annual consumption thresholds set in the directive for each of the three phases: 833 million cubic feet per year in the first phase; 530 million cubic feet per year in the second phase; and 177 million cubic feet per year in the final phase. That is, if opening the market to cogenerators consuming more than 833 million cubic feet in the first supplier phase year does not result in the liberalization of at least 20 percent of a country's total gas market, the threshold will be reduced in subsequent years until the 20-percent mark is achieved [14, p. 91]. Only in France, where there is little gas use for electricity generation, will the 833 million cubic feet threshold be inadequate to meet the 20 percent minimum opening.

In the December announcement of the Natural Gas Directive, there was no mention of how third-party access to offshore gas pipelines would be handled. In October, the British delegation presented a proposal that reportedly received "general acceptance." Britain does not want to obligate offshore pipeline operators to publish "indicative pipeline tariffs," which are considered to be commercially sensitive. 
Figure 50. Current Status of Western European Natural Gas Pipelines, 1997

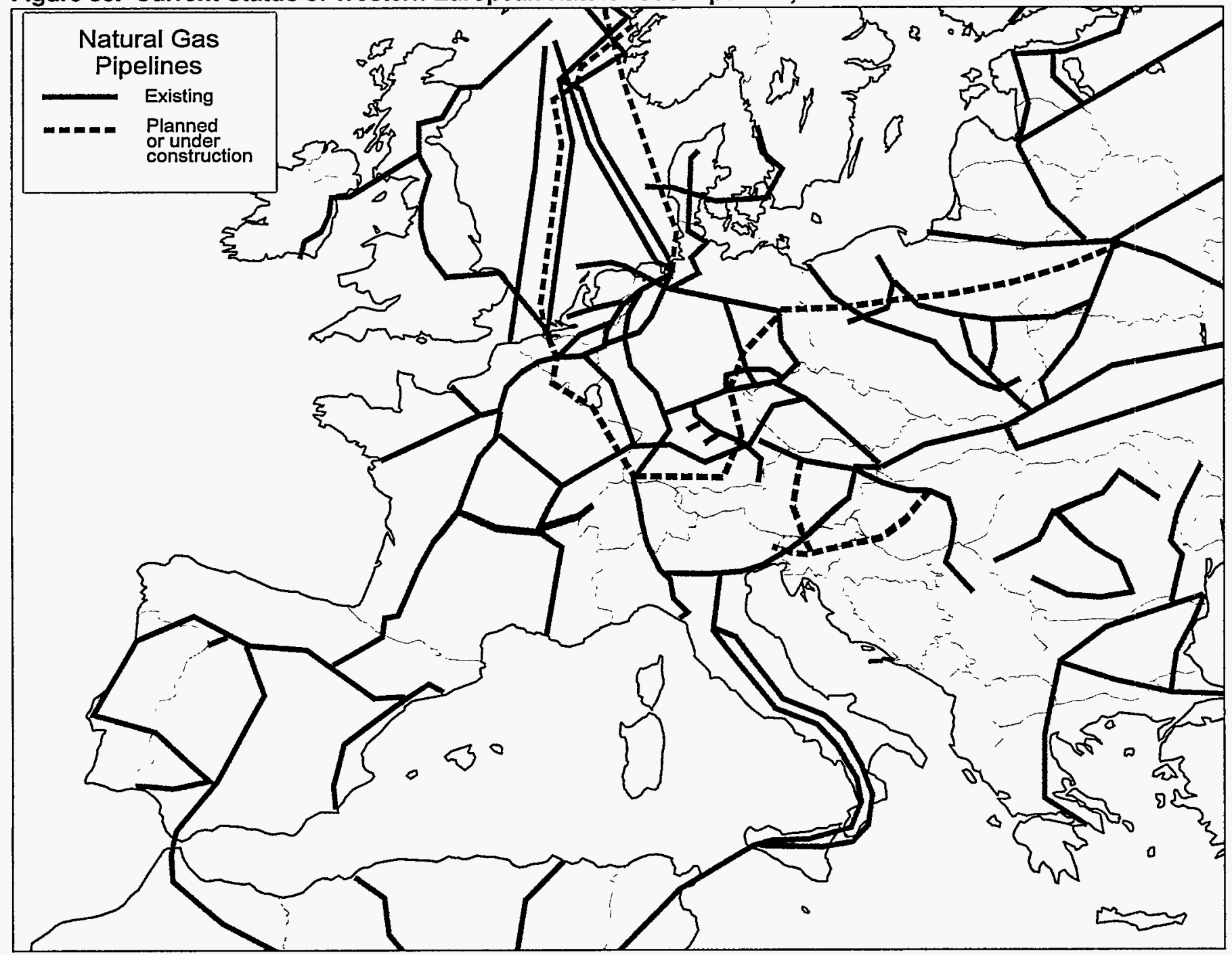

Source: DRI/McGraw-Hill, Towards a Competitive European Natural Gas Market (Lexington, MA, November 1997), p. 100.

Table 20. Contracts in Place for Natural Gas Sales from the United Kingdom's Interconnector to Mainland Europe

\begin{tabular}{|c|c|c|c|}
\hline Supplier/Buyer & Contract Signed & $\begin{array}{c}\text { Volume } \\
\text { (Billion Cubic Feet) }\end{array}$ & Years Covered $^{a}$ \\
\hline Conoco/Wingas. . . . . . . . & February 1996 & 353 & 10 \\
\hline BGT/Wingas . . . . . . . & July 1996 & 706 & 10 \\
\hline BP/Ruhrgas. . . . . . . & January 1997 & 530 & 15 \\
\hline BGT/Thyssengas . . . . . . . & May 1997 & 106 & 7 \\
\hline Mobil/Norsk Hydro . . . . . . . . & May 1997 & 424 & 15 \\
\hline
\end{tabular}

${ }^{\text {a } B e g i n n i n g ~ i n ~ t h e ~ t h i r d ~ q u a r t e r ~ o f ~} 1998$.

Source: "UK Gas Sales to Europe Top 60-Bcm as Interconnector Nears," World Gas Intelligence, Vol. 8, No. 10 (May 30, 1997), p. 10. 
Other countries in Western Europe will be able to take advantage of their resource bases or strategic geographic positions in the fast-growing gas sector. In Norway, for example, rich natural gas reserves are used mainly as an export commodity and for fairly moderate consumption in the country's offshore oil and gas facilities [16]. In fact, plans to construct two 350-megawatt gas-fired power plants on Norway's west coast to supply electricity to Sweden and Finland were met with protest from environmental groups, which argued that the additional thermal capacity would increase the country's greenhouse gas emissions (virtually all Norway's electricity is generated by hydroelectricity). Government approval was given to the plants, which are scheduled to begin operating in 1999, but it will be difficult to build additional plants in the future because of the environmental considerations. Interestingly, the resulting gas-generated electricity would replace coalfired generation in Sweden and Finland, thus reducing the regional emissions.

Norway secured several natural gas export contracts in 1997, including a contract to supply 1,412 billion cubic feet to $\mathrm{Gaz}$ de France over a 26-year period beginning in 2001. The gas will be delivered to France through the NorFra pipeline, currently the world's longest subsea pipeline. Another long-term NorFra supply contract was signed with Italy's Snam. Between 353 and 424 billion cubic feet of gas per year will be supplied for 25 years to Italy beginning in 1999-2000. A small contract (for 25 million cubic feet per day) was also signed with Ireland's Bord Gais Eireann for 1 year [17]. The gas will be shipped from the Froy field through the Frigg pipeline to St. Fergus in Scotland and from there to Ireland through Bord Gais' subsea pipeline. The contract will account for 25 percent of Ireland's total gas supply.

Norway has also taken steps to penetrate the East European gas market. The first contract by an East European country-the Czech Republic-for Norwegian gas was signed in April 1997. Norway will supply the Czech Republic's state gas importing company, Transgas, with 106 billion cubic feet per year for a 20-year period [18]. Gas deliveries began in May 1997.

In 1985, Norway supplied about 27 percent of the gas used in the United Kingdom from its share of the Frigg field [16]. But a sharp increase in UK gas production, coupled with declining output from Frigg and the refusal of the British government to authorize new gas imports, has caused the Norwegian share to drop to about 2 percent. Talks between the two countries began in 1996. Norway resolved problems with the United Kingdom in 1997 and now is able to export gas to the United Kingdom through the Frigg pipeline [19].

Norway has taken steps to bolster its natural gas infrastructure in order to accommodate the increased opportunities for gas exports. Gas is presently exported through the Europipe and Norpipe to Emden, Germany, and through the Zeepipe to Zeebrugge, Belgium. In 1995, Norwegian authorities approved construction of the NorFra System, which will run from the Sleipner area fields to Dunkirk, France. The Europipe II line, direct from Kårstø to Emden, should be built before 2000. The two planned export pipelines will help Norway meet the terms of existing contracts that will increase its gas exports to nearly 2,648 billion cubic feet per year.

Austria has the geographic vantage to become a major natural gas distribution point for Siberian gas supplies to western and southeastern Europe [20, pp. 19-20]. ÖMV, the largest oil company in Austria, has completed or begun construction on a number of pipeline projects designed to move gas into the European market, such as the Trans-Austria-Gasline (TAG), a 237-mile dual pipeline running across Austria from the Slovak border and supplying 90 percent of its gas to Italy's Snam. ÖMV is in the process of increasing the TAG pipeline capacity. At the end of 1998, the completed line will have a total capacity of 23 billion cubic meters. Other lines include the 152-mile West-Austria-Gasline, which runs from the Slovak border to upper Austria and Germany and supplies Russian gas to Germany and France; the 16mile South-East-Gasline, which supplies gas to Italy, France, Slovenia, and Croatia; and the 74-mile Hungaria-Austria-Gasline.

In Germany, several pipeline projects currently are underway, the three most important being Trans Europa Naturgas Pipeline (a Ruhrgas/Snam joint venture), Wedel Line (Bielefeld to Aachen), and a pipeline from Schnaitsee to the Austrian border. Trans Europa Naturgas Pipeline will expand an existing system that stretches from the German-Dutch border near Aachen to the Swiss-German border at Schwoerstadt with a line that will run parallel to the existing line. Rising demand in southern Germany and Switzerland has created the need for additional capacity, which should be completed by 2000 [14, pp. 156-158]. The first portion of the 50 -mile Wedel line has been completed, connecting Bielefeld to Soest. Construction on the second portion (136 miles from Soest to Aachen) is scheduled to begin early in 1998, and the entire pipeline should be completed by the end of the year. The Wedel line will enable German Wingas to supply gas to the Ruhr region, currently dominated by Ruhrgas.

Many other countries of Western Europe, including Italy, Spain, Greece, and Turkey, have extensive plans to increase natural gas use. In Italy, gas supplies are being secured from both pipeline and liquefied natural gas (LNG) sources. Snam, a subsidiary of the Italian oil and gas company Eni, has contracts with Gasunie (the Netherlands), Sonatrach (Algeria), and Gazprom 
(Russia) for a combined 1,236 billion cubic feet of gas imports per year [14, pp. 185-186]. Italy consumed 1,921 billion cubic feet of natural gas in 1995 [21, p. 8]. Snam has also signed an agreement to import between 212 and 282 billion cubic feet per year from Norway beginning in 2000 [14, p. 185]. Eni and Russia's Gazprom have contracted to provide Italy with an additional 194 billion cubic feet of gas per year. A project to double capacity on the Algeria-to-Italy Transmed pipeline to 847 billion cubic feet per year is already under construction. Enel signed a contract with Algeria's Sonatrach for the supply of 141 billion cubic feet of natural gas per year beginning in 1997, to be shipped through the Transmed 2 pipeline.

In addition to pipeline gas, Italy plans to increase the amount of LNG it imports. Snam plans to construct its second LNG terminal at Monfalcone, northwest of Trieste in the Gulf of Venice. The project would involve the construction of a terminal with an initial annual capacity of 282 billion cubic feet of methane, which could be expanded to 424 billion cubic feet. The existing Snam LNG terminal at Panigaglia near La Sezia, in the Gulf of Genoa, has a capacity of 106 billion cubic feet per year.

Enel had signed a contract to purchase 124 billion cubic feet of gas from the Bonny LNG project in Nigeria over a 20 -year period. At the end of 1996, however, the company canceled the contract, after determining that it would be unable to construct an LNG receiving terminal on the Luscany coast because of the costs associated with adhering to environmental stipulations attached to the project.

In 1993, the first Norwegian gas was imported to Spain [14, pp. 236-237]. The gas is piped via the French grid at 71 billion cubic feet per year. An even more important development for Spanish gas is the 859-mile Maghreb pipeline, which connects Seville, Spain, with the Hassi $\mathrm{R}^{\prime} \mathrm{Mel}$ gas fields in Algeria. The pipeline, with a potential capacity of 635 billion cubic feet per year, will also extend into Portugal. The first gas through Maghreb (initial capacity 247 billion cubic feet per year) arrived in Spain at the end of 1996.

Greece is attempting to introduce gas consumption in order to diversify its energy supplies, decrease dependence on oil and lignite, and reduce greenhouse gas emissions. The state-owned utility, DEPA, started importing gas from Bulgaria and Russia in July 1997 through a Bulgarian pipeline [20, pp. 49-50]. The company has contracts in place to supply natural gas to electric utilities and 17 industrial companies.

So far, there are plans for gas use in five Greek cities: Athens, Kavalla, Thessalonika, Volos, and Piraeus. A 248-mile pipeline should connect them, and Russia and
Algeria are expected to supply all of the gas consumed in Greece. The first gas deliveries from Russia to Thessalonika and Athens began in July 1997, through a 310-mile pipeline that runs from Bulgaria to Athens. The gas pipeline is designed to transport 247 billion cubic feet per year. Prometheus Gas-a joint venture between Russia's Gazprom and Greece's Kopelouzos-along with Stroytransgas and Zangas is also constructing a 372-mile distribution pipeline.

In addition, the European Investment Bank (EIB) is funding the construction of a high-pressure gas transmission and distribution system in Greece. The project is the largest energy investment (Ecu 200 million) in Greece by the EIB. The system includes a pipeline running from the Greek-Bulgarian border at Kula to Aghia Triada near Athens, plus an offshore pipeline running from Aghia Triada to Revithoussa Island and an LNG receiving terminal. The project is jointly supported by the EIB, the EU's Structural Fund, and the European Coal and Steel Community.

Turkey has extensive plans to increase natural gas use for electric power production. The country is attempting to attract enough foreign investment to install 4.2 gigawatts of gas-fired capacity [22]. A call for bids for six build-own-operate power plants was offered in early 1997. The proposed gas-fired plants include two 700megawatt plants in Gebze, one 700-megawatt plant in Adapazari (near Istanbul), one 700-megawatt plant in Ankara, and a 1,400-megawatt plant on the west coast in Izmir. Several pipeline projects have been proposed to supply gas to these facilities, as well as several LNG terminals. In addition, the state-owned gas transportation company, Botas, is expanding its gas transmission network along the Black Sea and the Aegean.

Turkey's plans to import gas from Turkmenistan through a pipeline under construction across Iran led to some controversy with the United States in 1997. The project initially appeared to be in violation of the U.S. Iran-Libya Sanctions Act; however, because Iran will only receive transit fees for moving the gas to Turkey, the United States determined that Turkey was not in violation of the Sanctions Act. The willingness of major world energy companies, such as France's Total, to risk violating the U.S. Sanctions Act clearly demonstrates how lucrative the Turkish gas markets are expected to become.

\section{Eastern Europe and the Former Soviet Union}

IEO98 projects a reversal of recent trends in natural gas markets in Eastern Europe and the former Soviet Union (EE/FSU). Natural gas consumption in the region as a whole is projected to grow from 23.4 trillion cubic feet in 1995 to 42.7 in 2020, an increase of 83 percent (Figure 51). The highest growth is projected for Eastern Europe, 
where consumption is projected to more than double, increasing from 2.7 trillion cubic feet in 1995 to 7.3 trillion cubic feet in 2020. Consumption growth in the FSU is projected to increase by 72 percent over 1995 levels by 2020, with slight growth between now and 2000 and most of the growth occurring in the post-2000 period. The projected growth in Eastern European is more rapid, with a relatively steady rise throughout the forecast.

\section{Figure 51. Natural Gas Consumption in the EE/FSU Region, 1970-2020}

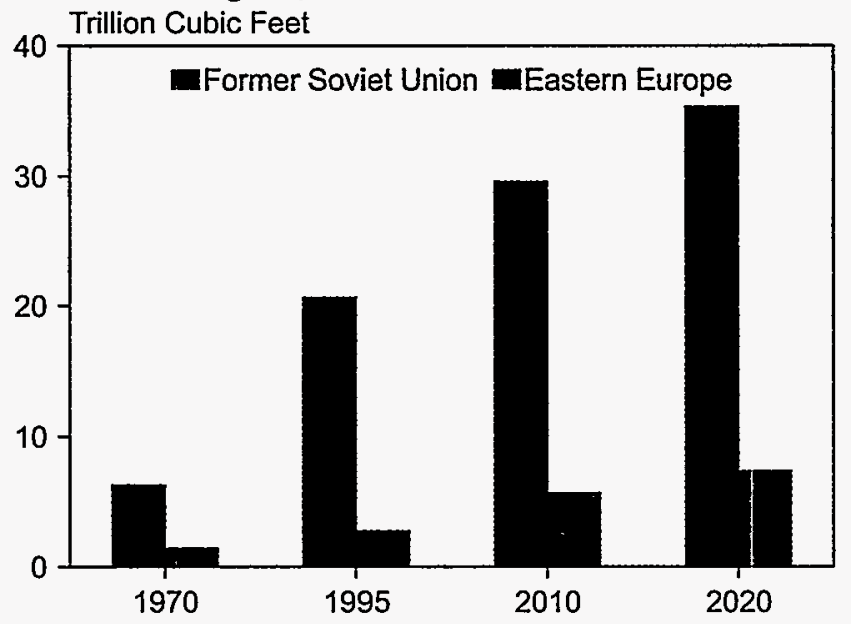

Sources: History: Energy Information Administration (EIA), Office of Energy Markets and End Use, International Statistics Database and International Energy Annual 1996, DOE/EIA0219(96) (Washington, DC, February 1998). Projections: EIA, World Energy Projection System (1998).

The FSU accounts for more than 40 percent of the world's natural gas reserves. With more than 34 percent of the world's proven reserves, Russia far exceeds any other country in production potential. Other FSU republics with significant reserves are Azerbaijan, Kazakhstan, Turkmenistan, Ukraine, and Uzbekistan, with reserves ranging from 0.1 percent of the world total for Azerbaijan to 2.0 percent for Turkmenistan [23]. Eastern European countries, although attempting to diversify their supply options, are heavily dependent on the FSU to meet their currently increasing natural gas demand. Proved reserves in all of Eastern Europe currently account for less than 0.5 percent of the world total.

As political and economic conditions stabilize within the $\mathrm{EE} / \mathrm{FSU}$, the downward trend in natural gas production and consumption seen between 1990 and 1995 is already beginning to be reversed. Natural gas production for 1996 in the FSU was 1.4 percent above 1995 levels, with increases in almost all of the gas-producing republics. Russia, the major producer (accounting for 25.1 percent of the world's total production), increased its output by 1.0 percent; Uzbekistan, the second largest producer, increased by 0.8 percent; and Turkmenistan and
Kazakhstan increased by 9.0 and 8.5 percent, respectively. Only Azerbaijan saw a decline, with production dropping by 4.5 percent from 1995 levels, primarily because of problems in recovering associated gas from its primary production source. FSU consumption increased by 0.7 percent over 1995 levels.

Russia significantly slowed its decline in natural gas consumption from 5.1 percent between 1994 and 1995 to 0.3 percent between 1995 and 1996. All the other major consuming republics, with the exception of Azerbaijan and Kazakhstan, showed increases. While Eastern European production declined in general, consumption increases were seen throughout the region $[3, \mathrm{pp} .23$ and 26].

In both Russia and Turkmenistan, production significantly outpaced consumption in 1996, with the excess production exported to satisfy both foreign demand and demand in other FSU republics. Very little gas is consumed internally in Turkmenistan, and most of its output went to other republics, in particular, Ukraine. Russia and Turkmenistan together accounted for 95 percent of the gas trade among the FSU republics, with Kazakhstan and Uzbekistan accounting for the other 5 percent [24, p. 57]. To date, most of Uzbekistan's gas production has been consumed internally. Although there is considerable potential for increased production to meet export demand, particularly to Ukraine, it has so far failed to materialize [24, p. 11]. Kazakhstan consumed most of its production internally and was in addition dependent on imports to satisfy a large portion of its gas demand.

Trade among the FSU republics has been in decline in the 1990s, in part because of a history among the importing republics of nonpayment for supplies and the subsequent amassing of enormous debt for natural gas, causing reluctance on the part of shippers to provide more gas until payments are made. Reduction of amassed debt was significant in 1996, and Ukraine alone reduced its debt from 7.03 billion rubles to 2.27 billion rubles. Russia had in the past treated Ukraine leniently, not only because Ukraine was Russia's largest gas market, but also because 90 percent of Russian export gas moved through Ukraine [24, p. 60]. Belarus, also significantly in arrears in gas debts, plans to reduce part of its debt through participation in the building of the portion of the Yamal-Europe pipeline that transits Belarus.

Infrastructure expansion within the EE/FSU is underway to meet projected demand growth. Russia, especially, is planning significant infrastructure expansion in order to serve expanding European markets. The most significant undertaking is the development of the Yamal gas fields in northern Siberia and the construction of the Yamal-Europe pipeline through 
Belarus and Poland to move the gas to market. Unlike other significant Russian gas fields, where the gas is in shallow reservoirs and easily developed, the Yamal fields are located in an area with extreme climatic conditions, and production costs in the Yamal fields will far exceed production costs at current producing fields. The additional cost of building the pipeline needed to serve these remote fields will significantly increase the cost of gas supplies from the region.

Russia has long felt that development of the Yamal fields will be necessary to supplement declining production in already developed fields and meet projected increases in natural gas demand; however, there has been considerable speculation in the trade press recently as to whether the development of the remote Yamal fields is necessary in the near future. Some analysts feel that demand increases can be satisfied by the development of lower cost sources, such as satellite fields in current producing regions, perhaps for the next 10 to 12 years [25]. Another blow to the development of the Yamal fields may have been dealt by the announcement of a strategic alliance between Gazprom and Royal Dutch Shell on November 17,1997 , one thrust of which will be the development of the gigantic Zapolyarnoye gas and condensate field in West Siberia. Significant output from the field would compete with higher priced Yamal gas [26].

Regardless of what eventually happens with the Yamal fields, earlier stages of the project will continue as planned. The Yamal pipeline project is being constructed from the market back, with the earliest stage designed to deliver gas to Germany and Poland from fields where the infrastructure is already in place. Work is underway on sections crossing Poland and Belarus, which will help reduce Gazprom's near-total dependence on Ukraine for moving its gas to Europe [27, p. 12]. Large amounts of gas are expected to flow into Germany by the end of 1998, and some sections of the pipeline are already carrying gas from new Siberian fields into Europe [27, p. 11]. Elsewhere in the EE/FSU region, considerable infrastructure expansion is either planned or underway.

Privatization and foreign investment continue to make inroads in the EE/FSU, where until recently most of the natural gas industry had been controlled by national governments. Since Gazprom relaxed rules barring foreign investors last year, international banks have been pouring money into the gas industry, with export projects-in particular, the construction of the YamalEurope pipeline-attracting most of the big loans. Gazprom shares, long barred to foreign investors, have been successfully traded on the London stock market since October 1996 [28]. The strategic alliance with Royal Dutch Shell also signals the change in Russian sentiment toward foreign investment in its gas industry.
In March 1997, Kazakhstan signed a foreign investment law establishing a state committee on investment, and privatization is expected to have a significant impact on the gas industry over the next several years. Turkmenistan is inviting foreign participation in the area of natural gas exploration and development, and the oil and gas industry is being restructured. Foreign investment in Uzbekistan has also increased dramatically, and several foreign companies have expressed interest in exploration and development joint ventures.

\section{Central and South America}

In Central and South America, vigorous expansion of the natural gas infrastructure is continuing. The region's natural gas consumption is expected to grow to five times its 1995 level by 2020, reaching 13 trillion cubic feet. In Brazil alone, gas use is expected to grow by 14 percent annually through 2020, to 4.3 trillion cubic feet. In 1995, 2.6 trillion cubic feet of natural gas was consumed in the entire region [21, p. 8] (Figure 52).

\section{Figure 52. Natural Gas Consumption in Brazil and Other Central and South America, 1970-2020}

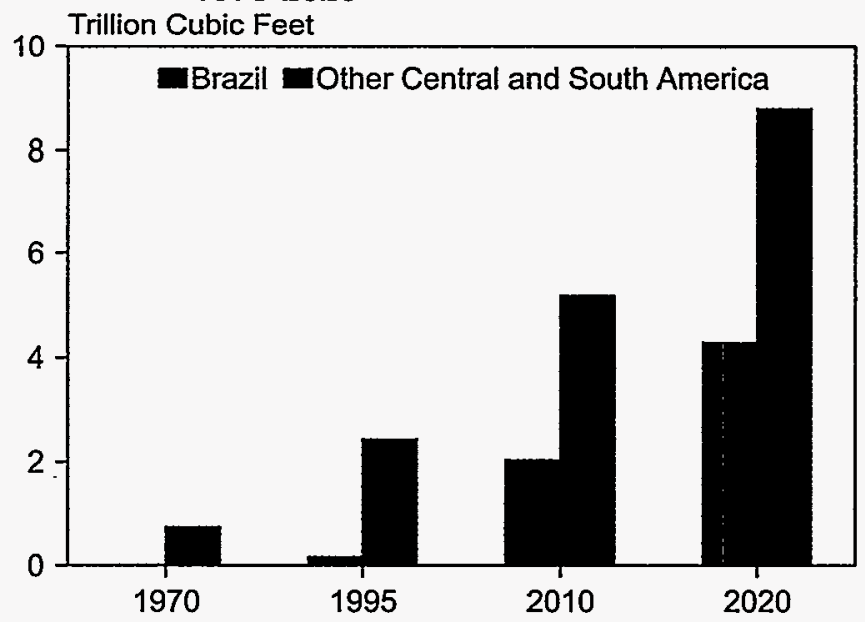

Sources: History: Energy Information Administration (EIA), Office of Energy Markets and End Use, International Statistics Database and International Energy Annual 1996, DOE/ElA0219(96) (Washington, DC, February 1998). Projections: EIA, World Energy Projection System (1998).

Argentina is attempting to solidify its position as a gas supplier to Chile and Brazil. As part of this effort, the 290-mile, $\$ 350$ million gas pipeline, GasAndes, began operating in August 1997, the first gas line link between Argentina and Chile [29]. The pipeline will be able to deliver 350 million cubic feet per day, initially transporting gas from the La Mora compressor station in the Mendoza area of Argentina to Santiago, Chile.

Two additional pipelines linking Chile and Argentina are being developed: the Atacama project (a $\$ 750$ million project consisting of a 575-mile pipeline to be built from 
northern Argentina to northern Chile and two 355megawatt gas-fired electric power plants by a consortium of Endesa, CMS Energy, and Argentina's Astra and Pluspetrol Energy) and the Norgas-Latin America (a $\$ 400$ million, 550-mile pipeline to be built from Salta, Argentina, to Tocopilla, Chile, by a consortium consisting of Edelnor, Electroandina, YPF, and Tecpetrol) $[30 ; 9$, pp. 39-40]. Companies involved in developing the two plans agree that constructing two parallel pipelines is excessive [31]. In fact, constructing both lines will triple capacity by 2003, whereas demand is expected only to double. Nevertheless, talks to reach a compromise on the projects broke down in October 1997, and it appears that both projects will be constructed.

The Atacama project advanced in 1997 as GasAtacama (a joint venture of CMS and Endesa) awarded a contract for laying the 250-mile pipeline. Construction is expected to begin in January 1998. The $\$ 750$ million project, which should be completed in early 1999, will provide gas from Argentina to power plants and industrial customers in northern Chile [32]. The Atacama also involves two 35-megawatt gas-fired generating plants in the port of Mejillones, both of which are scheduled to begin operating in 1999 [31].

Although there is substantial activity in developing gas infrastructure between Chile and Argentina, the prospects for exporting to Brazil are even greater. The most prominent project for Brazil is the $\$ 2$ billion BoliviaBrazil pipeline, a 1,875-mile line to run from Santa Cruz, Bolivia, to Porto Alegre, Brazil [33]. There are also plans to export gas from northeastern Argentina to industrial customers in southern Brazil [9, pp. 39-40]. Argentina's YPF and Brazil's Petrobas are studying the possibility of constructing a pipeline from Argentina to Sao Paolo, Brazil, including a proposed 1,400-mile pipeline from Argentina's Aguarague, Acambuco, and Ramos fields to Sao Paolo.

In northeastern Brazil, construction is continuing on the 230-mile Guamare-Pecem pipeline, running from the Rio Grande do Norte gas fields to the industrial areas of Ceara [34]. The project, scheduled to begin operating by mid-1998, will deliver 106 million cubic feet per day. When it is fully operational and another link is added, the Guamare-Pecem system should be able to deliver 565 million cubic feet per day-as much as the BoliviaBrazil pipeline.

The government of Colombia also would like to increase that country's access to gas dramatically. The government announced in 1997 that it intended to extend natural gas access to 80 percent of the population by 2010 [ 9 , pp. 126-127]. Government plans include a $\$ 27$ billion investment in the country's energy infrastructure, with $\$ 3$ billion dedicated to the construction of a nationwide natural gas supply system. Although legislation to allow the privatization of state-owned Ecogas failed in May 1997, privatization of the distribution system has begun, and two of Colombia's largest distributors already have been privatized. Enron acquired Ecopetrol's share of the country's largest distributor, Promigas, in early 1996, and in 1997 Ecopetrol's shares of Gas Natural were purchased by Spain's Gas Natural.

\section{Middle East}

Natural gas consumption in the Middle East is projected to grow by 2.6 percent annually over the 25-year forecast (Figure 53). Electricity generation consumes the largest share of natural gas use in the region, because of its clean-firing qualities, convenience of use, and moderate costs relative to oil. Energy policy trends are further promoting diversification of supply, substituting gas for oil so that oil can be exported, and substituting gas in domestic consumption in place of imported oil. Gas has made only modest inroads in residential and commercial use in Saudi Arabia, Algeria, and Iran [35, pp. 41-42].

\section{Figure 53. Natural Gas Consumption in the Middle East and Africa, 1970-2020}

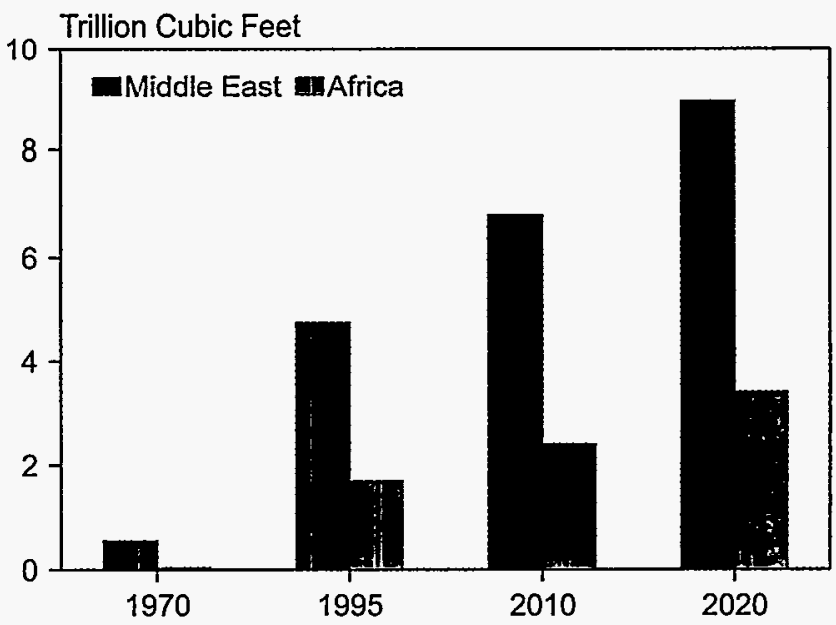

Sources: History: Energy Information Administration (EIA), Office of Energy Markets and End Use, International Statistics Database and International Energy Annual 1996, DOE/EIA0219(96) (Washington, DC, February 1998). Projections: EIA, World Energy Projection System (1998).

There have been increasing efforts to develop Middle Eastern LNG for export, especially to Asia. Algeria, Qatar, Oman, and the United Arab Emirates' (UAE) Abu Dhabi all have developed LNG schemes [35, p. 42]. The expansion of LNG sales is impeded somewhat, however, by the challenge of high costs associated with processing and delivering LNG in special refrigerator ships. In recent years, contract provisions for LNG have included the flexibility to allow customers to gauge prices to the fluctuations in crude oil prices or to negotiate lower prices in exchange for large supply volumes. Algeria's exports to Distrigas in the United States have been linked to the average U.S. price for delivered gas. Qatar has linked LNG prices to a 3-month 
average delivered LNG price to Japan (thereby indirectly linking the LNG prices to crude oil prices) and has lowered the floor price in the Korea Gas Corp-Ras Laffan contract. Mobil, the operator of Qatar's Ras Laffan, has even agreed to the lower floor price in exchange for larger sales volumes and has guaranteed part of the Ras Laffan debt if prices fall below $\$ 1.90$ per million Btu.

Iran has the world's second largest natural gas reserves, second only to Russia. DRI/McGraw-Hill estimates that, given current production levels, the Iranian reserves could last for almost 600 years [35, p. 167]. Developing the 321 trillion cubic feet South Pars field, which accounts for an estimated 40 percent of Iran's gas reserves, is a priority for the Iranian government [36]. The development of these reserves should help Iran maintain its oil output by using gas in enhanced oil recovery gas injection schemes, as well as providing a potentially important export commodity.

In September 1997, the energy companies Total (France), Gazprom (Russia), and Petronas (Malaysia) signed a \$2 billion agreement with the Iranian National Petroleum Company to develop 2 billion cubic feet per day of the South Pars reserves. The agreement was signed despite the threat of sanctions under the U.S. Iran-Libya Sanctions Act of 1996. The South Pars gas is to be used for domestic consumption, reinjection to enhance oil output, and ultimately for export to Turkey. Iran is committed to providing Turkey with 300 million cubic feet per day of gas beginning in 1999 [37]. Pakistan and India are also potential customers for Iran's gas, either by pipeline or as LNG.

There are several proposals for bringing natural gas to Israel. Israel is discussing the possibility of importing LNG from Qatar and also importing gas by pipeline directly from Egypt or Saudi Arabia [35, pp. 185-186]. The $\$ 4$ billion Qatar LNG import project would provide Eliat with gas for residential use, as well as for export to Europe. Saudi Arabia could also be a potential source of natural gas, supplying Saudi gas from the Tabuk field to Israel through a 62-mile pipeline.

Egypt is another potential Israeli supplier. In November 1993, Egypt agreed in principle to sell gas to Israel. Gas would be delivered through a 180-mile pipeline from Egypt's Delta region across the Gaza Strip into Israel. Most of the gas would be consumed for electricity generation, though sales are not expected to begin before 2005.

Expanding the gas sector is a priority for the government of the UAE, particularly in Abu Dhabi which accounts for 97 percent of the Emirates' proven reserves. The UAE would like to increase domestic use of natural gas, use for oil field reinjection in enhanced oil recovery schemes, and LNG exports. One of the largest gasbearing structures in the world is the UAE's offshore, nonassociated Khuff reservoir, which has not yet been fully developed [35, p. 258]. Khuff gas is expected to be transported to Dubai for oil field injection to extend the life of Dubai's oil fields.

In addition to the Khuff, expansion is expected to take place at the onshore Bab field-known as the Onshore Gas Development. Increased capacity from the Onshore Gas Development will be used to fuel electricity generation, as well as oil field injection. Much of Abu Dhabi's offshore gas production is being used to supply LNG exports for mostly Japanese customers. Capacity at Das Island doubled in 1994 with the construction of a third LNG train, raising capacity to more than 5 million tons of LNG per year. An expanded long-term contract was signed with Abu Dhabi's largest gas customer, the Japanese utility TEPCO, and an increasing number of spot gas sales have been made into Asian and European markets.

\section{Africa}

Ninety percent of all current natural gas consumption in Africa is attributed to four countries: Algeria, Egypt, Libya, and Nigeria [21, p.9]. Natural gas consumption in Africa is projected to grow to 3.4 trillion cubic feet by 2020, slightly more than doubling from the 1995 level.

Algeria has one of the largest gas fields in the world-the Hassi $R^{\prime}$ Mel field, which has more than 85 trillion cubic feet of reserves [35, pp. 68-69]. Gas exports are a major source of income for Algeria, and export infrastructure is being developed quickly, despite the country's economic problems. The capacity of the Transmed pipeline from the Hassi $\mathrm{R}^{\prime} \mathrm{Mel}$ field to Italy (via Tunisia) is being doubled from 459 billion cubic feet to 918 billion cubic feet. The 1,460-mile Transmed has been operating since 1983, supplying Tunisia, Italy, and Slovenia. Four long-term Transmed contracts are currently in place [35, p. 68]: 688 billion cubic feet per year to Italy's Snam beginning in 1983 and ending in 2019; 18 billion cubic feet per year to Tunisia's ETAP beginning in 1983 and ending in 2019; 21 billion cubic feet per year to Slovenia's Petrol Ljubljana beginning in 1992 and ending in 2007; and 141 billion cubic feet per year to Italy's Enel beginning in 1995 and ending in 2015.

A second major pipeline linking Algeria to the European markets is the Maghreb, which runs from the Hassi $\mathrm{R}^{\prime} \mathrm{Mel}$ field to Seville, Spain (through Morocco), was completed in October 1996, and an extension from Spain to Portugal was completed in February 1997 [38]. The 849-mile Maghreb will allow Algeria to ship gas as far as Germany through the European pipeline network [35, p. 68]. The cost of the Algeria-Spain segment was $\$ 1.9$ billion, and the extension to Portugal was estimated at $\$ 500$ million. The World Bank, European Investment 
Bank, and national governments helped finance the project.

Algeria has also been renovating its LNG plants at Bethiou, Arzew, and Skikda, which were constructed in the early 1970s with a combined capacity of about 1,094 billion cubic feet per year. Subsequent work on the project has increased capacity to 1,200 billion cubic feet per year. There are 11 existing contracts for 911 billion cubic feet of Algeria's LNG, with more than one-third of the contracted gas to be delivered to Gaz de France [35, p. 69].

In Nigeria, major efforts have been undertaken to end gas flaring in the country's oil fields. Shell Petroleum Development Corporation of Nigeria (SPDC) has planned four gas gathering projects to collect gas for Nigeria's Escravos-Lagos Pipe Network to use in various power plants and industrial applications in Odidi, South Forcados, Escravos, and the Greater Ughelli area of Delta State [39]. The Odidi project alone is expected to cost $\$ 250$ million and will be used to collect some 80 million cubic feet of gas per day [40].

Chevron and the Nigerian National Petroleum Corporation initiated the Escravos Gas Project to reduce flaring and to recover the gas and condensate from Chevron's offshore oil fields [41]. By September 1997, the project was producing 145 million cubic feet of gas, which was sold to the Nigerian Gas Company for industrial end users. The project also produces 8,000 barrels of liquefied petroleum gas and natural gas liquids per day. Recently, however, funding problems have forced Chevron to delay work on the second phase of the Escravos project, which was to expand the gas gathering system so that another 120 million cubic feet of gas per day could have been processed [42].

Nigeria has plans to develop a natural gas network for domestic consumption, using $\$ 50$ million in funding from the World Bank [35, pp. 124-125]. In addition, a number of export projects are either under consideration or already under construction, including plans to develop the $\$ 260$ million West African Gas Pipeline Project to provide Nigerian gas for electricity generation and for industrial customers in Ghana, Benin, and Togo [43]. Ghana is expected to consume about 75 percent of the gas from the pipeline at a proposed 300- to 400megawatt gas-fired power plant at Takadi and at the Valco aluminum smelting plant.

Although several African LNG projects to supply Europe and the United States have been under consideration for years, the Nigerian Bonny LNG project is farthest advanced. With a cost estimated at around $\$ 4.5$ billion, the project consists of gas transmission systems, two liquefaction trains, and export infrastructure with a capacity of 254 billion cubic feet. It is scheduled to be completed by 1999, with first scheduled deliveries to begin in 2000. Agreements for the LNG have been arranged with Spain's Enagas (56 billion cubic feet per year); Turkey's Botas (32 billion cubic feet year); and France's Gaz de France (18 billion cubic feet per year). Italy's Enel pulled out of an agreement to purchase 124 billion cubic feet per year-by far the largest share of Bonny LNG output-in December 1996 because of difficulties the utility was having in securing an LNG reception terminal. The dispute was resolved in October 1997 when Gaz de France offered to accept Italy's delivery at the Montoir LNG terminal in Brittany [44].

\section{Asia}

The 1997 Asian currency crisis resulted in the delay of many energy projects in developing Asia. Nevertheless, many natural gas projects in this part of the world are going forward, although some of the more expensive gas projects, such as the Natuna gas pipeline project and the Omani LNG project, face delays. The IEO98 forecast does not expect a long-term slowdown of economic growth in the region. In developing Asia, natural gas consumption is projected to grow nearly sixfold over the 25-year period, from 4.7 trillion cubic feet in 1995 to 27.7 trillion cubic feet by 2020 . In industrialized Asia (Australia, Japan, and New Zealand) gas use grows at a more conservative pace of 1.6 percent annually, from 3.1 trillion cubic feet in 1995 to 4.6 trillion cubic feet in 2020 (Figure 54).

\section{Figure 54. Natural Gas Consumption in Asia by Region, 1970-2020}

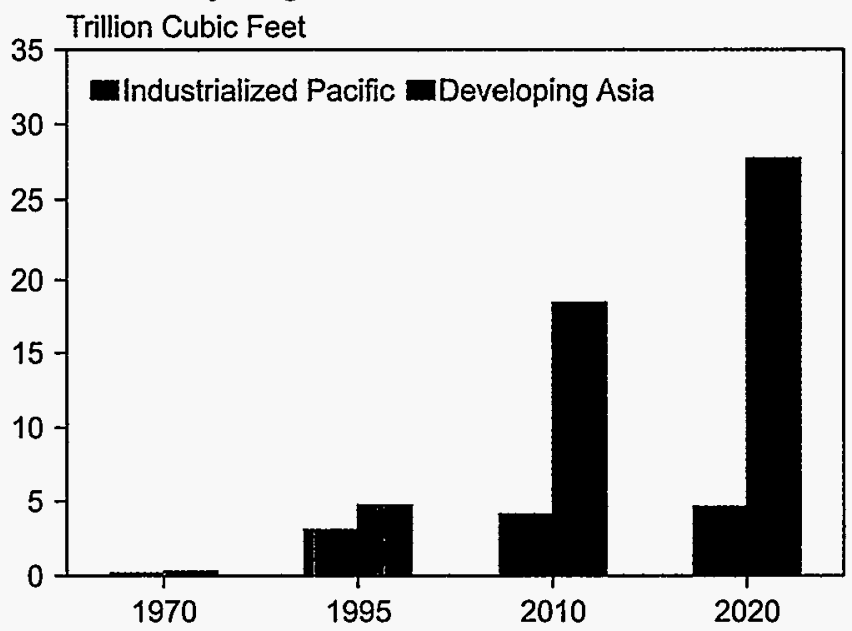

Sources: History: Energy Information Administration (EIA), Office of Energy Markets and End Use, International Statistics Database and International Energy Annual 1996, DOE/EIA0219(96) (Washington, DC, February 1998). Projections: EIA, World Energy Projection System (1998).

Thailand was hit particularly hard by the economic downturn. The economic recession has meant that many energy projects in the country are being renegotiated. The 50-percent devaluation of the Thai baht between 
May and October 1997 led to a postponement of a number of gas projects. Oman LNG announced that both the Petroleum Authority of Thailand (PTT) and Oman LNG had agreed to suspend the unsigned 25-year LNG agreement that would have brought 1 million tons of LNG per year to Thailand beginning in 2001, rising to 1.7 million tons in 2003 and 2.2 million in 2004 [45]. The PTT had wished to delay taking the Oman LNG by 10 years, because projections for gas demand for the next decade have been cut by 20 percent [46].

A project designed to pipe natural gas from Indonesia's Natuna gas field in the South China Sea also faces delay and renegotiation since Thailand's economic downturn. Indonesia's state-owned Pertamina negotiated a 2-year delay for PTT's purchase of Natuna gas, moving the startup date for the contract from 2003 to 2005 [47]. Moreover, price negotiations are expected to delay deliveries another 2 years, so that the first Natuna gas would be delivered to Thailand in 2007. PTT wanted to renegotiate the price of Natuna gas from the original terms to a price below that of gas from the MalaysiaThailand Joint Development Area; however, Pertamina would not agree. Originally, Thailand was to begin purchasing 500 million cubic feet per day from the Natuna project, increasing to 1 billion cubic feet per day after 2 years.

Despite the cuts, a number of natural gas projects are going forward, and a substantial number of companies still are interested in working on gas projects in Thailand. Unocal corporation announced in midNovember 1997 that it expected development on the first phase of its Pailin field-with production of 165 million cubic feet per day scheduled to begin at the end of 1998- to continue on schedule [48]. Moreover, in October, the U.S. energy company Enron signed a partnership with a Thai engineering company, EMC, to "pursue investment opportunities in infrastructure projects" in Thailand that will include natural gas pipelines and electric power plants [49]. The Canadian natural gas company, Nova Corporation, announced in November that it had an interest in participating in construction of gas pipelines and electric power plants in Thailand, in particular a third natural gas trunk line planned for the Gulf of Thailand [50].

PTT also signed an agreement in November to purchase gas from two fields in the Gulf of Thailand from Rutherford-Moran Oil Corporation [51]. The corporation already supplies PTT with 100 million cubic feet per day of gas. The new agreements will increase that amount to 300 million cubic feet per day when production at the two gas fields begins at the end of 1999.

Malaysia continued some aggressive gas development in 1997. There is concern that the country might face power shortages in the long term, accentuated by the indefinite postponement of the large-scale Bakun hydroelectric project earlier in the year in response to a combination of environmental criticism and the Asian economic crisis. As a result, Malaysia has decided to increase its gas-fired power generation capacity [52]. Malaysia has committed to accept delivery of $300 \mathrm{mil}-$ lion cubic feet per day of the first production from the Malaysia-Thailand Joint Development Area (JDA), which should begin operating in late 1999. Because it will take time for the electricity generating infrastructure to catch up with the gas production, much of the first gas is expected to be used by a proposed petrochemical plant.

Exploration in the JDA has been quite successful, with 10 trillion cubic feet of gas already discovered. Malaysia's Petronas and U.S. Triton Energy (forming the joint venture, Malaysia-Thailand Joint Authority-MTJA) believe another 10 trillion cubic feet of gas could be discovered [52]. In fact, in November 1997, the MTJA confirmed the discovery of an eighth field in the JDA, called Wira-1, with a gas flow of 9.1 million cubic feet per day. Four other finds were made in 1997 alone.

Pakistan is attempting to expand its natural gas consumption, which already accounts for almost 40 percent of its primary energy consumption [21, pp. 180, 186]. The country currently produces virtually all its own gas, but consumption is expected to overtake production soon, and efforts have been made to secure supplies from outside sources. In 1997, Unocal announced that Pakistan would be linked to Turkmenistan in a Central Asia Gas Pipeline project [53]. The 790-mile pipeline would deliver up to 2 billion cubic feet per day of natural gas from southeastern Turkmenistan's border to Multan, Pakistan, with a guarantee that up to 25 trillion cubic feet of gas could be supplied through the pipeline from the country's Dauletabad field. The consortium of six companies and the Turkmenistan government are also considering adding a 400mile extension to the pipeline, which would take gas to New Delhi, India, as well.

India is in the process of developing its import, transmission, and distribution grid to allow gas to penetrate major cities more rapidly. In an attempt to attract foreign investment in the natural gas sector, shares of the stateowned Gas Authority of India Limited (GAIL) were placed on the Bombay Stock Exchange in May 1997 [54]. GAIL was actually formed only 13 years ago. The company manages India's only major gas pipeline, the HBJ, which is used to deliver gas from the Bombay High field and other offshore fields to the cities of Hazira, Bijaipu, and Jagdishpu, as well as other northwest Indian cities. Most of the gas moved by HBJ is used at large electric power plants and for fertilizer plants, but the government would like to increase residential and small commercial use. 
In 1994, GAIL and the British BG plc (formerly British Gas) formed Mahanagar Gas, a distribution company that currently serves more than 3,000 domestic customers in Mumbai (formerly Bombay) [55]. BG plc is also working on bringing a 615-megawatt gas-fired power plant to Pipavav in Gujarat State that would burn imported LNG.

Royal Dutch Shell is attempting to bring LNG into India's southern state, Tamil Nadu [56]. The company is working with Britain's PowerGen to import Omani LNG for use in a 1.4-gigawatt power plant. Omani LNG should become available by 2000 . Shell has also applied to India's Industry Ministry for permission to construct an LNG and regasification terminal capable of handling 2.7 million tons of LNG per year [57]. The terminal would be constructed in Hazira, in the western state of Gujarat. Initially all gas would be used in industrial applications in Hazira, but it would be possible to expand the terminal to supply other customers after 2001.

China has plans to double its natural gas production capacity to 1.1 trillion cubic feet by 2005 according to China National Petroleum Corporation [58]. In the country's Ninth Five-Year Plan period (1996-2000), China expects to increase gas exploration, with the goal of adding 3.9 trillion cubic feet to the current 41.4 trillion cubic feet of proven natural gas reserves [59]. In 1997, the Changqing Petroleum Prospecting Administration announced plans to move into full-scale exploration of the Erdos Basin gas field located at the intersection of the Shaanxi-Gansu-Shanxi provinces and Ningxi Hui, Inner Mongolia, autonomous regions [60]. Erdos Basin has 10.2 trillion cubic feet of proven natural gas reserves, with an annual capacity of nearly 30 billion cubic feet of gas. In June 1996, gas supplies began to move to Xi'an, the capital of northwest China's Shaanxi Province, and in September 1996, to Beijing.

Arco, China National Offshore Oil Corporation (CNOOC), and Kuwait Foreign Petroleum Exploration Company are jointly developing the offshore, 3 trillion cubic foot Yacheng 13-1 gas field [61]. Most of the Yacheng gas is delivered to the Black Point Power Plant in Hong Kong by way of a 480-mile subsea pipeline. A second pipeline delivers gas to Hainan Island. Arco and CNOOC also signed an agreement to develop three Ledong gas fields in the South China Sea, which were discovered in 1996 by a subsidiary of CNOOC.

In 1997 there was some progress in bringing natural gas to China's residential sector [62]. Gas from the Changqing gas field began supplying residential customers in Beijing in October 1997. A 533-mile gas pipeline from Jingbian County to Beijing was completed in July 1997 and is able to supply the city with 353 million cubic feet of gas per day.
In industrialized Asia, natural gas consumption is expected to increase by 50 percent over the next 25 years. For Japan, a 1.5-percent annual rate of increase is projected. Recent setbacks in Japan's nuclear industry-including a series of accidents that have led to increasing public opposition to nuclear power (for example, the December 1995 sodium leak that caused the shutdown of the Monju reactor in Tsuruga, and the March 1997 fire at a nuclear waste handling facility in Tokaimura [63]-may result in faster-paced growth in gas-fired generation as a substitute for the extensive nuclear expansion anticipated by the Japanese nuclear industry only 2 years ago [64]. Currently there are 244 gas utilities in Japan, 71 of which are public utilities. They provided gas to 23.6 million customers in 1996, a 30-percent increase from 18.7 million gas customers in 1985 [65]. The country is already the largest importer of LNG in the world. In 1996, Japan imported 62 percent of the world's 3,600 billion cubic feet of LNG exports [3, p. 28].

The Asian currency crisis might also affect natural gas consumption in Japan. Developing Asian countries like Thailand are scaling back on plans to purchase LNG, and the resulting glut in LNG supplies means that Japan is in a position to negotiate deals for reduced prices [66]. In addition, Japan-along with South Korea and China-has shown interest in establishing a gas pipeline route from Russia's East Siberian Irkutsk region in Kovtyktinskoye. A 2,170-mile pipeline from Kovtyktinskoye across China extending to the Yellow Sea with a subsea pipeline to Japan would cost an estimated $\$ 10$ billion to construct [67].

The currency crisis has also affected plans to expand the LNG industry in Australia. There were plans to double the size of Woodside Petroleum's North West Shelf LNG project, along with Chevron's Gorgon offshore gas project in the North West Shelf Region, and the BHP Petroleum-Phillips Petroleum Bayu Undan joint venture in the Timor Sea [68]. However, the economic downturn in the region, which will make it more difficult to market the additional gas, might slow down these expansions.

\section{References}

1. "Gasline Tally Set for 34,000 Mile Boost," Financial Times: International Gas Report, No. 334 (October 31, 1997), p. 7.

2. "Troll Exports Surge in 4th Export Pipeline," World Gas Intelligence, Vol. 8, No. 17 (September 12, 1997), p. 1 .

3. British Petroleum Company, BP Statistical Review World Energy 1997 (London, UK, June 1997). 
4. "Canadian Gas Consumption To Grow 2\% Annually, Reaching 3.2 Tcf by 2010," Inside F.E.R.C.'s Gas Market Report (December 12, 1997), pp. 9-10.

5. Crossborder, Inc., "Electric Sector Restructuring," Mexican Energy Update (August 15, 1997), pp. 8-9.

6. Energy Information Administration, Natural Gas Deliverability in the Interstate Natural Gas Pipeline System, DOE/EIA-0618 (Washington, DC, April 1998).

7. J. Fisher, "NGSA, Others Seeks Removal of Mexico's Gas Import Tariff," Natural Gas Intelligence, Vol. 16, No. 41 (June 23, 1997), p. 14.

8. "Mexican Officials Want To Drop Natural Gas Import Tariff," Latin American Energy Alert, Vol. 5, No. 2 (November 20, 1997), pp. 1-2.

9. DRI/McGraw-Hill, World Energy Service: Latin American Outlook 1997 (Lexington, MA, Summer 1997).

10. "Mexico Planning To Call Tenders for Gas Storage Projects," Latin American Energy Alert, Vol. 5, No. 4 (December 15, 1997), p. 12.

11. "Mexico Calls Tender To Develop Northern Natural Gas Fields," Latin American Energy Alert, Vol. 4, No. 6 (February 1, 1997), pp. 1-2.

12. "EU Ministers Thrash Out Landmark Gas Deal," Financial Times: International Gas Report, Vol. 337 (December 12, 1997), p. 1.

13. DRI/McGraw-Hill, Towards a Competitive European Natural Gas Market: A Country-by-Country Analysis of Prices, Demand, Supply and Trade Prospects to 2020 (Lexington, MA, November 1997).

14. DRI/McGraw-Hill, World Energy Service: European Outlook (Lexington, MA, June 1997).

15. "UK Gas Sales to Europe Top $60-\mathrm{Bcm}$ as Interconnector Nears," World Gas Intelligence, Vol. 8, No. 10 (May 30, 1997), p. 10.

16. DRI/McGraw-Hill, World Energy Service: European Outlook (Lexington, MA, March 1997), pp. 88-89.

17. "What's New Around The World," World Gas Intelligence, Vol. 8, No. 2 (January 21, 1997), pp. 10-12.

18. "Norway Completes Czech Gas Deal," World Gas Intelligence, Vol. 8, No. 6 (March 28, 1997), p. 1.
19. "Texaco, Partners Commit to UK Atlantic Margin," World Gas Intelligence, Vol. 8, No. 10 (May 30, 1997), p. 7.

20. DRI/McGraw-Hill, World Energy Service: European Outlook (Lexington, MA, September 1997).

21. Energy Information Administration, International Energy Annual 1996, DOE/EIA-0219(96) (Washington, DC, February 1998).

22. "Turkey Clears Path for Gas-Fired Power Generation," World Gas Intelligence, Vol. 8, No. 14 (July 30, 1997), p. 2.

23. "Worldwide Look at Reserves and Production," Oil \& Gas Journal, Vol. 95, No. 52 (December 29, 1997), pp. 38-39.

24. PlanEcon, Inc., Energy Outlook for Eastern Europe and the Former Soviet Republics (Washington, DC, September 1997).

25. J.P. Stern, The Russian Natural Gas Bubble (London, UK: The Royal Institute of International Affairs, 1995).

26. PlanEcon, Inc., "Can the Strategic Alliance with Shell Shift Gazprom's Continued Production Fixation on the Yamal Fields?" Energy Service FAX ALERT No.7 (December 18, 1997).

27. "What's New Around the World," World Gas Intelligence, Vol. 8, No. 15 (August 15, 1997).

28. I. Gorst, "Gazprom Treats 'em Mean To Keep 'em Keen," Petroleum Economist, Vol. 64, No. 4 (April 1997), p. 6.

29. "Frei, Menem Inaugurate GasAndes Pipeline, Ceremonies Mark Completion of Historic Natural Gas Project," Canada News Wire (August 7, 1997), web site ww2.newswire.ca.

30. "Argentine Gas Producers Join Norgas [sic] Pipeline Project," Latin American Energy Alert, Vol. 5, No. 1 (November 1, 1997), p. 5.

31. "Atacama Energy Talks Short Circuit," Financial Times: Power in Latin America, No. 28 (October 1997), p. 6.

32. "Atacama Line Moves Ahead," Financial Times: International Gas Report, No. 334 (October 31, 1997), p. 33 . 
33. Enron, 1996 Annual Report, web site web.enron.com.

34. "Potential of Brazilian Northeast Arises from Obscurity," World Gas Intelligence, Vol. 8, No. 18 (September 30, 1997), p. 3.

35. DRI/McGraw-Hill, World Energy Service: Africa/Middle East Outlook (Lexington, MA, April 1997).

36. "Gas Development Gains Ground in Iran, But With Some Strings Attached," World Gas Intelligence, Vol. 8, No. 4 (February 28, 1997), p. 6.

37. "Why Total, Others Risk So Much for Slim Profits in Iran," Petroleum Intelligence Weekly, Vol. 36, No. 40 (October 6, 1997).

38. "South Europe's Slow Shift to Gas Gives Fuel Oil a Breather," Petroleum Intelligence Weekly, Vol. 36, No. 14 (April 7, 1997).

39. A. Korie, "Shell Maps Out Strategies to Gas Flaring by the Year 2008," web site www.nigeria.com (March 4, 1997).

40. "Shell Launches Gas Project," web site www. sierraclub.org.

41. Chevron, "NNPC/Chevron Begins Export of Nigeria's LPG," press release (September 30, 1997), web site www.chevron.com.

42. "Behind Glowing Reports, Nigerian Prospects Darken," Petroleum Intelligence Weekly, Vol.36, No. 44 (November 3, 1997); and "Chevron Seizes Inside Track On Gas Supplies For Ghana," World Gas Intelligence, Vol. 8, No. 4 (February 28, 1997), p. 2.

43. "West African Gas Pipeline Project Moving Again," Alexander's Gas \& Oil Connections (August 7, 1997), web site www.gasandoil.com.

44. "GdF Comes to the Rescue as Enel Revives Nigerian LNG Deal via France," Financial Times: European Energy Report (October 13, 1997).

45. K. Boonsong, "Jakarta May Be Receptive to Delay Bid," The Bangkok Post (November 13, 1997), web site www.bangkokpost.net.

46. "Oman/Thai LNG Talks Off," Financial Times: International Gas Report, Vol. 334 (October 31, 1997), pp. 23-24.

47. "PTT Shelves Natuna Gas Purchase for 2 More Years, Pertamina Fails To Agree to Proposed Price," Business Day (November 13, 1997), web site bday.net.
48. Unocal, "Unocal Says Thailand Natural Gas Projects Remain on Schedule," world news release (November 17, 1997), web site www.unocal.com.

49. "Enron Bucks Trend with Surprise Thai Entry," Financial Times: International Gas Report, Vol. 334 (October 31, 1997), p. 6.

50. K. Boonsong, "Canadian Firm Eyes Gas Projects," Bangkok Post (November 11, 1997), web site www.bangkokpost.net.

51. "Partners Ink Gas-Sale Deal with PTT," Bangkok Post (November 13, 1997), web site www.bangkokpost.net.

52. "Malaysia's Domestic Gas Priorities Shift to JDA," World Gas Intelligence, Vol. 6, No. 19 (October 31, 1997), p. 1.

53. Unocal, "Consortium Formed To Build Central Asia Gas Pipeline," press release (October 27, 1997), web site www.unocal.com.

54. "India's GAIL Adopts an International Profile," World Gas Intelligence, Vol 8, No. 16 (August 29, 1997), p. 6.

55. BG plc, "BG plc Makes Strategic Investment in India," press release (July 2, 1997), web site www.bgplc.com.

56. "Shell To Supply India with Omani LNG," Alexander's Gas \& Oil Connections (September 24, 1997), web site www.gasandoil.com.

57. "Shell Wishes To Set Up LNG-JV in India," Alexander's Gas \& Oil Connections (October 17, 1997), web site www.gasandoil.com.

58. "Ambitious Plan for China's Natural Gas Development," web site www.chinaeco.com (March 22, 1997).

59. "Changqing, China's Largest Onshore Natural Gas Producer," web site www.chinaeco.com (May 14, 1997).

60. “Major Gas Field in Northwest China Under Full Exploration," NewsPage web site www.newspage. com (November 18, 1997).

61. Arco, "Arco, CNOOC Sign Cooperation Agreement for Development of Ledong Gas Fields in South China Sea," press release (October 20, 1997), web site www.arco.com. 
62. "Natural Gas To Fuel Metropolitan Stoves," Land Economic Digest, No. 56 (August 30, 1997), web site www.lnd.cn.net.

63. "Radiation Leak in Japan," Associated Press news release, web site www.highlands.com/IPP/3.18.973.html (March 18, 1997).

64. "Nuclear Slowdown Has Japan Searching for Alternatives," Petroleum Intelligence Weekly, Vol. 36, No. 22 (June 2, 1997).

65. The Japan Gas Association, "Gas Facts in Japan 1996," web site www.gas.or.jp.
66. "Currency Troubles Creating LNG Surplus in Asia," Petroleum Intelligence Weekly, Vol. 36, No. 42 (October 20, 1997).

67. "Asian Buyers Claw for Control of East Siberian Gas," World Gas Intelligence, Vol. 8, No. 16 (August 2, 1997), p. 3.

68. "Aussies Fret on Asian Woes," Financial Times: International Gas Report, Vol. 337 (December 12, 1997), p. 25. 



\section{Substantial growth in overall coal use is expected to continue through 2020. China and India are projected to account for 85 percent of the world's total increase in coal use.}

Coal's role in energy use worldwide has shifted substantially over the decades, from a fuel used extensively in all sectors of the economy to one that is now used primarily for electricity generation and in a few key industrial sectors, such as steel, cement, and chemicals. Although coal has lost market share to petroleum products, natural gas, and nuclear power, it continues to be a key source of energy because of the dominant role it has maintained in its core markets and its success in penetrating markets in emerging economies. In 1995, coal accounted for 25 percent of the world's primary energy consumption and 36 percent of the energy consumed worldwide for electricity generation. Those shares are not projected to change substantially in the IEO98 reference case through 2020 (Figure 55).

Figure 55. Coal Share of World Energy Consumption by Sector, 1995 and 2020

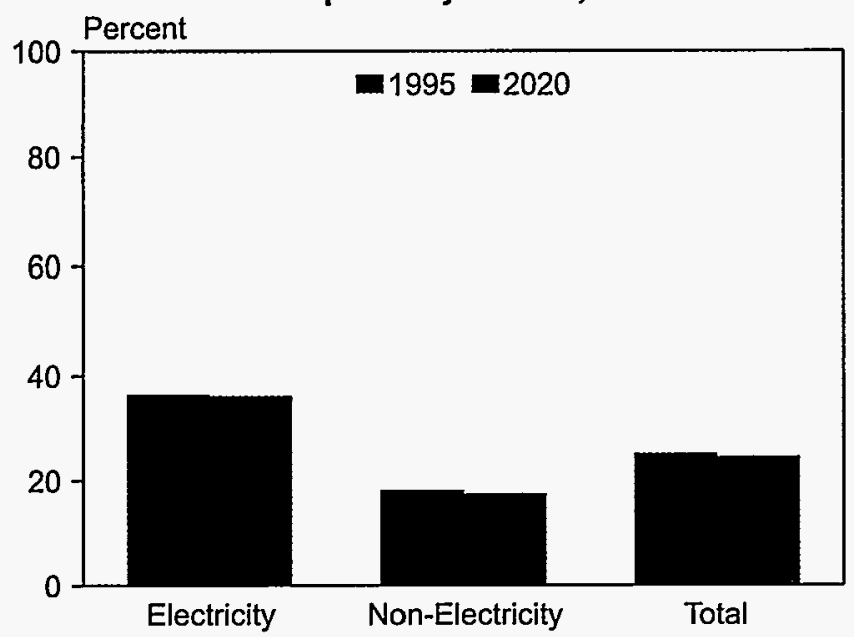

Sources: 1995: Energy Information Administration (EIA), Office of Energy Markets and End Use, International Energy Annual 1996, DOE/EIA-0219(96) (Washington, DC, February 1998). Projections: ElA, World Energy Projection System (1998).

The relatively stable outlook portrayed for coal in the IEO98 forecast could change, however, as a result of recent commitments announced by 38 of the industrialized countries of the world to reduce or curtail emissions of greenhouse gases. Those commitments are not represented in the IEO98 forecast, because they do not become binding until ratified by the governments of the individual countries. If the treaty is ratified, however, the coal industry could face a rapidly declining market for its product over the years ahead, despite any additional cost-cutting they may be able to achieve in the mining or preparation of coal. ${ }^{6}$ On the other hand, a trading program for greenhouse gases may reduce the compliance costs associated with the Kyoto agreement.

Highlights of the IEO98 projections for coal are as follows:

- World coal consumption is projected to increase by 3.5 billion tons, from 5.1 billion tons in 1995 to 8.6 billion tons in 2020. Coal use in developing Asia alone is projected to increase by 3.1 billion tons. $^{7}$

- Coal's share of the world's total primary energy consumption declines slightly, from 25 percent in 1995 to 24 percent by 2020 .

- Coal's share of energy consumed worldwide for electricity generation remains constant at 36 percent through 2020.

- China and India, taken together, are projected to account for 34 percent of the total increase in energy consumption worldwide between 1995 and 2020 and 85 percent of the world's total projected increase in coal use, on a Btu basis.

- In China, 59 percent of the total increase in coal demand is projected to occur in the non-electricity sectors. Elsewhere, overall coal consumption in the non-electricity sectors is expected to decline slightly.

- The forecast for electricity coal consumption indicates that China will need more than 340 gigawatts of additional coal-fired generating capacity by 2020, and that India will need approximately 70 more gigawatts.

\footnotetext{
6 In an unprecedented move, the United Mine Workers of America and leaders of the coal, electricity, and railroad industries in the United States have joined forces to oppose ratification of the global climate treaty. Both the union and industry executives indicate that the treaty could have a devastating effect on U.S. employment $[1,2]$.

7 Throughout this chapter, tons refers to short tons (2,000 pounds).
} 
- Recent agreements regarding limitations on coal subsidies in Germany, Spain, and France indicate that hard coal production in Western Europe will contract by an additional 40 million tons between 1995 and 2005.

- World coal trade is projected to increase from 503 million tons in 1996 to 740 million tons in 2020, continuing to account for approximately 9 percent of total world coal consumption.

- In the IEO98 forecast, steam coal (including coal for pulverized coal injection at blast furnaces) accounts for all of the projected increase in world coal trade.

\section{Trends in Coal Consumption}

Historically, trends in coal consumption have varied considerably by region. Consumption has continued to rise in the United States and Japan (on a Btu basis) over the past decade. Over the same period, however, coal use in other industrialized countries (primarily, the countries of Western Europe) has declined by about 20 percent, being displaced in considerable measure by growing use of natural gas and in France by nuclear power. Even sharper declines have occurred in the countries of Eastern Europe and former Soviet Union (EE/FSU), primarily as a result of reductions in economic activity.

Nonetheless, growth in overall coal use has been substantial and is expected to continue. Declines in coal usage in Western Europe and in the FSU have been more than offset by strong growth elsewhere, particularly in China and other Asian countries. In 1980, China accounted for 17 percent of world coal use (on a Btu basis); in 1995, its share was 29 percent. As a group, the developing countries of Asia accounted for 41 percent of world coal consumption in 1995, whereas in 1980 their share was about 23 percent. The United States accounted for 21 percent of the world total in both 1980 and 1995 .

Over the forecast period, coal is projected to account for approximately 24 percent of total energy consumption in the world. In the forecast, coal maintains its historical share because of the large increases in energy use projected for the developing countries of Asia and the strong role that coal plays in their economies. Together, two of the key countries in the region, China and India, are projected to account for 34 percent of the world's total increase in energy consumption over the forecast period and 85 percent of the world's total projected increase in coal use. The share of total energy consumption met by coal in these countries declines from 70 percent in 1995 to 63 percent in 2020 (Figure 56), because consumption of other energy sources rises in the forecast at a more rapid rate than consumption of coal (natural gas, oil, and renewable energy increase by $8.6,4.6$, and 5.1 percent per year, respectively, while coal consumption increases by 4.0 percent per year). Strong growth in the consumption of oil and natural gas results from fastpaced growth for petroleum products in the transportation sector and from the expanded use of natural gas for electricity generation, heating, and cooking.

\section{Figure 56. Coal Share of Regional Energy Consumption, 1970-2020}

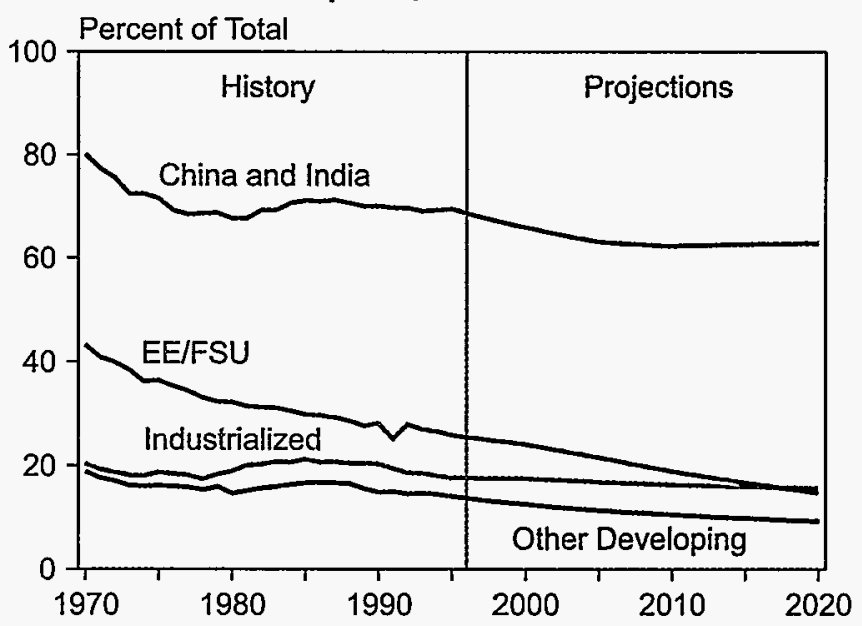

Sources: History: Energy Information Administration (EIA), Office of Energy Markets and End Use, International Statistics Database and International Energy Annual 1996, DOE/EIA0219(96) (Washington, DC, February 1998). Projections: EIA, World Energy Projection System (1998).

The most substantial decline in coal's share of total energy consumption is expected to occur in the EE/FSU, where its share decreases from 26 percent in 1995 to 15 percent in 2020 (Figure 56). In this region, natural gas is projected to capture an increasing share of the energy market over time. In the remaining regions-the industrialized countries and the other developing countriescoal's share of total energy consumption is projected to decline slightly over the forecast period. As in China and India, coal's declining share in these regions is attributable to a more rapid increase in the consumption of other sources of energy.

In physical units, coal usage increased from 4.1 billion tons in 1980 to a peak of 5.3 billion tons in 1989 (Figure 57). Recently, growth in coal consumption in the developing countries of Asia has led to a recovery in worldwide coal consumption from a low of 5.0 billion tons in 1993 to 5.1 billion tons in 1995. In the forecast, world coal consumption rises by 68 percent between 1995 and 2020, reaching 8.6 billion tons in 2020. Based on alternative assumptions about economic growth rates, 
Figure 57. World Coal Consumption in Three Cases, 1970-2020

Billion Short Tons

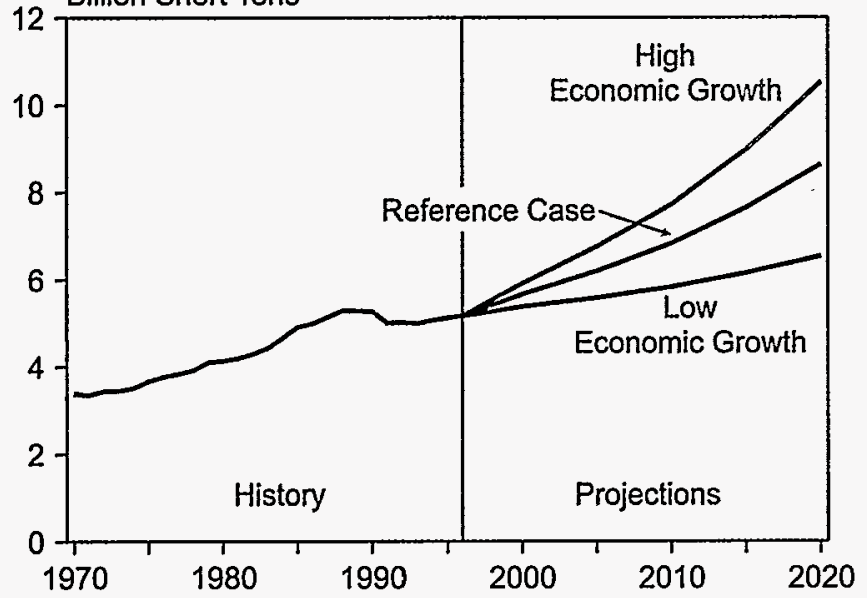

Sources: History: Energy Information Administration (EIA), Office of Energy Markets and End Use, International Statistics Database and International Energy Annual 1996, DOE/EIA0219(96) (Washington, DC, February 1998). Projections: EIA, World Energy Projection System (1998).

world coal consumption in 2020 could be as high as 10.5 billion tons or as low as 6.5 billion tons. ${ }^{8}$

With the exception of China, coal for electricity generation will account for virtually all of the projected growth in coal consumption worldwide. In the non-electricity sectors, other fuels-primarily, natural gas and electricity-are expected to gain market share. In China, however, coal should continue to be the primary fuel for industrial applications, in view of the nation's abundant coal reserves and limited access to alternative sources of energy. Consumption of coking coal is projected to decline slightly in most regions of the world as a result of technological advances in steelmaking, increasing output from electric arc furnaces, and continuing substitution of other materials for steel in end-use applications.

\section{Environmental Issues}

In future years, coal will face tough challenges, particularly in the environmental area. Increased concern about the adverse environmental impacts associated with coal use has taken a toll on coal demand throughout industrialized areas. Coal combustion produces several air pollutants that adversely affect ground-level air quality.
One of the most significant pollutants from coal is sulfur dioxide, which has been linked to acid rain. Many countries have implemented policies or regulations to limit sulfur dioxide emissions, which typically require electricity producers to switch to lower sulfur fuels or invest in technologies that reduce the amount of sulfur dioxide emitted. In addition, coal has the highest carbon content of all the fossil fuels. Carbon dioxide emissions per unit of energy obtained from coal are 80 percent higher than from natural gas and approximately 20 percent higher than from residual fuel oil-the petroleum product most widely used for electricity generation [3].

The first binding international legal agreement dealing directly with climate change-the United Nations Framework Convention on Climate Change ("the Rio Treaty")-became effective in March 1994. The Convention's primary objective is the "stabilization of greenhouse gas concentrations in the atmosphere at a level that would prevent dangerous anthropogenic interference with the climate system." Carbon dioxide, the predominant greenhouse gas, accounted for an estimated 99 percent of total greenhouse gas emissions in Annex I countries in 1990 on the basis of tons of gas emitted, and for 81 percent of the total on a carbon equivalent basis $[4] .{ }^{9}$

Followup meetings to the Convention have led to a strengthening of commitments. In the most recent meeting, held in Kyoto, Japan, in December 1997, commitments were obtained from 32 countries to reduce their greenhouse gas emissions (six different gases) ${ }^{10}$ to levels below those in 1990 [5]. Between 2008 and 2012, countries of the European Union must reduce their emissions by 8 percent from 1990 levels, the United States by 7 percent, and Japan by 6 percent. Countries of the European Union are permitted to act as a single entity for purposes of meeting the commitments of all its member states. ${ }^{11}$ For the same time frame, six additional countries agreed to curtail their emissions to levels at or slightly above their 1990 emissions. The agreement (the "Kyoto Protocol") allows for the trading of emissions allowances between Annex I nations and is binding on individual countries only when their governments complete ratification. Countries will be allowed to use net changes in carbon stocks, including reforestation, afforestation, and deforestation activities, to meet reduction commitments.

${ }^{8}$ In the IEO98 reference case, world gross domestic product (GDP) is projected to increase at a rate of 3.1 percent per year between 1995 and 2020. In the low and high economic growth cases, world economic growth rates are 1.3 percent lower and higher, respectively, than in the reference case. By region, the dispersion in economic growth rates across the cases is less symmetrical than for the world as a whole, resulting in slightly asymmetrical variations in the projections of world coal consumption.

${ }^{9}$ The carbon equivalent basis is a measure developed by the Intergovernmental Panel on Climate Change to estimate the relative impacts of various gases on global warming, as compared with the impact of carbon dioxide. Carbon dioxide's share of greenhouse gas emissions on a carbon equivalent basis is smaller than on a more simple ton of gas basis, because carbon dioxide is less effective than other gases in trapping the Earth's heat.

${ }^{10}$ The six greenhouse gases to be controlled are carbon dioxide, methane, nitrous oxide, hyrdofluorocarbons, perfluorocarbons, and sulfur hexafluoride.

${ }^{11}$ In addition to the countries of the European Union, Western Europe includes Iceland, Norway, Switzerland, and Turkey. Although Turkey is an Annex I country, it did not commit to a quantified reduction in emissions of greenhouse gases under the Kyoto Protocol. 
In the IEO98 forecast, carbon emissions are projected to rise between 1990 and 2010 in many countries, including an increase of 34 percent for the United States, 25 percent for Japan, and 13 percent for Western Europe (Figure 58). On the other hand, carbon emissions for the former Soviet Union are projected to be 20 percent lower in 2010, and emissions in Eastern Europe are projected to be 6 percent lower. Ratification of the reduced levels of emissions agreed to in Kyoto could have a substantial adverse impact on coal, particularly in the United States, which relies heavily on coal to meet its energy needs and faces relatively severe cutbacks in carbon emissions from those currently projected for 2010 (Figures 58 and 59).

Figure 58. Projected Cumulative Growth in World Carbon Emissions by Region, 1990-2010

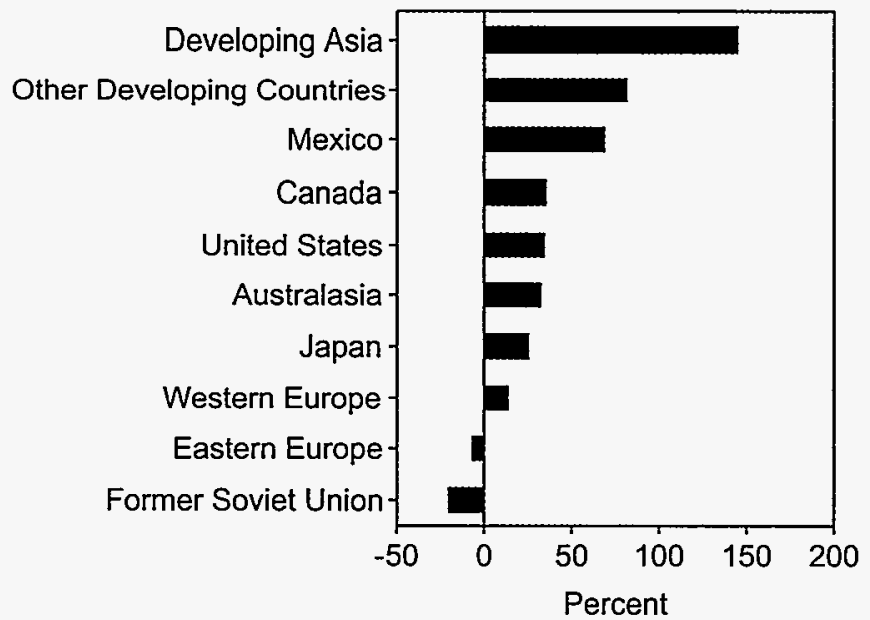

Source: Energy Information Administration, World Energy Projection System (1998).

Figure 59. Coal Share of Total Carbon Emissions by Region, 1995 and 2010

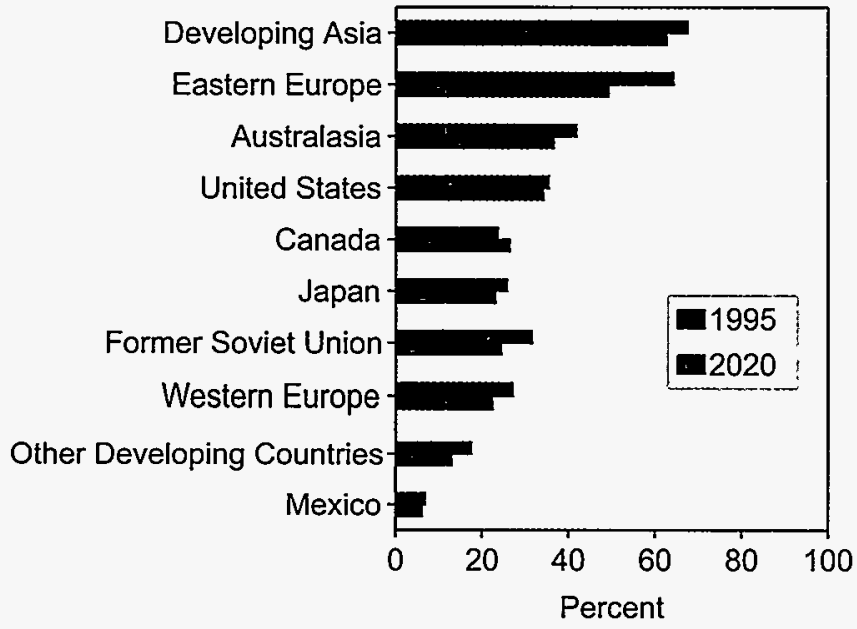

Sources: 1995: Energy Information Administration (EIA), Office of Energy Markets and End Use, International Energy Annual 1996, DOE/EIA-0219(96) (Washington, DC, February 1998). 2020: EIA, World Energy Projection System (1998).
In the IEO98 forecast, coal continues to be the second largest source of carbon emissions, accounting for 38 percent of the world total in 2020 . Oil, at 39 percent in 2020, remains the largest source of carbon emissions, and natural gas accounts for almost all the remaining portion. By country, the world's dominant coal consumers-the United States and China-were also the top two contributors to world carbon emissions in 1995, at 24 percent and 14 percent of the world total, respectively (Figure 60). By 2020, however, the roles of the two countries are expected to switch, with China accounting for 22 percent of carbon emissions worldwide, compared with 19 percent for the United States. The reversal is attributed to the relatively strong economic growth projected for China over the forecast period and the country's continuing reliance on coal as its primary source of energy.

Figure 60. Regional Shares of World Carbon Emissions, 1995 and 2020

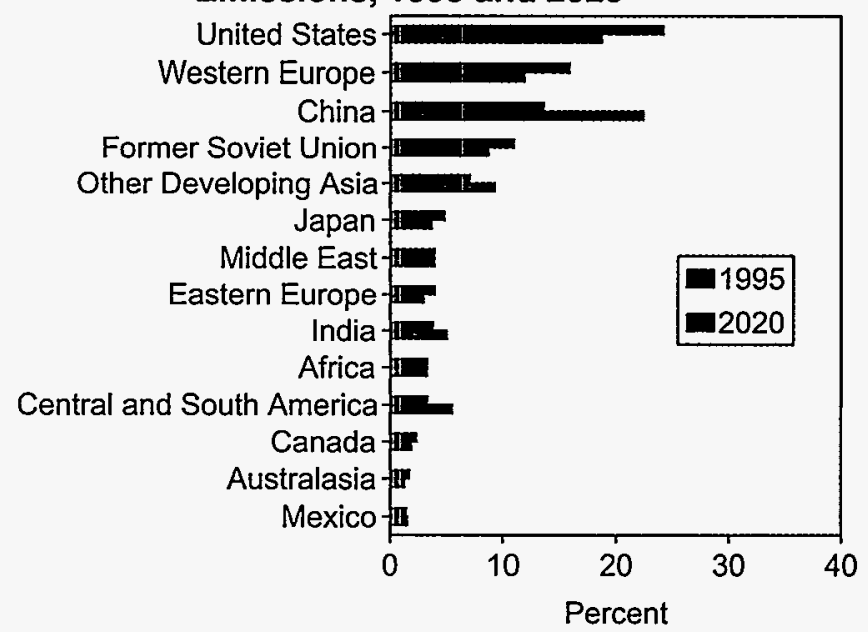

Sources: 1995: Energy Information Administration (EIA), Office of Energy Markets and End Use, International Energy Annual 1996, DOE/EIA-0219(96) (Washington, DC, February 1998). 2020: EIA, World Energy Projection System (1998).

In the future, environmental regulation will represent a major challenge for coal markets in many areas of the world. On the other hand, increases in coal use are possible in countries that have not yet committed to greenhouse gas emissions reduction programs. Although local air pollution problems in those areas may intensify and encourage greater use of alternative fuels, the available alternatives are more costly, and increased use will require multilateral policy decisions. In other areas, coal use will diminish or its growth will slow.

Competitive pressure from other fuels-particularly, oil and natural gas - has intensified because of their current low prices, the availability of new technologies that favor the use of natural gas for electricity generation, and increased costs of environmental compliance for coal-fired energy sources. Nonetheless, coal use in the 
IEO98 reference case is projected to grow by 3.5 billion tons (68 percent) worldwide between 1995 and 2020.

\section{Reserves}

Total recoverable reserves of coal are estimated at 1,142 billion tons-enough to last another 220 years at current production levels (Figure 61). ${ }^{12}$ Although coal deposits are widely distributed, 57 percent of the world's recoverable reserves are located in three regions: the United States ( 24 percent); FSU ( 23 percent); and China ( 11 percent). Another four countries-Australia, India, Germany, and South Africa-account for an additional 27 percent. In 1995, these seven regions accounted for 81 percent of total world coal production [6, Table 2.5].

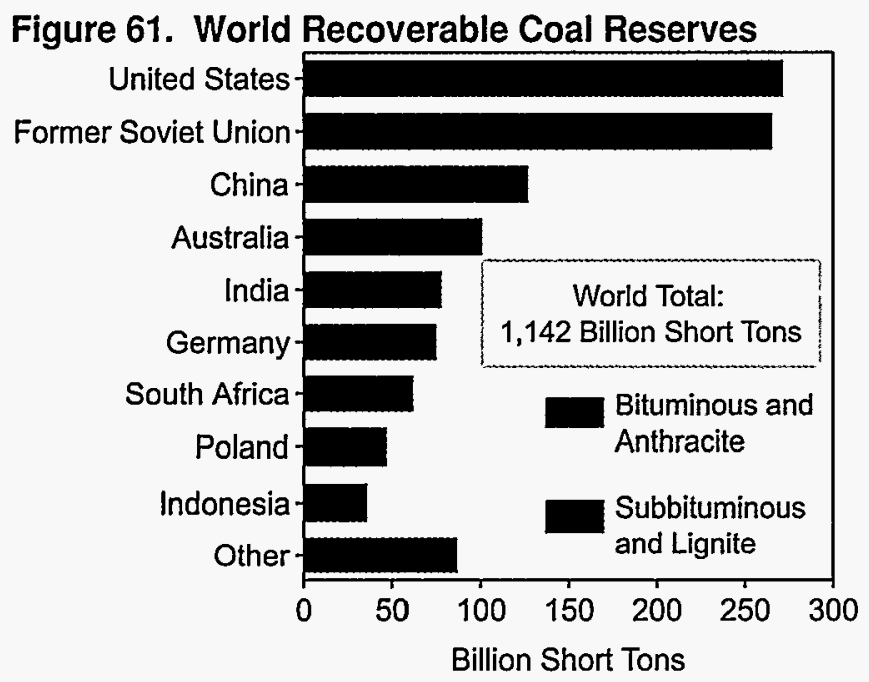

Note: Data shown for the United States represent recoverable coal reserves as of January 1, 1997. Data for all other countries are as of January 1, 1993.

Source: Energy Information Administration (EIA), Office of Energy Markets and End Use, International Energy Annual 1996, DOE/EIA-0219(96) (Washington, DC, February 1998), Table 8.2.

Quality and geological characteristics of coal deposits are other important parameters for coal reserves. Coal is a much more heterogeneous source of energy than is oil or natural gas, with quality varying significantly from one region to the next and even within an individual coal seam. For example, Australia, the United States, and Canada are endowed with substantial reserves of premium coals that can be used to manufacture coke. Together, these three countries supplied 86 percent of the metallurgical coal traded worldwide in 1996 (see Table 21, below).

At the other end of the spectrum are reserves of low-Btu lignite or brown coal. Coal of this type is not traded to any significant extent in world markets, because of its relatively low heat content (which raises transportation costs on a Btu basis) and other problems related to transport and storage. In 1995, lignite accounted for 19 percent of total world coal production (on a tonnage basis) [6, Tables 2.5 and 5.4]. The top three producers were Germany (213 million tons), Russia (108 million tons), and the United States (86 million tons). As a group, these countries accounted for 44 percent of the world's total lignite production in 1995. On a Btu basis, lignite deposits show considerable variation. Estimates by the International Energy Agency indicate that the average heat content of lignite from major producers in OECD countries varies from a low of 5.2 million Btu per ton in Greece to a high of 13.5 million Btu per ton in Canada [7, pp. II.xvii-II.xx].

Several new low-cost producers, including Indonesia, Colombia, and Venezuela, have entered the coal supply picture in recent years and are rapidly penetrating world coal trade markets. Indonesia currently ranks ninth in the world in recoverable coal reserves, with an estimated 35 billion tons. As recently as 1989, Indonesia's recoverable reserves were estimated at only 3 billion tons [8]. Indonesia's coal production has increased rapidly, rising from less than 1 million tons in 1980 to 41 million tons in 1995 [6, Table 2.5]. Some of its coal reserves have unique characteristics that have made them sought after in international markets. Some have extremely low sulfur content $(0.08$ percent average by weight). Other high-quality Indonesian reserves are finding acceptance as soft coking coals and in the growing market for pulverized coal injection at blast furnaces [9].

\section{Regional Consumption}

\section{Asia}

As a result of fast-paced economic growth, coal consumption is expected to grow most rapidly in the developing countries of Asia. In the IEO98 forecast, this region's share of total world coal consumption increases from 40 percent in 1995 to 60 percent in 2020 (on a tonnage basis). Coal consumption in the region is projected to increase by more than 3.1 billion tons, from 2.0 billion tons in 1995 to almost 5.2 billion tons in 2020 (Figure 62). In China alone, coal consumption is expected to increase by about 2.8 billion tons. India, too, is poised for a substantial increase in coal usage, with consumption projected to rise by 270 million tons between 1995 and 2020.

The large increases in coal consumption projected for China and India are based on an outlook for strong economic growth (7.9 percent per year in China and 5.5 percent per year in India) and the expectation that much of the increased demand for energy will be met by coal, particularly in the industrial and electricity sectors. The IEO98 forecast assumes no significant changes in

${ }^{12}$ Recoverable reserves are those quantities of coal which geological and engineering information indicates with reasonable certainty can be extracted in the future under existing economic and operating conditions. 
Figure 62. World Coal Consumption by Region, 1980, 1995, and 2020

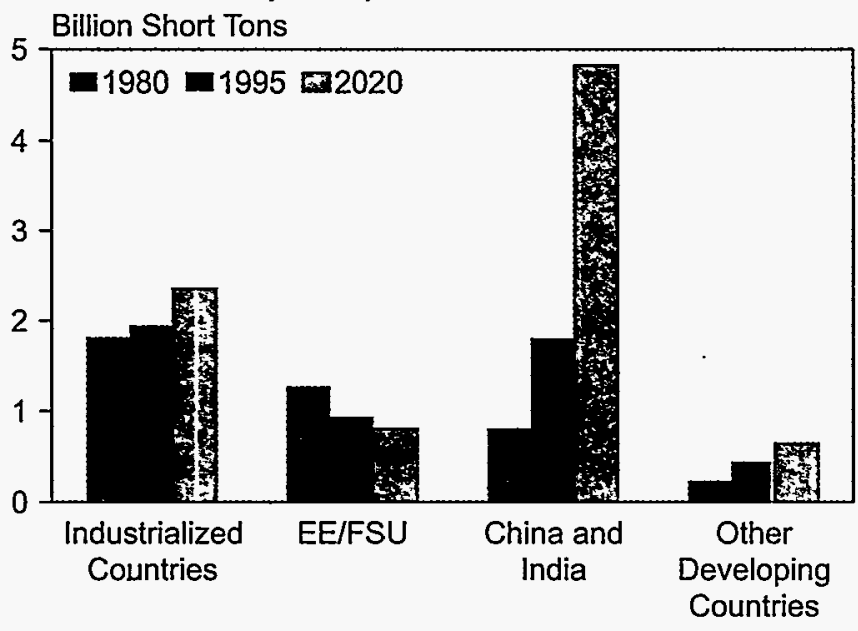

Sources: 1980 and 1995: Energy Information Administration (EIA), Office of Energy Markets and End Use, International Statistics Database and International Energy Annual 1996, DOE/EIA-0219(96) (Washington, DC, February 1998). 2020: EIA, World Energy Projection System (1998).

environmental policies in the two countries. It also assumes that necessary investments in the countries' mines, transportation, industrial facilities, and power plants will be made.

In China, 59 percent of the total increase in coal demand is projected to occur in the non-electricity sectors, primarily for steam and direct heat for industrial applications (primarily in the chemical, cement, and pulp and paper industries) and for the manufacture of coal coke for input to the steelmaking process. Strong growth in steel demand is expected in China, as infrastructure and capital equipment markets expand.

Coal remains the primary source of energy in China's industrial sector, primarily because China has limited reserves of oil and natural gas. In the non-electricity sectors, most of the increase in oil use comes from rising demand for energy for transportation. Growth in the consumption of natural gas comes primarily from increased use for space heating in the residential and commercial sectors. A substantial portion of the increase in demand for both natural gas and oil is projected to be satisfied by imports.

In the electricity sector in China, coal use is projected to grow by 5.3 percent a year, from 7.6 quadrillion Btu in 1995 to 27.5 quadrillion Btu in 2020. In comparison, coal consumption by electricity generators in the United States is projected to rise from 17.3 quadrillion Btu in 1995 to 23.0 quadrillion Btu in 2020. One of the key implications of the substantial rise in electricity coal demand in China is that large financial investments in new coal-fired power plants and in the associated transmission and distribution systems will be needed. The projected growth in coal demand implies that China will need approximately 480 gigawatts of coal-fired capacity in $2020 .^{13}$ In 1995, China had approximately 142 gigawatts of fossil-fuel-fired (coal, oil, and gas) generating capacity [6, Table 6.4].

In India, projected growth in coal demand matches the pattern expected in most other areas of the world, with virtually all of the increase occurring in the electricity sector. Between 1995 and 2020, coal use for electricity generation in India is projected to rise by 3.4 percent a year, from 4.2 quadrillion Btu in 1995 to 9.7 quadrillion Btu in 2020. This growth implies that India will need approximately 140 gigawatts of coal-fired capacity in 2020.14 In 1995, India's total fossil-fuel-fired generating capacity amounted to 69 gigawatts [6, Table 6.4].

In Japan, coal consumption is projected to increase at a much slower pace than in the other countries of Asia. In the electricity sector, coal use is projected to rise at a rate of only 1.3 percent a year, from 1.3 quadrillion Btu in 1995 to 1.8 quadrillion Btu in 2020. Projected growth in the non-electricity sectors is even smaller, with only a slight increase expected over the forecast period. The limited growth in the non-electricity sectors is attributable in part to continuing efforts by Japanese steelmakers to reduce the overall amount of coal required per ton of steel produced.

In the remaining areas of Asia, a substantial rise in coal consumption is expected over the forecast period, driven by strong growth in coal-fired electricity generation in Indonesia, South Korea, Taiwan, and the member countries of the Association of Southeast Asian Nations (the Philippines, Thailand, and Malaysia). South Korea's only electric utility, the Korean Electric Power Corporation, plans to build 25 additional coal-fired units (14 gigawatts) between 1995 and 2005 [10]. In the electricity sector, coal use in the other developing countries of Asia is projected to rise by 4.1 percent a year, from 2.3 quadrillion Btu in 1995 to 6.3 quadrillion Btu in 2020 .

\section{Western Europe}

Coal consumption in Western Europe has declined by 313 million tons since 1989 , to a level of 674 million tons in 1995. Over the forecast period, the decline in coal consumption is expected to slow, and a slight recovery is expected after 2005. In Western Europe, environmental concerns play an important role in the competition among coal, natural gas, and nuclear power. Recently,

\footnotetext{
13 Based on a 10-percent improvement in the average heat rate (or conversion efficiency) and a rise in the average capacity factor from approximately 55 percent in 1995 to 65 percent by 2020 .

${ }^{14}$ Based on a 10 percent improvement in the average heat rate (or conversion efficiency) and a rise in the average capacity factor from approximately 50 percent in 1995 to 60 percent by 2020 .
} 
other fuels, particularly natural gas, have been favored over coal.

Although coal consumption has declined substantially in Western Europe in recent years, much of the decline is attributable to the rapid contraction of Germany's lignite industry. Between 1989 and 1995, German lignite production declined by 267 million tons, while hard coal ${ }^{15}$ production in all of Western Europe declined by only 85 million tons [6, Tables 5.2, 5.3, and 5.4]. The sharp decline in German lignite production followed the conversion from lignite-based town gas ${ }^{16}$ to natural gas in the eastern states of Germany after reunification in 1990, as well as substitution of natural gas and other fuels for lignite in home heating $[7, \mathrm{p}$. II.157; 11]. A second factor was the collapse of industrial output in the eastern states [7, p. II.157; 12]. Reduced economic activity in eastern Germany contributed to an 8.5-percent decline in total energy consumption in Germany between 1988 and 1994.

In the IEO98 forecast, further declines in lignite production are projected to be small. This outlook is based on the competitiveness of German lignite with other imported fuels, as well as planned investments to refurbish or replace existing lignite-fired plants using best available combustion and pollution control technologies. A new 900-megawatt lignite plant to be built in the Rheinland area of Germany is expected to be the most up-to-date lignite-based power station in the world when it is completed in 2002, boasting a 43-percent conversion efficiency [7, p. I.162].

Two key trends in Western Europe are at play over the forecast period. In the European Union, hard coal production is expected to continue its long, relatively slow decline (see box on page 76). Following the closure of the last remaining coal mines in Belgium in 1992 and Portugal in 1994, only four member States of the European Union-the United Kingdom, Germany, Spain, and France-continue to produce hard coal $[13,14]$. As a result, coal consumption in these four countries is expected to decline slightly, because coal imports are not expected to fill the entire gap in energy supply left by the loss of indigenous coal. Rather, a combination of fuels-including natural gas, imported coal, and renewable energy - are expected to compensate for the reduction in domestic coal supply. Offsetting the decline in hard coal in Europe are projected increases in the consumption of indigenous lignite for electricity generation in Turkey and Greece. Much of the increase is in Turkey, where coal (both lignite and hard coal) and natural gas are expected to fuel a large increase in electricity demand [7, pp. II.301-II.308; 15].

\section{Eastern Europe and the Former Soviet Union}

In the EE/FSU countries, the process of economic reform continues, as the transition to a market-oriented economy replaces centrally planned economic systems. The dislocations associated with these institutional changes have contributed substantially to declines in both coal production and consumption. Coal consumption in the EE/FSU region has fallen by more than 513 million tons since 1988, reaching 934 million tons in 1995 [6, Table 1.4]. In the future, total energy consumption in the EE/FSU is expected to rise, driven primarily by increasing production and consumption of natural gas. In the forecast, coal's share of total EE/FSU energy consumption declines from 26 percent in 1995 to 15 percent in 2020, while the portion of consumption met by natural gas increases from 40 percent in 1995 to 49 percent in 2020.

The three main coal-producing countries of the FSURussia, the Ukraine, and Kazakhstan-are facing similar problems. The coal industries in Russia and the Ukraine continue to be state-run operations, although efforts are underway to privatize the industries in both countries. These efforts are aimed primarily at shutting down inefficient mines and transferring support activities, such as housing, kindergartens, and health and recreation facilities, to local municipalities. Even efficient mines, however, are hampered by the payment arrears of their large customers, which have been making it nearly impossible to pay workers and purchase needed mining supplies and equipment [16]. In Russia, the government provided the equivalent of $\$ 1.1$ billion in subsidies to the coal industry in 1997 [17]. To date, the World Bank has provided $\$ 900$ million in loan assistance to the Russian coal industry and $\$ 300$ million to the Ukraine $[18,19,20$, 21].

Poland is the key coal producer and consumer in Eastern Europe. In 1995, coal consumption in Poland totaled 178 million tons, 43 percent of Eastern Europe's total coal consumption for the year. Poland's hard coal industry produced 148 million tons in 1995, and lignite producers contributed an additional 70 million tons [6, Tables 5.2, 5.3, and 5.4]. In other Eastern European countries, coal consumption is dominated by the use of low-Btu subbituminous coal and lignite, produced from local reserves. In 1995, the region's other important coalconsuming countries were the Czech Republic (16 percent of the region's total coal use), Romania (12 percent), Serbia (11 percent), Bulgaria (8 percent), and Hungary (4 percent). Eastern Europe relies heavily on local production, with seaborne imports of coal to the region totaling less than 5 million tons in 1996 [22, p. 64].

${ }^{15}$ Internationally, the term "hard coal" is used to describe anthracite and bituminous coal. In data published by the International Energy Agency, coal of subbituminous rank is classified as hard coal for some countries and as brown coal (with lignite) for others. In data series published by the Energy Information Administration, subbituminous coal production is included in the bituminous category.

16 "Town Gas" (or "coal gas"), a substitute for natural gas, is produced synthetically by the chemical reduction of coal at a coal gasification facility. 


\section{Hard Coal Production and Subsidies in Western Europe}

Since 1989, all the major producers of hard coal in Western Europe have posted substantial declines in output. In Germany, Spain, and France, recent agreements between the governments, mining companies, and labor unions on future coal production subsidies indicate that further declines in output are forthcoming. In the United Kingdom, production subsidies have been phased out, forcing coal producers into direct competition with North Sea gas and international coal.

Under a treaty approved by the European Commission in December 1993, member countries in the European Union may continue to subsidize their respective hard coal industries through 2002 [23]. This action was based on the belief that immediate abandonment of state coal subsidies would have led to the collapse of the European coal industry, causing unacceptable social and economic disruptions. The intent of the treaty, however, is for member countries to reduce coal subsidies gradually over time through efforts to reduce mining costs or through the closure of uneconomical mines. Member countries are encouraged to solve or reduce the social and regional problems that may result from mine closures.

The Commission also directed that after December 31, 1996, all subsidies are to be funded directly through federal, regional, or local budgets. In previous years, subsidies in Germany and Spain were partly funded through a levy on electricity prices [7, pp. I.165-I.166; 24]. Article 3 of the Kyoto Protocol requests that signatory countries progressively reduce or phase out market imperfections, fiscal incentives, tax and duty exemptions, and subsidies that lead to increased emissions of greenhouse gases [5].

Coal subsidies continue to support high-cost production of hard coal in Germany, Spain,* and France, with 1996 approved subsidies of $\$ 6,951$ million in Germany, $\$ 1,117$ million in Spain, and $\$ 863$ million in France [14, pp. 34-36].** For each of these countries, the average subsidy per ton of coal produced exceeds the average value of imported coal (see table below). Currently, these countries are taking steps to reduce subsidy payments, acknowledging that some losses in coal production are inevitable. In the United Kingdom, direct subsidies for coal production came to an end in April 1995, following the privatization of both the electricity and coal industries that began in 1990.

Hard coal production in the United Kingdom declined from 111 million tons in 1989 to 52 million tons in 1995 [6, Tables 5.2 and 5.3]. Most of the decline resulted from privatization in the electricity sector, which led to a rapid increase in gas-fired generation at the expense of coal [7, Table 3.3; 25, Table 3.3]. The UK coal industry has seen substantial improvements in mining operations in recent years, with average labor productivity rising from less than 1,000 tons per miner-year in 1989 to 2,600 tons per miner-year in 1995 [7, Table 6.5].

Despite these productivity improvements and domestic production costs that are approaching parity with imported coal, British coal producers continue to face an uncertain future [16, p. 33]. Many coal contracts between producers and utilities negotiated prior to the privatization of the coal industry in 1994 are set to expire at the end of March 1998 [26; 14, p. 21]. Initial negotiations on the renewal of these contracts in late 1997 indicated a strong preference among British utilities to switch to lower cost natural gas and away from coal. The potential negative impacts on the British coal industry and mining jobs prompted the issuance of a temporary moratorium on the construction of new gasfired generating plants by the British government [27, 28]. In addition, Britain's energy minister requested an analysis of the nation's power industry to evaluate how the issues of fuel diversity and security of supply should be considered in the approval process for new power projects. In 1995, electricity producers in the United Kingdom consumed 66 million tons of coal, representing 78 percent of the country's total coal consumption [22, p. 43].

Germany's hard coal production, which is highly subsidized, declined from 88 million tons in 1989 to 62 (Continued on page 77)

Coal Industry Subsidies, Production, and Import Prices, 1996

\begin{tabular}{c|c|c|c|c}
\hline Country & $\begin{array}{c}\text { Coal Industry } \\
\text { Subsidies } \\
\text { (Million 1996 Dollars) }\end{array}$ & $\begin{array}{c}\text { Hard Coal } \\
\text { Production } \\
\text { (Million Tons) }\end{array}$ & $\begin{array}{c}\text { Average Subsidy per } \\
\text { Ton of Coal Produced } \\
\text { (1996 Dollars) }\end{array}$ & $\begin{array}{c}\text { Average Price per } \\
\text { Ton of Coal Imported } \\
\text { (1996 Dollars) }\end{array}$ \\
\hline Germany . . . . & 6,951 & 57.9 & 120 & 43 \\
Spain . . . . . . & 1,117 & 22.5 & 50 & 42 \\
France . . . . . & 863 & 8.0 & 108 & 48 \\
\hline
\end{tabular}

Sources: Coal Production Subsidies: Directorate-General XVII-Energy, European Commission, The Market for Solid Fuels in the Community and the Outlook for 1997, web site www.europa.eu.int (Brussels, Belgium, June 6, 1997). Production: Energy Information Administration, International Energy Annual 1996, DOE/EIA-0219(96) (Washington, DC, February 1998). Average Price of Coal Imports: International Energy Agency, Coal Information 1996 (Paris, France, July 1997). 


\section{Hard Coal Production and Subsidies in Western Europe (Continued)}

million tons in 1995 [6, Tables 5.2 and 5.3]. In March 1997 , the federal government, the mining industry, and the unions reached an agreement on the future structure of subsidies to the German hard coal industry. In summary, subsidies to the industry are to be reduced from DM10.5 billion in 1996 to DM5.5 billion by 2005, resulting in an estimated decline in production to 33 million tons [7, pp. I.165-I.165]. The agreement calls for the closure of 8 to 9 of Germany's 19 hard coal mines, resulting in an estimated decline in employment from 55,000 miners in 1996 to about 36,000 by 2005 .

In Spain, hard coal production declined from $29 \mathrm{mil}-$ lion tons in 1989 to 19 million tons in 1995 [6, Tables 5.2 and 5.3]. In 1997, an agreement reached between the government, labor unions, and the electricity sector will see subsidized coal production continue in Spain through 2005, with output set to gradually decline to 15 million tons [29]. In the electricity sector, the share of domestic coal that must be used in power generation will be reduced from the current level of about 40 percent to a level of 15 percent. Spain's coal mine labor force will be reduced from 24,000 in 1996 to approximately 18,000 by 2005 through "non-traumatic" means such as retirement and voluntary separations.

France's production of hard coal declined from 14 million tons in 1989 to 8 million tons in 1995 [6, Tables 5.2 and 5.3]. A modernization, rationalization, and restructuring plan submitted by the French Government to the European Commission at the end of 1994 foresees the closure of all coal mines in France by 2005 [14, p. 36]. The coal industry restructuring plan was based on a "Coal Agreement" reached between France's state-run coal company, Charbonnages de France, and the coal trade unions.

*In Spain, subsidies support the production of both hard coal and subbituminous coal.

**In local currencies, coal subsidies in 1996 were DM10.5 billion in Germany, Pta141.4 billion in Spain, and FF4.4 billion in France.

At present, Poland's hard coal industry is at a crossroads. The industry is faced with radical restructuring plans, such as the one proposed in a World Bank report in 1997 that recommended the closure of between 17 and 28 of Poland's 62 hard coal mines by as early as 2002 [30, 33]. The Polish government's own restructuring plan presented in 1995 (the Markowski Plan) recommended a much less severe downsizing of the industry. Nevertheless, the primary goal of both restructuring plans is to transform Poland's hard coal industry to a position of positive earnings, eliminating the need for government subsidies. Although Poland has abandoned the Markowski Plan, its Economics Ministry has indicated that a new restructuring plan will be forthcoming in 1998 [32]. Also affecting Poland's coal industry is the new Energy Law, passed in April 1997, which calls for the gradual freeing of prices for both liquid fuels and coal [33].

Over the forecast period, coal consumption in Eastern Europe is projected to decline by about 19 percent on a Btu basis. Increased use of natural gas, oil, and renewable energy compensate for the reduced output from coal in meeting the region's projected growth in energy demand.

\section{North America}

In North America, coal consumption is concentrated in the United States, which, at 941 million tons, accounted for 93 percent of the regional total in 1995. By 2020, U.S. coal consumption is projected to rise to 1,257 million tons. With its substantial supplies of coal reserves, the
United States has come to rely heavily on coal for electricity generation and continues to do so over the forecast. Coal provided 51 percent of total U.S. electricity generation in 1995 and is projected to provide 49 percent in 2020 [34]. To a large extent, EIA's projections of declines in both minemouth coal prices and coal transportation rates are the basis for the expectation that coal will continue to compete as a fuel for U.S. power generation (see box above). In Canada and Mexico (the other countries of North America), coal consumption is projected to rise from 72 million tons in 1995 to 108 million tons in 2020.

Canada's increased use of coal in the IEO98 forecast results primarily from the expected retirement of some of the country's older nuclear units after 2010, and the subsequent need to replace that generation [35]. During this period, Canada's nuclear generation is projected to decline by 24 percent. A temporary decrease in Canada's nuclear generation early in the forecast period also leads to some increased coal burn then. During the summer of 1997, Ontario Hydro shut down 7 of its 19 nuclear reactors for major overhauls after the discovery of widespread safety and performance problems [36].

In Mexico, the state-owned Comision Federal de Electricidad has plans to construct a 2.1-gigawatt dual coaland oil-fired plant on Mexico's Pacific coast [37]. When all of the plant's generating units are completed in the early 2000 s, its coal consumption is projected to exceed 5 million tons annually. A new coal import facility being constructed adjacent to the plant should have an annual throughput capacity of more than 9 million tons. 


\section{The Long-Term Decline in U.S. Minemouth Coal Prices}

EIA's Annual Energy Outlook 1998 (AEO98) forecasts a widening gap between coal and other fuels used to generate electricity in the United States. The average U.S. minemouth coal price fell from $\$ 47.08$ to $\$ 18.50$ (in constant 1996 dollars) between 1978 and 1996. Excluding the possible imposition of a substantial carbon. emission penalty if the Kyoto Protocol is ratified by the U.S. Senate, coal may still be the least expensive fuel for electricity generation in coming decades. The following historical trends have contributed to the decline in minemouth prices:

- Technological advances in underground mining. Longwall mining and high-capacity armored conveyors make it possible to mine at over 1,000 tons per hour, greatly reducing costs where suitable coal reserves exist in Appalachia, the Midwest, and the Rocky Mountain States.

- Large-Scale Surface Mining. Very large-scale surface mining of coal seams in the Wyoming portion of the Powder River Basin that are between 65 and 120 feet thick can produce up to 55 million tons per mine per year at $\$ 3.00$ per ton.

- Labor Productivity Growth and Industry Consolidation. The U.S. coal industry now employs only 35 percent of the work force needed in 1978, although production has risen by 61 percent. Labor productivity has grown by 6.4 percent per year since 1978. The coal industry, once dominated by hundreds of small familyowned firms with over 6,000 small mines, is consolidating into big firms with big mines. About 50 firms now produce 80 percent of U.S. coal from several hundred large mines.

- Consolidation of Coal Transportation and Technical Innovation. Rail mergers and technical innovation have reduced the real cost of long-distance overland coal transportation. As a result, coal mined in Wyoming at $\$ 0.23$ per million Btu can now compete with Appalachian coal mined at $\$ 1.00$ per million Btu in States such as Georgia and North Carolina, where coal from either source can be delivered at prices close to $\$ 1.50$ per million Btu.

Taken together, these factors have revolutionized economies of scale in mining, marketing, and shipping coal in the large quantities required by electricity generation plants. It is projected that these trends will continue, although at a gradually moderating pace.

Technical and managerial changes on the supply side are being matched on the demand side. Deregulation of the electricity generation business is making utilities more price conscious. Where regulated utilities once focused on obtaining "reliable fuel supplies at reasonable cost" through long-term cost-plus contracts, competition has made generation cost the primary issue. The quality of service is now taken for granted, and generators are aggressively minimizing fuel costs. Deregulation of power generation has created bigger, fully hedged markets for power and fuel. The result has been lower profit margins for coal mining firms.

Coal markets other than electric utilities, which historically have been less sensitive to prices than the electricity market, are now in long-term decline. With the migration of many manufacturers to economies with lower labor and environmental costs, there are fewer coal-fueled industries to be supplied. For those that remain, aging coal-based technology is gradually being replaced with natural gas or more efficient coal units in response to environmental requirements.

These market changes guarantee long-term price pressure on coal. By moving toward larger, less laborintensive operations, coal producers can continue to reduce supply and distribution costs for some time to come. Interregional competition can still substantially reduce the average minemouth price, since regional mine prices vary from $\$ 0.20$ to more than $\$ 1.00$ per million Btu. Such price competition will be influenced by long-distance railroad rates for coal. Past mergers have reduced the number of major coal-hauling railroads to four (Burlington/Santa Fe and Union Pacific/ Southern Pacific in the West; CSX and Norfolk/ Southern in the East). Any further mergers will produce transcontinental systems. Some analysts believe that a national rail duopoly might reverse the historical decline in coal rates and, in turn, stabilize the national minemouth coal price, since much of its historic decline has resulted from declining longdistance railroad rates.

The Clean Air Act Amendments of 1990 (CAAA) place a fixed cap on sulfur oxide emissions after January 1, 2000. As consumption grows so will emissions, unless the average sulfur content of coal burned declines or consumers retrofit expensive scrubbers on their boilers. The least expensive low-sulfur coal in most areas of the United States is subbituminous coal from the Powder River Basin in Wyoming and Montana, which has proven to be more popular than other low-sulfur coals or scrubbers. The 1990 CAAA established a limited number of sulfur oxide emissions allowances, the price of which will vary with demand. As the amount of coal consumed increases, the price of allowances will rise. The average allowance price for (Continued on page 79) 


\section{The Long-Term Decline in U.S. Minemouth Coal Prices (Continued)}

1996 was estimated in the AEO98 at $\$ 76.85$ per ton of sulfur oxides emitted, or about $\$ 0.202$ per million Btu for high-sulfur coal. ${ }^{*}$ This is equal to about $\$ 0.040$ per million Btu for Appalachian low-sulfur coals, or about $\$ 0.026$ per million for Powder River Basin subbituminous coal, which has very low sulfur content (see table below).**

Thus, in addition to lower mining cost, Powder River Basin coal has an environmental advantage over other coals. Wherever the Powder River subbituminous coal can be delivered at a price competitive with highsulfur coal, using it will result in about the same total cost as scrubbing high-sulfur coal, but without incurring the capital and operating cost penalties associated with a scrubber. ${ }^{* *}$ Therefore, until the mining and/or transportation cost of Powder River Basin coal rises by an amount equal to the levelized cost of retrofitting and operating a scrubber, consumers will use more of it in preference to scrubbing; and as its market share increases, the average U.S. minemouth price of coal will continue to decline.

Sulfur Allowance Penalties by Coal Type and Demand Region in the United States, 1996 (1996 Dollars per Million Btu)

\begin{tabular}{|c|c|c|c|c|c|}
\hline \multirow[b]{2}{*}{ Demand Region } & \multicolumn{5}{|c|}{ Coal Type } \\
\hline & $\begin{array}{c}\text { Powder River } \\
\text { Basin }\end{array}$ & $\begin{array}{c}\text { Other } \\
\text { Low-Sulfur }\end{array}$ & Medium-Sulfur & High-Sulfur & $\begin{array}{l}\text { Scrubbed } \\
\text { High-Sulfur }\end{array}$ \\
\hline New England. . . . . . . . . . . & - & 0.037 & 0.080 & 0.134 & 0.017 \\
\hline Middle Atlantic . . . . . . . . . . . . & - & 0.040 & 0.102 & 0.173 & 0.022 \\
\hline South Atlantic $\ldots \ldots \ldots \ldots$ & - & 0.041 & 0.068 & 0.210 & 0.027 \\
\hline Georgia and Florida . . . . . . . & 0.030 & 0.039 & 0.066 & 0.185 & 0.024 \\
\hline Ohio . . . . . . . . . . . . & 0.019 & 0.040 & 0.064 & 0.216 & 0.028 \\
\hline East North Central . . . . . . . & 0.024 & 0.035 & 0.078 & 0.205 & 0.027 \\
\hline Kentucky and Tennessee . . . . . & - & 0.035 & 0.078 & 0.205 & 0.027 \\
\hline Alabama and Mississippi. . . . . . & 0.024 & 0.038 & 0.082 & 0.175 & 0.023 \\
\hline West North Central. . . . . . . . . & 0.024 & 0.033 & 0.061 & 0.197 & 0.025 \\
\hline West South Central . . . . . . & 0.027 & 0.027 & 0.079 & 0.161 & 0.021 \\
\hline Mountain . . . . . . . . . . . & 0.030 & 0.030 & 0.056 & - & - \\
\hline Arizona and New Mexico . . . . . & - & 0.033 & 0.058 & - & 一 \\
\hline $\begin{array}{l}\text { California, Oregon, } \\
\text { Alaska, and Hawaii. }\end{array}$ & 0.020 & 0.030 & 0.061 & - & - \\
\hline Total United States . . . . . . . . . & 0.026 & 0.036 & 0.074 & 0.202 & 0.026 \\
\hline \multicolumn{6}{|c|}{$\begin{array}{l}\text { Note: Scrubbing is assumed to remove } 87 \text { percent of the sulfur oxides in high-sulfur coal. } \\
\text { Source: Energy Information Administration, Form ElA-423, assuming the Annual Energy Outlook } 1998 \text { historic } 1996 \text { allowance } \\
\text { price of } \$ 76.85 \text { per ton of sulfur oxide. }\end{array}$} \\
\hline \multicolumn{6}{|c|}{$\begin{array}{l}\text { *A sulfur allowance entitles the owner to emit } 1 \text { ton of } \mathrm{SO}_{\times} \text {. Allowances are priced in a national market, open to all. The sulfur allowance } \\
\text { penalty of } \$ 0.202 \text { per million Btu for high-sulfur coal is calculated from the national allowance price of } \$ 76.85 \text { per ton of } \mathrm{SO}_{x} \text { (as estimated } \\
\text { for } 1996 \text { by the National Energy Modeling System (NEMS) in ELA's } A E O 98, \text { based on the average heat and sulfur content for high-sulfur } \\
\text { coal purchased by electric utilities in } 1996) \text {. } \\
* * \text { The allowance prices shown differ from region to region because of variation in the heat and sulfur content of the coal consumed. The } \\
\text { NEMS Coal Market Module simulates } 34 \text { types of coal, the characteristics of which have been aggregated into the five categories shown } \\
\text { in the table. The national values are weighted averages. } \\
* * \text { Scrubbing achieves an average of about } 87 \text { percent removal of sulfur oxides from plant emissions. It therefore reduces the allowance } \\
\text { penalty associated with burning high-sulfur coal proportionately to about }(1.00-0.87) \times \$ 0.202=\$ 0.026 \text { per million Btu. }\end{array}$} \\
\hline
\end{tabular}

\section{Africa}

In Africa, coal production and consumption are concentrated almost entirely in South Africa. In 1995, South Africa produced 227 million tons of coal, 70 percent of which was routed to domestic markets and the remainder to exports [6, Table 2.5]. South Africa ranks third in the world in coal exports, behind Australia and the
United States, and is projected to maintain that position over the forecast. South Africa holds the distinction of being the world's largest producer of coal-based synthetic liquid fuels. In 1995, almost one-fifth of the coal consumed in South Africa (on a Btu basis) was used to produce coal-based synthetic fuels, which in turn accounted for approximately one-third of all liquid fuels consumed in South Africa during the year $[38,39]$. 
For Africa as a whole, coal consumption is projected to increase by 45 million tons between 1995 and 2020, primarily to meet increased demand for electricity. Contributing to the increase in electricity demand is South Africa's commitment to rural electrification. There are substantial opportunities for trade in electricity and natural gas between South Africa and neighboring countries. Such trades may occur, given government reform in South Africa and the subsequent removal of trade sanctions.

Elsewhere in Africa, the completion of four additional coal-fired units at Morocco's Jorf Lasfar plant near Casablanca should increase coal consumption there from about 2 million tons in 1996 to more than 5 million tons $[40,41]$. When all units are completed, the plant is expected to account for approximately one-third of Morocco's total power generation.

\section{South America}

Historically, coal has not been an important source of energy in South America, accounting for less than 5 percent of the region's total energy consumption. In the electricity sector, hydroelectric power currently meets much of South America's electricity demand. Over the forecast period, both hydropower and natural gas are projected to fuel much of the projected increase in electricity generation.

In 1995, Brazil accounted for 56 percent of South America's total coal demand, with Colombia, Chile, and Argentina accounting for much of the remaining portion [6, Table 1.4]. In Brazil, the steel industry accounts for almost two-thirds of the country's total coal consumption, relying on imports of metallurgical coal to produce coke for use in its blast furnaces $[6$, Table $1.4 ; 7$, p. III.136]. In the forecast, increased use of coal for steelmaking (both coking coal and coal for pulverized coal injection) accounts for much of the projected increase in Brazilian coal consumption [42]. New power projects in Colombia and Brazil account for most of the remaining growth in coal consumption projected for South and Central America [43].

\section{Middle East}

Israel and Iran accounted for most of the 10 million tons of coal consumed in the Middle East in 1995 [6, Table 1.4]. Over the forecast, Israel's coal consumption is projected to rise by approximately 6 million tons with the completion of two new coal-fired generating plants between 1999 and 2005 [7, III.136; 44]. Israel's stateowned utility, Israel Electric Corporation, estimates that coal-fired plants will meet approximately 60 percent of the country's electricity needs in the post-2000 period [45].

In Iran, approximately 1 million tons of coal consumption has been satisfied historically by indigenous suppliers [6, Table 2.5]. In addition, Iran's National Steel Corporation (NISCO) imports approximately 0.5 million tons of coking coal annually, and some additional imports are expected over the forecast period as a result of planned expansions in the country's steelmaking capacity $[46,47]$.

\section{Trade}

\section{Overview}

The amount of coal traded in international markets is small in comparison with total world consumption. In 1996, world imports of coal amounted to 503 million tons (Table 21 and Figure 63), representing 9 percent of total consumption. By 2020, coal imports are projected to rise to 740 million tons, accounting for the same share of world coal consumption as in 1996. Although coal trade has accounted for a relatively constant share of world coal consumption over time and should continue to do so in future years, the geographical composition of trade is shifting.

In recent years, international coal trade has been characterized by relatively stable demand for coal imports in Western Europe and expanding demand in Asia (Figure 63). Rising production costs in the indigenous coal industries in Western Europe, combined with continuing pressure to reduce industry subsidies, have led to substantial declines in production there, creating the potential for large increases in coal imports; however, slow economic growth in recent years and

Figure 63. Production and Imports of Hard Coal by Region, 1985, 1990, and 1996

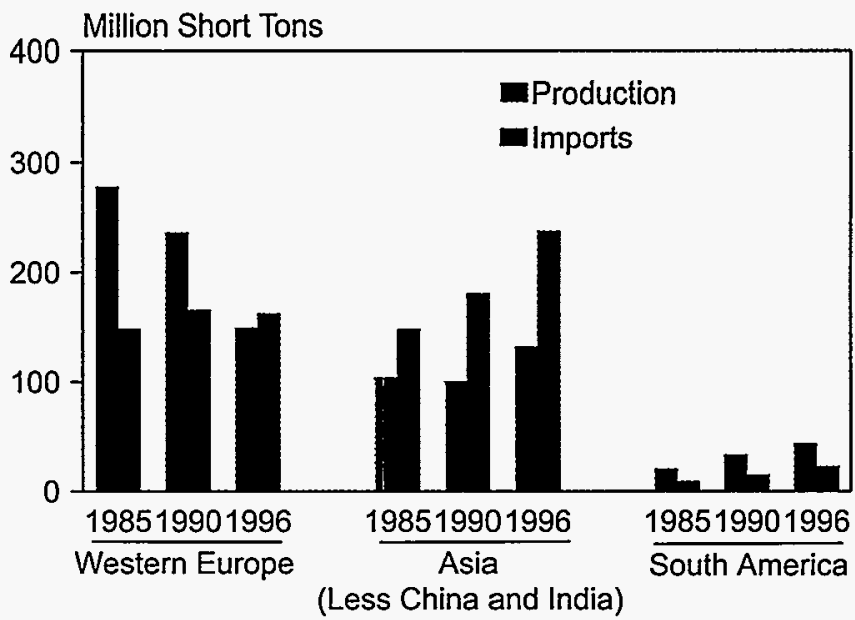

Note: Production and imports include data for anthracite, bituminous, and subbituminous coal.

Sources: Production: Energy Information Administration (EIA), Office of Energy Markets and End Use, International Statistics Database and International Energy Annual 1996, DOE/EIA-0219(96) (Washington, DC, February 1998). Imports: International Energy Agency, Coal Information 1994 (Paris, France, 1995), and Coal Information 1996 (Paris, France, July 1997). 
Table 21. World Coal Flows by Importing and Exporting Regions, Reference Case, 1996, 2010, and 2020 (Million Short Tons)

\begin{tabular}{|c|c|c|c|c|c|c|c|c|c|c|c|c|}
\hline \multirow{3}{*}{ Exporters } & \multicolumn{12}{|c|}{ Importers } \\
\hline & \multicolumn{4}{|c|}{ Steam } & \multicolumn{4}{|c|}{ Metallurgical } & \multicolumn{4}{|c|}{ Total } \\
\hline & Europe $^{a}$ & Asia & America $^{b}$ & Total & Europe $^{\mathbf{a}}$ & Asiac & America $^{b}$ & Total & Europe $^{a}$ & Asia & America $^{b}$ & Total \\
\hline & \multicolumn{12}{|c|}{1996} \\
\hline Australia. & 6.2 & 62.2 & 0.9 & 69.2 & 17.7 & 61.3 & 6.4 & 85.4 & 23.9 & 123.5 & 7.3 & 154.7 \\
\hline United States & 21.5 & 8.2 & 7.8 & 37.5 & 31.1 & 8.5 & 13.3 & 53.0 & 52.6 & 16.8 & 21.1 & 90.5 \\
\hline South Africa . . & 39.2 & 16.1 & 4.5 & 59.9 & 0.4 & 3.6 & 1.7 & 5.7 & 39.7 & 19.7 & 6.2 & 65.6 \\
\hline Former Soviet Union . & 4.1 & 3.0 & 9.8 & 16.9 & 1.4 & 3.7 & 0.1 & 5.3 & 5.5 & 6.7 & 9.9 & 22.2 \\
\hline Poland. . . . . . . . & 12.2 & 0.0 & 0.7 & 12.9 & 0.9 & 0.0 & 3.0 & 3.9 & 13.1 & 0.0 & 3.6 & 16.8 \\
\hline Canada ........ & 1.1 & 4.3 & 0.9 & 6.3 & 5.6 & 23.6 & 2.6 & 31.9 & 6.7 & 27.9 & 3.5 & 38.1 \\
\hline China . . . . . . . & 1.2 & 25.4 & -0.3 & 26.2 & 0.1 & 4.9 & -0.2 & 4.7 & 1.3 & 30.2 & -0.6 & 31.0 \\
\hline South America. . . . . & 21.2 & 0.1 & 8.7 & 30.0 & 1.8 & 0.3 & 0.2 & 2.3 & 22.9 & 0.4 & 8.9 & 32.3 \\
\hline Indonesia ${ }^{d} \ldots$ & 6.4 & 27.9 & 11.4 & 45.6 & 0.2 & 4.1 & 2.0 & 6.3 & 6.6 & 32.0 & 13.3 & 51.9 \\
\hline \multirow[t]{2}{*}{ Total . . . } & 113.1 & 147.1 & 44.3 & 304.5 & 59.3 & 110.1 & 29.1 & 198.5 & 172.4 & 257.2 & 73.4 & 503.0 \\
\hline & \multicolumn{12}{|c|}{2010} \\
\hline Australia. . . & 6.4 & 116.3 & 0.3 & 122.9 & 19.6 & 75.5 & 6.6 & 101.7 & 26.0 & 191.8 & 6.9 & 224.6 \\
\hline United States . & 37.0 & 14.3 & 9.5 & 60.7 & 25.7 & 8.7 & 16.4 & 50.9 & 62.7 & 23.0 & 25.9 & 111.6 \\
\hline South Africa . . . . . & 49.9 & 20.4 & 5.7 & 76.0 & 1.2 & 5.6 & 0.0 & 6.8 & 51.1 & 26.1 & 5.7 & 82.8 \\
\hline Former Soviet Union & 7.7 & 5.5 & 0.0 & 13.2 & 0.6 & 2.2 & 0.0 & 2.8 & 8.3 & 7.7 & 0.0 & 16.0 \\
\hline Poland. . . . . . . . & 10.5 & 0.0 & 0.0 & 10.5 & 3.6 & 0.0 & 0.0 & 3.6 & 14.1 & 0.0 & 0.0 & 14.1 \\
\hline Canada ........ & 3.8 & 3.9 & 0.1 & 7.8 & 5.0 & 25.1 & 1.5 & 31.5 & 8.8 & 28.9 & 1.6 & 39.4 \\
\hline China . & 0.0 & 35.9 & 0.0 & 35.9 & 0.0 & 3.3 & 0.0 & 3.3 & 0.0 & 39.2 & 0.0 & 39.2 \\
\hline South America. . . . . & 39.6 & 0.0 & 18.1 & 57.8 & 0.0 & 0.0 & 0.0 & 0.0 & 39.6 & 0.0 & 18.1 & 57.8 \\
\hline Indonesia $^{d} \ldots \ldots$ & 0.8 & 55.2 & 0.0 & 56.0 & 0.0 & 0.0 & 0.0 & 0.0 & 0.8 & 55.2 & 0.0 & 56.0 \\
\hline \multirow[t]{2}{*}{ Total . } & 155.7 & 251.6 & 33.6 & 440.9 & 55.7 & 120.4 & 24.5 & 200.6 & 211.4 & 372.0 & 58.1 & 641.5 \\
\hline & \multicolumn{12}{|c|}{2020} \\
\hline Australia. . . . . . . & 4.7 & 145.8 & 0.3 & 150.7 & 17.7 & 74.4 & 8.3 & 100.4 & 22.3 & 220.2 & 8.6 & 251.1 \\
\hline United States . . . . . & 47.4 & 20.4 & 11.1 & 78.9 & 24.2 & 6.0 & 18.6 & 48.8 & 71.6 & 26.4 & 29.7 & 127.7 \\
\hline South Africa . & 45.9 & 39.1 & 8.2 & 93.3 & 0.9 & 5.9 & 0.0 & 6.8 & 46.9 & 45.0 & 8.2 & 100.1 \\
\hline Former Soviet Union & 8.2 & 5.5 & 0.0 & 13.7 & 0.6 & 2.2 & 0.0 & 2.8 & 8.7 & 7.7 & 0.0 & 16.4 \\
\hline Poland. . . . . . . . & 10.5 & 0.0 & 0.0 & 10.5 & 3.4 & 0.0 & 0.0 & 3.4 & 13.9 & 0.0 & 0.0 & 13.9 \\
\hline Canada & 4.1 & 4.7 & 0.1 & 8.9 & 5.5 & 27.6 & 1.5 & 34.6 & 9.6 & 32.3 & 1.6 & 43.5 \\
\hline China & 0.0 & 42.6 & 0.0 & 42.6 & 0.0 & 3.3 & 0.0 & 3.3 & 0.0 & 45.9 & 0.0 & 45.9 \\
\hline South America. . . . & 51.3 & 0.0 & 23.5 & 74.7 & 0.0 & 0.0 & 0.0 & 0.0 & 51.3 & 0.0 & 23.5 & 74.7 \\
\hline Indonesia ${ }^{d} \ldots$ & 2.4 & 64.2 & 0.0 & 66.6 & 0.0 & 0.0 & 0.0 & 0.0 & 2.4 & 64.2 & 0.0 & 66.6 \\
\hline Total . & 174.5 & 322.2 & 43.2 & 539.8 & 52.3 & 119.4 & 28.4 & 200.1 & 226.8 & 441.6 & 71.6 & 740.0 \\
\hline
\end{tabular}

\footnotetext{
${ }^{\mathrm{a}}$ Coal flows to Europe include shipments to the Middle East and Africa.

${ }^{\mathrm{b}}$ For 1996, coal flows to America include a balancing item used by the International Energy Agency to reconcile discrepancies between reported exports and imports. The 1996 balancing items by coal type were 24.4 million tons (steam coal), 5.6 million tons (metallurgical coal), and 30.0 million tons (total). Negative quantities in the table are attributable to the balancing item.

${ }^{c}$ For 1996, includes 9.5 million tons of coal for pulverized coal injection at blast furnaces shipped to Japanese steelmakers.

${ }^{2}$ For 1996, coal exports from Indonesia include shipments from other countries not modeled for the forecast period. The 1996 nonIndonesian exports by coal type were 8.9 million tons (steam coal), 3.2 million tons (metallurgical coal), and 12.1 million tons (total).

Notes: Data exclude non-seaborne shipments of coal to Europe and Asia. Totals may not equal sum of components due to independent rounding. The sum of the columns may not equal the total, because the total includes a balancing item between importers' and exporters' data.

Sources: 1996: International Energy Agency, Coal Information 1996 (Paris, France, July 1997); Energy Information Administration, Quarterly Coal Report, October-December 1996, DOE/EIA-0121(96/4Q) (Washington, DC, May 1997); and International Coal Report, Coal Year 1997 (London, United Kingdom: Financial Times Energy Press, June 1997). Projections: Energy Information Administration, Annual Energy Outlook 1998, DOE/EIA-0383(98) (Washington, DC, December 1996), National Energy Modeling System run AEO98B.D100197A.
} 
increased electricity generation from natural gas, nuclear, and hydropower have curtailed the growth in coal imports. Conversely, growth in coal demand in Japan, South Korea, and Taiwan in recent years has contributed to a substantial rise in Asian coal imports.

\section{Asia}

Asia's demand for imported coal is poised for additional increases over the forecast period, driven by strong growth in electricity demand in the region and the consequent need for additional coal-fired generating capacity. Continuing the recent historical trend, Japan, South Korea, and Taiwan are projected to account for much of the regional growth in coal imports over the forecast period (Figure 64).

Figure 64. World Coal Trade, 1985, 1996, and 2020

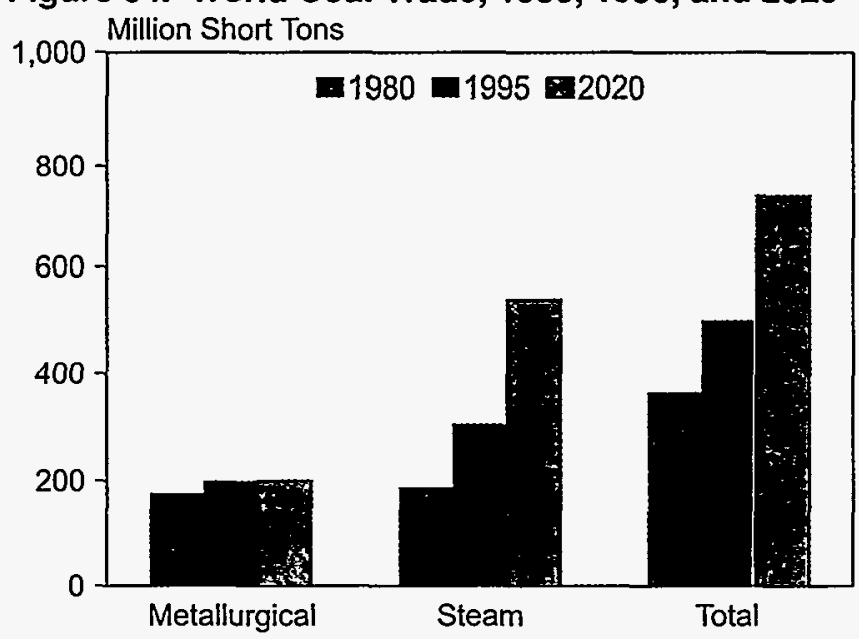

Sources: 1985: Energy Information Administration (EIA), Annual Prospects for World Coal Trade 1987, DOE/EIA0363(87) (Washington, DC, May 1987). 1996: ElA, Office of Energy Markets and End Use, International Energy Annual 1996, DOE/EIA-0219(96) (Washington, DC, February 1998). 2020: EIA, World Energy Projection System (1998).

Japan continues to be the world's leading importer of coal, accounting for 23 percent of total world imports in 2020 [48], as compared with its historical share of 28 percent in 1996 [7, Table 4.2]. In 1996, Japan produced 7 million tons of coal for domestic consumption and imported 139 million tons. The closure of Japan's Miike mine in March 1997, however, leaves the country with only about 3.5 million tons of production capacity at two remaining coal mines [49]. Production at these mines is expected to end when the government eliminates industry subsidies in 2001, leaving all of Japan's coal requirements to be met by imports $[7$, p. $1.158 ; 50]$.

China and India, which import relatively small quantities of coal at present, are expected to account for much of the remaining increase in Asian imports. Imports by China and India have the potential to be even higher than the projected amount, but it is assumed in the forecast that domestic coal will be given first priority in meeting the large projected increase ( 3.0 billion tons) in coal demand. In China, two factors may act to discourage coal imports, particularly with regard to private power projects: (1) coal consumers are required to get permission to import coal; and (2) coal imports add to a power project's potential for running into foreign exchange problems, making it difficult to obtain initial financing from lenders [51].

Australia should continue as the major exporter to Asia, meeting almost one-half of the region's total coal import demand in 2020, just as it did in 1996. Coal exports from China and Indonesia-Asia's internal coal suppliersshould keep pace with overall growth in Asian import demand. Together, they are projected to meet 25 percent of Asia's total import needs by 2020.

During the 1980s, Australia became the leading coal exporter in the world, primarily by meeting increased demand for steam coal in Asia. Some growth in exports of metallurgical coal also occurred, however, as countries such as Japan began using some of Australia's semisoft or weak coking coals in their coke oven blends. As a result, imports of hard coking coals from other countries, including the United States, were displaced. Australia's share of total world coal trade, which increased from 17 percent in 1980 to 31 percent in 1996, is projected to reach 34 percent in 2020 [52].

\section{Europe}

Coal imports to Europe also are projected to rise over the forecast period, although by less than one-third the amount projected for Asia. Among the uncertainties surrounding the prospects for European imports are the extent and pace of the decline in indigenous coal production (primarily in Germany and the United Kingdom) and the extent to which natural gas and other sources of energy will substitute for coal in electricity generation. In the IEO98 forecast, additional imports by Germany account for more than half of Europe's total increase in coal imports. Relatively smaller increases in imports are projected for Spain, France, Italy, Israel, Turkey, and Morocco.

In future years, the United States and South America are projected to meet an increasing share of European coal import demand, primarily at the expense of Australia and South Africa. Coal exporters in Australia and South Africa are expected to direct most of their additional shipments of coal to the rapidly expanding Asian import markets.

\section{The Americas}

Compared with European and Asian coal markets, imports of coal by North and South America are relatively small, amounting to only 45 million tons in 1996 
(Table 21). ${ }^{17}$ Brazil imported 31 percent of the 1996 total, followed by Canada (27 percent) and the United States (16 percent) [7, p. I.120]. Almost all (93 percent) of the imports to Brazil were metallurgical coal [7, p. III.13].

Over the forecast period, coal imports to the Americas increase by 27 million tons, with most of the additional tonnage going to South America and Mexico. Both Mexico and Brazil are projected to increase their imports of steam coal for electricity generation, and Brazil is expected to import additional amounts of coal for use at integrated steel plants $[43,53,54,55]$. Coal imports to the Brazilian steel industry are projected to rise as the result of strong growth in domestic steel demand and a continuing switch from charcoal to coal coke. Most of the additional imports of coal to the Americas are projected to be met by producers in Colombia, Venezuela, the United States, and South Africa.

\section{Metallurgical Coal}

Historically, metallurgical coal has dominated world coal trade, but its share has steadily declined, from 55 percent in 1980 to 39 percent in 1996 [56]. In the forecast, its share of world coal trade continues to shrink, falling to 27 percent by 2020 .

In absolute terms, metallurgical coal trade is projected to decline by only a small amount over the forecast. Factors that contribute to the decline are additional penetration of steel production from electric arc furnaces (which do not use coal coke as an input) and technological improvements at blast furnaces, including greater use of pulverized coal injection (PCI) equipment as well as higher average injection rates per ton of hot metal produced. One ton of pulverized coal (categorized as steam coal) used in steel production displaces approximately 1.4 tons of coking coal [57]. In 1996, an estimated 21 million tons of coal for PCI were traded worldwide, representing 10 percent of total coal imports for consumption at coke plants and blast furnaces [7]. Partly offsetting the downward pressure on metallurgical coal trade is an expected rise in imports to South Korea, Taiwan, India, and Brazil.

\section{References}

1."The News in Brief," The Christian Science Monitor (November 19,1997).

2. Martha Bryson Hodel, "Coal Union Joins Industry to Fight Against Global Warming Treaty," web site www.onlineathens.com (Associated Press, December 14, 1997).
3. Energy Information Administration, Emissions of Greenhouse Gases in the United States 1996, DOE/EIA0573(96) (Washington, DC, October 1997), Table B1.

4. United Nations, Framework Convention on Climate Change, Report of the Conference of Parties on Its First Session, Held at Berlin from 28 March to 7 April 1995, Part Two: Action Taken by the Conference of Parties at Its First Session, FCCC/CP/1995/7/Add.1, web site www.unfccc.de (June 6, 1995).

5. United Nations, Framework Convention on Climate Change, Report of the Conference of Parties on Its Third Session, Held at Kyoto from 1 to 10 December 1997, Kyoto Protocol to the United Nations Framework Convention on Climate Change, FCCC/CP/1997/L.7/Add.1, web site www.unfccc.de (December 10, 1997).

6. Energy Information Administration, International Energy Annual 1995, DOE/EIA-0219(95) (Washington, DC, December 1996).

7. International Energy Agency, Coal Information 1996 (Paris, France, July 1997).

8. Energy Information Administration, International Energy Annual 1989, DOE/EIA-0219(89) (Washington, DC, February 1991), Table 36.

9. "Indonesian Coal: Strategies for Growth," Coal Trans International, Vol. 9, No. 3 (May/June 1994), pp. 1621.

10. Jong-Hoon Park, General Manager KEPCO Vancouver Office, "KEPCO's Perspective on the Current and Projected Coal Demand," paper presented at the Western Coal Council's Pacific Coal Forum (Park City, UT, June 23-26, 1997).

11. "Eastern Germany Undergoes Swift Conversion to Natural Gas," Gas World International, Vol. 199, No. 4915 (June 1995), p. 36.

12. "Babcock Wins Landmark East German Power Contract," The Reuters European Business Report (October 17, 1995).

13. "Coal Industry: Extra ECSC Support Planned for Social Flanking Measures," Europe Energy (July 11, 1997).

14. Directorate-General XVII - Energy, European Commission, The Market for Solid Fuels in the Community and the Outlook for 1997, web site www. europa.eu.int (Brussels, Belgium , June 6, 1997).

\footnotetext{
${ }^{17}$ Excluding the balancing item used by the International Energy Agency to reconcile differences between reported exports and imports worldwide.
} 
15. Energy Information Administration, "Country Analysis Brief: Turkey," web site www.eia.doe.gov (May 12, 1997).

16. Richard M. Levine, "Mining Annual Review: Russia," The Mining Journal, Ltd (September 1997).

17. "Russian Coal Aid," The Mining Journal, Ltd (April 11, 1997), p. 290.

18. Adam Entous, "World Bank Releases $\$ 800$ Million to Aid Russia" (Reuters, December 19, 1997).

19. "At Least $\$ 100$ Million From World Bank Loan is Lost," Business Week (September 8, 1997), p. 52.

20. "World Bank Approves Loan for Ukrainian Coal Restructuring," East European Energy Report (January 24, 1997).

21. World Bank Press Release, "World Bank Helps Reform Russia's Coal Industry" News Release No. 97/1225ECA, web site www.worldbank.org (Washington, DC, December 23, 1996).

22. International Coal Report, Coal Year 1997 (London, United Kingdom: Financial Times Energy Press, June 1997).

23. European Commission, "Community Rules for State Aid to the Coal Industry. Decision 3632/93/ECSC," web site europa.eu.int (December 9, 1996).

24. "Spain Bows to EU Pressure," International Coal Report, No. 425 (June 2, 1997), p. 16.

25. International Energy Agency, Coal Information 1994 (Paris, France, 1995).

26. "Britain's Dwindling Coal Industry," BBC News, web site news.bbc.co.uk (November 25, 1997).

27. "Gas Halt Fails to Quell Mine Job Fears," BBC News, web site news.bbc.co.uk (December 4, 1997).

28. "Gas Power Stations Halted to Help Coal Industry," BBC News, web site news.bbc.co.uk (December 3, 1997).

29. "Spain Agrees $\$ 6.6$ Billion Support," International Coal Report, No. 429 (July 28, 1997), pp. 12-13.

30. Gerard McCloskey, "World Bank Judges Polish Restructuring Inadequate," International Coal Report, No. 433 (September 22, 1997), pp. 2-3.

31. "Survival Plan for Polish Coal," The Mining Journal (August 29, 1997), p. 176.
32. "Poland Returns to Interventionism," International Coal Report, No. 441 (January 26, 1998), p. 7.

33. Aleksandra Prus, American Embassy in Warsaw, U.S. and Foreign Commercial Service, Poland: Natural Gas Sector (July 1997).

34. Energy Information Administration, Annual Energy Outlook 1998, DOE/EIA-0383(98) (Washington, DC, December 1997), Table A8.

35. Natural Resources Canada, Canada's Energy Outlook: 1996-2020, web site www.nrcan.gc.ca (April 1997), pp. 48-50.

36. Howard Schneider, "Ontario to Split Power Company in Effort to Spur Competition, Exports," The Washington Post (November 7, 1997).

37. Francisco G. Jáuregui D., Fuels Purchasing Manager Comisión Federal de Electricidad, "Steam Coal Requirements of CFE," paper presented at the Western Coal Council's Pacific Coal Forum (Park City, UT, June 23-26, 1997).

38. Energy Information Administration, "Country Analysis Brief: South Africa," web site www. eia.doe.gov (August 1997).

39. Energy Information Administration, "Energy Balance: 1995 South Africa," web site www. eia.doe.gov (September 4, 1996).

40. "CMS to Tender for Jorf Supplies," International Coal Report, No. 434 (October 8, 1997), p. 8.

41. "CMS Generation Finalizing Moroccan Power Project" King's International Coal Trade (March 29, 1996), p. 13.

42. IEA Coal Research, Coal Prospects in Latin America to 2010, IEAPER/23 (London, United Kingdom: March 1996).

43. Ben George, Assistant Manager Fuel Division, Chilgener, "South America's Thermal Coal Report," paper presented at the Western Coal Council's Pacific Coal Forum (Park City, UT, June 23-26, 1997).

44. "International Market Report" King's International Coal Trade (July 19, 1996), pp. 9, 11.

45. "Market Chatter" King's International Coal Trade (January 24, 1997), p. 14.

46. Mining Journal, LTD, Mining Annual Review 1996 (London, United Kingdom: July 1996), p. 170. 
47. "International Market Report" King's International Coal Trade (June 21, 1996), p. 11.

48. Energy Information Administration, National Energy Modeling System, run AEO98B.D100197A (1997).

49. Katsahiko Saito, Managing Director Japan Coal Development Company Ltd., "JPU's Future Coal Demand and It's Significance for U.S. Western Mines With Outlet of LAXT," paper presented at the Western Coal Council's Pacific Coal Forum (Park City, UT, June 23-26, 1997).

50. "Pink Slips Come With a Big Heart in Japan Layoffs," The Christian Science Monitor June 13, 1997), p. 1.

51. "Private Power in China: The Implications for Coal," International Coal Report, No. 426 (June 16, 1997), pp. 21-28.

52. Energy Information Administration, Annual Prospects for World Coal Trade 1991, DOE/EIA0363(91) (Washington, DC, June 1991), Table 1.
53. Energy Information Administration, "Country Analysis Brief: Mexico," web site www.eia.doe.gov (May 1997).

54. "South American Imports To Shift," International Coal Report, No. 436 (November 3, 1997), pp. 13-14.

55. R. Buhler, "Recent Developments and Trends in Brazilian Steel Industry," paper presented at the Mississippi Valley Coal Trade and Transport Council's Fourteenth Annual World Coal Conference (New Orleans, LA, February 14-16, 1996).

56. Energy Information Administration, Annual Prospects for World Coal Trade 1987, DOE/EIA0363(87) (Washington, DC, May 1987), Tables A2 and A3.

57. Energy Information Administration, Coal Data: $A$ Reference, DOE/EIA-0064(93) (Washington, DC, February 1995), pp. 33-35. 



\section{Nuclear Power}

\section{Despite aggressive plans to expand nuclear power capacity in the near term, mainly in the Far East, retirements of existing units-particularly in the United States, where replacement by new nuclear units is not expected-lead to a long-term decline.}

In 1996, 2,280 billion kilowatthours of electricity was generated by nuclear power worldwide, to provide 17 percent of total electricity generation. Among the countries with nuclear power, national dependence on nuclear power plants for electricity varies greatly (Figure 65). Nine countries-five in Eastern Europe and the former Soviet Union (EE/FSU) and four in Western Europe-met over 40 percent of their total electricity demand with generation from nuclear reactors.

The prospects for nuclear power to maintain a significant share of worldwide electricity generation are uncertain, despite projected growth of 2.7 percent per year in

\section{Figure 65. Nuclear Shares of National Electricity} Generation, 1996

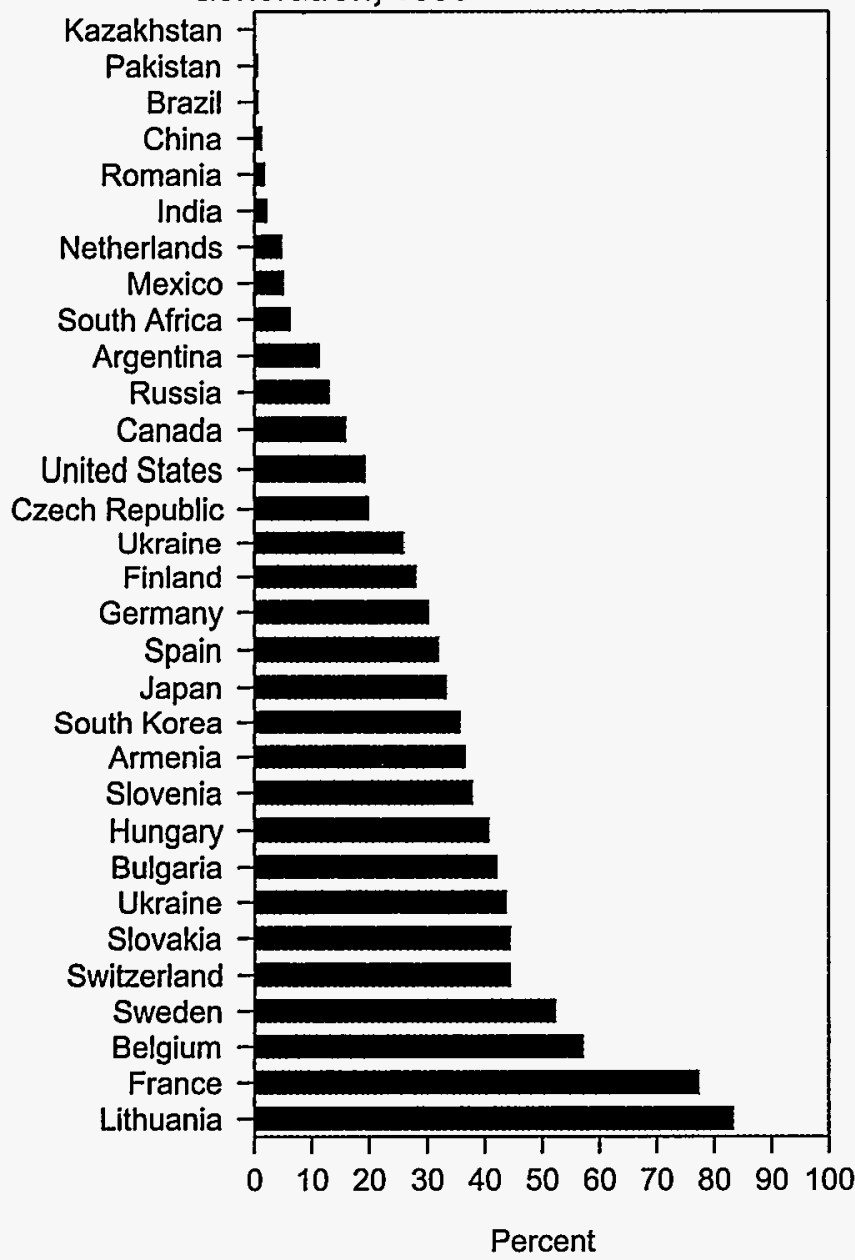

Source: International Atomic Energy Agency, Nuclear Power Reactors in the World 1996 (Vienna, Austria, April 1997). total electricity demand through 2020. Over the long term, of the regions shown in Figure 66, only the developing nations and Japan are projected to have net additions to nuclear power capacity. In other regions, countries that are operating older reactors and have other, more economical options for new generating capacity are expected to let their nuclear capacity fade as current nuclear units are retired.

In the IEO98 reference case, world wide nuclear capacity is projected to increase from 351 gigawatts in 1996 to 354 gigawatts in 2005, then begin to decline, reaching 302 gigawatts in 2020. Aggressive plans to expand nuclear capacity, mainly in the Far East, drive the near-term increase, whereas plant retirements in the United States and other countries exceed new additions later in the forecast. Developing Asian countries are projected to add 32.4 gigawatts by 2020 , but the industrialized nations overall lose 83.4 gigawatts.

As noted earlier (see page 18), no attempt has been made to assess the impacts of the Kyoto Climate Change Protocol on the projections that appear in IEO98. The Protocol could create new incentives for the use of

Figure 66. World Nuclear Capacity by Region, 1970-2020

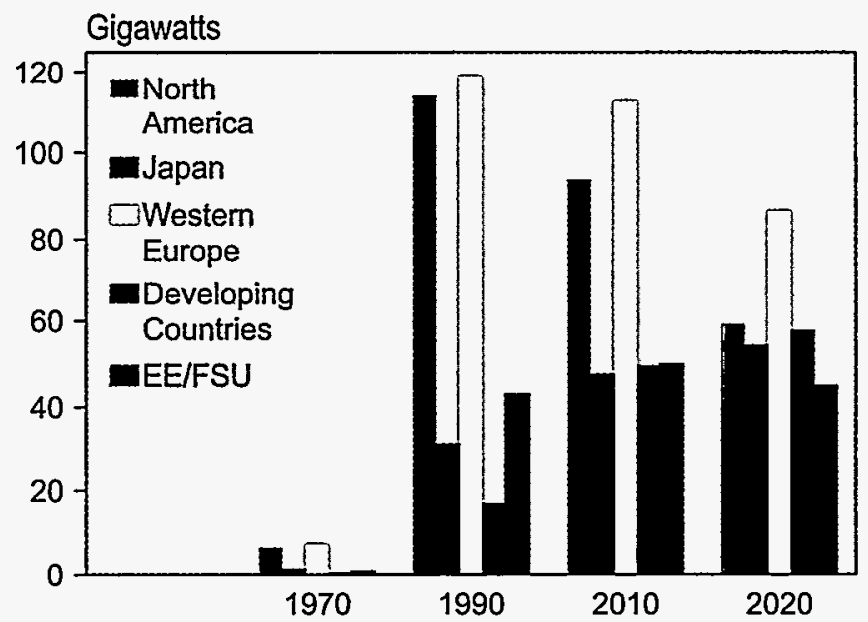

Sources: History: International Atomic Energy Agency, Nuclear Power Reactors in the World 1996 (Vienna, Austria, April 1997). Projections: Based on detailed assessments of country-specific nuclear power programs. For some countries, the World Integrated Nuclear Evaluation System (December 1997 run) was used to supplement the 2020 capacity projection. 
nuclear power, which does not produce carbon emissions. There were, however, two alternative cases developed for this report (Figure 67 and Table 22). Whereas the reference case for nuclear power reflects a continuation of present trends, the low and high growth cases present more pessimistic and more optimistic views of the future of the nuclear power industry. For the United States, the reference case assumes that the current trend of early reactor retirements will continue, with almost one-quarter of currently operating units being retired before their license expiration dates. The remainder are assumed, on average, to continue operating for their full 40-year lifetimes. For foreign nuclear projections, the reference case takes into account announced schedules for completion of units under construction and any announced retirement dates. Also considered are political environments, national energy plans, construction management experience, and financial conditions. Complete country-by-country listings of the projections for the reference, low, and high nuclear cases are provided in Tables A48, A49, and A50 in Appendix A.

\section{Figure 67. World Nuclear Capacity in Three Cases,}

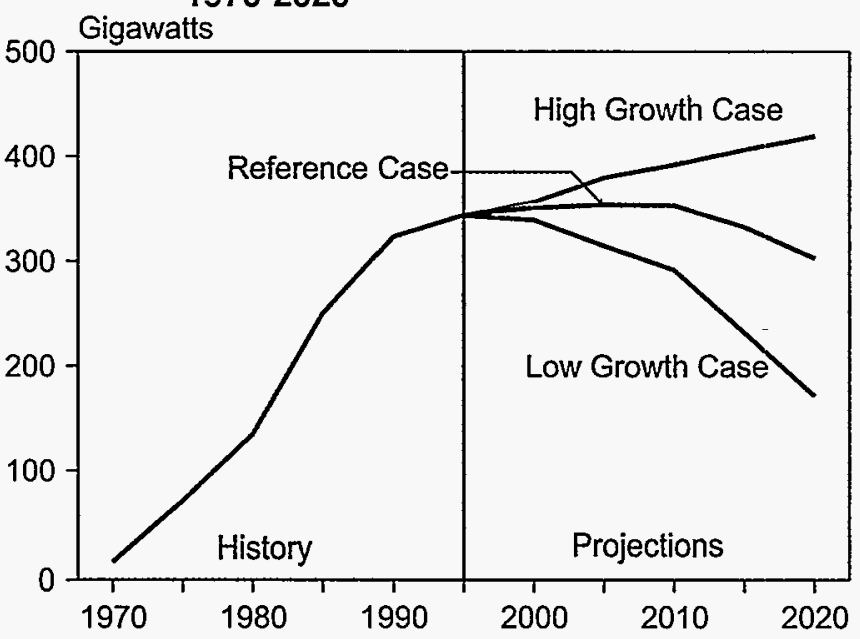

Sources: History: International Atomic Energy Agency, Nuclear Power Reactors in the World 1996 (Vienna, Austria, April 1997). Projections: Based on detailed assessments of country-specific nuclear power programs. For some countries, the World Integrated Nuclear Evaluation System (December 1997 run) was used to supplement the 2020 capacity projection.

The low growth case projects a more significant decline in nuclear capacity orders, and additional retirements of existing units. In the United States, all reactors are assumed to be retired after an average 30 years of operation. The forecast for worldwide capacity in 2020 is 172 gigawatts, a 51-percent decline from current capacity. The high growth case reflects a slight revival for the nuclear power industry, with net capacity growth of 1 percent annually over the forecast period. In the United States, the high growth case assumes that all plants will operate 10 years longer than in the reference case, except for units with announced firm retirement dates. The high growth projections are generally based on assumptions that construction times for new units will be shorter, and that provisions will be made to extend the operating lives of existing units beyond current estimates.

Nuclear generation in the reference case remains fairly flat, with a declining share of the world's electricity consumption (Figure 68). Among the most significant factors shaping the outlook for nuclear power are the following:

- Changes in electricity industries worldwide, introducing more competition in the generation sector. Nuclear power plants require relatively large amounts of capital and more time to build than other technologies (natural gas units, in particular). This will make nuclear power less attractive to investors in a competitive environment, where recovery of capital is not guaranteed. Competition may also affect how long current reactors will operate. In the United States, three reactors were permanently closed in the first half of 1997, all before their licenses expired, and all, at least in part, due to an inability to compete with the other available generating technologies. On the other hand, in the United Kingdom deregulation is further along, and British Energy (BE), the new private company created to operate the newest nuclear units, is expected to show a profit for the financial year 1996-1997. Average capacity factors have increased, and operating costs have decreased. $\mathrm{BE}$ is showing an interest in investing in overseas projects to improve performance of nuclear plants in newly deregulated markets [1]. In general, U.S. utilities operating nuclear power

\section{Figure 68. World Nuclear and Total Electricity Consumption, 1995-2020}

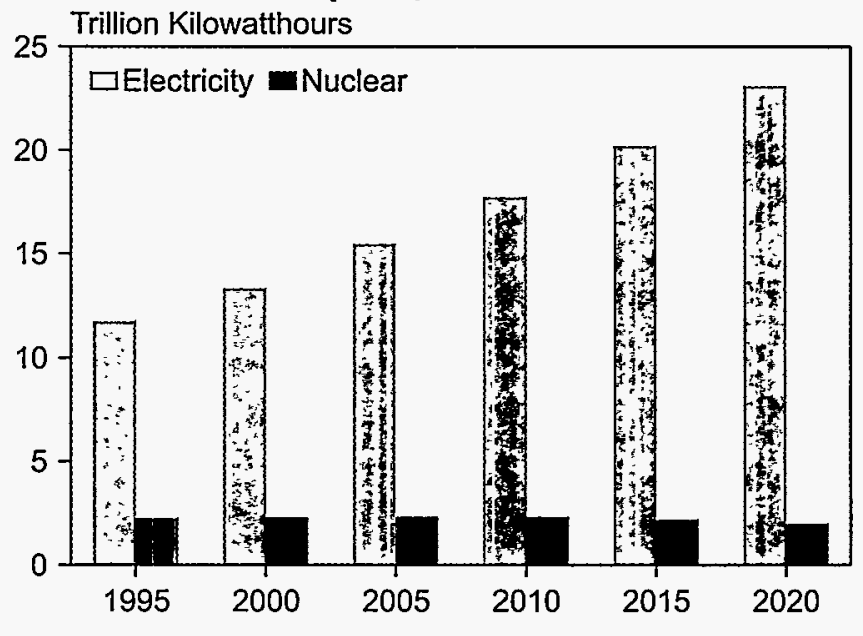

Sources: 1995 Energy Information Administration (EIA), International Energy Annual 1995, DOE/EIA-0219(95) (Washington, DC, December 1996). Projections: EIA, World Energy Projection System (1998). 
Table 22. Historical and Projected Operable Nuclear Capacities by Region, 1995-2020 (Net Gigawatts)

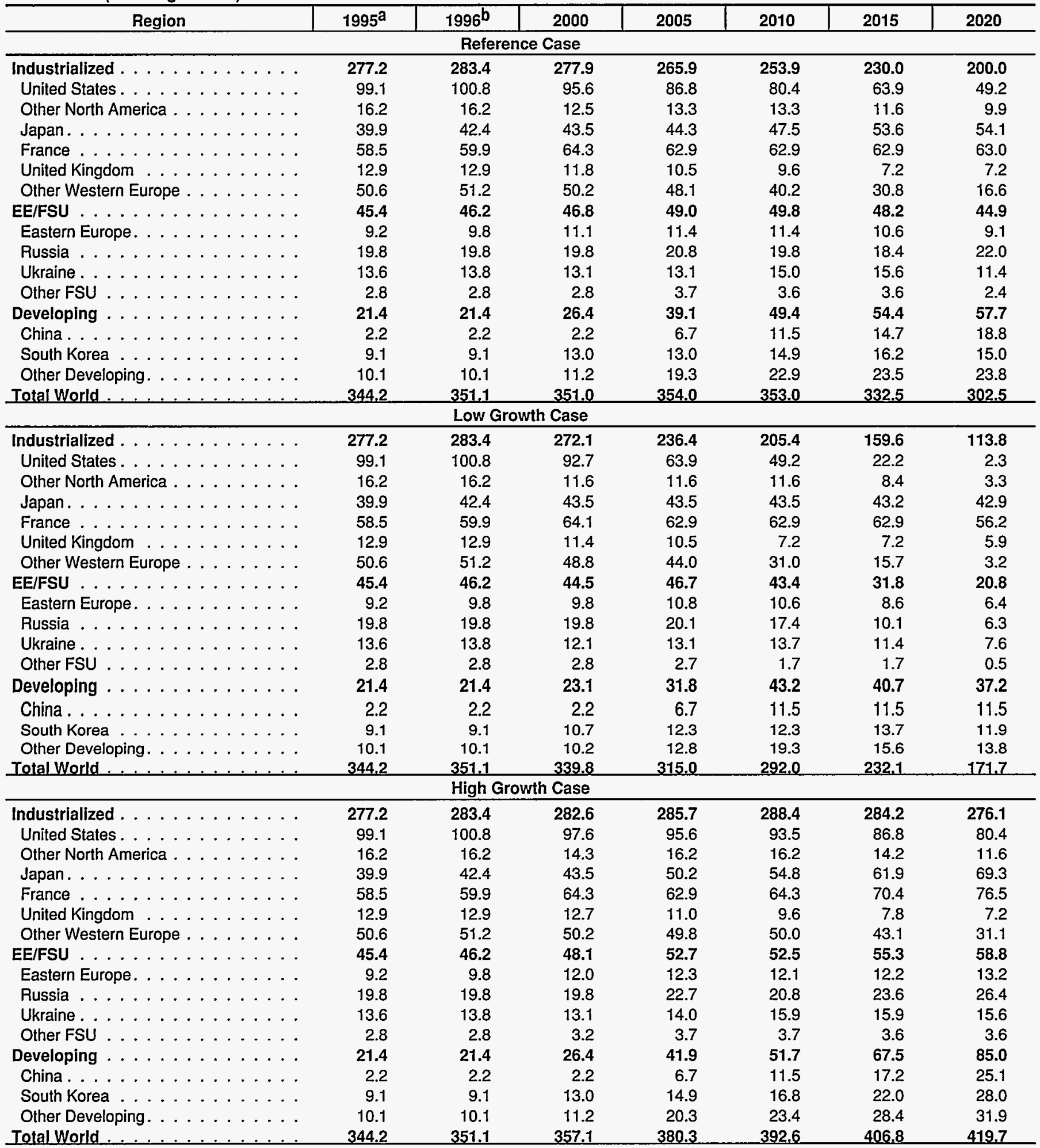

astatus as of December 31, 1995.

b Status as of December 31, 1996. Data are preliminary and may not match other EIA sources.

Notes: EE/FSU = Eastern Europe/Former Soviet Union. Totals may not equal sum of components due to independent rounding.

Sources: United States: Energy Information Administration, Annual Energy Outlook 1998, DOE/EIA-0383(98) (Washington, DC, December 1997). Foreign: Based on detailed assessments of country-specific nuclear power programs. For some countries, the World Integrated Nuclear Evaluation System (December 1997 run) was used to supplement the 2020 capacity projection. 
stations have already begun to reduce costs and improve performance. In 1996, more than twothirds of U.S. nuclear stations generated power at costs below 2 cents per kilowatthour [2].

- Public acceptance. The perceived risks of nuclear power continue to be an issue in technology choices for new generating capacity. Recently in Taiwan, funding to build a fourth reactor was approved by the government, but only after the objections of opposition parties were overcome [3]. In Sweden, the legislature voted to decommission two operating nuclear units, despite arguments from the operating utility and local members of parliament that the plant operates safely and economically [4].

- Nuclear waste issues. A central off-site facility is generally considered necessary for long-term storage of nuclear waste. But choosing a site for a facility can prove difficult. In the United States, it is unlikely that new nuclear construction will be considered before a solution to the nuclear waste problem is found. Taiwan has faced public opposition to all sites proposed. The European countries are performing research to determine the best site characteristics, but none has a permanent facility operating.

- Operating performance. Nuclear power plants generally have high fixed costs but low variable costs. As they increase output they become more economical. If significant time is lost in either planned or unplanned outages, their costs per unit of output will rise. In 1996, the average capacity factor of the world's nuclear power plants was 73 percent [5]. Nine countries operated nuclear programs with average capacity factors above 80 percent, including Finland, whose four units maintained an average 91.5 percent capacity factor for the year. In recent years, the worldwide average has been improving.

\section{Regional Overview}

\section{Developing Asia}

Countries in developing Asia with currently operating nuclear power plants include China, South Korea, Taiwan, India, and Pakistan. With the exception of South Korea, these programs are small, but all expect some growth in the future. At the end of 1996, these five countries had 18.0 gigawatts of nuclear capacity on line. By 2020, nuclear power plants are expected to be operable in North Korea as well (see box on page 92), and nuclear capacity for the region is projected to be between 31.9 and 75.7 gigawatts. South Korea, currently the largest operator of nuclear power in the region, with 11 operable units totaling 9.1 gigawatts, is projected to have between 11.9 and 28.0 gigawatts on line by 2020 . The dramatic drop in Asian stock markets toward the end of 1997, and the resulting economic crisis in South Korea in particular, could reduce the likelihood of investment in new nuclear construction. Indeed, in the IEO98 low growth and reference cases, only the units already planned are projected to be built. China's expected growth rate leads the region, reaching 9 times the current capacity by 2020 in the reference case.

At the end of 1996, 18 units were under construction in developing Asian countries, and as many as 16 more were in the planning stages. Seven of the units actively under construction at the end of 1996 were in South Korea, and one of those was connected to the grid during 1997. Wolsong 2, a 650-megawatt pressurized heavy-water reactor (PHWR), began commercial operation in July 1997. Two units remain to be completed at the Wolsong site [6]. The units under construction at other sites are all of the Korean standardized design, based on an advanced version of the $A B B$ Combustion Engineering Nuclear Systems (ABB-CENS) System 80 pressurized-water reactor (PWR). ABB-CENS will provide design engineering and components for the new units [7].

China also plans to build additional nuclear power plants to meet rapid growth in electricity demand. The next two units at the Qinshan site are 600-megawatt PWRs of a Chinese design, although foreign companies have been contracted to supply major components. Construction began on Qinshan 2 and 3 in 1996, and the units are expected to be complete in 2003. Two additional 700megawatt PHWRs supplied by Atomic Energy of Canada Limited will also be constructed at the site [8].

In Taiwan, GE Nuclear Energy was selected to provide two nuclear reactors for the Lungmen power station. Construction on the two 1,350-megawatt advanced boiling-water reactors (ABWRs) is not expected to begin until late 1998, with prospective dates for entering commercial service set at 2003 and 2004 [9]. Public opposition to new nuclear construction has been a problem in Taiwan, as has finding sites for low-level waste disposal. The Taiwan government has signed a deal to ship nuclear waste to North Korea for final disposal, which has raised concerns with several international groups. North Korea is not a member of the International Atomic Energy Agency, and there would be no way to monitor the handling of the waste [10].

\section{Other Developing Countries}

Other developing countries that currently operate nuclear power plants include Argentina, Brazil, and South Africa. Countries with the potential to have nuclear programs in place by 2020 include Cuba and Iran. Argentina's two nuclear units provided 11 percent of the country's electricity in 1996. Brazil's one nuclear 
unit supplied just 1 percent of total electricity generation. South Africa has two nuclear units currently operable, which provided 6 percent of the country's electricity generation in 1996. No new nuclear units are planned in South Africa.

Most of the other developing countries do not have the capital for large nuclear programs and, in fact, will likely require financial and technical assistance before undertaking nuclear power construction. Successful completion of Cuba's Juragua station, where construction was abandoned after reaching 75 percent completion in the mid-1980s, will require international assistance. Russia has agreed to complete two units for Iran, at the Bushehr site, where construction was started in the 1970s.

\section{Industrialized Asia}

In the industrialized countries of Asia, only Japan has a well-established nuclear program, with 53 units totaling 42.4 gigawatts of operable capacity at the end of 1996. Japan's nuclear share of electricity in 1996 was 33 percent. Two new nuclear units were brought on line during 1996: Kashiwazaki Kariwa 6 in January and Genkai 4 in November. A seventh unit was brought on line at the Kashiwazaki Kariwa site during 1997.

Japan has ambitious plans for further nuclear expansion, mainly as a means of reducing its dependence on imported fossil fuels. However, the uncertainties surrounding financial markets in Asia, as well as increases in public opposition to nuclear power in Japan, will affect new construction decisions. Japan's nuclear capacity is projected to increase by 11.7 gigawatts-to a total of 54.1 gigawatts-by 2020 in the reference case. The low and high case capacity forecasts for 2020 are 42.9 gigawatts and 69.3 gigawatts. The expansion plan includes 11 units, totaling 12.5 gigawatts, in the construction pipeline at the end of 1996. One unit was near completion at year's end; the other 10 units are in the planning stages. The reference case assumes that the 11 units will be completed by 2020 , but that no additional units will be built. The low growth case assumes that no new construction will be completed by 2020 .

\section{Western Europe}

Western Europe relies heavily on nuclear power for electricity. In 1996, nuclear generation from Western European countries represented 36 percent of worldwide nuclear generation. In France and Belgium, 77 and 57 percent, respectively, of the national demand for electricity was supplied from nuclear power plants. However, the overall trend in Western Europe is away from nuclear power builds. In fact, most countries in the region have frozen all nuclear construction plans. In the reference case, only France and Turkey are projected to have net increases in nuclear capacity between 1996 and 2020. Eight other West European countries are projected to have net decreases in total nuclear capacity due to plant retirements.

In France, Chooz-B1, a 1,450-megawatt PWR, supplied electricity to the grid for the first time on September 30, 1996. A second unit, Chooz-B2, was connected to the grid in April 1997. The two reactors are touted as the first wholly French designed PWRs, created by the French company Alsthom. The output from the two new reactors will be shared between France ( 75 percent) and Belgium (25 percent). France's remaining two units under construction are more than 50 percent complete and are expected on line by 1998. No further nuclear expansion has been announced. In the Netherlands, the 55 megawatt Dodewaard plant was shut down permanently in March 1997. The small boiling-water reactor had operated well for 28 years but could not compete economically with other generating units [15]. The Swedish government, which has long discussed plans to phase out nuclear power, has voted to retire the two units at Barsebaeck, the first in 1998 and the second in 2001 [16]. It is expected that the operating state utility, Sydkraft, will fight the decision.

Competition in the electricity markets of Western Europe may be one cause of declining nuclear capacity in the future. The European Union energy ministers have agreed to open up the electricity market to competition, although it will affect only a small fraction of consumers in the next few years. The trend to deregulate and privatize electric utilities requires nuclear plant operators to focus on the competitiveness of their current operating costs, as well as future costs to build new reactors. In Spain, for example, the government and utilities have agreed to lower electricity rates by 8 percent over the next 5 years to prepare for competition [17]. The latest French study analyzing costs to build new technologies shows that new nuclear capacity would be the cheapest technology under a variety of scenarios; however, nuclear loses to natural gas combined-cycle units in the lowest natural gas price scenario [18], which assumes natural gas prices below $\$ 2.70$ per million Btu and an exchange rate of around 5 French francs per U.S. dollar. (Because France imports all its natural gas, these scenarios must make assumptions about both gas prices and international exchange rates.) Nonfuel operating and maintenance costs at existing nuclear units in France have declined by 2 percent per year since 1992 [19].

\section{North America}

In North America, the United States, Canada, and Mexico all have nuclear programs. Although the United States has by far the largest amount of nuclear capacity in the region, reliance on nuclear power is similar in the United States and in Canada. In 1996, the nuclear share of electricity in the United States was 19 percent; in Canada it was 16 percent. Mexico's two units supplied 


\section{Nuclear Power in North Korea}

In August 1997; amid fireworks and confetti, North Korea broke ground on a two-unit nuclear power station located in Shinpo, on its eastern coast. The project is managed by a U.S.-led consortium known as the Korean Peninsula Energy Development Organization (KEDO), but South Korea is providing most of the labor and financing for the new reactors. The project is considered a breakthrough for the isolated North-for the first time in almost 50 years communication lines have been opened between North and South Korea. Telephone lines were installed from the project headquarters to South Korea, and mail service has also begun [11].

In the early 1990s, North Korea had a 50-megawatt experimental nuclear reactor operational in Yongbyon and another 200-megawatt unit under construction. The units were Soviet-designed heavy-water reactors, which produce spent fuel from which weapons-grade plutonium can be extracted. North Korea refused complete inspection by the International Atomic Energy Agency (IAEA) and threatened to withdraw from the Nuclear Nonproliferation Treaty in 1993. By 1994, North Korea was suggesting that it had nuclear weapons capability. Finally, in October 1994, Washington and Pyongyang signed the Agreed Framework, which stated that North Korea would shut down its nuclear program immediately in return for monetary and diplomatic incentives from the United States and its allies, including two new nuclear reactors of a different design. (They will be light-water reactors, from which it is much more difficult to extract weaponsgrade plutonium.)

In March 1995 KEDO was created, representing South Korea, Japan, and the United States, to carry out the commitments made in the Agreed Framework. It was determined that South Korea would provide the two advanced light-water reactors compatible with its own reactors. Financing for the new reactors would come mainly from South Korea and Japan. In the interim, the United States agreed to provide North Korea with

5 percent of the country's electricity during 1996. In the United States, one new unit (Watts Bar 1) came on line in 1996. There are no other U.S. projects actively under construction or planned, and no growth in nuclear capacity is expected in the region for the remainder of the forecast. By 2020, U.S. nuclear capacity in the IEO98 reference case is projected to be 51 percent lower than the 1996 level. In Canada, with no new orders projected in the reference case, nuclear capacity falls by 6.3 gigawatts from 1996 to 2020 as a result of retirements. Capacity projections for the region in 2020 range be-
9 thousand barrels per day of heavy fuel oil, to be used for energy production [12]. There are now 12 countries with membership in KEDO, including Canada, the European Union, Australia, and New Zealand. The United States has obtained pledges from the newest members to help pay for the fuel oil.

North Korea has allowed limited inspection of its existing unit by the United States and the IAEA. In accordance with the Agreed Framework, in April 1996, the United States began canning the spent fuel rods in the storage pools at the Yongbyon facility. Eventually, the waste will be removed from the country [13].

Even as the various components of the Agreed Framework are being carried out at the construction site of the new reactors and in the cleanup of the old, the United States and its allies have no assurance that North Korea did not already have the necessary materials for a nuclear weapon before the agreement was reached. The North Koreans still have not allowed the IAEA to carry out a detailed inspection of the site, which could indicate how much spent fuel was generated and how much was removed before the United States began canning what is currently at the reactor. North Korea has agreed to a full inspection, but not until the two new reactors are completed, which could take up to 10 years. In early 1997, one of North Korea's highest ranking officials defected to South Korea. He testified to the South Korea National Security Planning Agency that he believes North Korea has nuclear weapons [14].

An issue not addressed by the Agreed Framework or KEDO's mandate is how the power from the new reactors will reach the rest of the country. North Korea's existing transmission network is too out-ofdate to handle the output from the new reactors, and an upgrade to the system will be necessary. Likely lenders for the project, estimated to cost $\$ 200$ to $\$ 300$ million, are the Asian Development Bank and the World Bank [12]. tween 5.6 and 92.0 gigawatts in the low and high growth cases, based on different retirement assumptions.

In Canada, Ontario Hydro $(\mathrm{OH})$, the operating utility for the majority of the country's nuclear units, released an independent review of the management and operations of its nuclear power plants, showing poor performance and inefficient management throughout. $\mathrm{OH}$ later announced its intention to mothball seven of the oldest units - three at the Bruce A site and four at the Pickering A site. They will be taken out of service over the next 


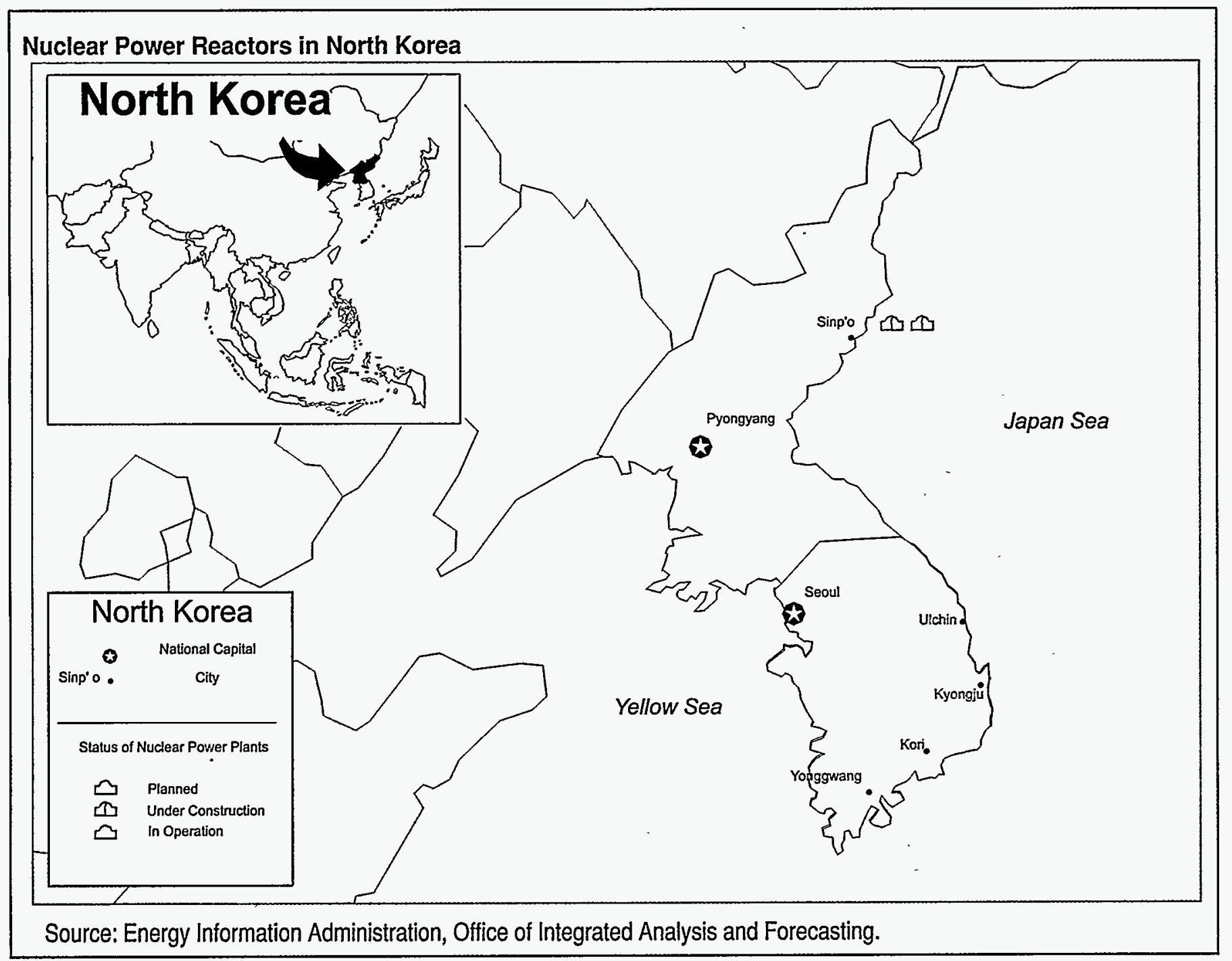

year. The seven units may be refurbished and brought back on line eventually, but the first priority for the utility is to improve performance at the units that will remain operable. Increased generation from coal-fired plants will replace the electricity generation lost from the mothballed nuclear units [20].

In the United States, several nuclear units have recently been retired before their operating licenses expired. In Connecticut, Haddam Neck was shut down during 1996 for refueling and maintenance, and in January 1997 it was announced that the plant would remain closed permanently. The decision was based on an economic analysis which showed that replacement power would be cheaper than continued operation [21]. On August 6, 1997, the board of directors of the Maine Yankee plant voted to close the plant permanently. It was agreed that they could not run the plant economically, and after attempts to sell the plant were unsuccessful, they decided to shut it down [22]. Big Rock Point, the oldest and longest running reactor in the United States, was retired in August 1997. Its small size (67 megawatts) made it too expensive to operate in a competitive environment [23].
Deregulation of the U.S. electricity industry will be a major factor in the future for nuclear power in North America. Until decisions are made about stranded cost recovery and the future recovery of decommissioning costs, there will be little incentive to invest in new nuclear capacity. And decisions about the future of currently operating nuclear plants will increasingly be based on the competitiveness of their operating costs. Data compiled by the Utility Data Institute (UDI) show that the average cost of electricity from nuclear generation in the United States was 1.89 cents per kilowatthour in 1996, and that it has declined by 4 percent per year since 1993 [24]. Capacity factors for nuclear power units in the United States have also been improving. The average annual capacity factor for 1996 was 76.4 percent, down slightly from 1995, but still much higher than just 5 years ago, when it hit 70 percent for the first time in history. Worldwide, 5 of the top 10 units for 1996 (based on capacity factor) were U.S. plants, as were 23 of the top 50 [25]. Continued improvements in cost and performance will be needed if nuclear units are to remain competitive in the deregulated environment. 


\section{Eastern Europe/Former Soviet Union}

In the EE/FSU region, 69 nuclear units produced 264.9 billion kilowatthours of electricity in 1996. More than 75 percent of that amount was generated in the FSU. Reliance on nuclear power varies in the region: Lithuania gets 83 percent of its electricity from nuclear power, Russia 11 percent, and Kazakhstan less than 1 percent. Several countries in the region have ambitious plans for additional nuclear capacity, but there are many challenges that will likely limit new nuclear builds. With the potential for future projects uncertain, the region's nuclear capacity is projected to decline by 1.3 gigawatts between 1996 and 2020 in the reference case. A loss of 25.5 gigawatts is projected in the low growth case and a gain of 12.5 gigawatts in the high growth case. Russia and the Ukraine have 13 units in the construction pipeline, of which 7 are at least 50 percent complete. The prospects for their completion depend on the ability to obtain financing.

During 1996 Romania brought on line a Canadian-built reactor at Cernavoda-the first Western-designed nuclear power plant in Eastern Europe. In the Ukraine, the Chernobyl 1 unit was shut down in November 1996; early in 1997 it was announced that this closing would be permanent. The Ukraine has signed a Memorandum of Understanding that all units at Chernobyl will be permanently shut down by 2000 , and it was determined that repairs necessary to keep unit 1 operating would not be cost-effective, given that it would soon be closed. There are still two units operable at the Chernobyl site, and the government has suggested it may need to continue operating them after 2000 to meet electricity demand. The Energy Minister has expressed frustration with the lack of funds promised to aid the Ukraine in completing two units under construction, and has suggested that the Chernobyl units can not be shut down until new units are operable and able to provide replacement power [26].

The lack of indigenous energy resources in many countries of the EE/FSU, combined with the problems in financing new nuclear projects, is resulting in continued operation of reactors that are considered unsafe by Western standards. Russia has significant fossil fuel resources, but significant amounts of its coal, natural gas, and oil supplies are being exported in exchange for hard currency. The Ministry of Atomic Energy (Minatom) of Russia had announced ambitious plans to begin bringing the next generation of nuclear reactors on line shortly after 2000 to replace older units that would be shut down. More recently, however, Minatom has announced that plans to build new reactors have been delayed due to lack of funds, and no new reactors are expected to be operable until at least 2010. As a result, the operation of existing units may be extended by 5 to 10 years [27]. The Ukraine is facing huge energy debts to foreign suppliers of natural gas and oil. Nuclear power satisfied 44 percent of total electricity in the Ukraine in 1996 , and the country is counting on completion of new units to help provide energy independence. Armenia's one unit provided 37 percent of the nation's electricity in 1996, and Lithuania's two units provided 83 percent of its total electricity. Both countries are operating older Soviet-designed reactors that, according to many experts, are unsafe and would never be licensed in the West [28].

\section{References}

1. "Privatized British Energy Produces Good Results," Nuclear News, Vol. 40, No. 8 (July 1997), p. 27.

2. "Virginia Power Stations Top Efficient Generators in 1996," Nucleonics Week, Vol. 38, No. 24 (June 12, 1997), p. 1.

3. "Late News," Nuclear News, Vol. 39, No. 12 (November 1996), p. 17.

4. A. Sains, "Barsebaeck Shutdown Won't Hike Electric Costs, Vattenfall Says," Nucleonics Week, Vol. 38, No. 40 (October 2, 1997), pp. 2-3.

5. "Tepco, Kansai, Virginia Power Top 1996 Capacity Factor List," Nucleonics Week, Vol. 38, No. 7 (February 13, 1997), p. 1.

6. "Wolsong-2 Reactor Starts Commercial Operation," Nuclear News, Vol. 40, No. 9 (August 1997), pp. 31-32.

7. "Late News," Nuclear News, Vol. 40, No. 1 (January 1997), p. 17.

8. "Chinese Candu Contract Signed for Qinshan Site," Nuclear News, Vol. 40, No. 1 (January 1997), p. 33.

9. "Taipower Issues Schedule for Lungmen Construction," Nuclear News, Vol. 40, No. 5 (April 1997), p. 46.

10. L. Tyson, "Nuclear Debate: Protests over Waste Disposal Plan," Financial Times (October 7, 1997), p. 5.

11. K. Sullivan and M. Jordan, "North Korea Opens a Window to World; Energy Project Allows Seoul and Others into Stalinist State," Washington Post Service.

12. The Economist Intelligence Unit, Ltd., "North Korea Update: The Hermit Stirs," EIU Business Asia (December 2, 1996).

13. K. Hart, "DOE Requests Additional \$4-Million for Canning North Korean Spent Fuel," Nuclear Fuel (May 6, 1996), p. 5. 
14. Shin Yong-bae, "Renewed Claim on North Korean Nuke Arms; NSP Chief Says Defector Believes North Has Weapons of Mass Destruction," The Korea Herald (May 10, 1997).

15. "Dodewaard Closed After 28 Years of Operation," Nuclear News, Vol. 40, No. 6 (May 1997), p. 52.

16. "Swedish Government Agrees To Shut 1,200-MW Barsebaeck Nuclear Plant," Electric Utility Week (February 17,1997$),$ p. 16.

17. A. MacLachlan, "Nuclear Utilities Cutting Costs as Spain, and EU, Move to Market," Nucleonics Week, Vol. 37, No. 46 (November 14, 1996), p. 5.

18. A. MacLachlan, "French Study Confirms Nuclear Costs Edge Slipping Against Gas," Nucleonics Week, Vol. 38, No. 18 (May 1, 1997), p. 1.

19. A. MacLachlan, "EdF Lowers O\&M Below a Cent/kWh, Says Nuclear Ready To Compete," Nucleonics Week, Vol.38, No. 12 (March 20, 1997), p. 1.

20. "Ontario Hydro Taking 4,700 MW Off Line as It Tries To Fix Its Nuclear Program," Electric Utility Week (August 18, 1997), p. 1.

21. "Haddam Neck: Connecticut Yankee Votes for Premature Shutdown," Nuclear News, Vol. 40, No. 1 (January 1997), p. 19.
22. "Maine Yankee: Board Votes for Closure; Decom To Start Right Away," Nuclear News, Vol. 40, No. 10 (September 1997), p. 14.

23. "Late News," Nuclear News, Vol. 40, No. 11 (October 1997), p. 18.

24. "Virginia Power Stations Top Efficient Generators in 1996," Nucleonics Week, Vol. 38, No. 24 (June 12, 1997), p. 1.

25. "Tepco, Kansai, Virginia Power Top 1996 Capacity Factor List," Nucleonics Week, Vol. 38, No. 7 (February 13, 1997), p. 1.

26. "Chernobyl-1 Formally Closed, To Be Decommissioned," Nuclear News, Vol. 40, No. 9 (August 1997), p. 31 .

27. M. Hibbs and A. MacLachlan, "Economic Crisis Forcing Russia To Extend Lives of 18 Reactors," Nucleonics Week, Vol. 38, No. 40 (October 2, 1997), p. 1.

28. A. Cooperman, "The Next Chernobyl?" U.S.Nerws and World Report, Vol. 120, No. 17 (April 29, 1996), pp. 46-49. 
. 


\title{
Hydroelectricity and Other Renewable Resources
}

\author{
While renewable energy sources are not expected to gain market share, \\ they are expected to retain an 8-percent share \\ of world energy use through 2020.
}

World events and low fossil fuel prices in 1997 have had mixed effects on the markets for hydroelectricity and other renewable energy sources. World oil prices have fallen from $\$ 24$ per barrel in 1996 to the 1997 price of $\$ 17$ per barrel, and they are expected to remain below \$23 per barrel through 2020 (prices in 1996 U.S. dollars). Low fossil fuel prices will continue to make it difficult for renewable energy sources to compete for market share. On the other hand, the climate change protocol developed in Kyoto, Japan, in 1997 increases interest in the potential role of renewables, inasmuch as many developed countries have committed to reducing carbon emissions substantially over the next decade or so. The IEO98 projections, however, do not take into account any policy initiatives that may result from the draft agreement.

The IEO98 reference case projects that, by 2020 , total consumption of renewable energy will reach 50 quadrillion Btu-an increase of 67 percent over 1995 levels (Figure 69). Renewables are not expected to gain market share in terms of world energy consumption. Renewable energy use grows just enough to maintain an 8-percent share of total world energy consumption throughout the

Figure 69. World Consumption of Hydroelectricity and Other Renewable Energy in Three Cases, 1970-2020

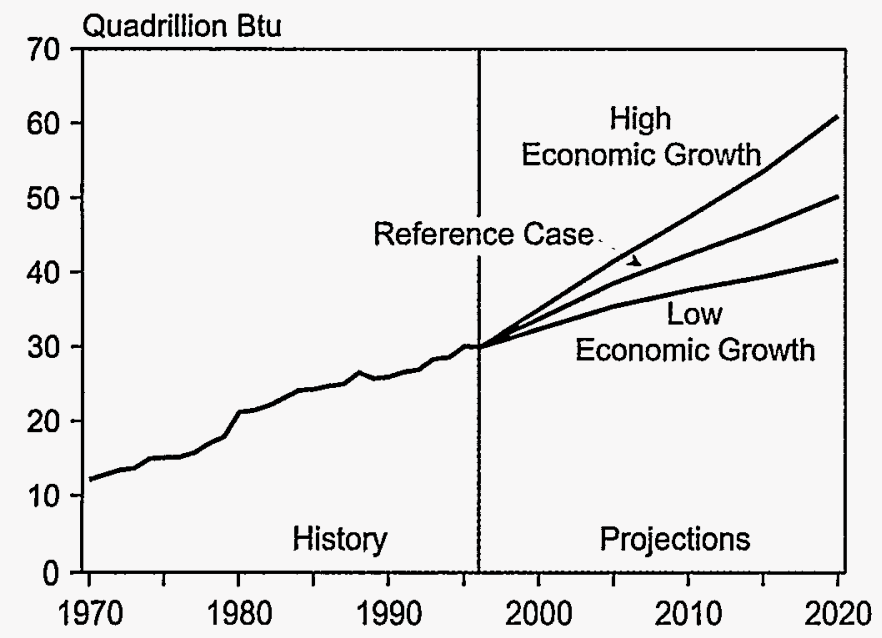

Sources: History: Energy Information Administration (EIA), Office of Energy Markets and End Use, International Statistics Database and International Energy Annual 1996, DOE/EIA0219(96) (Washington, DC, February 1998). Projections: EIA, World Energy Projection System (1998). projection period (Figure 70). Use in developed countries is projected to rise more slowly than in developing countries, where major hydroelectric development projects are underway (Figure 71).

Figure 70. Renewable Energy Share of World Energy Consumption, 1970-2020

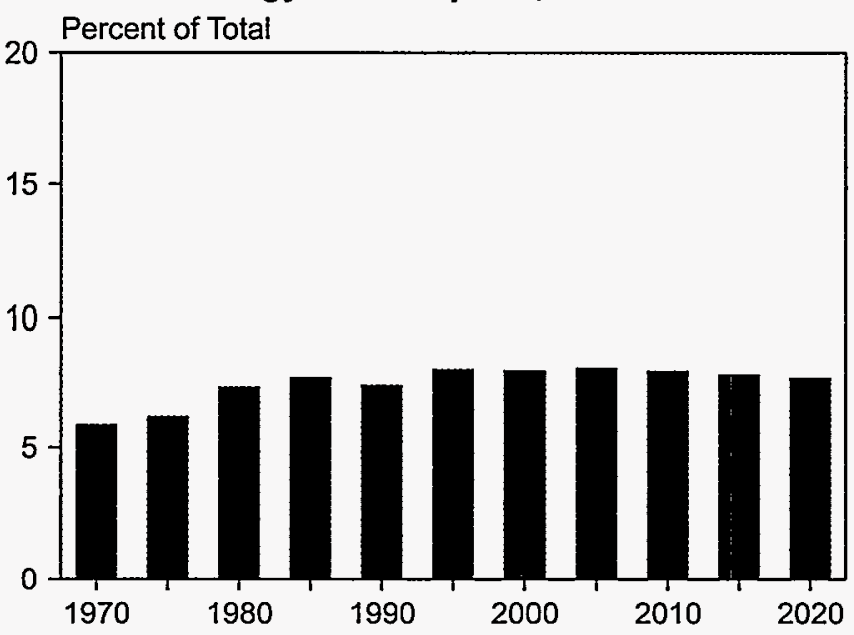

Sources: History: Energy Information Administration (EIA), Office of Energy Markets and End Use, International Statistics Database and International Energy Annual 1996, DOE/EIA0219(96) (Washington, DC, February 1998). Projections: EIA, World Energy Projection System (1998).

Noncommercial fuels from plant and animal sources remain an important source of energy, especially in the developing world; however, comprehensive data on the use of noncommerical fuels are not available and, as a result, are not included in the IEO98 projections. Similarly, because there are few extensive sources of international data on their use, dispersed renewables (renewable energy consumed on the site of its production, such as solar panels used for water heating) also are not considered in the projections.

Some key developments affecting world renewable energy in 1997 include:

- Most renewable energy development involves expanding or refurbishing sites for hydroelectric power generation-predominantly outside North America and Western Europe, where resources have for the most part been fully exploited. 
Figure 71. Renewable Energy Consumption by Region, 1970, 1995, and 2020

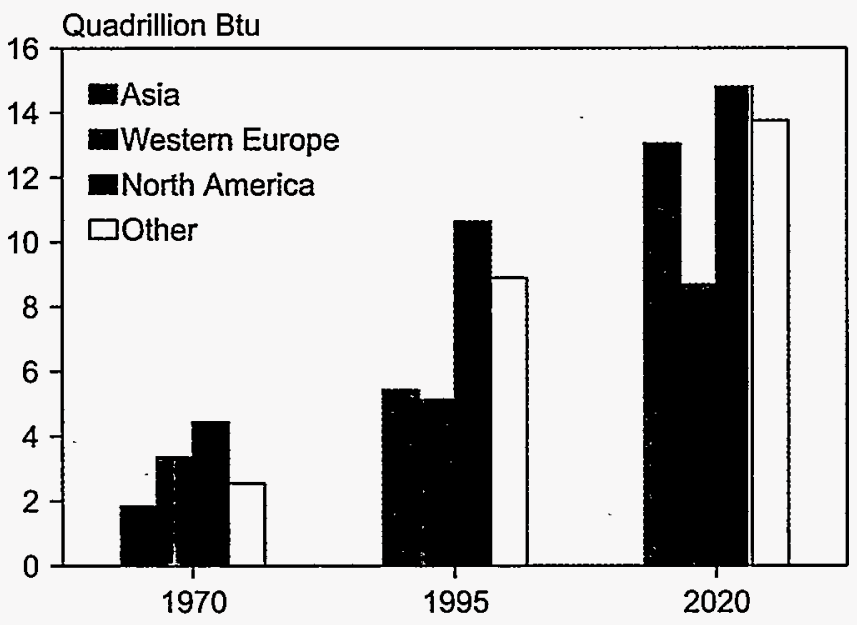

Sources: 1970 and 1995: Energy Information Administration (EIA), Office of Energy Markets and End Use, International Statistics Database and International Energy Annual 1996, DOE/EIA-0219(96) (Washington, DC, February 1998). 2020: EIA, World Energy Projection System (1998).

- Nonhydroelectric renewable energy development varies across regions, with wind generation receiving the greatest development support. The American Wind Energy Association reported in its 1997 survey that, for the second year in a row, more than 1,200 megawatts of new wind generating capacity was installed worldwide, most of it in Germany and India [1]. In 1996, installed wind energy grew by 25 percent over the 1995 level. Worldwide wind capacity was estimated at 6,259 megawatts at the end of 1996.

- The Asian financial crisis in the autumn of 1997 created difficulties for many renewable energy projects, as well as other energy projects that had been planned in the region. In Indonesia, 8 out of 13 power projects whose construction was postponed in September 1997 because of the financial crisis were geothermal power plants. And the future of the Laotian 681-megawatt Nam Thuen 2 hydroelectric dam, the output from which was slated to be exported to Thailand, remains uncertain, especially since a power purchase agreement between the state-owned Electricity Generating Authority of Thailand (EGAT) and the Nam Thuen 2 Electricity Consortium expired when the consortium could not meet its commitment to complete the project by 2000 . Malaysia's 1.8 gigawatt Bakun hydroelectric project was indefinitely postponed in 1997.

- Perhaps some of the most promising trends for the future of renewables involve new initiatives by large fossil-fuel-based companies. Enron Corporation formed Enron Renewable Energy
Corporation in January 1997 with its acquisition of Zond Corporation, an American wind energy power plant developer [2]. Further, in October 1997, Enron announced the acquisition of Tacke Windtechnik GmbH, a German wind turbine manufacturer [3]. In May 1997, British Petroleum announced plans to increase solar power sales to $\$ 1.1$ billion per year within the next decade, and in October Royal Dutch Shell announced that it would invest more than $\$ 500$ million in renewables over the next 5 years [4].

\section{Regional Activity}

\section{North America}

Over the next 25 years, renewable energy use is projected to increase by 1.3 percent annually in North America. At this rate, renewable energy consumption would increase from 10.6 quadrillion Btu in 1995 to 14.8 quadrillion Btu in 2020 and would account for about 10 percent of total projected energy use in the region (Figure 72).

\section{Figure 72. Renewable Energy Consumption in} North America, 1975-2020

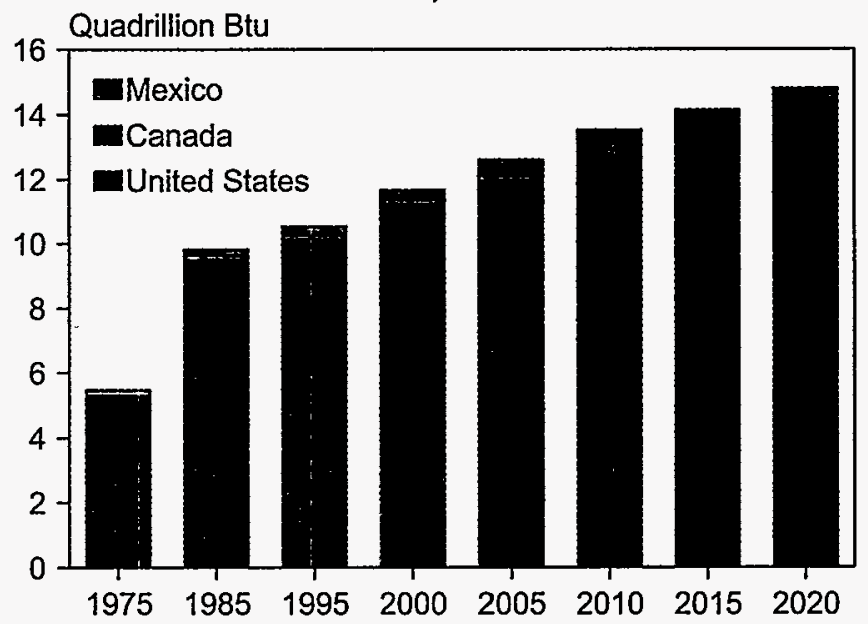

Sources: History: Energy Information Administration (EIA), Office of Energy Markets and End Use, International Statistics Database and International Energy Annual 1996, DOE/EIA0219(96) (Washington, DC, February 1998). Projections: EIA, World Energy Projection System (1998).

In the United States, most growth in renewable energy use for power generation involves municipal solid waste (MSW), wind, and biomass [5, p. 57]. The increase in MSW is attributed mostly to the recovery and use of landfill gas (methane); the increase in biomass is split between industrial cogeneration and gasification combined-cycle units owned by electricity generating firms.U.S. wind capacity is expected to double over the forecast period, with improvements in wind technology that include larger, more efficient turbines and improved turbine siting [5, p. 58]. At the end of 1996, 
Figure 73. Grid-Connected Wind Power Plants in the United States as of December 31, 1996

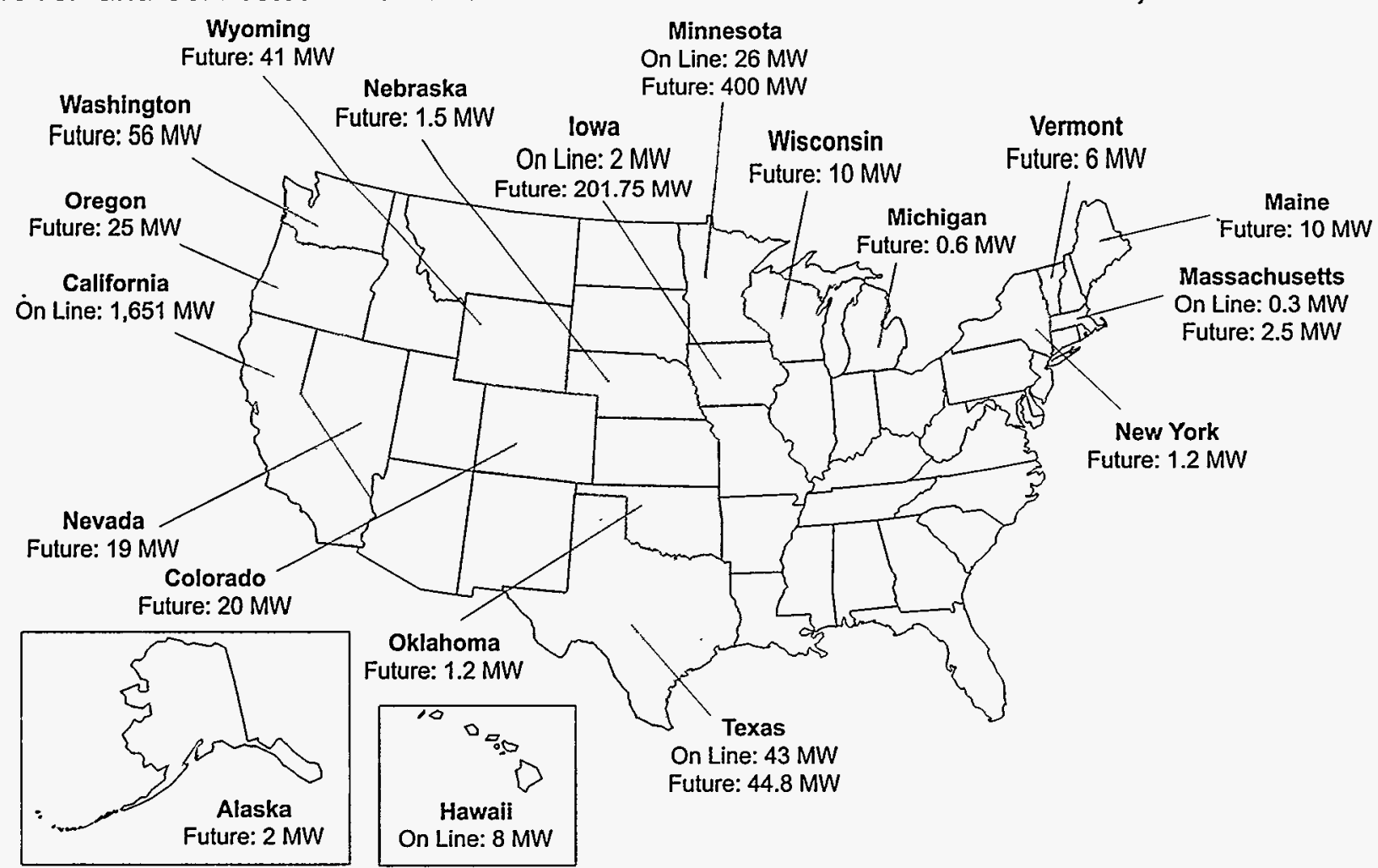

Source: International Energy Agency and National Renewable Energy Laboratory, IEA Wind Annual Report 1996 (Golden, CO, October 1997), p. 143.

approximately 1.8 gigawatts of.wind capacity was operating in the United States. There are 17 States with plans to add new capacity between 1997 and 2005 (Figure 73).

The U.S. Utility Wind Turbine Verification Program has been managed jointly by the U.S. Department of Energy and the Electric Power Research Institute [6]. The program-in place since 1992-was designed to increase the commercial viability of wind-powered electricity by evaluating advanced wind turbines operating at wind plants developed by U.S. electric utility companies. Under this program, two 6-megawatt projects have been built. The first was commissioned in 1995 and is owned by Central and South West Services Corporation in Fort Davis, Texas. The project uses 12 550-kilowatt wind turbines. The second project, with 11 550-kilowatt turbines, began operation in August 1997 and is owned by Green Mountain Power Corporation in Searsburg, Vermont. Seven other projects are currently planned or under construction:

- Iowa. In 1998, three 750-kilowatt turbines are to be installed in Algona. The project is expected to produce 5.4 million kilowatthours per year, providing enough electricity to supply an estimated 540 homes.

- Nebraska. Two 750-kilowatt turbines are scheduled to begin operating in north-central Nebraska by the end of 1998. The project is projected to produce 4.2 million kilowatthours annually, enough electricity for about 420 homes each year.

- Texas. Texas Wind Power Company will develop, construct, and operate six 750-kilowatt wind turbines in the Texas panhandle near Brownfield. The facility is expected to produce about 9 million kilowatthours of electricity each year (enough for about 900 homes) for Brownfield.

- Oklahoma and Texas. Central and South West Services Corporation (CSW) plans to install four 300-kilowatt wind turbines by the end of 1998 . CSW is currently evaluating potential sites in these two States.

- New York. Niagara Mohawk Power Corporation plans to install three 300-kilowatt turbines in northern New York by 1999.

- Wisconsin. EPRI and four utilities in eastern Wisconsin (Wisconsin Public Service Corporation, Madison Gas \& Electric Company, Wisconsin Electric Power Company, and Wisconsin Power \& Light Company) plan to install two 600-kilowatt turbines near Green Bay by the end of 1997. The two turbines should supply 3.6 million kilowatthours of electricity each year, enough for about 360 homes. 
- Alaska. Three 50-kilowatt wind turbines were installed in Kotzebue, Alaska, to supplement the Kotzebue Electric Association's existing dieselpowered station. The power station, located about 50 miles north of the Arctic Circle in the village of Kotzebue, serves the 2,100 residents of the village.

In Canada, hydroelectricity remains by far the largest source of renewable energy. Although plans for largescale hydroelectric projects have been scrapped for the most part, Hydro Quebec plans to complete construction of its 882-megawatt Sainte Marguerite 3 project, northwest of Sept-Iles on the Sainte Marguerite River [7]. The project will begin to operate in May 2001. Hydro Quebec began work on the project infrastructure in 1994 and finished building the primary road to the main dam site in November 1995. When complete, the two generating stations are expected to produce a total of 3.2 terawatthours of electricity annually. The 3.2-gigawatt Grand Baleine Complex in Quebec province is expected to be built in stages, with the first stage completed by 2019 [8, p. 57].

In aggregate, Canada projects nearly a one-third increase in hydroelectric capacity by 2020, with most of the increase after 2010. In the near term, electricity growth is expected to be relatively slow, with only modest additions to generating capacity planned [8, pp. 55-59]. The Canadian government has announced a range of initiatives to expand renewable energy use, and increased use of biomass and waste fuels is anticipated; however, only a small part of the country's total energy needs will be met from these sources.

All other future hydroelectric projects in Canada will be smaller than 500 megawatts of installed capacity [8, p. 52]. Other Quebec hydroelectric stations to be built when demand exceeds generating capability after 2010 include a combined 2.0 gigawatts of capacity at the following stations: Eastmain 1, Mercier, Kipawa, Haut Saint Maurice, and Ashuapmushan [8, p. 58]. In Manitoba, the Wukswatim and Notigi stations will provide an additional 405 megawatts of hydroelectric capacity after 2010. Four hydroelectric plants (Waneta, Billant, Keenleyside, and Murphy Creek) will be constructed after 2015 in British Columbia, with a combined 1.0 gigawatt of capacity. About 237 megawatts of capacity from small hydropower facilities is expected to be added between 1995 and 2020 [8, p. 61].

\section{Western Europe}

Consumption of hydroelectricity and other renewable energy sources in Western Europe climbs by almost 70 percent in the forecast, from 5.1 quadrillion Btu in 1995 to 8.7 quadrillion Btu in 2020 (Figure 74). Most of Europe's hydroelectric resources have already been developed, and the projected growth consists mostly of alternative energy sources, such as wind.
Figure 74. Renewable Energy Consumption in
Western Europe, 1980-2020

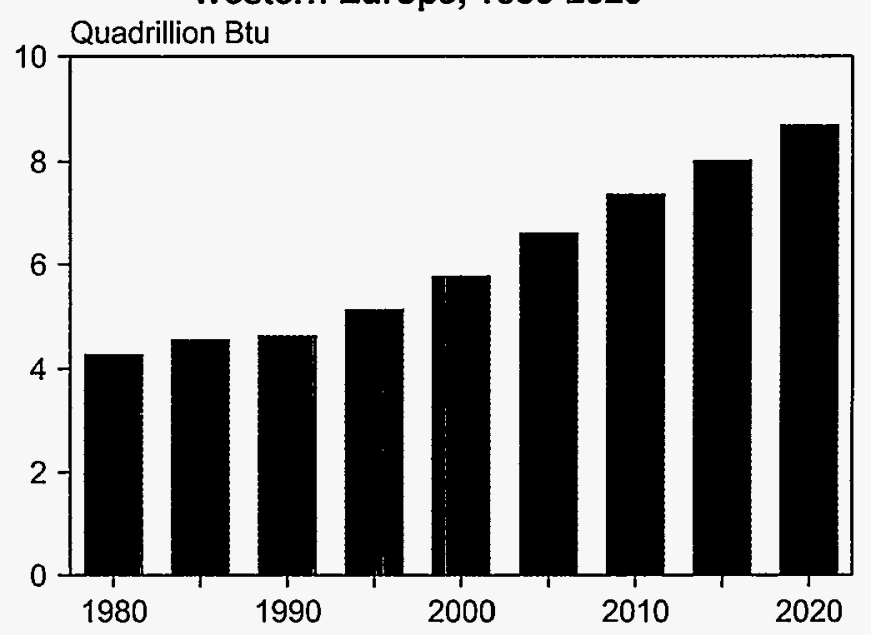

Sources: History: Energy information Administration (EIA), Office of Energy Markets and End Use, International Statistics Database and International Energy Annual 1996, DOE/EIA0219(96) (Washington, DC, February 1998). Projections: EIA, World Energy Projection System (1998).

The European Wind Energy Association projects wind power capacity to more than double in Europe by 2001, with particularly large increases forecast for Germany and Spain (1,500 megawatts and 1,200 megawatts, respectively) [9]. Germany remains the fastest-growing market for wind generation in Western Europe, adding 438 megawatts of wind capacity in 1996.

Under Germany's present Electricity Feed Law (EFL), utilities must accept renewables from independent power producers (IPP). The utilities are obligated to pay the IPPs a minimum price of 90 percent of their average electricity rate for wind and photovoltaic energy (today about 10 cents per kilowatthour) and 70 percent for energy from water, biomass, or biogas [10, 11]. The Christian Democrats-CSU party proposed to reduce the minimum required level for wind power fed into utility grids in an effort to ease the burden placed on utilities to use renewables [10]. However, strong public support for the EFL has kept the government from making any changes thus far, and the German ruling coalition parties have tabled decisions on the EFL until 1998 [12].

Individual German municipalities are also developing alternative energy sources. In Berlin, the Energie 2000 program was developed in an effort to increase solar electricity use. City officials and the area's power firm, Bewag AG, are investing \$22.5 million between 1997 and 2000 to support solar energy projects, and 44 potential solar installation sites have already been identified [13, p. 390].

In terms of wind development, Denmark, Spain, and the United Kingdom followed Germany and added, respectively, 190 megawatts, 90 megawatts, and 71 megawatts 
of capacity in 1996. Denmark still hopes to achieve its target of 1,500 megawatts of installed wind capacity by 2005 as set forth in the country's Energy 2000 program [14, p. 27]; however, the Danish transmission companies Elsam and Elkraft have not been able to meet their commitment to increase wind capacity. Public resistance to planned facilities has made it difficult to install the capacity; as a result, offshore wind plants are now being planned [13, p. 399]. The first offshore plant should be installed by 2000 .

The United Kingdom's Non-Fossil Fuel Obligation (NFFO) has helped to boost renewable installations-particularly wind-in that country. The NFFO, enacted as part of the Electricity Act of 1989, was seen primarily as a way to subsidize the nuclear power industry after the 1989 privatization of Britain's electricity supply industry [15]. The country's nuclear power plants were unable to attract private investors and, as a result, remained government-owned and needed public financial support to operate. Although most of the NFFO taxes were used to support the nuclear industry, a small portion of the proceeds was used to support renewables.

Four NFFO orders have already been made in England, as well as two in Scotland and two in Northern Ireland $[16$, p. 134]. Wind power has dominated each of the NFFOs-for example, in the fourth NFFO, projects comprising 341 megawatts of wind capacity were awarded. In November 1997, the British government announced plans for a fifth NFFO order for 1998. Bids for NFFO 5 are to be solicited from projects based on municipal and industrial waste incineration, landfill gas, small-scale hydropower, and onshore wind energy [17]. In 1998, there will be no further subsidies for the nuclear power industry, and all NFFO proceeds will be used to support renewable energy projects [18].

Several other European countries have plans to expand their use of renewable energy. In Greece, an estimated 100 megawatts of wind generation capacity could be developed in the Greek Islands by 2000 [19, p. 46-47]. Several wind facilities are already operating on islands in the Aegean Sea. The state-owned Public Power Commission installed four wind farms on the islands of Samos, Chios, Psara, and Andros. These facilities are part of a government effort to add 150 megawatts of wind capacity over the next several years. Since 1991, 13 wind farms have been constructed, with a combined capacity of 22 megawatts.

In June 1997, the Greek government announced the start of construction on the world's largest solar photovoltaic power station, on the island of Crete [20]. The government will fund the first 5-megawatt portion of a proposed 50-megawatt photovoltaic power station on Crete with the U.S. company, Enron Solar. The European
Union (EU) and the Greek government will fund 55 percent of the capital costs, with a total investment of $\$ 17.75$ million. Enron Solar plans to add 9 megawatts to the plant each year, reaching an installed capacity of 50 megawatts by 2003. Currently, the world's largest photovoltaic power station is in Italy, with a capacity of 3.3 megawatts. When completed, the Crete solar power station will be 15 times larger than any other solar photovoltaic installation in the world and should provide electricity for almost 100,000 people. Enron has estimated that, for the first 5 megawatts of the 50-megawatt proposal, the cost of generating electricity should be below 8.5 cents per kilowatthour.

Italian Vento Power Corporation (IVPC) installed 38 megawatts of wind capacity in Italy in 1996, with a total of 170 megawatts planned [21]. The potential for large increases in wind capacity in Italy are a result of 1992 legislation that promises a premium price for electricity from renewable energy and cogeneration. By mid-1995, Italy's Ministry of Industry had approved projects amounting to a total of 723 megawatts of installed capacity, and several hundred megawatts of capacity were added to plans in 1996. The premium is quite large, at 10.7 cents per kilowatthour for the electricity generated by plants installed in 1997, and it extends for the first 8 years of operation. After that, the price falls to 5.4 cents per kilowatthour. At present, wind projects generate electricity at costs ranging from 4.5 to 6.5 cents per kilowatthour, making the premium very attractive to investors.

Although the development of renewable energy in Ireland has been very small, the country has begun promoting the use of renewables for electricity generation through its Alternative Energy Requirement (AER) scheme [19, pp. 76-77]. In 1994, the first AER required the country's Electricity Supply Board (ESB) to offer contracts to purchase power from combined heat and power (CHP) projects, wind, hydroelectric, and waste and biomass sources for a combined 75 megawatts between 1995 and 1997. Thirty-four projects (mostly wind) were awarded (a total of 111 megawatts of capacity), but because of difficulties in obtaining planning permission for the projects, only 6 have obtained permission to proceed ( 41.2 megawatts), 2 are still in the process of obtaining permission (9.8 megawatts), and the remaining 26 ( 22.5 megawatts) have failed to obtain permission to proceed. A second AER was offered in December 1995, and a third in 1997. The government has announced that more AERs will be issued after 2000, planned for 30 megawatts each year through 2010.

Although Finland's potential for developing renewable energy is only marginal because of its geographical location and climate, the government plans to install 100 megawatts of wind capacity by 2005 . State grants and 
subsidies are being awarded to achieve this goal [14, p. 60]. The country also has plans to add two small hydroelectric plants-Pamilo (26 megawatts) and Vuotos (37 megawatts) -as well as a waste facilityVTS/Oulu (50 megawatts)—between 1997 and 2001.

In France, an estimated 85 percent of potential hydroelectric capacity has already been developed [14, p. 120]. In 1989, the government halted all hydroelectric development until 2000. Most of the other renewable energy development in France has been at the 240-megawatt La Rance tidal barrage. In 1996, however, Electricite de France and the Industry Ministry launched the EOLE 2005 wind development program. Under EOLE, the government hopes to install between 250 and 500 megawatts of wind capacity by 2005 . The first call for bids under EOLE was made in July 1996. At the end of February 1997, a 2.7-megawatt wind farm began operating in Dunkirk, near France's first 300 kilowatt wind turbine, which was commissioned in 1991. At the end of 1997, a third wind facility of 7.5 megawatts was scheduled to begin operating at Salleles-Limousis.

\section{Industrialized Asia}

Over the next 25 years, the countries of industrialized Asia are expected to increase their use of hydroelectricity and other renewable energy sources by 0.7 quadrillion Btu from the current level of 1.4 quadrillion Btu (Figure 75). In Japan, several programs are in place to promote renewable development: the government's New Sunshine Project, a $\$ 68.5$ million investment from the City of Tokyo, and a $\$ 102.8$ million investment to install 9,400 private solar roof arrays are expected to help the country install 400 megawatts of photovoltaic capacity by 2000 and 4,600 megawatts by 2010 [22].

\section{Figure 75. Renewable Energy Consumption in Asia, 1970-2020}

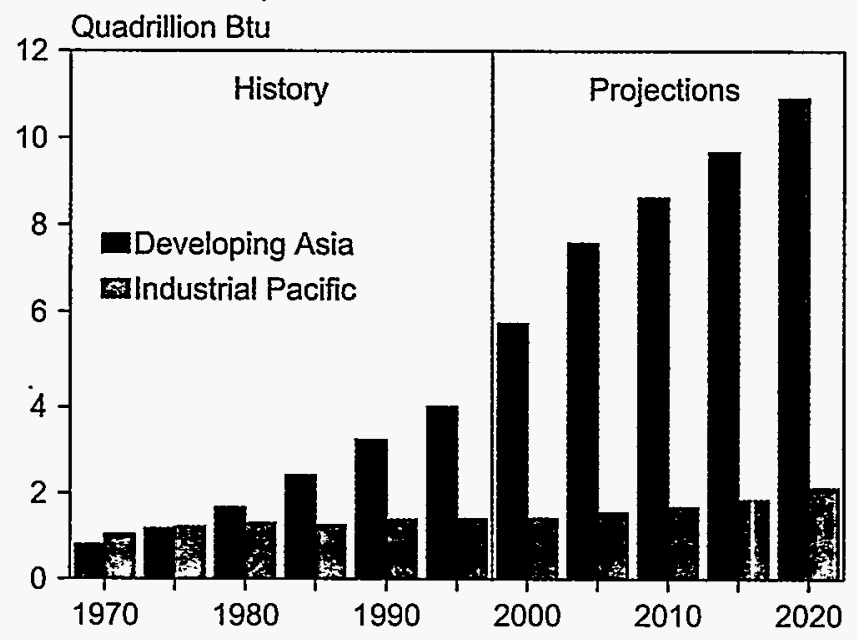

Sources: History: Energy Information Administration (EIA), Office of Energy Markets and End Use, International Statistics Database and International Energy Annual 1996, DOE/EIA0219(96) (Washington, DC, February 1998). Projections: EIA, World Energy Projection System (1998).
New Zealand generates the bulk of its electricity from hydroelectricity and other renewable resources. In 1995, almost 27 billion kilowatthours of the total 34 billion kilowatthours of electricity generated came from hydroelectricity. Another 2 billion kilowatthours was generated from geothermal and other renewable resources. There has been little development of New Zealand's wind resources. A demonstration project at Brooklyn and the Wairarapa Electricity's 3.5-megawatt wind farm at Hau Nui are, thus far, the only projects operating. The Electricity Corporation of New Zealand proposal for a wind farm at Baring Head was rejected, and the company is encountering strong public opposition to its proposed development at Makara (near Wellington) [23]. Economics have kept construction from beginning on Tararua Wind Power's proposed 137-turbine, 30-megawatt wind facility in Manawatu. Construction is now planned to begin in 1998.

In Australia the bulk of electricity continues to be generated from coal. In 1995 only 16 billion kilowatthours of the 163 billion kilowatthours of electricity generated came from hydroelectricity and other renewable sources (overwhelmingly hydro). Most of the development of wind and solar photovoltaic energy is planned for nongrid systems located in remote sites [24]. BP Solar Australia, the country's largest photovoltaic manufacturer, has been selected to supply 500 solar photovoltaic energy systems (producing 1 million kilowatthours per year) for the Sydney Athletes Village at Homebush [25]. The photovoltaic facility should be completed by December 1999, with some generation expected to begin as early as April 1998 [26].

\section{Developing Asia}

Despite the cancellation of Malaysia's large-scale Bakun hydroelectric project and the recent economic downturn in the region, robust growth in renewables is still expected for the countries of developing Asia over the projection period. In the reference case, consumption of hydroelectricity and other renewable sources grows from 4.0 quadrillion Btu in 1995 to 10.9 quadrillion Btu in 2020 (Figure 75).

In September 1997, the Malaysian government announced an indefinite delay of the 2.4-gigawatt Bakun hydroelectric project [27]. The $\$ 6.2$ billion project, first proposed in 1962, has been plagued by problems throughout its 35-year history [28]. A 1996 ruling by the Kuala Lampur High Court stated that the Bakun project's environmental impact assessment was invalid, further delaying construction of the dam [29]. Protests by international environmental groups, and complaints that compensation given to residents dislocated by the project were well short of the promised amounts, added to the controversy surrounding the project. The devaluation of the Malaysian ringitt in 1997 raised cost estimates for the project by 20 percent and caused the project to be shelved indefinitely. 
India has also had problems with public protests over several proposed hydroelectric projects. In October 1997, some 10,000 people gathered to protest construction of the proposed Maheshwar Dam on the Narmada River [30]. The cost of the 400-megawatt Maheshwar hydroelectric project has been projected at around $\$ 436$ million. It is part of the Narmada Valley Development Project, which is a plan to build 30 large, 135 medium, and 3,000 small dams on the Narmada River and its tributaries. In September, the state government of Sikkim agreed to scale back its 30-megawatt hydroelectric project at Rathongchu to an 18-megawatt project [31].

In Laos, environmental and economic problems associated with the $\$ 1.2$ billion Nam Thuen 2 (NT2) hydroelectric project have resulted in the World Bank's withholding (at least temporarily) of a partial loan guarantee of $\$ 100$ million to the Laos government [32]. The 680-megawatt dam probably will not be able to proceed without the World Bank guarantee. Additional problems relate to securing guaranteed purchase agreements for the project's output. A 1995 agreement with the Electricity Generating Authority of Thailand (EGAT) expired when the NT2 Electricity Consortium admitted it could not complete NT2 by 2000 as originally promised.

A number of hydroelectric projects under construction in developing Asia are expected to fuel the fast-paced growth of renewables in the region. For example, Japan's Kajima Corporation is constructing a 280megawatt hydroelectric project in Paunglaung, Myanmar [33], and in the Philippines construction has been started on the $\$ 168$ million 70-megawatt Bakun $A C$ scheme, which will be one of the first private hydroelectric projects in that country [34].

China is aggressively developing its hydroelectric resources. In addition to the controversial 18.2-gigawatt Three Gorges dam project on the Yangtze River (see box on page 105), the country has announced plans to construct 13 hydroelectric stations along the upper reaches of the Yellow River [35]. The Lijiaxia Hydropower Plant in Qinghai Province went into operation in August 1997, with 2 gigawatts of installed capacity and the ability to generate 5.9 billion kilowatthours of electricity per year. Construction on the Gaobazhou Hydropower Station on the Qingjiang River (through central Hubei Province) began in 1997. The facility will have three generating units of 84 megawatts each. It is the second of three generating stations planned for the Qingjiang River. The first station, Geheyan, which was completed in 1994, has a capacity of 1.2 gigawatts. The site for the final station, Shuibuya, is presently undergoing feasibility studies.

Hydroelectric projects are also underway on southwest China's Hongshui River [36]. The 1.2-gigawatt
Tianshengquiao hydroelectric facility is the first of 10 hydropower projects planned for the Hongshui. Tianshengquiao should begin generating electricity by the end of 1998.

China's Yunnan Province has established a memorandum of understanding with Thailand for electricity supplies from the proposed Jinhong and Mensong hydroelectric projects [37]. Construction of Jinhong is expected to begin in 1998. Thailand would like to purchase 1.2 gigawatts of capacity from the Jinhong site, beginning in 2004 or 2005, when the facility can begin generating electricity, and 80 percent of the project's 1.5 gigawatts of installed capacity would be exported to Thailand.

Several projects have been tabled or postponed in Indonesia. As part of government spending cuts-in reaction to the devaluation of the Indonesian rupiah against the U.S. dollar-Indonesia postponed 14 power generation projects worth $\$ 5.9$ billion, placed 9 others worth $\$ 4.9$ billion under review, and allowed only 6 projects to go ahead as scheduled [38]. Eight geothermal power projects were included on the postponed list (Table 23). The U.S. company, Unocal, had been given the construction contract for the $\$ 550$ million Sarulla geothermal project in Sumatra, which was supposed to be developed between 1998 and 2000 [39]. The geothermal plants Pathua unit 1 in West Java, Dieng units 1, 2 , and 3 in Central Java, and Bedugul in Bali are rumored to be under review [38].

There is some good news for Indonesian renewable development. The World Bank and the United Nations Global Environmental Facilities (GEF) have already provided Indonesia with $\$ 40$ million for development of rural solar power plant projects [40]. Construction of solar power plants in West Java, South Sulawesi, and Lampung provinces began in 1996. The World Bank has embarked on a $\$ 120$ million program to provide electricity from solar energy for 200,000 houses [41]. According to Indonesia's agency for the assessment of technology, the country began its solar energy program in 1989 in Sukabumi, West Java, providing solar energy devices to 85 houses. A new program, funded by the Australian government, would provide solar power to 35,000 houses in nine provinces in the eastern part of Indonesia.

Wind energy has enormous potential for developing Asia. India installed 264 megawatts of wind capacity in 1996, after installing 383 megawatts in 1995-enough to make it second only to Germany in terms of wind capacity additions [1]. Wind installations might slow further in 1997 because of a change in the corporate tax code reducing the tax shield provided by the 100 percent depreciation in the first year by almost 18 percent. India's renewable energy program does have some 
Table 23. Postponed Indonesian Geothermal Power Projects, 1997

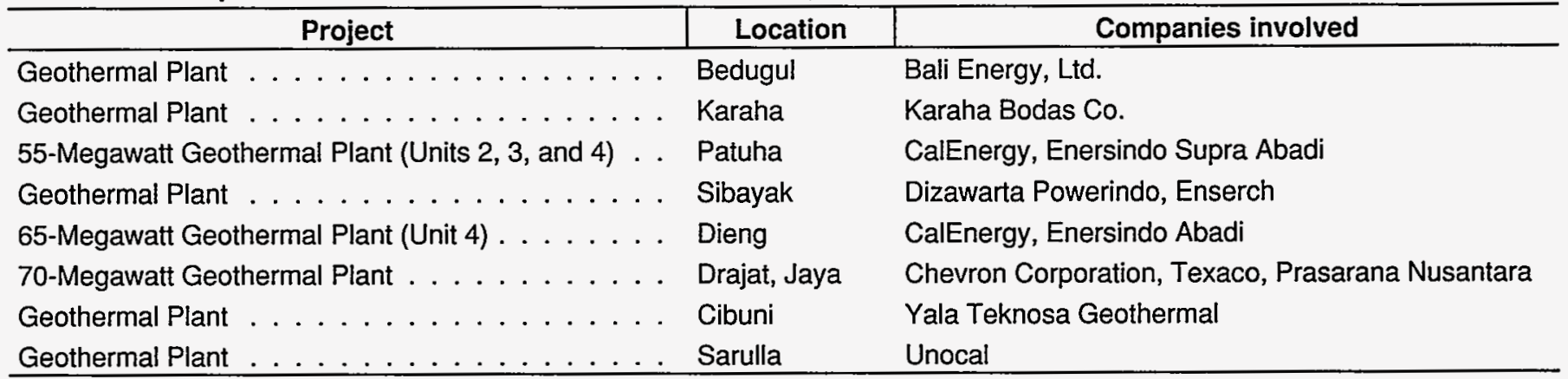

Source: "Indonesian IPP Schemes Hit by Currency Crisis," Financial Times: Power in Asia, No. 235 (September 22, 1997).

problems. Although total wind capacity has exceeded 732 megawatts, exceeding the Eighth Five-Year Plan target of 500 megawatts by 1997, some believe that private operators have exploited the tax holidays and 100 percent depreciation incentives offered by the federal Ministry of Nonconventional Energy Sources without yielding appreciable gains in energy supply [42]. The performance of wind farms, which are supposed to operate at 25 to 30 percent of the plant load factor, has declined in some cases to only 7 percent. Similar problems have arisen for India's solar energy programs.

\section{Eastern Europe and the Former Soviet Union}

In Eastern Europe and the former Soviet Union (EE/FSU), renewable energy grows by 2.1 percent annually over the forecast period, from 3.0 quadrillion Btu in 1995 to 5.1 quadrillion Btu in 2020. Most of the development is expected to be in the form of improvements to and expansions of existing hydroelectric capacity, along with some limited development of other renewable sources. Because the economies of the region have not recovered fully from the collapse of the Soviet Union in the early 1990s, conditions do not support an expansion of renewable energy applications. In Eastern Europe, where economic recovery has already begun, more activity is projected. Renewables are expected to grow by about 4.5 percent annually, mostly through improved hydroelectric utilization.

Several announcements for the upgrading and repair of hydroelectric facilities were made during 1997. Romania's state utility, RENEL RA, announced that the Iron Gates I project on the Danube River would be upgraded [57]. Iron Gates I is the largest hydroelectric plant in Romania, supplying about 10 percent of the country's electricity. Albania received a $\$ 50$ million loan from the World Bank to upgrade and repair five of its hydroelectric facilities [58]. The European Bank for Reconstruction and Development began coordinating financing to help upgrade Albania's hydroelectric capacity.
The Daugava River is the site of Latvia's three largest hydroelectric plants-the 848-megawatt Plavinas, the 260-megawatt Kegums, and the 402-megawatt Rigas units. The two other power plants owned by the Latvian energy company, Latvenergo, are 260-megawatt cogeneration units located in Riga. IVO Power Engineering, the international wing of the Finnish stateowned power corporation, Imatran Voima Oy (IVO), has secured a $\$ 10$ million contract to recondition the Daugava River hydroelectric dams managed by Latvenergo [59]. IVO intends to repair cracks and fissures in the walls of the Daugava River dams, and it is one of four international groups that have indicated an interest in privatizing Latvenergo. The Latvian state plans to divest a majority holding in the company in 1998. The task of finding Western investors for Latvenergo has fallen to the Latvian Privatization Agency, which is currently engaged in finding ways of clearing the power company's $\$ 80$ million debt ahead of any international bidding contest. Prospective owners will be required to agree to a $\$ 1$ billion, 10 -year modernization program for the company. Some 54 percent of that total capital sum will be needed to renovate the three hydroelectric plants on the Daugava River, as well as rebuilding whole areas of dam structure.

Hydroelectricity currently provides between 60 and 70 percent of Armenia's electricity generation [60]. The country has plans to expand its hydropower resources on the Razdan River with several new hydroelectric facilities, as well as plans to rehabilitate several older plants, some of which were constructed in the 1940s and 1950s. The country is considering a two-stage hydroelectric development program, to be funded in part by an IDA grant of $\$ 13.7$ million. The first stage, scheduled to be completed by 2000, involves upgrading of existing plants, privatizing small (less than 5 megawatts capacity) projects, and constructing 41 units with a combined capacity of 167 megawatts. In July 1997, Armenia obtained an $\$ 18$ million loan from Germany to rehabilitate the second unit at the Kanater hydroelectric plant. 


\section{China's Three Gorges Dam}

The Three Gorges Dam project is the world's largest and one of the most controversial energy projects currently under construction. When it is completed, more than 1 million people will need relocation as the system of dams creates a water basin more than 400 miles in length. The World Bank and U.S. ExportImport Bank have refused to help finance the project, primarily because of the adverse environmental effects this massive hydroelectric project might have. For one, the reservoir created by the dam may become a major pollution problem, slowing the flow of the Yangtze River and allowing silt to build up, possibly clogging the planned harbor at Chongqing within a few decades [43]. Critics of the project believe that sewage and industrial waste already emptied into the Yangtze will make the reservoir the "biggest open sewer in the world." Disrupting the flow of the river will place several rare plant and animal species at risk, including the endangered Yangtze river dolphin. The Chinese government, which has been considering construction of such a dam since the early part of the century (see table on page 106), is proceeding.

On November 8, 1997, China completed the first phase of the three-phase plan to build Three Gorges Dam across China's Yangtze River by diverting the river's main channel so that construction could begin on the hydroelectric plant and locks [44]. Construction on the project began in 1993. In addition to the work performed to block the flow of the Yangtze, population relocation was also part of the first phase of the project. As of November 1997, about 92,000 people had been resettled; by the time the project is completed, at least 1.2 million people will have been moved [45].

Phase 2 is expected to take place between 1998 and 2006, when the dam will be constructed, including a flood discharge system and the hydroelectric plant [46]. Between 2003 and 2006, 14 generators are scheduled to go on line. In the third phase, between 2004 and 2009, two five-stage locks and ship lifts will be constructed. In 2009, another 12 generators will be installed, and Three Gorges Dam will become fully operational.

By 2009 , the hydroelectric plant is expected to operate at an installed capacity of 18.2 gigawatts, equivalent to about 30 600-megawatt coal-fired power plants [47]. Three Gorges will be the world's largest hydroelectric project. The dam will be 610 feet high and 1.3 miles wide, two times the height of the Statue of Liberty and the width of 30 jumbo jets [48]. It will create a 412-milelong reservoir, which will submerge 13 cities, 140 towns, 1,352 villages, and some 650 factories [45]. Plans are to supply electricity to central and eastern China, including 2,000 megawatts to Chongqing in Sichuan

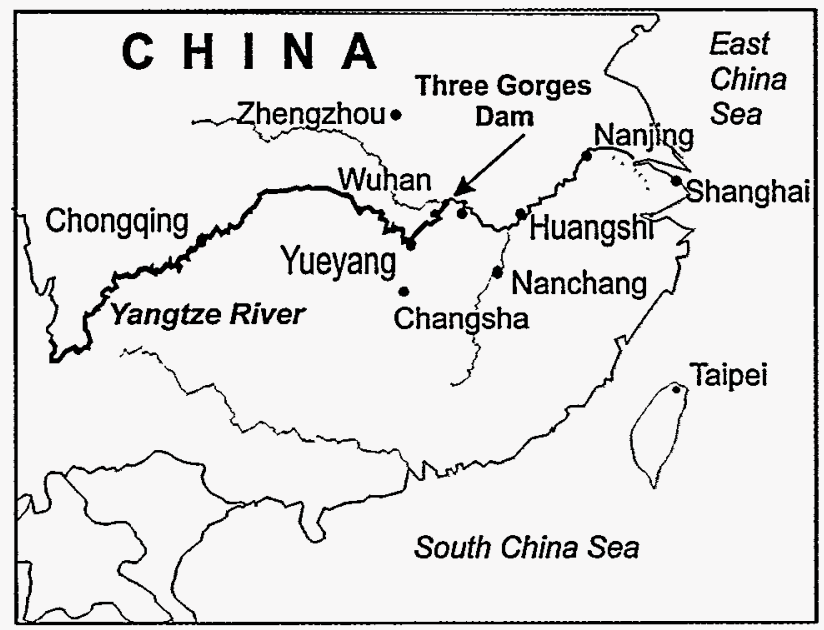

Source: Energy Information Administration, Office of Integrated Analysis and Forecasting.

province, 12,000 megawatts to central China, and 4,200 megawatts to eastern China [49]. The project will supply electricity to six major cities in addition to Chongqing: Zhengzhou, Wuhan, Nanjing, Shanghai, Nanchong, and Changsha [50]. Project advocates expect the dam to produce as much as 85 billion kilowatthours of electricity per year, which is still only about 10 percent of the 881 billion kilowatthours of electricity consumed in China in 1995 [50, 51].

Along with supplying electricity, Three Gorges Dam is being constructed to help control flooding along the Yangtze River. By some estimates, 317,000 people combined died in this century's worst three floods along the river in 1931, 1935, and 1954 [43]. The Chinese government estimates that 15 million people and 4 million acres of land along the Jinjiang section of the Yangtze are vulnerable to flooding [52]. The government believes the Three Gorges Dam will increase flood control capacity from a 10-year frequency to a 100-year frequency. Finally, the project is supposed to improve navigational capacity along the Yangtze (growing from the current 10 million tons per year to 50 million tons per year) and will allow vessels as large as 10,000 tons to sail upstream on the Yangtze as far as Chongqing, 1,500 miles inland from Shanghai [50].

Estimates of the cost of the project-including funds to help current residents relocate-have varied widely, from $\$ 29$ billion to $\$ 75$ billion, reflecting the difficulty of estimating costs for such large-scale projects with extensive time horizons [46]. The project has attracted the interest of many foreign construction firms. In August 1997, the Chinese awarded two major contracts to European and Canadian consortiums to build the first 14 generators and 14 hydroelectric turbines for the

(Continued on page 106) 


\section{China's Three Gorges Dam (Continued) History of the Three Gorges Dam Project}

1919 Chinese leader, Sun Yat Sen, proposes construction of a dam at Three Gorges to improve navigation of the Yangtze River and to make better use of the river's resources.

1944 John Lucian Savage, chief design engineer of the U.S. Bureau of Reclamation, surveys the Yangtze River and drafts a proposal for a dam at Three Gorges.

1946 In May, the resources committee of the Republic of China signs an agreement with its U.S. counterpart to jointly design the dam.

1947 The Chinese government orders suspension of the dam project because of high inflation and an economic crisis.

1949 Severe flooding occurs along the Yangtze River. China's new government decides to make flood control on the middle and lower portions of the river a priority. Three years later the Jingilang flood diversion project is completed on the Yangtze.

1953 Mao Zedong is presented with a proposal for constructing reservoirs. Mao requests that a dam be built at Three Gorges to control flooding.

1954 The Yangtze Valley suffers the worst floods of the century.

1958 In August, Zhou En Lai presides over a meeting at Beidaihe in northern China where the design of Three Gorges Dam is presented.

1970 The government decides to begin construction on the Gezhouba Dam Project as a part of the Three Gorges Project to help supply increasing demand for electric power in central China.

1979 China's Ministry of Water Resources submits its proposal for Three Gorges Dam to the State Council and recommends immediate approval by the central government.

1982 Deng Xiaoping pledges to proceed with the Three Gorges Dam project.

1984 State Council authorizes the Yangtze Valley Planning Office to draft a feasibility study on the Three Gorges Water Control Project.

1986 The central governments demands a reexamination of the project and more feasibility studies. Over the 1986-1989 period, the Ministry of Water Resources organizes 14 expert groups for a large-scale, thorough review of the project.

1989 The planning office revises the feasibility report and proposes beginning the project as soon as possible.

1990 A supervisory committee is formed for the Three Gorges Dam project, with Vice Premier Zou Jiahua as director.

1991 Zou Jiahua's committee approves the feasibility report and submits it to the State Council for final deliberation at the Seventh National People's Congress.

1992 On April 3, the Fifth Plenary Session of the Seventh National People's Congress approves a resolution to proceed with the Three Gorges Dam project, with 1,767 deputies for, 177 against, and 664 abstaining.

1993 The Three Gorges Project Construction Committee (TGPCC) is formed to represent China's State Council in decisionmaking and regulating vital issues. In July, the TGPCC approves a preliminary design plan for Three Gorges Dam, representing the beginning of the period of construction preparations. In August, the State Council presents the procedures for population resettlement.

1994 On December 14, Chinese Premier Li Peng announces the official launching of construction on Three Gorges Dam.

1996 Two major transportation projects--including the Xiling Bridge (across the Yangtze) and an airport in Yichang-are completed and become operational. On May 30, the U.S. Export-Import Bank decides that it cannot issue a letter of interest for the Three Gorges Dam project because the project's sponsors, China Yangtze Three Gorges Project Development Corporation, failed "to establish the project's consistency with the Bank's environmental guidelines." On December 18, the Japanese Export-Import Bank announces that it will provide financial backing and trade insurance for Japanese companies wishing to participate in Three Gorges.

1997 State Planning Commission approves the issuance of 1 billion yuan in corporate bonds, the first bond offering by the TGPCC to raise construction funds. The first phase of residents to be relocated from the reservoir region have been resettled by September. On October 1, the Qinjiantuo Bridge opens to traffic, concluding the construction of transportation infrastructure for the project. On November 8, the Yangtze River is blocked, signalling the completion of the first phase of construction on the Three Gorges Dam project.

Sources: Chinese Embassy, web site www.china-embassy.org; U.S. Import-Export Bank, web site www.exim.gov; and "Europeans Win Round in Three Gorges Bidding," The Nikkei Weekly, Vol. 35, No. 1787 (August 18, 1997), web site www. satellite.nikkei.co.jp. 


\section{China's Three Gorges Dam (Continued)}

project [53]. A consortium of the French company GEC Alsthom and the Swiss-Swedish company ABB Power Generation won contracts to construct 8 generators (the contract is worth $\$ 420$ million) [54]. The second contract was awarded to a consortium formed by General Electric Canada and the German companies Voith Hydro $\mathrm{GmbH}$ and Siemens AG for 6 generators and 6 turbines at a cost of $\$ 320$ million. Bidding for 12 more generators will occur in 1999 or 2000.

U.S. companies have not been able to participate substantially in the bidding for construction work on the project, mostly because of the refusal by the U.S.
Export-Import Bank in May 1996, based on environmental concerns, to guarantee loans for U.S. companies. The Chinese government insists on export credit guarantees, making it difficult for U.S. companies to compete for contracts [55]. In contrast, the governments of Canada, France, Germany, and Japan are giving their companies financial guarantees. American companies have been able to sell some equipment to dam developers. China has purchased earth-moving equipment-worth about $\$ 30$ million-from the U.S. company Caterpillar, Inc., and cranes and conveyor belts-worth about $\$ 50$ million-from the U.S.-based Rotec Industries, Inc. $[45,55,56]$.
In Eastern Europe the dispute between Slovakia and Hungary over the Gabcikovo hydroelectric project was resolved in the United Nations International Court of Justice at The Hague. The two countries had taken their dispute to The Hague in 1993. The Court issued its ruling on its first major environmental case on September 25,1997 [61]. It ruled that both countries were in breach of the 1977 treaty to construct a series of hydroelectric dams on the Danube River. The 1977 agreement between Hungary and the then Czechoslovakia was a joint project to construct a three-stage hydroelectric project of two dams-the Slovakian Gabcikovo and, 80 miles to the south, the Hungarian Nagymaros.

Hungary suspended work on its portion in 1989 because of protests from the populace and international environmental groups. In 1992, Czechoslovakia decided to complete Gabcíkovo without Hungarian cooperation. Today, the $\$ 500$ million, 180-megawatt Gabcikovo project supplies an estimated 12 percent of the electricity consumed in Slovakia [62]. The Court stated that Hungary was wrong to withdraw from the treaty, but that Slovakia also acted unlawfully by completing its part of the project on its own. After almost a year of talks to resolve the differences between the two countries, Hungary and Slovakia signed a protocol agreement on February 27, 1998, to construct a dam either at Nagymaros-the original site of the Hungarian portion of the project-or at Pilismarot [63]. Construction should be completed between 2004 and 2006.

There is little prospect for development of alternative energy sources in the region. The still weak economies in the FSU make it unlikely that renewable energy programs will flourish, although there are some small pilot projects and some opportunity for renewables in harsh climates where conditions are favorable to wind power generation. In 1997, construction began on a 40megawatt geothermal power station near the existing Klaipeda geothermal facility in Lithuania [64]. Work should be completed by the middle of 1999 . The geothermal energy will be used for space heating and hot water supplies for the city of Klaipeda. The project is estimated to cost about $\$ 18$ million and is being funded by a World Bank loan ( $\$ 5.9$ million), as well as funds from the Global Environment Fund ( $\$ 6.9$ million), Danish Environment Fund ( $\$ 2.6$ million), the Lithuanian government (\$2.6 million), and aid funds from the European Union (Ecu 85,000).

\section{Middle East and Africa}

Renewable energy remains a small part of the energy used in the countries of the Middle East and Africa. In the Middle East, two countries-Iran and Syriagenerate about 90 percent of the region's hydroelectricity; and in Africa, eight countries-Cameroon, Egypt, Ghana, Kenya, Nigeria, Congo (Kinshasa, formerly Zaire), and Zimbabwe-generate almost 80 percent of the region's hydroelectricity. Similarly, only three countries in the Middle East and AfricaJordan, Ethiopia, and Kenya-consume measurable amounts of other, grid-connected renewables.

In October 1997, Mozambique was able to provide South Africa with "trial-supplied electricity" from the Cabora Bassa hydroelectric project for the first time in 14 years [65]. The Cabora Bassa transmission line had been severely damaged during Mozambique's Civil War. South Africa may purchase as much as 75 percent of the 2-gigawatt dam's capacity. The country joined the South Africa Power Pool (SAPP) along with Angola, Botswana, Lesotho, Malawi, Namibia, South Africa, Swaziland, Tanzania, the former Zaire, and Zimbabwe. In October 1997, the government of Mozambique signed a memorandum of understanding with the government of Malawi for construction of a power transmission line between the two countries that would link Malawi to the SAPP grid [66]. The transmission line, which will run from Cabora Bassa to Malawi, will cost an estimated 
$\$ 37$ million. Zimbabwe has also been receiving Cabora Bassa electricity on a trial basis through an existing transmission line, and Mozambique hopes to be able to supply the country with 500 megawatthours of electricity early in 1998 [65].

A successful implementation of alternative renewables is the World Bank's Global Environment Facility solar photovoltaics program which is attempting to install solar energy lighting units in 9,000 Zimbabwean households by the end of 1997 [67]. By the beginning of November, more than 8,000 units had been installed in high-density areas, rural businesses, and community centers and clinics. The $\$ 5.6$ million project began in 1993 as a pilot program.

\section{Central and South America}

Hydroelectric resources are well established in Central and South America. In many countries of this region, the bulk of electricity is generated from hydropower resources. In fact, the trend seems to be toward diversifying the electricity supply by installing more thermal electricity generating capacity. Renewable energy is expected to grow by about 1.1 percent annually between 1995 and 2020, from 5.1 quadrillion Btu in 1995 to 6.6 quadrillion Btu in 2020. The renewables share of energy consumed for electricity generation actually drops by almost 25 percentage points over the forecast. Whereas renewables account for about 77 percent of the energy consumed for electricity at present, their share drops to about 52 percent in 2020. Increases in natural gas capacity account for most of the loss of share for renewables.

Hydroelectricity accounted for 92 percent of Brazil's generating capacity in 1996 [68, p. 65]. Although hydroelectricity should remain the main source of electricity generation through the projection period, the renewables share of energy consumed for electricity generation is projected to fall from about 95 percent in 1995 to 86 percent in 2020. Much of the country's hydroelectric potential has already been developed, and the cost of adding new capacity is increasing, because the remaining available resources are located far from the consuming centers. Moreover, continued heavy dependence on hydroelectricity leaves Brazil vulnerable to droughts, which result in power shortages.

Work on the 3-gigawatt, Brazilian Xingo plant should be completed by the end of 1997 [68, p. 65]. The government is also launching tenders for seven additional greenfield hydroelectric facilities (Table 24), according to the local business daily, Gazeta Mercantil [69].

Chile too is, at present, heavily dependent on hydroelectricity for its electricity supplies. Hydroelectricity accounted for 81 percent of the country's total electricity generation in 1996 [68, p. 95]. Endesa, Chile's major hydroelectric generation utility, has had to resort to running inefficient combustion turbines because of recent low water conditions. In fact, low water levels in 1997 led to several blackout events. To guard against the risk of droughts in the future, the country plans to add large quantities of thermal capacity which, according to DRI/McGraw-Hill, by 2020 might compose as much as 44 percent of total installed capacity.

Argentina currently has 22.5 gigawatts of total electricity generation capacity [68, p. 35]. Hydroelectricity accounts for more than half of Argentina's electricity generation. Thermal capacity is about 10 gigawatts, and nuclear plants provide about 0.9 gigawatts. The country still expects to provide a large amount of additional electricity capacity through hydroelectric projects. The 2.7gigawatt Yacyreta project ( $a$ joint venture between Argentina and Uruguay) is scheduled to become fully operational by 1998. Several other hydroelectric facilities are planned for the Alto Uruguay and Parana rivers after 2010 , with an estimated additional capacity of 4.6 gigawatts. Finally, there are plans to add several smaller hydroelectric facilities by 2020 . In the near term, there are plans to privatize the Pichi Picun hydroelectric dam in Patagonia [70]. The winner of the bid for this project is expected to receive a $\$ 25$ million subsidy from the Argentinean government to complete the project.

Table 24. Brazilian Hydroelectric Tenders

\begin{tabular}{|c|c|c|c|}
\hline Project & State & $\begin{array}{c}\text { Capacity } \\
\text { (Megawatts) }\end{array}$ & $\begin{array}{c}\text { Cost } \\
\text { (Million } 1996 \text { U.S. Dollars) }\end{array}$ \\
\hline Cana Brava . . . . . . . . . & Goias & 450 & 500 \\
\hline 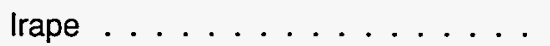 & Minas Gerais & 372 & 545 \\
\hline P. de Pedra . . . . . . . . & Minas Grosso & 176 & 160 \\
\hline Quiemado. . . . . . . . . . . . & Goias & 111 & 145 \\
\hline Campinho. . . . . . . . & Esp Santo & 45 & 45 \\
\hline 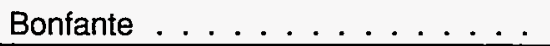 & Minas Gerais & 19 & 29 \\
\hline
\end{tabular}

Source: "Privatization: Brazil," Financial Times: Global Private Power, No. 25 (June 27, 1997). 


\section{References}

1.American Wind Energy Association, A Status Report on International Utility-Scale Wind Energy Markets (Washington, DC, April 28, 1997).

2."Enron Acquires Zond, Launches Enron Renewable EnergyCorp," News from the American Wind Energy Association (January 6, 1997), web site www. econet.org/awea.

3."Enron Wind Buys German Turbine Manufacturer," Wind Energy Weekly, Vol. 16, No. 769 (October 20, 1997), p. 1.

4. "Shell Invests US $\$ 0.5$ Billion in Renewables," Royal/Dutch Shell press release (October 16, 1997), web site www.shell.com.

5.Energy Information Administration, Annual Energy Outlook 1998, DOE/ELA-0383(97) (Washington, DC, November 1997), p. 57.

6."Turbine Demonstration Effort Builds Experience with Wind," Windletter, Vol. 24, No. 9 (September 1997), pp. 1, 3

7."News Briefs", HYDRO•WIRE, Vol. 18, No. 20 (October 14, 1997), p. 6.

8.Natural Resources Canada, Canada's Energy Outlook: 1996-2020 (Ottawa, Ontario, April 1997), web site www.es.nrcan.gc.ca.

9."EWEC's 150-GWe Target for Wind-Power Capacity Possible with Political Will: BTM," The Solar Letter, Vol. 7, No. 22 (October 24, 1997), pp. 398-399.

10. T. Weller, "Wind Energy in Germany-a Success Story," fair energy web site, ourworld.compuserve. $\mathrm{com} /$ homepages/renewable_energy/windgerm. htm.

11. K. Rackshaw, "Wind Around the World," Solar Today, Vol. 12, No. 2 (March/April 1998), pp. 22-25.

12. W. Mahoney, "German Ruling Parties Back Down on Curbing Wind-Power Payments," The Solar Letter, Vol. 7, No. 21 (October 10, 1997), p. 390.

13. W. Mahoney, "Berlin, Freiburg Pushing Citizens To Use More Solar-Electric Energy", The Solar Letter, Vol. 7, No. 21 (October 10, 1997), p. 390.

14. DRI/McGraw-Hill, World Energy Service: European Outlook (Lexington, MA, June 1997).
15. British Wind Energy Association, "The Government's Policy for Renewables," BWEA Factsheet, No. 6 , web site www.bwea.com (not dated).

16. International Energy Agency and National Renewable Energy Laboratory, IEA Wind Annual Report 1996 (Golden, CO, October 1997).

17. "Labour Announces Fifth NFFO Round," Wind Energy Weekly, Vol. 16, No. 776 (December 8, 1997), p. 5 .

18. British Wind Energy Association, "The Government's Policy for Renewables," Factsheet No. 6, web site www.bwea.com (not dated).

19. DRI/McGraw-Hill World Energy Service: European Outlook (Lexington, MA, September 1997).

20. Greenpeace, "Greece Builds World's Biggest Solar Photovoltaic (PV) Power Station," press release (June 12, 1997), web site www.greenpeace.org.

21. "Development of Wind Power Surges in Italy," Wind Energy Weekly, Vol. 16, No. 759 (August 11, 1997), p. 2.

22. W.G. Mahoney, "Europe Seen Restricting Renewables Investments as Asia Presses Ahead," The Solar Letter, Vol. 7, No. 22 (October 24, 1997), p. 410 .

23. "Hau Nui Reports World-Class Performance," Energy-Wise News, Issue 54 (August/September 1997), web site www.energywise.com.

24. DRI/McGraw-Hill, The Future of the Electric Power Industry Around the World, Vol. III, "Asia/Pacific" (Lexington, MA, November 1995), pp. 46-47.

25. "BP Solar Wins Bid," Financial Times: Power in Asia, No. 235 (September 22, 1997), p. 26.

26. "World's Largest Solar Suburb for Sydney," BP Press Release (September 15, 1997), web site 165.121.20.76/press/pr110.html.

27. "Bakun Dam Project Finally Gets the Axe," Financial Times: Power in Asia, No. 234 (September 8, 1997), pp. 1-2.

28. "ABB Pulls Out as Bakun Dam Flounders", Friends of the Earth press release (September 4, 1997).

29. "Focus on Bakun Hydro Project," web site www.malaysia.net/people/sajguc/bakun.htm (created June 25, 1996). 
30. "10,000 People Protest Maheshwar Dam on India's Narmada River," International Rivers Network press release, web site www.irn.org (October 10, 1997).

31. "Hydro Scheme Dropped," Financial Times: Power in Asia, Vol. 234 (September 8, 1997), p. 11.

32. "EdF Optimistic on Thailand, But Unsure on Laos," Financial Times: Power in Asia, Vol. 236 (October 6, 1997), p. 23.

33. "Malaysia To Generate, Distribute Power for Myanmar," NewsPage web site www.newspage.com (August 23, 1997).

34. "Philippines Hydro Scheme Closes Financing," Financial Times: Global Private Power, No. 25 (June 27, 1997), p. 18.

35. "Central China Starts Building Hydro-electric Power Station," Xinhua English Newswire (June 24, 1997).

36. "First Tiered Hydropower Station on Hongshui River," Xinhua English Newswire (May 15, 1997).

37. "Thailand Seeks China Power Deal," Financial Times: Power in Asia, No. 235 (September 22, 1997), p. 24.

38. "Indonesian IPP Schemes Hit by Currency Crisis," Financial Times: Power in Asia, No. 235 (September 22, 1997), p. 17.

39. R. Bromby, "Elsewhere in the News," The Solar Letter, Vol. 7, No. 21 (October 10, 1997), p. 394.

40. "WB Aids Indonesia's Solar Power Projects," NewsPage web site www.newspage.com (October 9, 1997).

41. L. Pardomuan, "Indonesia Shines with Solar Energy Potential," Reuters Newswire (October 15, 1997).

42. D. D'Monte, "Indian Renewable Energy Prógram Seen Falling Short of Objectives," The Solar Letter, Vol. 7, No. 21 (October 10, 1997), p. 389.

43. T. Poole, "China's Greatest Ambition May Prove Her Greatest Folly," web site www.virgin.net.

44. "Yangtze River Dam-'Miracle Created by Chinese People'," Lateline News (November 9, 1997), web site www.muzi.net.

45. S. Mufson, "The Yangtze Dam: Feat or Folly?" Washington Post (November 9, 1997), p. A01.
46. "Background Information on the Three Gorges Dam," web site www.washingtonpost.com (November 9,1997$)$.

47. "Dignitaries, Pomp and Firecrackers as Yangtze Blocked," web site www.energyonline.com/ restructuring/news_reports/news/1110chin.html (November 10, 1997).

48. C.F. Stiefel, "To Tame a River (Controversial Three Gorges Dam Project in China)," Part 3, Science World, Vol. 53, No. 8 (January 10, 1997).

49. "\$54b Plan for Gorges Power Grid," Hong Kong Standard China (October 6, 1997), web site www.htkstandard.com.

50. "The Three Gorges Dam-II: The Super Dam Along the Yangtze River," web site www.welcome-tochina.com (September 16, 1996).

51. Energy Information Administration, International Energy Annual 1996, DOE/EIA-0219(96) (Washington, DC, February 1998), p. 90.

52. Chinese Embassy, "The Three Gorges Project: A Brief Introduction," web site www.china-embassy. org.

53. "Europe and US Win Three Gorges Dam Bids," web site www.hkstandard.com (August 22, 1997).

54. "China Picks Suppliers for Three Gorges Dam Generators," U.S. Water News Online (September 1997), web site www.uswaternews.com.

55. R. Tomlinson, "DAM! America Misses Out on the World's Biggest Construction Project," Fortune (November 10, 1997), pp. 182-188.

56. W. Kazer, "China Finds Dam Financing Without U.S. Ex-Im Bank," web site www.cleanenergy.de (November 7, 1997).

57. "Sulzer Hydro/ABB To Upgrade Iron Gates," Financial Times: East European Energy Report, No. 73 (October 1997), p. 40.

58. "Fund Warning in Albania," Financial Times: East European Energy Report, No. 73 (October 1997), p. 40.

59. "IVO Secures Latvian Hydro Deal Ahead of Privatization," Financial Times: East European Energy Report, No. 72 (September 1997), p. 25.

60. "Armenia: Reforms High on the Agenda After Years of Conflict and Economic Collapse," Financial Times: East European Energy Report, No. 7 (August 1997). 
61. "U.N. Court Rules Against Hungary, Slovakia," The Washington Post (September 26, 1997), p. A18; and C. Spolar, "Danube Dam Dispute Divides Slovakia, Hungary: World Court to Decide Whether Communist-Era Hydroelectric Project Must be Completed," The Washington Post (September 24, 1997), p. A26.

62. WEFA Energy, World Power Service: Eastern European Report (London, UK, 1995), p. 8.7.

63. Central Europe Online, "Hungary Greens Say 'No' to Danube Dam," Reuters Release (March 2, 1998), web site www.centraleurope.com.

64. J. Perera, "Drilling Begins at Klaipeda, Lithuania, Geothermal Plant," The Solar Letter, Vol. 7, No. 21 (October 10, 1997), p. 391.

65. "Mozambique Trial-supplying Power to Zimbabwe", NewsPage web site www.newspage. com (November 11, 1997).
66. "Mozambique To Enhance Electric Power Coop with Malawi," NewsPage web site www.newspage. com (October 3, 1997).

67. "Solar Energy Scheme Ahead of Schedule in Zimbabwe," NewsPage web site www.newspage. com (November 4, 1997).

68. DRI/McGraw-Hill, World Energy Service: Latin American Outlook 1997 (Lexington, MA, Summer 1997).

69. "Privatization: Brazil," Financial Times: Global Private Power, No. 25 (June 27, 1997), p. 11.

70. "Chilenger and Endesa Interested in Patagonian Dam," NewsPage web site www.newspage.com (August 25, 1997). 


\section{Electricity}

\section{Between 1995 and 2020, the world's annual consumption of electricity is projected to rise from 12 trillion kilowatthours to 23 trillion kilowatthours. The greatest increases are expected in developing Asia and in Central and South America.}

Throughout the world, electricity is and will continue to be the fastest growing component of energy demand. Between 1995 and 2020, total world electricity demand is expected to rise from 12 trillion kilowatthours to 23 trillion kilowatthours (Table 25). Demand growth will be slowest in the industrialized countries; but even in the advanced economies, which currently account for about 60 percent of world electricity use, absolute and per capita consumption levels are expected to rise as new uses for electricity proliferate among residential, commercial, and industrial consumers. Aggregate demand for the industrialized countries in 2020 is projected to be more than 4 trillion kilowatthours higher than it was in 1995, exceeding 11 trillion kilowatthours.

In the developing countries, electricity demand is projected to grow at more than twice the rate of growth in the industrialized countries, with aggregate consumption more than tripling between 1995 and 2020, to 10 trillion kilowatthours. The greatest gains are expected in developing Asia and in Central and South America, where electricity demand growth has tended to outpace economic growth. Rising standards of living are leading to greater electrification and more intensive use of modern appliances, space heating, air conditioning, and lighting.

Highlights of recent developments in electricity markets around the world are as follows:
- Privatization and electricity reform measures continued apace in 1997. Central and South America has led the developing world in the privatization of electricity and the implementation of electricity reform. In 1997, Brazil followed the path, broken first by Chile and later by Argentina, in aggressively selling off state-owned electricity assets to the public. Several other Latin American countries have also sold off electricity assets. Central and South American energy needs have given rise to regional, cross-border investment, development, and trade in natural gas and electricity.

- European electricity markets are becoming increasingly integrated. Europe's electricity industry is likely to become more integrated in the future. In 1997, the European Parliament adopted a directive whose intent was to provide independent producers with greater access to other countries' power networks. In recent years, several cross-border investments have been made in the European electricity market, and regional electricity pools have emerged. The United Kingdom has become the largest target of foreign direct investment in electricity and has attracted billions of dollars in investment in recent years. Currently, a substantial portion of the UK electricity industry is owned by U.S. companies.

Table 25. World Net Electricity Consumption by Region, 1990-2020 (Billion Kilowatthours)

\begin{tabular}{|c|c|c|c|c|c|c|c|c|}
\hline \multirow[b]{2}{*}{ Region } & \multicolumn{2}{|c|}{ History } & \multicolumn{6}{|c|}{ Projections } \\
\hline & 1990 & 1995 & 2000 & 2005 & 2010 & 2015 & 2020 & $\begin{array}{c}\text { Average Annual } \\
\text { Percent Change, } \\
1995-2020 \\
\end{array}$ \\
\hline Industrialized Countries & 6,299 & 7,113 & 7,968 & 8,804 & 9,663 & 10,497 & 11,349 & 1.9 \\
\hline United States . . . . . . & 2,713 & 3,163 & 3,318 & 3,601 & 3,877 & 4,115 & 4,308 & 1.2 \\
\hline EE/FSU $\ldots$. & 1,908 & 1,552 & 1,509 & 1,685 & 1,881 & 2,056 & 2,248 & 1.5 \\
\hline Developing Countries & 2,224 & 3,102 & 3,886 & 5,007 & 6,220 & 7,684 & 9,548 & 4.6 \\
\hline Developing Asia . . . & 1,268 & 1,912 & 2,489 & 3,283 & 4,160 & 5,255 & 6,665 & 5.1 \\
\hline China . . . . . & 551 & 881 & 1,076 & 1,476 & 1,975 & 2,657 & 3,574 & 5.8 \\
\hline Other Developing Asia & 717 & 1,030 & 1,413 & 1,807 & 2,185 & 2,598 & 3,091 & 4.5 \\
\hline Total World . . . . . . . & 10,431 & 11,767 & 13,363 & 15,495 & 17,764 & 20,237 & 23,145 & 2.7 \\
\hline
\end{tabular}

Note: EE/FSU = Eastern Europe and the former Soviet Union.

Sources: History: Energy Information Administration (EIA), International Energy Annual 1996, DOE/EIA-0219(96) (Washington, DC, February 1998). Projections: EIA, World Energy Projection System (1998). 
Integration of national electricity industries has progressed furthest in the Scandinavian countries. Sweden and Norway now operate a joint electricity pool, and Finland is scheduled to join the pool in early 1998.

- The pace of foreign investment in developing nations' electricity sectors hinges strongly on the implementation of electricity reform and the application of transparent and consistent regulatory and investment policies. In 1996, the newly elected Indian state government of Maharashtra and the U.S. company Enron successfully renegotiated a lawsuit stemming from a claim that an earlier agreement between Enron and the former Maharashtra government unfairly favored the electricity supplier over consumers. The dispute has become illustrative of the difficulties surrounding the negotiation of electricity investments between foreign companies and developing countries. Currently, economic growth in several developing nations is being restrained by a shortage of electricity capacity. Expediting the negotiation phase of electric power developments is crucial to the successful realization of their full economic growth potential.

\section{Primary Fuel Use}

Growing electrification contributes substantially to rising world requirements for primary energy. However, growing reliance on electricity does not dictate increasing reliance on any particular source of primary energy input. As a result, there is considerable diversity among regions in the composition of energy use for electricity generation (Table 26). In aggregate, coal currently is the most widely used primary fuel, accounting for 36 percent of total fuel consumption for electricity production.

Coal is expected to maintain its share of the overall electricity generation market through 2020 . China shows the largest increase in coal consumption over the forecast period, triple the increase for the United States. India's coal use is expected almost to double. More than twothirds of the overall increase in world coal consumption is expected to occur in China and India. North America's coal consumption is expected to rise in absolute terms; however, some nations are expected to reduce their levels of coal use in both absolute and relative termsnotably, Germany and the United Kingdom, which in recent years have begun reducing subsidies for domestic coal production.

Renewable energy-primarily hydropower-is the next most important source of energy for power generation. Its relative share is expected to change little. Major hydropower developments in developing Asia will contribute substantial increments of energy for generation.

The most marked changes projected for primary energy use in electricity production involve nuclear power and natural gas. Of all the fuels used for electricity generation, natural gas is expected to show the largest increase in consumption. Due in large measure to advances in exploration and development technologies, the cost of finding natural gas reserves has fallen considerably in recent years [1], and the world's natural gas reserves-toproduction ratio has risen substantially. At the same time, power generation technologies have evolved to favor natural gas usage. The new technologies tend to economize on both capital and operating costs. Natural gas use for electricity is expected to rise from 16 percent of the total in 1995 to almost 25 percent in 2020. Increasingly, natural gas will be used as a fuel for baseload plants. Almost all regions of the world are expected to show substantial increases in the use of natural gas to generate electricity.

Increases in the availability of imported liquefied natural gas (LNG) have also led to greater usage of natural gas for power generation. Although currently accounting for just under 5 percent of world natural gas consumption, LNG imports have grown by 27 percent between 1992 and 1996 [2, p. 28]. Japan is the largest consumer of LNG, and South Korea has become a significant LNG importer in recent years. However, current economic uncertainties in Asia may slow nearterm demand growth and lead to a postponement of several major LNG developments involving increased trade between Asian customers and Middle East suppliers. On the other hand, several Asian countries are accelerating the internal development of natural gas and electricity markets to economize on the foreign exchange costs associated with the use of imported oil.

By 2020 nuclear power generation is projected to be in decline. The growth in nuclear use in Asia is expected to be more than offset by reduced output in North America and, to a lesser extent, in Western Europe, where Sweden is implementing a program to phase out its nuclear program. Although the United States produces less nuclear power than Europe, the decline in U.S. nuclear power consumption will exceed the European reduction.

In summary, over the projection period, fossil fuel use will increase in relative importance as a prime mover for power generation. Even among Annex I countries, the share of fossil-based primary energy used for electricity generation will increase in the reference case, as will the absolute level of utilization. In the United States, nuclear power is projected to decline by 43 percent, coal use to rise by 25 percent, and natural gas use to triple. 
Table 26. World Energy Consumption for Electricity Generation by Region and Fuel, 1995-2020

\begin{tabular}{|c|c|c|c|c|c|c|}
\hline Region and Fuel & 1995 & 2000 & 2005 & 2010 & 2015 & 2020 \\
\hline Industrialized $\ldots \ldots \ldots \ldots \ldots$ & 77.4 & 85.8 & 91.5 & 97.0 & 102.0 & 106.2 \\
\hline Oil. . . . . . . . . . . . . & 5.2 & 5.5 & 5.4 & 5.4 & 5.5 & 5.6 \\
\hline Natural Gas. . . . . . . . . . . . & 8.1 & 10.8 & 14.0 & 17.3 & 21.2 & 24.9 \\
\hline Coal. . . . . . . . . . . . & 27.6 & 30.4 & 31.8 & 33.2 & 34.5 & 35.4 \\
\hline Nuclear . . . . . . . . . . . . & 19.4 & 20.2 & 19.5 & 18.7 & 16.8 & 14.8 \\
\hline Renewables $\ldots \ldots \ldots \ldots$ & 17.2 & 18.8 & 20.7 & 22.5 & 24.0 & 25.6 \\
\hline EE/FSU $\ldots \ldots \ldots \ldots \ldots \ldots$ & 24.8 & 26.2 & 28.8 & 30.8 & 32.2 & 31.6 \\
\hline Oil. . . . . . . . . . . . & 2.8 & 2.7 & 3.1 & 3.6 & 4.1 & 4.6 \\
\hline Natural Gas. . . . . . . . . . . . . & 9.5 & 10.7 & 12.3 & 13.9 & 15.2 & 16.8 \\
\hline Coal. . . . . . . . . . . . & 6.8 & 6.7 & 6.7 & 6.2 & 5.3 & 5.0 \\
\hline Nuclear . . . . . . . . . . . & 2.7 & 3.0 & 3.1 & 3.1 & 2.9 & 0.0 \\
\hline Renewables $\ldots \ldots \ldots \ldots$ & 3.0 & 3.1 & 3.6 & 4.0 & 4.6 & 5.1 \\
\hline Developing $\ldots \ldots \ldots \ldots$ & 37.1 & 46.7 & 58.5 & 70.8 & 84.7 & 101.7 \\
\hline Oil. . . . . . . . . . . . . . . & 5.2 & 6.1 & 7.3 & 8.5 & 9.8 & 11.4 \\
\hline Natural Gas. . . . . . . . . . . & 4.6 & 6.5 & 8.8 & 11.6 & 14.4 & 17.8 \\
\hline Coal. . . . . . . . . . . . . & 16.3 & 20.7 & 25.8 & 31.9 & 39.4 & 46.5 \\
\hline Nuclear . . . . . . . . . . . . . & 1.2 & 1.5 & 2.4 & 3.2 & 3.6 & 6.5 \\
\hline Renewables $\ldots \ldots \ldots \ldots$ & 9.9 & 11.9 & 14.2 & 15.8 & 17.5 & 19.5 \\
\hline Total World . . . . . . . . . . . & 139.4 & 158.7 & 178.9 & 198.6 & 218.9 & 239.6 \\
\hline Oil. . . . . . . . . . . . & 13.1 & 14.3 & 15.8 & 17.5 & 19.5 & 21.6 \\
\hline Natural Gas. . . . . . . . . . . . & 22.2 & 28.1 & 35.2 & 42.8 & 50.9 & 59.5 \\
\hline Coal. . . . . . . . . . & 50.7 & 57.9 & 64.3 & 71.2 & 79.2 & 86.9 \\
\hline Nuclear . . . . . . . . . . . . . & 23.3 & 24.7 & 25.0 & 24.9 & 23.3 & 21.3 \\
\hline Renewables $\ldots \ldots \ldots \ldots$ & 30.1 & 33.8 & 38.6 & 42.4 & 46.0 & 50.2 \\
\hline
\end{tabular}

Note: $E E / F S U=$ Eastern Europe and the former Soviet Union.

Sources: 1995: Derived from Energy Information Administration (EIA), International Energy Annual 1996, DOE/EIA-0219(96) (Washington, DC, February 1998). Projections: EIA, World Energy Projection System (1998).

\section{The Financing of Electric Power Expansion}

Electricity is a capital-intensive industry, perhaps the most capital-intensive of all industries. To meet global power projections, it is estimated that more than $\$ 2.3$ trillion will have to be spent between 1995 and 2010 (Table 27). Roughly two-thirds of the investment will be needed in developing countries [3].

Particularly in the developing world, vast infusions of foreign capital will be required to sustain growth in electricity supply. Many developing countries are already coping with power shortages. The future power needs of such populous countries as Brazil, China, India, Indonesia, and Pakistan are immense, presenting investment demands beyond the financial means of their domestic capital markets or government resources. As a result, attracting foreign investment is critical to the successful expansion of the electric power sectors in these nations.

\section{Public Policy Reform in the Electricity Industry}

Throughout the world, a wide range of initiatives are underway to modify the regulatory arrangements affecting electric power supply and development. In emerging economies, the driving forces for change are capacity and capital shortages. Old arrangements wherein government enterprises developed and managed the provision of electricity services have been judged inadequate to cope with the change associated with buoyant economic development.

As a consequence, many countries are moving to privatize government enterprises and open entry for new enterprises, seeking to lower the cost and improve the availability of electrical services. The act of privatizing can ease capital shortage by replacing a credit-restrained management with one that has readier access to borrowing and superior ability to institute operating economies to free cash flow for investment. Removing entry 
Table 27. Cumulative Projected Worldwide Electric Power Investments by Region, 1995-2010 (Billion Nominal Dollars)

\begin{tabular}{|c|c|c|c|c|c|c|c|c|c|c|c|c|}
\hline Investment Type & $\begin{array}{c}\text { North } \\
\text { America }\end{array}$ & $\begin{array}{c}\text { Latin } \\
\text { America }\end{array}$ & $\begin{array}{l}\text { Western } \\
\text { Europe }\end{array}$ & China & $\begin{array}{c}\text { OECD } \\
\text { Pacific } \\
\text { Rim }\end{array}$ & $\begin{array}{l}\text { East } \\
\text { Asia }\end{array}$ & $\begin{array}{l}\text { South } \\
\text { Asia }\end{array}$ & $\begin{array}{l}\text { Central } \\
\text { and } \\
\text { Eastern } \\
\text { Europe }\end{array}$ & FSU & $\begin{array}{c}\text { Middle } \\
\text { East }\end{array}$ & Africa & $\begin{array}{l}\text { World } \\
\text { Total }\end{array}$ \\
\hline \multicolumn{13}{|l|}{ Generation } \\
\hline Solid Fuel & 94 & 22 & 102 & 222 & 51 & 100 & 71 & 19 & 24 & 2 & 27 & 734 \\
\hline Natural Gas & 32 & 23 & 89 & 1 & 14 & 41 & 13 & 10 & 33 & 27 & 16 & 298 \\
\hline Oil & 1 & 8 & 1 & 0 & 0 & 1 & 1 & 7 & 2 & 2 & 6 & 29 \\
\hline Nuclear & 6 & 3 & 8 & 18 & 39 & 21 & 6 & 3 & 26 & 0 & 0 & 129 \\
\hline Renewable. & 17 & 52 & 15 & 67 & 5 & 6 & 48 & 5 & 13 & 3 & 5 & 235 \\
\hline Subtotal . . . & 149 & 108 & 215 & 308 & 108 & 169 & 139 & 44 & 98 & 34 & 54 & 1,426 \\
\hline \multicolumn{13}{|l|}{ Other Investments } \\
\hline Transmission .. & 14 & 42 & 20 & 31 & 10 & 28 & 23 & 3 & 14 & 4 & 12 & 200 \\
\hline Distribution. . . . & 54 & 36 & 78 & 84 & 39 & 61 & 60 & 11 & 30 & 10 & 19 & 480 \\
\hline General ..... & 14 & 17 & 20 & 43 & 10 & 17 & 21 & 6 & 14 & 5 & 7 & 173 \\
\hline Subtotal . & 82 & 94 & 118 & 156 & 59 & 105 & 103 & 19 & 58 & 18 & 38 & 854 \\
\hline Total ...... & 231 & 202 & 333 & 467 & 167 & 275 & 242 & 63 & 156 & 52 & 91 & 2,279 \\
\hline Annual Average. . & 15 & 13 & 25 & 31 & 11 & 18 & 16 & 4 & 10 & 3 & 6 & 152 \\
\hline
\end{tabular}

Note: North America includes Canada and the United States; Western Europe includes European Union countries, Finland, Switzerland, Iceland, Norway, and Turkey. OECD Pacific Rim includes Australia, Japan, and New Zealand. Central and Eastern Europe includes Albania, Bulgaria, Czech Republic, Hungary, Poland, Romania, Slovakia, former Yugoslavia. East Asia includes Brunei, Hong Kong, Indonesia, Kampuchea, Laos, Malaysia, North Korea, Papua New Guinea, Philippines, Singapore, Republic of Korea, Taiwan, Thailand, Vietnam, Pacific Islands, Afghanistan, Mongolia. South Asia includes Pakistan, India, Bangladesh, Nepal, Sri Lanka. Latin America includes Mexico and all South and Central American nations, as well as the nations of the Caribbean. Middle East includes Israel, Jordan, Iran, Iraq, Kuwait, Lebanon, Oman, Qatar, Saudi Arabia, Syria, United Arab Emirates, and Yemen.

Source: Estimates by Resource Dynamics, based on International Energy Agency, World Energy Outlook 1995 (Paris, France, 1995), Capacity Constraints Scenario, base case.

barriers for domestic or foreign investors has spawned the development of independent power producers that significantly augment power generation capacity.

Although global capital markets and the global pool of savings are considered adequate to the task of funding future electricity investments, for several nations investment funds may not be forthcoming unless difficult electricity policy reforms are adopted. These reforms are necessary in order to provide investors (both foreign and domestic) with expectations of achieving adequate rates of return at acceptable levels of risk. The state and methodology of policy reform varies widely among developing nations. Clearly, however, there is strong pressure toward reform. Significant policy reforms are underway in developed countries as well, where the pressure for reform stems from an expectation that increased competition will reduce the cost of electricity. The precise character of reform varies widely among countries, and in most areas it is still evolving.

\section{Regional Highlights}

\section{Developing Asia}

Of all the regions, Asia is expected to show the most rapid increase in economic growth and electricity con- sumption over the next few decades. Whereas developing Asia accounted for only 16 percent of total world electricity consumption in 1995, it is expected to account for 42 percent of demand growth between now and 2020.

\section{China}

In part, China's vast size will drive the growth of electricity demand. China, with 1.2 billion people, is the world's most populous nation. It also has had one of the fastest growing economies in recent years, a trend that is projected to continue, although at a reduced rate.

Electricity consumption in China is expected to grow at a 5.8-percent annual rate over the forecast period. The high level of coal use in China's electricity industry reflects the country's ample coal reserves. China accounts for nearly one-third of all world coal production [4, p. 73] and has about 11 percent of the world's coal reserves [2, p. 30]. As a consequence, coal accounted for 76 percent of China's electricity fuel in 1995 (Figure 76). That share is expected to fall slightly by 2020 , even while overall coal consumption increases threefold. Renewables (largely hydropower), which accounted for 19 percent of China's electricity consumption in 1995, are expected to have a 14-percent share of the power 
market in 2020. Nuclear's share is expected to rise from 1 percent in 1995 to 3 percent in 2020. As electricity fuels, oil (at about 6 percent) and natural gas (less than 1 percent) provide the remaining inputs to China's electric power industry. The relative importance of both fuels is expected to change little over the forecast period.

\section{Figure 76. Energy Consumption for Electricity Generation in China, 1995 and 2020}

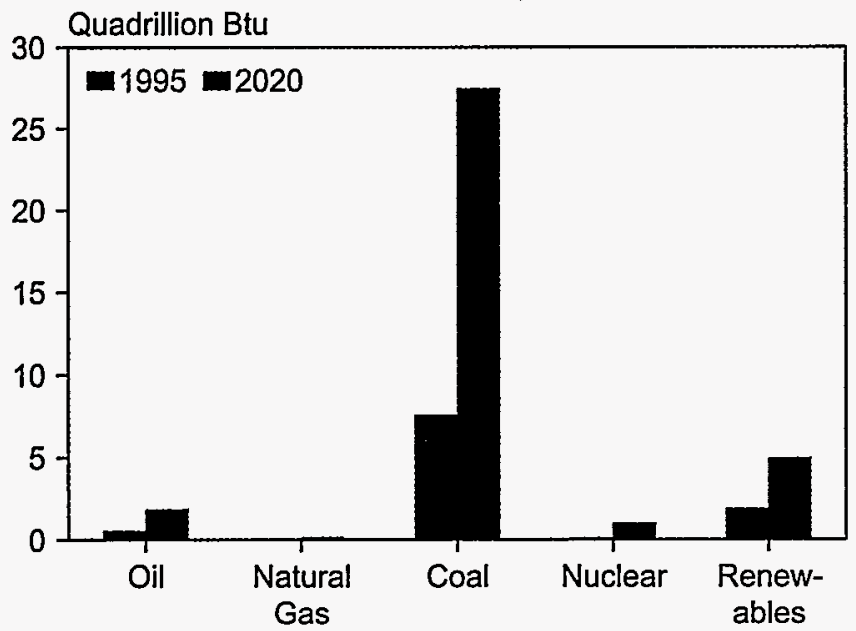

Sources: 1995: Derived from Energy Information Administration (EIA), Office of Energy Markets and End Use, International Energy Annual 1996, DOE/EIA-0219(96) (Washington, DC, February 1998). 2020: EIA, World Energy Projection System (1998).

China recently broke ground on what is to be the largest hydroelectric project in the world, the Three Gorges Dam project. Upon completion in 2010, the project is expected to have a total capacity of 18.2 gigawatts and produce 85 billion kilowatthours of electric power per year [5, p. 76]. Largely due to the Three Gorges project, hydroelectric power production is expected to more than double between 1995 and 2010 but remain relatively flat for the remainder of the forecast period. (For a more detailed discussion of China's Three Gorges Dam project, see pages 105-107.)

Rural electrification is a major goal of Chinese energy policy. Brownouts and blackouts are common, and electric power production has not kept pace with the rapidly expanding Chinese economy. It is estimated that onetenth of China's population-or roughly 100 million people-are currently without electricity. Per capita consumption in China is only 6 percent that of the United States [4].

China's growing electric power investment needs on top of other investment needs has led to the encouragement of foreign investment in its electricity market. Between 1979 and 1996, 10 percent of the investment in China's electric power industry was foreign [6]. Up until 1992, foreign investment in China's electricity sector was limited to "overseas export/import bank financings, supplier credits, and other concessionary financing techniques." Since 1992, the Chinese government has allowed foreign direct investment on a limited basis [7]. Relatively large investments in electric power by foreign entities require central government approval. In electricity most foreign investment has involved joint ventures of local and foreign entities, although build-operatetransfer (BOT) schemes have become a growing means of finance. Between 1996 and 2000, China intends to increase its electricity capacity by roughly half, at a cost of $\$ 100$ billion. China is expecting foreign investors to fund roughly a quarter of this investment [7]. China has taken measures to increase direct access to world capital markets for its large electricity enterprises in recent years. In 1994, China listed two major holding companies with electricity generation assets on the New York Stock Exchange [8]. In addition, investment capital has also been raised through the issuance of non-investment grade debt in United States fixed income markets [9].

In late 1996, China approved a new BOT framework for the Laiban B power project, a 700-megawatt coal-fired plant [10]. The contract was awarded through a competitive bidding process that allowed the winning bidder to assume 100 percent ownership. The purchasers were Electricite de France and GEC Alsthom for $\$ 650$ billion [11]. Unlike previous projects, where rates of return were negotiated, the cost per kilowatthour was negotiated, which provides the operators of Laiban B with a strong incentive to boost profits by reducing costs.

\section{India}

India's position as the world's second most populous nation, and one whose economic growth rate has increased in recent years, is expected to increase its consumption of electricity considerably over the forecast period. India is the other Asian giant. India's population, at nearly 1 billion people, is second only to China's. In Asia, India's future electric power needs are also second only to China's. Like China, India has in recent years stepped up its pace of economic growth. Currently, the Indian economy is expected to expand at about 5.5 percent per year through 2020. Electricity demand is expected to increase at a slightly higher rate of about 7 percent per year through 2005, before slowing to 4.4 percent between 2005 and 2020. At present, electricity shortages are a serious problem in India. Outages average 20 percent of demand during peak use hours and 10 percent during off-peak use [12].

Coal currently accounts for 78 percent of fuel use at India's electric power stations (Figure 77). As in China, India's high coal use is a reflection of its ample coal reserves. Renewable energy (almost entirely hydropower) is the next largest source of electricity supply in India. In 1995, renewables accounted for 14 percent of India's electricity generation. Natural gas (at about 5 percent), oil (at 2 percent), and nuclear power (at just 
under 2 percent) provided the remaining fuels to India's electricity industry. In the forecast, a growing role is projected for natural gas, nuclear, and renewables at the expense of coal and oil.

\section{Figure 77. Energy Consumption for Electricity Generation in India, 1995 and 2020}

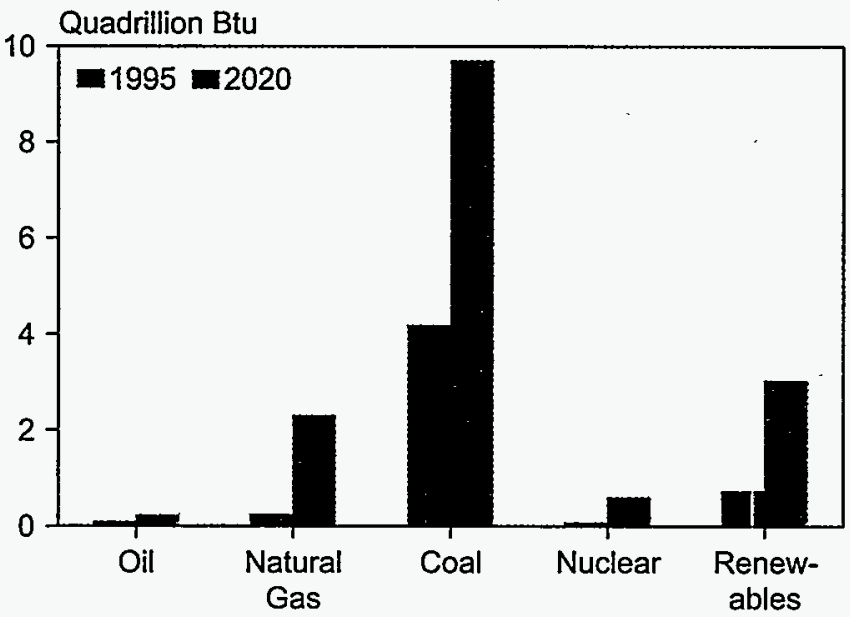

Sources: 1995: Derived from Energy Information Administration (EIA), Office of Energy Markets and End Use, International Energy Annual 1996, DOE/EIA-0219(96) (Washington, DC, February 1998). 2020: ElA, World Energy Projection System (1998).

To sustain the expected growth rate in electricity consumption, large investments in electricity infrastructure will have to be made. The Indian government is currently counting strongly on private sources for the necessary investment funds. Of the 40 gigawatts of generating capacity to be built between 1997 and 2002, nearly half is expected to be funded from private sources [13]. The central government's expectation is that foreign capital will account for much of that investment.

In 1991, the national government enacted legislation to encourage greater private sector involvement in independent power production. India has further encouraged foreign investment by eliminating industrial licensing, privatizing state-owned companies, and reducing tariffs and trade restrictions on the importation of electricity equipment. In 1994, the central government announced that it would offer counter guarantees to eight power purchasing agreements approved and sponsored by state electricity boards [14]. Later, the government allowed foreign investors to obtain 100-percent ownership in electric power projects. Initially, foreign investment was restricted to power generation projects, but in 1997 the electricity laws were amended to allow foreign investment in transmission lines [15].

Although in general the central government in India has taken a leading role in promoting national electricity reform, state governments have also played a role in shaping electricity policy, and not always a supportive one. In India, the state electricity boards share responsibility along with the national government for the provision of electricity. State governments run their respective electricity industries through the state electricity boards. Each state has a board, which is a vertically integrated electricity operation providing generation, transmission, and distribution services. Currently, many of the boards are bankrupt, largely because, in response to political pressures, they have set electricity tariffs that have been insufficient to cover costs [14].

Legally, both the national and state governments are responsible for the production, transport, and distribution of electricity, although each government's exact responsibility is unclear [16]. Decisions affecting electricity reform have often taken on a partisan political nature, as evidenced by a recent dispute between Enron and the state government in Maharashtra that has served to undermine India's creditworthiness with the international financial community. In 1995, a newly elected nationalist Maharashtra state government decided to cancel a $\$ 2.8$ billion power plant developed by the Enron Corporation after Enron and its partners (Bechtel Enterprises and the General Electric Company) had already spent $\$ 300$ million. Enron later successfully renegotiated a deal with the state government in early 1996, which called for a reduction in electricity rates and eventually allowed the project to proceed. The plant is initially to use oil as a fuel, but Enron's intention is to convert the facility so that it runs on imported LNG in future years.

Some Indian state governments have attempted to be more hospitable to foreign investment. Before the adoption of reform measures in Orissa, electricity shortages were common, tariffs were unsustainably low, and the state faced an insurmountable level of capital expenditures for much-needed industry upgrades and expansion. In April 1996, the Orissa state government appointed a new independent regulatory commission and did away with the former state electricity board [17]. Orissa was the first state to create an independent regulatory commission [18]. The regulatory commission was mandated with the task of setting tariffs, issuing licenses, conducting competitive procurement bids, and monitoring financial performance standards. Orissa also restructured its electricity industry along functional lines, creating different units responsible for generation, transmission, and distribution. Privatization of the stateowned electricity company, Grid Corporation is planned for 1998 [17]. Largely as a result of these reform efforts, foreign companies have targeted Orissa for electricity investments. For instance, the U.S.-based independent power producer AES plans to build two 250-megawatt coal plants in the state. 


\section{Paklstan}

India's neighbor to the northwest, Pakistan, has been one of the most aggressive of nations in adopting and implementing electricity reform. Although significantly smaller than India (Pakistan's economy is approximately one-eighth the size of India's), Pakistan has thus far attracted foreign investment sums into its electricity sector that easily exceed those committed to its neighbor. According to the World Bank, foreign direct investment commitments to Pakistan's electricity sector of roughly $\$ 9$ billion may even exceed commitments to electricity investments in China as well [19].

Two agencies are responsible for electricity supply in Pakistan. For Karachi, Pakistan's largest city, power is the responsibility of the Karachi Electric Supply Corporation (KESC), and the Water Power Development Authority (WAPDA) has the responsibility for the rest of the country. These agencies are vertically organized electric utilities providing both electricity generation and distribution services. At the urging of the World Bank, WAPDA is being reorganized and separated along functional lines. In the future Pakistan intends to privatize both KESC and WAPDA.

To meet its growing power needs, Pakistan has actively encouraged private investment to build power generation plants. The Pakistani government is also encouraging BOT agreements, both for new power projects and for some of the thermal power stations managed by the country's major utility. The first major project involving foreign investment is the 1,292megawatt Hub Power Company plant, which was completed in 1997. A consortium of domestic and foreign companies have provided funding for $\mathrm{Hub}$ Power. Prominent among them are National Power of the United Kingdom (25-percent share), Xenel of Saudi Arabia (15-percent share), and Entergy of the United States (10-percent share).

By 1996, Pakistan had reached financial closure on at least 10 independent power projects. Foreign investors involved in these projects include the U.S. companies AES, Coastal Power, and El Paso Energy; Tomen, Mitsubishi, and Toyota Tsucsho of Japan; Siemens of Germany; and Southern Electric Power of the United Kingdom.

\section{Southeast Asia}

In mid-1997, several Southeast Asian nations experienced financial difficulties characterized by steep currency depreciations and sharp drops in domestic asset values. The crisis was in part precipitated by the accumulation of excessive levels of foreign debt, trade imbalances, and speculative financial investments. Whether it is purely a financial crisis, or whether it will have an impact on the real economies of these nations, is at the moment uncertain. Currently, the crisis has diminished, but the near-term growth prospects for Malaysia, Thailand, Hong Kong, Indonesia, South Korea, and the Philippines have been affected. Nonetheless, fairly rapid recovery and a resumption of relatively high rates of economic expansion are expected.

Electricity demand in Southeast Asia is expected to be nearly three times higher in 2020 than it was in 1995. Over the past decade, electricity growth has averaged in the range of 10 percent per year, a rate of growth that is expected to continue. Much incremental demand was powered by oil, and the area's reliance on oil for generation is among the highest in the world. However, primary energy use is now being diversified. Taiwan and South Korea have nuclear capacity in place or under construction, and South Korea also consumes significant quantities of coal and growing quantities of imported LNG.

For the region as a whole, future capacity expansion is likely to favor natural gas. Malaysia, Thailand, Indonesia, and the Philippines all have pipeline-based power generation under construction or planned. In the long term, Indonesia hopes to phase out oil-fired generation to free up indigenous oil production for export. Malaysia and Thailand, along with Myanmar, are developing a gas pipeline network to exploit indigenous resources. The Philippines has little in the way of domestic fossil fuel resources, but natural gas discoveries offshore are expected to support large-scale independent power production within the decade. Both Taiwan and South Korea have significant plans for natural-gas-fired power generation; however, neither will have access to pipeline supplies, and thus they plan to rely on imported LNG.

To varying degrees, power shortages and high investment needs have induced changes in electric utility policy in several countries of Southeast Asia over the past decade. In the Philippines, power shortages led to the passage of legislation in the early 1990s that called for the eventual privatization of the nation's electric utility enterprises. In 1993, the entry of independent power producers was legislatively approved. Fast track approval of electric power contracts was also introduced. An Omnibus Electric Power Act, which is currently pending approval, is expected to lead to the privatization of the National Power Company and to a separation of its functional operations into separate entities.

These policy measures were effective in solving the Philippines electricity crises. A recently evolved independent power producing industry today provides 35 percent of the country's total generating capacity [20]. Currently, the Philippines has 33 independent power producers. Foreign investment has also played a critical 
role. Since 1990, an estimated \$1 billion in foreign dollars has flowed into Philippine electricity investments [21]. Under its 1996-2005 plan, the Philippines expects investments of $\$ 19$ billion in its electricity sector, 80 percent of which is expected to be private and 47 percent from overseas sources $[20,21]$.

Rapidly growing electricity consumption has induced electricity reform and encouraged the development of independent power projects in both Malaysia and Thailand. The Malaysian government aims to increase the country's electricity generating capacity from 9,300 megawatts in 1995 to 33,000 megawatts by 2020 . Currently, there are six independent power producers in various stages of development in Peninsular Malaysia.

In 1992, Thailand implemented several electricity industry reforms aimed at reducing the power of the national electricity monopolies through commercialization and privatization. The eventual privati-zation of EGAT, Thailand's state-owned electricity company, is planned [5, p. 341]. The Thai government has encouraged the development of an independent power production industry, and currently several independent power projects are underway. Thailand plans to allow independent power producers to provide over 4,000 megawatts of power by the year 2002, through BOT or build-own-operate (BOO) schemes. The Thai government intends to allow 100-percent foreign ownership in these projects [5, p. 342]. Currently, the U.S.-based companies Black and Veatch, Texaco, Unocal, and Westinghouse have acquired interests in Thai independent power [22].

To this point, government enterprises have dominated electricity supply development in South Korea and Taiwan, which have long been among Asia's most rapidly growing economies. Electricity consumption has also grown rapidly in both countries and is expected to continue to do so in the future. Between 1986 and 1995, electricity consumption in South Korea and Taiwan more than tripled [4, p. 87].

South Korea's electricity industry is dominated by the state-owned electricity company, the Korean Electric Power Corporation (KEPCO). Although the government of South Korea has indicated that it intends eventually to privatize KEPCO, no progress has been made to date.

South Korea is planning to significantly increase its use of natural gas, largely LNG, as an electrical fuel in future years. South Korea is the second largest importer of LNG after Japan [2, p. 28]. South Korea is also expected to rely increasingly on nuclear power as a source of electricity. In 1994, nuclear power provided about a third of its electricity [4, p. 93]. Coal accounted for 23 percent of South Korea's electricity fuel market in 1995 and it is expected to maintain its share [5, p. 294].

As in South Korea, electricity in Taiwan is dominated by a single company, the state-owned Taiwan Power Company, (Taipower) [5, p. 315]. Taipower is a vertically integrated monopoly that provides generation, transmission, and distribution services. The electricity fuel market is almost evenly supplied by coal ( 23 percent), nuclear (20 percent), and oil (21 percent). Hydropower (17 percent), other renewables (11 percent), and natural gas ( 8 percent) account for the remainder of the market. In the future, Taiwan will increase its reliance on natural gas, coal, and oil and significantly reduce its reliance on nuclear power.

\section{Central and South America}

In Central and South America, electricity consumption has grown substantially in recent years and is expected to maintain a fast rate of growth in the future. Between 1986 and 1995, electricity consumption in this region grew at a 4-percent annualized rate [4, p. 88], and electricity demand in the region is projected to grow at a 4.0-percent annual rate. To fund the necessary growth in electricity infrastructure just through the year 2010, Central and South American nations will need to spend an estimated $\$ 108$ billion [23].

Perhaps nowhere more than in Central and South America has there been a growing convergence between petroleum companies and electric power companies. Important progress in creating regional energy grids is underway for both natural gas and electricity. To this point, power generation in the region has relied heavily on hydropower, which will continue in the future; however, much of the future expansion of power generation will involve exploiting the region's abundant natural gas resources (Figure 78). Natural gas pipeline projects costing nearly $\$ 7$ billion are being implemented to connect natural gas producing areas in Argentina, Bolivia, Colombia, and Peru with consumers in Brazil and Chile. Other projects under consideration will connect Argentina with Paraguay and Uruguay [24, 25]. Much of the expected natural gas trade will fuel electric power plants in Brazil and Chile, both of which suffer from substantial air pollution problems and pending shortages of electric power supply. Among the participants in the natural gas pipeline projects are several U.S.-based companies, including CMS Energy, El Paso Energy, and Enron [26].

Brazil is far and away Central and South America's largest economy. It is the world's fifth most populous country and accounts for almost half of Central and South America's economic output. Brazil is projected to account for 77 percent of the growth in the region's 
Figure 78. Energy Consumption for Electricity Generation in Central and South America, 1995 and 2020

Quadrillion Btu

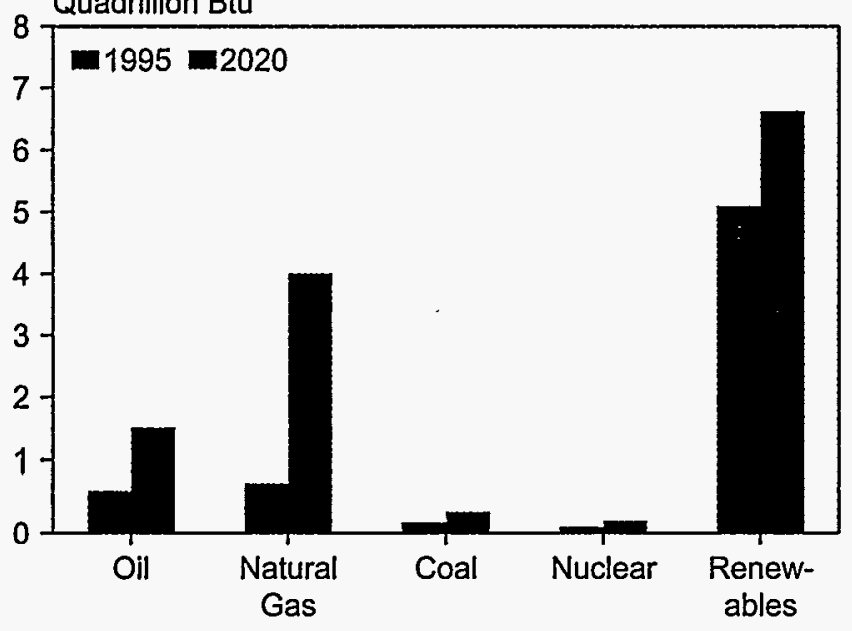

Sources: 1995: Derived from Energy Information Administration (EIA), Office of Energy Markets and End Use, International Energy Annual 1996, DOE/EIA-0219(96) (Washington, DC, February 1998). 2020: EIA, World Energy Projection System (1998).

electricity consumption between 1995 and 2020 . Currently, hydroelectricity accounts for more than 90 percent of Brazil's installed electricity capacity [27]. Over the 1995-2020 forecast period, Brazil's electricity consumption is expected to increase at a rate of 5.3 percent per year. Much of that expansion will be based on fossil fuels, in particular, natural gas.

Improved economic performance in Central and South America is a product of a variety of forces. Perhaps none is more important than reformed government policies that have promoted greater reliance on market forces to direct resource allocation and improve economic efficiency. Led by Chile, and later Argentina, there is a strong trend toward privatization across various industries and introduction of economic incentives to encourage greater domestic and international investment. The electric utility sector has been an important focus of reform efforts. In both Chile and Argentina the utility sector has been largely privatized.

In Brazil, the privatization process is underway but far from finished. Because of its size, in Brazil even partial progress involves many billions of dollars of new investment, much of which is coming from abroad. In the state of Sao Paulo, for instance, the former electric utility was transformed into 6 generation companies, 1 transmission company, and 14 distribution companies. Companhia Paulista de Foca e Luz, a Sao Paulo distribution company, was sold to a consortium of Brazilian companies for $\$ 3.02$ billion. In the state of Rio Grande de Sol, the electricity distribution company, Cetro Oeste de Distribuicao de Energia Eletrica, was sold to U.S.-based AES Corp for $\$ 1.37$ billion, and Norte-Nordeste de
Distribuicao de Energia Eletrica was sold to U.S.-based Community Energy Alternatives and two Brazilian partners for $\$ 1.5$ billion [28]. This was the second largest privatization in Brazil (the largest involved the sale of a mining company, Companhia Vale do Rio Doce SA). Public Service Enterprise Group and its partners agreed to purchase a 91-percent stake in one of the distribution companies for $\$ 1.49$ billion [29]. Chile's Chilectra has also invested in a Brazilian distribution company. Currently, the sale of the assets of the federally owned electricity company, Electrobras, is scheduled for 1998. Electrobras controls roughly half of all the generation capacity in Brazil.

In most other South American countries some form of regulatory reform and privatization is underway or about to begin; however, commitments to privatization and relaxation of restraints on private investment are not universal. Venezuela, for example, has postponed privatization plans for electricity, and only partial privatization has been approved in Bolivia, Peru, and Uruguay. Throughout the region, although the pace of reform may vary, the direction of change is consistently toward liberalization of conditions that would favor enhanced investment incentives.

\section{North America}

In North America energy trends in the United States and Canada closely resemble those in Western Europe and Australia, in that energy demand growth of slightly more than 1 percent per year is projected-about half the rate of growth in GDP. In contrast, Mexico's economic growth and energy demand are expected to be much more robust, in the range of 3 to 5 percent per year.

In both the United States and Canada, electricity consumption is expected to rise by about one-third over the forecast period and at a rate that exceeds growth in overall energy use. Although both countries have Annex I commitments under the Kyoto Protocol, current trends in primary energy use indicate growing reliance on fossil-based primary energy for power generation.

The United States is far and away the world's biggest consumer of electricity, consuming one-third of the world's total electricity supply. Electricity consumption in the United States is expected to grow at a modest 1.2percent annual rate from 1995 through 2020. Electricity consumption growth is expected to trail overall economic growth, as is typical for an advanced industrial economy.

Over the forecast period, nuclear power's role as a producer of electricity in the United States will diminish considerably. Nuclear power, which accounted for 20 percent of all U.S. electricity produced in 1995, is expected to account for only 9 percent in the year 2020 
(Figure 79). The last nuclear power plant to be commissioned in the United States was completed in 1996 [30], and there are currently no plans to build any others. Natural gas will largely make up for the shortfall in nuclear production. Natural gas, which accounted for just under 10 percent of electricity production in the United States in 1995, is expected to claim a 22-percent share of the electricity market in 2020. Greater domestic production of natural gas and increased imports from Canada will accommodate the increase in natural gas use as an electricity generation fuel. Coal's role as an electricity fuel is expected to change very little, accounting for 49 percent of the electricity fuel market in 1995 and 50 percent in 2020.

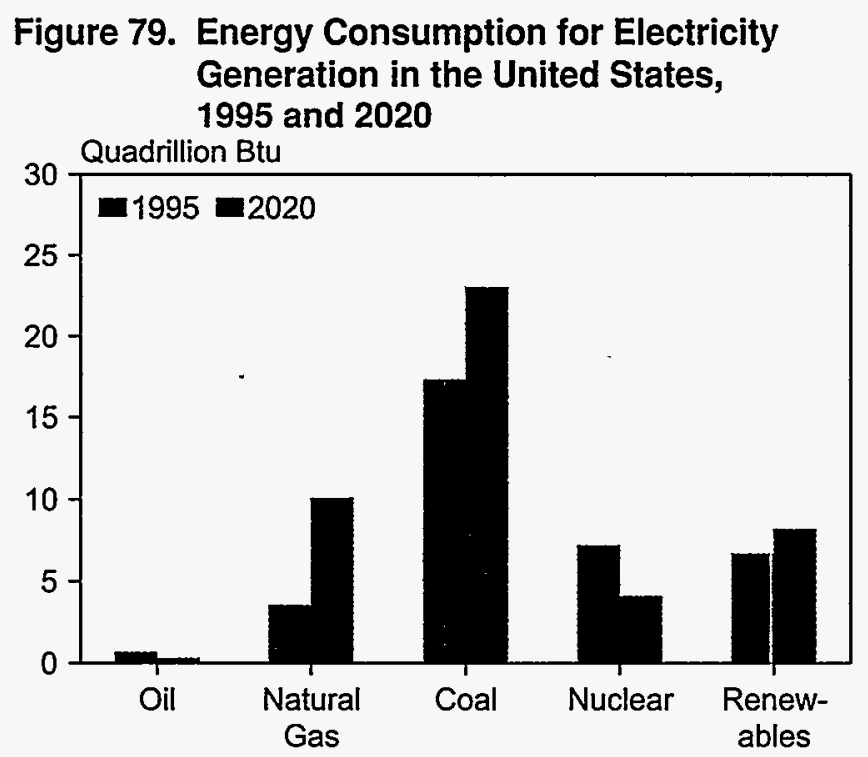

Source: Energy Information Administration, Annual Energy Outlook 1998, DOE/EIA-0383(98) (Washington, DC, December 1997), Table A2.

Future Canadian electricity supply will also depend significantly less on nuclear power and more on natural gas. Canada has an abundance of hydroelectric resources and in 1995 obtained almost 60 percent of its electricity from hydropower, a level that is expected to increase slightly over the forecast period.

In Mexico, electricity demand growth is expected to exceed 4 percent per year as living standards rise and electrification is extended. The course of development in the Mexican economy is expected to resemble that seen in other emerging economies in Latin America and in Asia. Although energy use per capita has risen substantially in Mexico in recent years, electricity consumption is still a small fraction of that enjoyed by its northern neighbors. Mexico is expected to show a relatively rapid rate of electricity consumption growth over the forecast period.

As in the rest of North America, primary fuel use is expected increasingly to favor natural gas. Coal and nuclear power account for relatively little generation in Mexico, which currently relies on oil-fired plants for roughly half of its electricity needs (Figure 80). Both cost and environmental concerns are encouraging increased use of natural gas. The share of electricity fired by natural gas is expected to rise from 11 percent in 1995 to 27 percent in 2020 . The rate of increase will be constrained more by infrastructure than by basic resource availability.

\section{Figure 80. Energy Consumption for Electricity Generation in Mexico, 1995 and 2020}

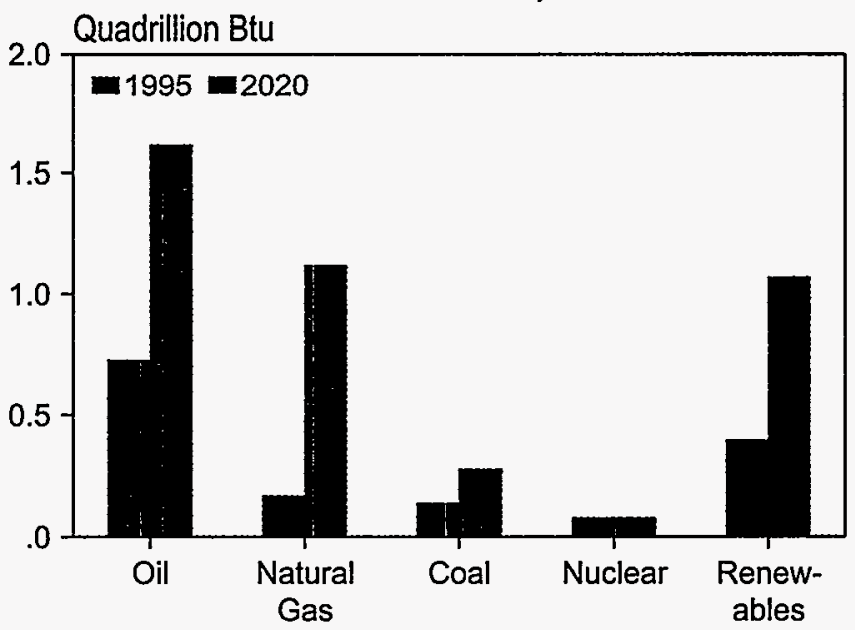

Sources: 1995: Derived from Energy Information Administration (EIA), Office of Energy Markets and End Use, International Energy Annual 1996, DOE/EIA-0219(96) (Washington, DC, February 1998). 2020: EIA, World Energy Projection System (1998).

Electric utility regulatory reform is underway throughout North America. In the United States and Canada the driving force of reform is the expectation that increased competition will lower costs of electricity supply. In the United States, reforms are being carried out at both the national and State levels. In 1996, the national regulator, the Federal Energy Regulatory Commission, issued Order 888 and Order 889 . Order 888 addresses the issue of open access and provides an additional guideline for the recovery of stranded costs [31]. Order 889 requires utilities to establish electronic systems on the availability of transmission capacity. Several States are also implementing reforms. Furthest along are California and several northeastern States. State-led reform efforts have often involved the creation of electricity pools, divestiture of transmission assets, the introduction of independent system operators, the adoption of different forms of pricing, and the unbundling of rates. Overshadowing efforts at electricity reform has been the problem of how to allocate the stranded costs largely associated with previous investments in nuclear power, which despite Order 888 are still yet unresolved.

As the use of natural gas for electricity generation has increased in recent years, there has been a growing 
integration of the U.S. natural gas and electricity industries. Just in the past few years, several large mergers and acquisitions have taken place between natural gas transmission and distribution companies and electricity companies. These transactions have been driven both by a changing economic environment and by regulatory changes.

Canada is also currently in the midst of several attempts to reform the commonwealth's electricity sector. Most reform efforts are taking place at the provincial level. Recent reforms are motivated by a desire to reduce Canadian electricity costs. The reforms should also serve to integrate the U.S. and Canadian electricity markets more closely. As with State governments in the United States, provincial governments in Canada are largely responsible for electricity policy. In recent years the provincial government of Alberta has been a leader in electricity reform. Alberta's Electric Utility Act of 1995 created a competitive market in generation, instituted location-based rates, and created a power pool for spot trading in electricity [32]. In 1996, the U.S. Federal Energy Regulatory Commission (FERC) approved a request by Alberta's main utility, TransAlta Utility Corporation, to sell power in the United States [33].

Ontario and Quebec are respectively Canada's first and second largest provinces and home to Canada's two largest utilities, Ontario Hydro and Hydro Quebec. Ontario Hydro is owned by the provincial government of Ontario. In November 1997, the Ontario provincial government announced its intention to break up-but not privatize-Ontario Hydro along lines of business [34]. Under the proposed plan, the utility would be broken into two separate companies [35]. Electricity generation would become the responsibility of the newly created Electricity Generation Corporation, and transmission and distribution would become the responsibility of the newly created Ontario Electric Services Corporation.

Although the new generation company will continue to be owned by the provincial government, it is to be operated as a commercial enterprise, competing with outside producers, earning a profit, and paying taxes. The transmission and distribution company is expected to continue to be a regulated monopoly. Both the transmission and distribution segments are to provide open access to outside producers. An independent system operator is to be established as a "separate publicly controlled Crown Corporation to oversee operations of the new system and to ensure that customers receive access to electricity at reasonable prices and in the most efficient way possible" [35]. As in the United States, stranded costs largely associated with past investments in nuclear power have severely hampered Ontario's attempts at electricity reform.
Hydro Quebec has targeted the U.S. market for future sales growth. Hydro Quebec currently owns Vermont Gas and has signed a deal with Enron to market electricity in the Northeast while selling Enron's gas in Quebec. In April 1997, Hydro Quebec petitioned the FERC to sell electricity in the United States. In return, it would allow U.S. competitors to wheel electricity into Quebec. In November 1997, Hydro Quebec received FERC approval to sell power in the United States at market-based rates.

In Mexico, regulatory reform is designed to enhance the availability of investment capital to fund industry expansion. Until recently, foreign investment in energyrelated activities was prohibited, and it is still prohibited in most upstream petroleum activities. However, regulations are being liberalized, especially for power generation and natural gas transmission and distribution. As a consequence, a variety of cogeneration and independent power generation projects have been proposed by U.S. sponsors, and some are already under construction.

\section{Western Europe}

Electricity consumption among Western European nations in IEO98 reference case is expected to grow by only 2.4 percent annually from 1995 through 2020 . The moderate growth in electricity use reflects the region's advanced state of economic development.

Of all regions, Western Europe relies most heavily on nuclear power as a source of electricity supply. Nuclear power accounts for a third of Western Europe's electricity supply' largely because France is the second largest producer of nuclear electricity after the United States. Coal ranks second as a source of electricity generation in Western Europe, followed by renewables (primarily hydropower), natural gas, and oil.

In future years, Western Europe is expected to reduce its reliance on nuclear power and, to a lesser extent, on coaland oil-fired generation (Figure 81). Natural gas use is expected to grow. In 2020, the nuclear share of the electricity market is expected to be about one-fifth of the total. Although use of coal as a generation fuel is expected to increase over the forecast period, its share of the overall electricity fuels market is also expected to decline, to 21 percent from 27 percent in 1995. In recent years, coal production in the United Kingdom and Germany has fallen off dramatically. In the United Kingdom, the reduction is largely due to the coal industry's privatization, the removal of coal subsidies, and the privatization of the electricity industry. In Germany, coal subsidies have been removed much more slowly, but German reunification and the retirement of a large number of former East Germany's obsolescent coal-fired electricity plants, have resulted in a sharp drop in coal 
Figure 81. Energy Consumption for Electricity Generation in Western Europe, 1995 and 2020

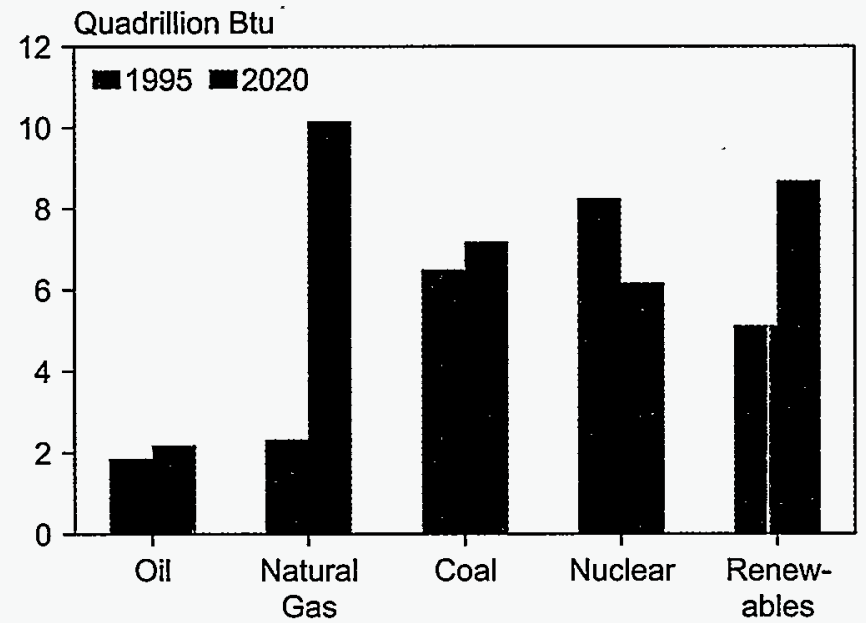

Sources: 1995: Derived from Energy Information Administration (EIA), Office of Energy Markets and End Use, International Energy Annual 1996, DOE/EIA-0219(96) (Washington, DC, February 1998). 2020: EIA, World Energy Projection System (1998).

demand. The growing availability of natural gas imports from the former Soviet Union, Norway, and North Africa, in concert with environmental considerations, has encouraged greater use of gas as a fuel for electricity generation. Recent advances in gas-fired electricity generation technology that reduce overall capital requirements have also encouraged the switch to gas.

Europe's electricity industry is likely to become more integrated in the future. In 1997, the European Parliament adopted a directive with the intent to provide independent producers with greater access to other countries' power networks [36]. Led by the United Kingdom, several Western European countries have undertaken important electricity reforms. To varying degrees these reforms have reduced government oversight and increased the role of market forces in balancing electricity supply and demand. Currently, Sweden and Norway operate a joint electricity pool, and Finland is scheduled to join the pool in early 1998.

The United Kingdom first began to privatize its electricity industry in 1990 and completed the final phase of privatization in 1996. Privatization of electricity in the United Kingdom occurred in the context of a wholesale privatization of several other state-owned industries. Through 1995, the treasury has raised more than $\$ 95$ billion in revenue from privatization [37]. The United Kingdom's electricity framework has become a model for electricity reforms elsewhere, most notably, in Argentina and Australia. Motivating the UK's effort at electricity reform was the belief that the industry could be made more competitive through deregulation and privatization.

Other European nations have also implemented major electricity reform in recent years, but not all have privatized. Most nations have generally maintained state ownership while introducing market-oriented reforms. Major electricity reform efforts have been undertaken by Scandinavian nations. Sweden, for example, has moved toward competitive generation and distribution markets in local, regional, and national networks. In recent years, there have been several foreign investments in Sweden's electricity sector. In 1996, Norway's Statkraft purchased a share of Sweden's Sydkraft for \$179 million [38]. In addition to the Sydkraft purchase, a 25-percent share of Graninge was purchased by Electricite de France and a 12-percent share by Germany's Preussen Elecktra [39]. Imatran Voima Oy (IVO), the state-owned Finnish power company, purchased a 50-percent share of Gullspangs Fraft, another Swedish utility [40].

In general, liberalization of regulatory rules throughout Europe is eroding national boundaries for industrial operation and for investment development strategies. Thus, throughout the area, the utility sector has become the potential focus of rivalry for a wide range of enterprises located in Europe and beyond. In Italy, for example, ENEL, the state-owned electricity company, is simultaneously being privatized while entering into investment alliances with two U.S. companies, Enron and Entergy. In Portugal, several foreign companies have invested in the country's electricity industry, include EdF (of France), Endesa (of Spain), National Power (UK), and PowerGen (UK).

Electricite de France (EdF), Europe's largest electricity company, is state owned. In recent years, it has sought to evolve from a national utility to an international energy company. As a consequence, it is involved in power projects in Argentina, Hungary, the Ivory Coast, Italy, Poland, Portugal, Spain, and Sweden. Similarly, Endesa, Spain's largest utility, has recently acquired electricity assets in Argentina, Chile, Costa Rica, El Salvador, Germany, Guatemala, Morocco, Nicaragua, Panama, Peru, and Venezuela [41].

U.S. companies are similarly evolving into international enterprises. The Energy Policy Act of 1992 (EPACT) liberalized the rules governing U.S. utility investment in electricity assets abroad, leading to a surge in investment overseas by U.S. electric utilities (Figure 82). Since 1992, U.S. companies have acquired 7 of the 12 electricity distribution companies in the United Kingdom. In the Australian state of Victoria, U.S. companies have acquired interests in all of the five electricity distribution companies, three of the state's five recently privatized electricity generation companies, and the state's 
Figure 82. U.S. Direct Investment in Overseas Utilities, 1988-1996

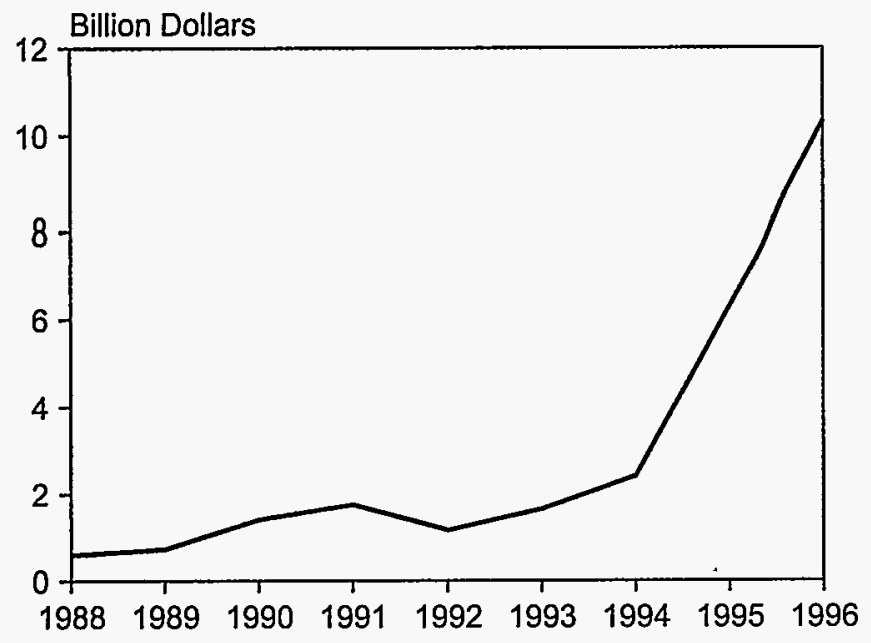

Note: These utilities include, in addition to electricity, natural gas distribution and sanitary services. However, the sharp upward climb in investments from 1994 through 1996 is almost entirely due to overseas electric utility investments by U.S. companies.

Source: U.S. Department of Commerce, Bureau of Economic Analysis, Survey of Current Business (Washington, DC, various issues).

transmission network. U.S. electricity companies have also made sizable electricity investments in several developing countries, including Argentina, Bolivia, Brazil, Columbia, India, and Pakistan.

\section{Japan and Australasia}

Japan is Asia's largest economy and its biggest consumer of electricity. Japan is the fourth largest electricity consumer in the world. Over the 1995 to 2020 forecast period, Japan is expected to show a relatively moderate electricity consumption growth rate of 1.8 percent per year, consuming more of all electricity fuels except for oil through 2020. Growth in natural gas consumption and coal and will outpace growth in the use of nuclear power and renewables (Figure 83). Japan's use of oil as an electricity fuel is expected to decline as its older oil-fired generation plants, many of which were built before the 1973 oil price shock, are retired [5, p. 163]. Japan is one of the few nations currently expanding its use of nuclear power, which now accounts for roughly one-third of its electricity supply.

\section{Australia and New Zealand}

In recent years, Australia and New Zealand have achieved relatively high rates of economic growth among the industrialized economies. Electricity demand in Australasia is expected to average nearly 3.2percent annual growth between 1995 and 2020. Australia has one of the world's most efficient coal industries, and coal accounts for 92 percent of the fuel input to its Australia's electricity industry. In contrast,
Figure 83. Energy Consumption for Electricity Generation in Japan, 1995 and 2020

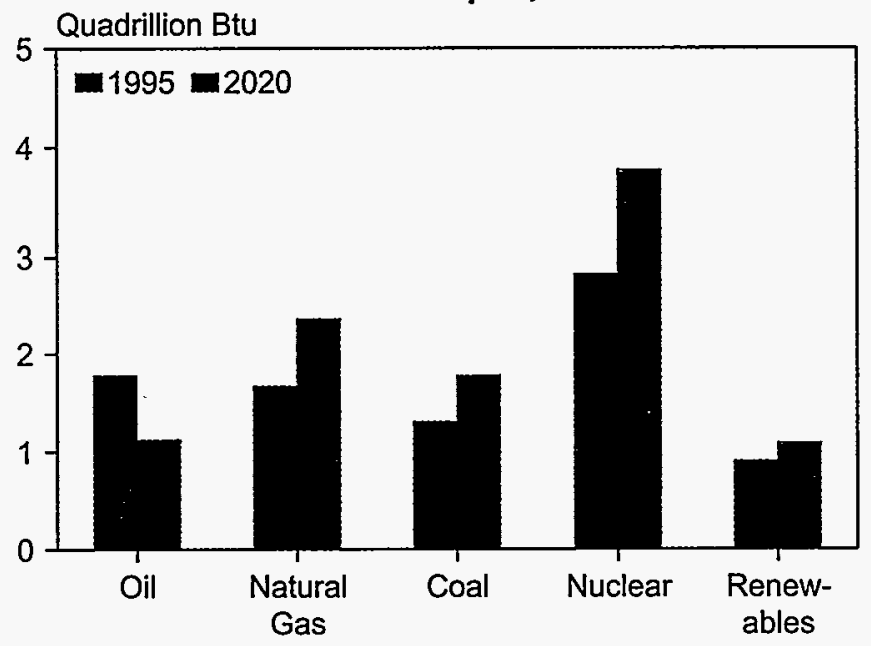

Sources: 1995: Derived from Energy Information Administration (EIA), Office of Energy Markets and End Use, International Energy Annual 1996, DOE/ElA-0219(96) (Washington, DC, February 1998). 2020: EIA, World Energy Projection System (1998).

New Zealand relies more heavily on hydroelectricity. Coal and hydropower are expected to continue to be the dominant sources of electricity for the two countries over the forecast period (Figure 84).

The winds of regulatory change are blowing in Asia as well. The electricity industry in Japan is highly concentrated and dominated by 10 vertically integrated regional electric utilities [5, p. 155]. Japan, like the United States, has long had an electricity industry that was privately owned. Utility companies supply 75 percent of

Figure 84. Energy Consumption for Electricity Generation in Australasia, 1995 and 2020

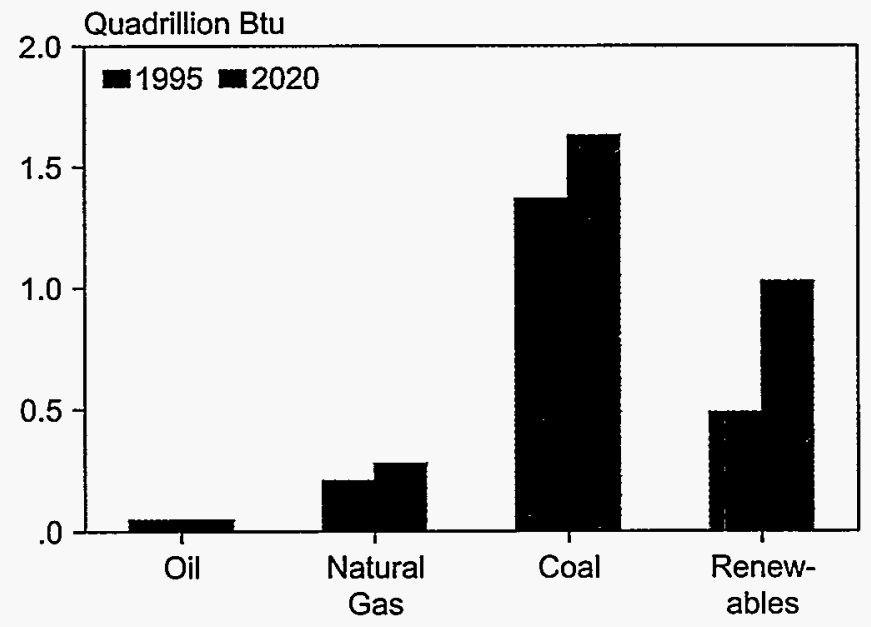

Sources: 1995: Derived from Energy Information Administration (EIA), Office of Energy Markets and End Use, International Energy Annual 1996, DOE/EIA-0219(96) (Washington, DC, February 1998). 2020: EIA, World Energy Projection System (1998). 
Japan's electric power, the remainder being supplied by the national organizations responsible for the supply of nuclear power and large-scale hydro and thermal power. The 10 vertically integrated regional electricity companies jointly own and operate Japan's national electricity transmission system [5, p. 155].

Currently, Japan has some of the highest electricity prices in the world. As a result, Japan is attempting to reform its electricity industry to increase competition. The goal of the effort is to cut electricity prices so that by the year 2001 they are comparable with those in other industrialized nations [42]. Japan has recently allowed independent power producers access to the grid and has encouraged regional utilities to purchase power directly from them [43]. Japan is also currently undertaking a study of its regulatory structure and the regulatory structures of other industrial nations to see what regulatory reform measures would best increase competition [44].

Since the early 1990s, Australia has undergone a series of national and state-sponsored electricity reform initiatives. The national government's reform process began in 1991, with a commitment to a completely competitive power market by 1999. Regulatory reform was also introduced, allowing for competition in generation and rate-cap regulation (rather than rate-of-return regulation) in transmission and distribution. Electricity marketing is currently being treated as a separate segmental unit and is gradually being deregulated.

Like the United States, Australia has a federal system of government. Also as in the United States, electricity reforms in Australia embody both national and state efforts. Thus far, the state of Victoria (Australia's second most populous state) has been the most aggressive in privatizing its state-owned energy industries. In 1995, Victoria began to privatize its electric power industry, in part in a manner modeled after the UK electric industry privatization program. Prior to privatization, the Victoria state government merged 29 electricity distribution companies into 5 companies, while splitting the state generating company into five enterprises, each with a power station. Since 1995, it has raised a total of $\$ 17$ billion through the privatization of electricity assets [45].

There have also been some privatization efforts outside Victoria. Northern States Power (of the United States) purchased a 37-percent equity stake for its services in rehabilitating and operating the 1,680-megawatt Gladstone Plant in Queensland [46, pp. 47-48]. SCE Corporation (also of the United States), through its Mission Energy Corporation subsidiary, plans to build a \$111 million power plant in Western Australia. Japan's Sithe Energies is constructing Australia's largest cogeneration plant, a 175-megawatt gas-fired plant near Sydney.

New Zealand started to privatize its electric power industry in 1987 in the midst of an ambitious attempt to introduce free-market economic reforms. An electricity transmission corporation was created in 1993, and monopolies in local distribution and retailing were eliminated. In 1995, the New Zealand government issued a new electricity policy designed to create a competitive power market. Over the past few years, a number of New Zealand's electric utilities have been purchased by U.S. utilities. IES Industries took a minority interest in Powerco Limited and Central Power Limited [46, pp. 47-48]. Further, Utilicorp purchased 20 percent of the common stock in Power New Zealand, New Zealand's second largest electric distribution company.

\section{Other Areas}

\section{The Former Soviet Union and Eastern Europe}

The Russian economy, which accounts for more than half of the economic output for the EE/FSU region, appears to have bottomed out in 1996 and to have shown slight positive growth in 1997. Russia is expected to move to a 3- to 5-percent economic growth path through the year 2001 [47]. Electricity consumption in the $\mathrm{EE} / \mathrm{FSU}$ region is expected to follow a similar recovery path. For the 1995 through 2020 forecast period, electricity consumption is expected to grow at an annual rate of 2.2 percent for Eastern Europe and 1.2 percent for the FSU.

Energy resource availability differs markedly in Eastern Europe and the FSU. As a result, while Eastern Europe relies on its ample supplies of coal for nearly two-thirds of its electricity fuel supply, the FSU relies for almost half of its electricity fuel supply on natural gas, which it has in abundance. In 2020, in contrast, coal is expected to account for only about 40 percent of Eastern Europe's generation fuel, with the difference made up by natural gas and renewables (Figure 85). Both the availability of increased natural gas to Eastern Europe from the FSU, and the desire to reduce severe air pollution problems in the area have been driving this trend. The FSU's consumption of natural gas as a generating fuel also is projected to grow, largely in response to environmental concerns, while both coal and nuclear power generation are expected to decline in absolute and relative terms.

The electric power industries of Eastern Europe and the FSU are very different from those in other parts of the world. In much of the developing world, electricity capacity is currently straining to keep pace with rapid increase in demand. In the developed world, electricity is a mature industry and future expansion is expected to 
Figure 85. Energy Consumption for Electricity Generation in Eastern Europe, 1995 and 2020

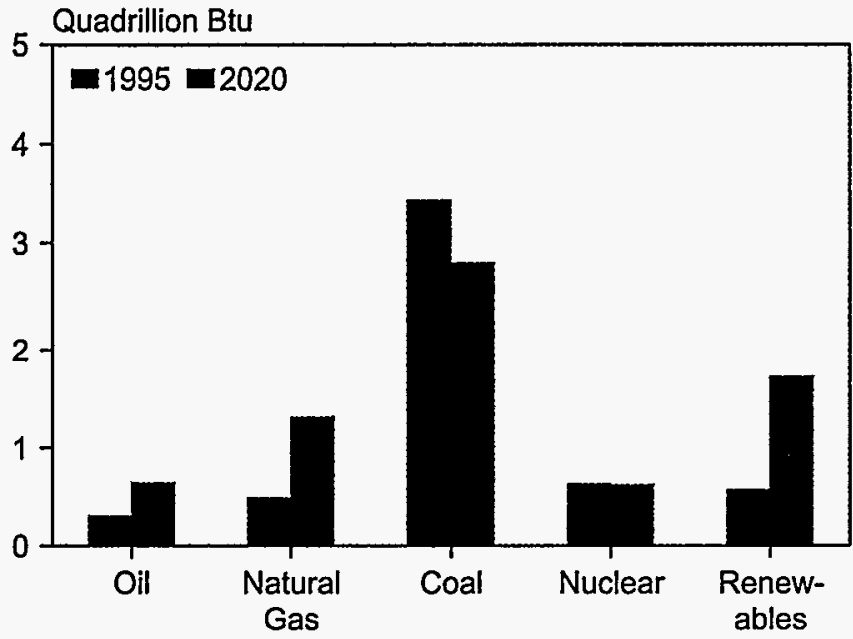

Sources: 1995: Derived from Energy Information Administration (EIA), Office of Energy Markets and End Use, International Energy Annual 1996, DOE/EIA-0219(96) (Washington, DC, February 1998). 2020: EIA, World Energy Projection System (1998).

be incremental. In contrast, in Eastern Europe and the FSU, electricity has been an overdeveloped industry-with no capacity shortage-but an industry suffering from outdated technology. Electricity in Eastern Europe was also a major source of pollution. As a result, future electricity investments in EE/FSU countries will to a large extent be directed at upgrading their electricity industries to industrial world standards.

Several of the countries of Eastern Europe have attempted to reform their electricity industries, motivated in part by the desire to ensure availability of the foreign funds needed for upgrades and expansion. Among Eastern European nations, Hungary has adopted the most ambitious privatization program. In 1991, the state-owned electricity company was converted into a corporation (MVR). MVR became a holding company for six regional power distribution companies [46, p. 47]. Subsequently, Hungary has sold the six power distribution companies and all generation assets, except for nuclear power and the transmission grid [48]. Similarly, Poland has disaggregated its power sector and now allows competition among independent generation companies. Independent transmission and distribution companies have been created that operate separately from generating companies. Privatization of electricity generation and distribution is also being considered, although the Polish government plans to maintain 51-percent ownership of the transmission grid [46, p. 47]. Thus far, Electricite de France has invested in a 450-megawatt coal-fired plant in Krakow, Poland, and Enron has negotiated a 20-year power-purchase agreement for a 116-megawatt gas-fired plant that it will build [46, p. 47; 49]. The Czech Republic is also privatizing its national generation and transmission company, and plans have been made to privatize regional distribution companies. In the Czech Republic, the U.S. companies NRG Energy and El Paso Energy, along with Japan's Nissho Iwai, and Sweden/Switzerland's Asea Brown Boveri, are contracted to add 316 megawatts to an existing power plant [49].

\section{Middle East}

Electricity consumption in the Middle East is expected to grow at a 2.6-percent annual rate from 1995 through 2020. Almost two-thirds of Middle East economic output is accounted for by Iran and Saudi Arabia, along with half of the region's electricity consumption. Iran is the most populous country in the Middle East, and Saudi Arabia has one of the highest per capita incomes. Other large users of electricity in the Middle East include Israel, Iraq, and Kuwait. Richly endowed with oil and natural gas resources, the Middle East naturally relies heavily on those resources as electricity generation fuels. In 1995, oil and natural gas provided roughly equal parts (about 45 percent) of the Middle East's electric fuels market, the remainder being supplied by coal and renewables. Natural gas use for electricity generation is expected to increase over the forecast period, while oil's share is expected to decline to roughly 40 percent (Figure 86).

\section{Figure 86. Energy Consumption for Electricity Generation in the Middle East, 1995 and 2020}

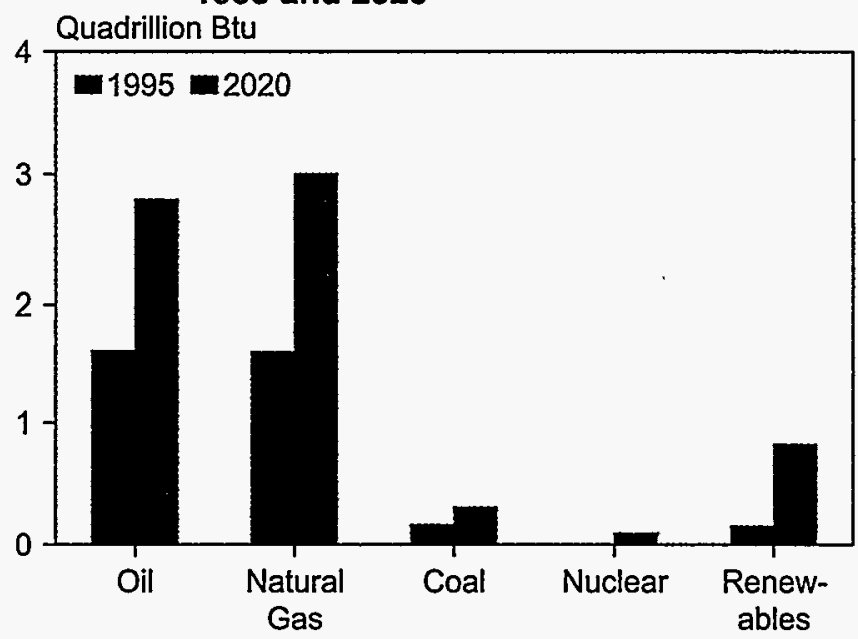

Sources: 1995: Derived from Energy Information Administration (EIA), Office of Energy Markets and End Use, International Energy Annual 1996, DOE/EIA-0219(96) (Washington, DC, February 1998). 2020: EIA, World Energy Projection System (1998).

With growing electric power needs, Iran is currently restructuring its national electricity industry [50]. Iran is considering allowing greater private participation in electricity supply and removing restrictions on foreign ownership. During the 1990s, electricity shortages were commonplace in Iranian cities [50]. Most of Iran's future 
capacity is expected to be powered by natural gas and hydropower.

In order to finance future power projects, the Saudi Arabian government has created a fund built on an electricity surcharge to consumers [50]. The Saudi government is also for the first time relying on international capital markets to fund electricity projects. Another first for the Saudi government was its opening of a planned 1,750-megawatt oil-fired project to bids from foreign companies. The plan calls for the project to be a buildown-operate (BOO) scheme. Several foreign companies have recently placed bids on the project, including Enron of the United States. The bids are currently being evaluated.

\section{Africa}

Over the 1995-2020 forecast period, Africa's electricity consumption is expected to grow at a 3.6-percent annual rate. The African economy is dominated by a few relatively large economies, South Africa being the largest, followed by Algeria, Egypt, Nigeria, Libya, and Morocco. South Africa currently accounts for more than two-thirds of all electricity consumption on the continent [51].

In 1995, coal was used for 50 percent of the electricity generation in Africa (Figure 87), largely as a result of South Africa's extensive coal reserves. Africa is expected to continue to rely heavily on coal as a generation fuel over the forecast period but slightly less so in the year 2020 than now. Both oil and natural gas are also important generation fuels, particularly among those nations with large petroleum reserves. Both fuels will provide a growing share of the continent's electricity

\section{Figure 87. Energy Consumption for Electricity} Generation in Africa, 1995 and 2020

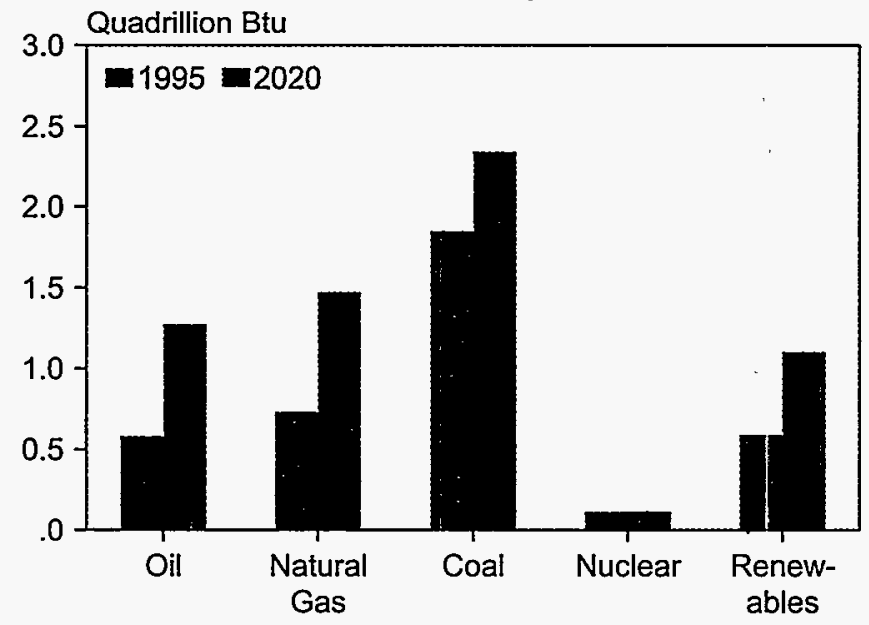

Sources: 1995: Derived from Energy Information Administration (EIA), Office of Energy Markets and End Use, International Energy Annual 1996, DOE/EIA-0219(96) (Washington, DC, February 1998). 2020: EIA, World Energy Projection System (1998). fuels markets over the forecast period. South Africa is the only country producing electricity from nuclear power, but it plans to retire its existing facilities. Currently, Angola, Cameroon, Ethiopia, Ghana, Kenya, Congo (Kinshasa, formerly Zaire), and Zambia depend on hydroelectricity for more than three-quarters of their electricity supply [4, pp. 91-95]. Egypt is the largest producer of hydroelectricity in Africa, but its generation mix is more diversified.

No country in Africa has been more aggressive in privatizing its electric power industry than Morocco. Morocco's reform of its electricity sector maintains the current state-owned electricity distribution monopoly (Office National de l'Electricite) but opens up its electricity sector to independent power projects. In 1997, the U.S.based company CMS Energy and the Swedish/Swiss company Asea Brown Boveri were contracted to build a $\$ 1.5$ billion BOT plant and to operate two existing coalfired plants [51]. The BOT arrangement calls for the companies to sell electricity to the Office National de l'Electricite for 30 years. Each company will hold a 50-percent share in the project. Two other private power projects in Morocco are currently pending [48].

\section{References}

1. Energy Information Administration, Performance Profiles of Major Energy Producers 1995, DOE/EIA0206(95) (Washington, DC, January 1997), p. 32.

2. British Petroleum Company, BP Statistical Review of World Energy 1997 (London, UK, June 1997).

3. "Financing Worldwide Electric Power: Can Capital Markets Do the Job?" special report produced by Resource Dynamics Corporation for the U.S. Department of Energy (Washington, DC, April 1996).

4. Energy Information Administration, International Energy Annual 1995, DOE/EIA-0219(95) (Washington, DC, December 1996).

5. DRI/McGraw-Hill, The Future of the Electric Power Industry Around the World, Vol. III, "Asia/Pacific" (Lexington, MA, November 1995).

6. Li Xiaolin, "FDI in China," Independent Energy, Vol. 27, No. 6 (July/August 1997), pp. 23-26.

7. E.C. Duffy, P.J.Halasz, and H.C. Lee, "China," International Financial Law Review (April 1996).

8. J.E. Lange and N.C. Howson, "Generating a Regulatory Framework," The China Business Review, Vol. 23, No. 5 (September-October 1996), p. 22. 
9. According to Forbes Magazine: "The Chinese have even discovered the U.S. junk bond market. Last year China Generating, an affiliate of Arlington Va.-based independent power producer AES Corp., offered $\$ 180$ million in high-yield bonds at 375 basis points over the ten-year treasury. Source: N. Weinberg, "Power-Hungry Asia," Forbes Magazine, Vol. 159, No. 4 (February 24, 1997), p. 132.

10. D. Orr, "China's New Rules," Infrastructure Finance, Vol. 5, No. 9 (December 1996/January 1997), p. 36.

11. N. Weinberg, "Power-Hungry Asia," Forbes Magazine, Vol. 159, No. 4 (February 2, 1997), p. 132.

12. "Success in India's Power Sector Exposure Uneven, Say IBRD," Financial Times: Asian Intelligence Wire (February 10, 1998).

13. "A Shorter Route to Private Power," Financial Times: Power in Asia, No. 235 (September 22, 1997), p. 12.

14. R. Lock, "Liberalization of India's Electric Power Sector: Evolution or Anarchy?" Electricity Journal, Vol. 9, No. 2 (March 1996), p. 78.

15. T. Mullen, "India's Transmission Reform Shatters Federal Lock on Projects," Electrical World, Vol. 211, No. 3 (March 1997), p. 64.

16. B. Edwards and M. Shukla, "The Mugging of Enron," Euromoney, No. 318 (October 1995), p. 28.

17. M. Kripalani, "India's Unlikely Model for Electricity Reform," Business Week, No. 3495 (September 30, 1996), p. 23.

18. Shao Shiwei, China: Power Sector Regulation in a Socialist Market Economy, World Bank Discussion Paper No. 361 (Washington, DC, March 1, 1997), p. 111.

19. I. Haidari, "Power Generation and Transmission in Pakistan," Economic Review, Vol. 28 (May 1997), p. 17.

20. A. Labita, "Profile-Philippines's Power Industry," Asia Pulse (September 30, 1997).

21. "Power: A Model for the Region," Infrastructure Finance, Vol. 6, No. 7 (September 1997), p. 7.

22. "Thailand: Electric Power Sector Overview," International Marketing Insight Reports (September 22, 1997).

23. Resource Dynamics, estimates based on International Energy Agency, World Energy Outlook,
Capacity Constraints Scenario, Base Case (Paris, France, 1995), p. 12.

24. W.R. True, "World Pipeline Construction Looks To Remain Robust to Century's Turn," Oil and Gas Journal, Vol. 95, No. 6 (February 10, 1997), p. 34.

25. D. Abramson, "El Paso Pushes into Latin America in Search of Good Investment Opportunities," The Oil Daily, Vol. 47, No. 66 (April 6, 1997), p. 3.

26. M. Davis, "Enron Wins Bid for Brazilian Project," The Houston Chronicle (June 17, 1997), p. 1.

27. Salomon Brothers, The Global Power Market: Trends and Projections 1996-2010 (New York, NY, September 1996), p. 23.

28. D. Wamsted, "AES, CEA Win Big in Brazilian Privatization," King Communication Group, Inc. (October 22, 1997).

29. "Brazil Utilities Sold in Bidding," New York Times (October 22, 1997), p. D2.

30. Energy Information Administration, International Energy Outlook 1997, DOE/EIA-0484(97) (Washington, DC, April 1997), p. 83.

31. Energy Information Administration, The Changing Structure of the Electric Power Industry: An Update, DOE/EIA-0562(96) (Washington, DC, December 1996), p. ix.

32. W.A. Koch, "Alberta Restructures Its Electricity Market," Electrical World, Vol. 210, No. 5 (May 1996), pp. 50-52.

33. P. Ross, "Hydro-Quebec Looks South," Energy Economist, No. 186 (April 1997), pp. 17-19.

34. T. Walkom, "Different Agendas at Play in Ontario Hydro Breakup," The Toronto Star (November 10, 1997), p. A17.

35. "Canada: Break up of Ontario Hydro: OPP'ties," Asia Intelligence Wire (November 24, 1997).

36. "The Battle for Liberalization," Petroleum Economist, Vol. 64, No. 6 (June 1997), p. 54.

37. "Sale of the Century," The Wall Street Journal (October 2, 1995), p. R17.

38. A.Sains, "Norwegian Utility Buys Shares in Swedish Nuclear Operator," Nuclear Week (April 18, 1996), p. 8. 
39. "Swedish Industry: Foreign Interest in Energy Heats Up," EIU NewsWire (May 23, 1996).

40. "EdF Preussen Elecktra and IVO Swoop in Raids on Swedish Utility," European Energy Report (April 26, 1996).

41. R. Pospisil, “Spain's Endesa Gets Thumbs-up for Prudent Risk-Taking," Electrical World, Vol. 210, No. 3 (March 1996), p. 23.

42. "MITI Panel Starts Debate on Lower Electricity Prices," Kyoto News Service (July 22, 1997).

43. "Japan Approves First Retail IPP, Will Study Open Market Potential," The McGraw-Hill Company Power Report, Section: Asia/Pacific Rim (July 11, 1997), p. 12.

44. "Japan Action Plan To Reduce Power Costs," U.S. and Foreign Commercial Service (July 1, 1997).
45. "Australia: Victoria's Energy Privatization," International Marketing Insight Reports (October 23, 1997).

46. Energy Information Administration, Privatization and the Globalization of Energy Markets, DOE/EIA0609 (Washington, DC, October 1996).

47. DRI/McGraw-Hill, World Economic Outlook: Third Quarter 1997, Vol. II (Lexington, MA, 1997), p. 291.

48. "International Energy Privatization: Weighing the Risk of Build Versus Buy," Electrical World, Vol. 209, No. 11 (November 1995), p. 25.

49. "Clearer Regs, New Power Laws Prompt Developer Interest in Eastern Europe," The International Chemical Report, Vol. 16, No. 24 (June 12, 1997), p. 7.

50. "Private Power Moves Forward Slightly Faster," Middle East Economic Digest (August 8, 1997), p. 9.

51. DRI/McGraw-Hill, World Energy Service: Africa/Middle East Outlook 1997 (Lexington, MA, 1997), p. 14. 
Appendix A

\section{World Energy Consumption, Carbon Emissions, Oil Production, and Nuclear Power Capacity Tables}



Table A1. World Total Energy Consumption by Region, Reference Case, 1990-2020 (Quadrillion Btu)

\begin{tabular}{|c|c|c|c|c|c|c|c|c|c|}
\hline \multirow[b]{2}{*}{ Region/Country } & \multicolumn{3}{|c|}{ History } & \multicolumn{5}{|c|}{ Projections } & \multirow{2}{*}{$\begin{array}{c}\text { Average Annual } \\
\text { Percent Change, } \\
1995-2020\end{array}$} \\
\hline & 1990 & 1995 & 1996 & 2000 & 2005 & 2010 & 2015 & 2020 & \\
\hline \multicolumn{10}{|l|}{ Industrialized Countries } \\
\hline North America $\ldots \ldots \ldots \ldots \ldots$ & 99.7 & 108.0 & 112.2 & 119.8 & 128.1 & 136.5 & 142.1 & 147.1 & 1.2 \\
\hline United States ${ }^{\mathrm{a}} \ldots \ldots \ldots \ldots$ & 83.9 & 90.4 & 94.0 & 99.8 & 105.8 & 112.2 & 115.7 & 118.6 & 1.1 \\
\hline Canada $\ldots \ldots \ldots \ldots \ldots \ldots$ & 10.9 & 12.2 & 12.6 & 13.3 & 14.3 & 15.4 & 16.4 & 17.5 & 1.5 \\
\hline Mexico $\ldots \ldots \ldots \ldots \ldots \ldots$ & 4.9 & 5.5 & 5.6 & 6.6 & 8.0 & 9.0 & 10.0 & 11.0 & 2.8 \\
\hline Western Europe $\ldots \ldots \ldots \ldots \ldots$ & 61.9 & 64.8 & 66.7 & 69.7 & 74.5 & 79.0 & 83.4 & 88.1 & 1.2 \\
\hline Industrialized Asia . . . . . . . . . & 23.0 & 26.3 & 26.9 & 28.4 & 30.1 & 32.1 & 34.1 & 36.3 & 1.3 \\
\hline Japan.$\ldots \ldots \ldots \ldots \ldots$ & 18.1 & 20.8 & 21.4 & 22.3 & 23.5 & 25.1 & 26.7 & 28.5 & 1.3 \\
\hline Australasia .............. & 4.9 & 5.6 & 5.5 & 6.1 & 6.6 & 7.0 & 7.4 & 7.8 & 1.4 \\
\hline Total Industrialized ........ & 184.7 & 199.1 & 205.8 & 217.9 & 232.8 & 247.6 & 259.6 & 271.5 & 1.2 \\
\hline \multicolumn{10}{|l|}{ EE/FSU } \\
\hline Former Soviet Union & 58.5 & 40.8 & 39.8 & 42.6 & 47.5 & 52.4 & 56.5 & 60.8 & 1.6 \\
\hline Eastern Europe . .......... & 15.2 & 12.4 & 12.6 & 13.7 & 15.1 & 16.5 & 18.0 & 19.5 & 1.8 \\
\hline Total EE/FSU ... & 73.6 & 53.2 & 52.4 & 56.3 & 62.6 & 69.0 & 74.5 & 80.4 & 1.7 \\
\hline \multicolumn{10}{|l|}{ Developing Countries } \\
\hline Developing Asia .... & 51.4 & 71.8 & 74.5 & 90.8 & 113.8 & 137.4 & 165.4 & 199.4 & 4.2 \\
\hline China...$\ldots \ldots \ldots$ & 27.0 & 36.4 & 37.1 & 46.0 & 58.0 & 71.3 & 88.4 & 109.7 & 4.5 \\
\hline India $\ldots \ldots \ldots \ldots \ldots \ldots$ & 7.7 & 11.1 & 11.5 & 14.7 & 18.1 & 21.7 & 25.6 & 30.2 & 4.1 \\
\hline Other Asia ............. & 16.7 & 24.4 & 25.9 & 30.1 & 37.8 & 44.4 & 51.4 & 59.6 & 3.6 \\
\hline Middle East $\ldots \ldots \ldots \ldots \ldots$ & 11.1 & 13.9 & 14.6 & 15.5 & 17.6 & 19.9 & 22.6 & 25.5 & 2.5 \\
\hline Africa $\ldots \ldots \ldots \ldots \ldots \ldots \ldots$ & 9.2 & 10.7 & 11.1 & 12.2 & 13.9 & 15.7 & 17.7 & 19.8 & 2.5 \\
\hline Central and South America .... & 13.7 & 16.8 & 17.7 & 20.3 & 25.0 & 30.0 & 35.8 & 42.7 & 3.8 \\
\hline Brazil ................ & 5.4 & 6.4 & 6.8 & 7.8 & 9.8 & 11.7 & 14.1 & 16.8 & 3.9 \\
\hline Other Central/South America ... & 8.3 & 10.4 & 10.9 & 12.5 & 15.2 & 18.2 & 21.7 & 25.9 & 3.7 \\
\hline Total Developing . ........ & 85.5 & 113.3 & 117.9 & 138.9 & 170.4 & 203.0 & 241.5 & 287.5 & 3.8 \\
\hline Total World ........ & 343.8 & 365.6 & 376.1 & 413.0 & 465.7 & 519.6 & 575.6 & 639.4 & 2.3 \\
\hline
\end{tabular}

${ }^{a}$ Includes the 50 States and the District of Columbia. U.S. Territories are included in Australasia.

Notes: EE/FSU = Eastern Europe/Former Soviet Union. Energy totals include net imports of coal coke and electricity generated from biomass in the United States. Totals may not equal sum of components due to independent rounding. The electricity portion of the national fuel consumption values consists of generation for domestic use plus an adjustment for electricity trade based on a fuel's share of total generation in the exporting country.

Sources: History: Energy Information Administration (EIA), International Energy Annual 1996, DOE/EIA-0219(96) (Washington, DC, February 1998). Projections: EIA, Annual Energy Outlook 1998, DOE/EIA-0383(98) (Washington, DC, December 1997), Table A1; and World Energy Projection System (1998). 
Table A2. World Total Energy Consumption by Region and Fuel, Reference Case, 1990-2020 (Quadrillion Btu)

\begin{tabular}{|c|c|c|c|c|c|c|c|c|c|}
\hline \multirow[b]{2}{*}{ Region/Country } & \multicolumn{3}{|c|}{ History } & \multicolumn{5}{|c|}{ Projections } & \multirow{2}{*}{$\begin{array}{c}\text { Average Annual } \\
\text { Percent Change, } \\
1995-2020\end{array}$} \\
\hline & 1990 & 1995 & 1996 & 2000 & 2005 & 2010 & 2015 & 2020 & \\
\hline \multicolumn{10}{|l|}{$\begin{array}{l}\text { Industrialized Countries } \\
\text { North America }\end{array}$} \\
\hline Oil $\ldots \ldots \ldots \ldots \ldots \ldots \ldots$ & 40.4 & 41.8 & 43.2 & 46.4 & 50.0 & 54.0 & 56.7 & 59.0 & 1.4 \\
\hline Natural Gas . . . . . . . . . . . & 22.7 & 26.2 & 26.8 & 29.4 & 32.5 & 35.5 & 38.1 & 40.6 & 1.8 \\
\hline Coal ................ & 20.4 & 21.1 & 22.0 & 24.0 & 25.2 & 26.1 & 27.1 & 27.9 & 1.1 \\
\hline Nuclear $\ldots \ldots \ldots \ldots \ldots \ldots$ & 7.0 & 8.3 & 8.2 & 8.3 & 7.8 & 7.3 & 6.0 & 4.8 & -2.1 \\
\hline Other $\ldots \ldots \ldots \ldots \ldots \ldots$ & 9.2 & 10.6 & 10.7 & 11.7 & 12.6 & 13.5 & 14.1 & 14.8 & 1.3 \\
\hline $\begin{array}{l}\text { Total } \ldots \ldots \ldots \ldots \ldots \ldots \ldots \\
\text { Western Europe }\end{array}$ & 99.7 & 108.0 & 110.9 & 119.8 & 128.1 & 136.5 & 142.1 & 147.1 & 1.2 \\
\hline Oil $\ldots \ldots \ldots \ldots \ldots \ldots \ldots$ & 26.7 & 29.2 & 29.5 & 29.4 & 30.2 & 30.8 & 31.3 & 31.8 & 0.3 \\
\hline Natural Gas . . . . . . . . . . & 10.1 & 12.5 & 13.9 & 16.0 & 19.7 & 23.3 & 27.5 & 31.9 & 3.8 \\
\hline Coal ................ & 13.1 & 9.7 & 9.7 & 9.7 & 9.5 & 9.6 & 9.6 & 9.6 & -0.1 \\
\hline Nuclear $\ldots \ldots \ldots \ldots \ldots$ & 7.4 & 8.2 & 8.6 & 8.8 & 8.6 & 8.0 & 7.0 & 6.2 & -1.2 \\
\hline Other $\ldots \ldots \ldots \ldots \ldots \ldots$ & 4.6 & 5.1 & 4.9 & 5.8 & 6.6 & 7.4 & 8.0 & 8.7 & 2.1 \\
\hline $\begin{array}{l}\text { Total } \ldots \ldots \ldots \ldots \ldots \ldots \\
\text { Industrialized Asia }\end{array}$ & 61.9 & 64.8 & 66.7 & 69.7 & 74.5 & 79.0 & 83.4 & 88.1 & 1.2 \\
\hline Oil $\ldots \ldots \ldots \ldots \ldots \ldots$ & 12.5 & 14.1 & 14.3 & 15.6 & 16.5 & 17.5 & 18.7 & 19.9 & 1.4 \\
\hline Natural Gas . . . . . . . . . . & 2.9 & 3.3 & 3.6 & 3.6 & 4.1 & 4.5 & 4.6 & 5.0 & 1.6 \\
\hline Coal $\ldots \ldots \ldots \ldots \ldots \ldots$ & 4.2 & 4.6 & 4.7 & 4.8 & 4.9 & 5.2 & 5.3 & 5.4 & 0.7 \\
\hline Nuclear $\ldots \ldots \ldots \ldots \ldots \ldots$ & 2.0 & 2.8 & 2.9 & 3.0 & 3.1 & 3.3 & 3.7 & 3.8 & 1.2 \\
\hline Other $\ldots \ldots \ldots \ldots \ldots \ldots$ & 1.4 & 1.4 & 1.4 & 1.4 & $\uparrow .5$ & 1.7 & 1.8 & 2.1 & 1.7 \\
\hline Total $\ldots \ldots \ldots \ldots \ldots$ & 23.0 & 26.3 & 26.9 & 28.4 & 30.1 & 32.1 & 34.1 & 36.3 & 1.3 \\
\hline \multicolumn{10}{|l|}{ EE/FSU } \\
\hline 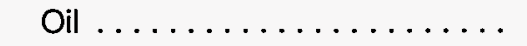 & 21.0 & 12.4 & 12.0 & 12.3 & 14.0 & 16.5 & 18.8 & 21.3 & 2.2 \\
\hline Natural Gas . . . . . . . . . . . & 26.0 & 21.4 & 21.7 & 24.6 & 28.4 & 32.2 & 35.4 & 39.1 & 2.4 \\
\hline Coal . . . . . . . . . . . . & 20.8 & 13.8 & 13.0 & 13.6 & 13.6 & 13.2 & 12.6 & 12.0 & -0.6 \\
\hline Nuclear $\ldots \ldots \ldots \ldots \ldots \ldots$ & 2.9 & 2.5 & 2.8 & 2.7 & 3.0 & 3.1 & 3.1 & 2.9 & 0.5 \\
\hline Other $\ldots \ldots \ldots \ldots \ldots \ldots$ & 2.8 & 3.0 & 2.9 & 3.1 & 3.6 & 4.0 & 4.6 & 5.1 & 2.1 \\
\hline Total $\ldots \ldots \ldots \ldots \ldots \ldots$ & 73.6 & 53.2 & 52.4 & 56.3 & 62.6 & 69.0 & 74.5 & 80.4 & 1.7 \\
\hline
\end{tabular}


Table A2. World Total Energy Consumption by Region and Fuel, Reference Case, 1990-2020 (Continued) (Quadrillion Btu)

\begin{tabular}{|c|c|c|c|c|c|c|c|c|c|}
\hline \multirow[b]{2}{*}{ Region/Country } & \multicolumn{3}{|c|}{ History } & \multicolumn{5}{|c|}{ Projections } & \multirow{2}{*}{$\begin{array}{l}\text { Average Annual } \\
\text { Percent Change } \\
1995-2020 \\
\end{array}$} \\
\hline & 1990 & 1995 & 1996 & 2000 & 2005 & 2010 & 2015 & 2020 & \\
\hline \multicolumn{10}{|l|}{$\begin{array}{l}\text { Developing Countries } \\
\text { Developing Asia }\end{array}$} \\
\hline$\ldots \ldots \ldots \ldots \ldots \ldots \ldots$ & 16.0 & 23.6 & 24.8 & 27.8 & 34.9 & 41.6 & 49.8 & 59.8 & 3.8 \\
\hline Natural Gas $\ldots \ldots \ldots \ldots \ldots$ & 3.0 & 5.1 & 5.7 & 10.3 & 15.3 & 20.0 & 24.5 & 30.0 & 7.4 \\
\hline$\ldots \ldots \ldots \ldots \ldots$ & 28.1 & 38.0 & 38.7 & 45.4 & 53.9 & 64.4 & 78.4 & 95.6 & 3.8 \\
\hline Nuclear $\ldots \ldots \ldots \ldots \ldots \ldots$ & 0.9 & 1.2 & 1.3 & 1.5 & 2.1 & 2.7 & 3.0 & 3.2 & 4.0 \\
\hline Other... & 3.2 & 4.0 & 4.0 & 5.7 & 7.6 & 8.6 & 9.7 & 10.9 & 4.1 \\
\hline Total $\ldots \ldots \ldots \ldots \ldots \ldots$ & 51.4 & 71.8 & 74.5 & 90.8 & 113.8 & 137.4 & 165.4 & 199.4 & 4.2 \\
\hline \multicolumn{10}{|l|}{ Middle East } \\
\hline Oil $\ldots . . .$. & 7.1 & 8.5 & 8.8 & 9.3 & 10.6 & 11.8 & 13.2 & 14.8 & 2.2 \\
\hline Natural Gas & 3.8 & 5.0 & 5.4 & 5.7 & 6.3 & 7.1 & 8.2 & 9.4 & 2.6 \\
\hline Coal................... & 0.1 & 0.2 & 0.2 & 0.3 & 0.3 & 0.3 & 0.4 & 0.4 & 2.6 \\
\hline Nuclear..$\ldots \ldots \ldots \ldots \ldots$ & 0.0 & 0.0 & 0.0 & 0.0 & 0.1 & 0.1 & 0.1 & 0.1 & - \\
\hline Other...$\ldots \ldots \ldots \ldots \ldots$ & 0.1 & 0.2 & 0.2 & 0.3 & 0.4 & 0.5 & 0.7 & 0.8 & 6.7 \\
\hline Total ................... & 11.1 & 13.9 & 14.6 & 15.5 & 17.6 & 19.9 & 22.6 & 25.5 & 2.5 \\
\hline \multicolumn{10}{|l|}{ Africa } \\
\hline Oil .. & 4.2 & 4.8 & 5.0 & 6.4 & 7.6 & 8.5 & 9.5 & 10.6 & 3.2 \\
\hline Natural Gas ............... & 1.4 & 1.9 & 2.0 & 1.8 & 2.1 & 2.6 & 3.2 & 3.8 & 2.8 \\
\hline Coal ....... & 3.0 & 3.3 & 3.4 & 3.3 & 3.4 & 3.7 & 3.9 & 4.2 & 0.9 \\
\hline Nuclear & 0.1 & 0.1 & 0.1 & 0.1 & 0.1 & 0.1 & 0.1 & 0.1 & 0.0 \\
\hline Other .. & 0.6 & 0.6 & 0.6 & 0.6 & 0.7 & 0.8 & 1.0 & 1.1 & 2.6 \\
\hline Total ................. & 9.2 & 10.7 & 11.1 & 12.2 & 13.9 & 15.7 & 17.7 & 19.8 & 2.5 \\
\hline \multicolumn{10}{|l|}{ Central and South America } \\
\hline 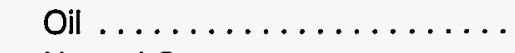 & 6.9 & 8.0 & 8.1 & 10.6 & 12.6 & 14.9 & 17.3 & 20.0 & 3.8 \\
\hline Natural Gas & 2.1 & 2.9 & 3.1 & 3.4 & 5.6 & 8.0 & 10.9 & 14.4 & 6.7 \\
\hline Coal ....... & 0.7 & 0.8 & 1.0 & 0.9 & 1.1 & 1.1 & 1.3 & 1.4 & 2.4 \\
\hline Nuclear & 0.1 & 0.1 & 0.1 & 0.1 & 0.2 & 0.2 & 0.2 & 0.2 & 2.4 \\
\hline Other .. & 3.9 & 5.1 & 5.4 & 5.3 & 5.5 & 5.8 & 6.2 & 6.6 & 1.1 \\
\hline Total $\ldots . . . \ldots \ldots \ldots \ldots$ & 13.7 & 16.8 & 17.7 & 20.3 & 25.0 & 30.0 & 35.8 & 42.7 & 3.8 \\
\hline \multicolumn{10}{|l|}{ Total World } \\
\hline Oil ....... & 134.9 & 142.5 & 145.7 & 157.8 & 176.3 & 195.5 & 215.3 & 237.3 & 2.1 \\
\hline Natural Gas & 72.0 & 78.1 & 82.2 & 94.8 & 113.8 & 133.3 & 152.5 & 174.2 & 3.3 \\
\hline Coal ....... & 90.6 & 91.6 & 92.8 & 102.0 & 112.0 & 123.6 & 138.6 & 156.4 & 2.2 \\
\hline Nuclear & 20.4 & 23.3 & 24.1 & 24.7 & 25.0 & 24.9 & 23.3 & 21.3 & -0.4 \\
\hline Other .. & 25.9 & 30.1 & 30.0 & 33.8 & 38.6 & 42.4 & 46.0 & 50.2 & 2.1 \\
\hline Total $\ldots \ldots \ldots \ldots \ldots \ldots$ & 343.8 & 365.6 & 374.7 & 413.0 & 465.7 & 519.6 & 575.6 & 639.4 & 2.3 \\
\hline
\end{tabular}

${ }^{a}$ Includes the 50 States and the District of Columbia. U.S. Territories are included in Australasia.

Notes: EE/FSU = Eastern Europe/Former Soviet Union. Energy totals include net imports of coal coke and electricity generated from biomass in the United States. Totals may not equal sum of components due to independent rounding. The electricity portion of the national fuel consumption values consists of generation for domestic use plus an adjustment for electricity trade based on a fuel's share of total generation in the exporting country.

Sources: History: Energy Information Administration (EIA), International Energy Annual 1996, DOEEEIA-0219(96) (Washington, DC, February 1998). Projections: EIA, Annual Energy Outlook 1998, DOE/EIA-0383(98) (Washington, DC, December 1997), Table A1; and World Energy Projection System (1998). 
Table A3. World Total Oil Consumption by Region, Reference Case, 1990-2020 (Million Barrels per Day)

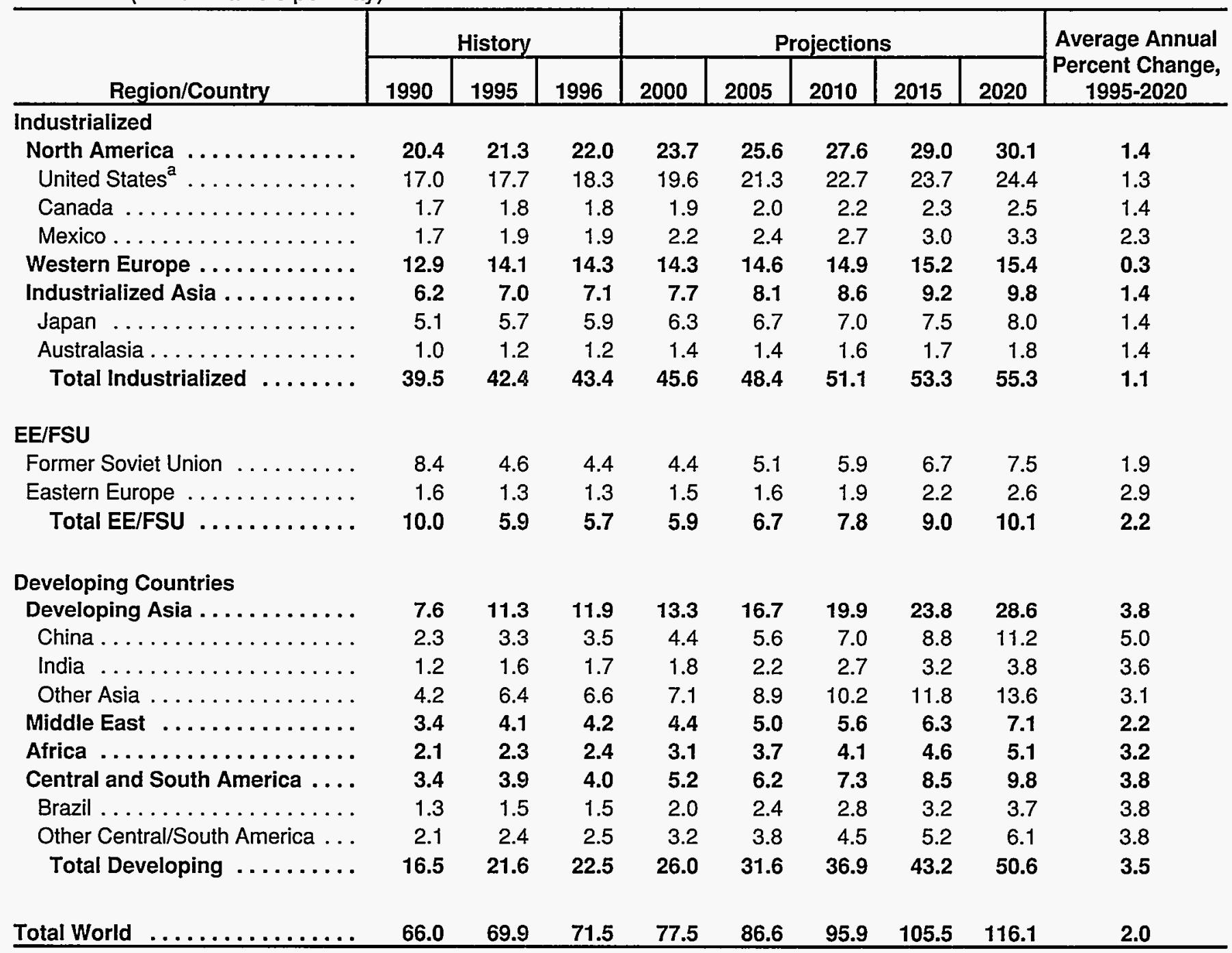

ancludes the 50 States and the District of Columbia. U.S. Territories are included in Australasia.

Notes: EE/FSU = Eastern Europe/Former Soviet Union. Totals may not equal sum of components due to independent rounding. The electricity portion of the national fuel consumption values consists of generation for domestic use plus an adjustment for electricity trade based on a fuel's share of total generation in the exporting country.

Sources: History: Energy Information Administration (EIA), International Energy Annual 1996, DOE/ElA-0219(96) (Washington, DC, February 1998). Projections: EIA, Annual Energy Outlook 1998, DOE/EIA-0383(98) (Washington, DC, December 1997), Table A21; and World Energy Projection System (1998). 
Table A4. World Total Natural Gas Consumption by Region, Reference Case, 1990-2020 (Trillion Cubic Feet)

\begin{tabular}{|c|c|c|c|c|c|c|c|c|c|}
\hline \multirow[b]{2}{*}{ Region/Country } & \multicolumn{3}{|c|}{ History } & \multicolumn{5}{|c|}{ Projections } & \multirow{2}{*}{$\begin{array}{c}\text { Average Annual } \\
\text { Percent Change, } \\
1995-2020\end{array}$} \\
\hline & 1990 & 1995 & 1996 & 2000 & 2005 & 2010 & 2015 & 2020 & \\
\hline \multicolumn{10}{|l|}{ Industrialized } \\
\hline North America & 22.0 & 25.4 & 26.0 & 28.5 & 31.5 & 34.4 & 36.9 & 39.4 & 1.8 \\
\hline United States $^{\mathrm{a}}$ & 18.7 & 21.6 & 21.9 & 24.1 & 26.2 & 28.8 & 30.6 & 32.2 & 1.6 \\
\hline Canada ..... & 2.4 & 2.9 & 3.1 & 3.1 & 3.2 & 3.4 & 3.9 & 4.4 & 1.7 \\
\hline Mexico .............. & 0.9 & 1.0 & 1.0 & 1.4 & 2.1 & 2.2 & 2.5 & 2.8 & 4.2 \\
\hline Western Europe $\ldots \ldots \ldots \ldots$. & 10.3 & 12.7 & 14.1 & 16.2 & 19.9 & 23.5 & 27.7 & 32.1 & 3.8 \\
\hline Industrialized Asia . . . . . . . . . & 2.6 & 3.1 & 3.3 & 3.3 & 3.7 & 4.1 & 4.3 & 4.6 & 1.6 \\
\hline Japan $\ldots \ldots \ldots \ldots \ldots \ldots \ldots$ & 1.9 & 2.2 & 2.4 & 2.2 & 2.5 & 2.8 & 2.9 & 3.2 & 1.5 \\
\hline Australasia $\ldots \ldots \ldots \ldots \ldots$. & 0.8 & 0.9 & 0.9 & 1.1 & 1.2 & 1.3 & 1.3 & 1.4 & 1.8 \\
\hline Total Industrialized ........ & 35.0 & 41.2 & 43.3 & 48.0 & 55.1 & 62.1 & 68.9 & 76.1 & 2.5 \\
\hline \multicolumn{10}{|l|}{ EE/FSU } \\
\hline Former Soviet Union & 25.0 & 20.6 & 20.7 & 23.0 & 26.2 & 29.6 & 32.2 & 35.4 & 2.2 \\
\hline Eastern Europe .... & 3.1 & 2.7 & 2.9 & 3.8 & 4.8 & 5.6 & 6.5 & 7.3 & 4.0 \\
\hline Total EE/FSU $\ldots . . \ldots \ldots$ & 28.1 & 23.4 & 23.7 & 26.8 & 31.0 & 35.2 & 38.7 & 42.7 & 2.4 \\
\hline \multicolumn{10}{|l|}{ Developing Countries } \\
\hline Developing Asia . . . . . . . . . & 3.0 & 4.7 & 5.3 & 9.5 & 14.1 & 18.5 & 22.6 & 27.7 & 7.3 \\
\hline China...$\ldots \ldots \ldots$ & 0.5 & 0.6 & 0.7 & 1.4 & 2.4 & 3.0 & 3.3 & 3.7 & 7.5 \\
\hline India $\ldots .$. & 0.4 & 0.6 & 0.7 & 1.5 & 2.3 & 3.3 & 4.5 & 5.9 & 9.4 \\
\hline Other Asia & 2.1 & 3.5 & 4.0 & 6.7 & 9.4 & 12.1 & 14.8 & 18.1 & 6.8 \\
\hline Middle East $\ldots \ldots \ldots \ldots \ldots \ldots$ & 3.6 & 4.7 & 5.2 & 5.4 & 6.0 & 6.8 & 7.8 & 8.9 & 2.6 \\
\hline Africa $\ldots \ldots \ldots \ldots \ldots \ldots$ & 1.4 & 1.7 & 1.8 & 1.7 & 1.9 & 2.4 & 2.9 & 3.4 & 2.8 \\
\hline Central and South America .... & 2.0 & 2.6 & 2.9 & 3.1 & 5.0 & 7.2 & 9.8 & 13.0 & 6.7 \\
\hline Brazil . . . . . . . . . . . & 0.1 & 0.2 & 0.2 & 0.4 & 1.2 & 2.0 & 3.0 & 4.3 & 14.1 \\
\hline Other Central/South America ... & 1.9 & 2.4 & 2.7 & 2.7 & 3.8 & 5.2 & 6.8 & 8.8 & 5.3 \\
\hline Total Developing ......... & 9.9 & 13.7 & 15.2 & 19.7 & 27.1 & 34.9 & 43.1 & 53.0 & 5.6 \\
\hline Total World & 73.0 & 78.3 & 82.2 & 94.5 & 113.2 & 132.1 & 150.7 & 171.8 & 3.2 \\
\hline
\end{tabular}

${ }^{a}$ Includes the 50 States and the District of Columbia. U.S. Territories are included in Australasia.

Notes: EE/FSU = Eastern Europe/Former Soviet Union. Totals may not equal sum of components due to independent rounding. The electricity portion of the national fuel consumption values consists of generation for domestic use plus an adjustment for electricity trade based on a fuel's share of total generation in the exporting country. To convert cubic feet to cubic meters, divide each number in the table by 35.315 .

Sources: History: Energy Information Administration (EIA), International Energy Annual 1996, DOE/EIA-0219(96) (Washington, DC, February 1998). Projections: EIA, Annual Energy Outlook 1998, DOE/EIA-0383(98) (Washington, DC, December 1997), Table A13; and World Energy Projection System (1998). 
Table A5. World Total Coal Consumption by Region, Reference Case, 1990-2020

(Million Short Tons)

\begin{tabular}{|c|c|c|c|c|c|c|c|c|c|}
\hline \multirow[b]{2}{*}{ Region/Country } & \multicolumn{3}{|c|}{ History } & \multicolumn{5}{|c|}{ Projections } & \multirow{2}{*}{$\begin{array}{c}\text { Average Annua } \\
\text { Percent Change } \\
1995-2020\end{array}$} \\
\hline & 1990 & 1995 & 1996 & 2000 & 2005 & 2010 & 2015 & 2020 & \\
\hline \multicolumn{10}{|l|}{ Industrialized } \\
\hline North America $\ldots \ldots \ldots \ldots \ldots$ & 957 & 1,013 & 1,056 & 1,148 & 1,209 & 1,263 & 1,319 & 1,365 & 1.2 \\
\hline United States $^{a} \ldots \ldots \ldots \ldots \ldots$ & 896 & 941 & 983 & 1,058 & 1,112 & 1,162 & 1,215 & 1,257 & 1.2 \\
\hline Canada $\ldots \ldots \ldots \ldots \ldots$ & 55 & 59 & 60 & 76 & 81 & 82 & 84 & 86 & 1.5 \\
\hline Mexico $\ldots \ldots \ldots \ldots \ldots$ & 7 & 13 & 14 & 14 & 17 & 19 & 20 & 22 & 2.1 \\
\hline Western Europe $\ldots \ldots \ldots \ldots \ldots$ & 958 & 674 & 671 & 679 & 670 & 676 & 681 & 686 & 0.1 \\
\hline Industrialized Asia . . . . . . . . . & 233 & 257 & 266 & 267 & 273 & 286 & 292 & 301 & 0.6 \\
\hline Japan $\ldots \ldots \ldots \ldots \ldots \ldots$ & 125 & 140 & 144 & 148 & 151 & 163 & 166 & 172 & 0.8 \\
\hline Australasia $\ldots \ldots \ldots \ldots \ldots$ & 108 & 117 & 121 & 120 & 122 & 123 & 126 & 129 & 0.4 \\
\hline Total Industrialized . . . . . . & 2,148 & 1,944 & 1,994 & 2,095 & 2,152 & 2,226 & 2,293 & 2,352 & 0.8 \\
\hline \multicolumn{10}{|l|}{ EE/FSU } \\
\hline Former Soviet Union & 848 & 508 & 472 & 499 & 496 & 490 & 477 & 462 & -0.4 \\
\hline Eastern Europe .... & 523 & 426 & 413 & 420 & 422 & 396 & 370 & 343 & -0.9 \\
\hline Total EE/FSU $\ldots \ldots \ldots \ldots$ & 1,372 & 934 & 885 & 919 & 918 & 887 & 848 & 805 & -0.6 \\
\hline \multicolumn{10}{|l|}{ Developing Countries } \\
\hline Developing Asia .... & 1,555 & 2,030 & 2,065 & 2,430 & 2,893 & 3,464 & 4,235 & 5,178 & 3.8 \\
\hline China ......... & 1,124 & 1,489 & 1,500 & 1,796 & 2,176 & 2,666 & 3,374 & 4,242 & 4.3 \\
\hline India $\ldots \ldots$ & 242 & 312 & 321 & 387 & 444 & 499 & 537 & 581 & 2.5 \\
\hline Other Asia . & 190 & 230 & 244 & 247 & 273 & 298 & 324 & 355 & 1.8 \\
\hline Middle East $\ldots \ldots \ldots \ldots \ldots$ & 6 & 8 & 9 & 10 & 12 & 13 & 15 & 16 & 2.6 \\
\hline Africa $\ldots \ldots \ldots \ldots \ldots \ldots \ldots$ & 152 & 172 & 174 & 171 & 178 & 191 & 203 & 217 & 0.9 \\
\hline Central and South America .... & 30 & 32 & 40 & 37 & 44 & 47 & 53 & 59 & 2.4 \\
\hline Brazil $\ldots \ldots \ldots \ldots \ldots \ldots \ldots$ & 17 & 19 & 27 & 21 & 25 & 26 & 29 & 33 & 2.2 \\
\hline Other Central/South America ... & 13 & 13 & 13 & 16 & 19 & 21 & 24 & 25 & 2.8 \\
\hline Total Developing ......... & 1,743 & 2,243 & 2,289 & 2,648 & 3,126 & 3,715 & 4,506 & 5,470 & 3.6 \\
\hline Total World $\ldots \ldots \ldots \ldots \ldots \ldots$ & 5,263 & 5,120 & 5,167 & 5,662 & 6,197 & 6,827 & 7,646 & 8,627 & 2.1 \\
\hline
\end{tabular}

${ }^{a}$ Includes the 50 States and the District of Columbia. U.S. Territories are included in Australasia.

Notes: EE/FSU = Eastern Europe/Former Soviet Union. Range values for Western Europe and the four regional totals are not equal to the sum of the component countries or country groups but consist of the base value adjusted by the quantity: the square root of the sum of the squared deviations of the respective component countries or country groups from their base value. Other totals may not equal sum of components due to independent rounding. The electricity portion of the national fuel consumption values consists of generation for domestic use plus an adjustment for electricity trade based on a fuel's share of total generation in the exporting country.To convert short tons to metric tons, divide each number in the table by 1.102 .

Sources: History: Energy Information Administration (EIA), International Energy Annual 1996, DOE/EIA-0219(96) (Washington, DC, February 1998). Projections: EIA, Annual Energy Outlook 1998, DOE/EIA-0383(98) (Washington, DC, December 1997), Table A16; and World Energy Projection System (1998). 
Table A6. World Net Nuclear Energy Consumption by Region, Reference Case, 1990-2020 (Billion Kilowatthours)

\begin{tabular}{|c|c|c|c|c|c|c|c|c|c|}
\hline \multirow[b]{2}{*}{ Region/Country } & \multicolumn{3}{|c|}{ History } & \multicolumn{5}{|c|}{ Projections } & \multirow{2}{*}{$\begin{array}{c}\text { Average Annual } \\
\text { Percent Change, } \\
1995-2020 \\
\end{array}$} \\
\hline & 1990 & 1995 & 1996 & 2000 & 2005 & 2010 & 2015 & 2020 & \\
\hline \multicolumn{10}{|l|}{ Industrialized } \\
\hline North America & 649 & 774 & 770 & 773 & 730 & 683 & 559 & 451 & -2.1 \\
\hline United States $^{\mathrm{a}}$ & 577 & 673 & 675 & 689 & 643 & 596 & 480 & 383 & -2.2 \\
\hline Canada ...... & 69 & 93 & 88 & 75 & 79 & 79 & 72 & 60 & -1.7 \\
\hline Mexico ........ & 3 & 8 & 7 & 8 & 8 & 8 & 8 & 8 & 0.0 \\
\hline Western Europe ............ & 703 & 785 & 824 & 841 & 821 & 763 & 674 & 588 & -1.2 \\
\hline Industrialized Asia . . . . . . . . . & 192 & 277 & 283 & 298 & 303 & 324 & 363 & 370 & 1.2 \\
\hline Japan $\ldots \ldots \ldots \ldots \ldots \ldots$ & 192 & 277 & 283 & 298 & 303 & 324 & 363 & 370 & 1.2 \\
\hline Australasia .............. & 0 & 0 & 0 & 0 & 0 & 0 & 0 & 0 & - \\
\hline Total Industrialized . . . . . . & 1,544 & 1,837 & 1,877 & 1,911 & 1,854 & 1,770 & 1,596 & 1,408 & -1.1 \\
\hline \multicolumn{10}{|l|}{ EE/FSU } \\
\hline Former Soviet Union $\ldots \ldots \ldots$ & 201 & 172 & 194 & 185 & 202 & 211 & 214 & 206 & 0.7 \\
\hline Eastern Europe ............ & 54 & 57 & 60 & 62 & 69 & 68 & 64 & 55 & -0.1 \\
\hline Total EE/FSU $\ldots \ldots \ldots \ldots$ & 256 & 229 & 254 & 248 & 271 & 279 & 278 & 261 & 0.5 \\
\hline \multicolumn{10}{|l|}{ Developing Countries } \\
\hline Developing Asia . . . . . . . . . & 88 & 117 & 128 & 152 & 205 & 269 & 299 & 313 & 4.0 \\
\hline China $\ldots \ldots \ldots \ldots \ldots \ldots$ & 0 & 12 & 14 & 13 & 38 & 69 & 86 & 111 & 9.2 \\
\hline India ..... & 6 & 6 & 7 & 11 & 16 & 30 & 41 & 52 & 8.7 \\
\hline Other Asia . & 82 & 98 & 107 & 128 & 150 & 170 & 172 & 150 & 1.7 \\
\hline Middle East $\ldots \ldots \ldots \ldots \ldots$ & 0 & 0 & 0 & 0 & 10 & 10 & 10 & 10 & - \\
\hline Africa $\ldots \ldots \ldots \ldots \ldots \ldots$ & 8 & 11 & 12 & 11 & 11 & 11 & 11 & 11 & 0.0 \\
\hline Central and South America .... & 9 & 9 & 9 & 10 & 17 & 17 & 17 & 17 & 2.4 \\
\hline Brazil $\ldots \ldots \ldots \ldots \ldots \ldots$ & 2 & 2 & 2 & 3 & 8 & 9 & 9 & 9 & 5.3 \\
\hline Other Central/South America ... & 7 & 7 & 7 & 7 & 9 & 8 & 8 & 8 & 0.7 \\
\hline Total Developing . ........ & 105 & 138 & 149 & 173 & 243 & 308 & 338 & 352 & 3.8 \\
\hline$\ldots \ldots \ldots \ldots \ldots$ & 1,905 & 2,203 & 2,280 & 2,332 & 2,368 & 2,357 & 2,212 & 2,021 & -0.3 \\
\hline
\end{tabular}

${ }^{a}$ Includes the 50 States and the District of Columbia. U.S. Territories are included in Australasia.

Notes: EE/FSU = Eastern Europe/Former Soviet Union. Totals may not equal sum of components due to independent rounding. The electricity portion of the national fuel consumption values consists of generation for domestic use plus an adjustment for electricity trade based on a fuel's share of total generation in the exporting country.

Sources: History: Energy Information Administration (EIA), International Energy Annual 1996, DOE/EIA-0219(96) (Wäshington, DC, February 1998). Projections: EIA, Annual Energy Outlook 1998, DOE/EIA-0383(98) (Washington, DC, December 1997), Table A8; and World Energy Projection System (1998). 
Table A7. World Consumption of Hydroelectricity and Other Renewable Energy by Region, Reference Case, 1990-2020

(Quadrillion Btu)

\begin{tabular}{|c|c|c|c|c|c|c|c|c|c|}
\hline \multirow[b]{2}{*}{ Region/Country } & \multicolumn{3}{|c|}{ History } & \multicolumn{5}{|c|}{ Projections } & \multirow{2}{*}{$\begin{array}{c}\text { Average Annual } \\
\text { Percent Change, } \\
\text { 1995-2020 }\end{array}$} \\
\hline & 1990 & 1995 & 1996 & 2000 & 2005 & 2010 & 2015 & 2020 & \\
\hline \multicolumn{10}{|l|}{ Industrialized } \\
\hline North America & 9.2 & 10.6 & 10.7 & 11.7 & 12.6 & 13.5 & 14.1 & 14.8 & 1.3 \\
\hline United States $^{a}$ & 5.8 & 6.8 & 6.6 & 7.2 & 7.5 & 7.8 & 8.0 & 8.2 & 0.7 \\
\hline Canada $\ldots \ldots \ldots \ldots \ldots \ldots$ & 3.1 & 3.4 & 3.6 & 4.0 & 4.5 & 5.0 & 5.2 & 5.5 & 1.9 \\
\hline Mexico ........ & 0.3 & 0.4 & 0.4 & 0.4 & 0.6 & 0.7 & 0.9 & 1.1 & 4.0 \\
\hline Western Europe . . . . . . . . . . & 4.6 & 5.1 & 4.9 & 5.8 & 6.6 & 7.4 & 8.0 & 8.7 & 2.1 \\
\hline Industrialized Asia . . . . . . . . . & 1.4 & 1.4 & 1.4 & 1.4 & 1.5 & 1.7 & 1.8 & 2.1 & 1.7 \\
\hline Japan $\ldots \ldots \ldots \ldots \ldots \ldots$ & 1.0 & 0.9 & 0.9 & 0.8 & 0.9 & 1.0 & 1.0 & 1.1 & 0.8 \\
\hline Australasia ......... & 0.4 & 0.5 & 0.5 & 0.6 & 0.6 & 0.7 & 0.9 & 1.0 & 3.0 \\
\hline Total Industrialized . . . . . . & 15.3 & 17.2 & 16.9 & 18.8 & 20.7 & 22.5 & 24.0 & 25.6 & 1.6 \\
\hline \multicolumn{10}{|l|}{$\mathrm{EE} / \mathrm{FSU}$} \\
\hline Former Soviet Union & 2.4 & 2.5 & 2.2 & 2.6 & 2.9 & 3.1 & 3.2 & 3.4 & 1.3 \\
\hline Eastern Europe .... & 0.4 & 0.6 & 0.6 & 0.5 & 0.7 & 1.0 & 1.4 & 1.7 & 4.5 \\
\hline Total EE/FSU $\ldots \ldots \ldots \ldots$ & 2.8 & 3.0 & 2.9 & 3.1 & 3.6 & 4.0 & 4.6 & 5.1 & 2.1 \\
\hline \multicolumn{10}{|l|}{ Developing Countries } \\
\hline Developing Asia .... . . & 3.2 & 4.0 & 4.0 & 5.7 & 7.6 & 8.6 & 9.7 & 10.9 & 4.1 \\
\hline China ........... & 1.3 & 1.9 & 1.9 & 2.9 & 4.2 & 4.7 & 4.8 & 5.0 & 3.9 \\
\hline India .... & 0.7 & 0.7 & 0.7 & 1.4 & 1.6 & 1.9 & 2.4 & 3.1 & 5.8 \\
\hline Other Asia & 1.2 & 1.4 & 1.4 & 1.5 & 1.8 & 2.0 & 2.4 & 2.9 & 3.0 \\
\hline Middle East & 0.1 & 0.2 & 0.2 & 0.3 & 0.4 & 0.5 & 0.7 & 0.8 & 6.7 \\
\hline Africa $\ldots \ldots \ldots \ldots \ldots \ldots$ & 0.6 & 0.6 & 0.6 & 0.6 & 0.7 & 0.8 & 1.0 & 1.1 & 2.6 \\
\hline Central and South America .... & 3.9 & 5.1 & 5.4 & 5.3 & 5.5 & 5.8 & 6.2 & 6.6 & 1.1 \\
\hline Brazil $\ldots \ldots \ldots \ldots \ldots \ldots$ & 2.2 & 2.7 & 2.8 & 2.8 & 2.9 & 3.0 & 3.2 & 3.3 & 0.8 \\
\hline Other Central/South America ... & 1.7 & 2.4 & 2.6 & 2.5 & 2.6 & 2.8 & 3.0 & 3.3 & 1.3 \\
\hline Total Developing . . . . . . . . & 7.8 & 9.9 & 10.2 & 11.9 & 14.2 & 15.8 & 17.5 & 19.5 & 2.8 \\
\hline Total World $\ldots \ldots \ldots \ldots \ldots$ & 25.9 & 30.1 & 30.0 & 33.8 & 38.6 & 42.4 & 46.0 & 50.2 & 2.1 \\
\hline
\end{tabular}

${ }^{a}$ Includes the 50 States and the District of Columbia. U.S. Territories are included in Australasia.

Notes: EE/FSU = Eastern Europe/Former Soviet Union. Totals may not equal sum of components due to independent rounding. The electricity portion of the national fuel consumption values consists of generation for domestic use plus an adjustment for electricity trade based on a fuel's share of total generation in the exporting country.

Sources: History: Energy Information Administration (EIA), International Energy Annual 1996, DOE/EIA-0219(96) (Washington, DC, February 1998). Projections: ElA, Annual Energy Outlook 1998, DOE/EIA-0383(98) (Washington, DC, December 1997), Table A1; and World Energy Projection System (1998). 
Table A8. World Total Net Electricity Consumption by Region, Reference Case, 1990-2020 (Billion Kilowatthours)

\begin{tabular}{|c|c|c|c|c|c|c|c|c|c|}
\hline \multirow[b]{2}{*}{ Region/Country } & \multicolumn{3}{|c|}{ History } & \multicolumn{5}{|c|}{ Projections } & \multirow{2}{*}{$\begin{array}{c}\text { Average Annual } \\
\text { Percent Change } \\
1995-2020 \\
\end{array}$} \\
\hline & 1990 & 1995 & 1996 & 2000 & 2005 & 2010 & 2015 & 2020 & \\
\hline \multicolumn{10}{|l|}{ Industrialized } \\
\hline North America & 3,255 & 3,759 & 3,859 & 3,984 & 4,347 & 4,713 & 5,050 & 5,354 & 1.4 \\
\hline United States $^{\mathrm{a}}$ & 2,713 & 3,163 & 3,243 & 3,318 & 3,601 & 3,877 & 4,115 & 4,308 & 1.2 \\
\hline Canada ..... & 435 & 462 & 473 & 499 & 528 & 574 & 625 & 680 & 1.6 \\
\hline Mexico ................ & 107 & 134 & 144 & 167 & 217 & 261 & 310 & 367 & 4.1 \\
\hline Western Europe . . . . . . . . & 2,115 & 2,286 & 2,330 & 2,720 & 3,064 & 3,419 & 3,781 & 4,182 & 2.4 \\
\hline Industrialized Asia . . . . . . . . & 930 & 1,068 & 1,090 & 1,263 & 1,393 & 1,531 & 1,666 & 1,812 & 2.1 \\
\hline Japan $\ldots \ldots \ldots \ldots \ldots \ldots$ & 750 & 864 & 882 & 976 & 1,063 & 1,162 & 1,258 & 1,363 & 1.8 \\
\hline Australasia ............. & 180 & 204 & 207 & 287 & 330 & 369 & 407 & 450 & 3.2 \\
\hline Total Industrialized . . . . . . . & 6,299 & 7,113 & 7,279 & 7,968 & 8,804 & 9,663 & 10,497 & 11,349 & 1.9 \\
\hline \multicolumn{10}{|l|}{ EE/FSU } \\
\hline Former Soviet Union & 1,488 & 1,168 & 1,133 & 1,108 & 1,236 & 1,366 & 1,472 & 1,586 & 1.2 \\
\hline Eastern Europe .... & 420 & 384 & 401 & 401 & 449 & 515 & 584 & 662 & 2.2 \\
\hline Total EE/FSU $\ldots \ldots \ldots \ldots$ & 1,908 & 1,552 & 1,535 & 1,509 & 1,685 & 1,881 & 2,056 & 2,248 & 1.5 \\
\hline \multicolumn{10}{|l|}{ Developing Countries } \\
\hline Developing Asia . . . . . & 1,268 & 1,912 & 2,002 & 2,489 & 3,283 & 4,160 & 5,255 & 6,665 & 5.1 \\
\hline China ........... & 551 & 881 & 925 & 1,076 & 1,476 & 1,975 & 2,657 & 3,574 & 5.8 \\
\hline India $\ldots \ldots \ldots$ & 257 & 367 & 378 & 541 & 706 & 888 & 1,092 & 1,344 & 5.3 \\
\hline Other Asia . . . . . & 460 & 663 & 699 & 872 & 1,101 & 1,297 & 1,505 & 1,747 & 4.0 \\
\hline Middle East $\ldots \ldots \ldots \ldots \ldots$ & 221 & 295 & 301 & 309 & 362 & 419 & 483 & 554 & 2.6 \\
\hline Africa $\ldots \ldots \ldots \ldots \ldots \ldots$ & 285 & 320 & 332 & 378 & 459 & 552 & 657 & 782 & 3.6 \\
\hline Central and South America .... & 449 & 575 & 604 & 711 & 902 & 1,088 & 1,290 & 1,548 & 4.0 \\
\hline Brazil ................ & 229 & 288 & 303 & 371 & 497 & 637 & 813 & 1,039 & 5.3 \\
\hline Other Central/South America ... & 220 & 286 & 301 & 340 & 406 & 451 & 477 & 509 & 2.3 \\
\hline Total Developing $\ldots \ldots \ldots \ldots$ & 2,224 & 3,102 & 3,239 & 3,886 & 5,007 & 6,220 & 7,684 & 9,548 & 4.6 \\
\hline$\ldots \ldots \ldots \ldots \ldots$ & 10,431 & 11,767 & 12,053 & 13,363 & 15,495 & 17,764 & 20,237 & 23,145 & 2.7 \\
\hline
\end{tabular}

${ }^{a}$ Includes the 50 States and the District of Columbia. U.S. Territories are included in Australasia.

Notes: EE/FSU = Eastern Europe/Former Soviet Union. Electricity consumption equals generation plus imports minus exports minus distribution losses.

Sources: History: Energy Information Administration (EIA), International Energy Annual 1996, DOE/EIA-0219(96) (Washington, DC, February 1998), Table 6.2. Projections: EIA, Annual Energy Outlook 1998, DOE/EIA-0383(98) (Washington, DC, December 1997), Table A8; and World Energy Projection System (1998). 
Table A9. World Total Carbon Emissions by Region, Reference Case, 1990-2020 (Million Metric Tons)

\begin{tabular}{|c|c|c|c|c|c|c|c|c|c|}
\hline \multirow[b]{2}{*}{ Region/Country } & \multicolumn{3}{|c|}{ History } & \multicolumn{5}{|c|}{ Projections } & \multirow{2}{*}{$\begin{array}{c}\text { Average Annual } \\
\text { Percent Change, } \\
\text { 1995-2020 }\end{array}$} \\
\hline & 1990 & 1995 & 1996 & 2000 & 2005 & 2010 & 2015 & 2020 & \\
\hline \multicolumn{10}{|l|}{ Industrialized } \\
\hline North America & 1,550 & 1,629 & 1,687 & 1,829 & 1,967 & 2,105 & 2,217 & 2,313 & 1.4 \\
\hline United States ${ }^{a}$ & 1,346 & 1,411 & 1,463 & 1,577 & 1,689 & 1,803 & 1,888 & 1,956 & 1.3 \\
\hline Canada $\ldots \ldots \ldots \ldots \ldots$ & 126 & 135 & 140 & 152 & 161 & 170 & 183 & 198 & 1.5 \\
\hline Mexico $\ldots \ldots \ldots \ldots \ldots \ldots$ & 78 & 82 & 84 & 99 & 117 & 132 & 145 & 159 & 2.7 \\
\hline Western Europe $\ldots \ldots \ldots \ldots$. & 971 & 925 & 947 & 978 & 1,037 & 1,101 & 1,169 & 1,239 & 1.2 \\
\hline Industrialized Asia $\ldots \ldots \ldots \ldots$. & 364 & 379 & 389 & 409 & 434 & 461 & 485 & 514 & 1.2 \\
\hline Japan $\ldots \ldots \ldots \ldots \ldots \ldots$ & 274 & 281 & 291 & 303 & 320 & 342 & 361 & 385 & 1.3 \\
\hline Australasia ............. & 90 & 99 & 99 & 107 & 113 & 119 & 124 & 129 & 1.1 \\
\hline Total Industrialized $\ldots \ldots \ldots$ & 2,885 & 2,933 & 3,023 & 3,216 & 3,437 & 3,667 & 3,870 & 4,066 & 1.3 \\
\hline \multicolumn{10}{|l|}{ EE/FSU } \\
\hline Former Soviet Union & 991 & 636 & 613 & 653 & 720 & 792 & 850 & 913 & 1.5 \\
\hline Eastern Europe .... & 299 & 230 & 228 & 249 & 266 & 280 & 293 & 310 & 1.2 \\
\hline Total EE/FSU $\ldots \ldots \ldots \ldots$ & 1,290 & 866 & 842 & 903 & 986 & 1,072 & 1,144 & 1,223 & 1.4 \\
\hline \multicolumn{10}{|l|}{ Developing Countries } \\
\hline Developing Asia . . . . . . . . & 1,065 & 1,427 & 1,474 & 1,758 & 2,161 & 2,603 & 3,158 & 3,835 & 4.0 \\
\hline China...$\ldots \ldots \ldots \ldots$ & 620 & 792 & 805 & 978 & 1,202 & 1,481 & 1,866 & 2,340 & 4.4 \\
\hline India $\ldots \ldots \ldots \ldots \ldots \ldots$ & 153 & 222 & 230 & 281 & 340 & 399 & 456 & 523 & 3.5 \\
\hline Other Asia . . . . . . . . . . & 293 & 413 & 439 & 499 & 620 & 723 & 836 & 971 & 3.5 \\
\hline Middle East $\ldots \ldots \ldots \ldots \ldots$ & 194 & 229 & 241 & 253 & 285 & 322 & 363 & 409 & 2.3 \\
\hline Africa $\ldots \ldots \ldots \ldots \ldots \ldots$ & 178 & 192 & 198 & 219 & 247 & 276 & 306 & 341 & 2.3 \\
\hline Central and South America .... & 174 & 194 & 206 & 250 & 318 & 391 & 475 & 574 & 4.4 \\
\hline Brazil $\ldots \ldots \ldots \ldots \ldots \ldots$ & 57 & 64 & 71 & 85 & 111 & 139 & 170 & 208 & 4.9 \\
\hline Other Central/South America ... & 117 & 130 & 135 & 165 & 206 & 252 & 305 & 366 & 4.2 \\
\hline Total Developing...$\ldots \ldots$ & 1,611 & 2,043 & 2,118 & 2,480 & 3,011 & 3,591 & 4,302 & 5,158 & 3.8 \\
\hline Total World $\ldots \ldots \ldots \ldots \ldots \ldots$ & 5,786 & 5,841 & 5,983 & 6,598 & 7,434 & 8,330 & 9,315 & 10,447 & 2.4 \\
\hline
\end{tabular}

${ }^{a}$ Includes the 50 States and the District of Columbia. U.S. Territories are included in Australasia.

Notes: EE/FSU = Eastern Europe/Former Soviet Union. The U.S. numbers include carbon emissions attributable to renewable energy sources.

Sources: History: Energy Information Administration (EIA), International Energy Annual 1996, DOE/EIA-0219(96) (Washington, DC, February 1998). Projections: EIA, Annual Energy Outlook 1998, DOE/EIA-0383(98) (Washington, DC, December 1997), Table A19; and World Energy Projection System (1998). 
Table A10. World Carbon Emissions from Oil Use by Region, Reference Case, 1990-2020 (Million Metric Tons)

\begin{tabular}{|c|c|c|c|c|c|c|c|c|c|}
\hline \multirow[b]{2}{*}{ Region/Country } & \multicolumn{3}{|c|}{ History } & \multicolumn{5}{|c|}{ Projections } & \multirow{2}{*}{$\begin{array}{c}\text { Average Annual } \\
\text { Percent Change, } \\
1995-2020\end{array}$} \\
\hline & 1990 & 1995 & 1996 & 2000 & 2005 & 2010 & 2015 & 2020 & \\
\hline \multicolumn{10}{|l|}{ Industrialized } \\
\hline North America . . . . . . . . . . . & 714 & 723 & 747 & 795 & 858 & 928 & 977 & 1,017 & 1.4 \\
\hline United States $^{a} \ldots \ldots \ldots \ldots$ & 591 & 600 & 621 & 656 & 708 & 762 & 796 & 822 & 1.3 \\
\hline Canada ............... & 61 & 62 & 64 & 67 & 72 & 77 & 82 & 88 & 1.4 \\
\hline Mexico . . . . . . . . . . . . & 62 & 61 & 62 & 72 & 78 & 90 & 99 & 107 & 2.3 \\
\hline Western Europe . . . . . . . . . . & 494 & 499 & 504 & 503 & 515 & 525 & 534 & 543 & 0.3 \\
\hline Industrialized Asia . . . . . . . . . . & 219 & 218 & 221 & 240 & 255 & 270 & 288 & 308 & 1.4 \\
\hline Japan $\ldots \ldots \ldots \ldots \ldots \ldots$ & 179 & 174 & 179 & 192 & 203 & 214 & 229 & 245 & 1.4 \\
\hline Australasia . . . . . . . . . . . & 40 & 44 & 43 & 48 & 52 & 56 & 59 & 63 & 1.4 \\
\hline Total Industrialized . . . . . . . & 1,427 & $1 ; 440$ & 1,473 & 1,538 & 1,627 & 1,724 & 1,799 & 1,868 & 1.0 \\
\hline \multicolumn{10}{|l|}{ EE/FSU } \\
\hline Former Soviet Union . . . . . . . . . & 355 & 174 & 165 & 164 & 190 & 223 & 252 & 281 & 1.9 \\
\hline Eastern Europe . . . . . . . . . & 71 & 47 & 48 & 54 & 58 & 69 & 81 & 96 & 2.9 \\
\hline Total EE/FSU $\ldots \ldots \ldots \ldots$ & 427 & 220 & 212 & 218 & 248 & 292 & 333 & 377 & 2.2 \\
\hline \multicolumn{10}{|l|}{ Developing Countries } \\
\hline Developing Asia . . . . . . . . . . . & 326 & 475 & 416 & 467 & 586 & 699 & 836 & 1,005 & 3.0 \\
\hline China $\ldots \ldots \ldots \ldots \ldots \ldots$ & 98 & 140 & 113 & 141 & 177 & 224 & 282 & 357 & 3.8 \\
\hline India $\ldots \ldots \ldots \ldots \ldots \ldots$ & 49 & 65 & 59 & 63 & 79 & 94 & 113 & 136 & 3.0 \\
\hline Other Asia ... & 178 & 270 & 244 & 263 & 330 & 380 & 441 & 512 & 2.6 \\
\hline Middle East $\ldots \ldots \ldots \ldots \ldots$ & 144 & 172 & 159 & 167 & 190 & 213 & 238 & 267 & 1.8 \\
\hline Africa $\ldots \ldots \ldots \ldots \ldots \ldots$. & 84 & 97 & 87 & 112 & 132 & 148 & 165 & 185 & 2.6 \\
\hline Central and South America . ... . & 140 & 158 & 138 & 180 & 214 & 252 & 292 & 339 & 3.1 \\
\hline Brazil . . . . . . . . . . . . & 54 & 60 & 51 & 66 & 79 & 93 & 107 & 124 & 3.0 \\
\hline Other Central/South America . . . & 86 & 98 & 87 & 114 & 135 & 160 & 185 & 214 & 3.2 \\
\hline Total Developing . . . . . . . . & 693 & 902 & 800 & 926 & 1,122 & 1,311 & 1,532 & 1,796 & 2.8 \\
\hline Total World & 2,547 & 2,562 & 2,485 & 2,681 & 2,998 & 3,327 & 3,664 & 4,040 & 1.8 \\
\hline
\end{tabular}

ancludes the 50 States and the District of Columbia. U.S. Territories are included in Australasia.

Notes: EE/FSU = Eastern Europe/Former Soviet Union.

Sources: History: Energy Information Administration (EIA), International Energy Annual 1996, DOE/EIA-0219(96) (Washington, DC, February 1998). Projections: EIA, Annual Energy Outlook 1998, DOE/EIA-0383(98) (Washington, DC, December 1997), Table A19; and World Energy Projection System (1998). 
Table A11. World Carbon Emissions from Natural Gas Use by Region, Reference Case, 1990-2020 (Million Metric Tons)

\begin{tabular}{|c|c|c|c|c|c|c|c|c|c|}
\hline \multirow[b]{2}{*}{ Region/Country } & \multicolumn{3}{|c|}{ History } & \multicolumn{5}{|c|}{ Projections } & \multirow{2}{*}{\begin{tabular}{|c} 
Average Annual \\
Percent Change, \\
$1995-2020$
\end{tabular}} \\
\hline & 1990 & 1995 & 1996 & 2000 & 2005 & 2010 & 2015 & 2020 & \\
\hline \multicolumn{10}{|l|}{ Industrialized } \\
\hline North America & 320 & 370 & 378 & 419 & 463 & 507 & 543 & 579 & 1.8 \\
\hline United States $^{\mathrm{a}}$ & 273 & 314 & 318 & 354 & 386 & 424 & 450 & 474 & 1.7 \\
\hline Canada $\ldots \ldots \ldots \ldots \ldots \ldots$ & 34 & 41 & 44 & 44 & 45 & 48 & 55 & 63 & 1.7 \\
\hline Mexico $\ldots \ldots \ldots \ldots \ldots \ldots$ & 13 & 15 & 15 & 21 & 32 & 34 & 38 & 42 & 4.2 \\
\hline Western Europe . . . . . . . . . & 141 & 176 & 196 & 226 & 277 & 329 & 388 & 449 & 3.8 \\
\hline Industrialized Asia . . . . . . . . . & 41 & 48 & 51 & 51 & 58 & 64 & 66 & 71 & 1.6 \\
\hline Japan $\ldots \ldots \ldots \ldots \ldots \ldots$ & 29 & 35 & 37 & 34 & 39 & 44 & 46 & 51 & 1.5 \\
\hline Australasia $\ldots \ldots \ldots \ldots \ldots$ & 12 & 13 & 13 & 16 & 19 & 19 & 20 & 21 & 1.8 \\
\hline Total Industrialized..$\ldots \ldots$ & 502 & 593 & 625 & 696 & 798 & 899 & 997 & 1,100 & 2.5 \\
\hline \multicolumn{10}{|l|}{ EE/FSU } \\
\hline Former Soviet Union & 323 & 262 & 264 & 292 & 333 & 375 & 409 & 449 & 2.2 \\
\hline Eastern Europe .... & 41 & 36 & 39 & 50 & 62 & 74 & 84 & 96 & 4.0 \\
\hline Total EE/FSU $\ldots \ldots \ldots \ldots$ & 365 & 298 & 303 & 342 & 395 & 449 & 494 & 545 & 2.4 \\
\hline \multicolumn{10}{|l|}{ Developing Countries } \\
\hline Developing Asia ............ & 40 & 69 & 79 & 141 & 210 & 274 & 336 & 411 & 7.4 \\
\hline 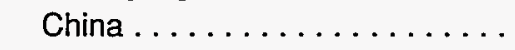 & 7 & 9 & 10 & 21 & 36 & 46 & 50 & 55 & 7.5 \\
\hline India $\ldots \ldots \ldots \ldots \ldots \ldots$ & 6 & 10 & 11 & 24 & 37 & 54 & 73 & 96 & 9.4 \\
\hline Other Asia ... & 27 & 50 & 57 & 96 & 136 & 175 & 213 & 260 & 6.8 \\
\hline Middle East $\ldots \ldots \ldots \ldots \ldots$ & 54 & 70 & 76 & 80 & 88 & 100 & 115 & 132 & 2.6 \\
\hline Africa $\ldots \ldots \ldots \ldots \ldots \ldots$ & 20 & 26 & 27 & 25 & 29 & 36 & 44 & 52 & 2.8 \\
\hline Central and South America .... & 29 & 39 & 43 & 47 & 77 & 110 & 150 & 199 & 6.7 \\
\hline Brazil $\ldots \ldots \ldots \ldots \ldots \ldots$ & 1 & 2 & 3 & 6 & 18 & 30 & 45 & 64 & 14.1 \\
\hline Other Central/South America ... & 28 & 37 & 40 & 41 & 59 & 80 & 105 & 136 & 5.3 \\
\hline Total Developing ......... & 143 & 204 & 225 & 294 & 404 & 521 & 645 & 794 & 5.6 \\
\hline Total World $\ldots \ldots \ldots \ldots \ldots$ & 1,009 & 1,095 & 1,152 & 1,331 & 1,597 & 1,869 & 2,136 & 2,438 & 3.3 \\
\hline
\end{tabular}

${ }^{a}$ Includes the 50 States and the District of Columbia. U.S. Territories are included in Australasia.

Notes: EE/FSU = Eastern Europe/Former Soviet Union.

Sources: History: Energy Information Administration (EIA), International Energy Annual 1996, DOE/EIA-0219(96) (Washington, DC, February 1998). Projections: EIA, Annual Energy Outlook 1998, DOE/EIA-0383(98) (Washington, DC, December 1997), Table A19; and World Energy Projection System (1998). 
Table A12. World Carbon Emissions from Coal Use by Region, Reference Case, 1990-2020 (Million Metric Tons)

\begin{tabular}{|c|c|c|c|c|c|c|c|c|c|}
\hline \multirow[b]{2}{*}{ Region/Country } & \multicolumn{3}{|c|}{ History } & \multicolumn{5}{|c|}{ Projections } & \multirow{2}{*}{$\begin{array}{c}\text { Average Annual } \\
\text { Percent Change, } \\
1995-2020\end{array}$} \\
\hline & 1990 & 1995 & 1996 & 2000 & 2005 & 2010 & 2015 & 2020 & \\
\hline \multicolumn{10}{|l|}{ Industrialized } \\
\hline North America $\ldots \ldots \ldots \ldots \ldots$ & 516 & 536 & 562 & 615 & 646 & 669 & 695 & 714 & 1.2 \\
\hline United States ${ }^{a} \ldots \ldots \ldots \ldots \ldots$ & 481 & 498 & 524 & 567 & 594 & 616 & 640 & 658 & 1.1 \\
\hline Canada $\ldots \ldots \ldots \ldots \ldots \ldots$ & 31 & 32 & 32 & 42 & 44 & 45 & 46 & 47 & 1.5 \\
\hline Mexico ............... & 3 & 6 & 6 & 6 & 7 & 8 & 9 & 9 & 2.1 \\
\hline Western Europe . . . . . . . . . & 335 & 250 & 246 & 249 & 245 & 247 & 247 & 247 & 0.0 \\
\hline Industrialized Asia .......... & 105 & 113 & 117 & 118 & 121 & 128 & 130 & 134 & 0.7 \\
\hline Japan $\ldots \ldots \ldots \ldots \ldots \ldots$ & 66 & 72 & 74 & 76 & 78 & 84 & 86 & 89 & 0.8 \\
\hline Australasia ............. & 39 & 41 & 43 & 42 & 43 & 44 & 45 & 46 & 0.4 \\
\hline Total Industrialized . . . . . . & 956 & 900 & 925 & 930 & 981 & 1,020 & 1,046 & 1,076 & 0.7 \\
\hline \multicolumn{10}{|l|}{ EE/FSU } \\
\hline Former Soviet Union . . . . . . . & 333 & 201 & 185 & 197 & 196 & 194 & 188 & 182 & -0.4 \\
\hline Eastern Europe $\ldots \ldots \ldots \ldots \ldots$ & 189 & 148 & 142 & 146 & 146 & 137 & 128 & 119 & -0.9 \\
\hline Total EE/FSU $\ldots \ldots \ldots \ldots$ & 522 & 348 & 327 & 343 & 342 & 331 & 317 & 301 & -0.6 \\
\hline \multicolumn{10}{|l|}{ Developing Countries } \\
\hline Developing Asia . . . . . . . . . & 714 & 962 & 980 & 1,150 & 1,365 & 1,630 & 1,985 & 2,419 & 3.8 \\
\hline China .......... & 514 & 677 & 682 & 816 & 989 & 1,212 & 1,534 & 1,928 & 4.3 \\
\hline India $\ldots \ldots$ & 101 & 156 & 160 & 194 & 223 & 251 & 269 & 291 & 2.5 \\
\hline Other Asia ... & 99 & 129 & 137 & 139 & 153 & 168 & 182 & 199 & 1.8 \\
\hline Middle East $\ldots \ldots \ldots \ldots \ldots$ & 4 & 5 & 5 & 6 & 7 & 8 & 10 & 10 & 2.6 \\
\hline Africa $\ldots \ldots \ldots \ldots \ldots \ldots$ & 74 & 82 & 84 & 82 & 86 & 92 & 98 & 104 & 0.9 \\
\hline Central and South America .... & 17 & 20 & 25 & 23 & 27 & 29 & 32 & 36 & 2.4 \\
\hline Brazil ................. & 9 & 12 & 17 & 13 & 15 & 16 & 18 & 20 & 2.2 \\
\hline Other Central/South America ... & 7 & 8 & 8 & 10 & 12 & 13 & 15 & 16 & 2.8 \\
\hline Total Developing ......... & 809 & 1,069 & 1,094 & 1,261 & 1,485 & 1,759 & 2,124 & 2,569 & 3.6 \\
\hline$\ldots \ldots \ldots \ldots$ & 2,287 & 2,317 & 2,345 & 2,533 & 2,808 & 3,110 & 3,487 & 3,947 & 2.2 \\
\hline
\end{tabular}

Includes the 50 States and the District of Columbia. U.S. Territories are included in Australasia.

Notes: EE/FSU = Eastern Europe/Former Soviet Union.

Sources: History: Energy Information Administration (EIA), International Energy Annual 1996, DOE/EIA-0219(96) (Washington, DC, February 1998). Projections: EIA, Annual Energy Outlook 1998, DOE/EIA-0383(98) (Washington, DC, December 1997), Table A19; and World Energy Projection System (1998). 
Table A13. World Total Energy Consumption in Oil-Equivalent Units by Region, Reference Case, 1990-2020 (Million Tons Oil Equivalent)

\begin{tabular}{|c|c|c|c|c|c|c|c|c|c|}
\hline \multirow[b]{2}{*}{ Region/Country } & \multicolumn{3}{|c|}{ History } & \multicolumn{5}{|c|}{ Projections } & \multirow{2}{*}{$\begin{array}{c}\text { Average Annual } \\
\text { Percent Change } \\
1995-2020\end{array}$} \\
\hline & 1990 & 1995 & 1996 & 2000 & 2005 & 2010 & 2015 & 2020 & \\
\hline \multicolumn{10}{|l|}{ Industrialized } \\
\hline North America & 2,513 & 2,723 & 2,828 & 3,018 & 3,229 & 3,440 & 3,580 & 3,706 & 1.2 \\
\hline United States $^{a}$ & 2,115 & 2,278 & 2,369 & 2,515 & 2,667 & 2,827 & 2,916 & 2,988 & 1.1 \\
\hline Canada ..... & 274 & 307 & 317 & 336 & 361 & 387 & 413 & 440 & 1.5 \\
\hline Mexico $\ldots \ldots \ldots \ldots \ldots$ & 124 & 138 & 142 & 167 & 202 & 226 & 251 & 278 & 2.8 \\
\hline Western Europe..$\ldots \ldots \ldots \ldots$ & 1,561 & 1,632 & 1,681 & 1,757 & 1,878 & 1,991 & 2,103 & 2,221 & 1.2 \\
\hline Industrialized Asia . . . . . . . . & 579 & 663 & 678 & 715 & 759 & 809 & 860 & 915 & 1.3 \\
\hline Japan $\ldots \ldots \ldots \ldots \ldots \ldots$ & 456 & 523 & 539 & 561 & 593 & 633 & 674 & 717 & 1.3 \\
\hline Australasia $\ldots \ldots \ldots \ldots$ & 123 & 140 & 139 & 154 & 165 & 176 & 186 & 198 & 1.4 \\
\hline Total Industrialized $\ldots \ldots \ldots$ & 4,654 & 5,018 & 5,187 & 5,490 & 5,866 & 6,241 & 6,543 & 6,842 & 1.2 \\
\hline \multicolumn{10}{|l|}{ EE/FSU } \\
\hline Former Soviet Union & 1,473 & 1,027 & 1,003 & 1,073 & 1,196 & 1,322 & 1,424 & 1,533 & 1.6 \\
\hline Eastern Europe .... & 382 & 312 & 316 & 345 & 381 & 416 & 453 & 492 & 1.8 \\
\hline Total EE/FSU $\ldots \ldots \ldots \ldots$ & 1,855 & 1,340 & 1,319 & 1,418 & 1,577 & 1,738 & 1,876 & 2,026 & 1.7 \\
\hline \multicolumn{10}{|l|}{ Developing Countries } \\
\hline Developing Asia .... & 1,294 & 1,811 & 1,879 & 2,288 & 2,868 & 3,461 & 4,169 & 5,026 & 4.2 \\
\hline China .......... & 680 & 917 & 935 & 1,160 & 1,460 & 1,797 & 2,229 & 2,764 & 4.5 \\
\hline India $\ldots \ldots \ldots$ & 195 & 279 & 291 & 370 & 456 & 547 & 645 & 760 & 4.1 \\
\hline Other Asia ..... & 420 & 614 & 653 & 758 & 951 & 1,118 & 1,296 & 1,502 & 3.6 \\
\hline Middle East & 281 & 350 & 369 & 391 & 444 & 502 & 569 & 644 & 2.5 \\
\hline Africa $\ldots \ldots \ldots \ldots \ldots \ldots$ & 233 & 270 & 279 & 309 & 351 & 397 & 445 & 499 & 2.5 \\
\hline Central and South America .... & 346 & 423 & 446 & 511 & 630 & 756 & 902 & 1,076 & 3.8 \\
\hline Brazil $\ldots \ldots \ldots \ldots \ldots \ldots$ & 136 & 161 & 173 & 196 & 246 & 296 & 354 & 424 & 3.9 \\
\hline Other Central/South America ... & 210 & 262 & 274 & 315 & 384 & 460 & 547 & 652 & 3.7 \\
\hline Total Developing ......... & 2,154 & 2,854 & 2,972 & 3,499 & 4,293 & 5,116 & 6,085 & 7,245 & 3.8 \\
\hline Total World & 8,663 & 9,212 & 9,478 & 10,408 & 11,736 & 13,095 & 14,504 & 16,112 & 2.3 \\
\hline
\end{tabular}

${ }^{a}$ Includes the 50 States and the District of Columbia. U.S. Territories are included in Australasia.

Notes: EE/FSU = Eastern Europe/Former Soviet Union.

Sources: History: Derived from Energy Information Administration (EIA), International Energy Annual 1996, DOE/EIA-0219(96) (Washington, DC, February 1998). Projections: EIA, AnnualEnergy Outlook 1998, DOE/EIA-0383(98) (Washington, DC, December 1997), Table A19; and World Energy Projection System (1998). 
Table A14. World Total Energy Consumption by Region, High Economic Growth Case, 1990-2020 (Quadrillion Btu)

\begin{tabular}{|c|c|c|c|c|c|c|c|c|c|}
\hline \multirow[b]{2}{*}{ Region/Country } & \multicolumn{3}{|c|}{ History } & \multicolumn{5}{|c|}{ Projections } & \multirow{2}{*}{$\begin{array}{c}\text { Average Annual } \\
\text { Percent Change, } \\
1995-2020\end{array}$} \\
\hline & 1990 & 1995 & 1996 & 2000 & 2005 & 2010 & 2015 & 2020 & \\
\hline \multicolumn{10}{|l|}{ Industrialized Countries } \\
\hline North America . . . . . . . . . . . & 99.7 & 108.0 & 112.2 & 121.2 & 132.4 & 143.4 & 152.5 & 161.6 & 1.6 \\
\hline United States $^{a} \ldots \ldots \ldots \ldots \ldots$ & 83.9 & 90.4 & 94.0 & 100.6 & 108.7 & 116.9 & 123.2 & 129.1 & 1.4 \\
\hline Canada $\ldots \ldots \ldots \ldots \ldots \ldots$ & 10.9 & 12.2 & 12.6 & 13.7 & 15.1 & 16.6 & 18.1 & 19.7 & 1.9 \\
\hline Mexico . . . . . . . . . . . . & 4.9 & 5.5 & 5.6 & 6.9 & 8.6 & 9.9 & 11.2 & 12.8 & 3.4 \\
\hline Western Europe . . . . . . . . . . & 61.9 & 64.8 & 66.7 & 71.9 & 78.9 & 85.6 & 92.4 & 99.8 & 1.7 \\
\hline Industrialized Asia . . . . . . . . . . & 23.0 & 26.3 & 26.9 & 29.5 & 32.1 & 35.1 & 38.2 & 41.7 & 1.9 \\
\hline Japan $\ldots \ldots \ldots \ldots \ldots \ldots$ & 18.1 & 20.8 & 21.4 & 23.2 & 25.2 & 27.6 & 30.1 & 32.9 & 1.9 \\
\hline Australasia . . . . . . . . . . . . & 4.9 & 5.6 & 5.5 & 6.3 & 6.9 & 7.5 & 8.1 & 8.8 & 1.8 \\
\hline Total Industrialized . . . . . . . & 184.7 & 199.1 & 205.8 & 222.7 & 243.3 & 264.1 & 283.1 & 303.0 & 1.7 \\
\hline \multicolumn{10}{|l|}{ EE/FSU } \\
\hline Former Soviet Union & 58.5 & 40.8 & 39.8 & 45.7 & 54.3 & 64.0 & 73.6 & 84.5 & 3.0 \\
\hline Eastern Europe ........... & 15.2 & 12.4 & 12.6 & 14.8 & 17.4 & 20.2 & 23.2 & 26.6 & 3.1 \\
\hline Total EE/FSU $\ldots \ldots \ldots \ldots$ & 73.6 & 53.2 & 52.4 & 60.5 & 71.7 & 84.2 & 96.7 & 111.2 & 3.0 \\
\hline \multicolumn{10}{|l|}{ Developing Countries } \\
\hline Developing Asia . . . . . . . . . . . & 51.4 & 71.8 & 74.5 & 96.1 & 126.7 & 159.5 & 200.0 & 251.0 & 5.1 \\
\hline China . . . . . . . . . . . . & 27.0 & 36.4 & 37.1 & 48.0 & 63.1 & 80.8 & 104.2 & 134.5 & 5.4 \\
\hline India $\ldots \ldots \ldots \ldots \ldots \ldots$ & 7.7 & 11.1 & 11.5 & 15.8 & 20.6 & 26.0 & 32.0 & 39.4 & 5.2 \\
\hline Other Asia . . . . . . . . . . . & 16.7 & 24.4 & 25.9 & 32.3 & 43.0 & 52.7 & 63.8 & 77.1 & 4.7 \\
\hline Middle East $\ldots \ldots \ldots \ldots \ldots \ldots$ & 11.1 & 13.9 & 14.6 & 16.3 & 19.5 & 23.1 & 27.4 & 32.4 & 3.5 \\
\hline Africa $\ldots \ldots \ldots \ldots \ldots \ldots$ & 9.2 & 10.7 & 11.1 & 12.9 & 15.4 & 18.1 & 21.2 & 24.8 & 3.4 \\
\hline Central and South America .... & 13.7 & 16.8 & 17.7 & 21.7 & 28.5 & 36.4 & 46.2 & 58.7 & 5.1 \\
\hline Brazil . . . . . . . . . . & 5.4 & 6.4 & 6.8 & 8.3 & 11.1 & 14.3 & 18.2 & 23.1 & 5.3 \\
\hline Other Central/South America ... & 8.3 & 10.4 & 10.9 & 13.4 & 17.4 & 22.2 & 28.1 & 35.6 & 5.0 \\
\hline Total Developing . . . . . . . . & 85.5 & 113.3 & 117.9 & 147.0 & 190.1 & 237.2 & 294.9 & 366.9 & 4.8 \\
\hline Total World & 343.8 & 365.6 & 376.1 & 430.2 & 505.1 & 585.5 & 674.7 & 781.1 & 3.1 \\
\hline
\end{tabular}

ancludes the 50 States and the District of Columbia. U.S. Territories are included in Australasia.

Notes: EE/FSU = Eastern Europe/Former Soviet Union. Energy totals include net imports of coal coke and electricity generated from biomass in the United States. Totals may not equal sum of components due to independent rounding. The electricity portion of the national fuel consumption values consists of generation for domestic use plus an adjustment for electricity trade based on a fuel's share of total generation in the exporting country.

Sources: History: Energy Information Administration (EIA), International Energy Annual 1996, DOE/EIA-0219(96) (Washington, DC, February 1998). Projections: EIA, Annual Energy Outlook 1998, DOE/EIA-0383(98) (Washington, DC, December 1997), Table A1; and World Energy Projection System (1998). 
Table A15. World Total Energy Consumption by Region and Fuel, High Economic Growth Case, 1990-2020 (Quadrillion Btu)

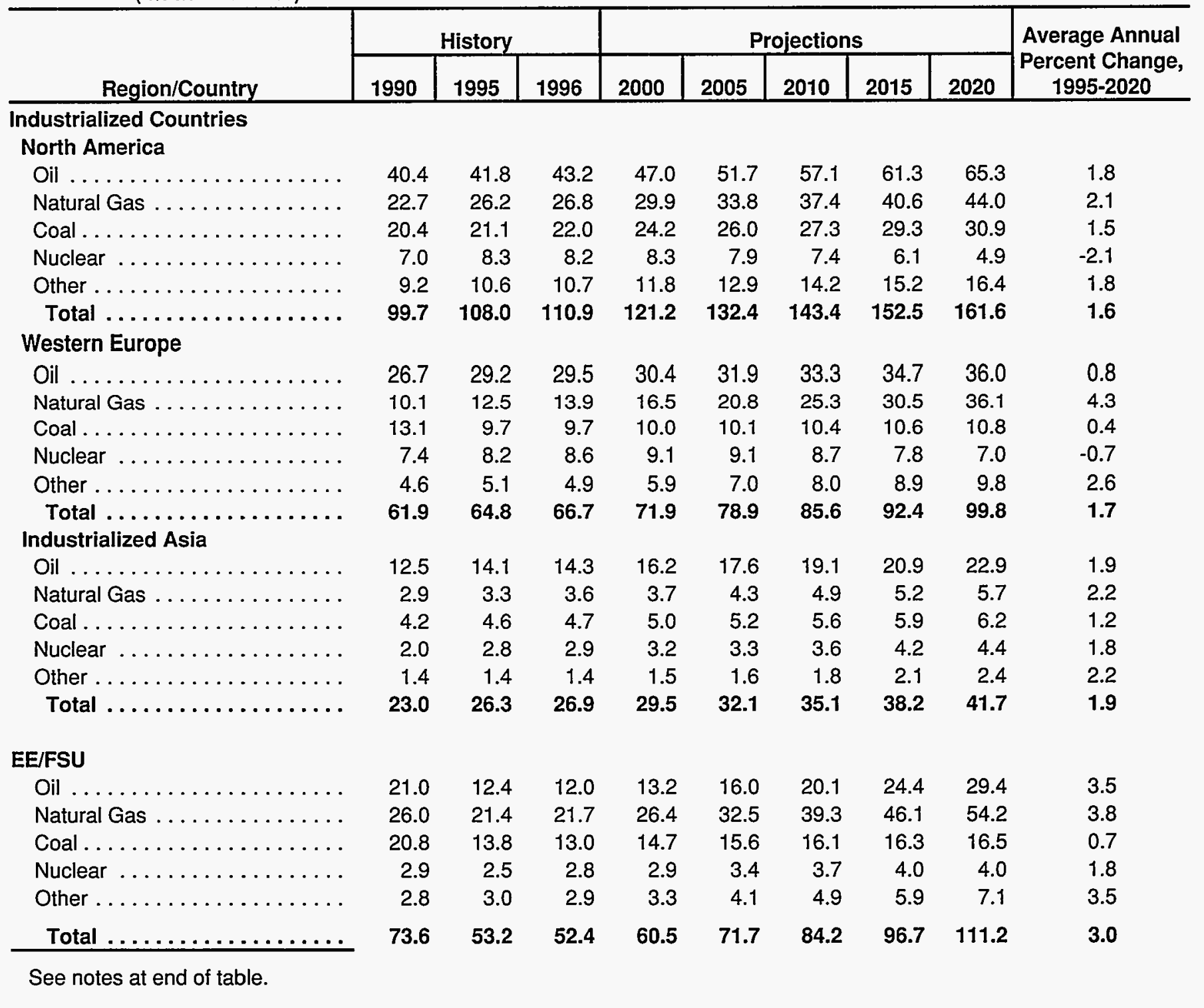


Table A15. World Total Energy Consumption by Region and Fuel, High Economic Growth Case, 1990-2020 (Continued)

(Quadrillion Btu)

\begin{tabular}{|c|c|c|c|c|c|c|c|c|c|}
\hline \multirow[b]{2}{*}{ Region/Country } & \multicolumn{3}{|c|}{ History } & \multicolumn{5}{|c|}{ Projections } & \multirow{2}{*}{$\begin{array}{c}\text { Average Annual } \\
\text { Percent Change, } \\
1995-2020 \\
\end{array}$} \\
\hline & 1990 & 1995 & 1996 & 2000 & 2005 & 2010 & 2015 & 2020 & \\
\hline \multicolumn{10}{|l|}{$\begin{array}{l}\text { Developing Countries } \\
\text { Developing Asia }\end{array}$} \\
\hline Oil $\ldots \ldots \ldots \ldots \ldots \ldots$ & 16.0 & 23.6 & 24.8 & 29.4 & 38.9 & 48.3 & 60.2 & 75.3 & 4.8 \\
\hline Natural Gas $\ldots \ldots \ldots \ldots \ldots$ & 3.0 & 5.1 & 5.7 & 10.9 & 17.0 & 23.2 & 29.6 & 37.7 & 8.4 \\
\hline 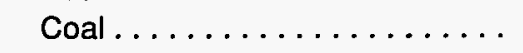 & 28.1 & 38.0 & 38.7 & 48.0 & 60.0 & 74.8 & 94.8 & 120.3 & 4.7 \\
\hline Nuclear $\ldots \ldots \ldots \ldots \ldots \ldots$ & 0.9 & 1.2 & 1.3 & 1.6 & 2.3 & 3.2 & 3.7 & 4.0 & 5.0 \\
\hline Other $\ldots \ldots \ldots \ldots \ldots \ldots$ & 3.2 & 4.0 & 4.0 & 6.1 & 8.4 & 10.0 & 11.7 & 13.7 & 5.0 \\
\hline Total $\ldots \ldots \ldots \ldots \ldots \ldots$ & 51.4 & 71.8 & 74.5 & 96.1 & 126.7 & 159.5 & 200.0 & 251.0 & 5.1 \\
\hline \multicolumn{10}{|l|}{ Middle East } \\
\hline Oil ....... & 7.1 & 8.5 & 8.8 & 9.8 & 11.7 & 13.7 & 16.1 & 18.8 & 3.2 \\
\hline Natural Gas . & 3.8 & 5.0 & 5.4 & 6.0 & 6.9 & 8.3 & 9.9 & 11.9 & 3.5 \\
\hline Coal $\ldots \ldots \ldots \ldots \ldots \ldots$ & 0.1 & 0.2 & 0.2 & 0.3 & 0.3 & 0.4 & 0.5 & 0.5 & 3.6 \\
\hline Nuclear $\ldots \ldots \ldots \ldots \ldots$. & 0.0 & 0.0 & 0.0 & 0.0 & 0.1 & 0.1 & 0.1 & 0.1 & - \\
\hline Other $\ldots \ldots \ldots \ldots \ldots \ldots$ & 0.1 & 0.2 & 0.2 & 0.3 & 0.4 & 0.6 & 0.8 & 1.1 & 7.8 \\
\hline $\begin{array}{c}\text { Total } \ldots \ldots \ldots \ldots \ldots \ldots \\
\text { Africa }\end{array}$ & 11.1 & 13.9 & 14.6 & 16.3 & 19.5 & 23.1 & 27.4 & 32.4 & 3.5 \\
\hline Oil ........ & 4.2 & 4.8 & 5.0 & 6.8 & 8.4 & 9.8 & 11.4 & 13.3 & 4.1 \\
\hline Natural Gas $\ldots \ldots \ldots \ldots \ldots$ & 1.4 & 1.9 & 2.0 & 1.9 & 2.4 & 3.1 & 3.8 & 4.7 & 3.8 . \\
\hline Coal ................... & 3.0 & 3.3 & 3.4 & 3.5 & 3.8 & 4.2 & 4.7 & 5.2 & 1.8 \\
\hline Nuclear...$\ldots \ldots \ldots \ldots$ & 0.1 & 0.1 & 0.1 & 0.1 & 0.1 & 0.1 & 0.1 & 0.1 & 0.9 \\
\hline Other $\ldots \ldots \ldots \ldots \ldots \ldots$ & 0.6 & 0.6 & 0.6 & 0.6 & 0.7 & 0.9 & 1.2 & 1.4 & 3.5 \\
\hline $\begin{array}{l}\text { Total } \ldots \ldots \ldots \ldots \ldots \ldots \\
\text { Central and South America }\end{array}$ & 9.2 & 10.7 & 11.1 & 12.9 & 15.4 & 18.1 & 21.2 & 24.8 & 3.4 \\
\hline 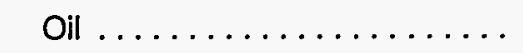 & 6.9 & 8.0 & 8.1 & 11.3 & 14.4 & 18.1 & 22.3 & 27.5 & 5.1 \\
\hline Natural Gas ........... & 2.1 & 2.9 & 3.1 & 3.6 & 6.3 & 9.7 & 14.0 & 19.8 & 8.1 \\
\hline Coal $\ldots \ldots \ldots \ldots \ldots \ldots$ & 0.7 & 0.8 & 1.0 & 1.0 & 1.2 & 1.4 & 1.7 & 2.0 & 3.8 \\
\hline Nuclear $\ldots \ldots \ldots \ldots \ldots$ & 0.1 & 0.1 & 0.1 & 0.1 & 0.2 & 0.2 & 0.3 & 0.3 & 3.7 \\
\hline Other .... & 3.9 & 5.1 & 5.4 & 5.6 & 6.3 & 7.0 & 8.0 & 9.1 & 2.4 \\
\hline Total $\ldots \ldots \ldots \ldots \ldots \ldots$ & 13.7 & 16.8 & 17.7 & 21.7 & 28.5 & 36.4 & 46.2 & 58.7 & 5.1 \\
\hline \multicolumn{10}{|l|}{ Total World } \\
\hline Oil $\ldots \ldots \ldots \ldots$ & 134.9 & 142.5 & 145.7 & 164.1 & 190.6 & 219.6 & 251.3 & 288.5 & 2.9 \\
\hline Natural Gas ............. & 72.0 & 78.1 & 82.2 & 99.0 & 124.1 & 151.2 & 179.8 & 214.2 & 4.1 \\
\hline 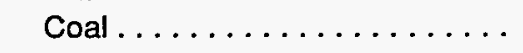 & 90.6 & 91.6 & 92.8 & 106.6 & 122.3 & 140.1 & 163.7 & 192.5 & 3.0 \\
\hline Nuclear $\ldots \ldots \ldots \ldots \ldots \ldots$ & 20.4 & 23.3 & 24.1 & 25.4 & 26.5 & 27.1 & 26.2 & 24.8 & 0.2 \\
\hline Other...$\ldots \ldots \ldots \ldots \ldots$ & 25.9 & 30.1 & 30.0 & 35.1 & 41.6 & 47.5 & 53.7 & 61.1 & 2.9 \\
\hline Total $\ldots \ldots \ldots \ldots \ldots \ldots$ & 343.8 & 365.6 & 374.7 & 430.2 & 505.1 & 585.5 & 674.7 & 781.1 & 3.1 \\
\hline
\end{tabular}

${ }^{a}$ Includes the 50 States and the District of Columbia. U.S. Territories are included in Australasia.

Notes: EE/FSU = Eastern Europe/Former Soviet Union. Energy totals include net imports of coal coke and electricity generated from biomass in the United States. Totals may not equal sum of components due to independent rounding. The electricity portion of the national fuel consumption values consists of generation for domestic use plus an adjustment for electricity trade based on a fuel's share of total generation in the exporting country.

Sources: History: Energy Information Administration (EIA), International Energy Annual 1996, DOE/EIA-0219(96) (Washington, DC, February 1998). Projections: EIA, Annual Energy Outlook 1998, DOEJEIA-0383(98) (Washington, DC, December 1997), Table A1; and World Energy Projection System (1998). 
Table A16. World Total Oil Consumption by Region, High Economic Growth Case, 1990-2020 (Million Barrels per Day)

\begin{tabular}{|c|c|c|c|c|c|c|c|c|c|}
\hline \multirow[b]{2}{*}{ Region/Country } & \multicolumn{3}{|c|}{ History } & \multicolumn{5}{|c|}{ Projections } & \multirow{2}{*}{\begin{tabular}{|c} 
Average Annual \\
Percent Change \\
$1995-2020$ \\
\end{tabular}} \\
\hline & 1990 & 1995 & 1996 & 2000 & 2005 & 2010 & 2015 & 2020 & \\
\hline \multicolumn{10}{|l|}{ Industrialized } \\
\hline North America . ............ & 20.4 & 21.3 & 22.0 & 24.0 & 26.4 & 29.2 & 31.3 & 33.4 & 1.8 \\
\hline United States $^{\mathrm{a}} \ldots \ldots \ldots \ldots$ & 17.0 & 17.7 & 18.3 & 19.8 & 21.8 & 23.8 & 25.4 & 26.8 & 1.7 \\
\hline Canada ..... & 1.7 & 1.8 & 1.8 & 1.9 & 2.1 & 2.3 & 2.6 & 2.8 & 1.9 \\
\hline Mexico & 1.7 & 1.9 & 1.9 & 2.3 & 2.5 & 3.0 & 3.4 & 3.8 & 2.9 \\
\hline Western Europe ........... & 12.9 & 14.1 & 14.3 & 14.7 & 15.5 & 16.2 & 16.8 & 17.4 & 0.8 \\
\hline Industrialized Asia . . . . . . . . & 6.2 & 7.0 & 7.1 & 8.0 & 8.7 & 9.4 & 10.3 & 11.3 & 1.9 \\
\hline Japan $\ldots \ldots \ldots \ldots \ldots$ & 5.1 & 5.7 & 5.9 & 6.6 & 7.1 & 7.7 & 8.5 & 9.3 & 2.0 \\
\hline Australasia $\ldots \ldots \ldots \ldots \ldots$ & 1.0 & 1.2 & 1.2 & 1.4 & 1.5 & 1.7 & 1.8 & 2.0 & 1.8 \\
\hline Total Industrialized ....... & 39.5 & 42.4 & 43.4 & 46.7 & 50.6 & 54.7 & 58.4 & 62.1 & 1.5 \\
\hline \multicolumn{10}{|l|}{ EE/FSU } \\
\hline Former Soviet Union & 8.4 & 4.6 & 4.4 & 4.7 & 5.8 & 7.3 & 8.7 & 10.4 & 3.3 \\
\hline Eastern Europe .... & 1.6 & 1.3 & 1.3 & 1.6 & 1.8 & 2.3 & 2.9 & 3.6 & 4.2 \\
\hline Total EE/FSU . .......... & 10.0 & 5.9 & 5.7 & 6.3 & 7.6 & 9.6 & 11.6 & 14.0 & 3.5 \\
\hline \multicolumn{10}{|l|}{ Developing Countries } \\
\hline Developing Asia . . . . . . . . . & 7.6 & 11.3 & 11.9 & 14.1 & 18.7 & 23.3 & 29.0 & 36.3 & 4.8 \\
\hline China ................. & 2.3 & 3.3 & 3.5 & 4.6 & 6.1 & 7.9 & 10.4 & 13.7 & 5.8 \\
\hline India ..... & 1.2 & 1.6 & 1.7 & 1.9 & 2.6 & 3.2 & 4.0 & 5.0 & 4.8 \\
\hline Other Asia ..... & 4.2 & 6.4 & 6.6 & 7.6 & 10.1 & 12.1 & 14.6 & 17.6 & 4.2 \\
\hline Middle East $\ldots \ldots \ldots \ldots \ldots$ & 3.4 & 4.1 & 4.2 & 4.6 & 5.6 & 6.5 & 7.6 & 9.0 & 3.2 \\
\hline Africa $\ldots \ldots \ldots \ldots \ldots \ldots$ & 2.1 & 2.3 & 2.4 & 3.3 & 4.0 & 4.7 & 5.5 & 6.4 & 4.1 \\
\hline Central and South America .... & 3.4 & 3.9 & 4.0 & 5.6 & 7.1 & 8.9 & 11.0 & 13.5 & 5.1 \\
\hline Brazil . ............... & 1.3 & 1.5 & 1.5 & 2.1 & 2.7 & 3.4 & 4.2 & 5.2 & 5.1 \\
\hline Other Central/South America ... & 2.1 & 2.4 & 2.5 & 3.4 & 4.4 & 5.5 & 6.8 & 8.4 & 5.1 \\
\hline Total Developing . . . . . . . & 16.5 & 21.6 & 22.5 & 27.6 & 35.4 & 43.4 & 53.1 & 65.2 & 4.5 \\
\hline Total World & 66.0 & 69.9 & 71.5 & 80.6 & 93.6 & 107.7 & 123.2 & 141.3 & 2.9 \\
\hline
\end{tabular}

${ }^{a}$ Includes the 50 States and the District of Columbia. U.S. Territories are included in Australasia.

Notes: EE/FSU = Eastern Europe/Former Soviet Union. Totals may not equal sum of components due to independent rounding. The electricity portion of the national fuel consumption values consists of generation for domestic use plus an adjustment for electricity trade based on a fuel's share of total generation in the exporting country.

Sources: History: Energy Information Administration (EIA), International Energy Annual 1996, DOE/EIA-0219(96) (Washington, DC, February 1998). Projections: EIA, Annual Energy Outlook 1998, DOE/EIA-0383(98) (Washington, DC, December 1997), Table A21; and World Energy Projection System (1998). 
Table A17. World Total Natural Gas Consumption by Region, High Economic Growth Case, 1990-2020 (Trillion Cubic Feet)

\begin{tabular}{|c|c|c|c|c|c|c|c|c|c|}
\hline \multirow[b]{2}{*}{ Region/Country } & \multicolumn{3}{|c|}{ History } & \multicolumn{5}{|c|}{ Projections } & \multirow{2}{*}{$\begin{array}{c}\text { Average Annual } \\
\text { Percent Change, } \\
1995-2020 \\
\end{array}$} \\
\hline & 1990 & 1995 & 1996 & 2000 & 2005 & 2010 & 2015 & 2020 & \\
\hline \multicolumn{10}{|l|}{ Industrialized } \\
\hline North America & 22.0 & 25.4 & 26.0 & 29.0 & 32.7 & 36.3 & 39.4 & 42.7 & 2.1 \\
\hline United States $^{a}$ & 18.7 & 21.6 & 21.9 & 24.4 & 27.1 & 30.2 & 32.4 & 34.5 & 1.9 \\
\hline Canada ...... & 2.4 & 2.9 & 3.1 & 3.1 & 3.3 & 3.7 & 4.2 & 5.0 & 2.2 \\
\hline Mexico ............ & 0.9 & 1.0 & 1.0 & 1.4 & 2.3 & 2.4 & 2.8 & 3.2 & 4.8 \\
\hline Western Europe..$\ldots \ldots \ldots \ldots$ & 10.3 & 12.7 & 14.1 & 16.7 & 21.0 & 25.5 & 30.6 & 36.3 & 4.3 \\
\hline Industrialized Asia . . . . . . . . . . & 2.6 & 3.1 & 3.3 & 3.4 & 4.0 & 4.5 & 4.8 & 5.3 & 2.2 \\
\hline Japan $\ldots \ldots \ldots \ldots \ldots \ldots$ & 1.9 & 2.2 & 2.4 & 2.3 & 2.7 & 3.1 & 3.3 & 3.7 & 2.1 \\
\hline Australasia ............... & 0.8 & 0.9 & 0.9 & 1.1 & 1.3 & 1.4 & 1.4 & 1.5 & 2.3 \\
\hline Total Industrialized . . . . . . & 35.0 & 41.2 & 43.3 & 49.1 & 57.7 & 66.3 & 74.8 & 84.2 & 2.9 \\
\hline \multicolumn{10}{|l|}{ EE/FSU } \\
\hline Former Soviet Union & 25.0 & 20.6 & 20.7 & 24.7 & 30.0 & 36.1 & 41.9 & 49.1 & 3.5 \\
\hline Eastern Europe .... & 3.1 & 2.7 & 2.9 & 4.1 & 5.5 & 6.9 & 8.3 & 10.0 & 5.3 \\
\hline Total EE/FSU $\ldots \ldots \ldots \ldots$ & 28.1 & 23.4 & 23.7 & 28.8 & 35.5 & 42.9 & 50.3 & 59.1 & 3.8 \\
\hline \multicolumn{10}{|l|}{ Developing Countries } \\
\hline Developing Asia . . . . . . . . . & 3.0 & 4.7 & 5.3 & 10.2 & 16.0 & 21.8 & 27.9 & 35.7 & 8.4 \\
\hline China...$\ldots \ldots \ldots \ldots$ & 0.5 & 0.6 & 0.7 & 1.5 & 2.6 & 3.4 & 3.9 & 4.5 & 8.4 \\
\hline India $\ldots \ldots \ldots$ & 0.4 & 0.6 & 0.7 & 1.6 & 2.6 & 4.0 & 5.6 & 7.7 & 10.6 \\
\hline Other Asia ... & 2.1 & 3.5 & 4.0 & 7.2 & 10.8 & 14.4 & 18.4 & 23.4 & 7.9 \\
\hline Middle East $\ldots \ldots \ldots \ldots \ldots$ & 3.6 & 4.7 & 5.2 & 5.7 & 6.6 & 7.9 & 9.5 & 11.3 & 3.5 \\
\hline Africa $\ldots \ldots \ldots \ldots \ldots \ldots$ & 1.4 & 1.7 & 1.8 & 1.8 & 2.1 & 2.8 & 3.4 & 4.2 & 3.8 \\
\hline Central and South America .... & 2.0 & 2.6 & 2.9 & 3.3 & 5.7 & 8.7 & 12.7 & 17.9 & 8.1 \\
\hline Brazil $\ldots \ldots \ldots \ldots \ldots \ldots$ & 0.1 & 0.2 & 0.2 & 0.4 & 1.4 & 2.5 & 3.9 & 5.9 & 15.5 \\
\hline Other Central/South America ... & 1.9 & 2.4 & 2.7 & 2.9 & 4.4 & 6.3 & 8.8 & 12.0 & 6.6 \\
\hline Total Developing $\ldots . \ldots \ldots$ & 9.9 & 13.7 & 15.2 & 21.0 & 30.5 & 41.2 & 53.5 & 69.1 & 6.7 \\
\hline Total World & 73.0 & 78.3 & 82.2 & 98.9 & 123.7 & 150.4 & 178.6 & 212.5 & 4.1 \\
\hline
\end{tabular}

${ }^{a}$ Includes the 50 States and the District of Columbia. U.S. Territories are included in Australasia.

Notes: EE/FSU = Eastern Europe/Former Soviet Union. Totals may not equal sum of components due to independent rounding. The electricity portion of the national fuel consumption values consists of generation for domestic use plus an adjustment for electricity trade based on a fuel's share of total generation in the exporting country. To convert cubic feet to cubic meters, divide each number in the table by 35.315 .

Sources: History: Energy Information Administration (EIA), International Energy Annual 1996, DOE/EIA-0219(96) (Washington, DC, February 1998). Projections: EIA, Annual Energy Outlook 1998, DOE/EIA-0383(98) (Washington, DC, December 1997), Table A13; and World Energy Projection System (1998). 
Table A18. World Total Coal Consumption by Region, High Economic Growth Case, 1990-2020 (Million Short Tons)

\begin{tabular}{|c|c|c|c|c|c|c|c|c|c|}
\hline \multirow[b]{2}{*}{ Region/Country } & \multicolumn{3}{|c|}{ History } & \multicolumn{5}{|c|}{ Projections } & \multirow{2}{*}{$\begin{array}{c}\text { Average Annual } \\
\text { Percent Change, } \\
1995-2020\end{array}$} \\
\hline & 1990 & 1995 & 1996 & 2000 & 2005 & 2010 & 2015 & 2020 & \\
\hline \multicolumn{10}{|l|}{ Industrialized } \\
\hline North America & 957 & 1,013 & 1,056 & 1,163 & 1,263 & 1,332 & 1,420 & 1,504 & 1.6 \\
\hline United States $^{a}$ & 896 & 941 & 983 & 1,070 & 1,160 & 1,223 & 1,305 & 1,382 & 1.5 \\
\hline Canada $\ldots \ldots \ldots$. & 55 & 59 & 60 & 79 & 85 & 89 & 93 & 97 & 2.0 \\
\hline Mexico $\ldots \ldots \ldots \ldots \ldots \ldots$ & 7 & 13 & 14 & 14 & 18 & 21 & 23 & 26 & 2.7 \\
\hline Western Europe ........... & 958 & 674. & 671 & 701 & 709 & 732 & 754 & 775 & 0.6 \\
\hline Industrialized Asia $\ldots \ldots \ldots \ldots$. & 233 & 257 & 266 & 277 & 290 & 312 & 325 & 344 & 1.2 \\
\hline Japan $\ldots \ldots \ldots \ldots \ldots$ & 125 & 140 & 144 & 154 & 161 & 179 & 187 & 199 & 1.4 \\
\hline Australasia .............. & 108 & 117 & 121 & 123 & 129 & 133 & 139 & 145 & 0.9 \\
\hline Total Industrialized & 2,148 & 1,944 & 1,994 & 2,141 & 2,263 & 2,376 & 2,500 & 2,623 & 1.2 \\
\hline \multicolumn{10}{|l|}{ EE/FSU } \\
\hline Former Soviet Union & 848 & 508 & 472 & 536 & 568 & 598 & 621 & 641 & 0.9 \\
\hline Eastern Europe .... & 523 & 426 & 413 & 454 & 486 & 483 & 478 & 468 & 0.4 \\
\hline Total EE/FSU & 1,372 & 934 & 885 & 989 & 1,054 & 1,082 & 1,099 & 1,110 & 0.7 \\
\hline \multicolumn{10}{|l|}{ Developing Countries } \\
\hline Developing Asia . ... & 1,555 & 2,030 & 2,065 & 2,555 & 3,185 & 3,973 & 5,050 & 6,420 & 4.7 \\
\hline China ......... & 1,124 & 1,489 & 1,500 & 1,874 & 2,368 & 3,021 & 3,977 & 5,200 & 5.1 \\
\hline India $\ldots \ldots \ldots$ & 242 & 312 & 321 & 415 & 506 & 598 & 672 & 759 & 3.6 \\
\hline Other Asia & 190 & 230 & 244 & 265 & 310 & 354 & 402 & 460 & 2.8 \\
\hline Middle East $\ldots \ldots$ & 6 & 8 & 9 & 11 & 13 & 15 & 18 & 20 & 3.6 \\
\hline Africa $\ldots \ldots \ldots \ldots \ldots \ldots$ & 152 & 172 & 174 & 180 & 197 & 220 & 244 & 271 & 1.8 \\
\hline Central and South America .... & 30 & 32 & 40 & 40 & 50 & 57 & 68 & 80 & 3.8 \\
\hline Brazil $\ldots \ldots \ldots \ldots \ldots \ldots$ & 17 & 19 & 27 & 23 & 28 & 31 & 37 & 45 & 3.5 \\
\hline Other Central/South America ... & 13 & 13 & 13 & 17 & 22 & 26 & 31 & 35 & 4.2 \\
\hline Total Developing...$\ldots \ldots$ & 1,743 & 2,243 & 2,289 & 2,785 & 3,445 & 4,266 & 5,380 & 6,791 & 4.5 \\
\hline Total World $\ldots \ldots \ldots \ldots \ldots$ & 5,263 & 5,120 & 5,167 & 5,916 & 6,761 & 7,724 & 8,979 & 10,524 & 2.9 \\
\hline
\end{tabular}

${ }^{a}$ Includes the 50 States and the District of Columbia. U.S. Territories are included in Australasia.

Notes: EE/FSU = Eastern Europe/Former Soviet Union. Range values for Western Europe and the four regional totals are not equal to the sum of the component countries or country groups but consist of the base value adjusted by the quantity: the square root of the sum of the squared deviations of the respective component countries or country groups from their base value. Other totals may not equal sum of components due to independent rounding. The electricity portion of the national fuel consumption values consists of generation for domestic use plus an adjustment for electricity trade based on a fuel's share of total generation in the exporting country.To convert short tons to metric tons, divide each number in the table by 1.102.

Sources: History: Energy Information Administration (EIA), International Energy Annual 1996, DOE/EIA-0219(96) (Washington, DC, February 1998). Projections: EIA, Annual Energy Outlook 1998, DOE/EIA-0383(98) (Washington, DC, December 1997), Table A16; and World Energy Projection System (1998). 
Table A19. World Net Nuclear Energy Consumption by Region, High Economic Growth Case, 1990-2020 (Billion Kilowatthours)

\begin{tabular}{|c|c|c|c|c|c|c|c|c|c|}
\hline \multirow[b]{2}{*}{ Region/Country } & \multicolumn{3}{|c|}{ History } & \multicolumn{5}{|c|}{ Projections } & \multirow{2}{*}{$\begin{array}{c}\text { Average Annual } \\
\text { Percent Change, } \\
1995-2020\end{array}$} \\
\hline & 1990 & 1995 & 1996 & 2000 & 2005 & 2010 & 2015 & 2020 & \\
\hline \multicolumn{10}{|l|}{ Industrialized } \\
\hline North America & 649 & 774 & 770 & 775 & 735 & 690 & 568 & 460 & -2.1 \\
\hline United States $^{a}$ & 577 & 673 & 675 & 689 & 643 & 596 & 480 & 383 & -2.2 \\
\hline Canada ................ & 69 & 93 & 88 & 77 & 83 & 85 & 79 & 68 & -1.3 \\
\hline Mexico ............... & 3 & 8 & 7 & 8 & 9 & 9 & 9 & 9 & 0.6 \\
\hline Western Europe . .......... & .703 & 785 & 824 & 867 & 869 & 828 & 750 & 671 & -0.6 \\
\hline Industrialized Asia . . . . . . . . . & 192 & 277 & 283 & 311 & 324 & 356 & 409 & 427 & 1.8 \\
\hline Japan $\ldots \ldots \ldots \ldots \ldots \ldots$ & 192 & 277 & 283 & 311 & 324 & 356 & 409 & 427 & 1.8 \\
\hline Australasia . . . . . . . . . & 0 & 0 & 0 & 0 & 0 & 0 & 0 & 0 & 0.0 \\
\hline Total Industrialized ....... & 1,544 & 1,837 & 1,877 & 1,953 & 1,928 & 1,874 & 1,727 & 1,558 & -0.7 \\
\hline \multicolumn{10}{|l|}{ EE/FSU } \\
\hline Former Soviet Union ... & 201 & 172 & 194 & 199 & 231 & 258 & 278 & 286 & 2.1 \\
\hline Eastern Europe ...... & 54 & 57 & 60 & 67 & 79 & 82 & 83 & 75 & 1.1 \\
\hline Total EE/FSU $\ldots \ldots \ldots \ldots$ & 256 & 229 & 254 & 266 & 310 & 340 & 361 & 362 & 1.8 \\
\hline \multicolumn{10}{|l|}{ Developing Countries } \\
\hline Developing Asia .... & 88 & 117 & 128 & 162 & 230 & 312 & 359 & 388 & 4.9 \\
\hline China ........... & 0 & 12 & 14 & 13 & 40 & 74 & 94 & 125 & 9.7 \\
\hline India $\ldots \ldots \ldots$ & 6 & 6 & 7 & 12 & 18 & 36 & 51 & 68 & 9.9 \\
\hline Other Asia & 82 & 98 & 107 & 138 & 171 & 202 & 214 & 195 & 2.8 \\
\hline Middle East $\ldots \ldots \ldots \ldots \ldots$ & 0 & 0 & 0 & 0 & 11 & 12 & 13 & 13 & 0.0 \\
\hline Africa $\ldots \ldots \ldots \ldots \ldots \ldots$ & 8 & 11 & 12 & 12 & 12 & 13 & 14 & 14 & 0.9 \\
\hline Central and South America .... & 9 & 9 & 9 & 11 & 20 & 21 & 22 & 24 & 3.7 \\
\hline Brazil ................. & 2 & 2 & 2 & 3 & 9 & 11 & 11 & 12 & 6.7 \\
\hline Other Central/South America ... & 7 & 7 & 7 & 8 & 11 & 10 & 11 & 12 & 2.0 \\
\hline Total Developing . . . . . . . . & 105 & 138 & 149 & 185 & 273 & 358 & 408 & 439 & 4.7 \\
\hline$\ldots \ldots \ldots \ldots \ldots \ldots$ & 1,905 & 2,203 & 2,280 & 2,404 & 2,511 & 2,572 & 2,495 & 2,359 & 0.3 \\
\hline
\end{tabular}

${ }^{a}$ Includes the 50 States and the District of Columbia. U.S. Territories are included in Australasia.

Notes: EE/FSU = Eastern Europe/Former Soviet Union. Totals may not equal sum of components due to independent rounding. The electricity portion of the national fuel consumption values consists of generation for domestic use plus an adjustment for electricity trade based on a fuel's share of total generation in the exporting country.

Sources: History: Energy Information Administration (EIA), International Energy Annual 1996, DOE/EIA-0219(96) (Washington, DC, February 1998). Projections: EIA, Annual Energy Outlook 1998, DOE/EIA-0383(98) (Washington, DC, December 1997), Table A8; and World Energy Projection System (1998). 
Table A20. World Consumption of Hydroelectricity and Other Renewable Energy by Region, High Economic Growth Case, 1990-2020

(Quadrillion Btu)

\begin{tabular}{|c|c|c|c|c|c|c|c|c|c|}
\hline \multirow[b]{2}{*}{ Region/Country } & \multicolumn{3}{|c|}{ History } & \multicolumn{5}{|c|}{ Projections } & \multirow{2}{*}{$\begin{array}{c}\text { Average Annual } \\
\text { Percent Change } \\
1995-2020 \\
\end{array}$} \\
\hline & 1990 & 1995 & 1996 & 2000 & 2005 & 2010 & 2015 & 2020 & \\
\hline \multicolumn{10}{|l|}{ Industrialized } \\
\hline North America & 9.2 & 10.6 & 10.7 & 11.8 & 12.9 & 14.2 & 15.2 & 16.4 & 1.8 \\
\hline United States $^{a}$ & 5.8 & 6.8 & 6.6 & 7.2 & 7.5 & 8.0 & 8.4 & 8.9 & 1.1 \\
\hline Canada .... . & 3.1 & 3.4 & 3.6 & 4.1 & 4.7 & 5.4 & 5.8 & 6.3 & 2.4 \\
\hline Mexico ....... & 0.3 & 0.4 & 0.4 & 0.4 & 0.7 & 0.8 & 1.0 & 1.2 & 4.6 \\
\hline Western Europe ..... & 4.6 & 5.1 & 4.9 & 5.9 & 7.0 & 8.0 & 8.9 & 9.8 & 2.6 \\
\hline Industrialized Asia $\ldots \ldots \ldots \ldots$. & 1.4 & 1.4 & 1.4 & 1.5 & 1.6 & 1.8 & 2.1 & 2.4 & 2.2 \\
\hline Japan & 1.0 & 0.9 & 0.9 & 0.9 & 1.0 & 1.1 & 1.1 & 1.3 & 1.3 \\
\hline Australasia $\ldots \ldots \ldots \ldots \ldots$ & 0.4 & 0.5 & 0.5 & 0.6 & 0.7 & 0.8 & 0.9 & 1.1 & 3.4 \\
\hline Total Industrialized . ....... & 15.3 & 17.2 & 16.9 & 19.2 & 21.6 & 24.0 & 26.1 & 28.7 & 2.1 \\
\hline \multicolumn{10}{|l|}{ EE/FSU } \\
\hline Former Soviet Union & 2.4 & 2.5 & 2.2 & 2.8 & 3.4 & 3.7 & 4.2 & 4.8 & 2.7 \\
\hline Eastern Europe .... & 0.4 & 0.6 & 0.6 & 0.5 & 0.8 & 1.2 & 1.7 & 2.4 & 5.8 \\
\hline Total EE/FSU $\ldots \ldots \ldots \ldots$ & 2.8 & 3.0 & 2.9 & 3.3 & 4.1 & 4.9 & 5.9 & 7.1 & 3.5 \\
\hline \multicolumn{10}{|l|}{ Developing Countries } \\
\hline Developing Asia .... & 3.2 & 4.0 & 4.0 & 6.1 & 8.4 & 10.0 & 11.7 & 13.8 & 5.1 \\
\hline China ......... & 1.3 & 1.9 & 1.9 & 3.0 & 4.6 & 5.3 & 5.7 & 6.1 & 4.7 \\
\hline India & 0.7 & 0.7 & 0.7 & 1.5 & 1.9 & 2.3 & 3.0 & 4.0 & 7.0 \\
\hline Other Asia & 1.2 & 1.4 & 1.4 & 1.6 & 2.0 & 2.4 & 3.0 & 3.7 & 4.1 \\
\hline Middle East & 0.1 & 0.2 & 0.2 & 0.3 & 0.4 & 0.6 & 0.8 & 1.1 & 7.8 \\
\hline Africa $\ldots \ldots \ldots \ldots \ldots \ldots$ & 0.6 & 0.6 & 0.6 & 0.6 & 0.7 & 0.9 & 1.2 & 1.4 & 3.5 \\
\hline Central and South America .... & 3.9 & 5.1 & 5.4 & 5.6 & 6.3 & 7.0 & 8.0 & 9.1 & 2.4 \\
\hline Brazil ............ & 2.2 & 2.7 & 2.8 & 3.0 & 3.3 & 3.6 & 4.1 & 4.6 & 2.1 \\
\hline Other Central/South America ... & 1.7 & 2.4 & 2.6 & 2.7 & 3.0 & 3.4 & 3.9 & 4.5 & 2.6 \\
\hline Total Developing $\ldots \ldots \ldots \ldots$ & 7.8 & 9.9 & 10.2 & 12.6 & 15.9 & 18.6 & 21.7 & 25.4 & 3.9 \\
\hline Total World & 25.9 & 30.1 & 30.0 & 35.1 & 41.6 & 47.5 & 53.7 & 61.2 & 2.9 \\
\hline
\end{tabular}

${ }^{\mathrm{a}}$ Includes the 50 States and the District of Columbia. U.S. Territories are included in Australasia.

Notes: $E E / F S U=$ Eastern Europe/Former Soviet Union. Totals may not equal sum of components due to independent rounding. The electricity portion of the national fuel consumption values consists of generation for domestic use plus an adjustment for electricity trade based on a fuel's share of total generation in the exporting country.

Sources: History: Energy Information Administration (EIA), International Energy Annual 1996, DOE/EIA-0219(96) (Washington, DC, February 1998). Projections: EIA, Annual Energy Outlook 1998, DOE/EIA-0383(98) (Washington, DC, December 1997), Table A1; and World Energy Projection System (1998). 
Table A21. World Total Net Electricity Consumption by Region, High Economic Growth Case, 1990-2020 (Billion Kilowatthours)

\begin{tabular}{|c|c|c|c|c|c|c|c|c|c|}
\hline \multirow[b]{2}{*}{ Region/Country } & \multicolumn{3}{|c|}{ History } & \multicolumn{5}{|c|}{ Projections } & \multirow{2}{*}{$\begin{array}{c}\text { Average Annual } \\
\text { Percent Change, } \\
\text { 1995-2020 }\end{array}$} \\
\hline & 1990 & 1995 & 1996 & 2000 & 2005 & 2010 & 2015 & 2020 & \\
\hline \multicolumn{10}{|l|}{ Industrialized } \\
\hline North America & 3,255 & 3,759 & 3,859 & 4,039 & 4,508 & 4,985 & 5,444 & 5,857 & 1.8 \\
\hline United States $^{\mathrm{a}}$ & 2,713 & 3,163 & 3,243 & 3,352 & 3,718 & 4,077 & 4,405 & 4,708 & 1.6 \\
\hline Canada ...... & 435 & 462 & 473 & 514 & 558 & 620 & 689 & 752 & 2.0 \\
\hline Mexico ........ & 107 & 134 & 144 & 174 & 233 & 288 & 349 & 397 & 4.4 \\
\hline Western Europe . . . . . . . . . . & 2,115 & 2,286 & 2,330 & 2,806 & 3,244 & 3,706 & 4,190 & 4,527 & 2.8 \\
\hline Industrialized Asia . . . . . . . . . & 930 & 1,068 & 1,090 & 1,315 & 1,484 & 1,673 & 1,865 & 2,031 & 2.6 \\
\hline Japan $\ldots \ldots \ldots \ldots \ldots \ldots$ & 750 & 864 & 882 & 1,019 & 1,136 & 1,275 & 1,417 & 1,547 & 2.4 \\
\hline Australasia . . . . . . . . . . . . & 180 & 204 & 207 & 296 & 348 & 397 & 447 & 484 & 3.5 \\
\hline Total Industrialized . . . . . . . & 6,299 & 7,113 & 7,279 & 8,160 & 9,237 & 10,363 & 11,499 & 12,415 & 2.3 \\
\hline \multicolumn{10}{|l|}{ EE/FSU } \\
\hline Former Soviet Union & 1,488 & 1,168 & 1,133 & 1,190 & 1,414 & 1,668 & 1,916 & 2,202 & 2.6 \\
\hline Eastern Europe .... & 420 & 384 & 401 & 415 & 516 & 628 & 753 & 866 & 3.3 \\
\hline Total EE/FSU $\ldots \ldots \ldots \ldots$ & 1,908 & 1,552 & 1,535 & 1,605 & 1,931 & 2,296 & 2,670 & 3,068 & 2.8 \\
\hline \multicolumn{10}{|l|}{ Developing Countries } \\
\hline Developing Asia .... & 1,268 & 1,912 & 2,002 & 2,638 & 3,664 & 4,843 & 6,365 & 7,982 & 5.9 \\
\hline China ......... & 551 & 881 & 925 & 1,122 & 1,607 & 2,238 & 3,131 & 4,040 & 6.3 \\
\hline India $\ldots . . .$. & 257 & 367 & 378 & 581 & 804 & 1,063 & 1,366 & 1,683 & 6.3 \\
\hline Other Asia ... & 460 & 663 & 699 & 935 & 1,253 & 1,542 & 1,868 & 2,259 & 5.0 \\
\hline Middle East $\ldots \ldots \ldots \ldots \ldots$ & 221 & 295 & 301 & 325 & 401 & 487 & 586 & 693 & 3.5 \\
\hline Africa $\ldots \ldots \ldots \ldots \ldots \ldots$ & 285 & 320 & 332 & 397 & 506 & 636 & 788 & 920 & 4.3 \\
\hline Central and South America .... & 449 & 575 & 604 & 760 & 1,029 & 1,322 & 1,667 & 2,116 & 5.4 \\
\hline Brazil $\ldots \ldots \ldots \ldots \ldots \ldots$ & 229 & 288 & 303 & 331 & 403 & 461 & 529 & 631 & 3.2 \\
\hline Other Central/South America ... & 220 & 286 & 301 & 429 & 625 & 860 & 1,138 & 1,485 & 6.8 \\
\hline Total Developing . . . . . . . . & 2,224 & 3,102 & 3,239 & 4,121 & 5,601 & 7,287 & 9,406 & 11,711 & 5.5 \\
\hline Total World $\ldots \ldots \ldots \ldots \ldots$ & 10,431 & 11,767 & 12,053 & 13,885 & 16,768 & 19,946 & 23,575 & 27,194 & 3.4 \\
\hline
\end{tabular}

ancludes the 50 States and the District of Columbia. U.S. Territories are included in Australasia.

Notes: EE/FSU = Eastern Europe/Former Soviet Union. Electricity consumption equals generation plus imports minus exports minus distribution losses.

Sources: History: Energy Information Administration (EIA), International Energy Annual 1996, DOE/EIA-0219(96) (Washington, DC, February 1998), Table 6.2. Projections: EIA, Annual Energy Outlook 1998, DOE/EIA-0383(98) (Washington, DC, December 1997), Table A8; and World Energy Projection System (1998). 
Table A22. World Total Carbon Emissions by Region, High Economic Growth Case, 1990-2020 (Million Metric Tons)

\begin{tabular}{|c|c|c|c|c|c|c|c|c|c|}
\hline \multirow[b]{2}{*}{ Region/Country } & \multicolumn{3}{|c|}{ History } & \multicolumn{5}{|c|}{ Projections } & \multirow{2}{*}{$\begin{array}{c}\text { Average Annual } \\
\text { Percent Change, } \\
\text { 1995-2020 }\end{array}$} \\
\hline & 1990 & 1995 & 1996 & 2000 & 2005 & 2010 & 2015 & 2020 & \\
\hline \multicolumn{10}{|l|}{ Industrialized } \\
\hline North America $\ldots \ldots \ldots \ldots \ldots$ & 1,550 & 1,629 & 1,687 & 1,850 & 2,034 & 2,212 & 2,380 & 2,541 & 1.8 \\
\hline United States $^{\mathrm{a}} \ldots \ldots \ldots \ldots$ & 1,346 & 1,411 & 1,463 & 1,591 & 1,739 & 1,883 & 2,014 & 2,134 & 1.7 \\
\hline Canada $\ldots \ldots \ldots \ldots \ldots \ldots$ & 126 & 135 & 140 & 156 & 170 & 183 & 202 & 223 & 2.0 \\
\hline Mexico .............. & 78 & 82 & 84 & 103 & 126 & 145 & 163 & 184 & 3.3 \\
\hline Western Europe ........... & 971 & 925 & 947 & 1,008 & 1,097 & 1,192 & 1,294 & 1,402 & 1.7 \\
\hline Industrialized Asia . . . . . . . . . & 364 & 379 & 389 & 426 & 462 & 504 & 542 & 589 & 1.8 \\
\hline Japan $\ldots \ldots \ldots$ & 274 & 281 & 291 & 316 & 342 & 376 & 406 & 444 & 1.9 \\
\hline Australasia $\ldots \ldots \ldots \ldots \ldots$ & 90 & 99 & 99 & 110 & 120 & 128 & 136 & 144 & 1.5 \\
\hline Total Industrialized $\ldots \ldots \ldots$ & 2,885 & 2,933 & 3,023 & 3,284 & 3,593 & 3,908 & 4,216 & 4,532 & 1.8 \\
\hline \multicolumn{10}{|l|}{ EE/FSU } \\
\hline Former Soviet Union & 991 & 636 & 613 & 701 & 824 & 967 & 1,107 & 1,268 & 2.8 \\
\hline Eastern Europe .... & 299 & 230 & 228 & 269 & 306 & 341 & 379 & 423 & 2.5 \\
\hline Total EE/FSU .. & 1,290 & 866 & 842 & 971 & 1,130 & 1,308 & 1,485 & 1,691 & 2.7 \\
\hline \multicolumn{10}{|l|}{ Developing Countries } \\
\hline Developing Asia $\ldots \ldots \ldots \ldots \ldots$ & 1,065 & 1,427 & 1,474 & 1,860 & 2,406 & 3,023 & 3,818 & 4,827 & 5.0 \\
\hline China . . . . . . . . & 620 & 792 & 805 & 1,021 & 1,309 & 1,678 & 2,199 & 2,869 & 5.3 \\
\hline India . & 153 & 222 & 230 & 302 & 387 & 477 & 570 & 684 & 4.6 \\
\hline Other Asia & 293 & 413 & 439 & 537 & 710 & 867 & 1,048 & 1,274 & 4.6 \\
\hline Middle East $\ldots \ldots \ldots \ldots \ldots$ & 194 & 229 & 241 & 267 & 316 & 373 & 441 & 519 & 3.3 \\
\hline Africa $\ldots \ldots \ldots \ldots \ldots \ldots \ldots$ & 178 & 192 & 198 & 230 & 272 & 318 & 368 & 426 & 3.2 \\
\hline Central and South America .... . & 174 & 194 & 206 & 267 & 362 & 475 & 613 & 789 & 5.8 \\
\hline Brazil $\ldots \ldots \ldots \ldots \ldots \ldots$ & 57 & 64 & 71 & 90 & 127 & 168 & 220 & 286 & 6.2 \\
\hline Other Central/South America ... & 117 & 130 & 135 & 176 & 235 & 307 & 394 & 503 & 5.6 \\
\hline Total Developing...$\ldots \ldots$ & 1,611 & 2,043 & 2,118 & 2,624 & 3,356 & 4,189 & 5,239 & 6,560 & 4.8 \\
\hline Total World & 5,786 & 5,841 & 5,983 & 6,879 & 8,079 & 9,404 & 10,941 & 12,783 & 3.2 \\
\hline
\end{tabular}

Includes the 50 States and the District of Columbia. U.S. Territories are included in Australasia.

Notes: EE/FSU = Eastern Europe/Former Soviet Union. The U.S. numbers include carbon emissions attributable to renewable energy sources.

Sources: History: Energy Information Administration (EIA), International Energy Annual 1996, DOE/EIA-0219(96) (Washington, DC, February 1998). Projections: EIA, Annual Energy Outlook 1998, DOE/EIA-0383(98) (Washington, DC, December 1997), Table A19; and World Energy Projection System (1998). 
Table A23. World Carbon Emissions from Oil Use by Region, High Economic Growth Case, 1990-2020 (Million Metric Tons)

\begin{tabular}{|c|c|c|c|c|c|c|c|c|c|}
\hline \multirow[b]{2}{*}{ Region/Country } & \multicolumn{3}{|c|}{ History } & \multicolumn{5}{|c|}{ Projections } & \multirow{2}{*}{$\begin{array}{c}\text { Average Annual } \\
\text { Percent Change } \\
1995-2020\end{array}$} \\
\hline & 1990 & 1995 & 1996 & 2000 & 2005 & 2010 & 2015 & 2020 & \\
\hline \multicolumn{10}{|l|}{ Industrialized } \\
\hline North America & 714 & 723 & 747 & 804 & 886 & 978 & 1,050 & 1,120 & 1.8 \\
\hline United States $^{\mathrm{a}}$ & 591 & 600 & 621 & 660 & 727 & 796 & 848 & 897 & 1.6 \\
\hline Canada $\ldots \ldots \ldots \ldots \ldots \ldots$ & 61 & 62 & 64 & 69 & 76 & 83 & 91 & 99 & 1.9 \\
\hline Mexico ................ & 62 & 61 & 62 & 75 & 84 & 99 & 111 & 124 & 2.9 \\
\hline Western Europe . ........... & 494 & 499 & 504 & 518 & 545 & 569 & 592 & 614 & 0.8 \\
\hline Industrialized Asia . . . . . . . . & 219 & 218 & 221 & 250 & 272 & 295 & 323 & 353 & 1.9 \\
\hline Japan $\ldots \ldots \ldots \ldots \ldots$ & 179 & 174 & 179 & 201 & 217 & 235 & 258 & 283 & 2.0 \\
\hline Australasia ............. & 40 & 44 & 43 & 50 & 54 & 61 & 65 & 70 & 1.8 \\
\hline Total Industrialized . ....... & 1,427 & 1,440 & 1,473 & 1,572 & 1,703 & 1,843 & 1,965 & 2,088 & 1.5 \\
\hline \multicolumn{10}{|l|}{ EE/FSU } \\
\hline Former Soviet Union & 355 & 174 & 165 & 176 & 218 & 273 & 329 & 390 & 3.3 \\
\hline Eastern Europe .... & 71 & 47 & 48 & 58 & 66 & 84 & 104 & 130 & 4.2 \\
\hline Total EE/FSU $\ldots \ldots \ldots \ldots$ & 427 & 220 & 212 & 234 & 284 & 356 & 433 & 521 & 3.5 \\
\hline \multicolumn{10}{|l|}{ Developing Countries } \\
\hline Developing Asia . ........... & 326 & 475 & 416 & 494 & 653 & 811 & 1,011 & 1,264 & 4.0 \\
\hline China...$\ldots \ldots \ldots \ldots$ & 98 & 140 & 113 & 147 & 193 & 253 & 332 & 437 & 4.7 \\
\hline India $\ldots \ldots \ldots \ldots \ldots \ldots$ & 49 & 65 & 59 & 68 & 90 & 113 & 141 & 178 & 4.1 \\
\hline Other Asia $\ldots \ldots \ldots \ldots \ldots$ & 178 & 270 & 244 & 280 & 369 & 445 & 537 & 650 & 3.6 \\
\hline Middle East $\ldots \ldots \ldots \ldots \ldots$ & 144 & 172 & 159 & 176 & 210 & 247 & 289 & 339 & 2.8 \\
\hline Africa $\ldots \ldots \ldots \ldots \ldots \ldots$ & 84 & 97 & 87 & 118 & 145 & 170 & 198 & 231 & 3.5 \\
\hline Central and South America .... & 140 & 158 & 138 & 192 & 244 & 306 & 378 & 466 & 4.4 \\
\hline Brazil ................ & 54 & 60 & 51 & 71 & 90 & 112 & 139 & 171 & 4.3 \\
\hline Other Central/South America ... & 86 & 98 & 87 & 122 & 154 & 194 & 239 & 295 & 4.5 \\
\hline Total Developing...$\ldots \ldots$ & 693 & 902 & 800 & 980 & 1,253 & 1,535 & 1,876 & 2,300 & 3.8 \\
\hline Total World & 2,547 & 2,562 & 2,485 & 2,786 & 3,240 & 3,734 & 4,274 & 4,909 & 2.6 \\
\hline
\end{tabular}

a Includes the 50 States and the District of Columbia. U.S. Territories are included in Australasia. Notes: EE/FSU = Eastern Europe/Former Soviet Union.

Sources: History: Energy Information Administration (EIA), International Energy Annual 1996, DOE/EIA-0219(96) (Washington, DC, February 1998). Projections: EIA, Annual Energy Outlook 1998, DOE/EIA-0383(98) (Washington, DC, December 1997), Table A19; and World Energy Projection System (1998). 
Table A24. World Carbon Emissions from Natural Gas Use by Region, High Economic Growth Case, 1990-2020 (Million Metric Tons)

\begin{tabular}{|c|c|c|c|c|c|c|c|c|c|}
\hline \multirow[b]{2}{*}{ Region/Country } & \multicolumn{3}{|c|}{ History } & \multicolumn{5}{|c|}{ Projections } & \multirow{2}{*}{$\begin{array}{c}\text { Average Annual } \\
\text { Percent Change } \\
1995-2020\end{array}$} \\
\hline & 1990 & 1995 & 1996 & 2000 & 2005 & 2010 & 2015 & 2020 & \\
\hline \multicolumn{10}{|l|}{ Industrialized } \\
\hline North America & 320 & 370 & 378 & 426 & 481 & 534 & 579 & 627 & 2.1 \\
\hline United States $^{2}$ & 273 & 314 & 318 & 359 & 399 & 444 & 476 & 508 & 1.9 \\
\hline Canada $\ldots \ldots \ldots \ldots \ldots$ & 34 & 41 & 44 & 45 & 48 & 52 & 61 & 71 & 2.2 \\
\hline Mexico . . . . . . . . . . . & 13 & 15 & 15 & 22 & 34 & 37 & 42 & 49 & 4.8 \\
\hline Western Europe . . . . . . . . . & 141 & 176 & 196 & 233 & 293 & 356 & 429 & 508 & 4.3 \\
\hline Industrialized Asia . . . . . . . . & 41 & 48 & 51 & 53 & 61 & 69 & 74 & 82 & 2.2 \\
\hline Japan $\ldots \ldots \ldots \ldots \ldots$ & 29 & 35 & 37 & 36 & 42 & 49 & 52 & 59 & 2.1 \\
\hline Australasia ............. & 12 & 13 & 13 & 17 & 20 & 21 & 22 & 23 & 2.3 \\
\hline Total Industrialized $\ldots \ldots \ldots$ & 502 & 593 & 625 & 712 & 836 & 959 & 1,082 & 1,217 & 2.9 \\
\hline \multicolumn{10}{|l|}{ EE/FSU } \\
\hline Former Soviet Union & 323 & 262 & 264 & 314 & 381 & 458 & 533 & 624 & 3.5 \\
\hline Eastern Europe .... & 41 & 36 & 39 & 54 & 71 & 90 & 109 & 131 & 5.3 \\
\hline Total EE/FSU $\ldots \ldots \ldots \ldots$ & 365 & 298 & 303 & 367 & 453 & 548 & 642 & 755 & 3.8 \\
\hline \multicolumn{10}{|l|}{ Developing Countries } \\
\hline Developing Asia . .......... & 40 & 69 & 79 & 149 & 233 & 318 & 406 & 517 & 8.4 \\
\hline China ........... & 7 & 9 & 10 & 22 & 39 & 52 & 59 & 68 & 8.4 \\
\hline India $\ldots \ldots \ldots$ & 6 & 10 & 11 & 26 & 43 & 64 & 92 & 125 & 10.6 \\
\hline Other Asia ..... & 27 & 50 & 57 & 102 & 152 & 202 & 256 & 324 & 7.7 \\
\hline Middle East $\ldots \ldots \ldots \ldots \ldots$ & 54 & 70 & 76 & 84 & 98 & 117 & 140 & 167 & 3.5 \\
\hline Africa $\ldots \ldots \ldots \ldots \ldots \ldots$ & 20 & 26 & 27 & 27 & 32 & 42 & 52 & 64 & 3.8 \\
\hline Central and South America .... & 29 & 39 & 43 & 50 & 88 & 134 & 194 & 274 & 8.1 \\
\hline Brazil ................. & 1 & 2 & 3 & 6 & 20 & 37 & 58 & 87 & 15.5 \\
\hline Other Central/South America ... & 28 & 37 & 40 & 44 & 67 & 97 & 136 & 187 & 6.7 \\
\hline Total Developing ......... & 143 & 204 & 225 & 310 & 451 & 611 & 793 & 1,023 & 6.7 \\
\hline Total World $\ldots \ldots \ldots \ldots \ldots$ & 1,009 & 1,095 & 1,152 & 1,390 & 1,740 & 2,118 & 2,516 & 2,995 & 4.1 \\
\hline
\end{tabular}

ancludes the 50 States and the District of Columbia. U.S. Territories are included in Australasia.

Notes: EE/FSU = Eastern Europe/Former Soviet Union.

Sources: History: Energy Information Administration (EIA), International Energy Annual 1996, DOE/EIA-0219(96) (Washington, DC, February 1998). Projections: EIA, Annual Energy Outlook 1998, DOE/EIA-0383(98) (Washington, DC, December 1997), Table A19; and World Energy Projection System (1998). 
Table A25. World Carbon Emissions from Coal Use by Region, High Economic Growth Case, 1990-2020 (Million Metric Tons)

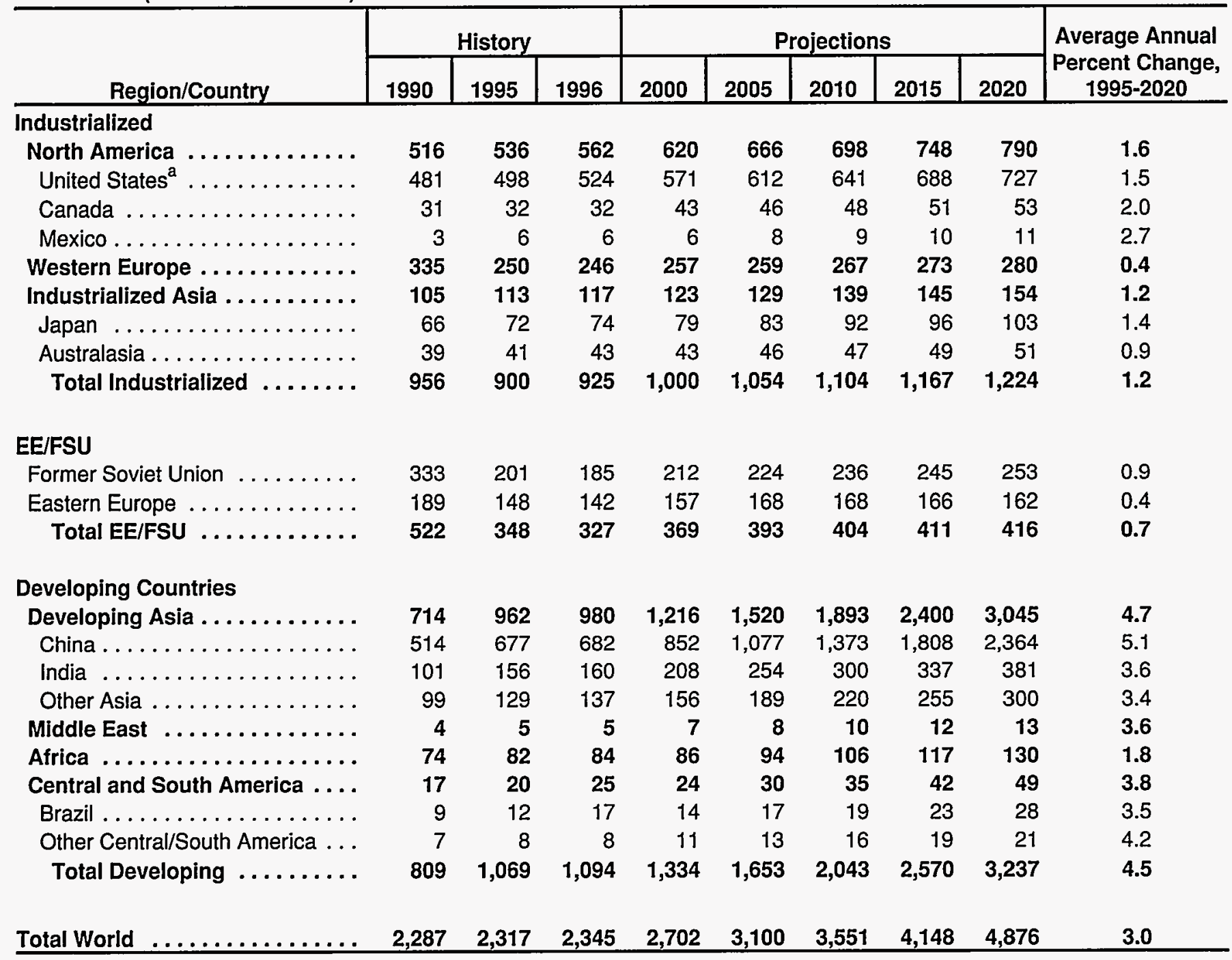

${ }^{a}$ Includes the 50 States and the District of Columbia. U.S. Territories are included in Australasia.

Notes: EE/FSU = Eastern Europe/Former Soviet Union.

Sources: History: Energy Information Administration (EIA), International Energy Annual 1996, DOE/EIA-0219(96) (Washington, DC, February 1998). Projections: EIA, Annual Energy Outlook 1998, DOE/EIA-0383(98) (Washington, DC, December 1997), Table A19; and World Energy Projection System (1998). 
Table A26. World Total Energy Consumption in Oil-Equivalent Units by Region, High Economic Growth Case, 1990-2020

(Million Tons Oil Equivalent)

\begin{tabular}{|c|c|c|c|c|c|c|c|c|c|}
\hline \multirow[b]{2}{*}{ Region/Country } & \multicolumn{3}{|c|}{ History } & \multicolumn{5}{|c|}{ Projections } & \multirow{2}{*}{$\begin{array}{c}\text { Average Annual } \\
\text { Percent Change, } \\
1995-2020\end{array}$} \\
\hline & 1990 & 1995 & 1996 & 2000 & 2005 & 2010 & 2015 & 2020 & \\
\hline \multicolumn{10}{|l|}{ Industrialized } \\
\hline North America & 2,513 & 2,723 & 2,828 & 3,055 & 3,336 & 3,614 & 3,843 & 4,071 & 1.6 \\
\hline United States ${ }^{\mathrm{a}}$ & 2,115 & 2,278 & 2,369 & 2,536 & 2,738 & 2,947 & 3,104 & 3,253 & 1.4 \\
\hline Canada $\ldots \ldots \ldots \ldots$ & 274 & 307 & 317 & 346 & 381 & 418 & 456 & 497 & 1.9 \\
\hline Mexico $\ldots \ldots \ldots \ldots \ldots$ & 124 & 138 & 142 & 174 & 216 & 249 & 283 & 321 & 3.4 \\
\hline Western Europe ........... & 1,561 & 1,632 & 1,681 & 1,812 & 1,987 & 2,157 & 2,329 & 2,514 & 1.7 \\
\hline Industrialized Asia . . . . . . . . . & 579 & 663 & 678 & 745 & 809 & 885 & 964 & 1,050 & 1.9 \\
\hline Japan $\ldots \ldots \ldots \ldots \ldots$ & 456 & 523 & 539 & 586 & 634 & 696 & 759 & 829 & 1.9 \\
\hline Australasia $\ldots \ldots \ldots \ldots \ldots$ & 123 & 140 & 139 & 159 & 175 & 189 & 205 & 221 & 1.8 \\
\hline Total Industrialized . ....... & 4,654 & 5,018 & 5,187 & 5,612 & 6,132 & 6,656 & 7,135 & 7,636 & 1.7 \\
\hline \multicolumn{10}{|l|}{ EE/FSU } \\
\hline Former Soviet Union ... & 1,473 & 1,027 & 1,003 & 1,151 & 1,369 & 1,613 & 1,854 & 2,130 & 3.0 \\
\hline Eastern Europe $\ldots \ldots \ldots \ldots \ldots$ & 382 & 312 & 316 & 373 & 438 & 508 & 584 & 672 & 3.1 \\
\hline Total EE/FSU . ... & 1,855 & 1,340 & 1,319 & 1,524 & 1,807 & 2,121 & 2,438 & 2,801 & 3.0 \\
\hline \multicolumn{10}{|l|}{ Developing Countries } \\
\hline Developing Asia .... & 1,294 & 1,811 & 1,879 & 2,421 & 3,192 & 4,019 & 5,040 & 6,326 & 5.1 \\
\hline China ........... & 680 & 917 & 935 & 1,210 & 1,590 & 2,036 & 2,627 & 3,388 & 5.4 \\
\hline India $\ldots$. & 195 & 279 & 291 & 398 & 520 & 654 & 806 & 994 & 5.2 \\
\hline Other Asia .... & 420 & 614 & 653 & 813 & 1,082 & 1,329 & 1,607 & 1,944 & 4.7 \\
\hline Middle East $\ldots \ldots \ldots \ldots \ldots \ldots$ & 281 & 350 & 369 & 412 & 491 & 583 & 691 & 818 & 3.5 \\
\hline Africa $\ldots \ldots \ldots \ldots \ldots \ldots \ldots$ & 233 & 270 & 279 & 325 & 388 & 457 & 534 & 624 & 3.4 \\
\hline Central and South America .... & 346 & 423 & 446 & 547 & 718 & 918 & 1,165 & 1,479 & 5.1 \\
\hline Brazil $\ldots \ldots \ldots \ldots \ldots \ldots$ & 136 & 161 & 173 & 210 & 281 & 359 & 458 & 583 & 5.3 \\
\hline Other Central/South America ... & 210 & 262 & 274 & 337 & 438 & 559 & 707 & 896 & 5.0 \\
\hline Total Developing.$\ldots \ldots \ldots$ & 2,154 & 2,854 & 2,972 & 3,704 & 4,790 & 5,977 & 7,431 & 9,246 & 4.8 \\
\hline$\ldots \ldots \ldots \ldots \ldots$ & 8,663 & 9,212 & 9,478 & 10,840 & 12,728 & 14,755 & 17,003 & 19,683 & 3.1 \\
\hline
\end{tabular}


Table A27. World Total Energy Consumption by Region, Low Economic Growth Case, 1990-2020 (Quadrillion Btu)

\begin{tabular}{|c|c|c|c|c|c|c|c|c|c|}
\hline \multirow[b]{2}{*}{ Region/Country } & \multicolumn{3}{|c|}{ History } & \multicolumn{5}{|c|}{ Projections } & \multirow{2}{*}{$\begin{array}{c}\text { Average Annual } \\
\text { Percent Change, } \\
1995-2020\end{array}$} \\
\hline & 1990 & 1995 & 1996 & 2000 & 2005 & 2010 & 2015 & 2020 & \\
\hline \multicolumn{10}{|l|}{ Industrialized Countries } \\
\hline North America ....... & 99.7 & 108.0 & 112.2 & 118.3 & 123.6 & 129.3 & 131.3 & 132.7 & 0.8 \\
\hline United States $^{a}$ & 83.9 & 90.4 & 94.0 & 98.9 & 102.6 & 106.9 & 107.7 & 107.7 & 0.7 \\
\hline Canada ...... & 10.9 & 12.2 & 12.6 & 12.9 & 13.6 & 14.2 & 14.8 & 15.5 & 1.0 \\
\hline Mexico ................. & 4.9 & 5.5 & 5.6 & 6.4 & 7.4 & 8.2 & 8.8 & 9.5 & 2.2 \\
\hline Western Europe..$\ldots \ldots \ldots \ldots$ & 61.9 & 64.8 & 66.7 & 67.6 & 70.4 & 72.9 & 75.3 & 77.8 & 0.7 \\
\hline Industrialized Asia . . . . . . . . . . & 23.0 & 26.3 & 26.9 & 27.3 & 28.2 & 29.4 & 30.5 & 31.6 & 0.7 \\
\hline Japan $\ldots \ldots \ldots \ldots \ldots \ldots$ & 18.1 & 20.8 & 21.4 & 21.3 & 22.0 & 22.9 & 23.7 & 24.6 & 0.7 \\
\hline Australasia . ................ & 4.9 & 5.6 & 5.5 & 5.9 & 6.2 & 6.5 & 6.7 & 7.0 & 0.9 \\
\hline Total Industrialized ....... & 184.7 & 199.1 & 205.8 & 213.1 & 222.2 & 231.5 & 237.1 & 242.1 & 0.8 \\
\hline \multicolumn{10}{|l|}{ EE/FSU } \\
\hline Former Soviet Union & 58.5 & 40.8 & 39.8 & 41.1 & 44.3 & 47.4 & 49.4 & 51.5 & 0.9 \\
\hline Eastern Europe ..... & 15.2 & 12.4 & 12.6 & 13.2 & 14.1 & 14.9 & 15.8 & 16.7 & 1.2 \\
\hline Total EE/FSU $\ldots \ldots \ldots \ldots$ & 73.6 & 53.2 & 52.4 & 54.2 & 58.4 & 62.4 & 65.2 & 68.2 & 1.0 \\
\hline \multicolumn{10}{|l|}{ Developing Countries } \\
\hline Developing Asia ........... & 51.4 & 71.8 & 74.5 & 83.9 & 97.8 & 110.7 & 125.1 & 141.5 & 2.7 \\
\hline China ............ & 27.0 & 36.4 & 37.1 & 42.2 & 48.8 & 55.4 & 63.4 & 72.6 & 2.8 \\
\hline India $\ldots \ldots \ldots \ldots \ldots \ldots$ & 7.7 & 11.1 & 11.5 & 13.7 & 15.9 & 18.1 & 20.4 & 23.0 & 3.0 \\
\hline Other Asia . . . . . . . . & 16.7 & 24.4 & 25.9 & 28.0 & 33.1 & 37.2 & 41.3 & 45.9 & 2.6 \\
\hline Middle East $\ldots \ldots \ldots \ldots \ldots$ & 11.1 & 13.9 & 14.6 & 14.7 & 15.9 & 17.1 & 18.6 & 20.1 & 1.5 \\
\hline Africa $\ldots \ldots \ldots \ldots \ldots \ldots \ldots$ & 9.2 & 10.7 & 11.1 & 11.6 & 12.6 & 13.6 & 14.7 & 15.8 & 1.6 \\
\hline Central and South America .... & 13.7 & 16.8 & 17.7 & 19.0 & 21.9 & 24.6 & 27.6 & 30.9 & 2.5 \\
\hline Brazil ................. & 5.4 & 6.4 & 6.8 & 7.3 & 8.6 & 9.7 & 10.9 & 12.2 & 2.6 \\
\hline Other Central/South America ... & 8.3 & 10.4 & 10.9 & 11.7 & 13.3 & 15.0 & 16.8 & 18.7 & 2.4 \\
\hline Total Developing...$\ldots \ldots$ & 85.5 & 113.3 & 117.9 & 129.3 & 148.2 & 166.1 & 186.0 & 208.4 & 2.5 \\
\hline …....... & 343.8 & 365.6 & 376.1 & 396.6 & 428.8 & 460.0 & 488.4 & 518.8 & 1.4 \\
\hline
\end{tabular}

${ }^{a}$ Includes the 50 States and the District of Columbia. U.S. Territories are included in Australasia.

Notes: EE/FSU = Eastern Europe/Former Soviet Union. Energy totals include net imports of coal coke and electricity generated from biomass in the United States. Totals may not equal sum of components due to independent rounding. The electricity portion of the national fuel consumption values consists of generation for domestic use plus an adjustment for electricity trade based on a fuel's share of total generation in the exporting country.

Sources: History: Energy Information Administration (EIA), International Energy Annual 1996, DOE/EIA-0219(96) (Washington, DC, February 1998). Projections: EIA, Annual Energy Outlook 1998, DOE/EIA-0383(98) (Washington, DC, December 1997), Table $\mathrm{A1}$; and World Energy Projection System (1998). 
Table A28. World Total Energy Consumption by Region and Fuel, Low Economic Growth Case, 1990-2020 (Quadrillion Btu)

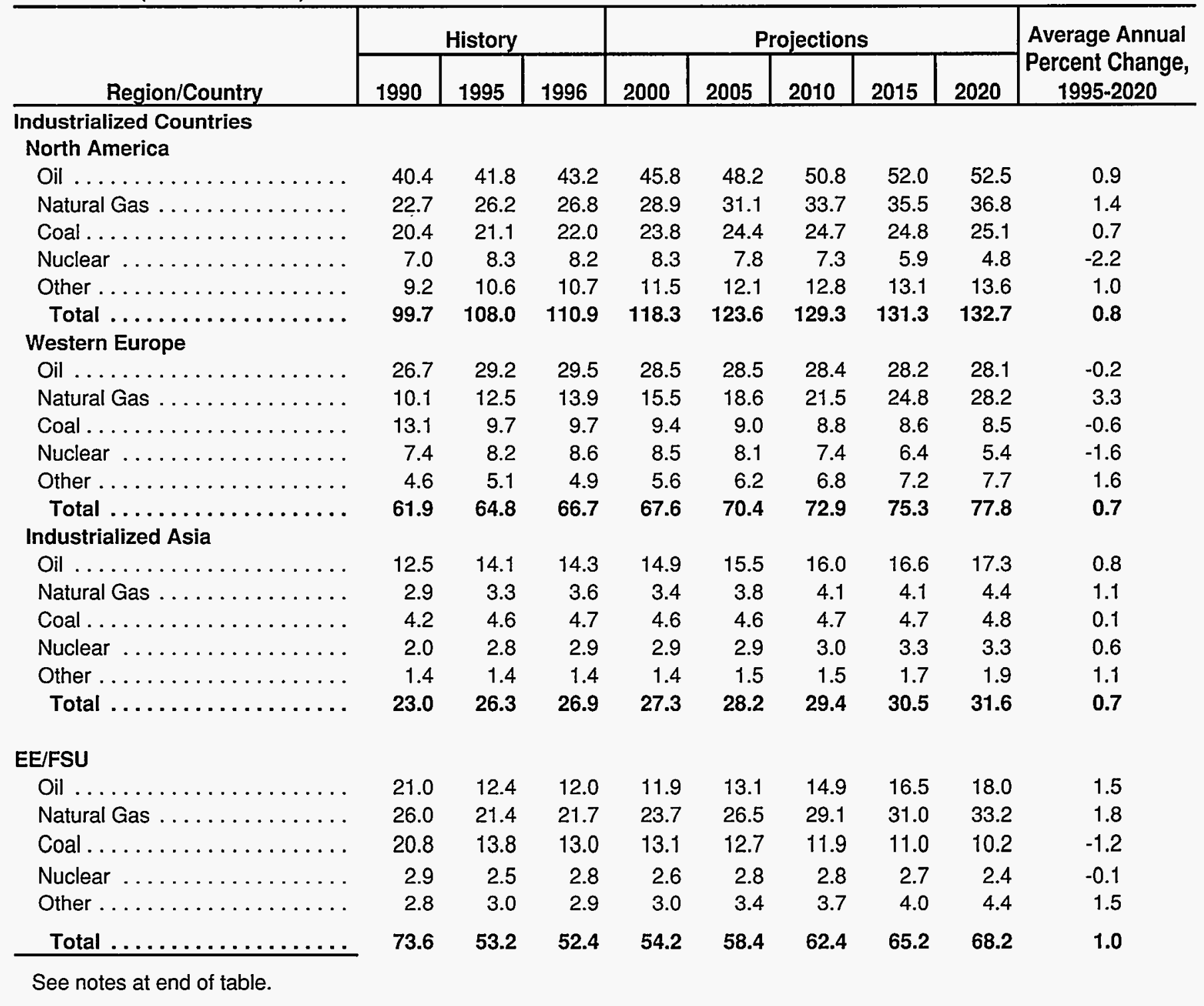


Table A28. World Total Energy Consumption by Region and Fuel, Low Economic Growth Case, 1990-2020 (Continued)

(Quadrillion Btu)

\begin{tabular}{|c|c|c|c|c|c|c|c|c|c|}
\hline \multirow[b]{2}{*}{ Region/Country } & \multicolumn{3}{|c|}{ History } & \multicolumn{5}{|c|}{ Projections } & \multirow{2}{*}{$\begin{array}{c}\text { Average Annual } \\
\text { Percent Change, } \\
1995-2020 \\
\end{array}$} \\
\hline & 1990 & 1995 & 1996 & 2000 & 2005 & 2010 & 2015 & 2020 & \\
\hline \multicolumn{10}{|l|}{$\begin{array}{l}\text { Developing Countries } \\
\text { Developing Asia }\end{array}$} \\
\hline Oil ............. & 16.0 & 23.6 & 24.8 & 25.7 & 30.0 & 33.5 & 37.7 & 42.5 & 2.4 \\
\hline Natural Gas . & 3.0 & 5.1 & 5.7 & 9.5 & 13.1 & 16.1 & 18.5 & 21.3 & 5.9 \\
\hline Coal.................. & 28.1 & 38.0 & 38.7 & 42.0 & 46.3 & 51.9 & 59.3 & 67.8 & 2.3 \\
\hline Nuclear ... & 0.9 & 1.2 & 1.3 & 1.4 & 1.8 & 2.2 & 2.3 & 2.2 & 2.6 \\
\hline Other .. & 3.2 & 4.0 & 4.0 & 5.3 & 6.5 & 7.0 & 7.3 & 7.7 & 2.7 \\
\hline Total $\ldots \ldots \ldots \ldots \ldots \ldots$ & 51.4 & 71.8 & 74.5 & 83.9 & 97.8 & 110.7 & 125.1 & 141.5 & 2.7 \\
\hline \multicolumn{10}{|l|}{ Middle East } \\
\hline Oil ....... & 7.1 & 8.5 & 8.8 & 8.8 & 9.5 & 10.2 & 10.9 & 11.7 & 1.3 \\
\hline Natural Gas $\ldots \ldots \ldots \ldots \ldots$ & 3.8 & 5.0 & 5.4 & 5.4 & 5.7 & 6.1 & 6.7 & 7.4 & 1.6 \\
\hline Coal $\ldots \ldots \ldots \ldots \ldots \ldots$ & 0.1 & 0.2 & 0.2 & 0.2 & 0.3 & 0.3 & 0.3 & 0.3 & 1.6 \\
\hline Nuclear $\ldots \ldots \ldots \ldots \ldots \ldots$ & 0.0 & 0.0 & 0.0 & 0.0 & 0.1 & 0.1 & 0.1 & 0.1 & - \\
\hline Other... & 0.1 & 0.2 & 0.2 & 0.3 & 0.4 & 0.4 & 0.6 & 0.7 & 5.7 \\
\hline$\underset{\text { Africa }}{\text { Total }} \ldots \ldots \ldots \ldots \ldots \ldots \ldots$ & 11.1 & 13.9 & 14.6 & 14.7 & 15.9 & 17.1 & 18.6 & 20.1 & 1.5 \\
\hline Oil .. & 4.2 & 4.8 & 5.0 & 6.1 & 6.9 & 7.3 & 7.9 & 8.5 & 2.3 \\
\hline Natural Gas & 1.4 & 1.9 & 2.0 & 1.8 & 1.9 & 2.3 & 2.6 & 3.0 & 1.9 \\
\hline Coal...... & 3.0 & 3.3 & 3.4 & 3.1 & 3.1 & 3.2 & 3.3 & 3.3 & 0.0 \\
\hline Nuclear & 0.1 & 0.1 & 0.1 & 0.1 & 0.1 & 0.1 & 0.1 & 0.1 & -0.9 \\
\hline Other... & 0.6 & 0.6 & 0.6 & 0.5 & 0.6 & 0.7 & 0.8 & 0.9 & 1.7 \\
\hline Total $\ldots \ldots \ldots \ldots \ldots \ldots$ & 9.2 & 10.7 & 11.1 & 11.6 & 12.6 & 13.6 & 14.7 & 15.8 & 1.6 \\
\hline \multicolumn{10}{|l|}{ Central and South America } \\
\hline Oil $\ldots \ldots \ldots \ldots \ldots \ldots$ & 6.9 & 8.0 & 8.1 & 9.9 & 11.1 & 12.2 & 13.3 & 14.5 & 2.4 \\
\hline Natural Gas & 2.1 & 2.9 & 3.1 & 3.2 & 4.9 & 6.5 & 8.4 & 10.5 & 5.3 \\
\hline$\ldots \ldots \ldots \ldots \ldots$ & 0.7 & 0.8 & 1.0 & 0.8 & 0.9 & 0.9 & 1.0 & 1.0 & 1.1 \\
\hline Nuclear .... & 0.1 & 0.1 & 0.1 & 0.1 & 0.2 & 0.2 & 0.2 & 0.1 & 1.1 \\
\hline Other... & 3.9 & 5.1 & 5.4 & 4.9 & 4.9 & 4.8 & 4.8 & 4.8 & -0.2 \\
\hline Total $\ldots \ldots \ldots \ldots \ldots \ldots$ & 13.7 & 16.8 & 17.7 & 19.0 & 21.9 & 24.6 & 27.6 & 30.9 & 2.5 \\
\hline \multicolumn{10}{|l|}{ Total World } \\
\hline Oil $\ldots \ldots \ldots \ldots \ldots \ldots \ldots$ & 134.9 & 142.5 & 145.7 & 151.7 & 162.6 & 173.3 & 183.1 & 193.1 & 1.2 \\
\hline Natural Gas $\ldots \ldots \ldots \ldots \ldots$ & 72.0 & 78.1 & 82.2 & 91.4 & 105.6 & 119.6 & 131.8 & 144.7 & 2.5 \\
\hline Coal $\ldots \ldots \ldots \ldots \ldots \ldots$ & 90.6 & 91.6 & 92.8 & 97.1 & 101.3 & 106.4 & 113.0 & 121.0 & 1.1 \\
\hline Nuclear $\ldots \ldots \ldots \ldots \ldots \ldots$ & 20.4 & 23.3 & 24.1 & 24.0 & 23.7 & 23.0 & 20.9 & 18.5 & -0.9 \\
\hline Other.$\ldots \ldots \ldots \ldots \ldots \ldots$ & 25.9 & 30.1 & 30.0 & 32.4 & 35.5 & 37.7 & 39.5 & 41.6 & 1.3 \\
\hline Total $\ldots \ldots \ldots \ldots \ldots \ldots \ldots$ & 343.8 & 365.6 & 374.7 & 396.6 & 428.8 & 460.0 & 488.4 & 518.8 & 1.4 \\
\hline
\end{tabular}

${ }^{a}$ Includes the 50 States and the District of Columbia. U.S. Territories are included in Australasia.

Notes: EE/FSU = Eastern Europe/Former Soviet Union. Energy totals include net imports of coal coke and electricity generated from biomass in the United States. Totals may not equal sum of components due to independent rounding. The electricity portion of the national fuel consumption values consists of generation for domestic use plus an adjustment for electricity trade based on a fuel's share of total generation in the exporting country.

Sources: History: Energy Information Administration (EIA), International Energy Annual 1996, DOE/EIA-0219(96) (Washingtón, DC, February 1998). Projections: EIA, Annual Energy Outlook 1998, DOE/EIA-0383(98) (Washington, DC, December 1997), Table A1; and World Energy Projection System (1998). 
Table A29. World Total Oil Consumption by Region, Low Economic Growth Case, 1990-2020 (Million Barrels per Day)

\begin{tabular}{|c|c|c|c|c|c|c|c|c|c|}
\hline \multirow[b]{2}{*}{ Region/Country } & \multicolumn{3}{|c|}{ History } & \multicolumn{5}{|c|}{ Projections } & \multirow{2}{*}{$\begin{array}{c}\text { Average Annual } \\
\text { Percent Change, } \\
1995-2020\end{array}$} \\
\hline & 1990 & 1995 & 1996 & 2000 & 2005 & 2010 & 2015 & 2020 & \\
\hline \multicolumn{10}{|l|}{ Industrialized } \\
\hline North America & 20.4 & 21.3 & 22.0 & 23.4 & 24.6 & 25.9 & 26.6 & 26.8 & 0.9 \\
\hline United States $^{\mathrm{a}}$ & 17.0 & 17.7 & 18.3 & 19.5 & 20.5 & 21.5 & 21.8 & 21.8 & 0.8 \\
\hline Canada $\ldots \ldots \ldots \ldots \ldots \ldots$ & 1.7 & 1.8 & 1.8 & 1.8 & 1.9 & 2.0 & 2.1 & 2.2 & 0.9 \\
\hline Mexico. & 1.7 & 1.9 & 1.9 & 2.1 & 2.2 & 2.5 & 2.7 & 2.8 & 1.7 \\
\hline Western Europe $\ldots \ldots \ldots \ldots$. & 12.9 & 14.1 & 14.3 & 13.8 & 13.8 & 13.8 & 13.7 & 13.6 & -0.2 \\
\hline Industrialized Asia . . . . . . . . . & 6.2 & 7.0 & 7.1 & 7.3 & 7.6 & 7.9 & 8.2 & 8.5 & 0.8 \\
\hline Japan $\ldots \ldots \ldots \ldots \ldots$ & 5.1 & 5.7 & 5.9 & 6.0 & 6.2 & 6.4 & 6.7 & 7.0 & 0.8 \\
\hline Australasia $\ldots \ldots \ldots \ldots \ldots$ & 1.0 & 1.2 & 1.2 & 1.3 & 1.4 & 1.5 & 1.5 & 1.6 & 0.9 \\
\hline Total Industrialized $\ldots \ldots \ldots$ & 39.5 & 42.4 & 43.4 & 44.6 & 46.0 & 47.6 & 48.4 & 48.9 & 0.6 \\
\hline \multicolumn{10}{|l|}{ EE/FSU } \\
\hline Former Soviet Union & 8.4 & 4.6 & 4.4 & 4.2 & 4.7 & 5.4 & 5.9 & 6.3 & 1.3 \\
\hline Eastern Europe .... & 1.6 & 1.3 & 1.3 & 1.4 & 1.5 & 1.7 & 2.0 & 2.3 & 2.3 \\
\hline Total EE/FSU $\ldots \ldots \ldots \ldots$ & 10.0 & 5.9 & 5.7 & 5.6 & 6.2 & 7.1 & 7.8 & 8.6 & 1.5 \\
\hline \multicolumn{10}{|l|}{ Developing Countries } \\
\hline Developing Asia $\ldots \ldots \ldots \ldots$. . . & 7.6 & 11.3 & 11.9 & 12.3 & 14.4 & 16.2 & 18.4 & 20.8 & 2.5 \\
\hline China $\ldots \ldots \ldots \ldots \ldots \ldots$ & 2.3 & 3.3 & 3.5 & 4.0 & 4.7 & 5.4 & 6.3 & 7.4 & 3.2 \\
\hline India $\ldots \ldots \ldots \ldots \ldots \ldots$ & 1.2 & 1.6 & 1.7 & 1.7 & 2.0 & 2.2 & 2.6 & 2.9 & 2.5 \\
\hline Other Asia $\ldots \ldots \ldots \ldots \ldots$ & 4.2 & 6.4 & 6.6 & 6.6 & 7.8 & 8.6 & 9.5 & 10.5 & 2.0 \\
\hline Middle East $\ldots \ldots \ldots \ldots \ldots$ & 3.4 & 4.1 & 4.2 & 4.2 & 4.5 & 4.8 & 5.2 & 5.5 & 1.3 \\
\hline Africa $\ldots \ldots \ldots \ldots \ldots \ldots$ & 2.1 & 2.3 & 2.4 & 2.9 & 3.3 & 3.5 & 3.8 & 4.1 & 2.3 \\
\hline Central and South America .... & 3.4 & 3.9 & 4.0 & 4.9 & 5.4 & 6.0 & 6.5 & 7.1 & 2.4 \\
\hline Brazil $\ldots \ldots \ldots \ldots \ldots \ldots$ & 1.3 & 1.5 & 1.5 & 1.9 & 2.1 & 2.3 & 2.5 & 2.7 & 2.4 \\
\hline Other Central/South America ... & 2.1 & 2.4 & 2.5 & 3.0 & 3.4 & 3.7 & 4.0 & 4.4 & 2.4 \\
\hline Total Developing $\ldots \ldots \ldots$ & 16.5 & 21.6 & 22.5 & 24.3 & 27.7 & 30.6 & 33.9 & 37.6 & 2.2 \\
\hline$\ldots \ldots \ldots \ldots \ldots \ldots$ & 66.0 & 69.9 & 71.5 & 74.6 & 80.0 & 85.3 & 90.2 & 95.1 & 1.2 \\
\hline
\end{tabular}

${ }^{\mathrm{a}}$ Includes the 50 States and the District of Columbia. U.S. Territories are included in Australasia.

Notes: EE/FSU = Eastern Europe/Former Soviet Union. Totals may not equal sum of components due to independent rounding. The electricity portion of the national fuel consumption values consists of generation for domestic use plus an adjustment for electricity trade based on a fuel's share of total generation in the exporting country.

Sources: History: Energy Information Administration (EIA), International Energy Annual 1996, DOE/EIA-0219(96) (Washington, DC, February 1998). Projections: EIA, Annual Energy Outlook 1998, DOE/EIA-0383(98) (Washington, DC, December 1997), Table A21; and World Energy Projection System (1998). 
Table A30. World Total Natural Gas Consumption by Region, Low Economic Growth Case, 1990-2020 (Trillion Cubic Feet)

\begin{tabular}{|c|c|c|c|c|c|c|c|c|c|}
\hline \multirow[b]{2}{*}{ Region/Country } & \multicolumn{3}{|c|}{ History } & \multicolumn{5}{|c|}{ Projections } & \multirow{2}{*}{$\begin{array}{c}\text { Average Annual } \\
\text { Percent Change, } \\
1995-2020 \\
\end{array}$} \\
\hline & 1990 & 1995 & 1996 & 2000 & 2005 & 2010 & 2015 & 2020 & \\
\hline \multicolumn{10}{|l|}{ Industrialized } \\
\hline North America & 22.0 & 25.4 & 26.0 & 28.0 & 30.2 & 32.7 & 34.4 & 35.7 & 1.4 \\
\hline United States ${ }^{\mathrm{a}}$ & 18.7 & 21.6 & 21.9 & 23.7 & 25.2 & 27.6 & 28.7 & 29.4 & 1.2 \\
\hline Canada ........ & 2.4 & 2.9 & 3.1 & 3.0 & 3.0 & 3.1 & 3.5 & 3.9 & 1.2 \\
\hline Mexico ............... & 0.9 & 1.0 & 1.0 & 1.3 & 2.0 & 2.0 & 2.2 & 2.4 & 3.6 \\
\hline Western Europe . . . . . . . . . & 10.3 & 12.7 & 14.1 & 15.7 & 18.8 & 21.7 & 25.0 & 28.4 & 3.3 \\
\hline Industrialized Asia . . . . . . . . & 2.6 & 3.1 & 3.3 & 3.2 & 3.5 & 3.8 & 3.8 & 4.0 & 1.1 \\
\hline Japan $\ldots \ldots \ldots \ldots \ldots \ldots$ & 1.9 & 2.2 & 2.4 & 2.1 & 2.3 & 2.6 & 2.6 & 2.8 & 1.0 \\
\hline Australasia ............ & 0.8 & 0.9 & 0.9 & 1.1 & 1.2 & 1.2 & 1.2 & 1.2 & 1.4 \\
\hline Total Industrialized & 35.0 & 41.2 & 43.3 & 46.9 & 52.5 & 58.2 & 63.3 & 68.1 & 2.0 \\
\hline \multicolumn{10}{|l|}{ EE/FSU } \\
\hline Former Soviet Union & 25.0 & 20.6 & 20.7 & 22.2 & 24.5 & 26.7 & 28.2 & 30.0 & 1.5 \\
\hline Eastern Europe .... & 3.1 & 2.7 & 2.9 & 3.7 & 4.4 & 5.1 & 5.7 & 6.3 & 3.4 \\
\hline Total EE/FSU $\ldots \ldots \ldots \ldots$ & 28.1 & 23.4 & 23.7 & 25.9 & 28.9 & 31.8 & 33.9 & 36.2 & 1.8 \\
\hline \multicolumn{10}{|l|}{ Developing Countries } \\
\hline Developing Asia . . . . . . . . . & 3.0 & 4.7 & 5.3 & 8.9 & 12.3 & 15.3 & 17.9 & 20.9 & 6.1 \\
\hline China...$\ldots \ldots \ldots \ldots \ldots$ & 0.5 & 0.6 & 0.7 & 1.3 & 2.0 & 2.4 & 2.4 & 2.4 & 5.8 \\
\hline India $\ldots$. & 0.4 & 0.6 & 0.7 & 1.4 & 2.0 & 2.8 & 3.6 & 4.5 & 8.2 \\
\hline Other Asia . & 2.1 & 3.5 & 4.0 & 6.2 & 8.3 & 10.2 & 11.9 & 13.9 & 5.7 \\
\hline Middle East $\ldots \ldots \ldots \ldots \ldots$ & 3.6 & 4.7 & 5.2 & 5.2 & 5.4 & 5.9 & 6.4 & 7.0 & 1.6 \\
\hline Africa...$\ldots \ldots \ldots \ldots \ldots$ & 1.4 & 1.7 & 1.8 & 1.6 & 1.8 & 2.1 & 2.4 & 2.7 & 1.9 \\
\hline Central and South America .... & 2.0 & 2.6 & 2.9 & 2.9 & 4.4 & 5.9 & 7.6 & 9.4 & 5.3 \\
\hline 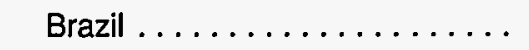 & 0.1 & 0.2 & 0.2 & 0.4 & 1.1 & 1.7 & 2.3 & 3.1 & 12.6 \\
\hline Other Central/South America ... & 1.9 & 2.4 & 2.7 & 2.5 & 3.3 & 4.2 & 5.2 & 6.3 & 3.9 \\
\hline Total Developing . . . . . . . . & 9.9 & 13.7 & 15.2 & 18.5 & 23.9 & 29.1 & 34.3 & 40.1 & 4.4 \\
\hline Total World ................ & 73.0 & 78.3 & 82.2 & 91.2 & 105.3 & 119.2 & 131.4 & 144.4 & 2.5 \\
\hline
\end{tabular}

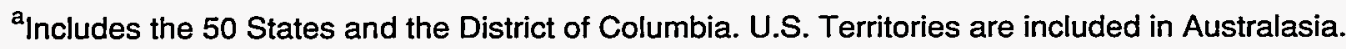

Notes: EE/FSU = Eastern Europe/Former Soviet Union. Totals may not equal sum of components due to independent rounding. The electricity portion of the national fuel consumption values consists of generation for domestic use plus an adjustment for electricity trade based on a fuel's share of total generation in the exporting country. To convert cubic feet to cubic meters, divide each number in the table by 35.315 .

Sources: History: Energy Information Administration (EIA), International Energy Annual 1996, DOE/EIA-0219(96) (Washington, DC, February 1998). Projections: ElA, Annual Energy Outlook 1998, DOE/EIA-0383(98) (Washington, DC, December 1997), Table A13; and World Energy Projection System (1998). 
Table A31. World Total Coal Consumption by Region, Low Economic Growth Case, 1990-2020 (Million Short Tons)

\begin{tabular}{|c|c|c|c|c|c|c|c|c|c|}
\hline \multirow[b]{2}{*}{ Region/Country } & \multicolumn{3}{|c|}{ History } & \multicolumn{5}{|c|}{ Projections } & \multirow{2}{*}{\begin{tabular}{|c} 
Average Annual \\
Percent Change, \\
$\mathbf{1 9 9 5 - 2 0 2 0}$ \\
\end{tabular}} \\
\hline & 1990 & 1995 & 1996 & 2000 & 2005 & 2010 & 2015 & 2020 & \\
\hline \multicolumn{10}{|l|}{ Industrialized } \\
\hline North America & 957 & 1,013 & 1,056 & 1,138 & 1,168 & 1,194 & 1,207 & 1,233 & 0.8 \\
\hline United States $^{a}$ & 896 & 941 & 983 & 1,051 & 1,076 & 1,101 & 1,113 & 1,138 & 0.8 \\
\hline Canada . . . . . & 55 & 59 & 60 & 74 & 76 & 76 & 76 & 76 & 1.0 \\
\hline Mexico ......... & 7 & 13 & 14 & 13 & 16 & 17 & 18 & 19 & 1.5 \\
\hline Western Europe..$\ldots \ldots \ldots$. . & 958 & 674 & 671 & 658 & 633 & 624 & 615 & 606 & -0.4 \\
\hline Industrialized Asia...$\ldots \ldots$. . . & 233 & 257 & 266 & 257 & 257 & 263 & 262 & 264 & 0.1 \\
\hline Japan $\ldots \ldots \ldots \ldots \ldots \ldots$ & 125 & 140 & 144 & 141 & 141 & 149 & 147 & 149 & 0.2 \\
\hline Australasia $\ldots \ldots \ldots \ldots \ldots$ & 108 & 117 & 121 & 116 & 116 & 114 & 115 & 115 & 0.0 \\
\hline Total Industrialized $\ldots \ldots \ldots$ & 2,148 & 1,944 & 1,994 & 2,054 & 2,058 & 2,081 & 2,085 & 2,104 & 0.3 \\
\hline \multicolumn{10}{|l|}{ EE/FSU } \\
\hline Former Soviet Union & 848 & 508 & 472 & 482 & 463 & 443 & 418 & 391 & -1.0 \\
\hline Eastern Europe .... & 523 & 426 & 413 & 404 & 394 & 358 & 326 & 294 & -1.5 \\
\hline Total EE/FSU $\ldots \ldots \ldots \ldots$ & 1,372 & 934 & 885 & 885 & 857 & 802 & 743 & 685 & -1.2 \\
\hline \multicolumn{10}{|l|}{ Developing Countries } \\
\hline Developing Asia . . . . . . . . & 1,555 & 2,030 & 2,065 & 2,238 & 2,461 & 2,737 & 3,108 & 3,525 & 2.2 \\
\hline China ............ & 1,124 & 1,489 & 1,500 & 1,647 & 1,832 & 2,070 & 2,419 & 2,808 & 2.6 \\
\hline India $\ldots \ldots \ldots$ & 242 & 312 & 321 & 361 & 389 & 416 & 428 & 443 & 1.4 \\
\hline Other Asia . . . & 190 & 230 & 244 & 230 & 239 & 250 & 260 & 274 & 0.7 \\
\hline Middle East $\ldots \ldots \ldots \ldots \ldots$ & 6 & 8 & 9 & 10 & 10 & 11 & 12 & 13 & 1.6 \\
\hline Africa $\ldots \ldots \ldots \ldots \ldots \ldots$ & 152 & 172 & 174 & 162 & 161 & 166 & 169 & 173 & 0.0 \\
\hline Central and South America .... & 30 & 32 & 40 & 35 & 38 & 39 & 41 & 42 & 1.1 \\
\hline Brazil $\ldots \ldots \ldots \ldots \ldots \ldots$ & 17 & 19 & 27 & 20 & 21 & 21 & 22 & 24 & 0.8 \\
\hline Other Central/South America ... & 13 & 13 & 13 & 15 & 17 & 17 & 18 & 18 & 1.5 \\
\hline Total Developing ......... & 1,743 & 2,243 & 2,289 & 2,444 & 2,671 & 2,952 & 3,330 & 3,754 & 2.1 \\
\hline Total World & 5,263 & 5,120 & 5,167 & $\mathbf{5 , 3 8 4}$ & $\mathbf{5 , 5 8 5}$ & 5,835 & 6,158 & 6,542 & 1.0 \\
\hline
\end{tabular}

${ }^{a}$ Includes the 50 States and the District of Columbia. U.S. Territories are included in Australasia.

Notes: EE/FSU = Eastern Europe/Former Soviet Union. Range values for Western Europe and the four regional totals are not equal to the sum of the component countries or country groups but consist of the base value adjusted by the quantity: the square root of the sum of the squared deviations of the respective component countries or country groups from their base value. Other totals may not equal sum of components due to independent rounding. The electricity portion of the national fuel consumption values consists of generation for domestic use plus an adjustment for electricity trade based on a fuel's share of total generation in the exporting country.To convert short tons to metric tons, divide each number in the table by 1.102 .

Sources: History: Energy Information Administration (EIA), International Energy Annual 1996, DOE/EIA-0219(96) (Washington, DC, February 1998). Projections: EIA, Annual Energy Outlook 1998, DOE/EIA-0383(98) (Washington, DC, December 1997), Table A16; and World Energy Projection System (1998). 
Table A32. World Net Nuclear Energy Consumption by Region, Low Economic Growth Case, 1990-2020 (Billion Kilowatthours)

\begin{tabular}{|c|c|c|c|c|c|c|c|c|c|}
\hline \multirow[b]{2}{*}{ Region/Country } & \multicolumn{3}{|c|}{ History } & \multicolumn{5}{|c|}{ Projections } & \multirow{2}{*}{$\begin{array}{c}\text { Average Annual } \\
\text { Percent Change, } \\
1995-2020\end{array}$} \\
\hline & 1990 & 1995 & 1996 & 2000 & 2005 & 2010 & 2015 & 2020 & \\
\hline \multicolumn{10}{|l|}{ Industrialized } \\
\hline North America & 649 & 774 & 770 & 770 & 725 & 676 & 552 & 443 & -2.2 \\
\hline United States $^{a}$ & 577 & 673 & 675 & 689 & 643 & 596 & 480 & 383 & -2.2 \\
\hline Canada ...... & 69 & 93 & 88 & 73 & 75 & 73 & 65 & 53 & -2.2 \\
\hline Mexico ............... & 3 & 8 & 7 & 8 & 7 & 7 & 7 & 7 & -0.6 \\
\hline Western Europe . . . . . . . . & 703 & 785 & 824 & 815 & 775 & 703 & 606 & 514 & -1.7 \\
\hline Industrialized Asia ........... & 192 & 277 & 283 & 285 & 284 & 295 & 322 & 320 & 0.6 \\
\hline Japan $\ldots \ldots \ldots \ldots \ldots \ldots$ & 192 & 277 & 283 & 285 & 284 & 295 & 322 & 320 & 0.6 \\
\hline Australasia .............. & 0 & 0 & 0 & 0 & 0 & 0 & 0 & 0 & 0.0 \\
\hline Total Industrialized . ....... & 1,544 . & 1,837 & 1,877 & 1,871 & 1,784 & 1,674 & 1,479 & 1,277 & -1.4 \\
\hline \multicolumn{10}{|l|}{ EE/FSU } \\
\hline Former Soviet Union .. & 201 & 172 & 194 & 179 & 188 & 191 & 187 & 175 & 0.1 \\
\hline Eastern Europe ...... & 54 & 57 & 60 & 60 & 64 & 61 & 56 & 47 & -0.7 \\
\hline Total EE/FSU $\ldots \ldots \ldots \ldots$ & 256 & 229 & 254 & 239 & 252 & 252 & 243 & 222 & -0.1 \\
\hline \multicolumn{10}{|l|}{ Developing Countries } \\
\hline Developing Asia . . . . . . . . . & 88 & 117 & 128 & 141 & 177 & 218 & 229 & 223 & 2.6 \\
\hline China $\ldots \ldots \ldots \ldots \ldots \ldots$ & 0 & 12 & 14 & 11 & 31 & 51 & 57 & 68 & 7.0 \\
\hline India $\ldots \ldots \ldots \ldots \ldots \ldots$ & 6 & 6 & 7 & 10 & 14 & 25 & 33 & 40 & 7.6 \\
\hline Other Asia . . . . . . & 82 & 98 & 107 & 119 & 132 & 142 & 138 & 116 & 0.7 \\
\hline Middle East $\ldots \ldots \ldots \ldots \ldots$ & 0 & $\mathbf{0}$ & 0 & 0 & 9 & 9 & 8 & 8 & 0.0 \\
\hline Africa $\ldots \ldots \ldots \ldots \ldots \ldots$ & 8 & 11 & 12 & 11 & 10 & 10 & 9 & 9 & -0.9 \\
\hline Central and South America .... & 9 & 9 & 9 & 9 & 15 & 14 & 13 & 12 & 1.1 \\
\hline Brazil $\ldots \ldots \ldots \ldots \ldots \ldots$ & 2 & 2 & 2 & 3 & 7 & 7 & 7 & 6 & 4.0 \\
\hline Other Central/South America ... & 7 & 7 & 7 & 7 & 8 & 7 & 7 & 6 & -0.6 \\
\hline Total Developing . ......... & 105 & 138 & 149 & 161 & 211 & 251 & 260 & 253 & 2.5 \\
\hline Total World & 1,905 & 2,203 & 2,280 & 2,270 & 2,248 & 2,178 & 1,982 & 1,752 & -0.9 \\
\hline
\end{tabular}

${ }^{a}$ Includes the 50 States and the District of Columbia. U.S. Territories are included in Australasia.

Notes: EE/FSU = Eastern Europe/Former Soviet Union. Totals may not equal sum of components due to independent rounding. The electricity portion of the national fuel consumption values consists of generation for domestic use plus an adjustment for electricity trade based on a fuel's share of total generation in the exporting country.

Sources: History: Energy Information Administration (EIA), International Energy Annual 1996, DOE/EIA-0219(96) (Washington, DC, February 1998). Projections: EIA, Annual Energy Outlook 1998, DOE/EIA-0383(98) (Washington, DC, December 1997), Table A8; and World Energy Projection System (1998). 
Table A33. World Consumption of Hydroelectricity and Other Renewable Energy by Region, Low Economic Growth Case, 1990-2020

(Quadrillion Btu)

\begin{tabular}{|c|c|c|c|c|c|c|c|c|c|}
\hline \multirow[b]{2}{*}{ Region/Country } & \multicolumn{3}{|c|}{ History } & \multicolumn{5}{|c|}{ Projections } & \multirow{2}{*}{$\begin{array}{c}\text { Average Annual } \\
\text { Percent Change, } \\
1995-2020\end{array}$} \\
\hline & 1990 & 1995 & 1996 & 2000 & 2005 & 2010 & 2015 & 2020 & \\
\hline \multicolumn{10}{|l|}{ Industrialized } \\
\hline North America . . . . . . . . . . . & 9.2 & 10.6 & 10.7 & 11.5 & 12.1 & 12.8 & 13.1 & 13.6 & 1.0 \\
\hline United States $^{\mathrm{a}} \ldots \ldots \ldots \ldots \ldots$ & 5.8 & 6.8 & 6.6 & 7.2 & 7.3 & 7.6 & 7.6 & 7.7 & 0.5 \\
\hline Canada . . . . . . . . . . . & 3.1 & 3.4 & 3.6 & 3.9 & 4.2 & 4.6 & 4.7 & 4.9 & 1.4 \\
\hline$\ldots \ldots \ldots \ldots \ldots$ & 0.3 & 0.4 & 0.4 & 0.4 & 0.6 & 0.7 & 0.8 & 0.9 & 3.4 \\
\hline Western Europe . . . . . . . . . . & 4.6 & 5.1 & 4.9 & 5.6 & 6.2 & 6.8 & 7.2 & 7.6 & 1.6 \\
\hline Industrialized Asia . . . . . . . . . . & 1.4 & 1.4 & 1.4 & 1.4 & 1.5 & 1.5 & 1.7 & 1.9 & 1.1 \\
\hline Japan $\ldots \ldots \ldots \ldots \ldots$ & 1.0 & 0.9 & 0.9 & 0.8 & 0.9 & 0.9 & 0.9 & 0.9 & 0.2 \\
\hline Australasia . . . . . . . . . . & 0.4 & 0.5 & 0.5 & 0.6 & 0.6 & 0.7 & 0.8 & 0.9 & 2.5 \\
\hline Total Industrialized . . . . . . & 15.3 & 17.2 & 16.9 & 18.4 & 19.8 & 21.1 & 22.0 & 23.1 & 1.2 \\
\hline \multicolumn{10}{|l|}{ EE/FSU } \\
\hline Former Soviet Union & 2.4 & 2.5 & 2.2 & 2.5 & 2.7 & 2.8 & 2.8 & 2.9 & 0.6 \\
\hline Eastern Europe .... & 0.4 & 0.6 & 0.6 & 0.4 & 0.6 & 0.9 & 1.2 & 1.5 & 3.8 \\
\hline Total EE/FSU $\ldots \ldots \ldots \ldots$ & 2.8 & 3.0 & 2.9 & 3.0 & 3.4 & 3.7 & 4.0 & 4.4 & 1.5 \\
\hline \multicolumn{10}{|l|}{ Developing Countries } \\
\hline Developing Asia . . . . . . . . . . . & 3.2 & 4.0 & 4.0 & 5.3 & 6.5 & 6.9 & 7.3 & 7.8 & 2.7 \\
\hline China ............... & 1.3 & 1.9 & 1.9 & 2.6 & 3.5 & 3.6 & 3.5 & 3.3 & 2.2 \\
\hline India $\ldots \ldots \ldots \ldots \ldots \ldots$ & 0.7 & 0.7 & 0.7 & 1.3 & 1.4 & 1.6 & 1.9 & 2.3 & 4.7 \\
\hline Other Asia . . . . . . . . . . . . & 1.2 & 1.4 & 1.4 & 1.4 & 1.5 & 1.7 & 1.9 & 2.2 & 2.0 \\
\hline Middle East $\ldots \ldots \ldots \ldots \ldots$ & 0.1 & 0.2 & 0.2 & 0.3 & 0.4 & 0.4 & 0.6 & 0.7 & 5.7 \\
\hline Africa $\ldots \ldots \ldots \ldots \ldots \ldots$ & 0.6 & 0.6 & 0.6 & 0.5 & 0.6 & 0.7 & 0.8 & 0.9 & 1.7 \\
\hline Central and South America .... & 3.9 & 5.1 & 5.4 & 4.9 & 4.9 & 4.8 & 4.8 & 4.8 & -0.2 \\
\hline Brazil . . . . . . . . . . & 2.2 & 2.7 & 2.8 & 2.6 & 2.5 & 2.5 & 2.4 & 2.4 & -0.4 \\
\hline Other Central/South America ... & 1.7 & 2.4 & 2.6 & 2.3 & 2.3 & 2.3 & 2.3 & 2.4 & 0.0 \\
\hline Total Developing ......... & 7.8 & 9.9 & 10.2 & 11.0 & 12.3 & 12.9 & 13.5 & 14.2 & 1.5 \\
\hline Total World $\ldots \ldots \ldots \ldots \ldots$ & 25.9 & 30.1 & 30.0 & 32.4 & 35.5 & 37.7 & 39.5 & 41.7 & 1.3 \\
\hline
\end{tabular}

${ }^{a}$ Includes the 50 States and the District of Columbia. U.S. Territories are included in Australasia.

Notes: EE/FSU = Eastern Europe/Former Soviet Union. Totals may not equal sum of components due to independent rounding. The electricity portion of the national fuel consumption values consists of generation for domestic use plus an adjustment for electricity trade based on a fuel's share of total generation in the exporting country.

Sources: History: Energy Information Administration (EIA), International Energy Annual 1996, DOE/EIA-0219(96) (Washington, DC, February 1998). Projections: EIA, Annual Energy Outlook 1998, DOE/EIA-0383(98) (Washington, DC, December 1997), Table A1; and World Energy Projection System (1998). 
Table A34. World Total Net Electricity Consumption by Region, Low Economic Growth Case, 1990-2020 (Billion Kilowatthours)

\begin{tabular}{|c|c|c|c|c|c|c|c|c|c|}
\hline \multirow[b]{2}{*}{ Region/Country } & \multicolumn{3}{|c|}{ History } & \multicolumn{5}{|c|}{ Projections } & \multirow{2}{*}{$\begin{array}{c}\text { Average Annual } \\
\text { Percent Change, } \\
\text { 1995-2020 }\end{array}$} \\
\hline & 1990 & 1995 & 1996 & 2000 & 2005 & 2010 & 2015 & 2020 & \\
\hline \multicolumn{10}{|l|}{ Industrialized } \\
\hline North America & 3,255 & 3,759 & 3,859 & 3,935 & 4,182 & 4,442 & 4,647 & 4,763 & 1.0 \\
\hline United States $^{\mathrm{a}} \ldots \ldots \ldots \ldots$ & 2,713 & 3,163 & 3,243 & 3,289 & 3,479 & 3,673 & 3,807 & 3,876 & 0.8 \\
\hline Canada $\ldots \ldots \ldots \ldots \ldots \ldots$ & 435 & 462 & 473 & 484 & 500 & 532 & 566 & 591 & 1.0 \\
\hline Mexico $\ldots \ldots \ldots \ldots \ldots \ldots$ & 107 & 134 & 144 & 161 & 202 & 237 & 274 & 296 & 3.2 \\
\hline Western Europe ........... & 2,115 & 2,286 & 2,330 & 2,637 & 2,893 & 3,153 & 3,410 & 3,525 & 1.7 \\
\hline Industrialized Asia . . . . . . . . & 930 & 1,068 & 1,090 & 1,213 & 1,307 & 1,400 & 1,487 & 1,543 & 1.5 \\
\hline Japan $\ldots \ldots \ldots \ldots \ldots \ldots$ & 750 & 864 & 882 & 934 & 994 & 1,057 & 1,116 & 1,157 & 1.2 \\
\hline Australasia . . . . . . . . . . & 180 & 204 & 207 & 279 & 313 & 343 & 371 & 386 & 2.6 \\
\hline Total Industrialized . . . . . . & 6,299 & 7,113 & 7,279 & 7,784 & 8,382 & 8,995 & 9,544 & 9,830 & 1.3 \\
\hline \multicolumn{10}{|l|}{ EE/FSU } \\
\hline Former Soviet Union & 1,488 & 1,168 & 1,133 & 1,069 & 1,154 & 1,235 & 1,288 & 1,343 & 0.6 \\
\hline Eastern Europe .... & 420 & 384 & 401 & 370 & 418 & 466 & 514 & 543 & 1.4 \\
\hline Total EE/FSU .......... & 1,908 & 1,552 & 1,535 & 1,439 & 1,572 & 1,701 & 1,802 & 1,886 & 0.8 \\
\hline \multicolumn{10}{|l|}{ Developing Countries } \\
\hline Developing Asia .... & 1,268 & 1,912 & 2,002 & 2,302 & 2,827 & 3,363 & 3,986 & 4,509 & 3.5 \\
\hline China ........... & 551 & 881 & 925 & 986 & 1,243 & 1,533 & 1,905 & 2,182 & 3.7 \\
\hline India $\ldots .$. & 257 & 367 & 378 & 504 & 618 & 741 & 871 & 983 & 4.0 \\
\hline Other Asia ... & 460 & 663 & 699 & 812 & 966 & 1,089 & 1,210 & 1,344 & 2.9 \\
\hline Middle East $\ldots \ldots \ldots \ldots \ldots$ & 221 & 295 & 301 & 293 & 327 & 361 & 397 & 429 & 1.5 \\
\hline Africa $\ldots \ldots \ldots \ldots \ldots \ldots$ & 285 & 320 & 332 & 359 & 416 & 478 & 547 & 589 & 2.5 \\
\hline Central and South America .... & 449 & 575 & 604 & 664 & 790 & 894 & 995 & 1,115 & 2.7 \\
\hline Brazil $\ldots \ldots \ldots \ldots \ldots \ldots$ & 229 & 288 & 303 & 289 & 310 & 312 & 316 & 333 & 0.6 \\
\hline Other Central/South America ... & 220 & 286 & 301 & 375 & 480 & 582 & 679 & 782 & 4.1 \\
\hline Total Developing . . . . . . . & 2,224 & 3,102 & 3,239 & 3,619 & 4,360 & 5,095 & 5,925 & 6,642 & 3.1 \\
\hline Total World & 10,431 & 11,767 & 12,053 & 12,842 & 14,314 & 15,792 & 17,271 & 18,358 & 1.8 \\
\hline
\end{tabular}

a Includes the 50 States and the District of Columbia. U.S. Territories are included in Australasia.

Notes: EE/FSU = Eastern Europe/Former Soviet Union. Electricity consumption equals generation plus imports minus exports minus distribution losses.

Sources: History: Energy Information Administration (EIA), International Energy Annual 1996, DOE/EIA-0219(96) (Washington, DC, February 1998), Table 6.2. Projections: EIA, Annual Energy Outlook 1998, DOE/EIA-0383(98) (Washington, DC, December 1997), Table A8; and World Energy Projection System (1998). 
Table A35. World Total Carbon Emissions by Region, Low Economic Growth Case, 1990-2020 (Million Metric Tons)

\begin{tabular}{|c|c|c|c|c|c|c|c|c|c|}
\hline Region/Country & 1990 & 1995 & 1996 & 2000 & 2005 & 2010 & 2015 & 2020 & $\begin{array}{c}\text { Average Annual } \\
\text { Percent Change, } \\
1995-2020\end{array}$ \\
\hline North America . . . . . . . . . . . & 1,550 & 1,629 & 1,687 & 1,807 & 1,897 & 1,990 & 2,044 & 2,082 & 1.0 \\
\hline United States $^{a} \ldots \ldots \ldots \ldots \ldots$ & 1,346 & 1,411 & 1,463 & 1,564 & 1,636 & 1,713 & 1,749 & 1,770 & 0.9 \\
\hline Canada ............. & 126 &, 135 & 140 & 148 & 152 & 157 & 166 & 175 & 1.0 \\
\hline Western Europe ........... & 971 & 925 & 947 & 948 & 979 & 1,016 & 1,055 & 1,095 & 0.7 \\
\hline Industrialized Asia . . . . . . . . . . & 364 & 379 & 389 & 393 & 407 & 422 & 433 & 448 & 0.7 \\
\hline Japan $\ldots \ldots \ldots \ldots \ldots$ & 274 & 281 & 291 & 290 & 299 & 312 & 320 & 332 & 0.7 \\
\hline Australasia . . . . . . . . . & 90 & 99 & 99 & 104 & 107 & 111 & 113 & 115 & 0.6 \\
\hline Total Industrialized . . . . . . & 2,885 & 2,933 & 3,023 & 3,148 & 3,283 & 3,428 & 3,532 & 3,625 & 0.9 \\
\hline Total EE/FSU $\ldots \ldots \ldots \ldots \ldots$ & 1,290 & 866 & 842 & 870 & 920 & 969 & 1,002 & 1,038 & 0.7 \\
\hline \multicolumn{10}{|l|}{ Developing Countries } \\
\hline Developing Asia . . . . . . . . . . . & 1,065 & 1,427 & 1,474 & 1,624 & 1,857 & 2,097 & 2,389 & 2,721 & 2.6 \\
\hline China $\ldots \ldots \ldots \ldots \ldots \ldots$ & 620 & 792 & 805 & 897 & 1,013 & 1,150 & 1,338 & 1,549 & 2.7 \\
\hline India $\ldots \ldots \ldots \ldots \ldots \ldots$ & 153 & 222 & 230 & 262 & 297 & 333 & 364 & 399 & 2.4 \\
\hline Other Asia . . . . . . . . . . . & 293 & 413 & 439 & 466 & 547 & 615 & 687 & 773 & 2.5 \\
\hline Middle East $\ldots \ldots \ldots \ldots \ldots \ldots$ & 194 & 229 & 241 & 241 & 257 & 277 & 298 & 321 & 1.4 \\
\hline Africa ............... & 178 & 192 & 198 & 208 & 224 & 239 & 255 & 272 & 1.4 \\
\hline Central and South America .... . & 174 & 194 & 206 & 233 & 278 & 321 & 366 & 416 & 3.1 \\
\hline
\end{tabular}

${ }^{a}$ Includes the 50 States and the District of Columbia. U.S. Territories are included in Australasia.

Notes: EE/FSU = Eastern Europe/Former Soviet Union. The U.S. numbers include carbon emissions attributable to renewable energy sources.

Sources: History: Energy Information Administration (EIA), International Energy Annual 1996, DOE/EIA-0219(96) (Washington, DC, February 1998). Projections: EIA, Annual Energy Outlook 1998, DOE/EIA-0383(98) (Washington, DC, December 1997), Table A19; and World Energy Projection System (1998). 
Table A36. World Carbon Emissions from Oil Use by Region, Low Economic Growth Case, 1990-2020 (Million Metric Tons)

\begin{tabular}{|c|c|c|c|c|c|c|c|c|c|}
\hline \multirow[b]{2}{*}{ Region/Country } & \multicolumn{3}{|c|}{ History } & \multicolumn{5}{|c|}{ Projections } & \multirow{2}{*}{$\begin{array}{c}\text { Average Annual } \\
\text { Percent Change, } \\
1995-2020\end{array}$} \\
\hline & 1990 & 1995 & 1996 & 2000 & 2005 & 2010 & 2015 & 2020 & \\
\hline \multicolumn{10}{|l|}{ Industrialized } \\
\hline North America $\ldots \ldots \ldots \ldots \ldots$ & 714 & 723 & 747 & 787 & 829 & 876 & 900 & 912 & 0.9 \\
\hline United States ${ }^{\mathrm{a}} \ldots \ldots \ldots \ldots \ldots$ & 591 & 600 & 621 & 652 & 689 & 723 & 738 & 741 & 0.9 \\
\hline Canada ...... & 61 & 62 & 64 & 65 & 68 & 71 & 75 & 78 & 0.9 \\
\hline Mexico ....... & 62 & 61 & 62 & 70 & 72 & 82 & 87 & 92 & 1.7 \\
\hline Western Europe . . . . . . . . . & 494 & 499 & 504 & 487 & 486 & 485 & 482 & 479 & -0.2 \\
\hline Industrialized Asia . . . . . . . . . & 219 & 218 & 221 & 231 & 239 & 247 & 257 & 268 & 0.8 \\
\hline Japan $\ldots \ldots \ldots \ldots \ldots \ldots$ & 179 & 174 & 179 & 184 & 190 & 194 & 203 & 212 & 0.8 \\
\hline Australasia ............... & 40 & 44 & 43 & 47 & 49 & 52 & 54 & 56 & 0.9 \\
\hline Total Industrialized $\ldots \ldots \ldots$ & 1,427 & 1,440 & 1,473 & 1,505 & 1,554 & 1,608 & 1,640 & 1,658 & 0.6 \\
\hline \multicolumn{10}{|l|}{ EE/FSU } \\
\hline Former Soviet Union & 355 & 174 & 165 & 158 & 178 & 202 & 221 & 238 & 1.3 \\
\hline Eastern Europe $\ldots \ldots \ldots \ldots \ldots$ & 71 & 47 & 48 & 52 & 54 & 62 & 71 & 82 & 2.3 \\
\hline Total EE/FSU $\ldots \ldots \ldots \ldots$ & 427 & 220 & 212 & 210 & 232 & 264 & 292 & 320 & 1.5 \\
\hline \multicolumn{10}{|l|}{ Developing Countries } \\
\hline Developing Asia ........... & 326 & 475 & 416 & 432 & 504 & 563 & 633 & 713 & 1.6 \\
\hline China $\ldots \ldots \ldots \ldots \ldots \ldots \ldots$ & 98 & 140 & 113 & 129 & 149 & 174 & 202 & 236 & 2.1 \\
\hline India $\ldots \ldots \ldots \ldots \ldots \ldots$ & 49 & 65 & 59 & 59 & 69 & 79 & 90 & 104 & 1.9 \\
\hline Other Asia $\ldots . \ldots \ldots \ldots \ldots$ & 178 & 270 & 244 & 244 & 285 & 310 & 340 & 373 & 1.3 \\
\hline Middle East $\ldots \ldots \ldots \ldots \ldots$ & 144 & 172 & 159 & 158 & 171 & 183 & 196 & 210 & 0.8 \\
\hline Africa $\ldots \ldots \ldots \ldots \ldots \ldots$ & 84 & 97 & 87 & 106 & 119 & 128 & 137 & 148 & 1.7 \\
\hline Central and South America .... & 140 & 158 & 138 & 168 & 187 & 207 & 226 & 245 & 1.8 \\
\hline Brazil ................ & 54 & 60 & 51 & 62 & 69 & 76 & 83 & 90 & 1.6 \\
\hline Other Central/South America ... & 86 & 98 & 87 & 106 & 119 & 131 & 143 & 155 & 1.9 \\
\hline Total Developing...$\ldots \ldots$ & 693 & 902 & 800 & 864 & 982 & 1,081 & 1,191 & 1,316 & 1.5 \\
\hline Total World & 2,547 & 2,562 & 2,485 & 2,579 & 2,768 & 2,953 & 3,123 & 3,294 & 1.0 \\
\hline
\end{tabular}

Includes the 50 States and the District of Columbia. U.S. Territories are included in Australasia.

Notes: EE/FSU = Eastern Europe/Former Soviet Union.

Sources: History: Energy Information Administration (EIA), International Energy Annual 1996, DOE/EIA-0219(96) (Washington, DC, February 1998). Projections: EIA, Annual Energy Outlook 1998, DOE/EIA-0383(98) (Washington, DC, December 1997), Table A19; and World Energy Projection System (1998). 
Table A37. World Carbon Emissions from Natural Gas Use by Region, Low Economic Growth Case, 1990-2020

(Million Metric Tons)

\begin{tabular}{|c|c|c|c|c|c|c|c|c|c|}
\hline \multirow[b]{2}{*}{ Region/Country } & \multicolumn{3}{|c|}{ History } & \multicolumn{5}{|c|}{ Projections } & \multirow{2}{*}{$\begin{array}{c}\text { Average Annual } \\
\text { Percent Change, } \\
1995-2020\end{array}$} \\
\hline & 1990 & 1995 & 1996 & 2000 & 2005 & 2010 & 2015 & 2020 & \\
\hline \multicolumn{10}{|l|}{ Industrialized } \\
\hline North America & 320 & 370 & 378 & 412 & 444 & 481 & 506 & 525 & 1.4 \\
\hline United States $^{a}$ & 273 & 314 & 318 & 349 & 371 & 406 & 423 & 433 & 1.3 \\
\hline Canada $\ldots \ldots \ldots \ldots \ldots \ldots$ & 34 & 41 & 44 & 42 & 43 & 45 & 50 & 56 & 1.2 \\
\hline Mexico $\ldots \ldots \ldots \ldots \ldots \ldots$ & 13 & 15 & 15 & 20 & 30 & 31 & 33 & 37 & 3.6 \\
\hline Western Europe $\ldots \ldots \ldots \ldots \ldots$ & 141 & 176 & 196 & 219 & 262 & 303 & 350 & 397 & 3.3 \\
\hline Industrialized Asia . . . . . . . . . . & 41 & 48 & 51 & 49 & 54 & 58 & 59 & 62 & 1.1 \\
\hline Japan $\ldots \ldots \ldots \ldots \ldots \ldots$ & 29 & 35 & 37 & 33 & 37 & 40 & 41 & 44 & 1.0 \\
\hline Australasia . & 12 & 13 & 13 & 16 & 18 & 18 & 18 & 18 & 1.4 \\
\hline Total Industrialized ....... & 502 & 593 & 625 & 679 & 760 & 843 & 916 & 985 & 2.0 \\
\hline \multicolumn{10}{|l|}{ EE/FSU } \\
\hline Former Soviet Union & 323 & 262 & 264 & 282 & 311 & 339 & 358 & 381 & 1.5 \\
\hline Eastern Europe .... & 41 & 36 & 39 & 48 & 58 & 67 & 74 & 82 & 3.4 \\
\hline Total EE/FSU & 365 & 298 & 303 & 330 & 369 & 406 & 432 & 462 & 1.8 \\
\hline \multicolumn{10}{|l|}{ Developing Countries } \\
\hline Developing Asia .... & 40 & 69 & 79 & 130 & 180 & 221 & 254 & 292 & 5.9 \\
\hline China...$\ldots \ldots \ldots$ & 7 & 9 & 10 & 19 & 30 & 35 & 36 & 37 & 5.8 \\
\hline India $\ldots \ldots \ldots$ & 6 & 10 & 11 & 22 & 33 & 45 & 58 & 73 & 8.2 \\
\hline Other Asia ....... & 27 & 50 & 57 & 89 & 117 & 141 & 160 & 182 & 5.3 \\
\hline Middle East $\ldots \ldots \ldots \ldots \ldots$ & 54 & 70 & 76 & 76 & 79 & 86 & 95 & 103 & 1.6 \\
\hline Africa $\ldots \ldots \ldots \ldots \ldots \ldots$ & 20 & 26 & 27 & 24 & 27 & 31 & 36 & 41 & 1.9 \\
\hline Central and South America .... & 29 & 39 & 43 & 44 & 67 & 90 & 116 & 144 & 5.3 \\
\hline Brazil $\ldots \ldots \ldots \ldots \ldots \ldots$ & 1 & 2 & 3 & 5 & 16 & 25 & 35 & 46 & 12.6 \\
\hline Other Central/South America ... & 28 & 37 & 40 & 39 & 52 & 66 & 81 & 98 & 4.0 \\
\hline Total Developing . ......... & 143 & 204 & 225 & 274 & 354 & 429 & 501 & 581 & 4.3 \\
\hline Total World $\ldots \ldots \ldots \ldots \ldots$ & 1,009 & 1,095 & 1,152 & 1,284 & 1,483 & 1,678 & 1,849 & 2,028 & 2.5 \\
\hline
\end{tabular}

${ }^{a}$ Includes the 50 States and the District of Columbia. U.S. Territories are included in Australasia.

Notes: EE/FSU = Eastern Europe/Former Soviet Union.

Sources: History: Energy Information Administration (EIA), International Energy Annual 1996, DOE/EIA-0219(96) (Washington, DC, February 1998). Projections: EIA, Annual Energy Outlook 1998, DOE/EIA-0383(98) (Washington, DC, December 1997), Table A19; and World Energy Projection System (1998). 
Table A38. World Carbon Emissions from Coal Use by Region, Low Economic Growth Case, 1990-2020 (Million Metric Tons)

\begin{tabular}{|c|c|c|c|c|c|c|c|c|c|}
\hline \multirow[b]{2}{*}{ Region/Country } & \multicolumn{3}{|c|}{ History } & \multicolumn{5}{|c|}{ Projections } & \multirow{2}{*}{$\begin{array}{c}\text { Average Annual } \\
\text { Percent Change, } \\
1995-2020 \\
\end{array}$} \\
\hline & 1990 & 1995 & 1996 & 2000 & 2005 & 2010 & 2015 & 2020 & \\
\hline \multicolumn{10}{|l|}{ Industrialized } \\
\hline North America & 516 & 536 & 562 & 609 & 737 & 772 & 788 & 791 & 1.6 \\
\hline United States $^{\mathrm{a}}$ & 481 & 498 & 524 & 563 & 689 & 723 & 738 & 741 & 1.6 \\
\hline Canada ................ & 31 & 32 & 32 & 40 & 42 & 42 & 42 & 42 & 1.0 \\
\hline Mexico $\ldots \ldots \ldots \ldots \ldots \ldots$ & 3 & 6 & 6 & 6 & 7 & 7 & 8 & 8 & 1.5 \\
\hline Western Europe $\ldots \ldots \ldots \ldots \ldots$ & 335 & 250 & 246 & 241 & 231 & 228 & 223 & 219 & -0.5 \\
\hline Industrialized Asia . . . . . . . . & 105 & 113 & 117 & 114 & 114 & 117 & 117 & 118 & 0.1 \\
\hline Japan $\ldots \ldots \ldots \ldots \ldots \ldots$ & 66 & 72 & 74 & 73 & 73 & 77 & 76 & 77 & 0.2 \\
\hline$\ldots \ldots \ldots \ldots$ & 39 & 41 & 43 & 41 & 41 & 40 & 41 & 41 & 0.0 \\
\hline Total Industrialized ........ & 956 & 900 & 925 & 964 & 1,082 & 1,117 & 1,127 & 1,127 & 0.9 \\
\hline \multicolumn{10}{|l|}{ EE/FSU } \\
\hline Former Soviet Union & 333 & 201 & 185 & 190 & 183 & 175 & 165 & 154 & -1.0 \\
\hline Eastern Europe .... & 189 & 148 & 142 & 140 & 136 & 124 & 113 & 102 & -1.5 \\
\hline Total EE/FSU $\ldots \ldots \ldots \ldots$ & 522 & 348 & 327 & 330 & 319 & 299 & 278 & 256 & -1.2 \\
\hline \multicolumn{10}{|l|}{ Developing Countries } \\
\hline Developing Asia .... . & 714 & 962 & 980 & 1,062 & 1,173 & 1,313 & 1,502 & 1,717 & 2.3 \\
\hline China ........... & 514 & 677 & 682 & 749 & 833 & 941 & 1,100 & 1,277 & 2.6 \\
\hline India $\ldots$. & 101 & 156 & 160 & 181 & 195 & 209 & 215 & 222 & 1.4 \\
\hline Other Asia & 99 & 129 & 137 & 133 & 145 & 164 & 187 & 218 & 2.1 \\
\hline Middle East & 4 & 5 & 5 & 6 & 7 & 7 & 8 & 8 & 1.6 \\
\hline Africa $\ldots \ldots \ldots \ldots \ldots \ldots \ldots$ & 74 & 82 & 84 & 78 & 77 & 80 & 81 & 83 & 0.0 \\
\hline Central and South America .... & 17 & 20 & 25 & 21 & 23 & 24 & 25 & 26 & 1.1 \\
\hline Brazil $\ldots \ldots \ldots \ldots \ldots \ldots$ & 9 & 12 & 17 & 12 & 13 & 13 & 14 & 15 & 0.8 \\
\hline Other Central/South America ... & 7 & 8 & 8 & 9 & 10 & 11 & 11 & 11 & 1.5 \\
\hline Total Developing ......... & 809 & 1,069 & 1,094 & 1,168 & 1,280 & 1,424 & 1,616 & 1,834 & 2.2 \\
\hline Total World & 2,287 & 2,317 & 2,345 & 2,462 & 2,682 & 2,840 & 3,021 & 3,217 & 1.3 \\
\hline
\end{tabular}

${ }^{a}$ Includes the 50 States and the District of Columbia. U.S. Territories are included in Australasia.

Notes: EE/FSU = Eastern Europe/Former Soviet Union.

Sources: History: Energy Information Administration (EIA), International Energy Annual 1996, DOE/EIA-0219(96) (Washington, DC, February 1998). Projections: EIA, Annual Energy Outlook 1998, DOE/EIA-0383(98) (Washington, DC, December 1997), Table A19; and World Energy Projection System (1998). 
Table A39. World Total Energy Consumption in Oil-Equivalent Units by Region, Low Economic Growth Case, 1990-2020 (Million Tons Oil Equivalent)

\begin{tabular}{|c|c|c|c|c|c|c|c|c|c|}
\hline \multirow[b]{2}{*}{ Region/Country } & \multicolumn{3}{|c|}{ History } & \multicolumn{5}{|c|}{ Projections } & \multirow{2}{*}{$\begin{array}{c}\text { Average Annual } \\
\text { Percent Change, } \\
\text { 1995-2020 }\end{array}$} \\
\hline & 1990 & 1995 & 1996 & 2000 & 2005 & 2010 & 2015 & 2020 & \\
\hline \multicolumn{10}{|l|}{ Industrialized } \\
\hline North America $\ldots \ldots \ldots \ldots \ldots$ & 2,513 & 2,723 & 2,828 & 2,980 & 3,114 & 3,257 & 3,310 & 3,345 & 0.8 \\
\hline United States $^{\mathrm{a}} \ldots \ldots \ldots \ldots$ & 2,115 & 2,278 & 2,369 & 2,493 & 2,585 & 2,693 & 2,714 & 2,715 & 0.7 \\
\hline Canada ..... & 274 & 307 & 317 & 326 & 342 & 359 & 374 & 390 & 1.0 \\
\hline Mexico . . . . . . . . & 124 & 138 & 142 & 161 & 188 & 206 & 222 & 240 & 2.2 \\
\hline Western Europe $\ldots \ldots \ldots \ldots \ldots$ & 1,561 & 1,632 & 1,681 & 1,703 & 1,773 & 1,837 & 1,898 & 1,960 & 0.7 \\
\hline Industrialized Asia $\ldots \ldots \ldots \ldots$ & 579 & 663 & 678 & 687 & 712 & 740 & 767 & 796 & 0.7 \\
\hline Japan $\ldots \ldots \ldots \ldots \ldots$ & 456 & 523 & 539 & 537 & 555 & 577 & 598 & 620 & 0.7 \\
\hline Australasia . & 123 & 140 & 139 & 150 & 157 & 163 & 170 & 176 & 0.9 \\
\hline Total Industrialized ........ & 4,654 & 5,018 & 5,187 & 5,370 & 5,599 & 5,834 & 5,975 & 6,102 & 0.8 \\
\hline \multicolumn{10}{|l|}{ EE/FSU } \\
\hline Former Soviet Union & 1,473 & 1,027 & 1,003 & 1,035 & 1,117 & 1,195 & 1,246 & 1,299 & 0.9 \\
\hline Eastern Europe .... & 382 & 312 & 316 & 332 & 355 & 377 & 398 & 421 & 1.2 \\
\hline Total EE/FSU $\ldots \ldots \ldots \ldots$ & 1,855 & 1,340 & 1,319 & 1,367 & 1,472 & 1,572 & 1,644 & 1,720 & 1.0 \\
\hline \multicolumn{10}{|l|}{ Developing Countries } \\
\hline Developing Asia $\ldots \ldots \ldots \ldots$. . . & 1,294 & 1,811 & 1,879 & 2,114 & 2,464 & 2,789 & 3,154 & 3,567 & 2.7 \\
\hline China...$\ldots \ldots \ldots$ & 680 & 917 & 935 & 1,063 & 1,230 & 1,395 & 1,598 & 1,830 & 2.8 \\
\hline India & 195 & 279 & 291 & 345 & 399 & 456 & 514 & 580 & 3.0 \\
\hline Other Asia & 420 & 614 & 653 & 706 & 835 & 938 & 1,042 & 1,157 & 2.6 \\
\hline Middle East $\ldots \ldots \ldots \ldots \ldots$ & 281 & 350 & 369 & 372 & 400 & 432 & 468 & 506 & 1.5 \\
\hline Africa $\ldots \ldots \ldots \ldots \ldots$ & 233 & 270 & 279 & 293 & 318 & 344 & 370 & 399 & 1.6 \\
\hline Central and South America .... & 346 & 423 & 446 & 478 & 552 & 621 & 696 & 780 & 2.5 \\
\hline Brazil $\ldots \ldots \ldots \ldots \ldots \ldots \ldots$ & 136 & 161 & 173 & 183 & 216 & 243 & 274 & 308 & 2.6 \\
\hline Other Central/South America ... & 210 & 262 & 274 & 295 & 336 & 378 & 422 & 472 & 2.4 \\
\hline Total Developing ......... & 2,154 & 2,854 & 2,972 & 3,257 & 3,734 & 4,185 & 4,687 & 5,251 & 2.5 \\
\hline Total World $\ldots \ldots \ldots \ldots \ldots \ldots$ & 8,663 & 9,212 & 9,478 & 9,994 & 10,805 & 11,591 & 12,307 & 13,073 & 1.4 \\
\hline
\end{tabular}

${ }^{a}$ Includes the 50 States and the District of Columbia. U.S. Territories are included in Australasia.

Notes: EE/FSU = Eastern Europe/Former Soviet Union.

Sources: History: Derived from Energy Information Administration (EIA), International Energy Annual 1996, DOE/EIA-0219(96) (Washington, DC, February 1998). Projections: EIA, Annual Energy Outlook 1998, DOE/EIA-0383(98) (Washington, DC, December 1997), Table A19; and World Energy Projection System (1998). 
Table A40. World Oil Production Capacity by Region and Country, Reference Case, 1990-2020 (Million Barrels per Day)

\begin{tabular}{|c|c|c|c|c|c|c|c|}
\hline \multirow[b]{2}{*}{ Region/Country } & \multicolumn{2}{|c|}{ History (Estimates) } & \multicolumn{5}{|c|}{ Projections } \\
\hline & 1990 & 1996 & 2000 & 2005 & 2010 & 2015 & 2020 \\
\hline \multicolumn{8}{|l|}{ OPEC } \\
\hline \multicolumn{8}{|l|}{ Persian Gulf } \\
\hline $\operatorname{Iran} \ldots \ldots$ & 3.2 & 3.9 & 4.0 & 4.3 & 4.5 & 5.7 & 6.8 \\
\hline Iraq $\ldots \ldots \ldots \ldots \ldots$ & 2.2 & 0.6 & 0.6 & 2.1 & 3.2 & 5.9 & 7.8 \\
\hline Kuwait ............... & 1.7 & 2.6 & 2.8 & 3.1 & 3.3 & 4.3 & 5.2 \\
\hline Qatar $\ldots \ldots \ldots \ldots \ldots$ & 0.5 & 0.6 & 0.5 & 0.6 & 0.6 & 0.6 & 0.7 \\
\hline Saudi Arabia $\ldots \ldots \ldots \ldots$ & 8.6 & 10.6 & 10.9 & 11.2 & 13.5 & 17.2 & 23.8 \\
\hline United Arab Emirates . . . . . . & 2.5 & 2.6 & 2.8 & 3.1 & 3.5 & 4.7 & 5.5 \\
\hline Total Persian Gulf . ..... & 18.7 & 20.9 & 21.6 & 24.4 & 28.6 & 38.4 & 49.8 \\
\hline \multicolumn{8}{|l|}{ Other OPEC } \\
\hline Algeria .... & 1.3 & 1.4 & 1.6 & 1.9 & 2.2 & 2.1 & 2.0 \\
\hline Indonesia $\ldots \ldots \ldots \ldots \ldots$ & 1.5 & 1.7 & 1.5 & 1.5 & 1.5 & 1.4 & 1.3 \\
\hline Libya $\ldots \ldots \ldots \ldots \ldots \ldots$ & 1.5 & 1.5 & 1.5 & 1.6 & 1.7 & 1.6 & 1.5 \\
\hline Nigeria $\ldots \ldots \ldots \ldots \ldots$ & 1.8 & 2.2 & 2.4 & 2.7 & 3.1 & 3.0 & 2.8 \\
\hline Venezuela...$\ldots \ldots \ldots$. & 2.4 & 3.2 & 3.7 & 4.2 & 5.2 & 5.7 & 5.9 \\
\hline Total Other OPEC $\ldots \ldots$ & 8.5 & 10.0 & 10.7 & 11.9 & 13.7 & 13.8 & 13.5 \\
\hline Total OPEC . . . . . . . . . . . & 27.2 & 30.9 & 32.3 & 36.3 & 42.3 & 52.2 & 63.3 \\
\hline \multicolumn{8}{|l|}{$\begin{array}{l}\text { Non-OPEC } \\
\text { Industrialized }\end{array}$} \\
\hline United States . . . . . . . . . & 9.7 & 9.4 & 9.1 & 9.0 & 8.9 & 8.7 & 8.5 \\
\hline Canada $\ldots \ldots \ldots \ldots \ldots$ & 2.0 & 2.5 & 2.8 & 3.2 & 3.3 & 3.3 & 3.4 \\
\hline Mexico ............. & 3.0 & 3.3 & 3.8 & 4.0 & 4.1 & 4.0 & 3.9 \\
\hline Australia $\ldots \ldots \ldots \ldots$ & 0.7 & 0.8 & 0.8 & 0.8 & 0.8 & 0.8 & 0.7 \\
\hline North Sea...$\ldots \ldots \ldots$ & 4.2 & 6.3 & 7.6 & 7.8 & 7.1 & 6.4 & 5.9 \\
\hline Other $\ldots \ldots \ldots \ldots \ldots \ldots$ & 0.5 & 0.7 & 0.6 & 0.6 & 0.6 & 0.5 & 0.5 \\
\hline Total Industrialized . . . . . & 20.1 & 23.0 & 24.7 & 25.4 & 24.8 & 23.7 & 22.9 \\
\hline \multicolumn{8}{|l|}{ Eurasia } \\
\hline China...$\ldots \ldots \ldots \ldots$ & 2.8 & 3.1 & 3.4 & 3.5 & 3.6 & 3.6 & 3.5 \\
\hline Former Soviet Union . . . . . & 11.4 & 7.1 & 7.5 & 9.5 & 12.1 & 12.6 & 13.2 \\
\hline Eastern Europe $\ldots \ldots \ldots$ & 0.3 & 0.3 & 0.3 & 0.4 & 0.4 & 0.4 & 0.4 \\
\hline Total Eurasia . . . . . . . . & 14.5 & 10.5 & 11.2 & 13.4 & 16.1 & 16.6 & 17.1 \\
\hline \multicolumn{8}{|l|}{ Other Non-OPEC } \\
\hline Central and South America . & 2.4 & 3.3 & 4.1 & 4.5 & 4.7 & 4.9 & 4.9 \\
\hline Middle East $\ldots \ldots \ldots \ldots$ & 1.4 & 2.0 & 2.0 & 2.3 & 2.2 & 2.1 & 1.9 \\
\hline Africa $\ldots \ldots \ldots \ldots \ldots$ & 2.2 & 2.6 & 2.8 & 3.5 & 4.0 & 4.6 & 5.3 \\
\hline Asia $\ldots \ldots \ldots \ldots \ldots$ & 1.7 & 2.1 & 2.4 & 2.9 & 3.2 & 3.3 & 3.3 \\
\hline Total Other Non-OPEC .. & 7.7 & 10.0 & 11.3 & 13.2 & 14.1 & 14.9 & 15.4 \\
\hline Total Non-OPEC .......... & 42.3 & 43.5 & 47.2 & 52.0 & 55.0 & 55.2 & 55.4 \\
\hline Total World & 69.5 & 74.4 & 79.5 & 88.3 & 97.3 & 107.4 & 118.7 \\
\hline
\end{tabular}

Note: OPEC = Organization of Petroleum Exporting Countries.

Sources: History: Energy Information Administration (EIA), Energy Markets and Contingency Information Division. Projections: EIA, Office of Integrated Analysis and Forecasting, World Energy Projection System and "DESTINY" International Energy Forecast Software (Dallas, TX: Petroconsultants, Fourth Quarter 1997). 
Table A41. World Oil Production Capacity by Region and Country, High Oil Price Case, 1990-2020 (Million Barrels per Day)

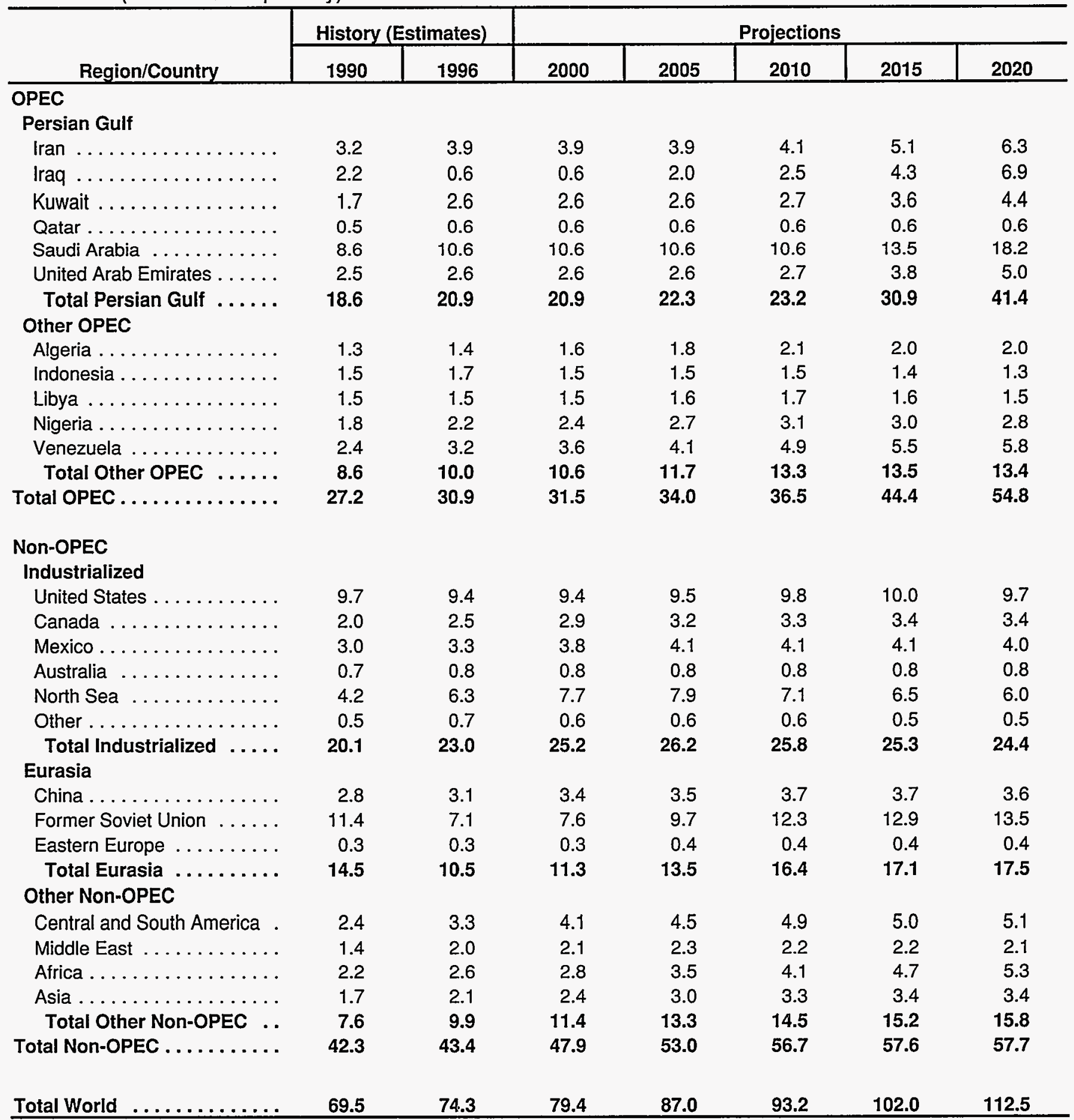

Note: OPEC $=$ Organization of Petroleum Exporting Countries.

Sources: History: Energy Information Administration (EIA), Energy Markets and Contingency Information Division. Projections: EIA, Office of Integrated Analysis and Forecasting, World Energy Projection System and "DESTINY" International Energy Forecast Software (Dallas, TX: Petroconsultants, Fourth Quarter 1997). 
Table A42. World Oil Production Capacity by Region and Country, Low Oil Price Case, 1990-2020 (Million Barrels per Day)

\begin{tabular}{|c|c|c|c|c|c|c|c|}
\hline \multirow[b]{2}{*}{ Region/Country } & \multicolumn{2}{|c|}{ History (Estimates) } & \multicolumn{5}{|c|}{ Projections } \\
\hline & 1990 & 1996 & 2000 & 2005 & 2010 & 2015 & 2020 \\
\hline \multicolumn{8}{|l|}{ OPEC } \\
\hline Iran ...... & 3.2 & 3.9 & 4.2 & 4.6 & 5.2 & 6.0 & 7.0 \\
\hline Iraq $\ldots \ldots \ldots \ldots \ldots$ & 2.2 & 0.6 & 0.6 & 2.5 & 4.2 & 6.5 & 8.1 \\
\hline Kuwait .............. & 1.7 & 2.6 & 3.0 & 3.3 & 3.7 & 4.8 & 5.5 \\
\hline Qatar ................ & 0.5 & 0.6 & 0.6 & 0.6 & 0.7 & 0.7 & 0.7 \\
\hline Saudi Arabia . .......... & 8.6 & 10.6 & 11.8 & 14.1 & 17.2 & 24.1 & 33.7 \\
\hline United Arab Emirates . . . . . . & 2.5 & 2.6 & 3.0 & 3.4 & 4.2 & 5.1 & 6.0 \\
\hline Total Persian Gulf . . . . . . & 18.7 & 20.9 & 23.2 & 28.5 & 35.2 & 47.2 & 61.0 \\
\hline \multicolumn{8}{|l|}{ Other OPEC } \\
\hline Algeria ............... & 1.3 & 1.4 & 1.8 & 2.0 & 2.3 & 2.2 & 2.1 \\
\hline Indonesia ............ & 1.5 & 1.7 & 1.6 & 1.6 & 1.6 & 1.5 & 1.5 \\
\hline Libya ................ & 1.5 & 1.5 & 1.6 & 1.7 & 1.7 & 1.7 & 1.6 \\
\hline Nigeria $\ldots \ldots \ldots \ldots \ldots$ & 1.8 & 2.2 & 2.6 & 2.9 & 3.3 & 3.2 & 3.1 \\
\hline Venezuela ............ & 2.4 & 3.2 & 3.9 & 5.6 & 6.8 & 7.1 & 7.0 \\
\hline Total Other OPEC $\ldots . .$. & 8.5 & 10.0 & 11.5 & 13.8 & 15.7 & 15.7 & 15.3 \\
\hline Total OPEC .............. & 27.2 & 30.9 & 34.7 & 42.3 & 50.9 & 62.9 & 76.3 \\
\hline \multicolumn{8}{|l|}{$\begin{array}{l}\text { Non-OPEC } \\
\text { Industrialized }\end{array}$} \\
\hline United States . . . . . . . . . & 9.7 & 9.4 & 8.7 & 8.1 & 7.8 & 7.5 & 7.3 \\
\hline Canada .............. & 2.0 & 2.5 & 2.8 & 3.1 & 3.2 & 3.3 & 3.3 \\
\hline Mexico ............. & 3.0 & 3.3 & 3.7 & 3.9 & 3.9 & 3.9 & 3.8 \\
\hline Australia $\ldots \ldots \ldots \ldots$ & 0.7 & 0.8 & 0.8 & 0.8 & 0.7 & 0.7 & 0.7 \\
\hline North Sea ............ & 4.2 & 6.3 & 7.6 & 7.8 & 7.0 & 6.3 & 5.8 \\
\hline Other...$\ldots \ldots \ldots \ldots$ & 0.5 & 0.7 & 0.6 & 0.5 & 0.5 & 0.5 & 0.4 \\
\hline Total Industrialized $\ldots \ldots$ & 20.1 & 23.0 & 24.2 & 24.2 & 23.1 & 22.2 & 21.3 \\
\hline \multicolumn{8}{|l|}{ Eurasia } \\
\hline China...$\ldots \ldots \ldots \ldots$ & 2.8 & 3.1 & 3.3 & 3.4 & 3.5 & 3.5 & 3.3 \\
\hline Former Soviet Union . ..... & 11.4 & 7.1 & 7.4 & 9.3 & 11.7 & 12.2 & 12.6 \\
\hline Eastern Europe ......... & 0.3 & 0.3 & 0.3 & 0.3 & 0.4 & 0.4 & 0.4 \\
\hline $\begin{array}{l}\text { Total Eurasia } \ldots \ldots \ldots \ldots \\
\text { Other Non-OPEC }\end{array}$ & 14.5 & 10.5 & 11.0 & 13.0 & 15.6 & 16.1 & 16.3 \\
\hline Central and South America . & 2.4 & 3.3 & 4.0 & 4.4 & $4: 6$ & 4.7 & 4.7 \\
\hline Middle East $\ldots \ldots \ldots \ldots$ & 1.4 & 2.0 & 2.0 & 2.2 & 2.2 & 2.0 & 1.9 \\
\hline Africa $\ldots \ldots \ldots \ldots \ldots$ & 2.2 & 2.6 & 2.8 & 3.4 & 3.9 & 4.5 & 5.0 \\
\hline Asia $\ldots \ldots \ldots \ldots \ldots \ldots$ & 1.7 & 2.1 & 2.4 & 2.9 & 3.1 & 3.1 & 3.2 \\
\hline Total Other Non-OPEC ... & 7.7 & 10.0 & 11.2 & 12.9 & 13.8 & 14.3 & 14.8 \\
\hline Total Non-OPEC . . . . . . . . . & 42.3 & 43.5 & 46.4 & 50.1 & 52.5 & 52.6 & 52.4 \\
\hline Total World & 69.5 & 74.4 & 81.1 & 92.4 & 103.4 & 115.5 & 128.7 \\
\hline
\end{tabular}

Note: OPEC = Organization of Petroleum Exporting Countries.

Sources: History: Energy Information Administration (EIA), Energy Markets and Contingency Information Division. Projections: EIA, Office of Integrated Analysis and Forecasting, World Energy Projection System and "DESTINY" International Energy Forecast Software (Dallas, TX: Petroconsultants, Fourth Quarter 1997). 
Table A43. World Oil Production Capacity by Region and Country, High Non-OPEC Supply Case, 1990-2020 (Million Barrels per Day)

\begin{tabular}{|c|c|c|c|c|c|c|c|}
\hline \multirow[b]{2}{*}{ Region/Country } & \multicolumn{2}{|c|}{ History (Estimates) } & \multicolumn{5}{|c|}{ Projections } \\
\hline & 1990 & 1996 & 2000 & 2005 & 2010 & 2015 & 2020 \\
\hline \multicolumn{8}{|l|}{$\begin{array}{l}\text { OPEC } \\
\text { Persian Gulf }\end{array}$} \\
\hline Iran $\ldots . .$. & 3.2 & 3.9 & 3.9 & 3.9 & 4.3 & 5.2 & 6.3 \\
\hline Iraq $\ldots \ldots \ldots \ldots \ldots \ldots$ & 2.2 & 0.6 & 0.6 & 1.9 & 2.5 & 4.9 & 6.8 \\
\hline Kuwait $\ldots \ldots \ldots \ldots \ldots$ & 1.7 & 2.6 & 2.6 & 2.6 & 2.7 & 3.5 & 4.4 \\
\hline Qatar ...... & 0.5 & 0.6 & 0.6 & 0.6 & 0.6 & 0.6 & 0.6 \\
\hline Saudi Arabia ......... & 8.6 & 10.6 & 10.6 & 10.6 & 12.0 & 15.7 & 21.6 \\
\hline United Arab Emirates . . . . . . & 2.5 & 2.6 & 2.6 & 2.6 & 3.1 & 3.7 & 4.9 \\
\hline $\begin{array}{l}\text { Total Persian Gulf } \ldots \ldots \\
\text { Other OPEC }\end{array}$ & 18.7 & 20.9 & 20.9 & 22.2 & 25.2 & 33.6 & 44.6 \\
\hline Algeria......$\ldots \ldots$ & 1.3 & 1.4 & 1.6 & 1.8 & 2.0 & 2.0 & 2.0 \\
\hline Indonesia.. & 1.5 & 1.7 & 1.5 & 1.5 & 1.5 & 1.4 & 1.3 \\
\hline Libya .... & 1.5 & 1.5 & 1.5 & 1.5 & 1.6 & 1.6 & 1.5 \\
\hline Nigeria ... & 1.8 & 2.2 & 2.4 & 2.6 & 3.0 & 2.9 & 2.8 \\
\hline Venezuela ........... & 2.4 & 3.2 & 3.6 & 3.9 & 4.9 & 5.4 & 5.7 \\
\hline Total Other OPEC $\ldots \ldots$ & 8.5 & 10.0 & 10.6 & 11.3 & 13.0 & 13.3 & 13.3 \\
\hline Total OPEC .............. & 27.2 & 30.9 & 31.5 & 33.5 & 38.2 & 46.9 & 57.9 \\
\hline \multicolumn{8}{|l|}{$\begin{array}{l}\text { Non-OPEC } \\
\text { Industrialized }\end{array}$} \\
\hline United States & 9.7 & 9.4 & 9.1 & 9.0 & 8.9 & 8.7 & 8.5 \\
\hline Canada ........ & 2.0 & 2.5 & 2.9 & 3.3 & 3.5 & 3.6 & 3.7 \\
\hline Mexico ............. & 3.0 & 3.3 & 3.9 & 4.3 & 4.4 & 4.5 & 4.5 \\
\hline Australia $\ldots \ldots \ldots$ & 0.7 & 0.8 & 0.8 & 0.8 & 0.8 & 0.8 & 0.8 \\
\hline North Sea $\ldots \ldots \ldots \ldots$ & 4.2 & 6.3 & 7.9 & 8.3 & 7.5 & 7.0 & 6.5 \\
\hline Other $\ldots \ldots \ldots \ldots \ldots$ & 0.5 & 0.7 & 0.6 & 0.6 & 0.6 & 0.6 & 0.5 \\
\hline $\begin{array}{l}\text { Total Industrialized } \ldots . . \\
\text { Eurasia }\end{array}$ & 20.1 & 23.0 & 25.2 & 26.3 & 25.7 & 25.2 & 24.5 \\
\hline China...$\ldots \ldots \ldots \ldots$ & 2.8 & 3.1 & 3.4 & 3.6 & 3.8 & 3.9 & 3.8 \\
\hline Former Soviet Union . . . . . & 11.4 & 7.1 & 7.7 & 10.0 & 13.0 & 13.9 & 14.5 \\
\hline Eastern Europe $\ldots \ldots \ldots$. & 0.3 & 0.3 & 0.3 & 0.4 & 0.5 & 0.5 & 0.5 \\
\hline Total Eurasia . . . . . . . . & 14.5 & 10.5 & 11.4 & 14.0 & 17.3 & 18.3 & 18.8 \\
\hline Other Non-OPEC & & & & & & & \\
\hline Central and South America & 2.4 & 3.3 & 4.3 & 4.8 & 5.2 & 5.4 & 5.6 \\
\hline Middle East $\ldots \ldots \ldots \ldots$ & 1.4 & 2.0 & 2.2 & 2.4 & 2.3 & 2.2 & 2.1 \\
\hline Africa $\ldots \ldots \ldots \ldots \ldots$ & 2.2 & 2.6 & 2.9 & 3.9 & 4.9 & 5.5 & 5.8 \\
\hline Asia . . . . . . . . . . & 1.7 & 2.1 & 2.6 & 3.1 & 3.5 & 3.6 & 3.7 \\
\hline Total Other Non-OPEC & 7.7 & 10.0 & 12.0 & 14.2 & 15.9 & 16.7 & 17.2 \\
\hline Total Non-OPEC . ......... & 42.3 & 43.5 & 48.6 & 54.5 & 58.9 & 60.2 & 60.5 \\
\hline Total World & 69.5 & 74.4 & 80.1 & 88.0 & 97.1 & 107.1 & 118.4 \\
\hline
\end{tabular}

Note: $\mathrm{OPEC}=$ Organization of Petroleum Exporting Countries.

Sources: History: Energy Information Administration (EIA), Energy Markets and Contingency Information Division. Projections: EIA, Office of Integrated Analysis and Forecasting, World Energy Projection System and "DESTINY" International Energy Forecast Software (Dallas, TX: Petroconsultants, Fourth Quarter 1997). 
Table A44. World Oil Production by Region and Country, Reference Case, 1990-2020 (Million Barrels per Day)

\begin{tabular}{|c|c|c|c|c|c|c|c|}
\hline \multirow[b]{2}{*}{ Region/Country } & \multicolumn{2}{|c|}{ History (Estimates) } & \multicolumn{5}{|c|}{ Projections } \\
\hline & 1990 & 1996 & 2000 & 2005 & 2010 & 2015 & 2020 \\
\hline \multicolumn{8}{|l|}{ OPEC } \\
\hline Persian Gulf . . . . . . . . . . & 16.2 & 18.5 & 19.4 & 22.6 & 27.2 & 36.4 & 47.3 \\
\hline Other OPEC $\ldots \ldots \ldots \ldots$ & 8.3 & 9.8 & 10.5 & 11.6 & 13.4 & 13.5 & 13.2 \\
\hline Total OPEC . ........... & 24.5 & 28.3 & 29.9 & 34.2 & 40.6 & 49.9 & 60.5 \\
\hline \multicolumn{8}{|l|}{$\begin{array}{l}\text { Non-OPEC } \\
\text { Industrialized }\end{array}$} \\
\hline United States . . . . . . . . . & 9.7 & 9.4 & 9.1 & 9.0 & 8.9 & 8.7 & 8.5 \\
\hline Canada .............. & 2.0 & 2.5 & 2.8 & 3.2 & 3.3 & 3.3 & 3.4 \\
\hline Mexico ............... & 3.0 & 3.3 & 3.8 & 4.0 & 4.1 & 4.0 & 3.9 \\
\hline Western Europe . . . . . . . . & 4.6 & 7.0 & 8.2 & 8.3 & 7.5 & 6.8 & 6.3 \\
\hline Other $\ldots \ldots \ldots \ldots \ldots \ldots$ & 0.8 & 0.8 & 0.9 & 1.0 & 0.9 & 0.9 & 0.8 \\
\hline Total Industrialized ..... & 20.1 & 23.0 & 24.8 & 25.5 & 24.7 & 23.7 & 22.9 \\
\hline \multicolumn{8}{|l|}{ Eurasia } \\
\hline China...$\ldots \ldots \ldots \ldots$ & 2.8 & 3.1 & 3.4 & 3.5 & 3.6 & 3.6 & 3.5 \\
\hline Former Soviet Union . ..... & 11.4 & 7.1 & 7.5 & 9.5 & 12.1 & 12.6 & 13.2 \\
\hline Eastern Europe ......... & 0.3 & 0.3 & 0.3 & 0.4 & 0.4 & 0.4 & 0.4 \\
\hline Total Eurasia . . . . . . . . & 14.5 & 10.5 & 11.2 & 13.4 & 16.1 & 16.6 & 17.1 \\
\hline \multicolumn{8}{|l|}{ Other Non-OPEC } \\
\hline Central and South America . & 2.4 & 3.3 & 4.1 & 4.5 & 4.7 & 4.9 & 4.9 \\
\hline Pacific $\operatorname{Rim} \ldots \ldots \ldots$ & 1.7 & 2.1 & 2.4 & 2.9 & 3.2 & 3.3 & 3.3 \\
\hline Other $\ldots \ldots \ldots \ldots \ldots \ldots$ & 3.5 & 4.6 & 4.8 & 5.7 & 6.2 & 6.7 & 7.2 \\
\hline Total Other Non-OPEC . . & 7.6 & 10.0 & 11.3 & 13.1 & 14.1 & 14.9 & 15.4 \\
\hline Total World...$\ldots \ldots \ldots$ & 66.7 & 71.8 & 77.2 & 86.2 & 95.5 & 105.1 & 115.9 \\
\hline \multicolumn{8}{|l|}{$\begin{array}{l}\text { Persian Gulf Production } \\
\text { as a Percentage of }\end{array}$} \\
\hline
\end{tabular}

Notes: OPEC = Organization of Petroleum Exporting Countries. Production includes crude oil (including lease condensates), natural gas liquids, other hydrogen and hydrocarbons for refinery feedstocks, refinery gains, alcohol, and liquids produced from coal and other sources. Totals may not equal sum of components due to independent rounding.

Sources: History: Energy Information Administration (EIA), Energy Markets and Contingency Information Division. Projections: EIA, Office of Integrated Analysis and Forecasting, World Energy Projection System and "DESTINY" International Energy Forecast Software (Dallas, TX: Petroconsultants, Fourth Quarter 1997). 
Table A45. World Oil Production by Region and Country, High Oil Price Case, 1990-2020 (Million Barrels per Day)

\begin{tabular}{|c|c|c|c|c|c|c|c|}
\hline \multirow[b]{2}{*}{ Region/Country } & \multicolumn{2}{|c|}{ History (Estimates) } & \multicolumn{5}{|c|}{ Projections } \\
\hline & 1990 & 1996 & 2000 & 2005 & 2010 & 2015 & 2020 \\
\hline \multicolumn{8}{|l|}{ OPEC } \\
\hline Persian Gulf . . . . . . . . . . . & 16.2 & 18.5 & 17.8 & 19.5 & 22.2 & 29.4 & 39.4 \\
\hline Other OPEC $\ldots \ldots \ldots \ldots$ & 8.3 & 9.8 & 10.4 & 11.4 & 13.1 & 13.2 & 13.1 \\
\hline Total OPEC . . . . . . . . & 24.5 & 28.3 & 28.2 & 30.9 & 35.3 & 42.6 & 52.5 \\
\hline \multicolumn{8}{|l|}{$\begin{array}{l}\text { Non-OPEC } \\
\text { Industrialized }\end{array}$} \\
\hline United States . . . . . . . . . & 9.7 & 9.4 & 9.4 & 9.5 & 9.8 & 10.0 & 9.7 \\
\hline Canada .............. & 2.0 & 2.5 & 2.9 & 3.2 & 3.3 & 3.4 & 3.4 \\
\hline Mexico ............. & 3.0 & 3.3 & 3.8 & 4.1 & 4.1 & 4.1 & 4.0 \\
\hline Western Europe . . . . . . . . & 4.6 & 7.0 & 8.2 & 8.4 & 7.6 & 6.9 & 6.4 \\
\hline Other $\ldots \ldots \ldots \ldots \ldots \ldots$ & 0.8 & 0.8 & 0.9 & 1.0 & 1.0 & 0.9 & 0.9 \\
\hline Total Industrialized . . . . & 20.1 & 23.0 & 25.2 & 26.2 & 25.8 & 25.3 & 24.4 \\
\hline \multicolumn{8}{|l|}{ Eurasia } \\
\hline China $\ldots \ldots \ldots \ldots \ldots$ & 2.8 & 3.1 & 3.4 & 3.5 & 3.7 & 3.7 & 3.6 \\
\hline Former Soviet Union . . . . . & 11.4 & 7.1 & 7.6 & 9.7 & 12.3 & 12.9 & 13.5 \\
\hline Eastern Europe . . . . . . . . & 0.3 & 0.3 & 0.3 & 0.4 & 0.4 & 0.4 & 0.4 \\
\hline Total Eurasia . . . . . . . . & 14.5 & 10.5 & 11.3 & 13.6 & 16.4 & 17.0 & 17.5 \\
\hline \multicolumn{8}{|l|}{ Other Non-OPEC } \\
\hline Central and South America & 2.4 & 3.3 & 4.1 & 4.5 & 4.9 & 5.0 & 5.1 \\
\hline Pacific $\operatorname{Rim} \quad \ldots \ldots \ldots \ldots$ & 1.7 & 2.1 & 2.4 & 3.0 & 3.3 & 3.4 & 3.4 \\
\hline Other $\ldots \ldots \ldots \ldots \ldots \ldots$ & 3.5 & 4.6 & 4.9 & 5.8 & 6.3 & 6.9 & 7.4 \\
\hline Total Other Non-OPEC ... & 7.6 & 10.0 & 11.4 & 13.3 & 14.5 & 15.3 & 15.9 \\
\hline Total World . . . . . . . . . & 66.7 & 71.8 & 76.1 & 84.0 & 92.0 & 100.2 & 110.3 \\
\hline $\begin{array}{l}\text { Persian Gulf Production } \\
\text { as a Percentage of } \\
\text { World Consumption . . . . . . . . }\end{array}$ & $24.6 \%$ & $25.7 \%$ & $23.2 \%$ & $23.1 \%$ & $24.1 \%$ & $29.2 \%$ & $35.6 \%$ \\
\hline
\end{tabular}

Notes: OPEC = Organization of Petroleum Exporting Countries. Production includes crude oil (including lease condensates), natural gas liquids, other hydrogen and hydrocarbons for refinery feedstocks, refinery gains, alcohol, and liquids produced from coal and other sources. Totals may not equal sum of components due to independent rounding.

Sources: History: Energy Information Administration (EIA), Energy Markets and Contingency Information Division. Projections: EIA, Office of Integrated Analysis and Forecasting, World Energy Projection System and "DESTINY" International Energy Forecast Software (Dallas, TX: Petroconsultants, Fourth Quarter 1997). 
Table A46. World Oil Production by Region and Country, Low Oil Price Case, 1990-2020 (Million Barrels per Day)

\begin{tabular}{|c|c|c|c|c|c|c|c|}
\hline \multirow[b]{2}{*}{ Region/Country } & \multicolumn{2}{|c|}{ History (Estimates) } & \multicolumn{5}{|c|}{ Projections } \\
\hline & 1990 & 1996 & 2000 & 2005 & 2010 & 2015 & 2020 \\
\hline \multicolumn{8}{|l|}{ OPEC } \\
\hline Persian Gulf . . . . . . . . . . . & 16.2 & 18.5 & 20.9 & 26.3 & 33.4 & 44.9 & 58.0 \\
\hline Other OPEC $\ldots \ldots \ldots \ldots$ & 8.3 & 9.8 & 11.2 & 13.6 & 15.4 & 15.4 & 15.0 \\
\hline Total OPEC . . . . . . . . . . & 24.5 & 28.3 & 32.1 & 39.9 & 48.8 & 60.3 & 73.0 \\
\hline \multicolumn{8}{|l|}{$\begin{array}{l}\text { Non-OPEC } \\
\text { Industrialized }\end{array}$} \\
\hline United States . . . . . . . . . & 9.7 & 9.4 & 8.7 & 8.1 & 7.8 & 7.5 & 7.3 \\
\hline Canada $\ldots \ldots \ldots \ldots \ldots$ & 2.0 & 2.5 & 2.8 & 3.1 & 3.2 & 3.3 & 3.3 \\
\hline Mexico ............... & 3.0 & 3.3 & 3.7 & 3.9 & 3.9 & 3.9 & 3.8 \\
\hline Western Europe ......... & 4.6 & 7.0 & 8.1 & 8.2 & 7.4 & 6.7 & 6.2 \\
\hline Other $\ldots \ldots \ldots \ldots \ldots$ & 0.8 & 0.8 & 0.9 & 0.9 & 0.9 & 0.8 & 0.8 \\
\hline Total Industrialized ..... & 20.1 & 23.0 & 24.2 & 24.2 & 23.2 & 22.2 & 21.4 \\
\hline \multicolumn{8}{|l|}{ Eurasia } \\
\hline China...$\ldots \ldots \ldots \ldots$ & 2.8 & 3.1 & 3.3 & 3.4 & 3.5 & 3.5 & 3.3 \\
\hline Former Soviet Union ...... & 11.4 & 7.1 & 7.4 & 9.3 & 11.7 & 12.2 & 12.6 \\
\hline Eastern Europe ........ & 0.3 & 0.3 & 0.3 & 0.3 & 0.4 & 0.4 & 0.4 \\
\hline Total Eurasia . . . . . . . . & 14.5 & 10.5 & 11.0 & 13.0 & 15.6 & 16.1 & 16.3 \\
\hline \multicolumn{8}{|l|}{ Other Non-OPEC } \\
\hline Central and South America & 2.4 & 3.3 & 4.0 & 4.4 & 4.6 & 4.7 & 4.7 \\
\hline Pacific Rim $\ldots . \ldots \ldots \ldots$ & 1.7 & 2.1 & 2.4 & 2.9 & 3.1 & 3.1 & 3.2 \\
\hline Other $\ldots \ldots \ldots \ldots \ldots \ldots$ & 3.5 & 4.6 & 4.8 & 5.6 & 6.0 & 6.4 & 6.9 \\
\hline Total Other Non-OPEC .. & 7.6 & 10.0 & 11.2 & 12.9 & 13.7 & 14.2 & 14.8 \\
\hline Total World.......$\ldots$ & 66.7 & 71.8 & 78.5 & 90.0 & 101.3 & 112.8 & 125.5 \\
\hline $\begin{array}{l}\text { Persian Gulf Production } \\
\text { as a Percentage of } \\
\text { World Consumption .... }\end{array}$ & $24.6 \%$ & $25.7 \%$ & $26.4 \%$ & $29.1 \%$ & $32.9 \%$ & $39.7 \%$ & $46.1 \%$ \\
\hline
\end{tabular}

Notes: OPEC = Organization of Petroleum Exporting Countries. Production includes crude oil (including lease condensates), natural gas liquids, other hydrogen and hydrocarbons for refinery feedstocks, refinery gains, alcohol, and liquids produced from coal and other sources. Totals may not equal sum of components due to independent rounding.

Sources: History: Energy Information Administration (EIA), Energy Markets and Contingency Information Division. Projections: EIA, Office of Integrated Analysis and Forecasting, World Energy Projection System and "DESTINY" International Energy Forecast Software (Dallas, TX: Petroconsultants, Fourth Quarter 1997). 
Table A47. World Oil Production by Region and Country, High Non-OPEC Supply Case, 1990-2020 (Million Barrels per Day)

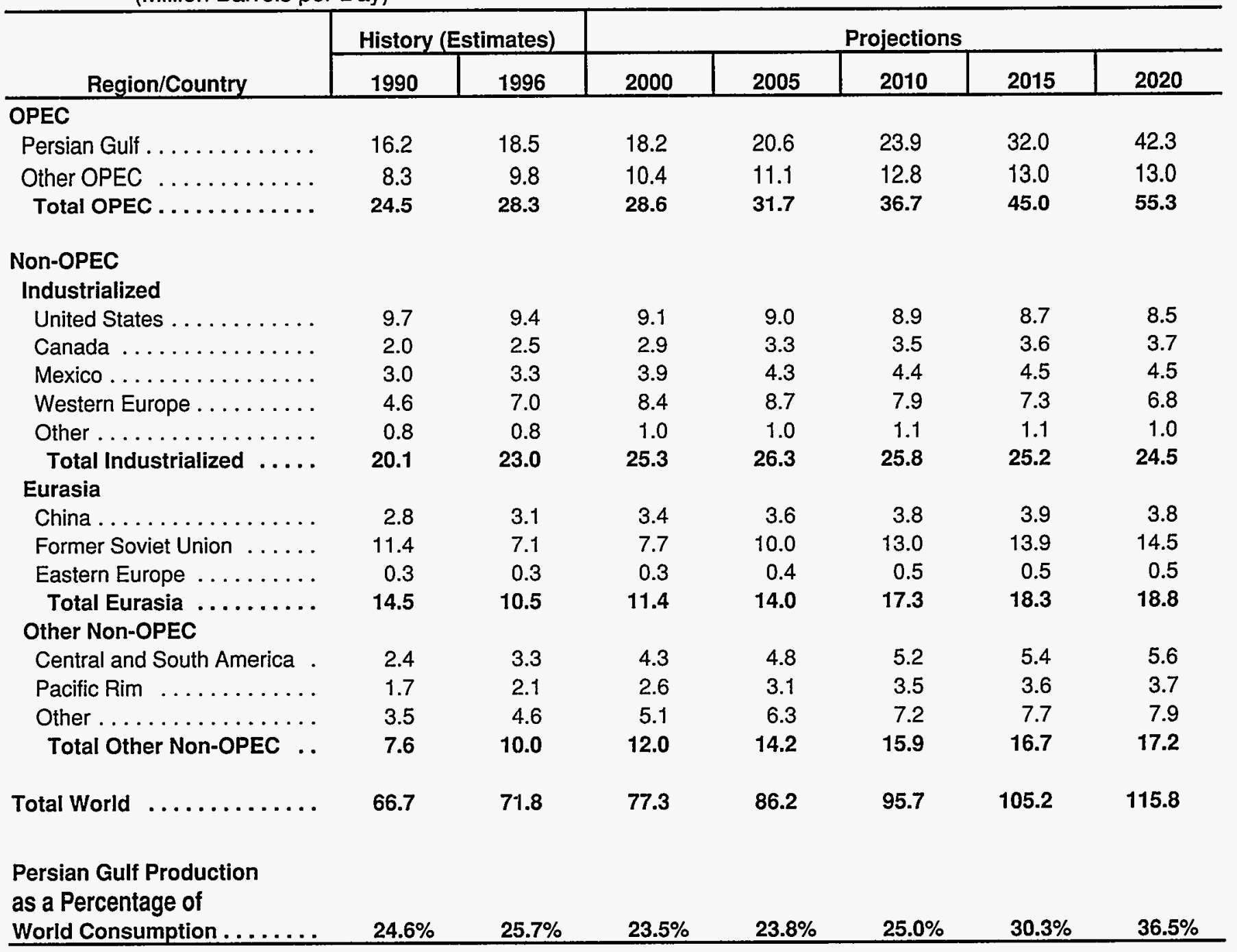

Notes: OPEC = Organization of Petroleum Exporting Countries. Production includes crude oil (including lease condensates), natural gas liquids, other hydrogen and hydrocarbons for refinery feedstocks, refinery gains, alcohol, and liquids produced from coal and other sources. Totals may not equal sum of components due to independent rounding.

Sources: History: Energy Information Administration (EIA), Energy Markets and Contingency Information Division. Projections: EIA, Office of Integrated Analysis and Forecasting, World Energy Projection System and "DESTINY" International Energy Forecast Software (Dallas, TX: Petroconsultants, Fourth Quarter 1997). 
Table A48. World Nuclear Generating Capacity by Region and Country, Reference Case, 1995-2020 (Megawatts)

\begin{tabular}{|c|c|c|c|c|c|c|c|}
\hline \multirow[b]{2}{*}{ Region/Country } & \multicolumn{2}{|c|}{ History } & \multicolumn{5}{|c|}{ Projections } \\
\hline & 1995 & 1996 & 2000 & 2005 & 2010 & 2015 & 2020 \\
\hline \multicolumn{8}{|l|}{$\begin{array}{l}\text { Industrialized } \\
\text { North America }\end{array}$} \\
\hline United States . & 99,148 & 100,817 & 95,605 & 86,800 & 80,357 & 63,881 & 49,217 \\
\hline Canada ............. & 14,907 & 14,902 & 11,146 & 11,994 & 11,994 & 10,298 & 8,631 \\
\hline Mexico .............. & 1,308 & 1,308 & 1,308 & 1,308 & 1,308 & 1,308 & 1,308 \\
\hline \multicolumn{8}{|l|}{ Industrialized Asia } \\
\hline \multicolumn{7}{|l|}{ Western Europe } & 54,107 \\
\hline Belgium $\ldots \ldots \ldots \ldots \ldots$ & 5,631 & 5,712 & 5,712 & 5,712 & 3,966 & 3,966 & 1,015 \\
\hline Finland $\ldots \ldots \ldots \ldots \ldots$ & 2,310 & 2,355 & 2,610 & 2,610 & 2,610 & 0 & 0 \\
\hline France $\ldots \ldots \ldots \ldots \ldots$ & 58,493 & 59,948 & 64,303 & 62,870 & 62,870 & 62,870 & 62,950 \\
\hline Germany ............. & 22,017 & 22,282 & 21,063 & 20,083 & 16,120 & 11,800 & 5,250 \\
\hline Netherlands . . . . . . . . & 504 & 504 & 449 & 449 & 0 & 0 & 0 \\
\hline Spain $\ldots \ldots \ldots \ldots \ldots$ & 7,124 & 7,207 & 7,207 & 7,054 & 6,614 & 6,614 & 3,842 \\
\hline Sweden...$\ldots \ldots \ldots$ & 10,002 & 10,040 & 10,040 & 9,440 & 8,840 & 6,085 & 4,148 \\
\hline Switzerland .......... & 3,050 & 3,077 & 3,077 & 2,712 & 2,000 & 1,030 & 1,030 \\
\hline Turkey ............... & 0 & 0 & 0 & 0 & 0 & 1,300 & 1,300 \\
\hline United Kingdom . . . . . . . . & 12,908 & 12,928 & 11,772 & 10,518 & 9,568 & 7,158 & 7,158 \\
\hline Total Industrialized . . . . & 277,295 & 283,449 & 277,817 & 265,871 & 253,773 & 229,933 & 199,956 \\
\hline \multirow{2}{*}{\multicolumn{8}{|c|}{$\begin{array}{l}\text { EE/FSU } \\
\text { Eastern Europe }\end{array}$}} \\
\hline & & & & & & & \\
\hline Bulgaria ...... & 3,538 & 3,538 & 3,538 & 2,722 & 2,722 & 1,906 & 1,906 \\
\hline Czech Republic . . . . . . . & 1,648 & 1,648 & 2,560 & 3,472 & 3,472 & 3,472 & 3,472 \\
\hline Hungary .............. & 1,729 & 1,729 & 1,729 & 1,729 & 1,729 & 1,729 & 866 \\
\hline Romania ............ & 0 & 650 & 650 & 1,300 & 1,300 & 1,300 & 1,300 \\
\hline Slovakia .. & 1,632 & 1,632 & 2,020 & 1,592 & 1,592 & 1,592 & 1,592 \\
\hline Slovenia $\ldots \ldots \ldots \ldots$ & 632 & 632 & 632 & 632 & 632 & 632 & 0 \\
\hline \multicolumn{8}{|l|}{ Former Soviet Union } \\
\hline Armenia $\ldots \ldots \ldots \ldots$ & 376 & 376 & 376 & 752 & 752 & 752 & 752 \\
\hline Kazakhstan ........... & 70 & 70 & 70 & 570 & 500 & 500 & 500 \\
\hline Lithuania . . . . . . . . . & 2,370 & 2,370 & 2,370 & 2,370 & 2,370 & 2,370 & 1,185 \\
\hline$\ldots \ldots \ldots \ldots \ldots$ & 19,843 & 19,843 & 19,843 & 20,785 & 19,832 & 18,350 & 21,980 \\
\hline Ukraine $\ldots \ldots \ldots \ldots \ldots$ & 13,629 & 13,765 & 13,065 & 13,090 & 14,990 & 15,577 & 11,400 \\
\hline Total EE/FSU $\ldots \ldots \ldots \ldots$ & 45,467 & 46,253 & 46,853 & 49,014 & 49,891 & 48,180 & 44,953 \\
\hline
\end{tabular}

See notes at end of table. 
Table A48. World Nuclear Generating Capacity by Region and Country, Reference Case, 1995-2020 (Continued)

(Megawatts)

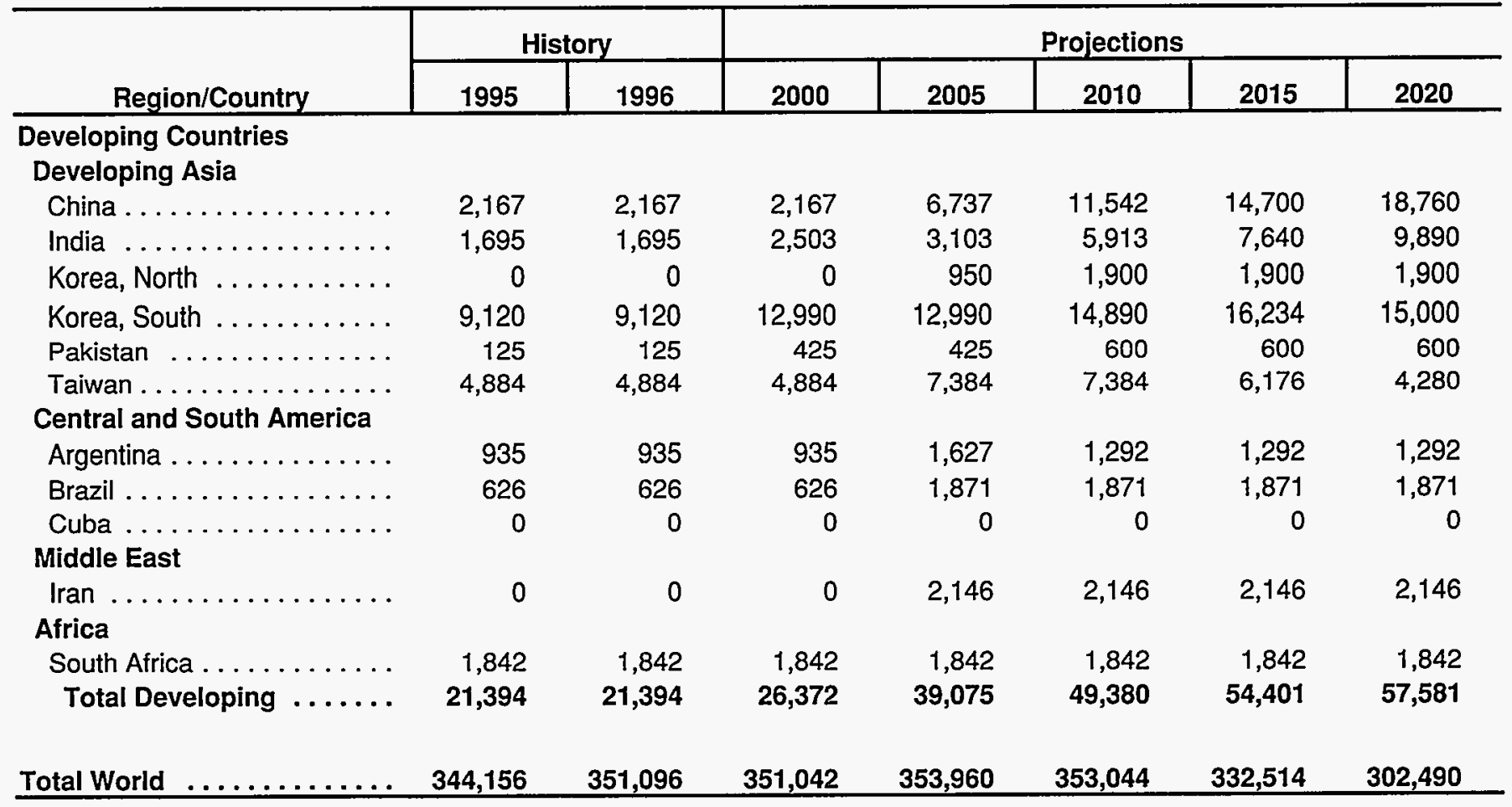

Note: EE/FSU = Eastern Europe/Former Soviet Union.

Sources: History: International Atomic Energy Agency, Nuclear Power Reactors in the World (Vienna, Austria, April 1997). Projections: Energy Information Administration, Office of Coal, Nuclear, Electric and Alternate Fuels, based on detailed assessments of country-specific nuclear power plants. For some countries, the World Integrated Nuclear Evaluation System (WINES) model (December 1997 run) was used to supplement the 2020 capacity projection. 
Table A49. World Nuclear Generating Capacity by Region and Country, Low Nuclear Case, 1995-2020 (Megawatts)

\begin{tabular}{|c|c|c|c|c|c|c|c|}
\hline \multirow[b]{2}{*}{ Region/Country } & \multicolumn{2}{|c|}{ History } & \multicolumn{5}{|c|}{ Projections } \\
\hline & 1995 & 1996 & 2000 & 2005 & 2010 & 2015 & 2020 \\
\hline \multicolumn{6}{|l|}{ Industrialized } & \multicolumn{2}{|c|}{ North America } \\
\hline United States & 99,148 & 100,817 & 92,653 & 63,881 & 49,217 & 22,154 & 2,320 \\
\hline Canada .............. & 14,907 & 14,902 & 10,298 & 10,298 & 10,298 & 7,136 & 2,643 \\
\hline \multicolumn{7}{|l|}{ Industrialized Asia } & 654 \\
\hline$\underset{\text { Western Europe }}{\text { Japan }} \ldots \ldots \ldots \ldots \ldots$ & \multicolumn{4}{|c|}{ Western Europe } & 43,525 & 43,205 & 42,864 \\
\hline Belgium ............ & 5,631 & 5,712 & 5,712 & 5,712 & 3,966 & 2,000 & 0 \\
\hline Finland $\ldots \ldots \ldots \ldots \ldots$ & 2,310 & 2,355 & 2,355 & 2,355 & 1,155 & 0 & 0 \\
\hline France ............... & 58,493 & 59,948 & 64,070 & 62,870 & 62,870 & 62,870 & 56,190 \\
\hline Germany...$\ldots \ldots \ldots$ & 22,017 & 22,282 & 20,723 & 18,916 & 13,075 & 7,896 & 1,269 \\
\hline Netherlands ........... & 504 & 504 & 449 & 0 & 0 & 0 & 0 \\
\hline Spain ............... & 7,124 & 7,207 & 7,054 & 6,614 & 6,614 & 4,797 & 1,906 \\
\hline Sweden .............. & 10,002 & 10,040 & 9,440 & 8,395 & 4,202 & 0 & 0 \\
\hline Switzerland $\ldots \ldots \ldots \ldots$ & 3,050 & 3,077 & 3,077 & 2,000 & 2,000 & 1,030 & 0 \\
\hline Turkey ............... & 0 & 0 & 0 & 0 & 0 & 0 & 0 \\
\hline United Kingdom . . . . . . . . & 12,908 & 12,928 & 11,352 & 10,518 & 7,158 & 7,158 & 5,908 \\
\hline Total Industrialized . . . . . & 277,295 & 283,449 & 272,016 & 236,392 & 205,388 & 159,554 & 113,754 \\
\hline \multicolumn{8}{|l|}{ EE/FSU } \\
\hline \multicolumn{8}{|l|}{ Eastern Europe } \\
\hline Bulgaria ............. & 3,538 & 3,538 & 3,538 & 2,722 & 1,906 & 953 & 0 \\
\hline Czech Republic . ........ & 1,648 & 1,648 & 1,648 & 3,472 & 3,472 & 3,472 & 3,472 \\
\hline Hungary ............. & 1,729 & 1,729 & 1,729 & 1,729 & 1,729 & 1,299 & 0 \\
\hline Romania $\ldots \ldots \ldots \ldots$ & 0 & 650 & 650 & 650 & 1,300 & 1,300 & 1,300 \\
\hline Slovakia .............. & 1,632 & 1,632 & 1,632 & 1,592 & 1,592 & 1,592 & 1,592 \\
\hline Slovenia $\ldots \ldots \ldots \ldots$ & 632 & 632 & 632 & 632 & 632 & 0 & 0 \\
\hline \multicolumn{8}{|l|}{ Former Soviet Union } \\
\hline Armenia ............. & 376 & 376 & 376 & 376 & 0 & 0 & 0 \\
\hline Kazakhstan ........... & 70 & 70 & 70 & 0 & 500 & 500 & 500 \\
\hline Lithuania . ........... & 2,370 & 2,370 & 2,370 & 2,370 & 1,185 & 1,185 & 0 \\
\hline Russia ............. & 19,843 & 19,843 & 19,843 & 20,132 & 17,397 & 10,050 & 6,275 \\
\hline Ukraine $\ldots \ldots \ldots \ldots \ldots$ & 13,629 & 13,765 & 12,140 & 13,090 & 13,677 & 11,400 & 7,600 \\
\hline Total EE/FSU $\ldots \ldots \ldots$ & 45,467 & 46,253 & 44,628 & 46,765 & 43,390 & 31,751 & 20,739 \\
\hline
\end{tabular}


Table A49. World Nuclear Generating Capacity by Region and Country, Low Nuclear Case, 1995-2020 (Continued) (Megawatts)

\begin{tabular}{|c|c|c|c|c|c|c|c|}
\hline \multirow[b]{2}{*}{ Region/Country } & \multicolumn{2}{|c|}{ History } & \multicolumn{5}{|c|}{ Projections } \\
\hline & 1995 & 1996 & 2000 & 2005 & 2010 & 2015 & 2020 \\
\hline \multicolumn{8}{|l|}{$\begin{array}{l}\text { Developing Countries } \\
\text { Developing Asia }\end{array}$} \\
\hline China...$\ldots \ldots$ & 2,167 & 2,167 & 2,167 & 6,737 & 11,542 & 11,542 & 11,542 \\
\hline India $\ldots .$. & 1,695 & 1,695 & 1,799 & 3,103 & 4,726 & 4,416 & 4,416 \\
\hline Korea, North & 0 & 0 & 0 & 0 & 950 & 950 & 950 \\
\hline Korea, South .......... & 9,120 & 9,120 & 10,730 & 12,340 & 12,340 & 13,684 & 11,939 \\
\hline Pakistan ............ & 125 & 125 & 125 & 300 & 300 & 600 & 600 \\
\hline Taiwan............... & 4,884 & 4,884 & 4,884 & 4,884 & 6,176 & 4,280 & 2,500 \\
\hline \multicolumn{8}{|l|}{ Central and South America } \\
\hline Argentina $\ldots \ldots \ldots \ldots \ldots$ & 935 & 935 & 935 & 935 & 1,292 & 1,292 & 1,292 \\
\hline Brazil .... & 626 & 626 & 626 & 626 & 1,871 & 1,871 & 1,871 \\
\hline Cuba ..... & 0 & 0 & 0 & 0 & 0 & 0 & 0 \\
\hline \multicolumn{8}{|l|}{ Middle East } \\
\hline $\operatorname{Iran} \ldots \ldots$ & 0 & 0 & 0 & 1,073 & 2,146 & 2,146 & 2,146 \\
\hline \multicolumn{8}{|l|}{ Africa } \\
\hline South Africa ........... & 1,842 & 1,842 & 1,842 & 1,842 & 1,842 & 0 & 0 \\
\hline Total Developing ....... & 21,394 & 21,394 & 23,108 & 31,840 & 43,185 & 40,781 & 37,256 \\
\hline Total World $\ldots \ldots \ldots \ldots \ldots$ & 344,156 & 351,096 & 339,752 & 314,997 & 291,963 & 232,086 & 171,749 \\
\hline
\end{tabular}

Note: EE/FSU = Eastern Europe/Former Soviet Union.

Sources: History: International Atomic Energy Agency, Nuclear Power Reactors in the World (Vienna, Austria, April 1997). Projections: Energy Information Administration, Office of Coal, Nuclear, Electric and Alternate Fuels, based on detailed assessments of country-specific nuclear power plants. 
Table A50. World Nuclear Generating Capacity by Region and Country, High Nuclear Case, 1995-2020 (Megawatts)

\begin{tabular}{|c|c|c|c|c|c|c|c|}
\hline \multirow[b]{2}{*}{ Region/Country } & \multicolumn{2}{|c|}{ History } & \multicolumn{5}{|c|}{ Projections } \\
\hline & 1995 & 1996 & 2000 & 2005 & 2010 & 2015 & 2020 \\
\hline \multicolumn{8}{|l|}{ Industrialized } \\
\hline United States . . . . . . . . . . & 99,148 & 100,817 & 97,635 & 95,555 & 93,525 & 86,800 & 80,357 \\
\hline Canada ............. & 14,907 & 14,902 & 13,024 & 14,902 & 14,902 & 12,842 & 10,298 \\
\hline $\begin{array}{l}\text { Mexico ............... } \\
\text { Industrialized Asia }\end{array}$ & 1,308 & 1,308 & 1,308 & 1,308 & 1,308 & 1,308 & 1,308 \\
\hline$\underset{\text { Japan } \ldots \ldots \ldots \ldots \ldots}{ }$ & 39,893 & 42,369 & 43,525 & 50,176 & 54,768 & 61,870 & 69,260 \\
\hline Belgium . . . . . . . . . . & 5,631 & 5,712 & 5,712 & 5,712 & 5,712 & 5,320 & 3,966 \\
\hline Finland $\ldots \ldots \ldots \ldots \ldots$ & 2,310 & 2,355 & 2,610 & 2,610 & 2,610 & 2,610 & 0 \\
\hline France ............ & 58,493 & 59,948 & 64,303 & 62,870 & 64,320 & 70,400 & 76,500 \\
\hline Germany .............. & 22,017 & 22,282 & 21,063 & 20,723 & 20,083 & 14,835 & 10,540 \\
\hline Netherlands . . . . . . . . & 504 & 504 & 449 & 449 & 449 & 0 & 0 \\
\hline Spain . . . . . . . . . . . . . & 7,124 & 7,207 & 7,207 & 7,207 & 7,054 & 6,614 & 6,614 \\
\hline Sweden .............. & 10,002 & 10,040 & 10,040 & 10,040 & 10,040 & 10,040 & 6,685 \\
\hline Switzerland . . . . . . . . & 3,050 & 3,077 & 3,077 & 3,077 & 2,712 & 2,355 & 2,000 \\
\hline Turkey ............... & 0 & 0 & 0 & 0 & 1,300 & 1,300 & 1,300 \\
\hline United Kingdom . . . . . . . . . & 12,908 & 12,928 & 12,682 & 11,035 & 9,568 & 7,768 & 7,158 \\
\hline Total Industrialized . . . . & 277,295 & 283,449 & 282,635 & 285,664 & 288,351 & 284,062 & 275,986 \\
\hline \multicolumn{8}{|l|}{ EE/FSU } \\
\hline \multicolumn{8}{|l|}{ Eastern Europe } \\
\hline Bulgaria . ............ & 3,538 & 3,538 & 3,538 & 2,722 & 2,722 & 2,859 & 3,812 \\
\hline Czech Republic . . . . . . . . & 1,648 & 1,648 & 3,472 & 3,472 & 3,472 & 3,472 & 3,472 \\
\hline Hungary . . . . . . . . . . & 1,729 & 1,729 & 1,729 & 1,729 & 1,729 & 1,729 & 1,729 \\
\hline Romania $\ldots \ldots \ldots \ldots$ & 0 & 650 & 650 & 1,300 & 1,950 & 1,950 & 1,950 \\
\hline Slovakia ... . . . . . . . . . . & 1,632 & 1,632 & 2,020 & 2,408 & 1,592 & 1,592 & 1,592 \\
\hline Slovenia $\ldots . \ldots \ldots \ldots$ & 632 & 632 & 632 & 632 & 632 & 632 & 632 \\
\hline \multicolumn{8}{|l|}{ Former Soviet Union } \\
\hline Armenia . . . . . . . . . . & 376 & 376 & 752 & 752 & 752 & 752 & 752 \\
\hline Kazakhstan ........... & 70 & 70 & 70 & 570 & 570 & 500 & 500 \\
\hline Lithuania . . . . . . . . . . & 2,370 & 2,370 & 2,370 & 2,370 & 2,370 & 2,370 & 2,370 \\
\hline Russia . . . . . . . . . . & 19,843 & 19,843 & 19,843 & 22,668 & 20,785 & 23,590 & 26,360 \\
\hline Ukraine ........... & 13,629 & 13,765 & 13,065 & 14,040 & 15,940 & 15,940 & 15,577 \\
\hline Total EE/FSU $\ldots \ldots \ldots$ & 45,467 & 46,253 & 48,141 & 52,663 & 52,514 & 55,386 & 58,746 \\
\hline
\end{tabular}

See notes at end of table. 
Table A50. World Nuclear Generating Capacity by Region and Country, High Nuclear Case, 1995-2020 (Continued)

(Megawatts)

\begin{tabular}{|c|c|c|c|c|c|c|c|}
\hline \multirow[b]{2}{*}{ Region/Country } & \multicolumn{2}{|c|}{ History } & \multicolumn{5}{|c|}{ Projections } \\
\hline & 1995 & 1996 & 2000 & 2005 & 2010 & 2015 & 2020 \\
\hline \multicolumn{8}{|l|}{$\begin{array}{l}\text { Developing Countries } \\
\text { Developing Asia }\end{array}$} \\
\hline China $\ldots \ldots \ldots \ldots \ldots \ldots$ & 2,167 & 2,167 & 2,167 & 6,737 & 11,542 & 17,160 & 25,070 \\
\hline India $\ldots \ldots \ldots$ & 1,695 & 1,695 & 2,503 & 3,103 & 5,913 & 9,180 & 14,000 \\
\hline Korea, North . ...... & 0 & 0 & 0 & 1,900 & 1,900 & 1,900 & 1,900 \\
\hline Korea, South . . . . . . . . & 9,120 & 9,120 & 12,990 & 14,890 & 16,790 & 21,957 & 27,987 \\
\hline Pakistan $\ldots \ldots \ldots \ldots$ & 125 & 125 & 425 & 425 & 600 & 600 & 600 \\
\hline Taiwan $\ldots \ldots \ldots \ldots \ldots$ & 4,884 & 4,884 & 4,884 & 7,384 & 7,384 & 7,384 & 6,176 \\
\hline \multicolumn{8}{|l|}{ Central and South America } \\
\hline Argentina $\ldots \ldots \ldots \ldots \ldots$ & 935 & 935 & 935 & 1,627 & 1,292 & 1,292 & 1,292 \\
\hline Brazil $\ldots \ldots \ldots \ldots \ldots \ldots$ & 626 & 626 & 626 & 1,871 & 1,871 & 3,100 & 3,100 \\
\hline 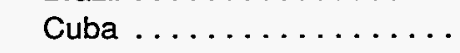 & 0 & 0 & 0 & 0 & 408 & 816 & 816 \\
\hline \multicolumn{8}{|l|}{ Middle East } \\
\hline $\operatorname{Iran} \ldots \ldots$ & 0 & 0 & 0 & 2,146 & 2,146 & 2,146 & 2,146 \\
\hline \multicolumn{8}{|l|}{ Africa } \\
\hline South Africa . . . . . . . . . & 1,842 & 1,842 & 1,842 & 1,842 & 1,842 & 1,842 & 1,842 \\
\hline Total Developing ....... & 21,394 & 21,394 & 26,372 & 41,925 & 51,688 & 67,377 & 84,929 \\
\hline Total World $\ldots \ldots \ldots \ldots \ldots$ & 344,156 & 351,096 & 357,148 & 380,252 & 392,553 & 406,825 & 419,661 \\
\hline
\end{tabular}

Note: EE/FSU = Eastern Europe/Former Soviet Union.

Sources: History: International Atomic Energy Agency, Nuclear Power Reactors in the World (Vienna, Austria, April 1997). Projections: Energy Information Administration, Office of Coal, Nuclear, Electric and Alternate Fuels, based on detailed assessments of country-specific nuclear power plants. For some countries, the World Integrated Nuclear Evaluation System (WINES) model (December 1997 run) was used to supplement the 2020 capacity projection. 
Appendix B

\section{World Energy Projection System}

The projections of world energy consumption published annually by the Energy Information Administration (EIA) in the International Energy Outlook (IEO) are derived from the World Energy Projection System (WEPS). WEPS is an integrated set of personalcomputer-based spreadsheets containing data compilations, assumption specifications, descriptive analysis procedures, and projection models. The WEPS accounting framework incorporates projections from independently documented models and assumptions about the future energy intensity of economic activity (ratios of total energy consumption divided by gross domestic product [GDP]) and about the rate of incremental energy requirements met by natural gas, coal, and renewable energy sources (hydroelectricity, geothermal, solar, wind, biomass, and other renewable sources).

WEPS provides projections of total world primary energy consumption, as well as projections of energy consumption by primary energy type (oil, natural gas, coal, nuclear, and hydroelectric and other renewable resources), and projections of net electricity consumption. By fuel projections of energy consumed for electricity generation and energy consumed at the transportation sector are also provided. Carbon emissions resulting from fossil fuel use are derived from the energy consumption projections. All projections are computed in 5-year intervals through the year 2020. For both historical series and projection series, WEPS provides analytical computations of energy intensity and energy elasticity (the percentage change in energy consumption per percentage change in GDP).

WEPS projections are provided for regions and selected countries. Projections are made for 7 individual countries, 4 of which-United States, Canada, Mexico, and Japan-are part of the designation "industrialized countries." Individual country projections are also made for China, India, and Brazil, all of which are considered "developing countries." Beyond these individual countries, the rest of the world is divided into regions. Industrialized regions include North America (Canada, Mexico, and the United States), Western Europe, and Pacific (Japan and Australasia-Australia, New Zealand, and the U.S. Territories). Developing regions include developing Asia (China, India, and Other Asia), Middle East, Africa, and Central and South America
(Brazil and Other Central and South America). The transitional economies consisting of the countries in Eastern Europe (EE) and the former Soviet Union (FSU) are considered as a separate country grouping, neither industrialized nor developing.

The process of creating the projections begins with the calculation of a reference case total energy consumption projection for each country or region for each 5-year interval in the forecast period. The total energy consumption projection for each forecast year is the product of an assumed GDP growth rate, an assumed energy elasticity, and the total energy consumption for the prior forecast year. For the first year of the forecast, the prior year consumption is based on historical data. Subsequent calculations are based on the energy consumption projections for the preceding years.

Projections of world oil supply are provided to WEPS from EIA's International Energy Module, which is a submodule of the National Energy Modeling System (NEMS). Projections of world nuclear energy consumption are derived from nuclear power electricity generation projections from EIA's International Nuclear Model (INM), PC Version (PC-INM). All U.S. projections are taken from EIA's Annual Energy Outlook (AEO).

A full description of the WEPS is provided in a model documentation report: Energy Information Administration, World Energy Projection System Model Documentation, DOE/EIA-M050(97) (Washington, DC, September 1997). The report presents a description of each of the spreadsheets associated with the WEPS, along with descriptions of the methodologies and assumptions used to produce the projections. It is available through EIA's home page (http://www.eia.doe.gov).

The WEPS model will be made available for downloading through the Internet on EIA's home page by May 1998. The package will allow users to replicate the projections that appear in IEO98. It is coded in Excel, version 5.0, and can be executed on any IBM-compatible personal computer in a Windows environment. The package requires about 5 megabytes of hard disk space and about 640 kilobytes of random access memory (RAM). 
Appendix C

\section{A Status Report on Developing Transportation for Caspian Basin Oil and Gas Production}

Prior to the breakup of the Soviet Union, the petroleum transportation networks in Azerbaijan, Kazakhstan, and Turkmenistan were designed to provide petroleum to the internal Soviet economy and, in particular, to meet the Soviet military's need for petroleum [1]. Investment in the Caspian Basin petroleum transportation system was, however, severely deficient. In order for the producers in the Caspian Sea area to become major petroleum exporters, existing petroleum transport lines, which generally head northward into Russia, will need upgrading. More importantly, new lines will need to be built to transport Caspian Sea oil to export markets, in some combination of westward to the Mediterranean, eastward to China, and southward to the Indian Ocean.

A major impediment to the construction of petroleum transportation lines is the fact that Azerbaijan, Kazakhstan, and Turkmenistan are landlocked countries in a region that lacks political stability. Virtually all the current pipeline routes are beset with problems. In order to reach export markets, Azeri, Kazakhstani, and Turkmeni petroleum will have to transverse one if not several neighboring countries. Outlets to Mediterranean export markets for Azerbaijan and Kazakhstan may depend on the cooperation of Armenia, Georgia, Russia, and Turkey. Access to oil ports and markets to the south might mean transport through Iran, Afghanistan, Pakistan, and India and, to the east, through Uzbekistan and China.

In recent years, the Caspian region countries have pursued several ad hoc measures for exporting crude oil, including oil swaps with Iran, rail shipments of oil across Russia, and shipments through the Volga/Don canal. These measures have allowed the Caspian nations some greater degree of access to export markets and-together with some reconstruction of existing pipelines-should allow for an increase in exports over the next several years. In order for the Caspian nations to reach their full oil production and export potential, however, some very large pipeline projects will have to be completed. This appendix details recent pipeline upgrades and new pipeline projects currently under consideration in the Caspian Basin.

\section{Pipelines from Azerbaijan}

- Baku to Navorossisk. The first major export pipeline project to be completed was an upgrade of anexisting pipeline running north from Baku,
Azerbaijan, to the Russian port of Navorossisk (see map). The pipeline project, with a capacity of 100,000 barrels per day, was completed in November 1997 at a cost of $\$ 50$ million. It was sponsored by the Azerbaijani International Oil Consortium (AIOC) (see below).

- Baku to Supsa. An alternative to the Baku/ Novorossisk route is another pipeline, also with a capacity of 100,000 barrels per day, that is being rebuilt by the AIOC. The line runs between Baku and Supsa, Georgia, on the Black Sea, bypassing Russia altogether. It is expected to be completed in late 1998. From Supsa, oil could be transported via tanker across the Black Sea to Samsun, Turkey, then via a new pipeline to Ankara, and from Ankara via an existing pipeline to the Mediterranean port of Ceyhan. Oil could also be transported across the Black Sea to Bulgaria and Romania and from there to Greek ports. Another possibility would be the construction of a new pipeline from Supsa directly to Midyat, Turkey, from which oil could travel through an existing pipeline to Ceyhan.

- Baku to Midyat. A third route, which currently has not moved beyond the proposal stage, would involve the construction of a 1 million barrel per day pipeline running along the Black Sea from Baku to Midyat, connecting with the existing pipeline to Ceyhan. This route is the most expensive of the transportation options, but it would bypass Russia and forestall any need for shipping oil across the Caspian Sea.

\section{Pipelines from Kazakhstan}

- Tengiz to Novorossisk. On May 16, 1997, Kazakhstan reached an agreement with Oman, Russia, and several foreign petroleum companies to build a pipeline between Tengiz and Novorossisk on the Black Sea. The first leg of this $\$ 2.2$ billion pipeline $(1,340,000$ barrels per day capacity) would run from Tengiz and Azerbaijan's major petroleum city Baku. From Baku, Kazakhi crude oil could travel on the newly upgraded pipeline running to the Russian port of Novorossisk, and then by ship through the Black Sea. 
Figure C1. Caspian Sea Region Oil Production and Export Potential, 1990-2020

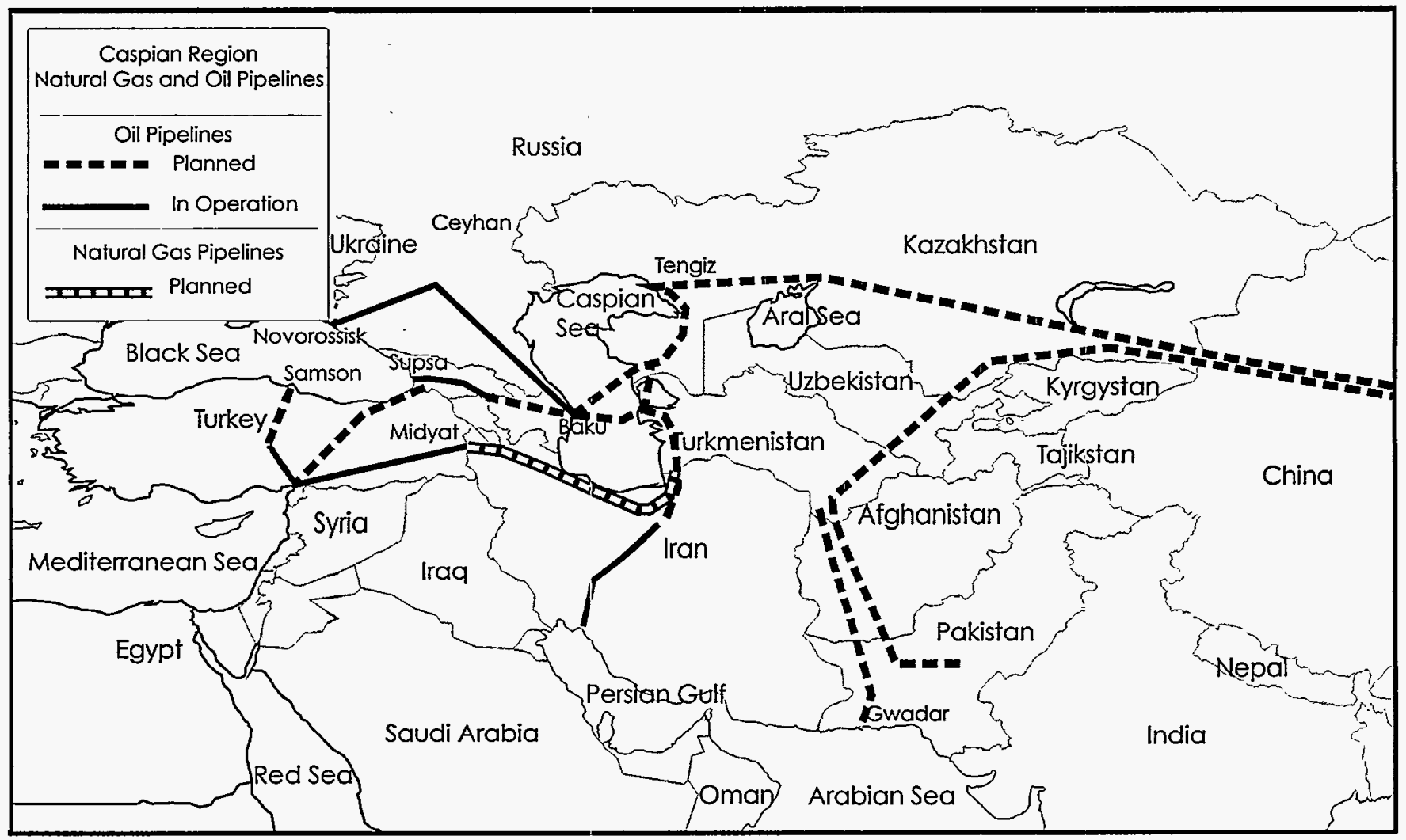

Source: Energy Information Administration, Office of Integrated Analysis and Forecasting (1998).

- Tengiz to Baku. Another possible pipeline route being considered would also transport Kazakhi oil to Baku, then through the currently proposed Baku/Supsa pipeline. From Supsa, Georgia, Kazakhi oil would then flow to world markets via tanker or through other proposed and existing pipelines running through Turkey.

- Tengiz to China. In September 1997, China and Kazakhstan successfully negotiated an agreement to ship Kazakhi oil to China via Turkmenistan. The cost of this pipeline is expected to be $\$ 3.5$ billion, and China has committed an additional $\$ 6$ billion to develop Kazakhi oil and gas reserves.

\section{Pipelines from Turkmenistan}

- Turkmenistan to Pakistan. In contrast to Azerbaijan and Kazakhstan, Turkmenistan's petroleum wealth stems largely from natural gas rather than oil. Turkmenistan has the third largest natural gas reserves in the world and accounts for 2 percent of the world's total natural gas reserves. In 1995, Turkmenistan negotiated a treaty with its neighbor to the south, Pakistan, to build a Unocalsponsored natural gas pipeline that could transport as much as 1.6 billion cubic feet of natural gas per day to Pakistan through Afghanistan. Turkmenistan has also negotiated to build a crude oil pipeline through Afghanistan to Pakistan's
Indian Ocean port of Gwadar. The cost for the two projects is estimated at $\$ 4.5$ billion.

- Turkmenistan to Turkey. Another natural gas pipeline option for Turkmenistan would be to Turkey through Iran. Iran has agreed to finance half the construction costs of a 1,600-mile, $\$ 6$ billion pipeline.

- Turkmenistan to China. Turkmenistan has also announced an intention to build a 4,200-mile, $\$ 10$ billion natural gas pipeline to China via Uzbekistan and Kazakhstan. The pipeline may eventually run all the way to Japan. This project is supported by Exxon, Mitsubishi, and the China National Petroleum Corporation (CNPC).

\section{Pipeline Investors}

- AIOC. The Azerbaijani International Oil Consortium consists of 12 companies: the U.S. companies Amoco (17 percent), Unocal (10 percent), Exxon (8 percent), and Pennzoil (5 percent); British Petroleum (17 percent) and Ramco Energy (2 percent) of the United Kingdom; Lukoil of Russia (10 percent); Statoil of Norway ( 9 percent); the Turkish Petroleum Company, TPAO (7 percent); Itochu of Japan (4 percent); Delta-Nimar of Saudi Arabia (2 percent); and the State Oil Company of the Azerbaijan Republic (SOCAR). The United 
States successfully resisted an attempt by Iran to join the AIOC in 1995 [2].

- CPC. The Caspian Pipeline Consortium (CPC) includes the governments of Kazakhstan and Oman and 11 companies: Chevron of the United States (15 percent); Lukarco of Russia and the United States (12.5 percent); Rosneft-Shell of Russia, the Netherlands, and the United Kingdom (7.5 percent); Mobil of the United States (7.5 percent); British Gas ( 2 percent); Agip of Italy (2 percent); Oryx of the United States (1.75 percent); and Kazak Munaigaz (1.75 percent).

\section{References}

1. G. Kemp, Energy Super Bowl: Strategic Politics and the Persian Gulf and Caspian Basin (Washington, DC: Nixon Center for Peace and Freedom, 1997), p. 49.

2. J. Pearson (Azerbaijani International Oil Consortium), "New Opportunities in the Black Sea Region," business conference organized by the Black Sea Economic Cooperation Business Council (April 28-30, 1997). 



\section{Index}

A

Abu Dhabi, 61

Africa. See also specific countries

coal consumption in, 79

description of, iv- $v$

economic growth in, 22

electricity industry in, 128

energy projections for, 13, 21-22

hydroelectricity in, 107-108, 128

natural gas consumption in, 60, 61

natural gas industry in, 61-62

oil production in, 32

petroleum exports from, 35, 36

Agreed Framework, 92

Alaska, 33

Albania, 104

Algeria

liquefied natural gas exports from, 60,62

natural gas consumption in, 60,61

natural gas industry in, 56, 57, 61

oil production potential in, 32

Alsthom (France), 91

Alternative growth cases, 9-12

American Automobile Manufacturers Association, 44

American Wind Energy Association, 98

Angola, 33, 35

Annex I countries. See also specific countries

carbon emissions from, 2, 3, 16, 19, 71

description of, $v$

energy consumption in, 3

greenhouse gas stabilization and, 15

primary energy used for electricity in, 114

renewable energy projections for, 5

Annual Energy Outlook (AEO), 189

Arco, 64

Argentina

economic growth projections for, 28

electricity industry in, 113, 121

hydroelectricity in, 108 .

natural gas industry in, 59-60

nuclear power industry in, 90

oil production in, 33

Armenia, 104

Asea Brown Boveri (Sweden/Switzerland), 127, 128

Asia. See also Developing Asia; specific countries

coal consumption in, 69, 73-74

coal trade and, 82

currency rates per U.S. dollar in, 12

electricity industry in, 116-120, 125

energy development projects in, 9 natural gas industry in, 62-64

oil demand in, 27

oil production in, 32,36

renewable energy in, 102-107

Association of International Automobile

Manufacturers, 44

Astra and Pluspetrol Energy, 60

Atacama project, 59, 60

Australia

coal industry in, 73, 82

electricity industry in, 124-126

liquefied natural gas industry in, 64

oil production in, 32-33

renewable energy in, 102

Austria, 56

Automobile ownership, 29

Azerbaijan

natural gas reserves in, 58

oil reserves in, 34

pipeline development in, 191

Azerbaijani International Oil Consortium (AIOC), 192-193

B

Bangladesh, 33

Bayu Undan joint venture (BHP Petroleum-Phillips Petroleum), 64

Belarus, 58, 59

Belgium

closing of coal mines in, 75

natural gas industry in, 53, 54

nuclear power industry and, 91

Berlin Mandate, 15

BHP Petroleum-Phillips Petroleum, 64

Biomass, 98

Bolivia, 121

Bolivia-Brazil pipeline, 4, 50, 60

Bord Gais Eireann (Ireland), 56

Brazil

coal consumption in, 80

coal trade and, 83

crude oil imports from, 35

electricity industry in, 113, 120-121

hydroelectricity in, 108, 121

natural gas demand in, 4, 59

nuclear power industry in, 90-91

oil production in, 33,37

British BG plc, 64

British Petroleum, 98

Bulgaria, 57, 75 
C

Cabora Bassa hydroelectric project, 107, 108

California, 44, 45

Cameroon, 107

Canada

carbon emissions from, 19

coal consumption in, 77

coal reserves in, 73

coal trade and, 83

electricity industry in, 121-123

Kyoto Protocol and, 16

natural gas consumption in, 52

natural gas pipeline capacity in, 50

nuclear power industry in, 91-93

oil demand in, 27

oil production in, 33,38

renewable energy in, 100

Canadian Gas Association (CGA), 52

Capacity Constraints Case (IEA CC), 21

Carbon cycle, 17

Carbon emissions. See also Greenhouse gases

from Annex I countries, 2, 3, 16, 19

from coal use, 18, 72, 145, 159

description of, 17

high economic growth case, 156-159

low economic growth case, 170-173

from natural gas use, 18, 144, 158

from oil use, 18, 40, 143, 157

projections for, 2, 18-19, 72

reference case, 2, 142-145

by region, $3,18,19,71,72,142-145,156-159$

Carbon permits, 16

Caspian Basin

oil production from, 26, 33, 34

pipeline development in, 191-192

pipeline investors for, 192-193

Caspian Pipeline Consortium (CPC), 193

Central and South America. See also specific countries

coal industry in, 80, 82-83

description of, $v$

economic growth in, 22

electricity consumption in, 5, 113

electricity industry in, 120-121

gasoline regulations in, 44-45

hydroelectricity in, 49, 108

leaded gasoline use in, 41

natural gas demand in, 4,49

natural gas industry in, 50, 59-60

oil demand in, 28

oil production in, 33, 36

Central and South West Services Corporation (CSW), 99

Central Asia Gas Pipeline project, 63

Central Power Limited (New Zealand), 126

Chad, 33

Changqing Petroleum Prospecting Administration, 64

Charbonnages de France, 77

Chernobyl power plants, 94
Chevron, 62, 64

Chile

economic growth projections for, 28

electricity industry in, 113, 120, 121

hydroelectricity in, 108

natural gas industry in, 50, 59, 60

China

carbon emissions from, 19, 72

coal consumption in, 69, 70, 73-74, 114

coal reserves in, 73

coal trade and, 82

economic growth in, 10, 12, 22

effect of economic crisis in Southeast Asia on, 10

electricity industry in, 116-117

energy-intensive industrial activity in, 14-15

hydroelectric projects in, 5, 103, 105-107, 116, 117

natural gas industry in, 64

nuclear power industry in, 90

oil demand in, 28

oil production in, 33

petroleum exports from, 35

transportation sector in, 28

unleaded gasoline use in, 41-42

vehicle ownership in, 29-30

China National Offshore Oil Corporation (CNOOC), 64

China National Petroleum Corporation, 64

Clean Air Act Amendments of 1990 (CAAA), 44, 78

CMS Energy, 60, 120, 128

Coal

carbon emissions from, $18,72,145,159$

for electricity generation, 69, 71, 74, 80, 114, 117, 128

environmental issues related to, $5,69,71-73$

low-sulfur, 78-79

minemouth prices of, 78-79

recoverable reserves of, 73

types of, 73, 78-79

Western Europe production of, 74-75, 80, 123

Coal consumption

in Africa, 79

in Asia, 70, 73-74, 114

in Eastern Europe and Former Soviet Union, 75, 77

high economic growth case, 152

Kyoto Protocol and, 5

low economic growth case, 166

in Middle East, 80

in North America, 77, 78-79

projections for, $4-5,69-71$

reference case, 138

in South America, 80

trends in, 70-71

in Western Europe, 74-75

Coal Export Submodule (CES), iii

Coal trade

in Asia, 82

in Europe, 83

metallurgical, 83

in North and South America, 82-83

overview of, 80,82 
projections for, 70

by region, 81

Colombia

coal industry in, 80

coal reserves in, 73

coal trade and, 83

crude oil imports from, 35

gasoline regulations in, 44-45

natural gas industry in, 60

oil production in, 33

Comision Federal de Electricidad (CFE), 52

Congo Brazzaville, 33

Congo Kinshasa, 33, 107

Cook Inlet (Alaska), 33

Crude oil, 35, 36. See also specific listings under oil

Cuba, 90, 91

Czech Republic

coal industry in, 75

electricity industry in, 127

natural gas demand in, 50, 56

D

Danish Environment Fund, 107

Denmark

diesel fuel regulations in, 45

renewable energy in, 100, 101

DEPA (Greece), 57

Department of Energy, U.S., 99

Developing Asia. See also Asia; specific countries

automobile ownership in, 29

coal consumption in, 70-71

description of, iv

economic growth in, 9, 22

electricity consumption in, 5, 113

electricity generation in, 20

electricity industry in, 116-120

energy projections for, 7,8

hydroelectric projects in, 5, 102-107, 114

leaded gasoline use in, 41-42

liquefied natural gas in, 64

natural gas demand in, 49

nuclear power industry in, 87,90

oil demand in, 26-29

renewable energy in, 102-107

Developing countries. See also specific countries

carbon emissions from, 2, 18

economic growth in, 9, 10

electricity consumption in, 5

energy consumption in, 7,13

natural gas demand in, 4, 49

nuclear power industry in, 90-91

oil demand in, 27-28

oil projections for, 4

transportation energy demand in, 29

vehicle ownership in, 29-30

Diesel fuel, 45-46

Distrigaz, 53
$\mathrm{DRI} / \mathrm{McGraw}-\mathrm{Hill}$ (DRI)

natural gas projections of, 61

oil price projections of, $38-40$

oil production projections of, 39,40

E

Eastern Europe and Former Soviet Union (EE/FSU). See also Former Soviet Union (FSU); specific countries carbon emissions from, 16, 72

coal consumption in, 5, 70, 75, 77

description of, iv

economic growth in, 9, 10, 12, 22

electricity industry in, 126-127

energy intensity and, 13

leaded gasoline use in, 41

natural gas demand in, 49, 50

natural gas industry in, 57-59

nuclear power industry in, 20, 94

oil demand in, 28

oil production in, 40

renewable energy in, 104, 107

Economic crisis in Southeast Asia

details of, 11

effects of, 10, 22, 98, 119

energy projections and, 1, 2, 4, 7, 9

oil market and, 26

Economic growth

alternative cases for, 9-12

energy use and, 9

forecast comparisons and, 22

projections for world, 9, 11-12

by region and selected countries, 10

standard of living and, 13

uncertainties in, 11-12

Ecopetrol, 60

Ecuador, 33

Edelnor, 60

EGAT (Thailand), 120

Egypt

hydroelectricity in, 107

natural gas industry in, 61

oil production in, 33

El Paso Energy, 120, 127

Electric Power Research Institute, 99

Electricite de France, 102, 117, 124, 127

Electricity consumption

in Africa, 128

in Central and South America, 120-121

in developing Asia, 116-118

in Eastern Europe and Former Soviet Union, 126

high economic growth case, 155

low economic growth case, 169

in Middle East, 127

in North America, 121, 122

projections for, 5,113

reference case, 141

by region, 113 
in Southeast Asia, 119

in Western Europe, 123

Electricity Feed Law (EFL) (Germany), 101

Electricity Generating Authority of Thailand (EGAT), 98

Electricity generation. See also Hydroelectricity;

Renewable energy

coal for, $69,71,72,73,74,75,76,78,114,117,128$

energy consumption for, 122,124

natural gas for, 20, 49, 52, 60, 114, 122-123, 127

nuclear power for, 5, 20, 87, 88, 91, 114

oil for, 114,117

projections for, 4

in Western Europe, 56

Electricity Generation Corporation (Ontario), 123

Electricity industry

in Africa, 128

in Asia, 116-120, 125

in Australia and New Zealand, 125-126

in Central and South America, 120-121

in Eastern Europe and Former Soviet Union, 126-127

economics of, 115, 116

in Middle East, 127-128

in North America, 52, 121-123

public policy reform in, 115-116

recent developments in, 113-114

regulatory reform in, $5,72,91,93,113,115,122,123$, 127

in Western Europe, 123-125

Electricity Transit Directive (European Union), 54

Electroandina, 60

EMC (Thailand), 63

Endesa (Chile), 60, 108

ENEL (Italy), 57, 124

Energy consumption. See also specific types of energy

alternative growth cases and, 9-12

carbon emissions and, 18-19

by economic growth case, 12

energy intensity trends and, 13-15

by energy source, $4,8,134-135,148-149,162-163$

forecast comparisons and, 21-24

greenhouse gas emissions and, 15-18

growth in, 1, 21

high economic growth case, 12, 21, 147-149

Kyoto Protocol and, 8, 15-18. See also Kyoto Climate Change Protocol

low economic growth case, 161-163, 174

projections for, 1, 2, 7-9, 12, 21-24, 189

reference case, 20, 133-135, 146

by region, 3, 8, 9, 14, 133-135

standard of living and, 13, 14

Energy elasticity, 14

Energy intensity, 13-15

Energy Policy Act of 1992 (EPACT), 124

Energy Savings Case (IEA ES), 21

Eni (Italy), 56, 57

Enron Corporation, 60, 114, 118, 120

Enron Renewable Energy Corporation, 98
Enron Solar, 101

Environmental issues

coal use and, 5, 69, 71-73

transportation fuel use and, 40-47

Environmental policies

international efforts to create, $71-72$

for reformulated fuels, 43-47

Environmental Protection Agency (EPA), 44

EPRI, 99

Equatorial Guinea, 33

Escravos Gas Project, 62

Ethiopia, 107

European Gas Directive, 50

European Investment Bank (EIB), 57

European Parliament, 44, 45

European Union (EU)

coal production in, 76

electricity industry deregulation in, 91

greenhouse gas reduction in, 71

Lithuanian geothermal projects and, 107

Natural Gas Directive, 53, 54

renewable energy investments in, 20

restructuring of gas markets by, 50,53

European Wind Energy Association, 100

\section{$\mathbf{F}$}

Finland

electricity generation and, 56

electricity industry in, 114

reformulated fuels in, 44,45

renewable energy in, 101-102

Former Soviet Union (FSU). See also Eastern Europe

and Former Soviet Union (EE/FSU); specific countries

carbon emissions from, 72

coal consumption in, 70

coal industry in, $73,75,77$

economic growth in, 22

electricity industry in, 126

energy consumption in, 16, 21

energy-intensive industrial activity in, 14-15

natural gas industry in, 57-59

nuclear power industry in, 20, 94

oil demand in, 28

oil production in, 32,33

renewable energy in, 104, 107

Framework Convention on Climate Change (United Nations) (1992), 15, 71

France

coal production in, 75,77

natural gas industry in, 54

nuclear power industry and, 91

renewable energy in, 102

\section{G}

G-7 countries, v

Gas Authority of India Limited (GAIL), 63, 64

Gas Natural (Spain), 60 
Gas Research Institute (GRI), 38

GasAndes pipeline, 50, 59

GasAtacama, 60

Gasoline

diesel, 45-46

emissions from, 40, 41

environmental policies related to, 41-42

lead removal from, 42-43

reformulated, 44-45

Gas-to-liquids (GTL) processes, 46

Gasunie (Netherlands), 56

Gaz de France, 53, 56, 62

Gazprom (Russia), 56-57, 59, 61

Geothermal projects

in Indonesia, 103, 104

in Lithuania, 107

Germany

coal consumption in, 75

coal production in, $75,77,114,123$

coal reserves in, 73

coal trade and, 82

electricity consumption in, 124

natural gas industry in, 56

renewable energy in, 100

Ghana, 62, 107

Global Environment Fund, 107

Greece

coal consumption in, 75

gasoline regulations in, 44

natural gas consumption in, 57

renewable energy in, 101

Green Mountain Power Corporation, 99

Greenhouse gases. See also Carbon emissions; specific greenhouse gases

coal use and, 69, 71-73

credits for controlling, 2

gases identified as, 16

Kyoto Protocol and emissions of, 15-18

trading program for, 69

Guamare-Pecem pipeline, 60

\section{H}

HBJ (India), 63

Hibernia oil project (Newfoundland), 33

High economic growth case

assumptions for, 10

carbon emissions, 156-159

coal consumption, 152

electricity consumption, 155

energy consumption, 12, 21, 147-149, 160

hydroelectricity and renewable energy consumption, 154

natural gas consumption, 151

nuclear energy consumption, 88, 153

oil consumption, 150

High non-OPEC supply case, 178, 182

High nuclear case, 88, 187-188

High oil price case, 176, 180
Hungary, 107, 127

Hydro Quebec, 100, 123

Hydroelectricity

in Central and South America, 49, 108, 121

in developing Asia, 5, 102-107, 117

in Eastern Europe and Former Soviet Union, 104, 107

in industrialized Asia, 102

in Middle East and Africa, 107-108, 128

in North America, 98-100

overview of, 97-98

in Western Europe, 100-102

Hydroelectricity consumption. See also Renewable energy consumption

high economic growth case, 154

Kyoto Protocol and, 5

low economic growth case, 168

projections for, 20

reference case, 140

Hydrofluorocarbons, 16, 17

I

IES Industries (New Zealand), 126

India

coal consumption in, 69, 73-74, 114

coal reserves in, 73

coal trade and, 82

diesel fuel regulations in, 45-46

electricity industry in, 114, 117-118

hydroelectric projects in, 103

natural gas industry in, 63-64

natural gas supplies to, 61

nuclear power industry in, 90

oil demand in, 28, 29

unleaded gasoline use in, 42

wind energy in, 103-104

Indonesia

coal reserves in, 73

coal trade and, 82

economic crisis in, 2, 11

electricity industry in, 119

energy use and economic growth in, 9

oil production potential in, 32

renewable energy in, 98, 103, 104

unleaded gasoline use in, 42

Industrialized countries. See also specific countries

carbon emissions from, 18

coal consumption in, 5, 70

description of, iv

economic growth in, 9, 10

electricity consumption in, 5

greenhouse gas stabilization and, 15

Kyoto Protocol and, 2, 8

leaded gasoline use in, 41

natural gas demand in, 49, 50

nuclear power industry in, 91-93

oil consumption in, 4, 26-29

renewable energy growth in, 20

vehicle ownership in, 30 
International Atomic Energy Agency (IAEA), 92

International Energy Agency (IEA)

economic growth projections and, 22

energy forecasts of, 21

on heat content of lignite, 73

oil price projections of, 38,39

International Energy Module, 189

International Energy Outlook 1997 (IEO97), 32, 37

International Energy Outlook 1998 (IEO98)

description of, iii

forecast comparisons with, 21-23

oil production 1997 vs., 32

International Energy Outlook (IEO), 23-24

International Monetary Fund (IMF), 11

International Nuclear Model, PC Version (PC-INM), iii, 189

Iran

coal consumption in, 80

electricity industry in, 127-128

hydroelectricity in, 107

natural gas industry in, 60, 61

nuclear power industry and, 90, 91

South Par project in, 50

Iranian National Petroleum Company, 61

Iraq

electricity consumption in, 127

U.N. sanctions on, $3,4,26$

Ireland, 101

Israel

coal consumption in, 80

electricity consumption in, 127

natural gas supplies to, 61

Israel Electric Corporation, 80

Italian Vento Power Corporation (IVPC), 101

Italy

electricity industry in, 124

natural gas industry in, 56-57, 61

renewable energy in, 101

IVO Engineering, 104

Ivory Coast, 33

\section{J}

Japan

carbon emissions from, 72

coal consumption in, 70,74

coal trade and, 82

diesel fuel regulations in, 45

economic crisis in Southeast Asia and, 10

economic growth in, 22

electricity industry in, 20, 125-126

liquefied natural gas consumption in, 114

natural gas consumption in, 64

nuclear power industry in, 64,91

renewable energy in, 102

vehicle ownership in, 29, 30
Jordan, 107

\section{K}

Karachi Electric Supply Corporation (KESC), 119

Kazakhstan

coal production in, 75

natural gas industry in, 58, 59

nuclear power industry in, 94

oil reserves in, 34

pipeline development in, 191-192

Kenya, 107

Korea Gas Corp-Ras Laffan contract, 61

Korean Electric Power Corporation (KEPCO), 120

Korean Peninsula Energy Development Organization (KEDO), 92

Kotzebue Electric Association, 100

Kuwait, 127

Kuwait Foreign Petroleum Exploration Company, 64

Kyoto Climate Change Protocol, 5, 69, 71

coal consumption and, 5, 69, 78

energy growth and, $1-2,8$

greenhouse gas reduction commitments at, 15-18, 71-72

nuclear power and, 5

oil demand and, 27

renewable energy and, 5

$\mathbf{L}$

Laos, 103

Latvia, 104

Lead emissions, 40, 41

Lignite, 73, 75. See also Coal; Coal consumption

Liquefied natural gas (LNG)

Africa and, 60, 62

developing Asia and, 64, 114, 120

Italy and, 56, 57

Middle East and, 60-61, 114

Oman and, 62-64

Lithuania

nuclear power industry in, 94

renewable energy in, 107

Low economic growth case

assumptions for, 10

carbon emissions, 170-173

coal consumption, 166

electricity consumption, 169

energy consumption, 12, 21, 161-163, 174

hydroelectricity and other renewable energy

consumption, 168

natural gas consumption, 165

nuclear energy consumption, 88, 167

oil consumption, 164

Low nuclear case, $88,185-186$

Low oil price case, 177,180 


\author{
M \\ Maghreb pipeline, $61-62$ \\ Malaysia \\ coal consumption in, 74 \\ economic crisis in, 2, 11 \\ electricity industry in, 119, 120 \\ energy use and economic growth in, 9 \\ natural gas industry in, 63 \\ oil demand in, 28 \\ oil production in, 33 \\ renewable energy in, 98,102 \\ Malaysia-Thailand Joint Authority (MTJA), 63 \\ Markowski Plan, 77 \\ Methane emissions, 16, 17 \\ Methyl tertiary butyl ether (MTBE), 43, 44, 46, 47 \\ Metrogas (Chile), 50 \\ Mexico \\ coal industry in, 77 \\ coal trade and, 82 \\ crude oil imports from, 35 \\ diesel fuel regulations in, 45, 46 \\ economic trends in, 9-10 \\ electricity industry in, 121-123 \\ natural gas industry in, 52-53 \\ nuclear power industry in, 91-92 \\ oil demand in, 27 \\ oil production in, 32,33 \\ Middle East. See also specific countries \\ coal consumption in, 80 \\ description of, iv \\ economic growth in, 22 \\ electricity industry in, 127-128 \\ energy projections for, 13, 21 \\ hydroelectric projects in, 107 \\ liquefied natural gas and, 114 \\ natural gas industry in, 60-61 \\ oil distillation refining capacity in, 36 \\ Mission Energy Corporation, 126 \\ Mongolia, 33 \\ Morocco, 80, 128 \\ Mozambique, 107 \\ Municipal solid waste (MSW), 98 \\ MVR (Hungary), 127
}

\section{N}

Nam Thuen 2 Electricity Consortium, 98

National Energy Modeling System (NEMS), iii, 189

National Steel Corporation (NISCO) (Iran), 80

Natuna gas pipeline, 62,63

Natural gas consumption

in Africa, 60, 61

in Asia, 62-64

carbon emissions from, 18, 72, 144, 158

in Central and South America, 59

in Eastern Europe and Former Soviet Union, 57-58

for electricity generation, $20,49,52,60,114,127$

growth in, 4, 20, 49-50 high economic growth case, 151

in Middle East, 60

in North America, 52

reference case, 137

in Western Europe, 53

Natural Gas Directive (European Union), 53, 54

Natural gas industry

in Africa, 61-62

in Asia, 62-64

in Central and South America, 59-60

in Eastern Europe and Former Soviet Union, 57-59

in Middle East, $60-61$

in North America, 52-53

overview of, 51

in Western Europe, 53-57

Natural gas pipelines

construction of, 20, 49-50

developments in, 50

in North America, 52-53

in South America, 120

in Western Europe, 53-57

Natural Resources Canada (NRCan), 38, 39

NatWest Securities, Ltd. (NatWest)

oil price projections of, 38

oil production projections of, 39,40

Netherlands, 91

New Zealand

electricity industry in, 125, 126

renewable energy in, 102

Niagra Mohawk Power Corporation, 99

Nigeria

hydroelectricity in, 107

natural gas industry in, 57, 62

offshore oil production potential in, 32

petroleum exports from, 35

Nigerian Gas Company, 62

Nissho Iwai (Japan), 127

Nitrous oxide emissions

description of, 17

from gasoline, 40

Kyoto Protocol and, 16

Nonconventional oil, 38

Non-Fossil Fuel Obligation (NFFO) (United Kingdom), 101

NorFra pipelines, 50,56

Norgas-Latin America, 60

North Korea, 90, 92, 93

North Sea, 32, 36, 37

North West Shelf LNG project (Woodside Petroleum), 64

Northern States Power, 126

Norway

diesel fuel regulations in, 45

electricity industry in, 114, 124

natural gas industry in, 56

oil production in, 32

supply of natural gas to Czech Republic from, 50

Nova Corporation (Canada), 63 
NRG Energy, 127

Nuclear Nonproliferation Treaty, 92

Nuclear power capacity

high nuclear case, 187-188

low nuclear case, $185-186$

reference case, 183,184

by region, 88,89

Nuclear power consumption

for electricity generation, 5, 20, 87, 88, 91, 114

high economic growth case, 153

low economic growth case, 167

projections for, iii, 5, 7, 20, 114

reference case, 139

Nuclear power industry

in developing Asia, 90, 92, 93

in developing countries, 90-91

in Eastern Europe and Former Soviet Union, 94 economic issues related to, 88

factors shaping outlook for, 88,90

in industrialized Asia, 64, 87, 91

in North America, 77, 91-93, 121-122

in Western Europe, 91

Nuclear power plants

Chernobyl, 94

expansion projections for, 5

retirement of, 20, 92-93

Oil. See also Crude oil; Petroleum

estimates of undiscovered, 33, 37-38

extraction and processing of, 38

political, economic, and environmental issues effecting, 3-4

Oil consumption

emissions from, 18, 40, 41, 72, 143, 157

high economic growth case, 150

in industrialized countries, $26-27$

low economic growth case, 164

oil prices and, 20, 25

projections for, 4,20

reference case, 4,136

during 1990s, 25

Southeast Asian crisis and, 4

Oil prices

comparison of forecasts for, $38-40$

Iraqi exports and, 4

oil demand growth and, 20

projections for, $2-3,37-38$

trends in, 25-26

year-end 1996, 2

Oil production

comparison of forecasts for, $38-40$

cost per barrel and, 31

high non-OPEC supply case, 33-35, 178, 182

high oil price case, 176,180

low oil price case, 177,180

non-OPEC projections for, 2-3

offshore, 26 reference case, 31-32, 175, 179

technological advances in, 20, 25, 26, 33, 37

Oil supply

expansion of OPEC production capacity and, 30-31

non-OPEC, 32-33

political and economic issues and, 4

Oman

liquefied natural gas and, 62-64

oil production in, 32

Omani LNG project, 62-64

ÖMV (Austria), 56

Onshore Gas Development, 61

Ontario Electric Services Corporation, 123

Ontario Hydro (OH), 92, 93, 123

Organization for Economic Cooperation and Development (OECD), v

Organization of Petroleum Exporting Countries

(OPEC)

description of, $v$

expansion of production capacity of, 30-31

oil markets and, 3

oil projections for, 3,37

output quotas of, 26

\section{$\mathbf{P}$}

Pacific Rim Developing Countries, $v$

Pakistan

electricity industry in, 119

natural gas industry in, 61, 63

nuclear power industry in, 90

Perfluorocarbons, 16, 17

Persian Gulf

description of, $\mathrm{v}$

oil production in, 31,32

petroleum exports from, 35,36

Personal income, 13-14

Peru, 121

Petroleos Mexicano (PEMEX), 53

Petroleum. See also specific listings under oil

Caspian Basin transportation networks for, 191-193

worldwide trade in, 35-37

Petroleum Authority of Thailand (PTT), 63

Petroleum Economics, Ltd. (PEL)

economic growth projections and, 22

energy forecasts of, 21

oil price projections of, 38,39

oil production projections of, 39,40

Petroleum Industry Research Associates (PIRA)

economic growth projections and, 22

energy forecasts and, 21

oil price projections of, 38,40

oil production projections of, 39,40

Petronas (Malaysia), 61, 63

Philippines

coal consumption in, 74

electricity industry in, 119-120

oil production in, 32

renewable energy in, 103 
Poland, 75, 77, 127

Portugal

closing of coal mines in, 75

electricity industry in, 124

gasoline regulations in, 44

Powerco Limited (New Zealand), 126

PowerGen (Great Britain), 64

Promigas, 60

Q

Qatar, 60-61

\section{$\mathbf{R}$}

Reference case

Asia and, 7, 12

carbon emissions, 2, 142-145

coal consumption, 138

description of, 1

electricity consumption, 141

energy consumption, 20, 133-135, 146

hydroelectricity and other renewable energy

consumption, 140

natural gas consumption, 137

nuclear energy consumption, 139

nuclear generation capacity, 183, 184

oil consumption, 4, 136

oil production, 31-32, 175, 179

petroleum trade in, 35-37

preparation of, iii

primary energy consumption, 20

Reformulated fuels

diesel, 45-46

gasoline, 44-45

requirements for, 43-44, 46-47

Renewable energy. See also Hydroelectricity

in Central and South America, 108

in developing Asia, 102-107

in Eastern Europe and Former Soviet Union, 104, 107

in industrialized Asia, 102

in Middle East and Africa, 107-108

in North America, 98-100

overview of, 97-98

in Western Europe, 100-102

Renewable energy consumption. See also

Hydroelectricity consumption; specific types of renewable energy

high economic growth case, 154

low economic growth case, 168

for power generation, 114

projections for, 5,20

reference case, 140

by region, 98

Rio Treaty. See United Nations Framework Convention on Climate Change (1992)

Romania

coal industry in, 75

hydroelectric projects in, 104 nuclear power industry in, 94

Royal Dutch Shell, 59, 64, 98

Russia

coal production in, 75

coal reserves in, 73

electricity industry in, 126

leaded gasoline in, 40

natural gas industry in, $57-59$

nuclear power industry in, 94

\section{$\mathbf{S}$}

Saudi Arabia electricity industry in, 127,128

natural gas industry in, 60, 61

oil production by, 3,26

SCE Corporation, 126

Serbia, 77

Shale, 38

Shell Petroleum Development Corporation of Nigeria (SPDC), 62

Siberia, 58,59

Slovakia, 107

Slovenia, 61

Snam (Italy), 56, 57

Sonatrach (Algeria), 56, 57

South Africa

coal industry in, 73, 79-80

coal trade and, 83

electricity industry in, 128

nuclear power industry in, 90,91

oil production in, 33

use of hydroelectricity in, 107

South Africa Power Pool (SAPP), 107-108

South America. See Central and South America

South Korea

coal consumption in, 74

diesel fuel regulations in, 45

economic crisis in, 2, 11

energy use and economic growth in, 9

liquefied natural gas and, 114, 120

natural gas pipelines and, 64

nuclear power industry in, 90, 92

oil demand in, 28

vehicle ownership in, 29, 30

South Par project (Iran), 50, 61

Southeast Asia. See Asia; Developing Asia; Economic crisis in Southeast Asia; specific countries

Spain

coal production in, 75-77

nuclear power industry in, 91

renewable energy in, 100

Standard of living, 13-15

Steam coal, 70

Sudan, 33

Sulfur emissions, 78-79

Sulfur hexafluoride, 17

Sweden

electricity industry in, 56, 114, 124 
nuclear power industry in, 91

reformulated fuels in, 44,45

Synthetic fuels, 79

Syria, 32, 107

\section{$\mathrm{T}$}

Tacke Windtechnik $\mathrm{GmbH}, 98$

Taiwan

coal consumption in, 74

electricity industry in, 120

nuclear power industry in, 90

oil demand in, 28

Taiwan Power Company, 120

Tar sands, 38

Tecpetrol, 60

TEPCO (Japan), 61

Texas Wind Power Company, 99

Thailand

coal consumption in, 74

economic crisis in, 2, 11, 62-63

electricity industry in, 119, 120

energy use and economic growth in, 9

oil demand in, 28

renewable energy in, 98, 103

unleaded gasoline use in, 41

Three Gorges Dam Project (China), 5, 103, 105-107, 117

Total (France), 61

Trans-Austria-Gasline (TAG), 56

TransEuropa Naturgas Pipeline, 56

Transgas (Czech Republic), 56

Transmed pipeline, 61

Transportation sector

in China, 28

oil demand and, 28-30

policies to lessen environmental damage from, 40-47

Tunisia, 33, 61

Turkey

coal consumption in, 75

natural gas industry in, 57, 61

nuclear power industry and, 91

Turkmenistan

natural gas reserves in, 58,59

oil reserves in, 34

pipeline development in, 192

\section{U}

Ukraine

coal production in, 75

natural gas reserves in, 58

nuclear power industry in, 94

United Arab Emirate (UAE), 61

United Kingdom

coal production in, $75,76,82,114,123$

electricity industry in, 113, 124

natural gas industry in, 53, 54

oil production in, 32

renewable energy in, 100, 101
United Nations Framework Convention on Climate Change (1994), 15, 71

United Nations Global Environmental Facilities (GEF), 103

United States

carbon emissions from, 19,72

coal consumption in, 70, 77

coal reserves in, 73

coal trade and, 83

diesel fuel regulations in, 45

electricity industry in, 121-123

Kyoto Protocol and, 16

natural gas consumption in, 52

natural gas pipeline capacity in, 50

nuclear power industry in, 88, 91-93

oil demand in, 27

oil production in, 33

renewable energy in, 98-100

Unocal (U.S.), 63, 103

Uruguay, 121

U.S. Export-Import Bank, 105

U.S. Federal Energy Regulatory Commission (FERC), 123

U.S. Geological Survey (USGS), 33, 37-38

U.S. Iran-Libya Sanctions Act (1996), 50, 57

U.S. Utility Wind Turbine Verification Program, 99

Utility Data Institute (UDI), 93

Uzbekistan, 58, 59

V

Venezuela

coal reserves in, 73

coal trade and, 83

crude oil imports from, 35

electricity industry in, 121

oil production potential in, 32

Vietnam, 32

Volatile organic compounds (VOCs), 40

W

Water Power Development Authority (WAPDA)

(Pakistan), 119

Wedel Line, 56

West African Gas Pipeline Project, 62

Western Europe. See also specific countries

carbon emissions from, 72

coal consumption in, 70, 74-75

coal production in, 74-77, 82, 123

coal trade in, 80

electricity industry in, 113-114, 123-125

natural gas industry in, 53-57

nuclear power industry in, 91

renewable energy in, 20, 100-102

Wind energy. See also Renewable energy

in Asia, 102-104

in United States, 98-100

in Western Europe, 20, 100-102 
Woodside Petroleum, 64

World Bank, 103, 105, 107, 108

World Energy Outlook (International Energy Agency), 21

World Energy Projection System Model Documentation (DOE), 189

World Energy Projection System (WEPS), 189

World Integrated Nuclear Evaluation System (WINES), iii

World Petroleum Congress, 37
$\mathbf{Y}$

Yamal-Europe pipeline, 58-59

Yemen, 32

YPF, 60

$\mathbf{Z}$

Zimbabwe, 107, 108

Zond Corporation, 98 